UR. JERNEJ WEISS

NOVA GLASBA

V "NOVI" EVROPI

MED OBEMA SVETOVNIMA

VOJNAMA

NEW MUSIC

IN THE "NEW" EUROPE

BETWEEN THE TWO

WORLD WARS 
studia musicologica labacensia

ISSN 2536-2445 
studia musicologica

labacensia 
Izid monografije so podprli

\section{- C FestIVAL 2: LJUBLJANA \\ LJUBLJANAFESTIVAL.SI}

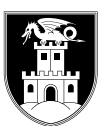

Mestna občina Ljubljana

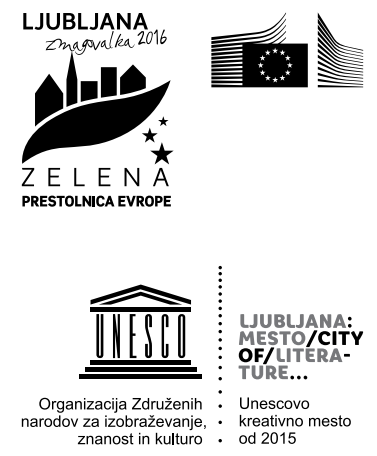

i. REPUBLIKA SLOVENIJA MINISTRSTVO ZA KULTURO 
nova glasba $\mathrm{v} »$ novi « Evropi med obema svetovnima vojnama

new music

in the "new" europe between the two world wars

ur. Jernej Weiss 
Znanstvena monografija $\mathrm{z}$ mednarodno udeležbo

Nova glasba $v$ "novi "Evropi med obema svetovnima vojnama

- New Music in the "New" Europe Between the Two World Wars

Uredil Jernej Weiss

Studia musicologica Labacensia, 2 (ISSN 2536-2445)

Glavni urednik - Jernej Weiss (Ljubljana/Maribor)

Odgovorni urednik - Jonatan Vinkler (Koper)

Tehnična urednica - Tjaša Ribizel (Ljubljana)

Uredniški odbor - Matjaž Barbo (Ljubljana), Primož Kuret (Ljubljana), Helmut Loos (Leipzig),

John Tyrrell (Cardiff), Michael Walter (Graz), Jernej Weiss (Ljubljana/Maribor)

Recenzenta Primož Kuret in Igor Grdina

Oblikovanje in prelom $\cdot$ Jonatan Vinkler

Prevod : Amidas d. o. o.

Jezikovni pregled (slovensko besedilo) - Jernej Weiss

Izdali in založili

Založba Univerze na Primorskem (zanjo: prof. dr. Dragan Marušič, rektor)

Titov trg 4, SI-60oo Koper

Glavni urednik - Jonatan Vinkler

Vodja založbe - Alen Ježovnik

Festival Ljubljana (zanj: Darko Brlek, direktor)

Trg francoske revolucije 1, SI-10oo Ljubljana

Koper, Ljubljana 2018

ISBN 978-961-7023-72-5 (spletna izdaja: pdf)

http://www.hippocampus.si/ISBN/978-961-7023-72-5.pdf

ISBN 978-961-7023-73-2 (spletna izdaja: html)

http://www.hippocampus.si/ISBN/978-961-7023-73-2/index.html

ISBN 978-961-7023-74-9 (tiskana izdaja)

Naklada tiskane izdaje: 200 izvodov (tiskovina ni namenjena prodaji)

DOI: https://doi.org/10.26493/978-961-7023-72-5

(C) 2018 Festival Ljubljana

Kataložni zapis o publikaciji (CIP) pripravili v Narodni in univerzitetni knjižnici v Ljubljani

COBISS.SI-ID $=293344512$

ISBN 978-961-7023-72-5 (Založba Univerze na Primorskem, pdf)

ISBN 978-961-7023-73-2 (Založba Univerze na Primorskem, html) 


\section{Vsebina}

Jernej Weiss

9 Nova glasba $v$ »novi« Evropi med obema svetovnima vojnama Jernej Weiss

13 New Music in the "New" Europe Between the Two World Wars

Primož Kuret

17 Padci in vzponi

John Tyrrell

23 Janáček's maestoso

Helmut Loos

51 Heilige Nüchternheit. Der Komponist in der Moderne. Kontinuität statt Bruch

Peter Andraschke

63 Vielfalt der Moderne. Die Musiktage in Donaueschingen und Baden-Baden in den 1920er Jahren

Hartmut Krones

73 Sprechen und „Sprechgesang“ als Ausdrucksform für sozialkritische Inhalte in der Musik der Zwischenkriegszeit

Luba Kijanovska

89 Ukrainische Komponistenschule in der Zwischenkriegsperiode des XX Jahrhunderts: Zwischen Modernismus und sozialistischem Realismus 


\section{Lubomír Spurný}

107 Work and Performance: A few Comments

on the Czech Modern Music

Nada Bezić

115 »Intimni glasbeni večeri« (1923-1926)

ali Kako je Hrvaški glasbeni zavod v Zagrebu odprl vrata v sodobnost

Matjaž Barbo

135 Anton Dolinar kot doktorski študent Guida Adlerja

Jurij Snoj

159 Misel o glasbi v spisih treh slovenskih medvojnih glasbenih esejistov

Niall O'Loughlin

175 Slavko Osterc's Compositional Journey and his Assimilation

of New Techniques

Gregor Pompe

187 Slavko Osterc in Lucijan Marija Škerjanc:

estetski razkol in poetsko bratstvo

Jernej Weiss

201 Alois Hába and Slovene Students of Composition at the State Conservatory in Prague

Karmen Salmič Kovačič

217 O polislogovnosti klasicističnega modernizma po razkritju "adornovske zmote« - na primerih iz opusa Demetrija Žebreta Andrej Misson

239 Nekaj misli o slovenskem zborovskem skladanju med obema svetovnima vojnama

Darja Koter

257 Idejna in umetniška identiteta mladinskih zborov med obema vojnama

Katarina Bogunović Hočevar in Ana Vončina

275 Radio Ljubljana v prvem desetletju svojega delovanja - medij, ideologija in inštitucija v luči glasbe

Ivan Florjanc

295 Ustvarjalnost primorskih skladateljev med italijansko okupacijo Primorske v času fašizma - kompozicijski, slogovni in družbeni uvidi Sara Zupančič

317 Kačji pastir - La Libellula: Glasbena večjezičnost opere Pavleta Merkuja 
343 Povzetki

357 Summaries

373 Avtorji

381 Contributors

389 Imensko kazalo/Index 



\section{Nova glasba $v \gg$ novi $\ll$ Evropi med obema svetovnima vojnama}

Jernej Weiss

Univerza v Ljubljani / Univerza v Mariboru

Pričujoča znanstvena monografija se posveča raziskavam slogovne in kompozicijsko-tehnične raznolikosti obdobja med obema svetovnima vojnama in vzpostavljanjem kavzalnega odnosa med slogovnimi specifikami posameznih zgodovinskih segmentov in družbenimi spremembami v t. i. "novi« Evropi po prvi svetovni vojni. Le ta je ne le povsem na novo začrtala evropske meje, temveč vplivala tudi na postopno preoblikovanje nacionalnih ideologij ter miselnih okvirov večine tedanjega prebivalstva. Slovenci smo po véliki vojni v novi kulturno-politični realnosti Kraljevine Srbov, Hrvatov in Slovencev prekinili državljanske vezi z Dunajem ali kot duhovito zapiše eden boljših poznavalcev življenja v Habsburški monarhiji, Igor Grdina, popkovnica s prestolnico ob lepi modri Donavi je bila poslej dokončno prerezana.

Seveda so nekatere slogovne in estetske premene na domala vseh umetniških področjih že več desetletij poprej preroško napovedovale začetek prve velike svetovne morije. Sicer pa je prav 20. stoletje v duhovnozgodovinskem pogledu večinoma prekinjalo $\mathrm{z}$ osnovnimi potezami, ki so zaznamovale 19. stoletje, $v$ nekaterih pogledih pa je določene značilnosti še stopnjevalo. To v prvi vrsti velja za poudarjen subjektivizem in željo po inovaciji. Prav zahteva po novem je postala eden izmed osrednjih estetskih postulatov modernizma 2o. stoletja. Posledično je za omenjeno obdobje značilen ne samo odmik od tradicionalnih izrazil, ki so v pretežni meri še vedno zaznamovala 19. stoletje, temveč hitro menjavanje oziroma 
vpeljevanje številnih novih kompozicijskih tehnik. Odslej si je torej domala vsak ustvarjalec $-\mathrm{v}$ kolikor je bil prepričan o takrat zdi se edinem zares pomembnem kazalcu »modernega« o napredku - skušal postavljati lastna kompozicijska pravila.

In vendar bi se lahko istočasno vprašali, ali niso vse novosti, če jih podrobneje opazujemo, večidel stare stvari, katerim posamezniki občasno zgolj nadanejo nova oblačila oziroma jih postavijo v drug kontekst? Kot primer bi, recimo, lahko navedli Schönberga - kot enega največjih novotarjev v prvi polovici 2o. stoletja - ki je iskal novo predvsem $\mathrm{v}$ predrugačenem kontekstu, prek gledanja na staro $\mathrm{z}$ drugega zornega kota, kar med drugim izčrpno izpričuje njegov članek Brahms the Progressive.

Za novo glasbo se zdi tako pomembno, denimo za Schönbergovo skladateljsko poetiko osnovno, prevrednotenje vrednot - kar pomeni, da je »konservativni revolucionar" opazoval »pravila« komponiranja iz druge izhodiščne točke in jih pravzaprav izpeljal iz starih postulatov. Kar je bilo resnično novo je torej nastalo zaradi premene odnosov med vertikalo in horizontalo ter zavoljo spremenjenih zahtev strukturiranja obeh temeljnih principov gradnje.

Poraja se torej upravičen dvom v smiselnost polarizacije med "staro" in »novo« glasbo, ki je posebej dobila na veljavi tedaj, ko je Adorno leta 1949 razvil »filozofijo nove glasbe«, slednja pa je kot ideološko-nacionalni konstrukt iz intelektualne zgodovine bolj ali manj nekritično prevzela koncept »razvoja« nasproti »restavraciji«. Če torej v dosedaj prevladujoči historiografski tradiciji, ki jo je po Bekkerjevi definiciji Nove glasbe najbolj zaznamovala prav postadornovska miselnost, obstajajo izrazitejše vrednostno pogojene ločnice med »tradicionalno« in »novo" glasbo, bo zdi se glede na najnovejše in vedno soglasnejše poglede različnih teoretikov na dosedanjo interpretacijo zgodovine in filozofije glasbe 20. stoletja, potrebno njene postulate temeljito prevetriti in jih morebiti postaviti na drugačna izhodišča.

Nenazadnje se zdijo novosti vselej odvisne od kontekstov v katerih nastajajo oziroma izbire parametrov s katerimi jih definiramo. Slovenskega skladatelja Slavka Osterca bi tako v širšem evropskem prostoru težko uvrstili med osrednje novotarje prve polovice 20. stoletja, tovrstne vloge pa mu kljub vsemu verjetno ne bi mogli odreči v kontekstu slovenske glasbe. Tako prihaja do svojevrstnega paradoksa, ki ga poraja vprašanje ali je bila denimo v začetku 2o. let $\mathrm{v}$ očeh Osterčevih slovenskih sodobnikov njegova glasba nova zgolj zato ker si tedaj na Slovenskem nihče drug ni upal zagovarjati ali znal oziroma hotel zapisati disonančnega stavka? Istočasno pa 
bi se lahko vprašali ali ne gre pri recepciji medvojne slovenske glasbe, ki jo večkrat primerjamo s težko primerljivimi "vrhovi« sočasne evropske glasbene dediščine, za domala pretiran občutek zaostajanja, posnemanja in dohitevanja, če vemo, da so se naši skladatelji v 2o. stoletju šolali po vsej Evropi in pri nekaterih najvplivnejših evropskih avantgardistih?

Razloge za specifično, regionalno obarvano prevzemanje slogovne raznovrstnosti in posameznih kompozicijskih tehnik je v okviru nekaterih najnovejših raziskovalnih izsledkov ARRS projekta Slogovna in kompozicijsko-tehnična raznolikost slovenske glasbe od leta 1918 do sodobnosti v luči družbenih sprememb $\mathrm{v}$ pričujoči publikaciji skušalo podati nekaj osrednjih slovenskih in tujih muzikologov ter tako nakazati smernice za nadaljnje raziskave slovenske glasbe med obema svetovnima vojnama. Gotovo je to področje, ki je bilo doslej pri nas manj raziskano, tudi zaradi posledic prej omenjene "adornovske « miselnosti na naših tleh. Tako se zdi pomemben del poti raziskovanja specifik obdobja med obema vojnama $\mathrm{z}$ vsemi svojimi zanimivimi odtenki še pred nami. 



\section{New Music in the "New" Europe Between the Two World Wars}

Jernej Weiss

University of Ljubljana / University of Maribor

The focus of the present monograph is an exploration of the diversity of styles and compositional techniques that characterised the interwar period and the establishment of a causal relationship between the specific stylistic characteristics of individual segments of history and social changes in the "new" Europe of the period following the First World War. The latter did not only redraw the boundaries of Europe, it also led to a gradual transformation of the national ideologies and mental frameworks of the majority of the European population of the time. Following the Great War, in the new cultural and political reality of the Kingdom of Serbs, Croats and Slovenes, we Slovenes broke our ties with Vienna, or as Igor Grdina, an expert on life in the Habsburg Monarchy, wittily puts it: the umbilical cord tying us to the capital on the beautiful blue Danube was finally cut.

Certain stylistic and aesthetic shifts in practically all artistic fields had, of course, been prophetically predicting the start of the First World War for decades. In the cultural historical sense, the twentieth century in many ways represented a break with the essential features that had marked the nineteenth century, although in some senses it actually intensified specific characteristics. This applies above all to the emphasis on subjectivism and the desire for innovation. The call for the new, in fact, became one of the central aesthetic postulates of twentieth-century modernism. As a result, the period is marked not only by a retreat from the traditional forms of expression that for the most part still characterised the nineteenth century, 
but also by the rapid alternation of compositional techniques and the introduction of numerous new ones. From this moment onwards, practically all composers - to the extent that they were convinced by what appears to have been the only truly significant indicator of the "modern" or progress at that time - would attempt to establish their own compositional rules.

At the same time, however, one might ask whether all innovations, if observed in closer detail, are not for the most part old things that are from time to time simply dressed in new attire or placed in a different context. As an example, we could cite Schönberg - one of the greatest innovators of the first half of the twentieth century - who sought the new above all in an altered context, by looking at the old from a different point of view, as he exhaustively demonstrates in his essay Brahms the Progressive.

For new music, a re-evaluation of values thus seems important - or indeed essential in the case of Schönberg's compositional approach. This means that the "conservative revolutionary" observed the "rules" of composition from a different starting point and actually derived them from old postulates. What was truly new thus came into being as a result of a shift of relations between the vertical and horizontal and because of the changed requirements of structuring the two fundamental principles of building.

This gives rise to a legitimate doubt about the logic of the polarisation between "old" and "new" music, which gained particular currency when Adorno developed his "philosophy of new music" in 1949 and the latter, as an ideological/national construct from intellectual history, more or less uncritically adopted the concept of "development" versus "restoration". If clear value-based dividing lines between "traditional" and "new" music exist in the historiographical tradition that has prevailed to date - which according to Bekker's definition of New Music is characterised above all by a post-Adornian mentality - it will be necessary, in the light of the most recent and increasingly unanimous views of various theorists with regard to the earlier interpretation of the history and philosophy of twentieth-century music, to subject its postulates to a thorough shake-up and perhaps base them on different premises.

Last but not least, innovations always appear to depend on the context in which they emerge, or the choice of parameters by which we define them. It would be difficult to rank the Slovene composer Slavko Osterc among the central innovators of the first half of the twentieth century in the broader European context, yet we probably cannot deny him this role in the context of Slovene music. This leads to a unique paradox originating in the question 
of whether, say, Osterc's music in the early 1920 appeared new in the eyes of his Slovene contemporaries merely because no one else in Slovenia at that time dared to defend dissonance or was capable of or interested in writing dissonant music. At the same time we could ask ourselves whether, in the reception of interwar Slovene music, which we frequently compare with the hardly comparable "pinnacles" of contemporary European musical heritage, the sense of backwardness, imitation and catching up is not perhaps exaggerated, if we consider that Slovene composers in the twentieth century trained throughout Europe with some of the most influential members of the European avant-garde.

Several leading Slovene and foreign musicologists have attempted to offer reasons for the specific, regionally coloured adoption of stylistic diversity and individual compositional techniques in the context of some of the latest research findings of the project The Stylistic and Compositional-Technical Diversity of Slovenian Music from 1918 to the Present Day in the Light of Social Changes (Slovenian Research Agency), and in this way indicate guidelines for further research of Slovene music between the two World Wars. This is undoubtedly still an under-researched field in Slovenia, in part because of the consequences of the previously mentioned "Adornian" mentality in this country. It thus appears that an important part of the journey of researching the specific characteristics of the period between the two World Wars, with all its interesting nuances, still lies ahead of us. 



\title{
Padci in vzponi
}

\author{
Primož Kuret \\ Univerza v Ljubljani \\ University of Ljubljana
}

Po kataklizmi, ki jo je povzročila prva svetovna vojna, je nastala v Evropi tudi v umetnostih nova situacija. Bilanca je bila strahovita: 13 milijonov mrtvih, 11 milijonov invalidov, 50 milijonov vojakov, 6 milijard izstrelkov, 30 milijard kubičnih metrov plina. ${ }^{I}$ Vojna je bila velika zareza, kontinuiteta je bila pretrgana. Danes govorimo, da je bil čas pred letom 1914 čas velikih utopij, za njim pa čas njihovega zdravljenja. Veliki imperiji so razpadli, med njimi ni obstajala več Avstro-Ogrska, katere del smo bili tudi Slovenci. Nastale so nove države, med njimi tudi država Slovencev, Hrvatov in Srbov, pozneje Jugoslavija, kjer je zavladalo novo navdušenje, vendar se je le-ta kmalu izkazala kot utopija, ki v političnem življenju ni imela realne podlage. Zanašanje na Ameriko in na načelo predsednika Wilsona o etničnih mejah za Slovence ni veljalo. Med kupčkanjem velesil smo izgubili tretjino Slovenije in Rapalska pogodba je leta 1920 dodelila četrtino slovenskega naroda Italiji. Na severni meji je samo odločen poseg generala Rudolfa Maistra rešil Maribor. Po koroškem plebiscitu pa smo leta 1920 izgubili še Koroško. V novi državi razmere niso bile ugodne, razmahnil se je kapitalizem. Nadaljevalo se je izseljevanje, vprašanje beguncev iz po Italiji zasedenih slovenskih ozemelj je ostala nerešeno. Pesnik Srečko Kosovel je leta 1925 zapisal, da je bil to čas najbolj sramotnih kupčij z narodom, zatajenih mnenj, splošne depresije. Ko je bilo vse, kar je dišalo po novem, tako rekoč pregnano iz uradne slovenske kulturne dužbe in sta bili otopelost, brezduš- 
nost tako rekoč zaščiteni po zakonu za zaščito države, je prišel v slovenske dežele blaženi mrtvaški mir. ${ }^{2}$ Velika gospodarska kriza, ki je sledila, je še stopnjevala občutek brezizhodnosti.

Kljub vsemu temu pa je v novi državi slovenski jezik dobil mesto na vseh šolah do univerze, ni bilo več nemškega političnega pritiska na Štajerskem, dobili smo Prekmurje. Kljub grožnjam po unitarizmu, diktaturi kralja Aleksandra, je ostala živa ideja in želja po rešitvi narodnega vprašanja na Slovenskem. Mora vojnih let je počasi izginjala, začele so nastajati nove spodbude. Evropa pa tudi Slovenci so hoteli nadomestiti zamujeno med vojno.

Glasbeno življenje je bilo razgibano, pojavili so se novi mediji, nove glasbene prireditve (SIMC), novo vrenje pa kažejo zlasti gibanja med dunajsko šolo Arnolda Schönberga in neoklasicizmom Igorja Stravinskega. Nase so opozorili Francozi z Milhaudom in Honeggerjem. Na umetnost so vplivali novi izumi tehnike, čezoceanski poleti, boksarski dvoboji, upori delavcev, hotelske avle in tovarne. Črnski jazzovski glasbeniki so prinesli v Evropo nove ritme. Leto 1928 je še posebej zanimivo, saj je prineslo Schönbergove Variacije op. 31, Brechtovo in Weillovo Opero za tri groše, Ravelov Bolero, balet Stravinskega Apollon Musagette, Honeggerjev Rugby, Gershwinovega Amerikanca v Parizu.

Na Slovenskem je odmevala leta 1929 premiera Kogojeve opere Črne maske po libretu Leonida Andrejeva. V tem času je nastala Osterčeva opera Krog s kredo (po Klabundu) pa tudi njegove enodejanke Iz komične opere in nekaj kasneje še druge. Slovenska umetnost je postala očitno zanimiva tudi za tuje kulture. Tako je berlinska revija Der Sturm v posebni številki izdala članke o »mladi slovenski umetnosti«. ${ }^{3} \mathrm{~V}$ njej je med drugim tudi prispevek Marija Kogoja z naslovom Ueber die neue Musik, kjer med drugim zapiše,

"die neue Kunst wird im Namen ihrer apostolischen Sendung die Diktatur des Geistes übernehmen, die Menschen aufrütteln und sie neu leben lehren. Stark leben, weise leben über die Zeit leben«.

Kogoj je bil v dvajsetih letih najprodornejša glasbena osebnost na Slovenskem in edini enakovredni protigralec vodilnim možem Glasbene matice, tako s svojim glasbenim opusom kot s svojimi članki o glasbi. Tako se je priključil tudi skupini okrog revije Trije labodi. Kajti predvsem literatura tistega časa je pod vplivi futurizma in nedavne preteklosti iskala nova

2 Lino Legiša, Zgodovina slovenskega slovstva VI, 158.

3 Der Sturm 19(10) (januar 1929, Berlin). 
pota. Bila je polna vojnih podob v poeziji Antona Podbevška, Vladimirja Premruja in Franceta Oniča. Pri Premruju vdrejo v pesem tulež parnikov, letalni stroji, telo padajočega letalca, vizijski prizori o titanih, ki vtiskajo $\mathrm{v}$ prsi brušena bodala, da kaplje škropijo po drevju in podobno. ${ }^{4}$ Pri pesniku Srečku Kosovelu se je povojna Evropa spremenila v ekstazo smrti, vse se pogreza v morje rdeče krvi. Vendar Kosovel protestira zoper smrt, je ne mistificira, in se proti njej bojuje. Futurizem je bil kljub hrupnemu nastopu bolj ali manj epizoden pojav $\mathrm{v}$ slovenski umetnosti, predvsem $\mathrm{v}$ poeziji. $\mathrm{V}$ glasbi skoraj neopazen. Zato pa je o novih pojavih $\mathrm{v}$ glasbi zavzeto spregovoril v svojih člankih Stanko Vurnik in se zanje zavzel. Skrbno je spremljal tudi vse, kar je novega nastalo doma, in se zavzemal za bolj polno in bogato glasbeno življenje doma: za stalno filharmonijo, za muzikološko stolico na univerzi, bogatejše koncertno življenje in spremljanje vsega, kar se je novega dogajalo po svetu. Ostro in sarkastično je zapisal:

"Kakšne duhovne probleme rešuje Evropal,/ nas še nikoli ni brigalo; kadar so bili že rešeni, smo rezultat sprejeli in dobili moderno pet let potem, ko je isto Evropa že vrgla ad acta. S takšno moderno ne moremo več na mednarodno poprišče, zakaj svet hoče od nas kaj novega, česar še sam ni videl, prežvečil in odvgel. Žal, vedno smo tako za Evropo neaktualni in nam je to $v$ vsestransko škodo ... O že poznam vse ugovore! Kaj nas briga Evropa, mi smo Slovenci in nacionalisti in sovražimo import! Kaj nam Stravinski, on je vendar Rus! Pa zraven nemara še jud, in Schönberg - hvala lepa! Nam Slovencem vse to ne pristoja. Smo močne osebnosti in nočemo naprej, tičimo v svoji lupini in beremo časopise o vsem tem in se temu smejemo. Bistvo tega nacionalizma v muzikantstvu pri nas je često zgolj lenoba in komodnost, veliko pa je zraven nesodobne vzgoje in omejenosti. Mi moramo pomagati novi kolektivni kulturi na noge, nikakor s kopiranjem Rusov in judov, nego $z$ novo duhovno orientacijo, izpovedano v slovenskem jeziku in $z$ našimi močmi! «s

Obenem je Vurnik skrbno zasledoval vse, kar se je dogajalo v glasbi po svetu in doma. Tako je prvi kritično ocenil in podrobno analiziral Kogojeve Črne maske in ga uvrstil med Schrekerja in Berga. Ocenil je Osterca in Bravničarja, pri čemer je Osterca uvrstil v naprednejšo smer čiste glasbe,

4 Pot skozi noč: Izbor iz slovenske futuristične in ekspresionistične lirike, ur. Franc Zadravec, 116.

5 Stanko Vurnik, Slovensko glasbeno življenje v l. 1928, 62. 
»kateri sledi v najnovejšem času novi realizem, odrešenje od more evropskega materialističnega viška v začetku našega stoletja«. ${ }^{6}$

Slovenska operna produkcija je v tem času ponovno oživela in Vurniku je šlo za hitrejši in kvalitetnejši razvoj ter rast slovenske glasbe, za njeno aktualnost in odmevnost na sodobne duhovne in umetniške probleme. Ko je ob koncu dvajsetih let začela izhajati glasbena revija Nova muzika - urednik je bil Emil Adamič - se je v njej že v prvi številki oglasil Slavko Osterc, ki je udarno napovedal novo obdobje slovenske glasbe in se s tem pridružil Stanku Vurniku, ki pa je žal že kmalu nato umrl (1932). V tem času pa je Osterc že utrdil svoje mesto $v$ slovenski glasbi. Še vedno je pomembno posegal v slovensko glasbo Anton Lajovic, ki je v tem času zastopal zlasti avtonomnost slovenske kulture nasproti jugoslovanskemu unitarizmu in sploh pogosto posegal v aktualno politično dogajanje. Lajovic je ob tem dogajanju čedalje manj komponiral. Zato pa se je začela uveljavljati nova skupina skladateljev. Prevladujoči osebnosti sta bila Lucijan Marija Škerjanc in Slavko Osterc, dva nasprotna pola $v$ glasbi. Zlasti Osterc je po vrnitvi iz Prage, kjer je študiral in spoznal Hábo, postal znanilec in zagovornik njegovih idej v Jugoslaviji. Ob njiju so se uveljavili Matija Bravničar, Blaž Arnič, Danilo Švara, Vilko Ukmar, Srečko Koporc, Karol Pahor, Marjan Kozina in drugi. Med seboj različni. Nekateri so se šolali v tujini (npr. Švara v Frankfurtu pri Seklesu, Arnič na Dunaju, Varšavi in Parizu, Ukmar na Dunaju, Koporc in Kozina na Dunaju in v Pragi, Osterc v Pragi, Škerjanc v Pragi, na Dunaju, Baslu in v Parizu). Vsem pa je bila skupna skrb za slovensko glasbo, kljub težavam, ki jih je povzročila huda gospodarska kriza v začetku tridesetih let. Skupino danes imenujemo "prva slovenska glasbena avantgarda", ki se ji je kmalu pridružila naslednja generacija. Izšla je v glavnem iz Osterčeve šole, med njimi so se uveljavili Pavel Šivic, Marijan Lipovšek, Demetrij Žebre, Franc Šturm, Karol Pahor in pozneje še Primož Ramovš, Uroš Krek in Zvonimir Ciglič.

Osterc se je trudil, da ostane v stiku $\mathrm{z}$ razvojem glasbe $\mathrm{v}$ svetu ter da nanjo reagira. Njegova prizadevanja so se kazala predvsem v okviru SIMC (Societe intrenationale de la musique contemporaine). Družba je organizirala festivale in Osterc je dosegel, da so se pojavljala na njih ne samo njegova dela, ampak tudi dela drugih jugoslovanskih skladateljev. Leta 1932 je celo prevzel vodstvo jugoslovanske sekcije SIMC in 1936 postal član mednarodne žirije za pariški festival. Obenem je skrbel tudi za izvedbe doma. Tako je njegova sodelovanje s SIMC koristilo ne le njegovi lastni mednarodni uveljavitvi, ampak tudi uveljavitvi drugih jugoslovanskih skladateljev 
$\mathrm{v}$ tujini. Obenem si je prizadeval za izmenjalne koncerte s češko, avstrijsko in madžarsko sekcijo ter bil v stiku s številnimi pomembnimi tujimi glasbeniki kot so npr., Alois Hába, Alfredo Casella, Luigi Dallapiccola, Arthur Honegger, Pančo Vladigerov, Josef Suk pa tudi s številnimi dirigenti in intrumentalisti. Na ta način je veliko njegovih skladb doživelo prve izvedbe $\mathrm{v}$ tujini, kjer so bile $\mathrm{v}$ glavnem pozitivno ocenjene. $\mathrm{S}$ tem je rasel njegov ugled pa tudi zanimanje zanj in za slovensko glasbo.

Pomembno vlogo je imel v tem času Lucijan Marija Škerjanc, in sicer kot skladatelj, dirigent, pianist, pedagog in glasbeni kritik. Čeprav je konec dvajsetih let še eksperimentiral z modernimi sredstvi, je vendar ostal zvest svoji lirični naravi, smislu za zvočne barve in oblikovno dognanost. Čeprav je vztrajal na tradiciji, pa ji je dal novo podobo in svoje osebnostne značilnosti. V marsičem se je ločil od Osterca, njuni umetnostni nazori so bili pač različni. S svojim zgledom in velikim znanjem je pomembno vplival na vrsto glasbenih generacij v Jugoslaviji, ki so pri njem študirale.

Trideseta leta pomenijo za slovensko glasbo težnjo po uveljavljanju navzven in doma in njeno željo po preseganju stanja na vseh področjih ustvarjalnosti in poustvarjalnosti. Posebej pa je pomembno, da se je Osterčevimi pobudami začela prvič v večji meri uveljavljati v tujini, da so slovensko glasbo izvajali na tujih koncertnih odrih in da je zavest o slovenski glasbi začela prodirati v svet. Politične razmere so ta polet omejevale, začetek vojne leta 1941 pa je $\mathrm{z}$ vsemi svojimi posledicami usodno zarezal v razvoj slovenske glasbe. Nastale so povsem drugačne razmere in prilike, ki so zahtevale povsem drugačen odnos do glasbe in od glasbenikov.

\section{Bibliografija}

Kogoj, Marij. Ueber die neue Musik, Der Sturm 19(10) (Sonderheft, januar 1929), Berlin.

Kuret, Primož. Umetnik in družba. Ljubljana: Državna založba Slovenije, 1988. Legiša, Lino, ur. Zgodovina slovenskega slovstva VI. Ljubljana: Slovenska matica, 1969.

Piascator, Erwin. Das politische Theater (1929). V Jost Hermand, Frank Trommler. Die Kultur der Weimarer Republik. München, 1928.

Vurnik, Stanko. Slovensko glasbeno življenje v 1. 1928, Dom in svet XXXXII (1929).

Vurnik, Stanko. Nova slovenska opera, Dom in svet XXXXII (1929).

Zadravec, Franc, ur. Pot skozi noč: Izbor iz slovenske futuristične in ekspresionistične lirike. Ljubljana: Mladinska knjiga, 1966. 



\section{Janáček’s maestoso}

John Tyrrell

Univerza v Cardiffu

Cardiff University

Unlike his contemporary Gustav Mahler, Janáček was unadventurous in his use of expression marks. He used very few, almost always preferring Italian to his native Czech. The most common words he used were espressivo, dolce and dolcissimo, which occur when he wanted to characterize particularly tender music. The only other expression mark he commonly used is the term maestoso [majestic]. As will be shown below, the occasions on which he employed the term can be easily classified - until his final opera $Z$ mrtvého domu [From the House of the Dead], where he appears to use it in rather different contexts and, if one bears in mind the meaning of the word, in a strange way. The object of this paper is to explore this phenomenon and suggest some interpretations.

The term maestoso has been current since the Baroque as an indication of mood or as a tempo designation. An early definition was given by J. G. Walther in his Musicalisches Lexicon oder Musicalisches Bibliothec (Leipzig, 1732), who described the term as "ansehnlich und langsam, iedoch mit einer lebhaften Expression" [stately and slow, but with a lively expression]. In his Musikalisches Lexikon (Frankfurt am Main, 1802) H. C. Koch stated that, like con gravità, maestoso could imply the use of overdotting. This can be found, for instance, in Haydn's slow introductions, especially the middle symphonies (e.g. no. 50 (1773): Adagio e maestoso; no. 53, "Imperiale" (1773): Largo maestoso; and no. 54 (1774): Adagio maestoso) though as David Wyn Jones has pointed out, while all Classical composers used maestoso, this 
was not always prompted by the expected dotted-note figuration any more than maestoso guaranteed dotted notes.

The changeover between the typical Baroque-Classical, often double-dotted maestoso and the nineteenth-century maestoso mood, came with Beethoven's Ninth Symphony (1822-4). The first movement begins Allegro, ma non troppo, un poco maestoso and sets the model for later nineteenth-century orchestral movements where maestoso is not confined to a slow introduction; instead a solemn, majestical mood permeates the whole movement.

While Mendelssohn's Symphony no. 2 (“Lobgesang”, 1840) adheres to the Classical-Baroque model of maestoso introductions to its first two movements, later orchestral works follow the model of Beethoven's Ninth with a maestoso indication that covers entire movements. Here are some examples:

Brahms: Piano Concerto no. 1 (1859), I: Maestoso

Max Bruch: Symphony no. 1 (1867), I: Allegro maestoso

Max Bruch: Symphony no. 2 (1870), I: Allegro passionato ma un poco maestoso

Brahms: Academic Festival Overture (1880): Allegro, later L'istesso tempo, un poco maestoso

Bruckner: Symphony no. 6 (1881), I: Majestoso [sic]

Towards the end of the nineteenth century maestoso began to be used for particularly grandiose effects. A well known example is the final movement of Tchaikovsky's Fifth Symphony (1888), marked Andante maestoso. This constitutes the slow introduction to the movement, giving way after almost sixty bars to an Allegro vivace. But near the end of the movement (bar 472) the opening theme returns now with relentless triplet accompaniment, the grandness emphasized by the "molto" in the direction Moderato assai e molto maestoso. Here the weight and grandeur of the maestoso has an almost theatrical dimension, a trait shared with another famous example, the climax of Saint-Saëns's Third Symphony (1886). To a large symphony orchestra Saint-Saëns added two pianos and an organ. And it is the organ with a full, held forte chord that initiates the twenty-four-bar section marked maestoso ( 16 bars after fig. R). The dramatic impact of this is enhanced by its context: it follows a soft, subdued section in constant diminuendo and then an orchestral pause. 
Outside the European mainstream, maestoso was often harnessed to a nationalist, patriotic, even triumphalist agenda. This can be seen for instance in the final movement (marked Moderato e maestoso) of Elgar's Second Symphony (1911), dedicated to the memory of King Edward VII, and in his Coronation March (for the new king George V, also 1911) with a Molto maestoso opening. However it was in Czech nationalist music that the patriotic maestoso came into its own. The more patriotically inflated sections of Smetana's six-part cycle Má vlast [My Fatherland] are studded with maestoso indications, as are parts of his heroic-patriotic operas Dalibor and Libuše.

In his third opera, Dalibor (1865-7) Smetana accompanied the entry of the Czech hero Dalibor with maestoso music, a march for full orchestra. But even before then the opera began with a scene-setting Largo maestoso (there is no prelude) to invoke the solemn scene as people await the trial of Dalibor who, in avenging the death of his friend Zdeněk, has killed his attacker. In this and other works Smetana associated the term maestoso with notions of Czech kingship, so that King Vladislav, although in some ways the villain of the piece, is generally accompanied with maestoso music: his arrival in Act 1 is announced by Subito maestoso trumpets. His first utterance in the opera, sung over held chords, is marked maestoso, the opening of Act 3, with the entrance of King Vladislav and his court, is marked Moderato maestoso and his exit at the end of the scene is again maestoso.

What can be seen here are essentially two sorts of uses of patriotic maestoso: an association with the Bohemian medieval kingdom and another with the heroic character of Dalibor himself. Such notions recur in Smetana's next opera Libuše (1869-72), an opera about the beginnings of the Czech kingdom, when the reigning princess Libuše chooses Přemysl as her consort and together they found the first Czech dynasty. Apart from a few bars of lento, the opening prelude is entirely maestoso. At the end of Act 1, there is a long ensemble culminating in Libuše, "con somma esaltazione", proclaiming her love for the Czech nation. These five bars are marked maestoso; and a short orchestral act-end that follows is Maestoso assai. Another important association comes towards the end of the opera when Libuše (a prophetess as well as a queen) foresees the future of the Czechs. In Libuše's prophecy, essentially a musical tableau vivant, one section is devoted to the Hussite wars. The Hussites were a proto-Protestant sect that arose from the teachings of the church reformer Jan Hus, mar- 
tyred by the Catholics in 1415 . When a Crusade was mounted against his followers they successfully defended Prague and for the next couple of centuries were able to maintain their distinctive Protestant-type religion. In order to invoke the Hussites, Smetana quoted their most famous chorale, "Ktož jsú boží bojovnici" [Those who are warriors of God] and marked it Andante maestoso.

In Smetana's symphonic cycle Má vlast the fifth movement, Tábor (the name of the Hussite town) is devoted to the Hussites. Much of the time in Tábor Smetana elaborates fragments of the chorale used in Libuše but towards the end there is an exciting straight-through version of the chorale, the culmination of the piece. At the climax of the movement, the Piu mosso is suddenly slowed down to a Lento maestoso before accelerating to the close. This device goes back to the last movement of Beethoven's Ninth Symphony where in the middle of the final Prestissimo the tempo is held back by a four-bar maestoso at the words "Tochter aus Elysium" - a sort of grand ritenuto before the Prestissimo returns to bring the work to a swift conclusion. Here the maestoso has a structural function. I shall call it an "Eleventh-hour maestoso".

As well as celebrating the heroic Hussites in the Tábor movement, Má vlast repeats Smetana's association with the Bohemian kingdom in the first symphonic poem Vyšehrad, named after the Prague castle associated with Czech kings. After the balladic harps that open the piece, the main theme is given out Largo maestoso. The final symphonic poem in Má vlast is called Blanik, named after the mountain where Czech warriors wait in readiness to save the nation. At the end Smetana combined a grand version of the $V y$ šehrad theme with the Hussite chorale from Tábor in a passage marked Largamente maestoso, moving through a Grandioso, meno allegro to a Vivace that concludes the piece, i.e. another "Eleventh-hour maestoso".

By taking the majestic nature of the term maestoso and the type of music associated with it and placing it against heroic moments in Czech history and moments celebrating the ancient Bohemian kingdom, Smetana provided a musical reinforcement of such patriotic thoughts that would then become an important trope for Czech music. I shall call this "heroic-patriotic maestoso". 


\section{Heroic-patriotic maestoso in Janáček}

Janáček's first use of the term is shown in ex. 1

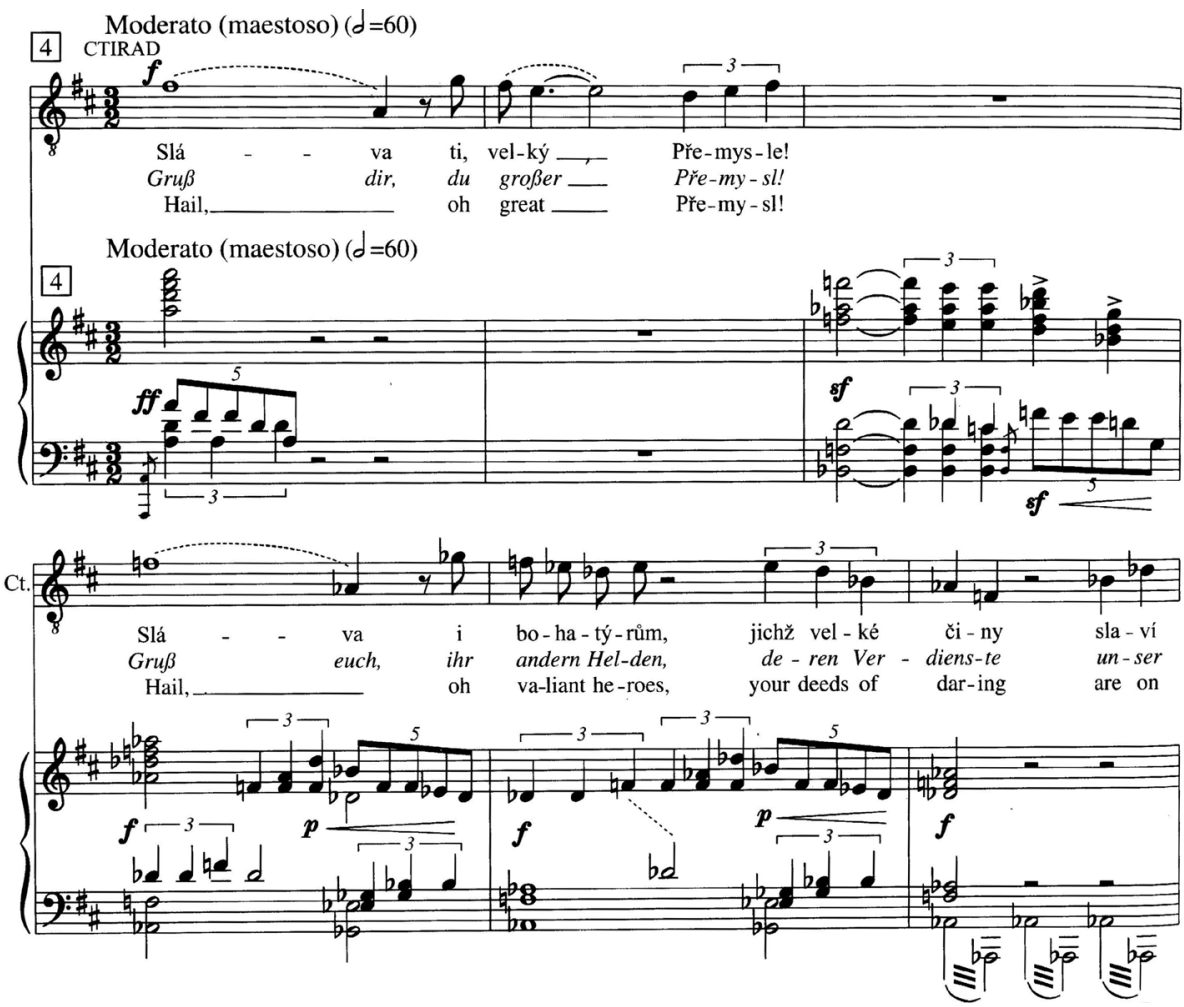

Example I: Janáček: Šárka, Act ı.C With kind permission by Universal Edition A.G., Wien, www.universaledition.com

This short passage comes soon after the beginning of Janáček's first opera, Šárka. Janáček wrote out a version of the opera in piano-vocal score in 1887 , but the next year, having shown it to Dvořák for his opinion and reacted to his criticisms, composed a second version. The opera is based on Czech mythic history and concerns events which took place after the death of the Queen Libuše. Her death meant there was not only a grieving widower (King Přemysl) but also an aggrieved female population, which had lost its female ruler. The women decide to take up arms against the men - the so-called "women's war" in which their most prominent fighter was Šárka. Soon after the opening of the opera, a young hero, Ctirad, arrives at the 
court of King Přemysl. The Moderato (maestoso) passage is Ctirad's greeting to the king and his warriors.

The version shown is one that Janáček revised thirty years later. The voice part (as in most of Janáček's 1919 revision of the opera) was much changed, but the orchestral accompaniment and its Moderato (maestoso) marking was there already in 1888 . Note the association of this marking with two characters: a hero (Ctirad) and a king (Přemysl). By doing so Janáček plugged into the Smetana tradition of associating maestoso music with heroes and Czech kingship.

Janáček had began as a Czech nationalist (his opera is a sequel to Smetana's Libuše), but this path was blocked: Šárka did not reach the stage until 1925 because the author of the text - whom Janáček had not consulted - refused his permission for it to be used. And so Janáček turned his back on this type of music altogether and instead began his involvement with Moravian folk music, which, after a few years, would transform his style and begin to move it nearer to the music now associated with him.

Janáček employed no more heroic-patriotic maestoso markings for almost thirty years since none of the music he composed during this time called for it. However, towards the end of the First World War the Habsburg Empire began to show signs of collapse and there was thus hope of realizing the nationalist dream of an independent Czech nation, Janáček, by then famous and successful, made his contribution with a group of patriotic pieces between 1917 and 1920 which employed heroic-patriotic maestoso. These comprise:

Výlety pana Broučka: Výlet pana Broučka do XV. století [The Excursions of Mr Brouček:The Excursion of Mr Brouček to the Fifteenth Century], opera (1917);

Taras Bulba, symphonic rhapsody (1918);

Ballada blanická [The Ballad of Blaník], symphonic poem (1919-20).

The Excursion of Mr Brouček to the Fifteenth Century takes the Prague nineteenth-century landlord Mr Brouček back to the heroic time of the Hussites and their defence of Prague in 1420. Musically this is characterized by Hussite chorales (Janáček used the original words but wrote new musical settings for them). One of the chorales, "Slyšte, rytieři boží" [Hear ye, warriors of God], is threaded through Act 1, each time marked maestoso, heard at first 'from afar' sung by the 'Armed People' (Ozbrojený lid), 
more loudly as they approach and finally fortissimo and maestoso as the act's conclusion.

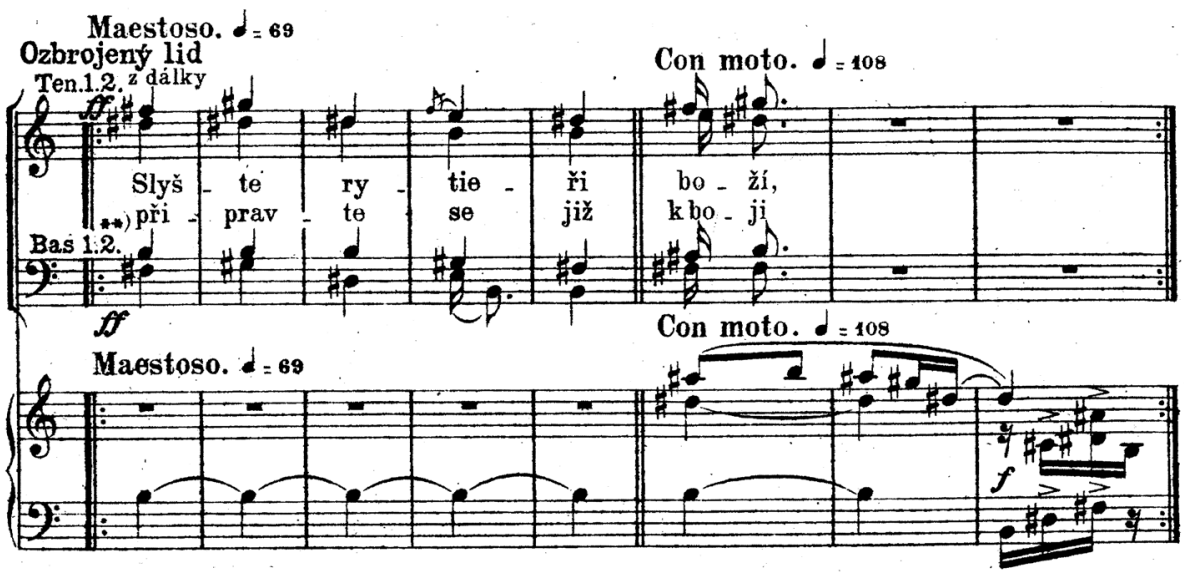

Example 2: Janáček: Výlety pánè Broučkovy: Výletpana Broučka do XV.století, Act I. (C) With kind permission by Universal Edition A.G., Wien. www.universaledition.com

This is not the only maestoso marking in the Fifteenth-Century Excursion. Soon after the beginning, a drunken Mr Brouček loses his way in the cellars of Vikárka pub and imagines that he has been transported back to the fifteenth century and into the jewel-chamber of King Václav [Wenceslas] IV. There is a maestoso marking (against grandiose music) when $\mathrm{Mr}$ Brouček manages to light a lamp and gets a glimmering of where he has ended up. Soon after, the author of the Brouček novels, Svatopluk Čech, is brought on stage to sing an invocation to the decisive day of battle ("Slunce velkého dne" [Sun of the great day]), once again marked maestoso.

A more ambiguous moment comes in Act 2 when Kunka, the daughter of Brouček's fifteenth-century host and protector Domšík, returns shattered from the battlefield. The mainly orchestral music is marked maestoso, which hardly seems to fit the initial despondent mood, but against this an ascending figure suggests a hopeful outcome to the battle, soon confirmed by a jaunty victory march and by another Hussite choral ("Dítky, $v$ hromadu se senděme") [Children, let's get together], again marked maestoso, sung by Kunka's lover Petřík and the chorus.

Janáček began composing his three-movement "rhapsody for orchestra" Taras Bulba, in 1915, in the early stages of the First World War in reaction to encouraging news from the front with early Russian victories 
against the Habsburgs (Janáček hoped at this point that the Russians would "liberate" their Slavonic brethren from the Habsburg yoke). Gogol's novella, the inspiration for Janáček's work, is a chapter in the history of how the Ukraine was gained for Russia from the Poles and Lithuanians. The chief character is the Ukrainian Cossack Taras Bulba, seen at the beginning taking his two young sons off to the fighting grounds to achieve their manhood. All three are killed.

As the Russians' war fortunes faded and the unlikelihood of getting a performance of a large-scale symphonic work seemed to have dawned on Janáček, he put the work aside until 1918. By then his own fortunes had changed with the huge success of his opera Jejípastorkyña [Jenůfa] in Prague as had the balance of forces in the war with the entry of the Americans.

The third movement of Janáček's work is entitled "Proroctví a smrt Tarase Bulby" [The prophecy and death of Taras Bulba]. The "prophecy" is Gogol's Russian chauvinist dream of the ultimate triumph of Russia and its Orthodox faith put into the mouth of Taras Bulba as he dies at the stake: "A tsar shall arise from Russian soil, and there shall not be a power in the world which shall not submit to him". In one of Janáček's commentaries on the work he wrote (adapting Gogol's own conclusion) that "such fires or tortures that could destroy the strength of the Russian people cannot be found on earth". By 1918, with the installation of a Bolshevik Government (which Janáček disapproved of), Janáček's Russophilia had somewhat abated. He deleted the word "Slavonic" from its original title ("Slav. rhapsodie" [Slavonic Rhapsody]) and transferred the triumphalism of the final movement to a more Czech-patriotic use with his later, though unofficial, dedication of the work to the Czechoslovak Armed Forces.

Janáček's music in the third movement includes an eight-bar maestoso section (bars 44-51) with a $p p$ melody marked dolcissimo on the violins answered by cor anglais and harp. As the work nears its end the overwhelmingly grandiose atmosphere is enhanced by two more brief maestoso passages (bars 123-8; bars 191-6). By the last of these the large orchestra has been swelled by addition of an organ.

Janáček's Ballad of Blaník, dedicated to the Czechoslovak President "the liberator T. G Masaryk", is a messianic work commemorating the same mountain that featured in Smetana's Má vlast. Maestoso markings appear early in the work. At bars 54-5 there is a two-bar motif played on horns and two harps (the harps reminiscent not only of those in Taras Bulba but also in Smetana's balladic maestoso harps in Vyšehrad). It is interrupted by a 
three-bar passage marked Vivo, and then resumes in the same texture with another short maestoso section. Although brief, the motif is important in the piece, to be brought back towards the end (bars 273-81), in a Meno section (though Janáček's autograph is marked maestoso at this point) which puts together the two previous maestoso sections without the Vivo interruption. Again the motif is played on two harps (though not horns, and with a fuller orchestral background). What is remarkable is that the motif is in fact the same as that found in Taras Bulba at bars 195-8, i.e. bars directly continuing from the third of the maestoso sections mentioned above. Although the purpose of the two symphonic works could not be more different, one a glorification of war, the other a plea of peace, both share similar maestoso apotheoses.

\section{Structural maestosos in Janáček, I: endings}

Though not particularly sympathetic towards Smetana, Janáček knew all the Smetana pieces described above and from the examples given it would appear that he took on board Smetana's distinctive uses of the term maestoso. He was, however, much more in tune with Smetana's younger contemporary, Antonín Dvořák. Dvořák's Seventh Symphony in D minor (1885), which Janáček conducted in Brno in 1886, has a first movement marked Allegro maestoso, the final movement concludes with a Molto maestoso. There is also a ten-bar "Eleventh-hour maestoso" in the final movement of Dvorák's Cello Concerto marked Andante maestoso before accelerating into a concluding Allegro vivo. Some of the pieces by Dvořák that Janáček knew particularly well were the four late symphonic poems based on poems by Karel Jaromír Erben: Vodník [The Water Goblin], Polednice [The Noonday Witch], Zlatý kolovrat [The Golden Spinning Wheel] and Holoubek [The Wild Dove]. Janáček published long analyses of them (JW XV/152, $\mathrm{XV} / 153, \mathrm{XV} / 154, \mathrm{XV} / 156)$ and even gave the first performance of the last one, The Wild Dove. Based on Bohemian folk-legend, the Erben symphonic poems have a patriotic cast to them and Dvoŕák used maestoso markings in all but one. There is, for instance, a Grandioso e maestoso section associated with the King in the Golden Spinning Wheel.

The really interesting one in this connection is The Noonday Witch, which has no association with kings or heroes. Apart from a one-bar stringendo, the final twenty bars are marked maestoso and constitute the dramatic end to the piece: a mother looking after a fractious child threatens it with the Noonday Witch. The father returns to find the mother in a faint 
with the dead child pressed to her bosom, its life taken by the Witch. The music here describes the horror of the parents as they realize what has happened - a depiction of supernatural horror.
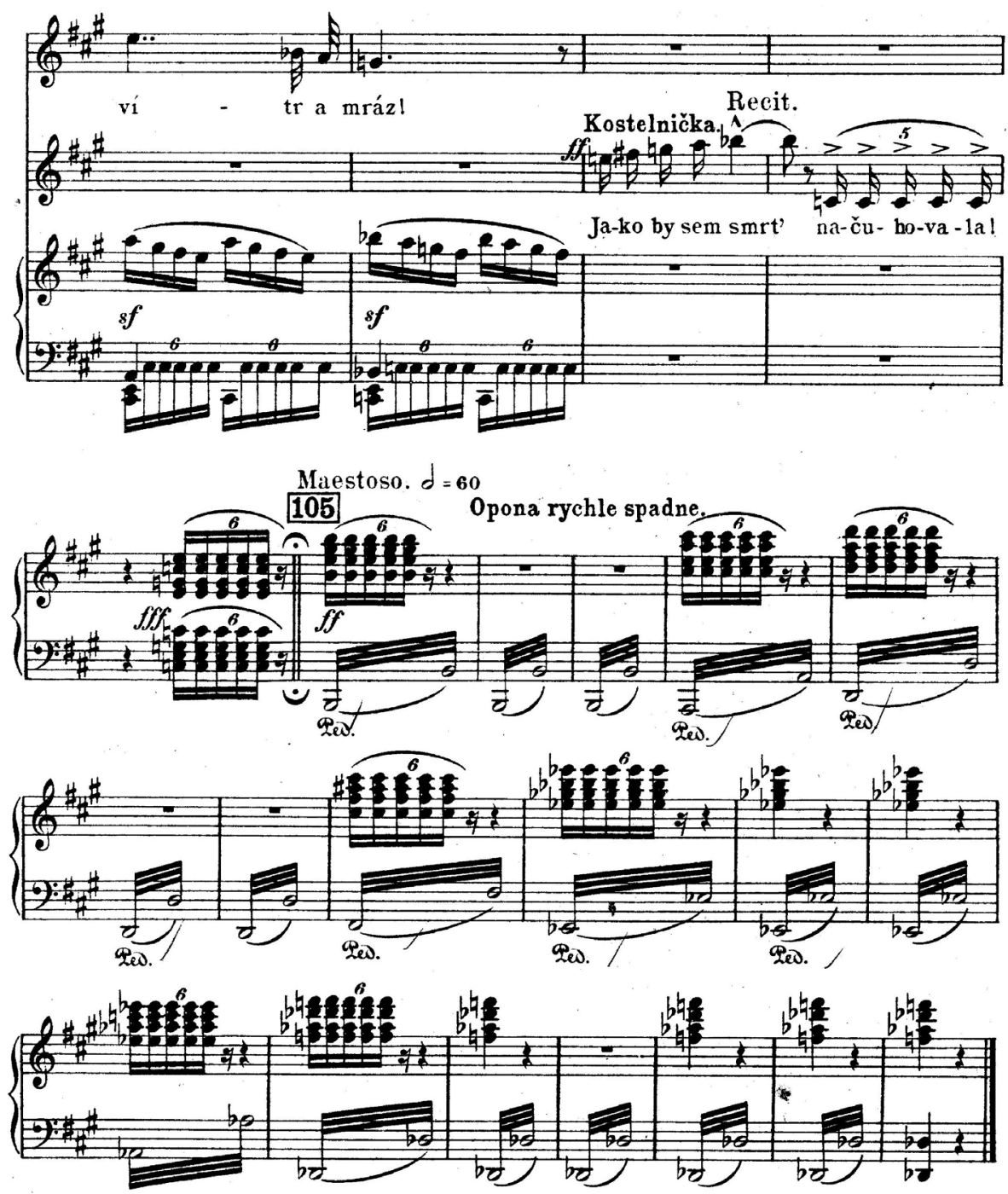

Example 3: Janáček: Jejípastorkyña (piano-vocal score published by Přátel uměnív Brně, 1908), Act 2. 
A few years after Dvořák composed his symphonic poem, Janáček embarked on the long journey of writing his third opera Jenúfa, finally completed in 1903 and staged in Brno in January 1904. Like the end of Dvořák's Noonday Witch, Act 2 concludes with a maestoso passage, invoking an almost supernatural frisson as the Kostelnička, who has returned from murdering her beloved stepdaughter's baby in the frozen river, begins to realize of the enormity of the crime she has committed and imagines death knocking at her door ("Jakoby sem smrt' načuhovala"). She utters these words in a dramatic, unaccompanied cry, the five syllables of her final word "na-čuho-va-la" echoed by the five chords in the orchestra which then launches the terror-filled orchestral maestoso based on this rhythm as the curtain falls (see ex. 3).

This type of concluding maestoso became a favourite in Janáček's operas for act endings, heightening the drama of what has just occurred on stage and bringing the act to a forceful conclusion. Examples can be found in:

Její pastorkyña [Jenůfa], opera (1903): end of Act 2; end of Act 3;

Osud [Fate], opera (1907): end of Act 2; end of Act 3

Šumařovo ditě [The Fiddler's Child], symphonic poem (1913): end;

Výlety pana Broučka: Výlet pana Broučka do XV. století [The Excursions of Mr Brouček: Excursion to the Fifteenth Century], opera (1917): end of Act 1;

Káta Kabanová, opera (1921): end of Act 1; end of Act 2; end of Act 3 ;

Př́hody lišky Bystroušky [The Cunning Little Vixen], opera (1923): end of Act 3;

Věc Makropulos [The Makropulos Affair], opera (1925): end of Act 2 ;

Sinfonietta (1926), end of movements I and V.

All of Janáček's operas from Jenůfa onwards include at least one maestoso act-ending (the Brouček example of course counts also as a heroic-patriotic maestoso). But Janáček did not confine the use to operas. Large-scale orchestral works such as his symphonic poem The Fiddler's Child conclude with a maestoso marking. His Sinfonietta has two because the Fanfare opening, where it first occurs, is recapitulated at the end of the work, now with the whole orchestra joining in the brass fanfares of the opening movement. 
These concluding maestosos can be further divided. The Act 2 Jenüfa can be categorized as melodramatic and exciting, but the orchestral conclusion to Act 3 of the opera (fig. 82), after the touching scene of forgiveness between Jenůfa and Laca, marked Maestoso con moto, is instead a type of redemptive, transcendental maestoso that can be found, for instance at the end of The Cunning Little Vixen. The six-bar maestoso orchestral conclusion to Fate Act 2 (Scene 5, bars 133-8) after Živný's discovery of the dead bodies of his wife Míla and her mother is clearly melodramatic. Makropulos Act 2 has a more substantial maestoso ending. It begins straight after Emilia Marty has demanded from Jaroslav Prus the envelope containing the formula for her father's elixir of life. A fortissimo orchestral unison, with a sforzando cymbal roll rings out, maestoso (bars 975-95). In its final bar Prus asks "A kdy?" [And when?], i.e. when would be their assignation in payment for the envelope. A softer, more relaxed Andante accompanies the pair's brief exchange, but Prus's final "Platí" [Agreed!] initiates the maestoso (bars 9921003), which brings the act to an end - another melodramatic act-ending.

All three acts of Káta Kabanová end in maestoso. The nine-bar orchestral conclusion to Act 1 (fig. 33), with Tichon's departure despite Káta's pleas for him stay (she rightly fears that her feelings for Boris will lead to disaster) is another, melodramatic maestoso, as is the seven-bar orchestral maestoso conclusion to Act 3. Here after Káta's suicide and her mother-in-law's triumph over the corpse Janáček combines the prominent themes of the voices of the Volga (calling Káta to her death) with the eight-note timpani theme (portending fateful events) heard in the early bars of the overture. By contrast, the conclusion to Act 2, as Káta slowly departs after her meeting with Boris, belongs to the transcendental type. Radiant fortissimo E-major chords (an unusual key for Janáček) highlight what has surely been the happiest moment of Káta's adult life. After the initial outburst, the chords slowly move down from their initial height and a double bass and then cello solo lead into the end of the act where the maestoso gives way to five bars of cadential Adagio.

It is not easy to characterize the maestoso at the end of The Fiddler's Child. If the composer is adhering at all to the story of Svatopluk Čech's poem that gives Janáček's symphonic poem its name, this is the point after the Mayor (the villain of the piece) has discovered the corpse of the fiddler's child: a melodramatic situation. But the long maestoso that follows (bars 438-84), after its initial fortissimo chords, soon subsides, producing a subdued ending that suggests pathos rather than transcendence. The same 
however cannot be said for the exuberant, apotheotic, maestoso ending of the Sinfonietta, a thrilling medley of trilling woodwind and strings over the brass fanfares of the first movement. Like the Káta Act 2 example, it does not end maestoso: seven bars of Adagio are devoted to a prolonged cadence.

Apart from the few words in Makropulos Act 2 and the Hussite chorale of Brouček's Excursion to the Fifteenth Century, Act 1 all of Janáček's maestoso act-endings in his operas are purely orchestral.

\section{Structural maestosos in Janáček, II:}

\section{Eleventh-hour maestosos}

Like Smetana and Dvořák before him Janáček also made use of "eleventh-hour maestoso". These present a rather more varied use and occur not only in operas, but in choral-orchestral and even chamber works:

String Quartet no. 1 (1923), IV: maestoso before the final Più mosso; The Makropulos Affair (1925): maestoso interlude before Marty's farewell in Act 3 (effectively the end of the opera);

Mša glagolskaja [Glagolitic Mass] (1926): maestoso episodes before the end of movements III and IV

Capriccio for piano left hand and wind ensemble (1926), IV: piano cadenza marked maestoso towards end of the movement

Although the grand associations of maestoso means that the term is seldom found in chamber works, Janáček made a few exceptions. The sixbar maestoso in the last movement of his First String Quartet (at bar 121) resembles the classic "eleventh-hour maestoso" in that it gives way to a Più mosso that brings the work to a close, heightened towards the end with a Più mosso (feroce). However the Maestoso Tempo I is less an interruption of the preceding Adagio than itself an intensification of it.

Janáček's Capriccio for piano left hand, flute/piccolo, two trumpets, two tenor tubas and three trombones has what is virtually a piano cadenza before the end of the work. At bar 134, thirty bars before the cadenza, there is a section, at first confined to the brass, marked maestoso-vivo (a most unusual combination). The brass bars highlight a theme, previously merely subsidiary, on which the rest of this section is based. Tempos are fast or moderate until a sudden Adagio at bar 163, two bars before the cadenza. Together the Adagio and the grander, two-bar beginning of the cadenza (marked maestoso) constitute a brief holding back of the tempo before 
plunging into Prestissimo for solo piano. After twenty bars the flute joins in, followed by the rest of the ensemble as the piece moves towards its close. Apart from the Grave for the final twelve bars this gives the impression of a rather more elaborate "eleventh-hour maestoso".

Towards the end of The Makropulos Affair, Emilia Marty tells her mysterious story as, among her hearers, disbelief turns slowly to grudging acceptance. She collapses, a doctor is called, and she is taken into the bedroom of her hotel suite. Fast and furious orchestral music, high and full of trills, gives way after eighteen bars to a passage marked maestoso (at bar 810). At first there are slow and solemn brass chords; then a theme, at first on a solo violin, transfers to the viola d'amore (an instrument which Janáček used occasionally to convey especial tenderness) and then, after the viola d'amore has ascended to the top of its range, a full forte orchestral version takes over, again marked maestoso (though no other instruction has intervened). An Adagio follows with the reappearance of Marty, described in the stage direction as "jako stín" [as a shadow], "a pale green light overflowing the stage and auditorium" contributing to the other-worldly atmosphere. This is the beginning of the finale in which Marty comes to terms with her mortality and accepts death.

With great clarity this passage depicts a change of state. Something is going on that transforms Emilia Marty from the bossy, confident figure we have seen so far, determined to get the formula to give her another three hundred years of life, into someone quietly reconciled to death. The long orchestral maestoso before the final scene is a structural marker, a development of the "eleventh-hour maestoso", but this wonderful section is also an example of what one might call a "redemptive maestoso".

There are more uses of maestoso as a near-end structural marker in two movements of Janáček's Glagolitic Mass In the third movement, “Slava" [Sanctus], a long passage starting "Sědej o desnuju otca" [Sitting at the right hand of the father] (bar 139) marked maestoso is dominated by the tenor solo (with increasing support from the chorus) though when the chorus takes over completely the pace increases to a Un poco mosso moving through Allegro with the return of the solo tenor, then Presto and finally a purely orchestral Allegro of nine bars to close the piece.

In the next movement, the "Veruju" [Creed] a long orchestral section describes Christ's suffering on the cross. The chorus comments briefly "raspect že zany, mučen i pogreben byst" [He was crucified also for us, he suffered and was buried] after which a five-bar maestoso (bar 244-8) on full orchestra including the organ, fortissimo, gives way a new Andante 
section, set vocally for chorus. This is more a marker for the central point in the narrative than an "eleventh-hour maestoso". However another maestoso occurs a little later that fulfils this function. The chorus repeats the hushed "Věruju" opening, which is followed by a five-bar orchestral maestoso, fortissimo (bars 336-40), the chorus overlaps in the first bar) heralding what is in effect the finale of the movement. After a pause bar the orchestra continues with a new swirling accompaniment against the tenor's words "Katoličesku i Apostolsku Crkov" [(I believe) in the Catholic and Apostolic Church]. A Un poco più mosso follows and drives to the movement to its end. The scale of this example and the Makropulos finale is of course very different from that in the final movement of Beethoven's Ninth Symphony, which is no more than an extended ritenuto. But the function is the same: a distinctive holding back before a section brings the movement or the act to a climactic end.

\section{Highlighting important words}

Most of the examples encountered so far in Janáček's operas have been purely orchestral. However, in a few cases in Janáček's operas words crucial to the plot are highlighted either by having them sung against a maestoso passage, or by placing a maestoso passage immediately afterwards. Thus in the final pages of Act 1 of Janáček's first opera, Šárka there is a three-bar section (fig. 30) marked Poco lento (Maestoso). Two orchestral bars announce a variant of the theme which will, at fig. 31, constitute the Adagio finale of the act, the first of Janáček's “slow cathartic waltzes". In the third bar of this marked Poco lento (Maestoso) the orchestra pauses for the temporarily defeated Šárka to declare "příšerně" [viciously] "Krví tvou záští ukojím” [I"ll assuage my anger with your blood!], a sentiment that will spur on her actions in the next act, culminating in the death of her male rival, Ctirad,

At the end of the first act of Fate Míla elopes with her lover Živný. The reaction to this by Míla's mother is decisive. In Act 2, Živný and Míla and their little son are living together. But with them is Míla's mother, whose horror at their out-of-wedlock liaison has driven her mad: her actions at the end of the act lead to her and her daughter's death. When in Act 1 Míla's mother hears of the elopement she cries out "To ne! To snad ne! S panem Živným!” [No! Surely not! With Mr Živný!] to which the orchestra reacts with a six-bar maestoso, fortissimo (Scene 15, bars 22-7).

In Káta Kabanová, Act 3 Scene 1 Dikoj, having heard what he regarded as a flippant answer to his question of what a storm is ("just electricity”), 
gives his own portentous explanation: "Bouře je za trest na nás abychom moc boží potitovali" [Storms are our punishment so that we feel the might of the Lord] (7 bars after fig. 5). His words are given out "přesvědčivě" [persuasively] in a maestoso passage of four bars against the theme (heard later in the act) of the voices that call Káta to her death. The storm depicted in this scene unnerves Káta to make her public declaration of adultery and, in the next scene, to seek her death.

In the final scene of the opera, Káta wanders alone, contemplating her fate and wanting death. She longs to see Boris and then, in what up to now has been a mainly soft soliloquy, she calls out, forte, "Vy větry bujné! Doneste mu žálostný můj stesk!" [Abundant winds, carry my sad longing to him!]. The four-bar passage (4 bars before fig. 27), is marked maestoso, and Káta's memorable tune is emphasized by the orchestra playing it in unison with her. Not long after, her wish is granted: Boris appears for a brief farewell scene before she throws herself into the Volga.

Finally, in The Makropulos Affair, in the middle of Marty's long story about her strange life she comes to describe how the Emperor Ferdinand, who has demanded her father make up an elixir of life for him, now insists that it be tried first on the young Elina Makropulos. Emilia's last word "zkusil" [tried] overlaps into an orchestral maestoso of five bars (bars 71115), at first a purely orchestral reaction, and then while the orchestra pauses on a single chord (as in the Šárka example above), she sings: "Pak jsem byla týden či jak dlouho bez sebe a uzdravila" [Then I was unconscious for a week or so, and got better], after which she resumes her narrative, the tempo now marked Moderato. The maestoso here underlines the fact that it was the young Elina Makropulos (now Emilia Marty) who, rather than the Emperor, was given the magic formula which has prolonged her life by three hundred years, the underlying basis for the plot of the opera.

\section{Marking important moments}

All the maestoso underlining of important words described above are short passages. But Janáček also used longer sections of maestoso to draw attention to important moment in a work. In Fate there is a long, purely orchestral passage (Scene 2, bars 143-200) marked maestoso. It comes early in Act 1 and therefore has none of the functions of the structural maestosos described above. However the length is striking and this long orchestral passage helps to highlight an important moment in the opera when Míla has caught sight of her former lover Živný, from whom she has involuntarily 
parted (the rest of Act 1 will see their reconciliation and finally elopement). The drama of the situation is furthermore heightened by the last eight bars (the maestoso marking is repeated) in which the texture thins down to tremolo violins, playing a triple forte version of the theme on which the maestoso passage before was based. Voices are heard only in the final two bars, after which normal conversation between the group (Míla and Živný and two others) resumes, the tempo now changed to moderato.

Janáček used the maestoso indication three times at the end of Act 3 of Fate. In response to the students' invitation to describe the opera to be given that evening Živný begins a long narration which, as he explains the plot, also reveals his personal involvement - it is in fact his story, and by the first maestoso (at Scene 3, bar 47) his utterances have become incoherently passionate and visionary, the transcendental mood emphasized by the widespaced orchestral accompaniment to his words. The students to whom this is addressed register their horror but Živný continues (Scene 4 with the maestoso seemingly continuing) describing the vision of his dead wife until he collapses in a faint, a total of thirty-four bars. A second maestoso comes a little later (Scene 4, bar 53) as the anxious students try and calm Živný, who attempts to echo the notes that he hears his dead wife singing. But when the student Verva suggests that this is from the missing last act of the opera Živný sits up and declares robustly "To jest v rukou božích a zůstane tam!" [That is in the hands of God and will stay there!]. These words are sung unaccompanied and maestoso. Then follows eleven bars of purely orchestral music that concludes the opera in high drama.

While the final maestoso in Fate can be regarded as a Structural I maestoso the other uses in this act help to underline the visionary, transcendental state that takes over Živný in his increasingly personal description of the opera.

This use of maestoso to create a strange, otherworldly atmosphere can be found outside Janáček's operas. In the second movement (bar 131) of his Sinfonietta the previously brisk tempo is halted by a strange maestoso with held wind chords, high violin and viola figuration pierced by Janáček's trumpets and then trombones in one of Janáček's more unusual time signatures (13/8). The uneven metre, and wide-spread orchestration combined with the maestoso marking contributes to a feeling of time standing still. It gives way to a Più mosso until arrested again by another maestoso with similar effects (though varied means). This strange maestoso section con- 
stitutes a central moment of timelessness in contrast to the otherwise busy outer sections of the movement.

Janáček used the same device in the fifth movement of the same work (bar 100) when the impetuous Più mosso, which has been driving the movement towards a climax, is suddenly interrupted by a six-bar maestoso. Again he used a wide-spread texture: growly thick trombones at the bottom, high tremolo violins at the top against which a very high flute wanders down, alternating and then combining with an E flat clarinet until swept away by a return to the previous Più mosso as the music heads towards an exciting climax with the return of the fanfares and its maestoso climax.

[71-72] Ty vlnky mé zlaté Kamily.

$5 / 1 / 1 / 1028$

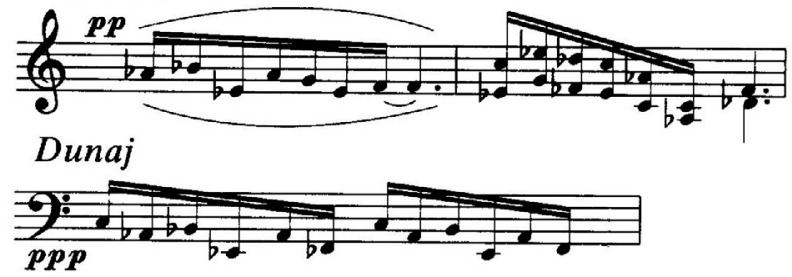

vlnka lká:
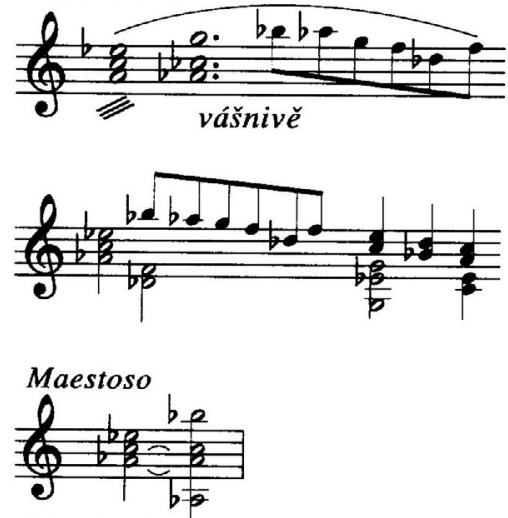

Ta slast!

Example 4: Janáček: Památnik pro Kamilu Stösslovou, ed. and transcribed by Jarmila Procházková (Brno: Moravské zemské muzeum,1994).

One of Janáček's more puzzling maestoso markings comes in the second movement of his Second String Quartet "Listy důvěrné" [Intimate Letters] at bar 6o. Here a theme already heard fortissimo four bars earlier is 
played again and elaborated for eight bars marked maestoso in espressione, a slowed-down intensification of the music before a Vivace continuation. Some clue as to what this meant for Janáček can perhaps be provided by a tiny fragment jotted down in the Památník pro Kamilu Stösslovou [Album for Kamila Stösslová], dated 5 August 1928, a week before he died and a few months after completing the Second String Quartet. Here, having written out themes to represent "Ty vlnky mé zlaté Kamily" [The waves (i.e. breasts) of my dear Kamila], and others to show the waves crying "passionately" ("vlnká lká"; "vášnivě") he writes two chords (the second very spread out), marked maestoso with the comment "Ta slast!" [That bliss!] (see ex. 4).

Janáček's maestoso passages in the years up to his last opera, From the House of the Dead, have a number of shared characteristics. They are mostly loud and slow, generally providing a contrast in speed to what comes before and (unless they end a piece) after. While some more extensive examples can be found, most are short sections. Apart from a few instances where Janáček used maestoso to highlight important words of moments in operas, Janáček limited his uses of maestoso to purely orchestral (or instrumental) music. Generally the marking is always appropriate to the solemn or majestic or occasionally otherworldly mood. Their uses can be categorized as follows:

a. Heroic/patriotic nationalism;

b. Structural (I): conclusion of act or movement;

c. Structural (II): dramatic stopping-point towards the end of a piece, followed by a precipitate close (= "11th-hour Maestoso")'

d. For highlighting important words;

e. For marking important moments;

f. To suggest a transcendental, visionary quality.

\section{Maestoso in From the House of the Dead}

The oddity of the way in which Janáček used maestoso in From the House of the Dead becomes clear when his usage there is compared to that in the three proceeding operas.

Káta Kabanová (1921): 5 occurrences: 
3 structural (ends of Act 1, Act 2 and Act 3);

2 key words, all Act 3: Dikoj declares that storms are a punishment from God to show his might; Káta calls out to Boris before their final meeting.

The Cunning Little Vixen comment. (1924): 1 occurrence:

1 structural (end of Act 3).

The Makropulos Affair (1926) 4 occurrences:

2 structural (end of Act 2, end of Act 3);

1 suggesting a transcendental change of state for Emilia to emerge "like a shadow", Act 3;

1 for important words, Act 3: Marty describes how they tried out the formula years on her and thus gave her a three-hundred-year life span.

In From the House of the Dead Janáček used maestoso in the following places:

A: Overture, bars 141-2

B: Act 1, bars 154-64: Arrival of Petrovič at the prison camp (orchestra only): includes motto theme;

C: Act 1, bars 327-8: Prisoners tell Nikita to release the eagle;

D: Act 1, bars 607-12: Prisoners dismiss the crazy Skuratov as a "useless fellow"; includes motto theme;

E: Act 3, bars 35-8: Prelude: end; this music recurs at end of the opera to words about freedom and the release of the eagle;

F, G, H: Act 3, bars 602-9, 759-72, 826-37): three important moments in Šškov's story about Akulka; $\mathrm{H}$ includes the motto theme.

The two-bar maestoso in the overture has all the hallmarks of an "eleventh-hour maestoso". It occurs towards the end after a long Allegro passage and is immediately swept aside by a Presto and then Allegro, which drives the music towards its climactic end.

As the summary above show, five of the uses of maestoso include sung words (C, D, F, G, H). To deal with these first, example $C$ has just three words, but these are key words to the opera. Janáček made a clear link between the eagle with a broken wing kept by the prisoners and Alexandr Petrovič Gorjančikov, whose arrival soon after the beginning of the opera 
and his departure at the end of opera constitutes the chief narrative thread of the piece. When Petrovic has been taken off to be beaten (we hear his cries of pain offstage), the prisoners bring out the eagle. They tell his keeper, Nikita, to release him - just two bars marked "Maestoso". But the eagle's wing is still broken and he is unable to fly. "Orel, car lesư" [Eagle, tsar of the forests!] the prisoners sing ironically. These are important words that are heard later in the opera.

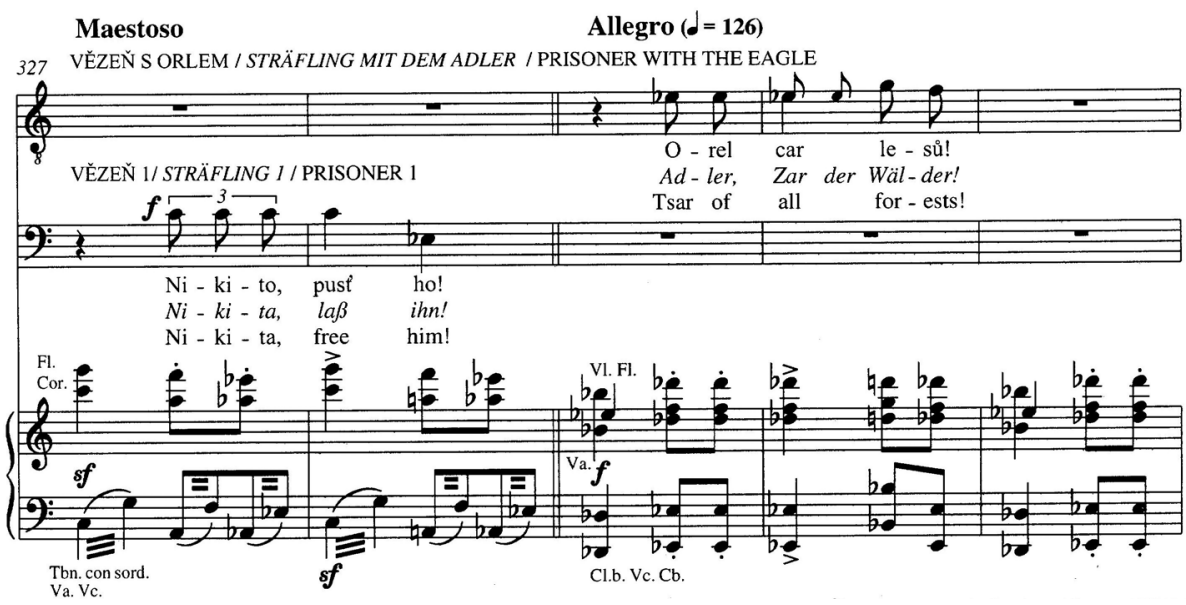

Example 5: Janáček: From the House of the Dead, Act I. (C) With kind permission by Universal Edition A.G., Wien. www.universaledition.com

The third act is dominated by the longest narrative in the opera, Šiškov's harrowing tale of how he married and murdered Akulka. He was persuaded to marry Akulka after his friend Filka Morozov has told all the village that he has slept with her and thus disgraced her. She is now considered damaged goods and the good-for-nothing Šiškov is encouraged to take her on. But, after the marriage when the couple have been left alone, he discovers that she is in fact a virgin - "Čistá, nevinná! Čestná z čestného rodu" [Pure, innocent! An honourable woman from an honourable family] he declares in a passage marked maestoso (from bar 602), Akulka's purity matched by the purity of the harmony and the dolcissimo marking.

Later in the same narrative Šiškov describes how Filka Morozov goes off to the army in place of a conscripted recruit. As Filka passes by Akulka's house he sees her. He jumps down from the cart and, bowing low before her, tells her that he has loved her for three years. The moment when 
he asks her forgiveness for maligning her is when the second of the three maestoso passages occurs. Although Šiškov is a baritone, normally notated in the bass clef Janáček notates Filka's reported words as if sung by a tenor.
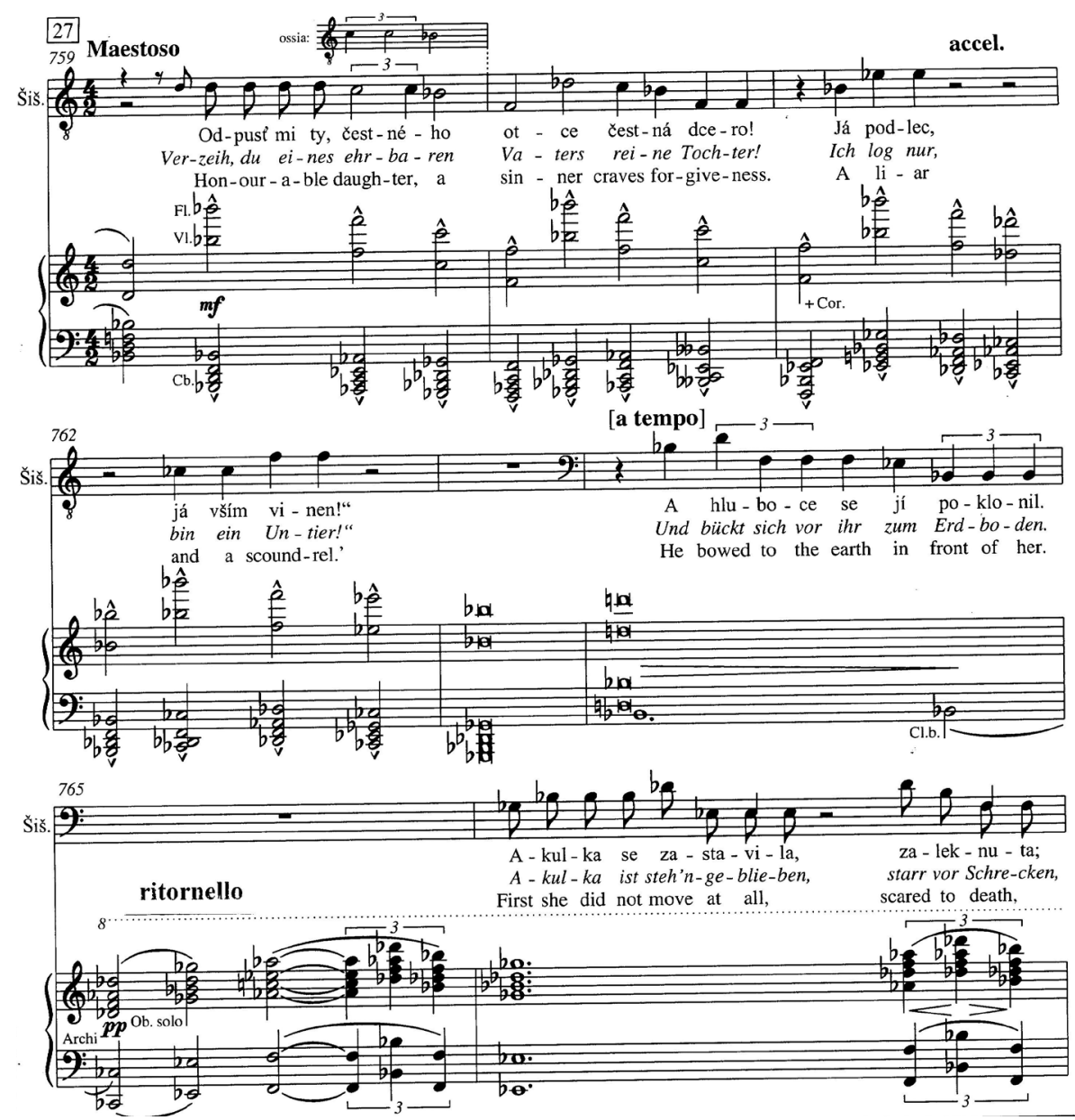

Example 6: Janáček: From the House of the Dead, Act 3. (C) With kind permission by Universal Edition A.G., Wien. www.universaledition.com

The use of maestoso comes with the words "Odpust" [Forgive me], recalling a similar maestoso moment at the end of Janáček's opera Jeni̊fa. The music is intensified by recalling the healing ritornello that runs through this monologue, associated with Akulka. These two examples have some- 
thing of the redemptive quality heard in examples above from Jenúfa and Makropulos.

What upsets Šiškov most is that Akulka (now his wife) readily forgives Filka. Her action seals her fate. In a two-bar maestoso passage he tells Akul$\mathrm{ka}$ that her end is come. What is striking about this final example is that Šškov's words are sung against the short and striking motif often known as the "motto theme" that dominates Act 1. This is the only instance where the maestoso in Janáček's autograph manuscript differs from that in the authorized copy. The latter has it in the position shown in the example; Janáček originally had it, less logically, two bars later.
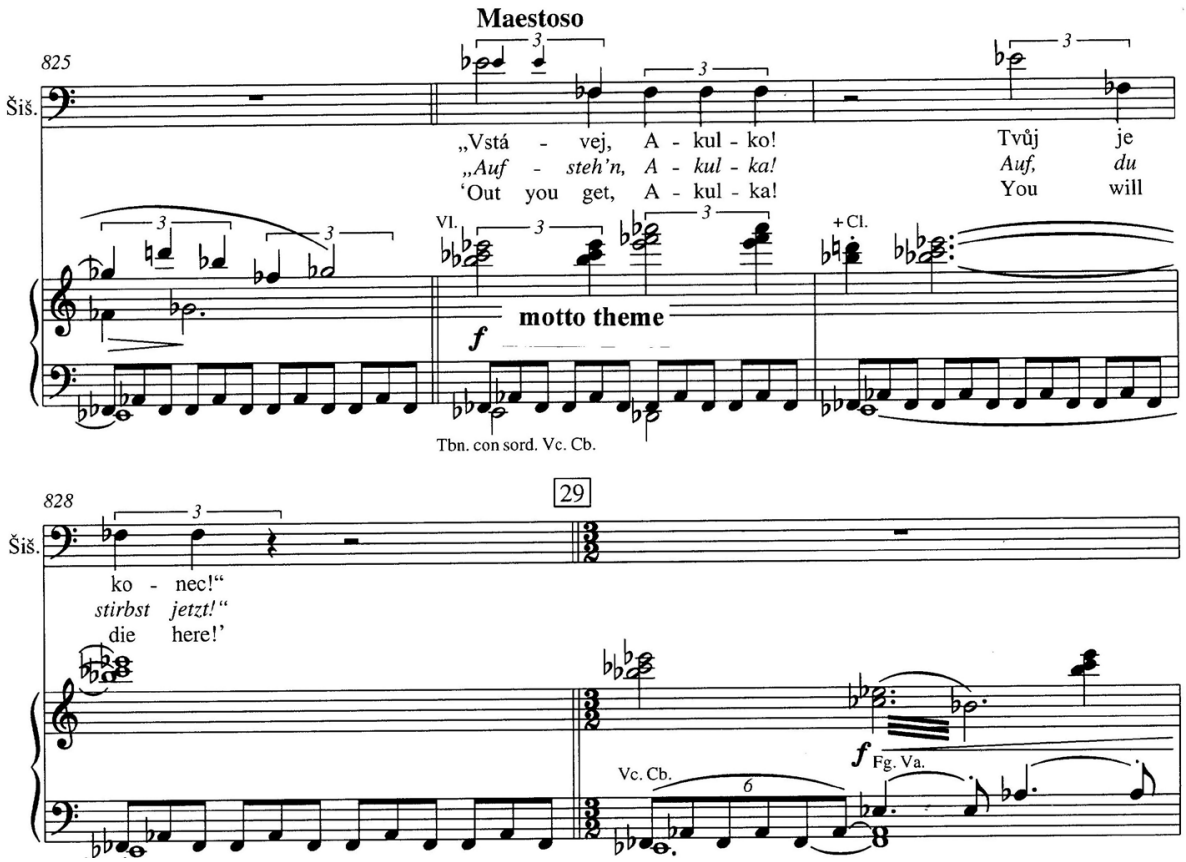

Example 7: Janáček: From the House of the Dead, Act 3. (C) With kind permission by Universal Edition A.G., Wien. www.universaledition.com

Soon after the beginning of the opera the prisoners in a Siberian prison camp await the arrival of the new prisoner, Alexander Petrovič Gorjančikov. This first maestoso in the act begins with the motto theme. There follows a very high, violin solo, set against low accompaniment, which seems to sug- 
gest the fear and loneliness of the man as he sees the prison for the first time.
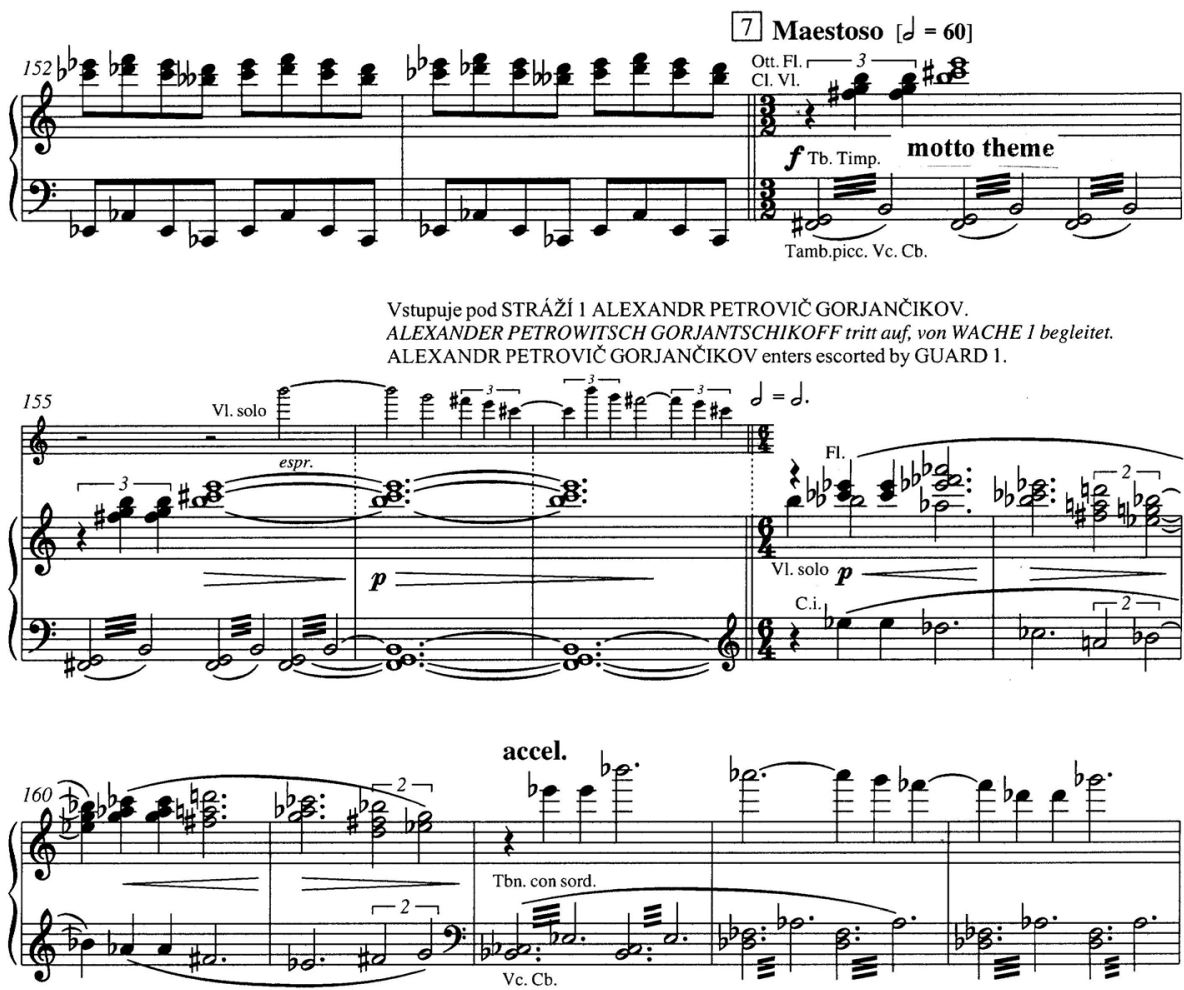

Example 8: Janáček: From the House of the Dead, Act I. (C) With kind permission by Universal Edition A.G., Wien. www.universaledition.com

Later in the act, one of the prisoners Skuratov, has gone almost mad in the prison. He does a wild dance and then collapses in exhaustion. Over repeated chords from the motto theme the rest of the prisoners comment saying that he is a useless imbecile. And, puzzlingly, this passage is marked maestoso (see ex. 10).

There are no occurrences of maestoso in Act 2, which is by far the most light-hearted act of the opera. But at the end of the short prelude to Act 3 there are three bars marked maestoso before the curtain goes up. They present a musical theme that is heard towards the end of the opera, associated with freedom. 


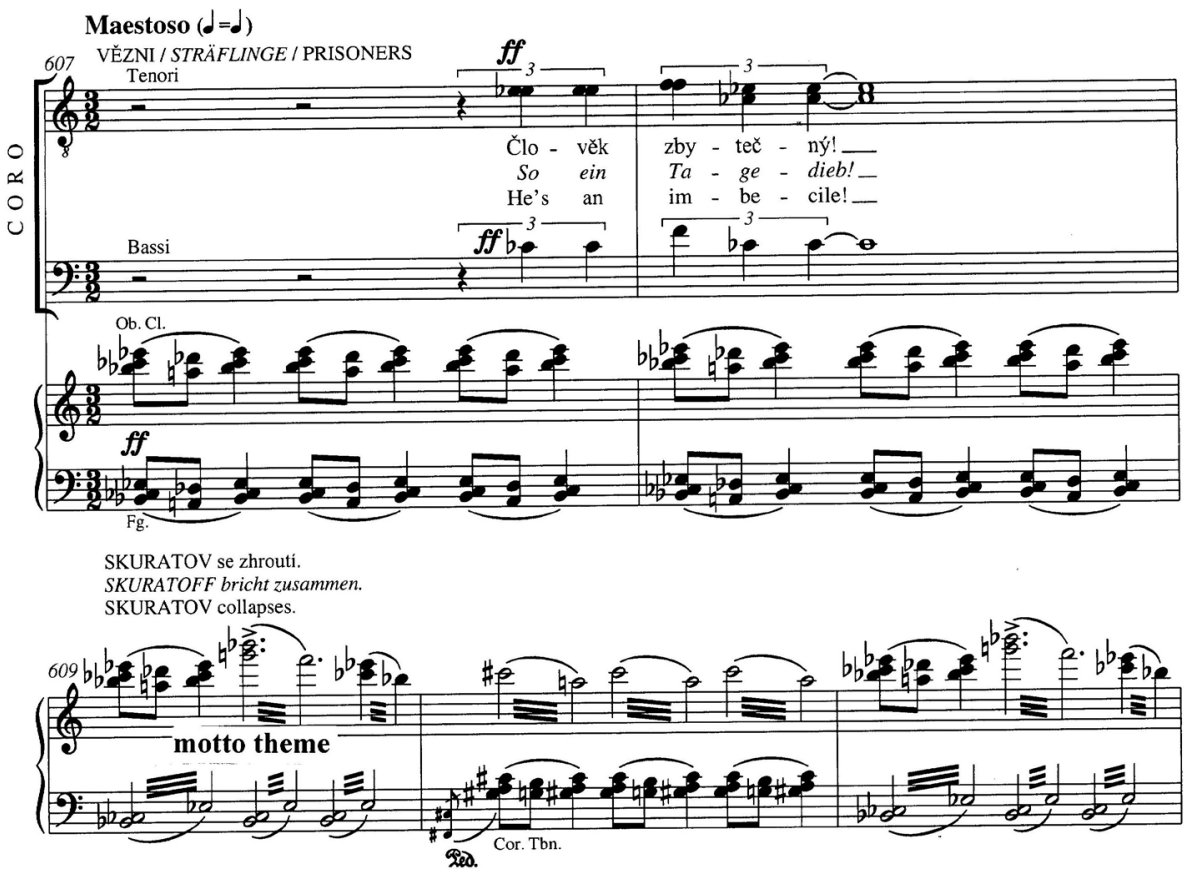

Example 9: Janáček: From the House of the Dead, Act r. (C) With kind permission by Universal Edition A.G., Wien. www.universaledition.com

At the end of the opera Petrovič is released from prison. He looks forward to his new life ("Nový život") and at the same time the other prisoners celebrate his freedom by letting the eagle out of the cage, its wing now healed. "Pust' ho Nikito!" they sing - repeating the words from Act 1 - and this time the eagle can fly and does fly. "Zlatá svoboda!" [Dear freedom] Petrovič sings to a repeat of the theme heard at the end of the Prelude. One might have expected this to be marked maestoso - but it is not.

As is evident there are more occurrences of maestoso here than in all of the previous three operas combined (eight compared with ten) and five of these $(\mathrm{C}, \mathrm{D}, \mathrm{F}, \mathrm{G}, \mathrm{H})$ include words, compared with three in the previous three operas. Only one of the House of the Dead examples is structural (the main use in the previous three opera). Three of the occurrences (B, D, $\mathrm{H})$ include one of the main musical themes of the opera, the motto theme. This theme opens Act 1 and recurs generally in association with painful events, for instance at the arrival of Petrovič in the prison camp and later during his brutal beating by the prison guards. It is heard when Skuratov 
has collapsed with exhaustion and is mocked by the other prisoners. And it is heard at the end of Šiškov's story when he tells Akulka that is about to kill her, both these passages ( $\mathrm{D}$ and $\mathrm{H}$ ) are marked maestoso.
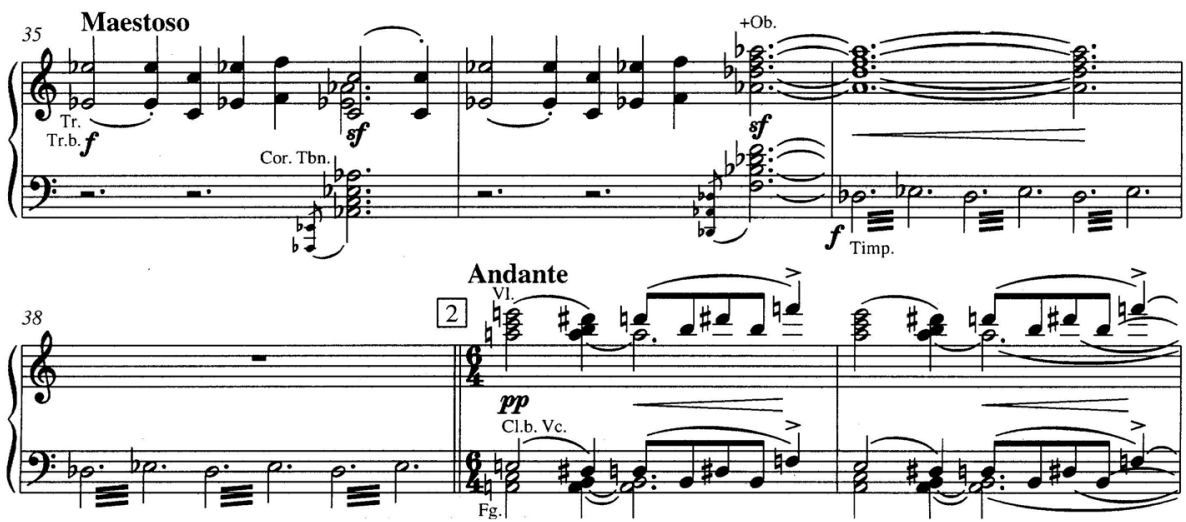

Example Io: Janáček: From the House of the Dead, Act 3. (C) With kind permission by Universal Edition A.G., Wien. www.universaledition.com

Most of the maestoso passages in From the House of the Dead are heard - unusually for Janáček - in sung passages and the words that are sung here perhaps provide a clue to Janáček's thinking. We have already noted two painful uses - with Skuratov and with the killing of Akulka. But equally there are others with positive associations. For instance when the prisoners tell Nikita to release the eagle, and the two moments of great tenderness and compassion, in Šiškov's story about Akulka.

Bearing in mind the original meaning of the term maestoso - majestically - and the earlier Czech preoccupation with its regal and heroic aspects, Janáček's use of the term in a prison setting and with common criminals, seems out of place. But we need to put these associations within the context of one more clue about Janáček's intentions in this opera. At the beginning of the score he wrote these words "V každém tvoru jiskra boži”" [In every creature a spark of God].

This thought is emphasized in the some lines found on Janáček after his death. In what seems to be notes for an article on the opera, he wrote:

Why do I go into the dark, frozen cells of criminals with the poet of Crime and Punishment? Into the minds of criminals and there 
I find a spark of God. You will not wipe away the crimes from their brow, but equally you will not extinguish the spark of God.

In From the House of the Dead the direction maestoso seems not so much an indication of how to play the music as a label to bestow dignity on his characters, to see in them this "spark of God". In this opera with a cast of criminals the indication that originally denoted and dignified Czech heroes is now used perhaps to suggest that even the dregs of society, the murderers that have been incarcerated in Siberian prisons, still retain their humanity. Janáček depicts their world and the terrible deeds they have done unflinchingly but also with huge compassion. And in what would be his final opera - almost his final work - he tries to find some sort of peace for them - forgiveness and a promise of freedom.

\section{Bibliography}

Koch, Heinrich Christoph. Musikalisches Lexikon, welches die theoretische und praktische Tonkunst, encylopädisch bearbeitet, alle alten und neuen Kunstwörter erklärt, und die alten und neuen Instrumente beschrieben, enthält. Frankfurt am Main: A. Hermann, 1802.

Simeone, Nigel, Tyrrell, John and Němcová, Alena. Janáček's Works: A Catalogue of the Music and Writings of Leoš Janáček. Oxford: Clarendon Press, 1997.

Tyrrell, John. "The Cathartic Slow Waltz and Other Finale Conventions in Janáček's Operas." In Essays on Drama and Music in Honour of Winton Dean, ed. Nigel Fortune. Cambridge University Press, 1987, 333-352.

Tyrrell, John. Janáček: Years of a Life, i: The Lonely Blackbird. London: Faber and Faber, 2006; ii: Tsar of the Forests. London: Faber and Faber, 2007.

Walther, Johann Gottfried. Musicalisches Lexicon, oder, Musicalisches Bibliothec. Leipzig: W. Deer, 1732. 



\title{
Heilige Nüchternheit.
}

Der Komponist in der Moderne.

Kontinuität statt Bruch

\author{
Helmut Loos \\ Univerza v Leipzigu \\ University of Leipzig
}

Die Apotheose des Künstlers hatte in der Zeit vor dem Ersten Weltkrieg unbestritten Hochkonjunktur. Eine Flut von esoterischen Bewegungen schrieb der Musik magische Kräfte zu und erhob ihre Vertreter zu höheren Wesen von göttlichem Rang. Der Komponist als Creator ex nihilo und der Dirigent als souveräner Beherrscher des Orchesterkollektivs bildeten Leitfiguren der Gesellschaft, die sie idealisierend herbeisehnte und willenlos anzubeten bereit war. Richard Strauss bot dem Publikum beides und verherrlichte neben anderen überragenden Ausnahmepersönlichkeiten vor allem den Komponisten als Held in seinen Sinfonischen Dichtungen und Opern. An Richard Wagner, Vorbild für die meisten Künstler des 2o. Jahrhunderts, schloss er 1894 mit seiner ersten Oper Guntram an. Die Titelfigur setzt sich als Kämpfer einer wohltätigen Ritterschaft für die gepeinigten armen Leute ein („das bedrängte Volk“). Gleichzeitig erweist er sich als hervorragender Sänger, ein im 19. Jahrhundert besonders beliebtes mittelalterliches Ideal, das dem romantischen Künstlerkult als willkommene Vorlage diente. (In der Ballade für Chor, Soli und Orchester Taillefer op. 52 von 1902 preist Strauss nach Ludwig Uhland den besten Kämpfer und Sänger des Normannenherzogs Wilhelms des Eroberers.) Als unwiderstehliches Mannsbild hält Guntram die Herzogin vom Selbstmord zurück, die ihm in Liebe verfällt. Als er mit seiner Kunst den tyrannischen Herzog zu befrieden sucht (Musik als versöhnende Macht), muss er dessen Angriff parieren und tötet ihn. Von der Schuld des Tyrannenmords befreit er sich - 
darin ganz ein treuer Nietzsche-Anhänger - in trotziger Selbstbehauptung der Welt entsagend ohne eine äußere entsühnende Instanz.

Stärker als sein erfolgreicherer Gegenspieler Strauss hat Hans Pfitzner seine Künstleroper religiös überhöht, indem er Giovanni Pierluigi da Palestrina zur Titelfigur erhob.

Zwanzig Jahre nach dem Guntram entstanden (UA 1917), schildert seine "Musikalische Legende“ keine aktive Heldengeschichte, sondern das intellektuelle Leben eines Künstlers, das im Schopenhauerschen Sinne schuld-

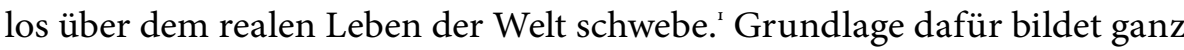
deutlich das Zwei-Welten-Modell der romantischen Musikanschauung. Dass Pfitzner trotz seiner Verwendung von Leitmotiven, die er Werken Palestrinas entnommen hat, zu einer ganz anderen, eigenständigen Musiksprache gefunden hat als der Wagner verhaftete Komponist des Guntram, muss hier nicht weiter ausgeführt werden. Beide Opern, Guntram und $\mathrm{Pa}$ lestrina, verkörpern vielmehr gewissermaßen zwei gegensätzliche Spielarten derselben romantischen Künstlerapotheose. (Sie äußert sich vor allem auch in der männlichen Attraktivität der Titelhelden, selbst bei Pfitzners Asexualität Schopenhauerscher Provenienz wird das Bild der verstorbenen Gemahlin Lukrezia als „eine schöne Frau in mittleren Jahren“ beschrieben, die seine Inspiration war.)

Die antiromantische Bewegung, die sich im frühen 20. Jahrhundert formierte, suchte eine neue Ästhetik der Tonkunst zu entwerfen. Ferruccio Busonis entsprechende Schrift von 1907 konterte Pfitzner 1917 mit seiner Futuristengefahr, zwei markante Beiträge zu einer breit geführten öffentlichen Kontroverse, zu der auch Felix Draesekes Konfusion in der Musik von 1906 Anlass gegeben hatte. Umso wichtiger ist es, die Gemeinsamkeiten herauszuarbeiten, die die Kontrahenden miteinander verbunden haben. Sie bestehen nicht nur in der Vorstellung von der Weltherrschaft oder Hegemonie der deutschen Musik, ${ }^{2}$ sondern auch in der emphatischen Künstlerapotheose. In seiner Oper Doktor Faust (1925) zeichnet Busoni den Titelhelden nicht als Wissenschaftler, sondern als Künstler. Den Fort-

1 Hans Pfitzner, „Mein Bekenntnis zu Schopenhauer“, in: Ders., Reden, Schriften, Brie$f e$, hrsg. von Walter Abendroth (Berlin: Luchterhand, 1955), S. 47; Bernhard Adamy, "Schopenhauer in Pfitzners „Palestrina“", in Schopenhauer-Jahrbuch 63 (1982): 6779.

2 Helmut Loos, „Probleme der Musikgeschichtsschreibung zwischen Ost- und Westeuropa", in Die Musik der Deutschen und ihrer Nachbarn im Osten. Ostseeraum Schlesien - Böhmen/Mähren - Donauraum. [Tagung] vom 23. bis 26. September 1992 in Köln, hrsg. von Klaus Wolfgang Niemöller und dems. (Bonn: Gudrun Schröder, 1994), S. 1-17. 
schrittsoptimismus jedoch, die Umwertung aller Werte, die Goethe in seinem Drama gegenüber dem Spießschen Faustbuch von 1587 vorgenommen hat, macht Busoni großenteils rückgängig: „Des Menschen Lied am Göttlichen verschallt: / also belehrt erkannt' ich meine Ziele / und wandte mich zurück - zum Puppenspiele." Die Faszination der Figur Faust bleibt jedoch bestehen, seine überragende Attraktivität als Mann, mit der er die Herzogin in ihrer Hochzeitsnacht verführt, durch „Wohlgestalt und Geist und Mannheit [...] behext in aller Form. “ Selbst sein Untergang wird heroisiert. Dabei findet sich ein Mystizismus in der Musiksprache Busonis, der dem Pfitzners längst nicht so fern ist, wie die Verlautbarungen der Kontrahenten erwarten ließen.

Die Apotheose der Musik gehört von Anbeginn zur Geschichte der Oper. Ihre besondere Aktualität offenbart Carl Orff 1924 mit seiner Neufassung von Claudio Monteverdis „Favola in Musica“ L'Orfeo (2. Fassung 1940). Der Stoff besitzt eine durchgehende Tradition von Monteverdi über Christoph Willibald Gluck, Joseph Haydn, Jacques Offenbach bis Darius Milhaud (1926 Les Malheurs d'Orphée, eine drastische Persiflage) und Ernst Krenek ${ }^{3}$ (1926 nach einem Drama von Oskar Kokoschka 1918 ${ }^{4}$ ). Die Wirkungsmacht der Musik bildet im antiken Mythos die zentrale Aussage, ihrem mythischen Ideal spürt Franz Schreker in Der ferne Klang (1912) nach, ihre Zauberkräfte demonstriert noch Werner Egk in der Volksoper Die Zaubergeige (1935). In der Neuzeit verlagert sich die Gewichtung, nicht die Kunst, sondern die Künstlerpersönlichkeit rückt ins Zentrum des Interesses. Den sich genialisch durchsetzenden bildenden Künstler hat bereits Hector Berlioz in seiner Oper Benvenuto Cellini (1838) thematisiert, Paul Hindemith mystifiziert die Bindung zwischen dem Künstler und seinem Werk in der Oper Cardillac (nach E. T. A. Hoffmann, erste Fassung 1924/25, Neufassung 1952/61). Die Künstlerapotheose in bester Wagnerscher Manier nach dem Hans Sachs aus den Meistersingern greift Hindemith in Mathis der Maler (1938) auf. Mathis, der alternde Künstler, ${ }^{6}$ verzichtet nicht nur einsichtig leidend auf die bedingungslose Liebe der jungen Verehrerin Ur-

3 Hans Knoch, Orpheus und Eurydike: Der antike Sagenstoff in den Opern von Darius Milhaud und Ernst Krenek (Regensburg: Bosse, 1977).

4 Ernst Krenek, Oskar Kokoschka und die Geschichte von Orpheus und Eurydike, hrsg. von Jürg Stenzl (= Ernst-Krenek-Studien, Bd. 1) (Schliengen: Ed. Argus, 2005).

5 Oswald Panagl, „Art. „Künstleroper“, in Österreichisches Musiklexikon online, Zugriff 27. Februar 2017, http://www.musiklexikon.ac.at/ml/musik_K/Kuenstleroper. $\mathrm{xml}$.

6 Gleich Hans Sachs auch Pfitzners Palestrina, siehe: Michael and Linda Hutcheon, „Portrait of the Artist as an Older Man. Hans Pfitzner's Palestrina and Paul 
sula, er enthält sich auch aller einseitiger Parteinahme, um sowohl den verfolgten aufständischen Bauern, als auch der bedrängten Fürstin mit großartiger Menschlichkeit beizustehen.

Mit der Zwischenkriegszeit ist eine Periode angesprochen, die in den Künsten meist als „Neue Sachlichkeit“ charakterisiert und als radikaler Bruch angesehen wird. Die Musikgeschichte spielt diesbezüglich eine Sonderrolle, in ihr wird meist ganz materialbezogen der epochemachende Neubeginn mit der „Neuen Musik“ auf 1909 und dem Bruch mit der Tonalität gleichsetzt. In beiden Fällen werden die Kontinuitäten unterbewertet, die hier wirksam und den Zeitgenossen offenbar sehr bewusst waren. Die antiromantische Bewegung hat ihre Einstellung zu Musik und schöpferischem Musiker vielfach umschrieben, es sei der Einstieg mit ihren Bühnenwerken genommen. Im Werk Kurt Weills spielt die Thematik keine große Rolle, nur die Erstlingsoper Der Protagonist (1926) handelt im Künstler-, sprich Schauspielermilieu, ihm liegt ein expressionistisches Theaterstück von Georg Kaiser zugrunde. Als für die Richtung aufschlussreich erweist sich der große Erfolg der berühmten Zeitoper Jonny spielt auf (1927) von Ernst Krenek, sie spielt im Musikermilieu. Der ernste Komponist Max wird von der Sängerin Anita aus seiner einsamen Gletscherwelt geholt, eine deutliche Anspielung auf die weltverachtende Abgeschiedenheit des Genies nach Nietzsches Vorstellungen. Max erweist sich als weltfremd, ziemlich lebensuntüchtig und leicht manipulierbar. Er muss sich sowohl gegen den amerikanischen „Negermusiker“ Jonny als auch gegen den „Balkanvirtuosen“" Daniello behaupten, dessen berühmte Geige von Jonny gestohlen und letztendlich besessen wird: Im Schlussbild spielt er die Geige auf der Bahnhofuhr stehend, die sich in eine Weltkugel verwandelt und damit die christliche Ikonographie von Maria auf der Weltkugel ins Dämonische umwendet. Diese Provokation des triumphierenden Jazzmusikers verfehlte ihre Wirkung nicht, nicht nur Julius Korngold richtete wütende Angriffe auf Komponist und Werk und wies den Anspruch auf „musikalische[n] Zeitausdruck“ vehement zurück. Die „Tonkunst“ sei doch gerade „die Zeitlose und von der Zeit souverän Unabhängige, gerade in ihren bedeutendsten Schöpfungen [habe sie] nie den Beruf [...], den Zeitinhalt oder, nennen wir das Kind beim rechten Namen, die Zeitmode wiederzu-

Hindemith's Mathis der Maler", in Masculinity in opera. Gender, history and new musicology, hrsg. von Philip Purvis (New York u. a.: Routledge, 2013), S. 216-235.

7 Julius Korngold, „Feuilleton. Operntheater. Jonny spielt auf von Ernst Krenek“, In Neue Freie Presse, Morgenblatt, 1. Jänner 1928, S. 1-5, hier S. 2. 
geben“. ${ }^{8}$ Den Komponisten Max sieht Korngold als „armseligen Schwätzer und Schwächling“. Am Ende entflieht er mit seiner Geliebten Anita nach Amerika. Trotz der schwachen Figur, die der Komponist abgibt, bleibt er mit seiner idealen Gletscherwelt am Ende der moralische Sieger, wo Unmoral triumphiert, und damit das emphatische Komponistenbild intakt. Dies betrifft auch die ganz ähnliche Geschichte von Richard Strauss' Intermezzo (1924), einer „bürgerlichen Komödie“ mit Verstrickungen in der Ehe des Hofkapellmeisters Storch und seiner Frau Christine, die allerdings anders als bei Krenek völlig souverän gelöst werden. Wie stark den Komponisten die selbstreflexive Darstellung ihrer Profession durch repräsentative Bühnenwerke am Herzen Lag, darauf verweist der Umstand, dass die genannten Komponisten Strauss (Guntram und Intermezzo), Pfitzner, Busoni, Hindemith und Krenek bei aller Verschiedenheit des musikalischen $\mathrm{Zu}$ griffs die Libretti ihrer Künstleropern selbst verfasst haben.

So wenig selbst bei Vertretern der antiromantischen Attitüde der Komponist als menschliche und moralische Autorität in Frage gestellt wird, so entschieden wird diese Vorstellung durch alle musikalischen Genres hindurch hochgehalten. Eine Ironisierung musikalischer Allmachtsphantasien findet sich eher früher, in der Mitte des 19. Jahrhunderts in der Operette Die Zaubergeige (1855) von Jacques Offenbach, in der gerade die Zerstörung des Instruments die Erlösung bringt. Denn in den Trümmern der Geige findet sich das Testament, das die junge Frau Rose wirtschaftlich dazu in die Lage versetzt, ihren geliebten Peter vom Militär freizukaufen und zu heiraten. Siebzig Jahre später finden wir in der Operette Paganini (1925) von Franz Lehár den Geigenvirtuosen ganz im positiven Sinne des Mythos als unwiderstehlichen Frauenschwarm („Gern hab ich die Fraun geküsst“, „Niemand liebt dich so wie ich“), ' der sich am Ende heroisch vom leichten Leben verabschiedet und der Tonkunst verschreibt. Wie stark sich gerade in den 1920er Jahren entsprechende Bühnenwerke häufen, mag eine skizzenhafte Übersicht verdeutlichen:

8 Ebd., S. 3.

9 „Gern hab' ich die Frau'n geküsst, / hab' nie gefragt, ob es gestattet ist; / dachte mir: nimm sie dir, / küss sie nur, dazu sind sie ja hier! “Was Paganini hier besingt, wird heute als übergriffig bezeichnet und unterliegt dem Strafbestand der sexuellen Belästigung. Wie präsent aber das Vorbild immer noch ist, lässt sich leicht bei Youtube nachvollziehen. Einige Filme von Interpretationen zeigen nicht nur den Sänger, sondern auch bildschöne Frauen aus dem Publikum, die das „tollen Mannsbild“ hingerissen anschmachten, beispielsweise: https://www.youtube.com/ watch?v=nFJzNEoBG8A, Zugriff 11. März 2017. Den Beginn des Duetts verfremden Musiker(innen) gerne leicht: „Niemand liebt dich wie so ich“. 
Benvenuto Cellini (H. Berlioz. 1838)

Alessandro Stradella (F. v. Flotow, 1844)

Der Schauspieldirektor (W. A. Mozart/L. Schneider, 1845)

Die Zaubergeige (J. Offenbach, 1855)

Boccaccio (F. v. Suppé, 1876)

Les contes d'Hoffmann (J. Offenbach, 1881)

André Chénier (U. Giordano, 1890)

Guntram (R. Strauss, 1894)

La Bohème (G. Puccini, 1896)

Mozart und Salieri (N. Rimski-Korsakow, 1898) nach Alexander Puschkin (1830)

Tosca (G. Puccini, 1900)

Der ferne Klang (F. Schreker, 1912)

Ariadne auf Naxos (R. Strauss 1916)

Das Dreimäderlhaus (H. Berté, 1916)

Palestrina (H. Pfitzner, 1917)

L'Orfeo (C. Monteverdi/C. Orff, 1924)

Cardillac (P. Hindemith, 1924/25)

Doktor Faust (F. Busoni, 1925)

Paganini (F. Lehár, 1925)

Der Protagonist (K. Weill, 1926)

Les Malheurs d'Orphée (D. Milhaud, 1926)

Orpheus und Eurydike (E. Krenek, 1926)

Jonny spielt auf (E. Krenek, 1927)

Sly (E. Wolf-Ferrari, 1927)

Friederike (F. Lehár, 1928)

Die Zaubergeige (W. Egk, 1935)

Mathis der Maler (P. Hindemith, 1938) 
Capriccio (R. Strauss, 1942)

Mozart in New York (H. Eder, 1991)

Der Gottgeliebte (Mozart/Salieri, 1995)

... fremd bin ich eingezogen (G. Schedl, 1997)

Mozart (S. Levay, 1999)

Falco meets Amadeus (200o)

Angesichts der aufgeführten Beispiele kann füglich die kritische Frage gestellt werden, welche Rolle denn die „neue Sachlichkeit“ im Musikleben wirklich gespielt habe. Die Abwendung vom „schlechten 19. Jahrhundert“ in der Musik mit seiner übersteigerten Sentimentalität und Monumentalität wurde in Deutschland zuerst vom „Wandervogel“ praktiziert und fand in der Jugendbewegung weite Verbreitung in fast allen Teilen der Gesellschaft. Natur statt Zivilisation, Selbermusizieren statt Konzert, Gemeinschaftserlebnis statt isolierter Überwältigung, so lassen sich ihre Grundrichtungen skizzieren. Die Reformpädagogik erhielt großen Aufschwung, bei Reformpädagogen wie Hermann Lietz, Gustav Wyneken und Paul Geheeb spielte die Musik eine große Rolle: August Halm zelebrierte in der Freien Schulgemeinde Wickersdorf (1906-1910, 1920-1929) eine Art von „Kultur-Theologie“. ${ }^{\circ}$ Mit seinem Buch Von zwei Kulturen der Musik (1913), einer theologischen Apotheose Anton Bruckners als Synthese von Bach und Beethoven (Fuge und Sonate) nahm er starken Einfluss auf die Musikwissenschaft. Ernst Kurth schloss mit seiner musikpsychologischen Energetik an die Arbeiten von Halm an.

In der Breite schuf die Jugendmusikbewegung entsprechende Institutionen, zahllose Gruppierungen formierten sich unter der Leitung charismatischer Führerpersönlichkeiten. ${ }^{\text {II }}$ In weiten Teilen ließen sie sich später von der nationalsozialistischen Propaganda einfangen und gingen in den Formierungen der NSDAP mehr oder weniger gezwungen auf. Nach dem Zweiten Weltkrieg fanden sie wieder zusammen, sahen sich dann aber einer heftigen Kritik vor allem durch Theodor W. Adorno ausgesetzt. Erich

10 Lee A. Rothfarb, „Musik und Theologie - August Halm am Kreuzungspunkt seines beruflichen und schöpferischen Weges“, in Musik in Baden-Württemberg 3 (1996): S. 115-134.

11 Die deutsche Jugendmusikbewegung in Dokumenten ihrer Zeit von den Anfängen bis 1933, hrsg. vom Archiv der Jugendmusikbewegung e. V. Hamburg (Wolfenbüttel u. a.: Möseler, 1980). 
Doflein lud Adorno 1952 zu einer Tagung des Instituts für Neue Musik und Musikerziehung nach Darmstadt ein. Wo Fritz Jöde noch nach altem musischen Muster das obligatorische gemeinsame Morgensingen leitete und insgesamt die Vertreter der Jungendmusikbewegung wie Siegfried Borris, Wilhelm Ehmann, Felix Oberborbeck, Wilhelm Twittenhoff und Gottfried Wolters den Ton angaben, trug Adorno seine Fundamentalkritik vor. Er arbeitete sie in den nächsten Jahren aus, es entstanden die Aufsätze „Thesen gegen die musikpädagogische Musik“ (1954), „Kritik des Musikanten“ (1956) und „Zur Musikpädagogik“ (1957). ${ }^{12}$ Die Position, die Adorno der „fremdbestimmten" Musik des aktivistischen Musikantentums und der Gemeinschaftsbildung entgegenstellte, war die des authentischen Kunstwerks im emphatischen Sinne fortschrittlichen Komponierens, wie er sie in der sogenannten „Wiener Schule“ verwirklicht sah. (Der Begriff ist wesentlich von Adorno geprägt worden und enthält den Korrespondenzgedanken der Wiener Klassik.)

Den Vorwurf, einen unangemessenen Kultus in kunstreligiösem Sinne mit der Musik zu betreiben, erhob Adorno nicht. Er kam aus den Reihen der Jugendmusikbewegung selbst, als Theodor Warner 1954 in seinem Buch Musische Erziehung zwischen Kult und Kunst den Pseudokult und Eklektizismus der Jugendbewegung anprangerte. ${ }^{13}$ Wie stark Adorno dagegen einem religiös geprägten, emphatischen Kunstbegriff verhaftet blieb, darauf verweist sein Angriff auf „die unheilige Nüchternheit der versierten Musikpädagogik “. ${ }^{14}$ Damit spielt Adorno auf einen Begriff an, den Stefan Zweig 1925 in die Debatte geworfen hatte, als er auf Nietzsches späte Wagner-Kritik zu sprechen kam, in der nicht mehr die Trunkenheit regiere, sondern „nach Hölderlins herrlichem Wort die ,heilige Nüchternheit: , Musik als

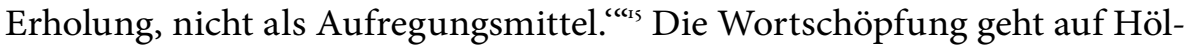
derlins Gedicht „Hälfte des Lebens“ zurück: „Und trunken von Küssen / Tunkt ihr das Haupt / Ins heilignüchterne Wasser. ${ }^{(166}$ Sie taucht auch bei Cle-

12 Wilfried Gruhn, Geschichte der Musikerziehung. Eine Kultur-und Sozialgeschichte vom Gesangunterricht der Aufklärungspädagogik zu ästhetisch-kultureller Bildung, 2. Aufl. (Hofheim: Wolke, 2003), S. 29of.

13 Theodor Warner, Musische Erziehung zwischen Kunst und Kult (Berlin-Darmstadt: Merseburger, 1954).

14 Theodor W. Adorno, „Dissonanzen. Musik in der verwalteten Welt“, in: Ders., Gesammelte Schriften, Bd. 14 (Frankfurt a. M.: Suhrkamp, 1973), S. 117.

15 Stefan Zweig, Hölderlin - Kleist - Nietzsche: Der Kampf mit dem Dämon (Leipzig 1925, Hamburg: Severus, 2014), S. 232. Stefan Zweig - Gesammelte Werke, 5. Auflage, S. 4962.

16 Friedrich Hölderlin, „Gedichte 1800-1804“, in: Ders., Sämtliche Werke. Kleine Stuttgarter Ausgabe, hrsg. von Friedrich Beissner (Stuttgart: Cotta, 1946-1962), Bd. 2, S. 121. 
mens Brentano auf: „Aber es tauchet der Schwan ins heilignüchterne Wasser / Trunken das Haupt, und singt sterbend dem Sternbild den Gruß. ${ }^{\alpha 17}$ Sie stammt aus dem orthodoxen Christentum, wo die Philokalie der heiligen Väter der Nüchternheit eine Anthologie von mystischen Schriften früher Asketen, Mönche und Kirchenväter beinhaltet. ${ }^{18}$ Nicht zufällig hat auch der am geistigen Leben der Zwischenkriegszeit als jüdischer Religionsphilosoph lebhaft beteiligte Ernst Simon den Begriff reflektiert, ${ }^{19}$ ebenso Johannes R. Becher. ${ }^{20}$ Tatsächlich bildet er ein Oxymoron, da Heiligkeit eine gewisse Emphase beinhaltet, die der Nüchternheit gerade widerspricht. In diesem Sinne hat Schopenhauer dem Genie alle Nüchternheit abgesprochen, ,als welche gerade darin besteht, daß man in den Dingen nichts weiter sieht, als was ihnen, besonders in Hinsicht auf unsere möglichen Zwecke, wirklich zukommt: daher kann kein nüchterner Mensch ein Genie seyn. ${ }^{{ }^{21}}$ Genauso verwendet Adorno den Begriff, wenn er Hindemith eine "eingeborene Nüchternheit" zuspricht und damit das Spätwerk diffamiert. ${ }^{22}$ Diese Kritik kann nur von einem Vertreter älterer romantischer Musikanschauung kommen, der den Geltungsanspruch der neuen Sachlichkeit verkennt bzw. nicht anzuerkennen bereit ist. Es ist nicht ein Kampf um Aufklärung und Entmythologisierung, nein, es ist ein Kampf um die richtigen Götter, ein Religionskrieg in der Sphäre, in der ich die Musik als Kunstreligion der Moderne bezeichne.

Theodor Warner hat den Kultcharakter der aus der Jugendbewegung hervorgegangenen musischen Erziehung bereits frühzeitig benannt und heftig kritisiert. Seine Ausführungen sind ohne Auswirkung geblieben, gerade auch im Vergleich mit der nur kurz später verbreiteten Kritik Adornos. Ich interpretiere dies so, dass die gesellschaftliche Akzeptanz der Musik

17 Clemens Brentano, „Ausgewählte Gedichte“, in: Ders., Werke, hrsg. von Friedhelm Kemp, 4 Bde. (München: Hanser, [1963-1968]), S. 278.

18 Nach Walter Nigg müsste der Titel wiederzugeben sein mit: „Die Liebe der heilig Nüchternen zur geistigen Schönheit.“

19 Ernst Simon, „Heilige Nüchternheit (1964)“, in: Ders., Brücken. Gesammelte Aufsät$z e$ (Heidelberg: L. Schneider, 1965), S. 466-470.

20 Johannes R. Becher, Macht der Poesie (1955), siehe Wulf Koepke, „Hölderlin in einer gottverlassenen Zeit", in Ästhetiken des Exils, hrsg. von Helga Schreckenberger (Amsterdamer Beiträge zur neueren Germanistik 54) (New York: Rodopi, 2003), S. 209234 .

21 Arthur Schopenhauer, „Die Welt als Wille und Vorstellung“, in: Ders., Werke in zehn Bänden, Bd. 4 (Zürich: Hanser, 1977), S. 461.

22 Theodor W. Adorno, „Ad vocem Hindemith. Eine Dokumentation“, in: Ders., Gesammelte Schriften, Bd. 17, Musikalische Schriften, Bd. 4 (Frankfurt a. M.: Suhrkamp, 1982), S. 240. 
als Kunstreligion noch eine derartige Verbindlichkeit besaß, dass Warners Ausführungen mit Stillschweigen übergangen, einfach ignoriert worden sind, weil sie nicht in das Weltbild der Moderne passten. Eine Gesellschaft schafft sich ihr Weltbild auch aus einer gezielten Auswahl der rezipierten Gedanken. Warner geht es bei seiner Kritik nicht um die Zerstörung, sondern um Reinigung und Vertiefung musischer Erziehungsarbeit, die stets den "ganzen Menschen“ in den Blick nehme. Aufgrund der fortschreitenden, aus Humanismus und Rationalismus erwachsenen Säkularisierung habe sich der Pädagoge "Ganzheitsziele humanistischer Art" gesetzt, die ihm in "gesamtmenschenführende[r] Funktion“ "priesterliche Hoffnungen“ aufnötigten und ihn dazu verleiteten, „auch summarische Verdammungsurteile“ abzugeben, „die jeder Orthodoxie Ehre machen würden. ${ }^{{ }^{\prime 23}}$ Die erstrebte „musische Ganzheit“, die Warner mit Blick auf Wagner auch als „Versuch eines laiengebundenen Gesamtkunstwerks" umschreibt, bedürfe, da "die künstlerischen Mittel der säkularen Einheit trotzten," des „Mythos als Bindemittel“ durch „Entgrenzung des Geistes“, eine „Selbstsetzung mythischer Ansprüche“ ${ }^{24}$ Dies habe durch quasi kultische Handlungen ${ }^{25}$ einen „Pseudokult und Eklektizismus“ gezeugt, da es außer der christlichen Mythenüberlieferung „keine wirklich geglaubten Mythen mehr“ gebe. ${ }^{26}$ Das „Wollen unter wahlloser Nutzung der Mittel; die Ablösung vom Kontinuum der Kultur wie der Realität" habe einem literarischen Eklektizismus den Weg bereitet, der in romantischer Tradition bei Rainer Maria Rilke und Stefan George „eine Setzung von Führertum und Geheimbund" hervorgebracht habe, ohne „die dort gegebene schonungslose Freilegung des Nihilismus“ zu erkennen. ${ }^{27}$ So suche die musische Bewegung „feierliche Ewigkeit“, indem sie „Lebensfülle“ abstoße und „Askese“ suche. ${ }^{28}$ In dem dabei zu leistenden „harten Dienst“ der Gemeinschaft (Bündische Jugend) sei sie „folgerichtig von der aktiven Askese der Männerbünde zu deren passiver Form, der Abstinenz" gelangt. ${ }^{29}$ "Aus dem positiven Ansatz der

23 Theodor Warner, Musische Erziehung zwischen Kunst und Kult (Berlin-Darmstadt: Merseburger, 1954), S. 7.

Ebd., S. 22.

„Wer wie der Verfasser einst an bedeutender musischer Stätte mit anderen Gutwilligen unter wiederholtem, einstimmigen Absingen von Beethovens ,Freude, schöner Götterfunken' feierlich-symbolisch einen Apfelbaum umkreiste, ist eine gebrannte Katze, kann nicht umhin, kritischen Sinnes zu werden." Ebd., S. 35.

Ebd., S. 36.

Ebd., S. 37.

Ebd., S. 63 f.

Ebd., S. 64f. 
gesuchten Askese“ sei eine Abstinenz geworden, „die zu Reduktionen der Lebensganzheit" geführt habe, also gerade nicht zum "ganzen Menschen“. ${ }^{\circ}$ So bleibe die Jugendbewegung aller Gegnerschaft zum Trotz „ein romantisches Phänomen“ und das Musische besitze wie dieses zwei Brennpunkte, "Kunst und Kult, einen religiösen und einen ästhetischen“. ${ }^{31}$ Letztendlich sieht Warner den Fehler der Jugendbewegung in ihrer trügerischen Abgeschlossenheit, ihre echte musische Aufgabe in der Selbstverwirklichung angesichts der unverstellten Totalität des Jetzt und Hier, das Abendland als Erbe und Auftrag. Und für die aufgeklärte Moderne wählt er dann das Zauberwort ihrer Erlösung: „Kult darf nur einem Bereich angehören, der über einen lebendigen Mythos verfügt; der Kult kann Kunst einschließen - dem Säkularen bleibt allein , heilig-nüchterne ' Vervollkommnung in härtester, ästhetischer Zucht. ${ }^{\text {(32 }_{2}}$

\section{Bibliographie}

Adamy, Bernhard. „Schopenhauer in Pfitzners „Palestrina““. In Schopenhauer-Jahrbuch 63 (1982): 67-79.

Adorno, Theodor W.. „Ad vocem Hindemith. Eine Dokumentation“. In: Ders.. Gesammelte Schriften, Bd. 17. Musikalische Schriften, Bd. 4. Frankfurt a. M.: Suhrkamp, 1982, S. 240.

Adorno, Theodor W.. „Dissonanzen. Musik in der verwalteten Welt“. In: Ders., Gesammelte Schriften, Bd. 14. Frankfurt a. M.: Suhrkamp, 1973, S. 117.

Brentano, Clemens. „Ausgewählte Gedichte“. In: Ders.. Werke. Hrsg. von Friedhelm Kemp, 4 Bde.. München: Hanser, [1963-1968], S. 278.

Die deutsche Jugendmusikbewegung in Dokumenten ihrer Zeit von den Anfängen bis 1933. Hrsg. vom Archiv der Jugendmusikbewegung e. V. Hamburg. Wolfenbüttel u. a.: Möseler, 1980.

Gruhn, Wilfried. Geschichte der Musikerziehung. Eine Kultur- und Sozialgeschichte vom Gesangunterricht der Aufklärungspädagogik zu ästhetisch-kultureller Bildung, 2. Aufl. Hofheim: Wolke, 2003, S. $290 f$.

Hölderlin, Friedrich. „Gedichte 1800-1804“. In: Ders.. Sämtliche Werke. Kleine Stuttgarter Ausgabe. Hrsg. von Friedrich Beissner. Stuttgart: Cotta, 19461962, Bd. 2, S. 121.

30 Ebd., S. 67.

31 Ebd., S. 7 of.

32 Ebd., S. 77. 
Hutcheon, Michael and Hutcheon, Linda. „Portrait of the Artist as an Older Man. Hans Pfitzner's Palestrina and Paul Hindemith's Mathis der Maler“. In Masculinity in opera. Gender, history and new musicology. Hrsg. von Philip Purvis. New York u. a.: Routledge, 2013, S. 216-235.

Koepke, Wulf. „Hölderlin in einer gottverlassenen Zeit“. In Ästhetiken des Exils. Hrsg. von Helga Schreckenberger. Amsterdamer Beiträge zur neueren Germanistik, 54. New York: Rodopi, 2003, S. 209-234.

Knoch, Hans. Orpheus und Eurydike: Der antike Sagenstoff in den Opern von Darius Milhaud und Ernst Krenek. Regensburg: Bosse, 1977.

Korngold, Julius. „Feuilleton. Operntheater. Jonny spielt auf von Ernst Krenek“. In Neue Freie Presse, Morgenblatt. 1. Jänner 1928, S. 1-5, hier S. 2.

Krenek, Ernst. Oskar Kokoschka und die Geschichte von Orpheus und Eurydike. Hrsg. von Jürg Stenzl (= Ernst-Krenek-Studien, Bd. 1). Schliengen: Ed. Argus, 2005.

Loos, Helmut. „Probleme der Musikgeschichtsschreibung zwischen Ost- und Westeuropa“. In Die Musik der Deutschen und ihrer Nachbarn im Osten. Ostseeraum - Schlesien - Böhmen/Mähren - Donauraum. [Tagung] vom 23. bis 26. September 1992 in Köln, hrsg. von Klaus Wolfgang Niemöller und dems. Bonn: Gudrun Schröder, 1994, S. 1-17.

Panagl, Oswald. „Art. „Künstleroper“. In Österreichisches Musiklexikon online. Zugriff 27. Februar 2017. http://www.musiklexikon.ac.at/ml/musik_K/Kuenstleroper.xml.

Pfitzner, Hans. „Mein Bekenntnis zu Schopenhauer“. In: Ders.. Reden, Schriften, Briefe. Hrsg. von Walter Abendroth. Berlin: Verlag, 1955, S. 47.

Rothfarb, Lee A.. „Musik und Theologie - August Halm am Kreuzungspunkt seines beruflichen und schöpferischen Weges“. In Musik in Baden-Württemberg 3 (1996): S. 115-134.

Schopenhauer, Arthur. „Die Welt als Wille und Vorstellung“. In: Ders.. Werke in zehn Bänden, Bd. 4. Zürich: Hanser, 1977, S. 461.

Simon, Ernst. „Heilige Nüchternheit (1964)“. In: Ders.. Brücken. Gesammelte Aufsätze. Heidelberg: L. Schneider,1965, S. 466-470.

Warner, Theodor. Musische Erziehung zwischen Kunst und Kult. Berlin-Darmstadt: Merseburger, 1954.

Zugriff 11. März 2017. https://www.youtube.com/watch?v=nFJzNEoBG8A.

Zweig, Stefan. Hölderlin - Kleist - Nietzsche: Der Kampf mit dem Dämon. Leipzig 1925, Hamburg: Severus, 2014, S. 232. 
Vielfalt der Moderne.

Die Musiktage in Donaueschingen und Baden-Baden in den r92oer Jahren

\author{
Peter Andraschke \\ Univerza Justus Liebig v Giessnu \\ Justus Liebig University Giessen
}

Die alljährlichen Musiktage in Donaueschingen seit 1921, ihre Fortsetzung in Baden-Baden ab 1927 und ihr Abschluß in Berlin 1930 spiegeln die Geschichte der zeitgenössischen Musik in den 1920er Jahren wider mit ihren vielfältigen Tendenzen zwischen Traditionsbezogenheit, Gebrauchsmusik, Experiment und avantgardistischem Kunstanspruch. Von ihnen gingen zahlreiche Anregungen aus. Es gibt deutliche Unterschiede zwischen den Konzeptionen von Donaueschingen und Baden-Baden.

Die Programme von Donaueschingen waren aufführungspraktisch bedingt zunächst auf die traditionelle Solo- und Kammermusik beschränkt. Der eigentliche Organisator der Musiktage war Heinrich Burkard (18881950), Fürstlich Fürstenbergischer Musikdirektor. Weitere Mitglieder des Programmausschusses waren Eduard Erdmann (1896-1958), Komponist und Pianist, der sich in seinen Konzerten für zeitgenössische Musik einsetzte und Joseph Haas (1879-1960), der an der Akademie der Tonkunst in München eine Kompositionsklasse leitete. Zunächst von seinem Lehrer Max Reger beeinflußt, fand er bald zu einer einfacheren und volksnahen Kompositionsart auf tonaler Grundlage. Gegenüber modernen Bestrebungen war er jedoch aufgeschlossen.

In einem Geleitwort zu den Musiktagen von 1921 formulierte der Programmausschuß in der Neuen Musik-Zeitung als Richtlinien für die Auswahlkriterien: 
"Als Leitsatz galt, durchaus unparteiisch und unbeeinflußt die Auslese aus den Eingängen vorzunehmen. Maßgebend für die Aufnahme in das Programm waren allein der innere Gehalt der Werke, die Stärke der künstlerischen Schöpferkraft, gleichviel aus welchem Boden der Tondichter seine Kräfte gezogen hat, gleichviel welcher Sprache er sich zum Ausdruck seines Fühlens bedient. Der Nachdruck wurde darauf gelegt, für noch nicht oder wenig bekannte Begabungen Aufmerksamkeit zu wecken; reife Werke schon eingeführter heute schaffender Tondichter wurden zurückgestellt zugunsten junger, aufstrebender Komponisten, ob auch deren Schaffen heute vielleicht noch mehr Verheißung als Erfüllung bedeutet. ${ }^{\text {“t }}$

Anschließend sind neben dem Protektor Fürst zu Fürstenberg die Mitglieder des Ehrenausschusses genannt: Ferruccio Busoni (1866-1924), Siegmund von Hausegger (1872-1948), Arthur Nikisch (1855-1922), Max von Pauer (1866-1945), Hans Pfitzner (1869-1949), Franz Schreker (1878-1949), Richard Strauß [sic!] (1864-1949), ebenso die drei Konzertprogramme und ihre Ausführenden. Donaueschingen und seine Musikkultur bildeten den Hauptteil dieses 20. Heftes der Neuen Musik-Zeitung 1921. Neben Aufsätzen zum Thema ${ }^{2}$ enthielt es ausführliche Informationen zu den Programmen, in denen die Komponisten mit Biographien, einer Werkauswahl und die aufzuführenden Werke mit knappen Analysen vorgestellt sind: Alois Hába (1893-1973), Karl Horwitz (1884-1925), Ernst Krenek (1900-1991), Franz Philipp (1890-1972), Arthur Willner (1881-1959), Philipp Jarnach (1892-1982), Rudolf Peters (1902-1962), Alban Berg (1885-1935) und Paul Hindemith (1895-1963).

Die Donaueschinger Musiktage wollten ausschließlich zeitgenössische Musik bringen, wenn möglich als Uraufführungen und dabei junge Talente fördern. Deshalb finden sich unter den Komponisten anfangs nur selten damals schon renommierte Persönlichkeiten. Allerdings zeigen die Programme, daß viele für das 20. Jahrhundert später wichtige Namen erscheinen. Angeregt durch die Donaueschinger Musiktage wurden die IGNM (frz. SIMC, engl. ISCM) am 11. August 1922 in Salzburg gegründet. Anders

Joseph Haas (zusammen mit Heinrich Burkard und Eduard Erdmann), „Die Donaueschinger Kammermusik-Aufführungen zur Förderung zeitgenössischer Tonkunst", in Donaueschinger Kammermusik-Aufführungen zur Förderung zeitgenössischer Tonkunst (= Neue Musik-Zeitung 42, 1921, Heft 20, 21. Juli 1921), S. 309. 214; Eduard Johne, „Die Fürstlich Fürstenbergische Hofbibliothek in Donaueschingen und ihre Musikbestände", ebenda, S. $321 f$. 
als die IGNM mußte Donaueschingen nicht auf einen internationalen Proporz Rücksicht nehmen und konnte eigenverantwortlich entscheiden. Bereits das Programm des ersten Jahres zeigt die Offenheit gegenüber verschiedensten Stilrichtungen und Schulen. Die Werke von Hába, Krenek, Horwitz, Berg und Hindemith dokumentieren die weite Spanne dessen, was damals kompositorisch angeboten wurde. Nationale Grenzen spielten bei der Auswahl keine Rolle.

Paul Hindemith löste 1924 Erdmann im Programmausschuss ab und ergriff sogleich die Initiative. Er versuchte Schwerpunkte zu bilden. Die Förderung von ausschließlich jungen Talenten wurde aufgegeben. So war das Jahr 1924 hauptsächlich der Zwölftonmusik und ihren Wurzeln gewidmet. ${ }^{3}$ Es wurden vor allem Komponisten aus dem Wiener Raum eingeladen, so der bereits international renommierte Arnold Schönberg (1874-1951), sein Schüler Anton Webern (1883-1945) und der Antipode Joseph Matthias Hauer (1883-1953). Egon Wellesz (1885-1974) war ein wichtiger Kontaktmann für Empfehlungen aus der Wiener Szene.

Das zentrale Werk dieser Musiktage war Schönbergs Serenade für Klarinette, Baßklarinette, Mandoline, Gitarre, Geige, Bratsche, Violoncello und eine tiefe Männerstimme op. 24 (1920-1923). Schönberg selbst dirigierte ihre erste öffentliche Aufführung, die er als eigentliche Uraufführung bewertete, am 20. Juli 1924 im Nachmittagskonzert um 17 Uhr. Von Anton Webern gab es zwei Uraufführungen: Das Amar-Quartett (mit Hindemith als Bratschist) spielte die 6 Bagatellen für Streichquartett op. 9. Die Trakl-Lieder op. 14 wurden unter seiner Leitung von Claudia Kwartin und Mitwirkenden der Schönberg-Serenade interpretiert. Weitere Werke von Komponisten aus dem Wiener Raum waren die Uraufführungen des Streichtrios op. 21 von Alexander (Sándor) Jemnitz (1890-1963) , der zwischen 1913 und 1915 für kurze Zeit Privatschüler bei Schönberg in Berlin gewesen war, von Hauer 5 Stücke für Streichquartett op. 30 und die Hölderlin-Lieder für tiefe Stimme und Klavier op. 23. Von Ernst Toch (1887-1964), einem gebürtigen Wiener, der damals an der Musikhochschule in Mannheim Komposition unterrichtete, erklang das 11. Streichquartett op. 34. In einer Sonderveranstaltung wurde das Persische Ballet op. 30 von Egon Wellesz in der reduzierten Fassung für neun Instrumente und Schlagzeug uraufgeführt.

3 Peter Andraschke, „Die Rezeption der Wiener Schule im ehemaligen Vorderösterreich am Beispiel von Freiburg i. Br. und Donaueschingen in den 1920er Jahren“, in Musikgeschichte in Mittel- und Osteuropa. Mitteilungen der internationalen Arbeitsgemeinschaft an der Universität Leipzig, Druck in Vorbereitung 
Burkard hat sich ein weiteres Mal an Schönberg gewandt' und wollte dessen Chöre op. 27 und 28 für die Musiktage 1926 zur Uraufführung. Schönberg hat abgesagt und schrieb am 7. April 1926 aus Berlin:

„[...] leider kann ich Ihrer freundlichen Einladung, die Uraufführung meiner Chöre in Donaueschingen machen zu lassen, nicht entsprechen. Vor allem ist der Stuttgarter Madrigalchor doch ein wenig zu schwach besetzt; soviel man mir gesagt hat. Denn meine Chöre müßten doch 4-5-fach besetzt werden. Dann muss ich eine Erstaufführung unbedingt selbst leiten, wenn schon nicht studieren und das ist auf diese Entfernung doch unmöglich. [...]"

In den folgenden Jahren verstärkte sich der Einfluß Hindemiths und es deutete sich ein Wechsel in der Programmgestaltung an. In die Konzerte wurden auch Chorwerke mit kleiner Besetzung integriert und neue Komponistennamen tauchten auf. Die Musik der Wiener Schule hat ihre Wurzeln vor allem im 19. Jahrhundert. Hindemith wollte mit dieser Traditionslinie brechen. Ihn interessierten mehr die Tendenzen des Neoklassizismus, wie sie Igor Strawinsky (1882-1971) damals vertrat. Auch Schönberg wurde von dieser Strömung zeitweise angeregt, beispielsweise in seiner Serenade op. 24. Aber er integrierte sie in seine eigene Ästhetik und Klangwelt. Im Jahr 1925 spielte Felix Petyrek (1892-1951) die Uraufführung von Strawinskys im Jahr zuvor entstandener Klaviersonate, Alfredo Casella (1883-1947) war mit der deutschen Erstaufführung des Concerto für Streichquartett op. 40 vertreten, gespielt vom Amar-Quartett. 1926 setzte das Schlußkonzert mit Uraufführungen von sechs Originalkompositionen für mechanische Musikinstrumente eine deutliche Neuorientierung, die sich in den folgenden Jahren in Baden-Baden fortsetzte. Vorgeführt wurden zwei Werke von Ernst Toch, der damals zunehmend Bedeutung erlangte und drei von Hindemith, darunter Das triadische Ballett mit Musik für eine kleine mechanische Orgel.

5 Original im Fürstlich Fürstenbergischen Archiv, zitiert nach einem Durchschlag in der Library of Congress in: Arnold Schönberg, Sämtliche Werke. Abteilung V: Chorwerke, Reihe B, Bd. 18,2. Chorwerke I. Kritischer Bericht zu Band 18A, Teil 2. Skizzen, Hrsg. von Tadeusz Okuljar und Dorothee Schubel (Mainz und Wien, 1996), S. XXVII.

6 Zitiert nach einer Kopie aus der Library of Congress in: Arnold Schönberg, Sämtliche Werke. Abteilung V: Chorwerke, Reihe B, Bd. 18,2. Chorwerke I. Kritischer Bericht zu Band 18A, Teil 2. Skizzen, Hrsg. von Tadeusz Okuljar und Dorothee Schubel (Mainz und Wien, 1996), S. XXVIII. 
In den sechs Jahren der Donaueschinger Musiktage traten einige Komponisten stärker in den Vordergrund. So standen Werke von Hindemith und Krenek zwischen 1921 und 1926 auf den Programmen von vier Jahren, an zwei Jahren wurden aufgeführt: Fidelio F. Finke (1891-1968), Hába, Jarnach, Petyrek, Hermann Reutter (1900-1985), Erwin Schulhoff (18941942), Josip Slavenski (1896-1955) und Toch. Die Musik aus dem deutschsprachigen Raum, einschließlich der aus der ehemaligen Habsburgischen Monarchie hervorgegangenen Territorien bildete einen Schwerpunkt. Vielleicht hängt das damit zusammen, daß das Fürstenhaus starke Bindungen dorthin hatte. Das südwestdeutsche Geschlecht des Hochadels besaß große Besitzungen in den österreichischen Erblanden, besonders in Böhmen. Ihm gehörten z.B. seit 1607 auch Schloß, Stadt und Herrschaft im Waldviertler Weitra. Seinen Kunstsinn bezeugt die Einrichtung eines Theaters im dortigen Schloß im 18. Jahrhundert, das noch heute bespielt wird. Die Niederösterreichische Landesausstellung 1994 widmete sich dem Thema: Die Fürstenberger. 8oo Jahre Herrschaft und Kultur in Mitteleuropa.?

Die Verlegung der Musiktage nach Baden-Baden brachte zahlreiche neue konzeptionelle Orientierungen, die von Hindemith geprägt wurden. Überblickt man die hier aufgeführten Komponisten und Werke, so zeigt sich dieser Wandel sehr deutlich. Die Tradition der Wiener Schule ist nur noch 1927 durch die deutsche Erstaufführung von Bergs 1926 entstandener Lyrischen Suite für Streichquartett vertreten. Die westeuropäische Musik und amerikanische Einflüsse wurden stärker berücksichtigt. Die Gebrauchsmusik in vielerlei Facetten war fortan zentrales Thema. Sie hatte bereits 1926 mit Originalkomposistionen für Militärmusik begonnen. Die Uraufführungen stammten von Krenek, Ernst Pepping (1901-1981), Toch und Hindemith. Die neuen technischen Medien rückten in den Mittelpunkt. Man versuchte eine ihnen entsprechende Musik zu erarbeiten. Provokation des etablierten bürgerlichen Kulturbetriebs war gewollt und an der Tagesordnung.

Die Entwicklungen in Baden-Baden stehen in engem Zusammenhang mit der Idee einer Gebrauchsmusik im weitesten Sinne. Dabei sollten die Grenzen zwischen Kunst und Nichtkunst in verschiedenen Gattungen und Bereichen aufgebrochen werden. Der Begriff »Gebrauchsmusik« hatte damals eine durchaus positive Bedeutung, allerdings verkam er Ende der

$7 \quad$ Arno Erchmeyer/Erwin H. Eltz, Hrsg., Die Fürstenberger. 800 Jahre Herrschaft und Kultur in Mitteleuropa. Niederösterreichische Landesausstellung, Schloß Weitra 1994 (Katalog des Niederösterreichischen Landesmuseums, Neue Folge Nr. 342), (Korneuburg, 1994). 
1920er Jahre zum Schlagwort. 1925 sprach der junge Ernst Krenek, der damals an seiner Oper Jonny spielt auf arbeitete, davon, daß „die Kunst gar nichts so Wichtiges vorstellt, wie wir immer gerne glauben möchten. [...] Vivere necesse est, artem facere non", d.h. viel wichtiger als die Kunst ist das Leben. ${ }^{8}$ Die Gebrauchsmusik war ein künstlerisches und zugleich ein soziologisches Phänomen. In der Abkehr von der Spätromantik veränderte sich das schöpferische Selbstverständnis des Komponisten grundsätzlich und zunehmend wandte sich das kompositorische Denken von der Idee einer l'art pour l'art zu einer funktionalen Musik, die einem neuen, breiten Hörerkreis dienen wollte.

Die Gebrauchskunstbewegung der 1920er Jahre ist im Zusammenhang und als Reaktion auf die Krise im Kulturleben Deutschlands in der Weimarer Zeit zu sehen, die wiederum bedingt war durch die Auswirkungen der wirtschaftlichen und sozialen Veränderungen nach dem Ersten Weltkrieg und die vehemente Inflation. Die sich allmählich stabilisierende positive wirtschaftliche Entwicklung, die durch die Sanierung der deutschen Währung im Jahre 1923 eingeleitet wurde, bewirkte zugleich eine Neuorientierung im kulturellen Bereich. Die früheren Träger und Rezipienten des öffentlichen Kulturlebens, das Bildungsbürgertum, hatten kein Geld und kamen immer weniger als Publikum der öffentlichen Veranstaltungen in Konzert und Oper in Betracht. Die am wirtschaftlichen Aufschwung partizipierende neue gesellschaftliche Mittelschicht war kulturell anders gebildet und orientiert, interessierte sich nicht für den traditionellen Bildungskanon und konnte deshalb die bisherigen öffentlichen Strukturen nicht weiter tragen. Kurt Weill beobachtete eine „Umschichtung des Publikums und folgerte, daß die musikalische Produktion eine neue Existenzberechtigung gewinnen muß ${ }^{\text {“. } . ~ D e r ~ n e u e ~ P u b l i k u m s g e s c h m a c k ~ r i c h t e t e ~ s i c h ~ a u f ~}$ leichtere Kost. Operette und Revue erlebten einen Aufschwung, ebenso die neue Unterhaltungsmusik in Kaffeehäusern, Tanzetablissements, auf Bällen und Festen und nicht zuletzt in den Kinos.

Die Entwicklung hin zu einer Gebrauchsmusik betraf natürlich nicht die gesamte zeitgenössische Musik der 1920er Jahre, beispielsweise nur bedingt die der Zweiten Wiener Schule, obgleich die moderne Tanz- und Un-

8 Ernst Krenek, „Musik in der Gegenwart“. Vortrag, gehalten am 19. Oktober 1925 auf dem Kongreß für Musikästhetik in Karlsruhe, in 25 Jahre neue Musik. Jahrbuch 1926 der Universal-Edition (Wien/Leipzig/New York: Universal-Edition, 1926), S. $58 \mathrm{f}$.

9 Kurt Weill, „Fünf Jahre ,Der deutsche Rundfunk', in: Ders., Stephen Hinton/Jürgen Schebera, Hrsg., Musik und Theater. Gesammelte Schriften (Berlin: Henschelverlag Kunst und Gesellschaft, 1990), S. 274f. 
terhaltungsmusik auch in manchen Werken Bergs und sogar Schönbergs Spuren hinterlassen hat. Der vielgliedrige Komplex der Gebrauchsmusik wirkte auf das Musiktheater ein, förderte bestimmte Musiksparten wie z.B. die Blasmusik, die Hausmusik und hier insbesondere die sogenannte "Spielmusik« und »Musik für Liebhaber«; beide führen Formen des Musizierens und Singens aus der Jugendbewegung weiter. Auf diesem Gebiet hat Paul Hindemith Vorbildliches geleistet. Die Idee der Gebrauchsmusik wirkte auf die neuen Medien ein, den Rundfunk, die Schallplatte und den Film und experimentierte auch mit mechanischen und elektronischen Musikinstrumenten. All diese Bereiche wurden zu Schwerpunkten der Musiktage und initiierten neue kompositorische Anregungen und Uraufführungen.

Die Tendenz ging insgesamt zu einer Vereinfachung der Schreibweise und führte zugleich zu einer Verkleinerung des Klangkörpers und zu knappen überschaubaren Formen. Auffallend ist ein häufig musikantischer Duktus, der eine romantische Haltung ablehnt und sich an der musikalischen Praxis vor dem 19. Jahrhundert orientiert. Dafür einige Beispiele.

1927 gab es wieder ein Konzert mit Originalwerken für mechanische Instrumente, darunter Arbeiten von Toch und Hindemith. Als neuer Name tauchte der Amerikaner George Antheil (1900-1959) auf mit dem Arrangement des 1. Teils seines Ballet mécanique für Orchester (1925), das er ursprünglich für einen Film von Fernand Léger (1881-1955) komponiert hatte. Neue Komponisten waren u.a. Hanns Eisler (1898-1962), Bohuslav Martinů (1890-1959), der Kroate Krsto Odak (1888-1965), ein Schüler von Vítězslav Novák (1870-1949) und Béla Bartók (1881-1945), der seine Klaviersonate selbst uraufführte. Das Festival startete eine Reihe Film und Musik, die 1928 mit der Veranstaltung Experimentalvorführung Film und Musik und 1929 mit der Uraufführung von Tonfilmen fortgesetzt wurde. Hinzu kamen 1929 zwei Uraufführungs-Konzerte mit Tonfilmen. 1929 begann die Auseinandersetzung mit dem Rundfunk. Im ersten der zwei Uraufführungs-Konzerte Originalmusik für Rundfunk dirigierte Hermann Scherchen (18911966) den bekannt gewordenen Lindberghflug von Brecht mit der Musik von Hindemith und Weill. Und 1927 kam die Auseinandersetzung mit neuen Konzeptionen des Musiktheaters dazu. An einem Abend wurden z.B. gegeben: Die Opéra-minute Die Entführung der Europa (L'Enlèvement d'Europe) von Darius Milhaud (1892-1974), Kurt Weills (1900-1950) Songspiel nach Bert Brecht (1898-1956) Mahagonny und Paul Hindemiths Sketch Hin und zurück (Marcellus Schiffer, 1892-1932). Das Genre der Minutenoper hat üb- 
rigens Slavko Osterc (1895-1941) zu seiner Salome inspiriert. ${ }^{10}$ An einem weiteren Abend mit Kammeropern wurde u.a. Walter Gronostays (19061937) In zehn Minuten uraufgeführt. 1929 stand die Uraufführung des Lehrstücks von Bert Brecht mit der Musik von Hindemith auf dem Programm, dessen Titel zur Gattungsbezeichnung anderer Werke wurde.

Die Verlegung der Musiktage 1930 nach Berlin hatte u.a. private Gründe. Sowohl Hindemith als Burkard, der Begründer des Donaueschinger Festivals waren inzwischen dort beruflich gebunden. Hindemith lehrte seit 1927 an der Berliner Musikhochschule, deren stellvertretender Direktor der Musikologe und engagierte Musikpädagoge Georg Schünemann (1884-1945) war. Burkard hatte zwischenzeitlich gute Verbindungen zum Rundfunk geknüpft. Schünemann ersetzte den Münchner Haas, der mit der politisch linksorientierten Ästhetik und Gesellschaftskritik der Musiktage, wie sie sich im Songspiel und Lehrstück zeigten, nicht einverstanden war, Gemeinsam mit Hindemith und dem wieder mitarbeitenden Burkard übernahm Schünemann die Leitung und die Organisation. Die Veranstaltungen Neue Musik Berlin 1930 fanden in der Musikhochschule statt. Die ihr angegliederte Rundfunk-Versuchstelle trug offiziell die Verantwortung.

Das erste Jahr in Berlin kann programmatisch als Fortsetzung der in Baden-Baden angestrebten Konzepte gesehen werden. Den neuen technischen Medien war ein Konzert mit Originalwerken für Schallplatte gewidmet. Es gab die Uraufführung des Rundfunk-Hörspiels Orpheus von Paul Dessau (Text: Robert Seitz, 1891-1938). Eine Veranstaltung galt Originalkompositionen für elektrische Instrumente. Den Schwerpunkt bildete die musikpädagogische Musik. Auf dem Programm standen Chöre für Liebhaber, die allerdings einige für Laien zu anspruchsvolle Werke enthielt, wie die späte Uraufführung von Strawinskys vier Frauenchören Russische Bauernlieder aus den Jahren 1914-17 sowie Volkslieder des gebürtigen Kroaten Josip Slavenski. Bei den Spielen und Liedern für Kinder erklangen u.a. Kinderchöre von Zoltan Kodály (1882-1967) sowie die Uraufführung von Hindemiths Wir bauen eine Stadt (Text: Seitz) mit dem Untertitel Spiel für Kinder, das noch heute bekannt ist.

10 Peter Andraschke, „Minutna opera ,Salome’ Slavka Osterca/Die Minutenoper, Salome' von Slavko Osterc", slowenisch/deutsch, in Slowenische Musik in Vergangenheit und Gegenwart. Slowenische Musiktage 1988. Sammelband der Vorträge (Ljubljana, 1992), S. 204-215. Ders., „Darius Milhauds ,opéras minutes’ - Komposition und Rezeption", in Geschichte und Dramaturgie des Operneinakters (Thurnauer Schriften zum Musiktheater, Bd. 10), (Laaber: Laaber Verlag, 1991), S. 337-345. 
Trotz der thematischen Kontinuität zu den Donaueschinger und $\mathrm{Ba}-$ den-Badener Musiktagen besaß die Veranstaltung in Berlin eine neue Ästhetik, die vom ursprünglichen Festivalcharakter abrücken wollte. So hieß es programmatisch:

„Die Veranstaltung trägt durchaus den Charakter einer Arbeitstagung, die (analog einer Materialprüfungsstelle in der Industrie) dazu da ist, neue künstlerische, technische und soziologische Ideen auf dem Gebiet musikalischer Arbeit auf ihre Verwertbarkeit im allgemeinen Musikleben zu untersuchen. “"

Eine Fortsetzung der Neuen Musik Berlin fand nicht statt. Die politische Situation in Deutschland begann sich zu verändern. Hitlers Machtergreifung Anfang 1933 bedeutete in seiner Einflußsphäre für die Künstler der Moderne aller Sparten ein Ende ihrer Arbeit. Viele wurden ins Exil gedrängt.

Es gab 1934 den Versuch der Stadt Donaueschingen, die Musiktage zurückzuholen, als eine „Wiedergeburt der Donaueschinger Musikfeste auf neuer Grundlage. ${ }^{(12}$ Man gewann den schwäbischen Komponisten Hugo Herrmann (1896-1967), der 1939 auch Mitglied der NSDAP wurde. Er beabsichtigte ein "den nationalsozialistischen Anschauungen entsprechendes Musikfest“", das „die frühere Tradition auf einer logischen Linie ${ }^{\text {(13 }_{3}}$ aufnehmen sollte. Diese Verbindung bedeutete für ihn als Musikpädagogen die Konzentration auf die Gemeinschafts- und Gebrauchsmusik. Allerdings waren die Prämissen jetzt andere. Das zeigen deutlich die Komponisten und ihre Texte, die sich unter bereits bekannten Themen wie Neue $\mathrm{Mu}$ sik für die Jugend, Neue Hausmusik, Neue Unterhaltungs- und Gebrauchsmusik versammelten. Beispielsweise begann das Eröffnungskonzert Neue deutsche Volksmusik der Musiktage 1934 mit Zwei Marschliedern mit Instrumenten für die HJ (Hitlerjugend) eines gewissen Alfons Schmid (19011979), gefolgt von der Straßenkantate für gleiche Stimmen mit Instrumenten und Sprecher nach dem Motto »Sei auch ein Träger dieser deutschen Tat" (Texte aus Reden von NS-Führern) von Karl Thieme (1909-2001, seit 1976 Kerstin Thieme). Erst nach dem Zweiten Weltkrieg wurden die neu gegründeten Donaueschinger Musiktage neben Darmstadt zu einem neuen und

11 Josef Häusler, Spiegel der Neuen Musik: Donaueschingen. Chronik - Tendenzen Werkbesprechungen (Kassel: Bärenreiter und Stuttgart/Weimar: J. B. Metzler, 1966),

S. 112.

12 Zitiert nach ebenda, S. 117.

13 Zitiert nach ebenda. 
einflußreichen Podium der Orientierung für die internationale musikalische Moderne und Avantgarde.

\section{Bibliographie}

Andraschke, Peter. „Minutna opera ,Salome’ Slavka Osterca/Die Minutenoper ,Salome' von Slavko Osterc“. In Slowenische Musik in Vergangenheit und Gegenwart. Slowenische Musiktage 1988. Sammelband der Vorträge, Ljubljana 1992, S. 204-215.

Andraschke, Peter. „Die Rezeption der Wiener Schule im ehemaligen Vorderösterreich am Beispiel von Freiburg i. Br. und Donaueschingen in den 1920er Jahren“. In Musikgeschichte in Mittel- und Osteuropa. Mitteilungen der internationalen Arbeitsgemeinschaft an der Universität Leipzig. Druck in Vorbereitung.

Erchmeyer, Arno/Eltz, Erwin H., Hrsg.. Die Fürstenberger. 800 Jahre Herrschaft und Kultur in Mitteleuropa. Niederösterreichische Landesausstellung, Schloß Weitra 1994 (Katalog des Niederösterreichischen Landesmuseums, Neue Folge Nr. 342). Korneuburg, 1994.

Häusler, Josef. Spiegel der Neuen Musik: Donaueschingen. Chronik - Tendenzen - Werkbesprechungen. Kassel: Bärenreiter und Stuttgart/Weimar, J. B. Metzler, 1966, S. 112.

Weill, Kurt. „Fünf Jahre ,Der deutsche Rundfunk'“. In: Ders., Stephen Hinton/ Jürgen Schebera, Hrsg.. Musik und Theater. Gesammelte Schriften. Berlin: Henschelverlag Kunst und Gesellschaft 1990, S. 274f. 


\title{
Sprechen und „Sprechgesang“
} als Ausdrucksform für sozialkritische Inhalte in der Musik der Zwischenkriegszeit

\author{
Hartmut Krones \\ Univerza za glasbo in upodabljajočo umetnost na Dunaju \\ University of Music and Performing Arts Vienna
}

Seit Schönbergs „Pierrot lunaire“ war der "Sprechgesang“ ein unorthodoxes Medium für unorthodoxe Inhalte, und eigentlich war er dies schon in Engelbert Humperdincks melodramatischer Märchen-Oper „Königskinder", in der eine Gänsemagd wegen des Hochmuts nicht nur der Ratsherren, sondern auch des gesamten Volkes nicht Königin werden kann, obwohl sich der Königssohn in sie verliebt hat. Genau genommen hatte aber bereits der Chor der griechischen Tragödie eine außerordentliche Funktion, die vor allem ethische, sozialkritische und somit politische Inhalte vermittelte; durch die Wucht seines dithyrambischen, wohl halb gesprochenen und halb gesungenen Rezitierens bzw. seines musikalisierten Sprechens griff er nicht selten gleichsam als „deus ex machina“ in die Handlung ein, entwirrte die Handlungsstränge, sprach Recht und sorgte für die moralische Katharsis schuldbeladener Personen.

Wir wollen nun die hier vor allem thematisierte Zwischenkriegszeit betrachten, müssen zunächst aber kurz in das Jahr 1912 blicken. Zwei Monate, bevor Arnold Schönberg seinen „Pierrot lunaire“ fertigstellte, veröffentlichte der Futurist Filippo Tommaso Marinetti (1876-1944) am 11. Mai 1912 sein „Manifesto tecnico della letteratura futurista“, dem er am 11. August noch ein „Supplemento al Manifesto [...]“ folgen ließ. Das Manifest forderte u. a. (hier in deutscher Übersetzung): 
„1. MAN MUSS DIE SYNTAX DADURCH ZERSTÖREN, DASS MAN DIE SUBSTANTIVE AUFS GERATEWOHL ANORDNET, SO WIE SIE ENTSTEHEN.

\section{MAN MUSS DAS VERB IM INFINITIV GEBRAUCHEN, damit es sich elastisch dem Substantiv anpaßt."}

Abschaffen mußte man nach Marinetti auch das Adjektiv, das Adverb und die Zeichensetzung, und außerdem sollte „JEDES SUBSTANTIV SEIN DOPPEL HABEN, dem es durch Analogie verbunden ist. Beispiel: Mann-Torpedoboot, Frau-Meerbusen [...]. “ (In der offensichtlich von Marinetti beeinflußten neuen deutschen Rechtschreibung würde man dieses Wort vielleicht wieder trennen: „Meer Busen“.)

Marinettis Mitstreiter Luigi Russolo (1885-1947) knüpfte dann direkt an dessen Überlegungen an und faßte seine Gedanken 1913 in seinem Manifest „L'arte dei rumori“ (Die Geräuschkunst) zusammen, das 1916 in das gleichnamige Buch Eingang fand; ich zitiere in deutscher Übersetzung:

„Es gibt in der Sprache einen Reichtum von Klängen, den kein Orchester besitzt. Die Natur hat dieses herrliche Instrument, die menschliche Sprache, mit abgestuften Geräuschen begabt, die in der Musik kein Gegenstück finden. Die Dichter haben aus dieser unversiegbaren Quelle der Geräusch-Klänge der Sprache [aber] nicht die Ausdrucks- und Erregungselemente ziehen können, die fähig gewesen wären, ihrer poetischen Sendung menschliche Resonanz zu geben."

Es ging also einerseits um die Zerstörung der herkömmlichen Sprache und deren Schreibweise, was bekanntlich nicht allgemein akzeptiert wurde, und andererseits um das Gewinnen neuer sprachlicher Ausdrucksbezirke, wie es dann Russolos oder Giacomo Ballas geräuschhaften stimmlichen Imitationen von Maschinengeräuschen gelang, wie es aber wenige Jahre später auch die Dadaisten vollzogen - etwa in der Gattung des „Poème simultan“, das Richard Huelsenbeck (1892-1974), Tristan Tzara (1896-

1 Filippo Tommaso Marinetti, „Technisches Manifest der futuristischen Literatur“, in: Umbro Apollonio, Der Futurismus. Manifeste und Dokumente einer künstlerischen Revolution (Köln: DuMont, 1972), S. 74f.

2 Diese Übersetzung des Russolo-Zitates findet sich in Raoul Hausmanns Aufsatz „Eidophonetische Morgenröte" aus den frühen 196oer Jahren. Zit. nach Karl Riha, $D a$ Dada da war ist Dada da (München-Wien: Hanser, 1980), S. 126. 
1963) und Marcel Janco (1895-1984) lasen, sangen, schluchzten, flüsterten, schrieen etc.:

„Das ist ein kontrapunktliches Rezitativ, in dem drei oder mehrere Stimmen gleichzeitig sprechen, singen, pfeifen oder dergleichen, so zwar, daß ihre Begegnungen den elegischen, lustigen oder bizarren Gehalt der Sache ausmachen. [...] Die Geräusche (ein minutenlang gezogenes rrrrr, oder Polterstöße oder Sirenengeheul und dergleichen) haben eine der Menschenstimme an Energie überlegene Existenz. [...] Das menschliche Organ vertritt die Seele [...]. Die Geräusche stellen den Hintergrund dar; das Unartikulierte, Fatale, Bestimmende. Das Gedicht will die Verschlungenheit des Menschen in den mechanistischen Prozeß verdeutlichen."

Und Hugo Ball, der erste Züricher Dadaist, beschrieb seine musikalisierte Vortrags-Manier, die später vor allem auch der in Berlin lebende gebürtige Wiener Raoul Hausmann in extremer Form anwandte, folgendermaßen:

„Da bemerkte ich, daß meine Stimme, der kein anderer Weg mehr blieb, die uralte Kadenz der priesterlichen Lamentation annahm [...] ich begann meine Vokalreihen rezitativartig im Kirchenstile zu singen. ${ }^{4}$

1919 - und wir sind jetzt in der Zwischenkriegszeit - erschien dann in Berlin aus der Feder von Rolf Sievers das „Musikalische Manifest dada“, das erstmals, vor allem angesichts der Vortragsweise(n) von Ball und Hausmann, ganz explizit auf die Musik rekurrierte und dabei das Idiom von Marinettis „Futuristischem Manifest" auf diese Kunstrichtung ausweitete:

„Weltrevolution dada knallt knallend gelbe Rolle auch in den Farbentaumeltanz der Töne, Musik. Darum sind wir so feierlich wie die alten Priester waren. [...] Aus Ofenröhren formt man den Kettenschrei brunftkranker Steinbaukästen [...].“6 ter, DADA - Kunst und Antikunst, 4. Auflage (Köln: DuMont, 1978), S. $28 f$. Ball, Die Flucht aus der Zeit, S. $99 f$.

5 Zu Filippo Tommaso Marinettis „Fondazione e Manifesto del Futurismo“ von 1909 siehe u. a. Richard Rubinig, „Die Lebensverwirklichung des Futurismus“, in: Otto Kolleritsch, Hrsg., „Der musikalische Futurismus“, Studien zur Wertungsforschung, Band 8 (Graz: Universal Edition, 1976), S. 78-91.

6 Zit. nach Riha, Da Dada da war ist Dada da, S. 55 f. 
In der Musik selbst führte die Verherrlichung von Geräusch und Lärm in erster Linie zu einem vermehrten Einsatz der Sprechstimme sowie zu ihrer Steigerung durch Schreie, Rufe, aber auch durch Flüstern und andere unorthoxe, bislang zumindest in der Kunstmusik nicht eingesetzte Lautgebungen. Der russisch-schweizerische Komponist Wladimir Vogel (1896-1984) etwa verfaßte 1922 „Drei Sprechlieder nach August Stramm“, die mitten in gesungene Worte hinein halbgesprochene Worte, ja einzelne Silben mit im Fünfliniensystem durchkreuzten Notenhälsen notierte, und dies vor allem bei extrem ausdrucksvollem Inhalt - z. B. in dem Lied „Untreu“ bei dem Text „Die glutverbissnen Lippen eisen“, wo „Die glutver-“ noch gesungen, „-bissnen“ dann aber auf Tonhöhe deklamiert wird (Abbildung 1). ${ }^{7}$ Vogel hat später selbst erklärt, daß nicht alle Texte, Wörter und Aussagen Musik benötigen, insbesondere aber solche, die nichts Musisches in sich bergen und vor allem einen logisch-realistischen Inhalt besitzen.

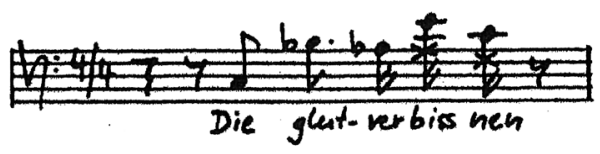

Abbildung I: Wladimir Vogel, „Untreu“.

Ab der Mitte der 1920er Jahre kreierte Vogel dann die Gattung des „Dramma oratorio“ mit seinen vielen Abstufungen zwischen Singen und Sprechen sowie mit verschiedenen Koppelungen der beiden Ausdrucksformen: 1926-1930 „Wagadus Untergang durch die Eitelkeit“, 1937-1939 „Thyl Claes I“ sowie 1943-1945 noch „Thyl Claes II“. Hier (Abbildung 2) arbeiten die „Sprechchöre“ mit drei (auf drei Linien notierten) Tonhöhen und exakten Rhythmen; Extreme erscheinen über bzw. unter das Dreiliniensystem gesetzt. ${ }^{8}$ Wichtig ist, daß die jeweiligen Inhalte der Worte adäquate Klangund Sprachfarben zugeteilt erhalten. In „Wagadus Untergang“ etwa wird dem Sprechchor sowohl eine Art „kultischer Kriegstanz“ als auch eine Anklage wegen Mordes überantwortet, in „Thyl Claes I“ der Bericht über die Plünderung Roms, weiters das „Charakterbild des habgierigen und grausamen Kaisers“, die Tierquälereien des 15jährigen Infanten Philipp, die Schilderung der Folterung einer „Hexe“ oder der Bericht von einem qualvollen

7 Friedrich Geiger, Die Dramma-Oratorien von Wladimir Vogel, 1896-1984 (Hamburg: Von Bockel, 1998), S. $216 f$.

8 Geiger, Die Dramma-Oratorien von Wladimir Vogel, 1896-1984, S. 226. 
Sterben; ${ }^{9}$ sie merken es: ein Freund der Aristokratie oder der Kirche war Vogel nicht.

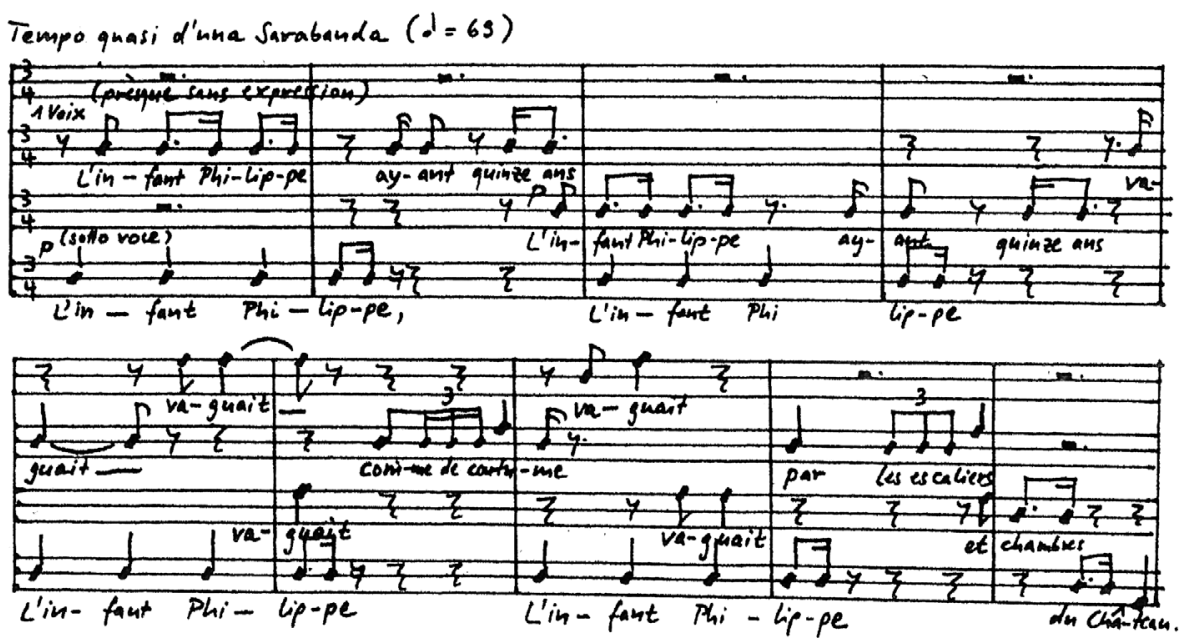

\section{Abbildung 2: Wladimir Vogel, „Thyl Claes II“.}

Und selbstverständlich setzte Vogel auch in politischen Liedern den Sprechchor vor allem für negative Inhalte ein, wie uns seine Komposition „Der heimliche Aufmarsch“ über Worte von Erich Weinert zeigt (Abbildung 3): „Es geht durch die Welt ein Geflüster, Arbeiter, hörst Du es nicht ? Das sind die Stimmen der Kriegsminister. Arbeiter, hörst Du es nicht ? ${ }^{\text {«io }}$

„Arbeiter, hörst Du es nicht ?" In den 1920er Jahren wurden in etlichen größeren Städten eigene Arbeiter-Sprechchöre gegründet, die manifestartige Kompositionen vortrugen. So berichtet die in Wien als „Organ des Reichsverbandes der Arbeitergesangvereine Deutschösterreichs“ erscheinende „Arbeiter=Sängerzeitung“ im Februar 1924 „Vom Allgemeinen Arbeiter=Bildungsinstitut in Leipzig" folgendes:

"Zwei Einrichtungen des Bildungsinstituts verdienen besondere Erwähnung. Die eine sind seine vier $K i$ nd e $r$ chöre (je einer im Osten, Norden, Westen und Süden der Stadt), die auch die beste Vorstufe für den Arbeitergesangverein bilden. Die andere ist der

9 Ebd., S. 93 f.

10 Hier wurde der Beginn des Werkes „Der heimliche Aufmarsch“ von Wladimir Vogel vorgespielt. 
„Der heimliche Aufmarsch gegen die Sowjetunion." „Тайный поход против Советского Союза“

Text: ERICH WEINERT.

MUSik: WLADIMIR VOGEL.
IIepesod X1. Ycoed.

С Мувњк ВЛАДИМИРА ФOTЕЛЯ.
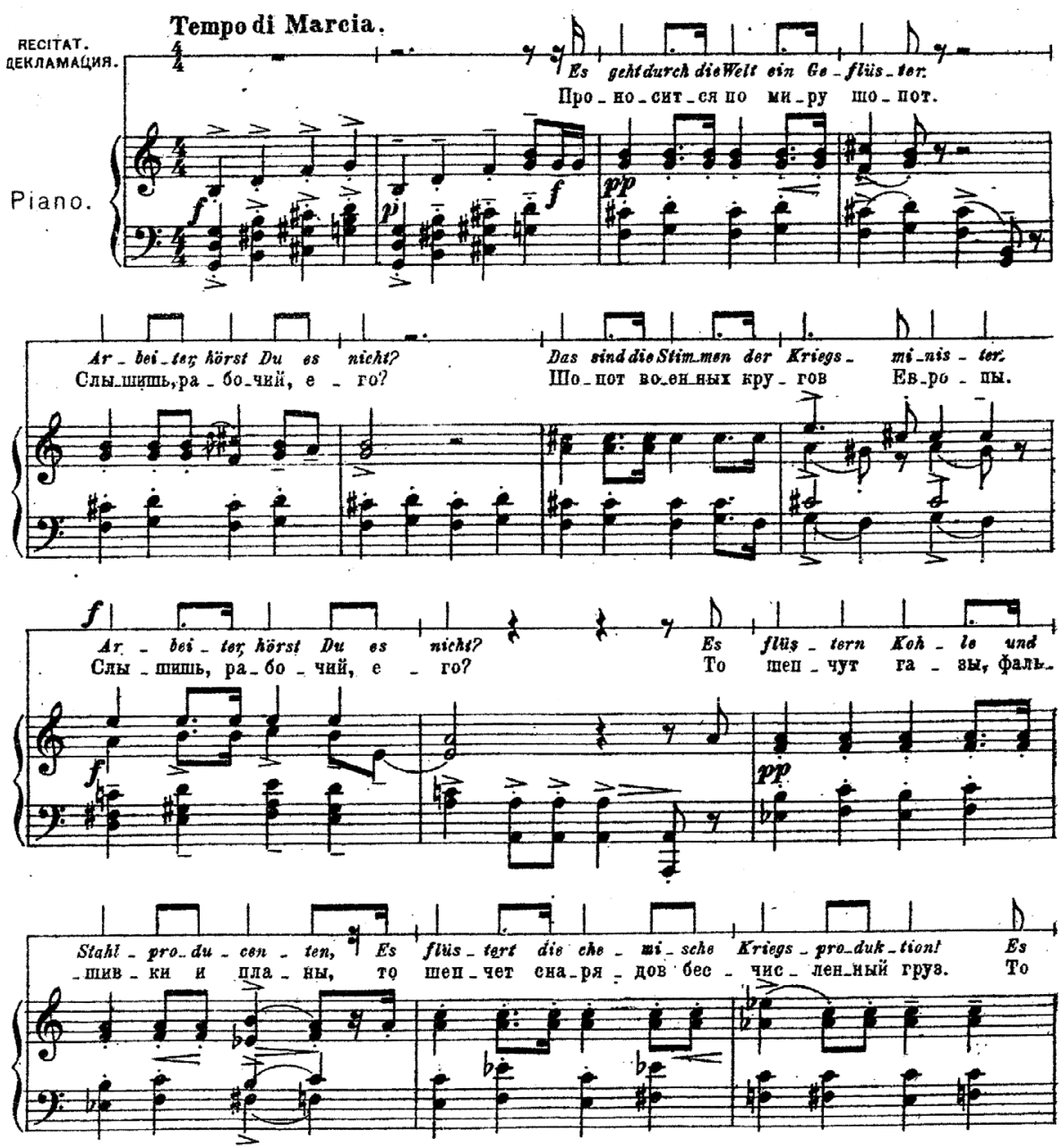

Abbildung 3: Wladimir Vogel, „Der heimliche Aufmarsch“. 
Sp rech chor. Das ist eine neue, seit dem Krieg emporgewachsene Kunstform der Arbeiterschaft, von einer unerhörten Wucht und Eindringlichkeit der Wirkung. Ein Sprechchorwerk ist etwas an Rang einem Schauspiel durchaus Gleichstehendes. Zutritt hat jedes Alter und jedes Geschlecht. Mit Hilfe des Sprechchors führt das ABI. [Arbeiter=Bildungsinstitut] eine neuartige Feier ein, die proletarischen Morgenfeiern, deren Aufgabe es ist, am Sonntag eine Stunde geistiger Erhebung und Sammlung den von der Wochenfron niedergedrückten Arbeitern zu geben. ${ }^{\text {"II }}$

1924 verfaßte auch die aus dem galizischen Wadowice stammende, seit 1885 in Deutschland lebende und seit 1923 in der „Roten Fahne“ publizierende Berta Lask das Werk „Die Toten rufen - Sprechchor zum Gedenken an Karl Liebknecht und Rosa Luxemburg“; sie emigrierte dann 1933 über Prag nach Moskau und kehrte 1953 in die DDR zurück, wo sie 1967 starb.

Und nach dem 1. Mai 1924, als der Sprechchor der sozialdemokratischen Kunststelle unter seiner Leiterin Elisa Karau Ernst Tollers „Tag des Proletariats" zu Gehör brachte, gelangten bald auch in den Wiener Arbeiter-Sinfoniekonzerten immer wieder Sprechchöre zur Aufführung; so im Rahmen der „Republikfeier“ vom 12. November 1925 der „Kerker“ von Fritz Rosenfeld. In Graz war an jenem Tag Ernst Fischers „Der ewige Rebell. Ein proletarisches Passionsspiel“ zu hören. In diesen Jahren entspann sich in den „linken“ Blättern auch eine rege Diskussion über das neue Genre, und Fritz Rosenfeld sah in ihm gar ein „Weihespiel bei Arbeiterfesten “'2. Ernst Fischer verfaßte 1927 ein „Rotes Requiem“, Fritz Rosenfeld 1928 „Die Stunde der Verbrüderung“, und ab 1925 schrieb auch Luitpold Stern regelmäßig „Kantaten“ für Sprechchor: „Die neue Stadt“ oder das „Klagenfurter Fakelspiel“.

Am 18. Jänner 1931 gelangte dann in einem Arbeiter-Sinfoniekonzert Edmund Nicks Gedichtmontage „Leben in unserer Zeit“ nach Texten Erich Kästners (für Soli, Sprechchor, Gesangschor, Tanztruppe und Jazzorchester) unter dem Dirigenten Paul Amadeus Pisk zur Aufführung, und am

11 [Red.], „Vom Allgemeinen Arbeiter=Bildungsinstitut in Leipzig“, in Arbeiter=Sängerzeitung. Organ des Reichsverbandes der Arbeitergesangvereine Deutschösterreichs XXIII (1924), Nr. 2 (Nr. 215), S. 3. Die Sperrungen sind original.

12 Jürgen Doll, „Sozialdemokratisches Theater im Wien der Zwischenkriegszeit. Vom Sprechchorwerk zu den Roten-Spieler-Szenen“, in Verdrängte Moderne - vergessene Avantgarde. Diskurskonstellationen zwischen Literatur, Theater, Kunst und Musik in Österreich 1918-1938, hrsg. von Primus-Heinz Kucher (Göttingen: V \& R unipress, 2016), S. 79-94, hier S. 80. 
19. März 1933 folgte Paul Amadeus Pisks „Campanella“ nach einem Gedicht von Josef Luitpold Stern. Es war dies jenes Konzert, bei dem auch Hanns Eislers „Das Lied vom Kampf“ nach Brecht erklang, ehe sich Eisler von Wien aus in die Emigration begab; Dirigent war Anton Webern, der durch seine Programmierung wahrscheinlich zu Eislers Retter wurde.

Auch in der traditionellen Gattung Oper hielten Sprechchöre ihren Einzug. Neben Schönbergs „Moses und Aron“ war dies vor allem die 1929 in Duisburg uraufgeführte Oper „Maschinist Hopkins ${ }^{\text {“(13 }}$ des Wieners Max Brand (1896-1980), der hier Sprechchöre einsetzte, um die starre Welt der Maschinen adäquat in Töne, besser: Geräusche fassen zu können. Hören wir in den Chor der Maschinen, die ihren Arbeitsrhythmus in motorisches Sprechen kleiden:

„Gelenke schwer, / Ganz ohne Wehr, / Erfüllt von Macht, / Die alles schaff, Sie folgen, folgen. // Und Tag für Tag / Schwingt jedes Rad, / Die Wellen laufen, / Kolben sausen, / Immerzu, immerzu. "“4

Besonders wichtig für unsere weiteren Betrachtungen werden jetzt zwei Schönberg-Schüler: Walter Gronostay und Hanns Eisler. Ersterer (19061937), der in Berlin neben Klavier auch Komposition bei Arnold Schönberg studierte und dann Korrepetitor am Deutschen Opernhaus war, feierte seinen ersten großen Erfolg 1928 in Baden-Baden mit seiner Kurzoper „In zehn Minuten“. Und 1932 schuf er für den Deutschen Arbeitersängerbund über Texte von Günther Weisenborn und Adolf Stemmle das Werk „Mann im Beton. Eine proletarische Ballade“ für Männerchor, Sprechchor, 7 Solosprecher, Lichtbilder und Blasorchester. (Gronostay vertonte 1936, obwohl er nie Mitglied der NSDAP war, die Olympiade-Dokumentationen „Jugend der Welt“ sowie Leni Riefenstahls „Olympia“.)

In seiner „proletarischen Ballade“ „Mann im Beton“ griff Gronostay das Problem der angesichts der Rationalisierungs-Maßnahmen unmenschlich gewordenen Arbeitswelt auf: Bruno Löwenberg äußerte sich dazu im Vorwort der Partitur folgendermaßen: „Dann kam das laufende Band; im-

13 Die „offizielle“ Handlung: Arbeiter \& Arbeiterin, Bill \& Nell, lieben sich, er klaut Betriebsgeheimnis und bringt dabei Vorarbeiter um, Aufstieg zum Wirtschaftsmagnaten, Maschinist Hopkins kommt der Sache auf die Spur, erpreßt Nell, sie gesteht Mord, Hopkins läßt sie fallen, sie landet in der Gosse, wird von Bill umgebracht, am Schluß ist Hopkins neuer Chef. Das Ganze geht flott dahin, Maschinen, Liebesszenen, Kabarett, ein gut gebautes, auf einem spannungsgeladenen Dreicksverhältnis basierendes Stück.

14 Hier wurde der „Chor der Maschinen“ aus Max Brands Oper „Maschinist Hopkins“ vorgespielt. 
mer stärker wurde mechanisiert und rationalisiert. [...] Immer schneller liefen die Maschinen, immer größer wurde die Produktion. Mit der Stoppuhr in der Hand überwachte der Betriebsleiter den Arbeitsgang. ,Bitte, seid Helden [der Arbeit], wenn ihr Zeit dazu habt ! Aber stört unseren Produktionsprozeß nicht!' Wo bliebe auch die Konkurrenzfähigkeit des Betriebes, wenn man sich mit Sentimentalitäten aufhielte. Freilich fallen Opfer. - Sie sinken an den Maschinen zusammen. Wenn sie noch sprechen, so sind ihre letzten Worte eine Anklage gegen dieses System, das sie mit mörderischem Tempo in den Tod treibt. ${ }^{\text {"1s }}$

Das Werk spielt in Amerika, der „Heimat des modernen Antreibesystems", und in diesem unmenschlichen Land wird der durch eine Unachtsamkeit im Beton eingeschlossene Hilfsarbeiter Jonny Miller von den Bauherren geopfert, um die rechtzeitige Sprengung eines Staudamms zu ermöglichen - er wird zum „Mann im Beton“. Auch viele seiner Kollegen tun nichts zu seiner Rettung; den zur Hilfe bereiten Arbeitern wird hingegen vorgegaukelt, daß sich Jonny Miller freiwillig opfert und so zum „Helden der Arbeit“ wird. Und man errichtet ihm nach der Sprengung ein Denkmal. Zum Höhepunkt wird der kurze Sprechchor „Hier trauern vereint zum ersten Mal Proletariat und Kapital“ (Abbildung 4), ehe die letzten Worte gesungen wiederholt werden. Im gesungenen Schlußchor hören wir dann die Anklage: „Er starb im Beton für Profit. “Und: „Es herrscht ein verdammtes System auf der Welt."

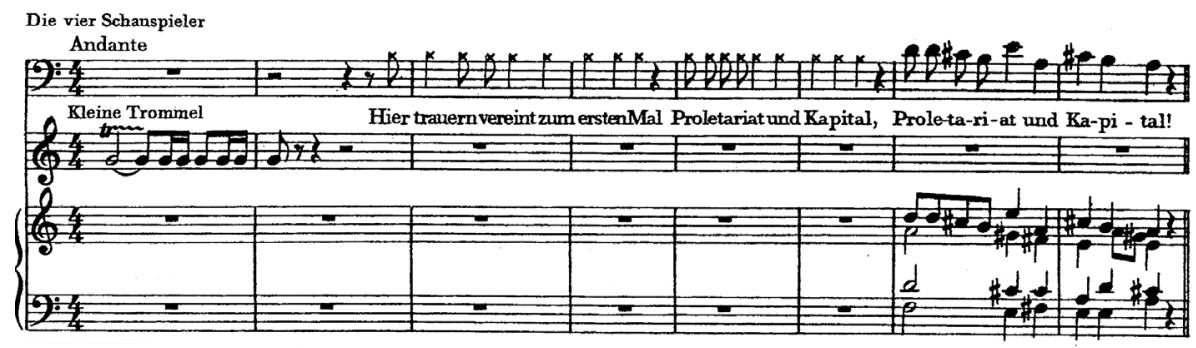

Abbildung 4: Walter Gronostay, aus „Mann im Beton“.

15 Bruno Löwenberg, „Mann im Beton“, in Mann im Beton. Eine proletarische Ballade, Text: Robert Adolf Stemmle und Günther Weisenborn, Musik: Walter Gronostay, Deutscher Arbeiter-Sängerbund. Berlin o. J., o. S.. 


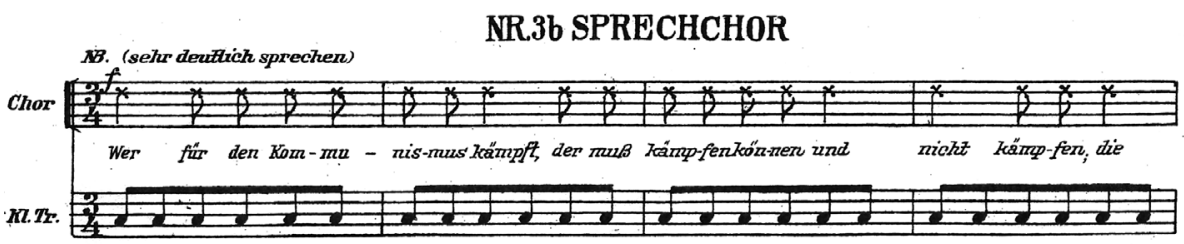

5

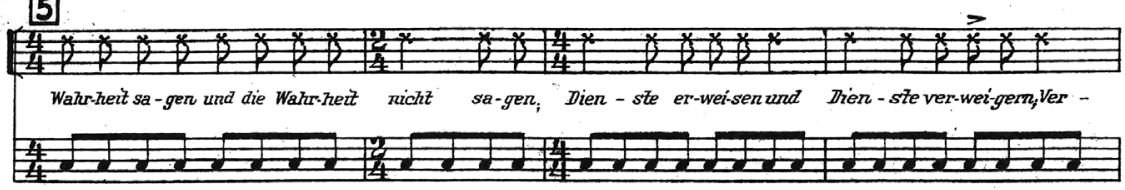

10

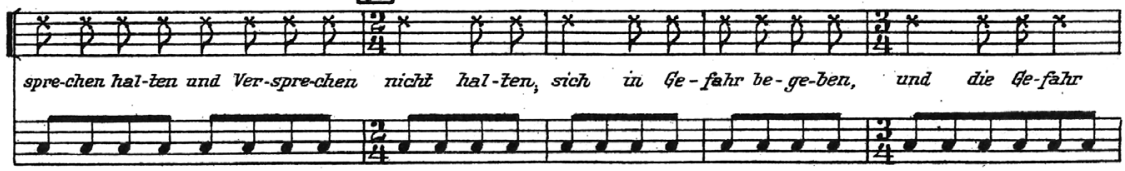

115

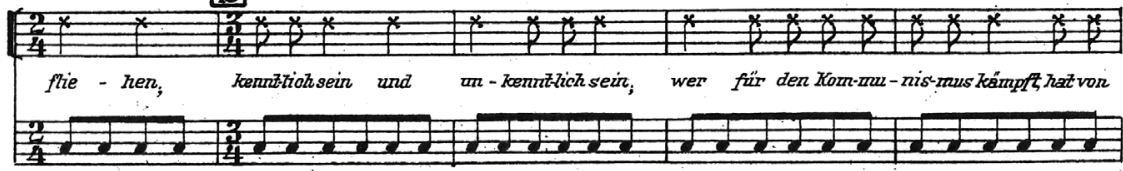

20
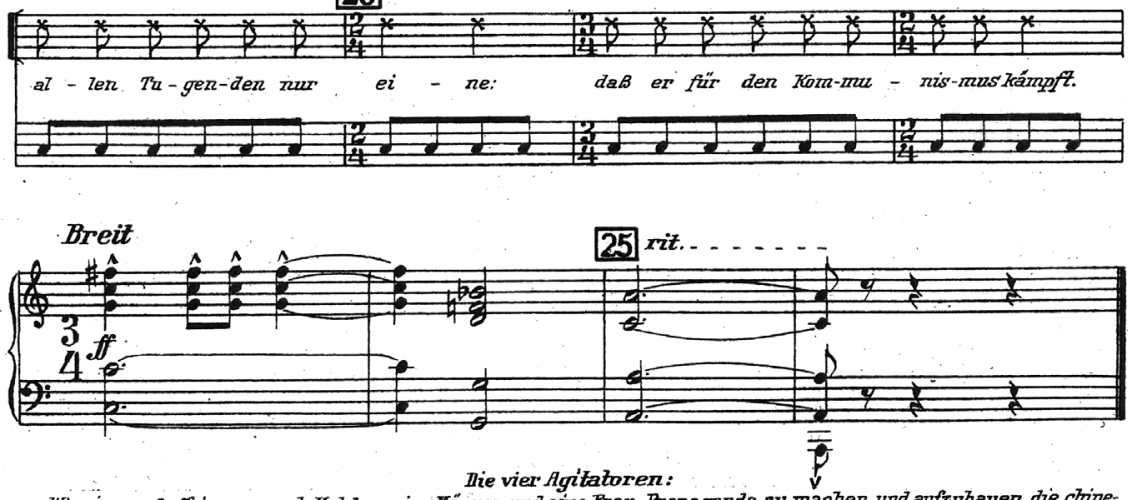

Wir gingen als Chimesen nach Mukzden, vier Mämer und eine Prau, Propaganda zu machen und aufunbauen die chinesische Partei durch die Lehre der Klassiker und der Propagandisten, das ABC des Kommumismus; den Ihwissenden Be

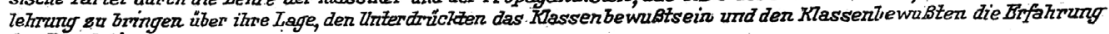
der Revalution.

NB. Das Tempo des Sprechchores ist etwa d =152 gedacht; es istjeitoch aufunbecingte Deuflichkeut der frissprache Rücksicht zu ruermen.

U. E. 2244

Abbildung 5: Hanns Eisler, „Wer für den Kommunismus kämpft“. 
Zutiefst politisch ist auch Hanns Eislers 1930 verfaßtes „Lehrstück“ über einen Text von Bert Brecht, „Die Maßnahme“, das auf dem ein Jahr zuvor geschriebenen Werk „Der Jasager“ basiert und eine chinesische kommunistische Zelle thematisiert. Einer von ihnen ist einverstanden, „sich [durch Selbstmord] aus der Gemeinschaft auszuschalten“, um diese vor ihren Verfolgern zu retten. „Zweck des Lehrstückes“ war es also, „politisch unrichtiges Verhalten zu zeigen und dadurch richtiges Verhalten zu lehren." Dabei wurden sowohl die "Agitatoren“ als auch das Parteigericht als „kommunistische Theoretiker“ gezeichnet, die ihre Ideologie ohne Rücksicht auf einzelne Menschen durchsetzen wollen und kein Mitleid mit ihnen empfinden.

Das wichtigste Element von Eislers Vertonung ist die dem Rhythmus der Sprache folgende rhythmische Gestaltung der Sing- und Sprechstimmen, deren Idiomatik den Kampfliedern des Komponisten nachgebildet ist. Hören wir in den gesprochenen „Kontrollchor“" „Wer für den Kommunismus kämpft“ (Abbildung 5), der den Kampf für den Kommunismus als "einzige" Tugend benennt. ${ }^{16}$

Interessant ist, wie sich in Österreich nach dem am 12. Februar 1934 von den Austro-Faschisten verhängten Verbot der sozialdemokratischen Partei und aller ihrer Unterorganisationen der Sprechchor als "linke“ Kunstform halten konnte. Prominent vertreten war hier u. a. der junge Pianist Karl Steiner, der 1938 einige Monate in Dachau inhaftiert war und Mai 1939 nach Shanghai emigrieren konnte; seine Eltern nachzuholen gelang ihm dann nicht mehr. Sein Vater starb noch in Wien an gebrochenem Herzen, die Mutter wurde 1942 in Auschwitz ermordet. (Ich habe vor 3 Jahren den Briefverkehr herausgegeben und Steiners Leben und Wirken ausführlich dargestellt. ${ }^{17}$ ) Steiner wurde noch vor dem 12. Februar 1934 - als Pianist wie als Komponist - in Kulturvereinigungen der Arbeiterbewegung tätig, vor allem in den Sprechchor-Veranstaltungen des Sozialdemokraten Karl Ibaschitz, der seine Gruppe „Sprechchor der freigewerkschaftlichen Angestelltenjugend“ nannte. Steiner schrieb u. a. die Musik zu dessen „Hiob“, einem „Oratorium für Fabrikarbeiter“, das Jänner 1934 erstmals zur Aufführung gelangte. Die „Arbeiter-Zeitung“ war unter dem Titel „Ein proletarisches Oratorium“ voll des Lobes und schrieb: „Hiob verkörpert den von den Glücksgütern der Erde Ausgeschlossenen, den Enterbten, den Prole-

16 Hier wurde der Sprechchor „Wer für den Kommunismus kämpft“ vorgespielt.

17 Hartmut Krones, Hrsg., „An: Karl Steiner, Shanghai. Briefe ins Exil an einen Pianisten der Wiener Schule“, Schriften des Wissenschaftszentrums Arnold Schönberg, Band 4 (Wien-Köln-Weimar: Böhlau, 2013). 
tarier. Seine Schicksale versinnbildlicht das Oratorium in packenden Szenen: Geburt in der trostlosen Armeleutewohnung, Lehre, Erniedrigung durch die Macht des Kapitals, aber auch erhebendes Solidaritätsbewußtsein, Glaube an die Zukunft des Arbeiters und Befreiung." Der Sprechchor war hier zudem auch als „Bewegungschor" eingesetzt. ${ }^{18}$

„Hiob“ wurde am 10. Februar (!) 1934 im „Bildungsverein Gartenstadt X.“ wiederholt und hier als „Ein Bild der Wirklichkeit aus den Leunawerken" angekündigt, welche Fabrik ja 13 Jahre zuvor schon von Berta Lask angeprangert wurde. - Nach dem 12. Februar konnte sich dann im „Volksheim Ottakring" unter dem Geschäftsführer Dr. Viktor Matejka eine freidenkerische Zelle bilden, die weiterhin liberales Gedankengut in künstlerische Produktionen einfließen ließ. Just der „Hiob“ brachte dann aber ein Ende dieser Aktivitäten mit sich, da eine Aufführung dieses „Oratoriums für Fabrikarbeiter" am 3. Juni 1936 zu einem Eklat und zur Absetzung Matejkas führte; Matejka behielt lediglich sein Amt als Bildungsreferent der Arbeiterkammer bei. ${ }^{19}$ (Nach 1945 war er bekanntlich einige Jahre Wiener Stadtrat für Kultur - einer der bislang wenigen guten.)

Trotzdem fanden - jetzt unter Titeln wie „Gemeinschaftsveranstaltung der Arbeiterschriftsteller" oder „Neue Arbeiter=Dichtung. Beiträge von Mitgliedern des österreichischen Arbeiter=Schriftsteller=Verbandes“ - weiter Abende mit „linken“ Sprechchören statt, von den Austrofaschisten immer mehr bedrängt und 1938 von den Nationalsozialisten endgültig verboten.

Der Vortrag darf nicht enden, ohne den berühmtesten Sprechchor jener Jahre, die „Fuge aus der Geographie“ (Abbildung 6) des Wieners Ernst Toch einzubeziehen. Es ist dies ein 1930 für die Berliner Festtage für zeitgenössische Musik aus geographischen Begriffen gebasteltes dadaistisches Szenario im besten Sinne, das von der konservativen Kritik sofort verteufelt wurde; bereits damals hing das Verdikt einer „entarteten Kunst“ in der Luft, das wenige Jahre später tatsächlich „offiziell“ ausgesprochen wurde und Ernst Toch ebenso wie Raoul Hausmann, Hanns Eisler, Wladimir Vogel und viele andere traf. Einer der erschrockensten „Spießbürger" war damals der Musikrezensent des „Berliner Tageblatt“, der später selbst zur Emigration gezwungene Alfred Einstein, der Tochs Werk exzessiv beschimpfte:

„Gute Musik, für die Schallplatte express geschrieben, kann ewig nur auf ihr reproduziert werden; also kann, schallplatteneige-

18 Arbeiter-Zeitung, 25. Jänner 1934, S. 8.

19 „Mitteilungen der Volkshochschule“, Wien Volksheim, 4. Mai 1936, S. 8. 


\section{FUGE AUS DER GEOGRAPHIE}

für sprechenden Chor

\section{Ernst Toch}
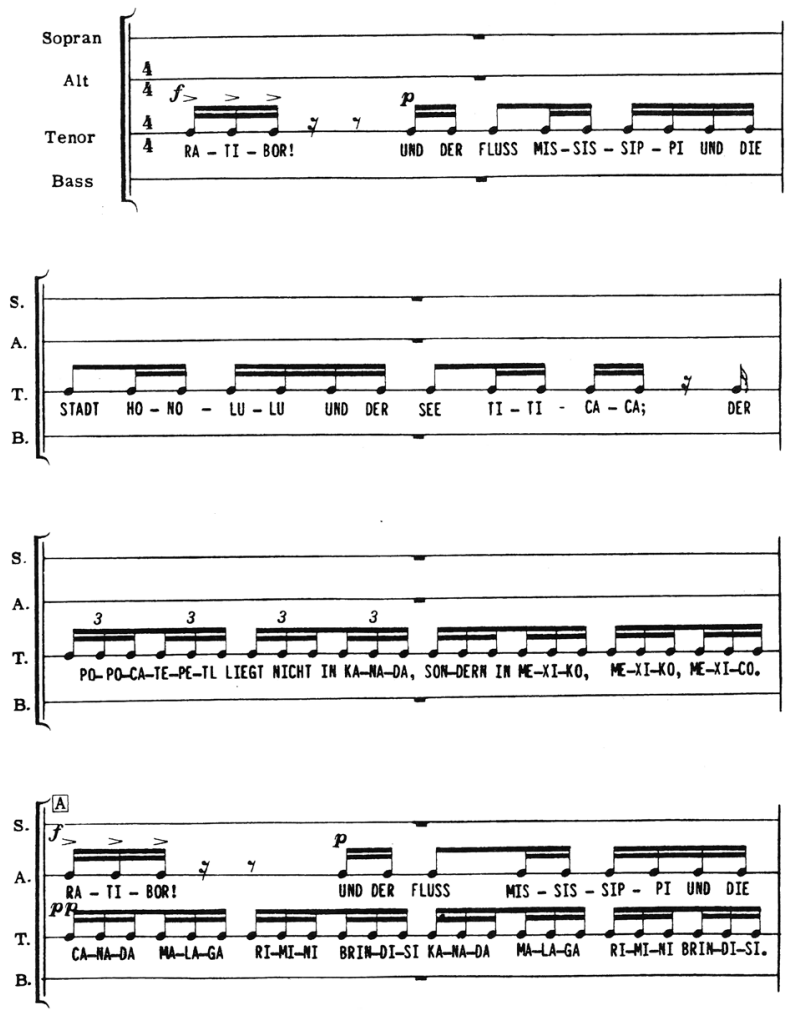

Abbildung 6: Ernst Toch, „Fuge aus der Geographie“.

ne' Musik nur Unmusik sein, akustisches Abfallprodukt, wie Toch ganz richtig sich ausdrückt, akustische Allotria. Toch lässt, einen vierstimmigen gemischten Kammerchor genau festgelegte Rhythmen, Vokale, Konsonanten, Silben und Worte so sprechen, dass [...] eine Art Instrumentalmusik entsteht . Das gibt ungefähr eine Mischung von Jazz und Hundegebell [...]."

Sie sehen, das Verdikt „entartete Kunst“ war schon vor dem Staatsrat Hans Severus Ziegler de facto vorhanden. Zu fürchten ist, daß wirklich

20 Alfred Einstein, „Neue Musik Berlin $1930 \mathrm{I}^{\prime}$, in Berliner Tageblatt und Handels-Zeitung 59, 285 (1930): S. 3. 
nur die Nazis die hochpolitische Dimension dieses Stücks verstanden, das heute leider sehr oft zum Ulk für Schul- und andere Chöre verkommt, obwohl es extrem politisch gemeint war; beginnt es doch mit dem Anfangsruf „Ratibor“, dem Namen einer schlesischen, damals deutschen Stadt, in der es 1930 angesichts der dort wohnenden polnischen Minderheit immer wieder Konflikte gab. Der Anfangsruf „Ratibor“ war somit semantisch eindeutig besetzt - als Synonym für Minderheitenprobleme bzw. für die (fallweise) Unterdrückung anderer Ethnien. Auch viele nachfolgende geographische Begriffe wie „Mississippi“, „Honolulu“ oder „Popocatepetl“ gemahnen deutlich an die Unterdrückung oder Ausrottung von Minderheiten oder gar nahezu der gesamten Urbevölkerung. „Athen“, die Wiege der Demokratie, wird gleichsam als Ostinato dagegengestellt. Und in der späteren englischen Version ist der eröffnende "geographische“ Beginn „Trinidad“ selbstverständlich ebenfalls unter diesem Aspekt zu sehen; gab es ja gerade in den 1940er Jahren in Trinidad ernste Auseinandersetzungen zwischen der weißen und der schwarzen Bevölkerung.

Alle, die diese Komposition auch heute noch als Ulk sehen, befinden sich in schlechter, sozusagen Einsteinscher Gesellschaft. Sie haben bis heute nicht die politische Dimension der Kunstform „Sprechchor“ verstanden, die auch den ungebildetsten Schulmusikern nahezubringen immer mein Anliegen war.

\section{Bibliographie}

Arbeiter-Zeitung. 25. Jänner 1934, S. 8.

Ball, Hugo. Die Flucht aus der Zeit. Luzern: J. Stocker, 1946, S. $79 f$.

Doll, Jürgen. „Sozialdemokratisches Theater im Wien der Zwischenkriegsze-

it. Vom Sprechchorwerk zu den Roten-Spieler-Szenen“. In Verdrängte Moderne - vergessene Avantgarde. Diskurskonstellationen zwischen Literatur, Theater, Kunst und Musik in Österreich 1918-1938. Hrsg. von Primus-Heinz Kucher. Göttingen: V \& R unipress, 2016, S. 79-94.

Einstein, Alfred. „Neue Musik Berlin 1930 I“. In Berliner Tageblatt und Handels-Zeitung 59, 285 (1930): S. 3.

Geiger, Friedrich. Die Dramma-Oratorien von Wladimir Vogel, 1896-1984. Hamburg: Von Bockel, 1998, S. $216 f$.

Krones, Hartmut, Hrsg.. „An: Karl Steiner, Shanghai. Briefe ins Exil an einen Pianisten der Wiener Schule“. Schriften des Wissenschaftszentrums Arnold Schönberg, Band 4. Wien-Köln-Weimar: Böhlau, 2013. 
Löwenberg, Bruno. „Mann im Beton“. In Mann im Beton. Eine proletarische Ballade. Text: Robert Adolf Stemmle und Günther Weisenborn. Musik: Walter Gronostay, Deutscher Arbeiter-Sängerbund. Berlin o. J., o. S..

Marinetti, Filippo Tommaso. „Technisches Manifest der futuristischen Literatur". In: Apollonio, Umbro. Der Futurismus. Manifeste und Dokumente einer künstlerischen Revolution. Köln: DuMont, 1972, S. 74f.

„Mitteilungen der Volkshochschule“. Wien Volksheim, 4. Mai 1936, S. 8.

[Red.]. „Vom Allgemeinen Arbeiter=Bildungsinstitut in Leipzig“. In Arbeiter=Sängerzeitung. Organ des Reichsverbandes der Arbeitergesangvereine Deutschösterreichs XXIII (1924), Nr. 2 (Nr. 215), S. 3. Die Sperrungen sind original.

Richter, Hans. DADA - Kunst und Antikunst. 4. Auflage. Köln: DuMont, 1978, S. $28 \mathrm{f}$.

Riha, Karl. Da Dada da war ist Dada da. München-Wien: Hanser, 1980, S. 126.

Rubinig, Richard. „Die Lebensverwirklichung des Futurismus“. In: Otto Kolleritsch, Hrsg.. „Der musikalische Futurismus“. Studien zur Wertungsforschung. Band 8. Graz: Universal Edition, 1976, S. 78-91. 

Ukrainische Komponistenschule in der Zwischenkriegsperiode des XX Jahrhunderts:

Zwischen Modernismus

und sozialistischem Realismus

\author{
Luba Kijanovska \\ Univerza v Lvovu \\ University of Lviv
}

Ukrainische professionelle Musik entwickelte sich in ziemlich komplizierten historischen und politischen Umständen, was in erster Reihe damit verbunden war, daß ethnische Gruppen von Ukrainern binnen mehrerer Jahrhunderte in verschiedenen Ländern und Staaten wohnten. Deswegen dient Kultur als ein unerlässlicher Teil des nationalen Identitätsbewusstseins, insofern benutzten Ukrainer - als staatsloses Volk - die Folklore und professionelle Kunst für Bewahrung und Unterstützung nationale Traditionen. Deswegen - ähnlich wie in anderen staatslosen Ethnien ${ }^{1}$ - bevorzugten ukrainischen Komponisten des XIX Jahrhunderts solche demokratischen Gattungen, wie Chor- oder Sololieder, wie auch die Oper, die als Manifestation der Nationalgeschichte und patriotischen Gefühlen diente. Als Kanon des Stils wurde die Romantik mit ihrer Poetisierung der Volkskunst angesehen.

Im XX. Jahrhundert, nach dem Ersten Weltkrieg und nach der Niederlage der Ukraine im Kampf für die Unabhängigkeit ihres Staates, in der Zwischenkriegsperiode verteilten sich die Ukrainer in folgender Weise: einen größten Teil, etwa 30 Mio. Einwohner des östlichen Teils, also, der sog.

1 Das besondere Interesse zur nationalen Kunst als wirksames Mittel des nationalen Bewusstseins merkt man auch in Slowenien, worüber Primož Kuret in seinem Artikel „Slowenien und seine Musikkultur“ schreibt: „Mit der Zeitschrift Novi akordi (1902-1913) erreichte auch slowenische Musik einen Aufschwung, wo konnten sich schon einige slowenische Komponisten profilieren“. Er erwähnte auch Fran Gerbicz, der aus Lemberg aus patriotischen Gründe nach Slowenien zurückkehrte. 
"Großen Ukraine ${ }^{\alpha_{2}}$, nach dem Zerfall des Russischen Imperiums blieben in der UdSSR und bildeten Ukrainische Sowjetische Sozialistische Republik; nach dem Zerfall des Habsburger Imperiums in den neuentstandenen Staaten wohnten 5, 6 Mio. im Polen, im II Rzecz Pospolita, etwa 790 Tausend - in rumänischer Bukowina, in hinterkarpatischen Erden, die damals zur Tschechoslowakei gehörten, lebten 725 Tausend Ukrainer².

Diese geographische Präzisierung scheint für darlegenden Vortrag wichtig, weil der Erklärung gewisser Spezifik nationaler Musikkunst in verschiedenen sozialpolitischen Umständen, d. h. in verschiedenen Staaten, dient.

Man könnte scheinen, solche Situation sollte zu tiefer Krise auch in der Kunst führen. Doch tatsächlich beobachtet man die ganz entgegengesetzten Prozesse, als erwartet: die ukrainische Komponistenschule begann in den 10-en - 20-en Jahren des XX. Jahrhunderts erfolgreich in den europäischen Kulturraum zu integrieren. Es merkt man entweder in Kyiv, Charkiv, Odessa, oder in Lviv und Tschernowitz. In diesen Jahren gestaltete sich ein eigenartiges ukrainisches Modern, der danach in den Modernismus umgestaltet wurde ${ }^{4}$. In Rahmen des kürzen Überblicks wäre nicht möglich, ausführliche Charakteristik entweder des Modernes oder des Modernismus in ihrer ukrainischen Dimension zu entfalten. Dadurch skizziert man nur die wichtigsten Richtlinien neuer ästhetischen Tendenzen in der Ukraine, wie auch ihrem historischen Schicksal.

Das Modern als eine Stilrichtung Fin de siècle korrespondierte ideal mit den Absichten junger ukrainischer Künstler. Über diese Absichten schreibt die Forscherin des ukrainischen Modernes Maria Karalus:

„Wenn man damals herrschende weltanschauliche Prinzipien vereinfachen und schematisieren könnte, denn bestätigt man, dass zwei Prinzipien als grundlegende sich etablierten: eigenartiger musikalischer Nationalismus und gleichzeitig die Strebung zur volllung (Moskau: Nauka, 2006). [Кабузан В. М., Украинцы в мире. Динамика численности и расселения.] 304. [Світлична В.В., Історія України. Навч. Посібник.] 
wertigen Funktionierung im System musikalischer Weltkultur, zum Eintritt in den Kontext Weltkultur".'

Dieselbe Forscherin betont, dass das Modern erfolgreich verschiedene seine nationalen Versionen inspirierte.

„Seine russische Variante stützt meistens auf den Akademismus, österreichischer Jugendstil entsteht als gewisse Übertreibung mancher romantischen Züge, polnische Sezession neigt vorzugsweise zum Impressionismus, letztendlich ukrainisches Modern erscheint in intensiver Suche nach dem Nationalstil. "

Aber, wie obenerwähnt, bildeten ukrainische Künstler zu dieser Zeit kein homogenes Milieu. Z. B. Kiever oder Odessaer Künstler stützten in der Gestaltung eigenes nationalen Stils auf russische Vorbilder. „Mehrere Fakten zeugen von der Aneignung russischer Einflüsse, die auf verschiedenen Ebenen sich realisierten... Das Modern der ersten Welle sprach meistens Russisch“7 In bildender Kunst als Vorbild diente die Ästhetik russischer Gruppe „Welt der Kunst“ (Мир искусства) ${ }^{8}$; in der Musik ukrainischer Modernisten wie Jakiv Stepowyj, Lewko Rewutskyj oder Wiktor Kossenko merkt man einen wesentlichen Einfluß von Aleksandr Skrjabin. Ausgesuchte koloristische Harmonie, die der klassischen Tonalität entgeht, räumliche Entgrenzung der Faktur, expressive melodische Wellen - alle diese ausdrucksvolle Mittel der Musik sind in ihren Klavierstücken und Liedern zu beobachten, nach dem Skrjabins Muster angenommen und mit den typischen ukrainischen Liedintonationen bereichert. Instrumentale und vokale Miniaturen nehmen eine führende Stellung in ihrem Schaffen ein, vermutlich wegen ihrer sinnlichen Plastizität, ihrer differenzierten Palette der Gefühle und Stimmungen, aber auch wegen der breiteren Möglichkeiten, die Miniaturen im Sinne der Interpretation vorschlagen.

5 Maria Karalus, „Stilistische Dominanten in ukrainischer Kunst“, in Kunstwissenschaftliche Studien 31, 3 (2010): 68. [Марія Каралюс, „Стильові домінанти модерну в українському мистецтві“, В Студії мистецтвознавчі.]

6 Karalus, „Stilistische Dominanten in ukrainischer Kunst“, 68

7 Maja Rzewska, „Musik der Ukraine bei Dnepr in erster Drittel des XX. Jahrhunderts in der Wechselwirkung und in der Umgestaltung der soziokulturellen Diskursen“, Referat der Habilitationsarbeit (Nationale Musikakademie Petro Tschaikowsky Kyiv, 2006), 9. [Ржевська Майя Юріївна, Музика Наддніпрянської України першої третини XX століття у взаємодії та перетвореннях соціокультурних дискурсів: автореф. дис... д-ра мистецтвознавства.]

8 Es war teilweise noch damit verbunden, dass manche Vertreter des russischen Modernes - z. B. die Maler Wiktor Wasnjetsow oder Michail Wrubel - wirkten in der Ukraine und ließen hier ihre bedeutende Fresken und Bilder. 
Etwas andere Prioritäten hatte das Modern in Galizien und Bukowina, damals ein Teil des Habsburg-Imperiums. Hier orientierten sich die Künstler vielmehr auf Wiener Sezession in allen Kunstarten - von der Architektur bis angewandte Kunst -und schon zu diesem Muster eigene nationale Ausdrucksformen und Mittel angepasst. Die Sezession in der Architektur und darstellenden Kunst entwickelte sich in origineller örtlicher Form, mit den Elementen karpatscher Volksarchitektur ${ }^{9}$ bereichert, die in den gegenwärtigen Forschungen als „huzulische Sezession“ bestimmt ist. Diese eigenartige ästhetische Kreuzung des Wiener Musters und eigentümlicher Traditionen entstand zuerst in der Architektur, dann überging in die Malerei und angewandte Kunst, eroberte allmählich auch die Musik.

Meistenteils studierten führende ukrainische Komponisten Galiziens dieser Zeit in großen europäischen Zentren, bei den berühmten Pädagogen: Stanislaw Ludkewytsch - bei Aleksander Zemlinski in Wien, Wassyl Barwinskyj, Nestor Nyshankiwskyj und Mykola Kolessa - bei Vítězslav Novák, in Prag. Deswegen erlebten die Komponisten persönlich die Eindrücke von den Aufführungen solchen prominenten österreichischen Komponisten, die auch die Elemente der Sezession eigenartig in ihrem Schaffen verwandten, wie Gustav Mahler, Richard Strauß oder Aleksander Zemlinski ${ }^{10}$. Mahler und Strauß gastierten als Dirigenten persönlich in Lemberg, ihre Werke sind oft hier aufgeführt, denn natürlicherweise gestalteten sie die Geschmacke und ästhetische Dominanten junger Generation von Musiker.

Die Wechselwirkung von „Nationalen - Alleuropäischen (in seiner österreichischen Dimension) "verläuft bei jedem Komponisten verschiedenartig. So, z. B. bei Nestor Nyshankiwskyj trat ein Spiel mit den kontrastierenden Stilarten schon in der der Wahl von Gattungen hervor: „Kleine Suite“ mit dem rein romantischen Programm „Briefe an Sie“ benachbart mit dem Barock-Zyklus Präludium und Fuge, die rein spätromantische „Improvisation" - mit dem sentimentalen Walzer auf Biedermeier-Art. Seine Gestalte sind nicht tief und dramatisch, der Komponist zog den dünnen, feinen Emp-

9 D.h. die Gebäuden, welche in den Karpatengebirgen gebaut und mit den eigentümlichen Ornamenten und Holzschnitzerei dekoriert wurden. Sieh dazu: Jurij Birjulow, Die Kunst Lviver Sezession (Lviv: Zentr Ewropy, 2005). [Бірюльов Ю. Мистецтво львівської сецесії.]

Sieh dazu: Roman Stelmaschtschuk, „Modernistische Tendenzen im Schaffen ukrainischer Komponisten 20-er - 30-er Jahre des XX Jahrhunderts“, Referat der Doktordissertation, (Kyiv, IMFE NAN der Ukraine, 2003) [Стельмащук Роман, Модерністичні тенденції у творчості українських композиторів Львова 20-Х-30-х pp. XX ст.: естетичні та стильові ознаки в контексті епохи. автореф. дис. ... канд. Мистецтв.] 
findungen, den farbreichen Bildern aus der Natur vor. In den besten seinen Klavierwerken konnte der Autor die feinen Nuancen delikaten Stimmungen zum Ausdruck bringen, repräsentierte die interessante Beziehung der impressionistischen Tonmalerei zu den melodischen Volksmotiven, vereinigte die einzelnen ausdrucksvollen Zeichen der Stile, die weit voneinander entfernt sind. Die Sezession mit ihren grellen Tonen und konstruktiven Zusammenhängen von Elementen entsprach völlig seinem Kunstgeschmack. Die Strebung des Komponisten zu den reichen dekorativen „Musikschmücken“ und äußeren Interpretationseffekten, zu den Programmerklärungen zeugte von seiner Nähe zu den gegenwärtigen ästhetischen Prinzipien ${ }^{11}$.

Im Gegensatz zum Nyshankiwskyj, pflegte Mykola Kolessa vielmehr typische „huzulische“ Elemente - die Gattungsformeln des huzulischen Tanzes „Kolomyjka“, sog. „huzulische Tonart“: Moll mit den hohen IV und VI Stufen, scharfe synkopierte Rhythmen etc. Der Komponist führte alle diese „huzulische“ Ausdruckselemente aufgrund der neuen kompositorischen Technik, deswegen sind sie so frisch und originell wahrgenommen.

Wenn das Modern wurde durch die ukrainischen Kunstmilieus am Ost und West wegen der verschiedenen Anziehungszentren (Petersburg Wien) eigenartig transformiert, aber immer als Resultat freier Wahl jedes Künstlers, ganz anders hat das Schicksal des Modernismus zusammengestellt. Eigentlich ist schon die Kategorie von Modernismus ziemlich mehrdeutig und flexibel. Die Forscherin des ukrainischen literarischen Modernismus, Solomia Pawlytschko bemerkte vortrefflich: „Der Modernismus enthält in sich mehr Paradoxen (als andere Stile und Stilrichtungen - L.K.), ist nicht den strikten Definitionen unterworfen, und darüber hinaus hat eine grundlegende nationale Unterschiede ${ }^{\mathrm{\alpha}_{12}}$.

Der spezifische ukrainische Modernismus stieß auf noch ein Hindernis: er hatte fast keine Voraussetzungen in den früheren Perioden, im Gegenteil, die vorherherrschende volkstümliche Ideologie mit ihren realistischen „Bildern aus der Natur“, der Beschreibung des Leidens armer Bauer hatte wenig mit dem Modernismus zu tun. Denn - wieder nach Solomia Pawlytschko -

11 Igor Sonewytskyj, „Das kompositorische Erbe von Nestor Nyshankiwskyj“, in Nachrichten der Wissenschaftlicher Gesellschaft „Taras Schewtschenko, Band CCXXVI: Forschungen der Musikwissenschaftlichen Kommission. (Lviv, 1993) 334. [Соневицький I. Композиторська спадщина Нестора Нижанківського В: Записки НТШ, Т. СCXXVI: Праці Музикознавчої комісії (Львів, 1993) 334].

12 Solomia Pawlytschko Der Diskurs des Modernismus in der ukrainischen Literatur, 2 Aufl. (Kyiv: Lybid', 1999), 32. [Павличко Соломія. Дискурс модернізму в українській літературі, 2-ге вид. (К.: Либідь, 1999), 32] 
„der allgemeine Diskurs des Modernismus enthält eine Reihe von separaten Diskursen; der Europäismus (so eine buchstäbliche Übersetzung - L.K.) oder westeuropäische Orientierung (insofern der Modernismus als ein intellektuelles System immer nach Westen orientiert ist), die Gegenwart (weil der Modernismus bezieht sich in erster Linie auf die aktuelle Zeit), der Intellektualismus, die Gegen-Volkstümlichkeit, der Individualismus, der Feminismus, die Entfernung der kulturellen Tabus, vor allem in der Sexualität, die Dekanonisierung, der Formalismus in der Kritik und Interesse an den formalen Teil der Kunstwerke, usw. ${ }^{{ }_{113}}$

Aber paradoxalerweise kommen dieselbe Modernisten ganz schnell $\mathrm{zu}$ solchem Punkt, den sie so sorgfältig vermeiden wollten, d. h. zu Folklore:

„Die volkstümliche Kultur als eine traditionelle, von grundlegender Bedeutung, zentrale als Symbol der Ukrainer beeinflusste bald theoretisierende Sprache von Modernisten. Dies beweist einfach das Niveau der Intertextualität. Einige Texte sind fast als modernistische Collagen volkstümlicher Sprache und volkstümlicher Ideen wahrgenommen" " ${ }^{14}$

Diese Konsequenzen zieht die Forscherin aus der ukrainischen modernistischen Literatur jener Zeit. In gewissem Sinne betrifft solche Charakteristik auch ukrainische bildende Kunst, wovon vor allem die sog. „Schule von Mychajlo Bojtschuk“ zeugt. Mychajlo Bojtschuk selbst, obwohl aus der armen Bauernfamilie stammte, besaß eine fundamentale Ausbildung: studierte an Wiener Akademie der Kunst, dann bei Leon Wytschulkowski (Wyczulkowski) an Krakauer Akademie der Kunst, später noch in München und Paris. Tiefe gründliche Erlernung mehrer europäischen Stilen und dabei die Faszination für alte nationale Kunsttraditionen (entweder christliche Ikonen oder sog. „primitive“ Volksmalerei) führte den Bojtschuk zu ihrer Synthese, als Ergebnis gestaltete er neue modernistische Kunstrichtung, den Neubysantinismus. Diesen Name gab dem Stil von Bojtschuk und seinen Nachfolgern der berühmte Dichter Guillaume Apollinaire nach der Ausstellung in Paris im Jahr 1907. Dieser kollektiver Stil (weil Bojtschuk den Prinzip des kollektiven Schaffens erklärte und auf diesem Grund eigene Schule formierte) synthesierte die Elemente byzantini-

13 Vgl. ebd., 36.

14 Vgl. ebd.. 
scher Ikonen, der Fresken des italienschen frühen Renaissance mit den innovativen künstlerischen Ausdrucksmitteln. Also, in irgendeiner Kunstart knüpfte unentbehrlich jede komplizierte innovative Ausdruckstechnik an ukrainische Folklore, oft an seine archaische Schichten, an.

Solche Treue den nationalen Traditionen geriet in Kollision mit den wichtigsten Merkmalen des Modernismus „Charakteristische Eigenschaft des Modernismus besteht darin, das der Prozeß überwiegt über die Beständigkeit und Stabilität, es bedeutet der Mangel an endgültige Festigkeit, Völligkeit, Bestimmtheit modernistischer Erscheinungen. Das ist mit dem Wesen des Modernismus verbunden, der in ständiger Bewegung, in den Suchen verblieb. Als „objektiver Ausdruck der Aktualität des Zeitgeistes“ der Modernismus könnte keine Festigkeit erwerben, seine ständige Bewegung aufhören, dementsprechend bleibt als ein „unvollendetes Projekt ${ }^{\text {“15 }}$.

Es ist gültig auch für die nationale Musikkunst. Der Modernismus als besonderes Phänomen in der Entwicklung der ukrainischen Musik der ersten Hälfte des 20. Jahrhunderts gestaltete vom Anfang an als eine widersprüchliche Erscheinung: einerseits, strebten manche Musiker, die sich als Modernisten halten, zur Deideologisierung nationaler Kultur, also, setzten die Prioritäten des „Allgemein-Verständlichen, Universalen“ im Gegenteil zu den früheren Idealen „National-Bestimmten“ auf allen Ebenen. Davon zeugt z. B. seltener getroffene Thematik der Musikwerke, wie Bibelsagen, phantastische Allegorien, antike Fabeln - oder ganz konstruktive „progressiv-außermenschliche“ Inhalte, die symbolisch vieldeutig interpretieren sind.

Wie hat ein Vertreter des ukrainischen musikalischen Modernismus Borys Janowskyj (Janowskyj war sein Pseudonym, eigene Familienname Siegl, Deutsche von Herkunft), der neue künstlerische Denkensart etwa von 1907 manifestierte, in seiner Selbstbiographie im Jahr 1927 geschrieben:

„Ich lebte die ganze Zeit in der Ukraine, ukrainische Lieder kannte ich und liebte. Aber mein Kunstverständnis wurde geändert. Ich habe verstanden, dass alte Oper vorbei ist, man braucht etwas Neues, man braucht irgendeine besondere Einstellung. Ich wandte die Aufmerksamkeit auf den Maeterlinck, der auch ganz und gar alte Traditionen abneigte. Mich entzückte seine "Schwester Beatrix“ (Soeur Béatrice). Ohne Zeit zu verlieren, schrieb ich nach diesem

15 Rzewska, „Musik der Ukraine bei Dnepr in erster Drittel des XX. Jahrhunderts in der Wechselwirkung und in der Umgestaltung der soziokulturellen Diskursen“, 8. 
Sujet die Oper, die 1907 in Kyiv aufgeführt wurde. Nach der „Beatrix" schufich noch die Oper "Sulamith" und "Kolombine“.

In diesem kurzen Fragment sind alle Voraussetzungen und Richtlinien der schöpferischen Umgestaltung mehrerer ukrainischer Modernisten klar skizziert. Es könnte man schematisch darstellen:

Volkslied als musikalischer Grundsatz - Änderung eines ästhetischen Bewusstseins - Faszination für die nicht-traditionellen Ideen

- ihre Verkörperung im Schaffen

Der Zwiespalt dieses schönen Schemas mit realen künstlerischen Resultaten besteht darin, dass diese in lange Schublade verschobene musikalische Volksschicht viel fester im Bewusstsein (oder Unterbewusstsein) eingewurzelt wurde, als es auf ersten Blick schien. Denn niemand, wer in der ukrainischer Musikkultur zum Modernismus strebte und als solchen sich hielt, vermied den irgendeinen Einfluß des Volksliedsgutes. Außer Borys Janowskyj, gehörten zu modernistischer Kohorte Fedir Jakymenko, Mychajlo Werykiwskyj, teilweise - obenerwähnter im Kontext von Moderne Lewko Rewutskyj in Großer Ukraine, Mykola Kolessa und Stefania Turkewytsch-Lukijanowytsch, teilweise Wassyl Barwinskyj, Antin Rudnyckyj und Zynowij Lyssko - in ukrainischem Milieu Galiziens ${ }^{17}$.

Oft haben die Komponisten entweder in Großer Ukraine oder in Galizien verschiedene Innovationen des modernistischen Ausdruckssystems auf den folkloristischen Elementen ausprobiert, was besonders in Bearbeitungen der Volkslieder - in der Gattung, die für jeden Modernisten trotz den allen universalen Idealen, wichtig bleibt - zu merken ist. Denn voll und ganz gerechtfertigt bestätigt man in den musikwissenschaftlichen Forschungen, diesem Thema gewidmet: „im Großen und Ganzen erwies sich der Modernismus in der ukrainischen Musikkultur erster Drittel des XX Jahrhunderts nicht auf der Ebene des ganzheitlichen Diskurses, aber in der Haltung der einzelnen Komponisten ${ }^{\mathrm{cs}_{1} 8}$.

16 Borys Karlowytsch Janowskyj, „Selbstbiographie“, in Musik: Almanach der Musikkultur nr. 5-6 (1927): 54. [Борис Карлович Яновський “Автобіографія”. В: Музика, двохмісячник музичної культури.]

17 In polnischem musikalischem Milieu war der ausdrucksvollste Vertreter des Modernismus Joseph Koffler, Anhänger von Arnold Schönberg.

18 Myroslava Nowakowytsch, „Kanon des ukrainischen musikalischen Modernismus im Schaffen von Borys Latoschynskyj“, Referat der Doktordissertation, (Lviver Nationale Musikakademie „Mykola Lyssenko“, Lviv, 2008). [Новакович Мирослава. Канон українського музичного модернізму в творчості Бориса Ляточинського: автореф. дис... канд. Мистецтвознавства.] 
Sie alle - jeder nach Möglichkeit und dem Maß des Talents - berücksichtigten neuste stilistische Kunstströmungen und adaptierten zu eigener Weltanschauung, zu den nationalen Traditionen. Die Transformation der aktuellen modernistischen Richtungen fand ziemlich punktuell statt. Manche Neuigkeiten wurden als solche, welche nicht den wichtigsten mentalen geistigen Gründen angepasst schienen, abgelehnt, obwohl den jungen Komponisten gut bekannt waren.

So, z.B. sind nicht speziell beliebt, d. h. in dem Schaffen ukrainischer Modernisten transformiert folgende modernistische Tendenzen: der Expressionismus, Urbanismus, Konstruktivismus, die Ästhetik „Neuer Sachlichkeit“, Fovismus usw., also, in Allgemeinen diese ästhetisch-stilistische Richtungen in Rahmen des Modernismus, welche etwas Hässliches, Ordinäres, Alltägliches, massenhaft Unindividuelles, also, alles, was mit den ursprünglichen Instinkten verbundenen Wesen als Zentralobjekt des Kunstausdrucks hervorgezogen haben.

Dementgegen, der Impressionismus und Symbolismus, Neuklassizismus und Neofolklorismus (im Sinne der Neubetrachtung der Volksgründe) eroberten in einige Jahre galizische Komponistenschule der ersten Jahrzehnte des XX Jahrhunderts und führten zur Umwandelung der früheren romantischen Prioritäten. Doch romantische Stilistik ist in diesem Kontext nicht abgemacht, wie in anderen Nationalschulen, ganz umgekehrt, sie bekam einen positiven Ansporn in der innovativen Wechselwirkung mit den Elementen des neuen modernistischen Ausdruckssystems.

Trotz den mehreren gemeinsamen Merkmalen des Ausdrucks, im Schaffen jeder Komponisten widerspiegelte sich individuell die Vielfältigkeit neuer künstlerischen Möglichkeiten. Dies ermöglicht,

„die Präsenz in der Musik der charakteristischen Merkmale des Modernismus zu behaupten, der sich zunächst auf der Ebene des musikalischen Ausdrucks manifestiert. Aber da die Unausgesprochenheit von Romantik (in der ukrainischen professionellen $\mathrm{Mu}$ sikkultur: es geht vor allem um die spätromantischen Leistungen, die ganz bescheiden in den nationalen Artefakten präsent sind L. K.) verpflichtete, noch manche Züge der Romantik fortzusetzen. Nur der einzige Komponist in ukrainischer Kultur erster Hälfte des $X X$. Jahrhunderts als echter Modernist bewertet sein sollte: Borys Latoschynskyj“. 
Er transformierte folgerichtig und dabei individuell in seinem individuellen Stil wichtigste Prinzipien neuer musikalischer Ästhetik.

Der Musiker mit der ausgezeichneten professionellen Ausbildung (sein Lehrer für Komposition und bester Freund war Reingold Glier) und mit einer breiten künstlerischen Erudition, Latoschynskyj gehörte zum Typ von Künstlern, im dessen Denken eine „spezifisch intellektuelle Sicht“ dominiert. Es ist bemerkenswert, dass Latoschynskyj als der bedeutendste ukrainische Symphonist etabliert wurde. In seinen fünf Symphonien repräsentierte er verschiedene Modi des Modernismus: von rein expressionistischen, scharfen trüben Gestalten, konstruktivistischen experimentellen Techniken - bis zu neuklassizistischen Allusionen zu den barocken Prototypen, polyphonischen Geflechten dissonanten Linien. Auch obligate Volksschicht vermied er nicht endgültig, obwohl nicht so häufig und eindeutig eingeführt, wie andere Komponisten. Manche typische Elemente nationaler Folklore erschienen in den Latoschynskis Werke auf verschiedene Weise. Manchmal benutzt der Komponist die archaischen Formen, etwas „fovistisch“, ähnlich wie bei Strawinsky oder Bartók (in der Oper "Goldener Ring"). In anderen Werken folgt er dem symbolischen Sinne eines Liedtextes (wie, z. B. in der Dritten Symphonie, in erstem Teil welcher als Nebensatzthema klingt das Volkslied „die Schwermut nach der Schwermut, die Armut nach der Armut“ (журба за журбою, біда за бідою). Genauso modernistisch sind seine zahlreichen Kammerwerke konzipiert. Als Pädagoge erzog er schon in 6o-er Jahre die Generation junger Komponisten, die bald unter dem Namen „Kyiver Avantgarde“ bekannt wurden und mehrere, von ihrem Lehrer nicht realisierte schöpferische Ideen schon auf dem neuen Niveau der Kulturentwicklung verkörperten.

Verschiedene individuelle Transformationen entweder des Modernes oder des Modernismus als natürlicher Prozeß der Entwicklung jeder Kunst in ihrer Mannigfaltigkeit wurde durch ungünstige politische Umstände, d. h. durch einen gewaltsamen Beitritt zur UdSSR, unterbrochen und verfälscht worden, mit dem tragischen Höhepunkt „Die erschossene Renaissance“ in den dreißiger Jahren des zwanzigsten Jahrhunderts. Alle früheren ästhetischen Richtungen, besonders die innovative, wie Expressionismus, Konstruktivismus usw. sind als „bürgerliche, unproletarische, dem Volk fremde" verurteilt und bald verboten. Ihre Vertreter sind nicht nur in allen möglichen Medien beseibern, aber meistens physisch vernichtet. So ging zugrunde alle Künstler aus der „Bojtschuk-Schule“ mit ihrem Haupt Mychajlo Bojtschuk, gegen fast alle Schauspieler des experimen- 
tellen Theaters von Les' Kurbas sind Repressalien ergreifen, Les' Kurbas selbst wurde erschossen. Nicht so radikale, doch selbstbewusste Künstler, die der ästhetische Wert eines Kunstwerkes nach dem nationalen Nutzen bestimmten, wurden nicht milder betrachtet und als „bürgerliche Nationalisten" verurteilt und dementsprechend getötet oder in bestem Fall völlig verschwiegen und vom Kulturleben ausgeschlossen.

Auch diese Künstler, die konsequent eine spezifische nationale Tradition mit den neuesten Richtungen synthetisierten, wurden grausam vernichtet, insbesondere Hnat Khotkevych, die ursprünglich in dem modernen expressiven System die Klangfarbe der alten ukrainischen Instrument Bandura $^{20}$ angewendet hat, oder Vasyl Werchowynets, der auf der Grundlage der ukrainischen Tanz ein Émile Jaques-Dalcroze-System angepasst hat. Beide wurden 1938 erschossen. Diese Biographien sind in mehreren Knotenpunkten ähnlich: talentvolle, freidenkende Künstler mit den breiten und mannigfaltigen Interessen wollten sich nur ihren geistigen Zielen widmen. Dabei hielten politisch so neutral wie möglich, gehörten zu keinen oppositionellen Organisationen und waren bereit, mit der neuen Macht ordentlich zusammenzuarbeiten. Ihre Hinrichtung steuerte nur auf ein Ziel los: die national- kulturelle Wiedergeburt von Ukrainer nicht zuzulassen, auf jede Art und Weise das Komplex der Minderwertigkeit ins Bewusstsein des Volks durchdringen zu lassen. Man brauchte zwanzig Jahre nach dem Tod (erst nach der „Chruschtschower Tau und Enthüllung des Stalins-Kultus in 1957), um sie zu rehabilitieren, aber auch dann ihr schöpferisches Erbe wurde kaum popularisiert und noch lange wenig bekannt.

Die genaue Zahl der Repressalien untergeworfen ukrainischen Künstler ist bis heute nicht bekannt. Einigen Berichten zufolge erreicht diese Zahl bis 30.000 Menschen $^{21}$.

In welcher Weise reagierten auf Verfolgung ukrainische Musiker? Einen Teil - darunter Borys Latoschynskyj, Lewko Rewutskyj, Mychajlo Werykiwskyj, Pylyp Kozytskyj usw. - gingen in sog. „innerliche Emigration“, d. h. schufen viel weniger und dabei traditioneller, als früher, manche Werke widmeten der Partei - Lenin - Stalin, trotzdem ständig kriti-

20 Bandura wurde in 30-er Jahren des XX. Jh. zu einem „bürgerlichen Instrument“ erklärt, deswegen sind mehr als 300 unsichtigen Musiker-Banduristen im Dezember 1933 schonungslos und dabei in tiefstem Geheimnis erschossen und beerdigt.

21 Sieh dazu: Grigorij Kasjanow. Ukrainische Intelligenz in 1920 - 30-er Jahre: das soziale Porträt und das geschichtliche Schicksal (Kyiv: Globus, Vik; Edmonton, Canadian Institut ukrainischer Studien an der Universität Alberta, 1992) [Касьянов Г. Українська інтелігенція 1920-30-х років: соціальний портрет та історична доля.] 
siert und beschuldigt wurden. Die ideologischen Hindernisse konnten die ukrainischen Komponisten doch nicht endgültig daran hindern, die moderne musikalische Sprache nach ihrem Glauben zu benutzen, so dass sie eine brutale Kritik an ideologischen Organen erlitten. Jede Neuerung wurde nach wie vor als „Verehrung des bürgerlichen Westens“, national charakteristische Themen - als „bürgerlicher Nationalismus“ bezeichnet. Zum Beispiel wurde Latoschynskyj von seinen „Notizhaken, die nach dem Westen schauen" beschuldigt. Um sein Schaffen und sogar das Leben zu retten, mussten Künstler die Kompositionen im Geist des sozialistischen Realismus schreiben. So beobachtete man ein Paradox der ambivalenten Individualgestaltung, als im Schaffen desselben Komponisten koexistierten innovative Artefakte - und ideologisch bedingte Opera, wo der Autor die kommunistische Thematik verkörperte und das Ausdruckssystem bewusst auf den Stil des 19. Jahrhunderts beschränkte, vor allem auf das Erbe des „Mächtigen Häufleins“ und Tschaikowski. Als krasse Beispiele könnte man die Oper „Schtschors“ von Latoschynskyj über den sowjetischen Helden, „Oktober-Kantate“ von Werykiwskyj zur Ehre der Oktoberrevolution, „Das Lied über Lenin“ von Rewutskyj u. m. a. erwähnen.

Eine einzige Möglichkeit, manche kreativen Ideen zu „schmuggeln“, ohne der gnadenlosen kommunistischen Kritik ausgesetzt zu sein, bot die mäßige Anwendung gewisser Elemente der heimischen Folklore (aber nicht heidnische archaische!), meistens in symphonischen und kammer-instrumentalen Werken. Die volkstümliche Sphäre diente oft für solche Komponisten als eigenartige Brücke zwischen den Pole des Modernismus und des sozialistischen Realismus. So entstanden solche Opera wie die Chöre nach Gedichten von Taras Schewtschenko von Latoschynskyj, die Chorbearbeitungen der Kindervolkslieder „Sönnchen“ von Rewutskyj, symphonische Suite „Frühlingslieder“ von Werykiwskyj.

Am Ende des Vortrags möchte ich eine brennende Frage beantworten: was bedeutet eigentlich die Methode des sozialistischen Realismus und auf welche Art und Weise verkörperte sie in ukrainischer Musik. Woher stammt der Begriff? Es gibt viele Vermutungen, eine von ihnen behauptet, dass der Terminus „sozialistischer Realismus“ ursprünglich hat ein slowenischer Priester geboten. „Zum ersten Mal wurde der Terminus „sozialistischer Realismus“ in Slowenien in Jahr 1896. Ein Priester, der die Veränderungen in der sozialdemokratischen Literatur beobachtete, hat gemerkt, 
dass jetzt nicht der einfache soziale Realismus, sonst ein echter sozialistischer Realismus geboren ist ${ }^{\text {‘22 }^{2}}$.

Diese Hypothese hat man nur einmal getroffen, andere Forscher sind einig, dass der Terminus „sozialistischer Realismus“ zum ersten Mal in der Moskauer „Literarische Zeitung“ von Ivan Gronski formuliert ist, dann während des Ersten Kongresses sowjetischer Schriftsteller erklärt und begründet wurde. Der Weg zu strikter Bezeichnung des Sinnes totalitärer Kunst war ziemlich lang und hat mehrere Versionen hervorgerufen. Lunatscharski (1904) nannte neue Literatur „den proletarischen Realismus“, Aleksiej Tolstoj (1924) - der monumentale Realismus.

In den Diskussionen anfangs der 30-er Jahre des XX Jahrhunderts in der Wohnung des proletarischen Schriftstellers Maxim Gorki, in welchen Stalin, Molotow und Woroschilow teilgenommen haben, sind zuerst zwei Methoden vorgeschlagen: „die rote Romantik“ und „der sozialistische Realismus“. Stalin unterstützte nur zweite Variante. So entstand sozialistischer Realismus als Projekt von Stalin und Gorki und hatte vom Anfang an eine politische Bedeutung. Er hat als grundlegende Methode der sowjetischen Literatur festgestellt, und

„erfordert vom Schriftsteller wahrhafte, historisch konkrete Darstellung der Wirklichkeit in ihrer revolutionären Entwicklung. Diese Wahrhaftigkeit und historische Exaktheit des künstlerischen Bildes muss mit der Aufgabe der ideologischen Verarbeitung und Erziehung der Arbeiter im Geiste des Sozialismus vereinigt werden“".23

Insofern der sozialistische Realismus einzige Methode der sowjetischen Literatur war, es bedeutete, dass andere Methoden ausgeschlossen sind. „Ideologische Verarbeitung" des Bewusstseins in der Literatur und Kunst gehörte zur Staatspolitik. Ästhetische Werte als Kern der Kunst, irgendeine idealistische, mythologische, sagenhafte Gestalten, die in jedem historischen Stil präsent sind, wurden nicht berücksichtigt ${ }^{24}$.

Die Wörter „erfordert vom Schriftsteller“ klingen wie ein militärischer Befehl und lassen kaum Platz für die schöpferische Freiheit. Deswe-

22 Borys Lobanowskyj, Realismus und sozialistischer Realismus in der ukrainischen Malerei sowjetischer Zeit (Kyiv: "LK. Maker", 1998), 89 [Лобановський Б. Реалізм та соиіалістичний реалізм в українському живописі радянського часу.]

23 Nadia Ferenc, Grundlagen der Literaturwissenschaft. Das Lehrbuch (Kyiv: Znannja 2011), 398 [Ференц Н. С. Основи літературознавства: підручник.]

24 Sieh dazu: Oleksij Rogotschenko, Der sozialistische Realismus und Totalitarismus (Kyiv: Fenix, 2007) [Роготченко О. Соціалістичний реалізм і тоталітаризм.] 
gen gestaltete sich die sozialistisch-realistische Kunst als eine totale Lüge, dazu sehr langweilig und unschön. In der Musik scheint schwerer zu lügen, als in der Literatur oder bildender Kunst, doch mit den entsprechenden Wörtern und Sujets - ganz möglich. Dass diese Musik unästhetisch, plakativ und banal war, merkt man auch bei den besten Komponisten, wie Latoschynskyj oder Rewutskyj, die gezwungen sind, die ideologisch engagierten Werken zu schreiben.

Ein gewisser Teil von ukrainischen Komponisten möchte doch gerne solches Kunstprodukt herstellen. An der Liste ukrainischer Musikwerke, die in der Zeitspanne 1930 bis 1985 geschaffen sind, findet man jede Menge Opera, die den kommunistischen Führern, flammenden Revolutionären, oder sowjetischen „roten Daten“ gewidmet sind, mit voller Überzeugung geschrieben. Manche Werke - wie schon früher erwähnt - sind zwangsläufig geschrieben, aber mangelt nicht an solche Autoren, die hauptsächlich dieser Methode Präferenz gegeben haben, wie z. B. Kostjantyn Boguslawskyj (obwohl seine Lieder über Rote Armee rettete ihn nicht vor den Repressalien), Walerian Dowshenko, Mykola Dremluha, u. m. a.

Für die Musik, nach der Methode des sozialistischen Realismus geschaffen, ist erforderlich und typisch:

- Strikt beschränkte Thematik - der revolutionäre Kampf, der Tod im Namen des Sieges revolutionärer Idealen, die Bestrafung der Verräter und Feinde, das Besingen der Führer und unzahlreiche ähnliche Themata;

- die Bevorzugung der sog. „demokratischen Gattungen“ - Massenlied, Chöre, wie auch pompöse Kantaten, Oratorien und Opern;

- ganz einfache Melodielinie in sich geschlossenen, "quadratischen" Periode entfaltet;

- drei vorherrschende rhythmische Modi: entweder geschlagener Marschrhythmus oder mäßige reguläre Bewegung nach dem Muster des russischen sog. „langgezogenen Lieds“ (протяжная песня), oder der Walzenrhythmus;

- $\quad$ traditionelle Harmonik, die nicht die Regeln des XIX. Jh. (Glinka, "das Mächtige Häuflein“) überwindet, monoton wiederholende einfachste diatonische Harmoniefolgen; 
- $\quad$ homogene Faktur mit ständig wiederholten Wendungen und Drehungen, ohne Individualisierung irgendeiner horizontalen Linie, ohne ausdrucksvolle Raumeffekte;

- $\quad$ einfache arme Instrumentierung, die die speziellen Klangeffekte und Differenzierung einzelner Klangfarben der Instrumente vermeidet (außer den Glocken oder Trompeterruf, die als revolutionäre Symbole betrachtet sind).

Wenn alle diese Charakteristika zusammenzusetzen, bekommt man eine treue klangliche Widerspiegelung wichtigster Idee der „grundlegenden ideologischen Methode" totalitärer Gesellschaft: keine stilistische Individualität, die den Massen unterworfen ist; kein ästhetischer Wert, der ideologisch nicht nützlich scheint; keine Mannigfaltigkeit der Gefühle, Assoziationen, Empfindungen, da alles nur schwarz-weiß angenommen sein sollte.

Denn die Autorin nimmt die Kultur nicht „schwarz-weiß“, bezeichnet man exemplarische interessante Beispiele auch in diesem Kreis, die meistens dank der Erfindungskraft von Autor entstanden und auf prinzipiell andere Intonationsideen fußten. Man erinnert in erster Linie an Prokofjew mit seiner Ironie in den „sowjetischen“ Opera, aber - was betrifft die Ukraine - auch Isaak Dunajewskij, der für seine populären Massenlieder die Melodien der jüdischen Hochzeit benutzte. Genauso führte Lemberger Komponist Anatol Kos-Anatolski huzulische Weisen in die Werke zu kommunistischen Texten ein.

Aber diese Ausnahmen bestätigen nur die wichtigste Konsequenz, die nach all diesem Material man ziehen könnte. Der ganze Reichtum von stilistischen Tendenzen, Strömungen, technischen Recherchen, thematische und ästhetische Mannigfaltigkeit ukrainischer Kultur, die genau zum Anfang des XX Jahrhunderts in den allgemeinen europäischen Prozess aktiv und erfolgreich integrieren begann, wurde in riesigem Topf totalitärer Vereinfachung und Primitivität des sozialistischen Realismus verbrannt. Es war eine echte humanistische Katastrophe für das ganze Volk, die seine natürliche Kulturentwicklung für eine längere Zeit als 30 Jahre geschlossen hat. Nur nach dem Stalins Tod kommt zum ersten Mal zur Überwindung dieser geistigen Erstarrung, auf der verbrannten Erde hat plötzlich ein Phänomen „einer Generation der 6o-er Jahre“ entstanden. In dieser Periode beginnt die Besinnung der Blütezeit in ukrainischer Kunst 20-er Jahre, wie auch das Andenken an die talentvollen nationalen Schriftsteller, Schauspieler, Maler, Musiker, die als die blutigen Opfer des Regimes in 30-er Jah- 
re gefallen sind. Diese Erinnerungen dienten als starker Ansporn für die jungen Künstler, die zu den Vertretern den sozialistischen Realismus nicht mehr gehören wollten und nach eigenen ethischen und ästhetischen Werten suchten.

\section{Bibliographie}

Birjulow, Jurij. Die Kunst Lviver Sezession. Lviv: Zentr Ewropy, 2005.

Ferenc, Nadia. Grundlagen der Literaturwissenschaft. Das Lehrbuch. Kyiv: Znannja, 2011.

Janowskyj, Borys Karlowytsch. „Selbstbiographie“. In Musik: Almanach der Musikkultur, Nr. 5-6 (1927): 53-55.

Kabuzan, Wladimir. Ukrainer in der Welt: Dynamik der Bevölkerungszahl und Siedlung. Moskau: Nauka, 2006.

Karalus, Maria. „Stilistische Dominanten in ukrainischer Kunst“. Kunstwissenschaftliche Studien 31, 3 (2010): 68.

Kasjanow, Grigorij. Ukrainische Intelligenz in 1920 - 30-er Jahre: das soziale Porträt und das geschichtliche Schicksal. Kyiv: Globus, Vik; Edmonton, Canadian Institut ukrainischer Studien an der Universität Alberta, 1992.

Lobanowskyj, Borys. Realismus und sozialistischer Realismus in der ukrainischen Malerei sowjetischer Zeit. Kyiv: “LK. Maker”, 1998.

Nowakowytsch, Myroslava. „Kanon des ukrainischen musikalischen Modernismus im Schaffen von Borys Latoschynskyj“. Referat der Doktordissertation. Lviver Nationale Musikakademie Mykola Lyssenko, 2008.

Pawlytschko, Solomia. Der Diskurs des Modernismus in der ukrainischen Literatur. 2 Aufl. Kyiv: Lybid', 1999.

Rogotschenko, Oleksij. Der sozialistische Realismus und Totalitarismus. Kyiv: Feniks, 2007.

Rzewska, Maja. „Musik der Ukraine bei Dnepr in erster Drittel des XX. Jahrhunderts in der Wechselwirkung und in der Umgestaltung der soziokulturellen Diskursen“. Referat der Habilitationsarbeit. Nationale Musikakademie Petro Tschaikowsky. Kyiv, 2006.

Sonewytskyj, Igor. „Das kompositorische Erbe von Nestor Nyshankiwskyj“. In Nachrichten der Wissenschaftlicher Gesellschaft „Taras Schewtschenko“. B. CCXXVI: Forschungen der Musikwissenschaftlichen Kommission. Lviv, 1993. 
Stelmaschtschuk, Roman. „Modernistische Tendenzen im Schaffen ukrainischer Komponisten 20-er - 30-er Jahre des XX Jahrhunderts“. Referat der Doktordissertation. Kyiv, IMFE NAN der Ukraine, 2003.

Switlytschna, Wira. Geschichte der Ukraine. Lehrbuch. Kyiv: Karavella, 2006 

Work and Performance:

A few Comments on the Czech Modern

Music

\author{
Lubomír Spurný \\ Masarykova univerza, Brno \\ Masaryk University, Brno
}

I.

To the destiny of today's musicologists belongs a pleasant but trying obligation of writing reviews on variety of texts of different levels and specializations which are connected to music. Also if musicology is to remain a science about music, it must consider phenomena which has not yet been given sufficient attention.

Recently, I got my hands on a habilitation thesis of one of my colleagues from the University of Technology. Even though its name New methods of encoding and reproduction of surround sound may sound intimidating, it proven itself to be an interesting contribution to the discussion devoted to capabilities of technical innovations. They ultimately also affect the music and its reception. This statement is sort of a positional preamble, explaining the reasons why I got into reading the aforementioned work.

Things such as musical events of national cultures or regions, eminent composers, the genesis of the styles and the processes of creating individual creative poetics, the matters of individual musical genres traditionally find themselves within the research interest of musicologists. The activity of musical associations, companies and institutions also became the topic of works focused on newer music. Not only the work of art itself but also the form of its reception or the organization of musical life became a predicative report about the nature of musical production. The historical knowledge was, fairly recently, appended by an intensive study of specific aspects 
of a musical piece composition, which lead to constitution of "new musical theory", musical analysis and the theory of interpretation (in the broad sense of this term).

The reasons why I began reading the aforementioned work were also personally motivated. Recently I requested a partnership on the upcoming project focused on performance practices in the 19th and 2oth centuries at the Faculty of Electrical Engineering and Communication at Brno University of Technology where the habilitation thesis was written. Task of my colleagues from the "Technical faculty" is to prepare a program suitable to analyze an audio recording of an analysis of recorded music. We are inspired by some foreign works. In the plethora of current production we were intrigued mostly by the book of Nicholas Cook, Beyond the Score. Music as Performance (2013) and the activity of authors concentrated around the Centre for the History and Analysis of Recorded Music (CHARM). ${ }^{.}$

While this topic is often discussed in the anglo-american musicology on a local scale this topic is rather marginal. A rare exception is the work of Milan Kuna, Miloš Bláha Time and Music. About the dramaturgy of the resources in the musical and interpretative performances (1982).

II.

The analysis of sound recordings is still a relatively new discipline of musicology although the approximate 120 years history of the musical data recording offers a wide range of possibilities. Musical recordings are preferable to live production in terms of the description of time resources in music for they allow more detailed and repeated measurement of time periods. The effort of musicology research is to find objective parameters and data from typically sound and time complicated musical recording or production in real time, which can be clearly and distinctly documented, analyzed and compared. The acquisition of this data in musicology research has always been the domain of a music theorist in the role of a listener of a live production or a recording, registering noticeable quantitative parameters of the music stream. In the early stages the authors gathered the time data using a stopwatch and careful acoustic verification. Such measurements are

1 About this topic more: José Antonio Bowen, “Tempo, duration, and flexibility: Techniques in the analysis of performance," Journal of Musicological Research 16, 2 (1996): 111-156; Hermann Danuser, Die Musik des 20. Jahrhunderts [= Neues Handbuch der Musikwissenschaft, 11] (Laaber: Laaber, 1992). Anders Friberg, "Generative rules for music performance: a formal description of a rule system," Computer Music Journal 15, 2 (1991): 56-71 
inextact because of reaction of the measuring person. (Studio tape recorders brought possibility of more precise measurement using the lengths of the tape at a constant speed with a resolution of up to $20 \mathrm{~ms}$. However, obtaining detailed and repeated measurements is a very challenging task even in this case.)

The claim that from the begining of the 2oth century the development of musical genres is also shaped by the relationship to sound recording, gramophone records or radio broadcasts will certainly not sound surprising. The abrupt development of mass media especially radio and sound film influenced the production of composers and gave future direction to modern performance tradition. Critical discussion on the topic of technical innovations and their incursion into musical practice has been happening in musicology for several years which influenced the choice of subject matter of variety of works and also a production focus (radio broadcasts and music for radio, changes in tempi and dynamics, analysis of interpretative performance etc.) Also the effort to add the possibility of a sound recording analysis (interpretative performance) to the methods of musical theory belongs to current trends in forreign and domestic musicology.

\section{III.}

My approach to this task, however, is not purely technical. Interpretation research is an overarching term for a variety of approaches and methods. We can for example examine deviations from the established ideal, such as the transformation of the tempo or dynamics, within a single work. We can also describe the historical background on which these changes take place.

The first analysis of performance and recommendations on performance practice come from Heinrich Schenker (1868-1935). He is the author of an extensive study Die Kunst des Vortrags. Even though he was working on it since 1911 it was never finished and was only maintained through handwritten notes. It was released in 2002 under the name The Art of Performance by Heribert Esser.

Subsequent interpretative style then significantly transformed. The conservative tradition that Schenker represents was replaced by the emerging performing practice. The situation after 1918 is characteristic in this respect. A category of artists who specialized on contemporary music appears. Such type was in many ways unique. Its novelty became evident in the choice of repertoire (most of these compositions were heard only once). The style of their interpretative execution was restrained and deprived of 
flashy gestures, it resigned on the popularity with wider audience. These artists have demonstrated extraordinary service to new production (new music). They were able to study a large amount of music and interpret it selflessly aside of the public interest. Many of these artists belonged to the circle of compositional schools and had songwriting ambitions themselves. The situation among the authors who belong to the circle of students and friends of Alois Hába is characteristic.

For example Alois Hába (1893-1973), composer and pianist Erwin Schulhoff (1894-1942), Karel Reiner (1910-1979), pianist and musicologist Václav Holzknecht (1904-1988), cellist Váša Černý (1900-1982) and clarinetist Milan Kostohryz (1911-1998) and expressed their opinions on the topic of interpretation. The same can be observed in the circuit pupil and friend of Arnold Schoenberg.)

The mentioned authors published a series of studies which are dedicated to the issues of performance practice of new music, not only Hába's but also works of other authors. They focus primarily on the way of phrasing and a technique of control of traditional or new (quarter-tone) instruments. All the listed authors are also the authors of the studies dedicated to the performance practice of new music. ${ }^{2}$ Authors of new music then connected the fates of their work with newly formed ensembles. Zika-Quartet and Czech Nontet are among the most significant.

Sound recordings are a testament of the level of interpretation of new music. The first ones come from the record company Esta which distributed them for Czechoslovak market in years 1930-1946 (between the two wars there were also other companies on the Czech market: His Master's Voice, Odeon, Parlophon, Ultraphon, Telefunken, Polydor). The most represented author of the contemporary music is Alois Hába with his quarter-tone pieces (besides the String Quartet No. 2 in the quarter-tone system, op. 7

2 See Váša Černý, “Čtvrttóny na violoncellu (K provedení Hábovy čtvrttónové fantasie pro violoncello)," [Quarter-tones for Cello (On the Performance of Hába’s Quarter-tone Fantasy for Cello)] Klíč, ii (1931/32): 162-164. Karel Reiner, "Technika hry na čtvrttónovém klavíru,” [Technique on a Quarter-tone Piano] Klíč, iii (1932/33): 2225; repr. Rytmus, iv, 1938/39, 51-53. Karel Reiner, "Interpretace nethematické hudby" [Interpretation of Nonthematic Music], Klíč, iv (1933/34): 46-48. Erwin Schulhoff, “Wie spielt man auf dem Vierteltonklavier?," Der Auftakt, vi (1926): 106. Václav Holzknecht, "Problém atonality v klavírní technice (Na okraj Hábovy Symfonické fantazie pro klavír a orchestr)," [The Problem of Atonality in Piano Technique (Some Remarks on Hába's Symphonic Fantasy for Piano and Orchestra)] Klíč, i (1930/31): 9-14. 
(1921) its suites and fantasias for the quarter-tone piano performed by Karel Reiner).

IV.

In the frame of interpretation research we can also compare the interpretative style of individual personalities, bodies or generations, so-called "interpretative schools" whose specificity is determined by the technique or the method of training, however increasingly more the ability to enlighten about (adequately get across) certain (national) repertoire from a certain complex interpretative point of view.

In the 2oth century the ideal of performance individualization was approached by the requirement of adequate portraying of author's periodic compositional style. The demand for the stylistic purity is applied especially categorically when introducing domestic music (works of the so-called classics of one or another national music).

Area that appears most suitable for processing is chamber music and particularly one specific part, so called Czech Quartet School. It is the area of music which has its tradition within the local music culture. It is one of few artistic activities in the field of Czech musical culture where we can observe the continual development (presumption of development of interpretive tradition, if we still believe in interpretive tradition) with all eventual divides and deviations. The founding significance belongs to the Bohemian Quartet. In the begining of the 2oth century it was primarily the Ševčík-Lhotský Quartet, Zika’s (Czechoslovak) and Prague Quartets. Interpretation of the Bohemian Quartet especially began to change with the inventions of the phonograph (roll) and a gramophone record.

The fact that music can be written not only in the sheet but also as a sound, not only its progression but also quallities elusive in the notation, redirects the attention to topical and currently ongoing flow of music. Here we can also find the impulse (which is often overlooked) of the development of new interpretive tradition. (Herbert von Karajan for example perfectly adapted to the gramophone industry.)

We encounter a particular phenomenon in the first recordings of the Bohemian Quartet: individual musicians are highlighting contemporary clichés, especially glissando when changing positions, rapid changes in tempo and dynamics. However on the contemporary sound recordings remarked with technical imperfections they sound artificial and amateurish. Similar characteristics also apply to the recordings of violinists Jan 
Kubelik (1880-1940), František Ondř́iček (1857-1922) and singer Emmy Destinn (1878-1930). Such an approach may resemble theatrical facial expressions and diction which with the onset of the film became dull (or perhaps comical). Each such recitation (interpretation) is significant, has its own semantics.

Study of the audio data offers wide possibilities for the study of performances and their mutual relations. Production and distributing of music media has one more audible effect. The artists from the second half of the 2oth century who have the opportunity to easily compare their own performance with the recordings of their colleagues usually present a homogenous interpretative style while the individuality and diversity are considered to be dominating feature of older records.

V.

In this context I would like to remind that the interpretation of the work was (and partially still is) considered as secondary in the history of music. Even the designation performing culture represents certain classification. Performance is only a reproduction, simple performance, standing against serious compositional work. For example Johannes Brahms said:

"If I perform something from Beethoven I am suppressing my own individuality and reproduce what the author has prescribed. Still, I have a lot of work to do."

Also the Austrian theorist Heinrich Schenker considered "individual contribution" of the artist to be unnecessary. Therefore, is the interpreter really just a mere executor of the musical text as claimed by Stravinskij? These ideas stem from the inequal ratio between the significance of the score and its execution (interpretation). Within the European tradition the term work is bound especially to its fixation (composition recorded in the notation), finality (the work is complete and other authors cannot make any input) and uniqueness (singularity; the work is tied to the author as to the unique creative personality).

We must still have the multilayer nature of music on our mind for its perceivable form is added only by its execution. Composer's notation is a precursor of the artifact of music not the music itself. The score itself is not

3 Heinrich Schenker, Der Tonwille. Flugblätter zum Zeugnis unwandelbarer Gesetze der Tonkunst einer neuen Jugend dargebracht, Heft 6 (Wien: Universal-Edition, 1923), 37. 
yet, and cannot be, a subject of admiration. For a parallel to this claim we can look into the theory of the theatre. In 1931 Otakar Zich wrote in his work The Aesthetics of Drama:

"The dramatic text is the beginning of a long and difficult march through which the dramatic work in the form of theatre performance is executed". ${ }^{4}$

But back to the music, is the artist really a mere executor of the musical text? Hardly, after all, the musical writing has to be realized. The score is a guide to action, however, it does not choose the means by which the action is carried out. There is a freedom of choice concerning the musical instruments and this detailed specification is missing from the notation. For example fingering and the way of realization of technical and execution specifications (espresivo, legato etc.) belong into the arsenal of viable means. The similar case are the passages of the same prescribed dynamics, for example in prescribed forte not all tones of a passage may be played with the same intensity.

Criteria of the quality of musical interpretation are seen in relatively perfect execution of notation, perfect delivery, the level of virtuosity and individuality of expression. This is associated with both, capturing the composer's individuality and also the exercise of the performers own approach.

I also owe you an answer to a comment stated in the beginning. The task of my colleagues from the "Technical faculty" was to prepare suitable software that would note down tempo and dynamics of a musical record and then convert them into a clear chart. They didn't yet achieve it. It is therefore necessary to be patient. Probably it is not necessary to create sophisticated software; much more important is the method of reading the results. Register necessary data is one thing, searching for the meaning in them is second and justifying them as an performance style of certain time period is third.

\section{Bibliography}

Bowen, José Antonio. "Tempo, duration, and flexibility: Techniques in the analysis of performance.” Journal of Musicological Research 16, 2 (1996): 111-156.

Cook, Nicholas. "The Conductor and the Theorist: Furtwängler, Schenker, and the irst Movement of Beethoven's Ninth Symphony“". In The Practice of

4 Otakar Zich, Estetika dramatického umèní (Praha: Spupraphon, 1986), 59. 
Performance: Studies in Musical Interpretation, ed. John Rink, 105-124. Cambridge: Cambridge University Press, 1995.

Cook, Nicholas. "Analysing Performance and Performing Analysis." In Rethinking Music, eds. Nicholas Cook, Mark Everist, 239-261. Oxford/New York: Oxford University Press, 1999.

Cook, Nicholas. Beyond the Score. Music as Performance. Oxford/New York: Oxford University Press, 2013.

Danuser, Hermann: Die Musik des 2o. Jahrhunderts [= Neues Handbuch der Musikwissenschaft, 11], Laaber: Laaber, 1992.

Friberg, Anders. "Generative rules for music performance: a formal description of a rule system." Computer Music Journal 15, 2 (1991): 56-71.

Kuna, Milan, and Miloš Bláha. Čas a hudba. K dramaturgii časových prostředkư v hudebně interpretačním výkonu. Praha: ČSAV, 1982.

Schenker, Heinrich. Der Tonwille. Flugblätter zum Zeugnis unwandelbarer Gesetze der Tonkunst einer neuen Jugend dargebracht. Heft 6, Wien: Universal-Edition, 1923.

Stravinsky,Igor. Poétique musicale. Cambridge: MA, 1942.

Zich, Otakar. Estetika dramatického umèní. Praha: Supraphon, 1986. 
»Intimni glasbeni večeri« (1923-1926) ali Kako je Hrvaški glasbeni zavod v Zagrebu odprl vrata v sodobnost

Nada Bezić

Hrvaški glasbeni zavod, Zagreb

Croatian Music Institute, Zagreb

Hrvaški glasbeni zavod, društvo ljubiteljev glasbe, ima posebno mesto v glasbenem življenju Hrvaške; aprila 2017 je praznovalo 190 let. To je najstarejša hrvaška kulturna institucija, ki je uspela preživeti vse politične režime in zadržati svojo samostojnost. Zavod je imel enako zgodovinsko pot kot druga podobna glasbena društva (musikvereini) v avstrijski monarhiji. Osnovne točke v tem razvoju so bile: ustanovitev leta 1827 (meščanska iniciativa za skupno muziciranje), dolgoročni cilji glasbene šole, odprte 1829 (od leta 1916 konservatorij), razširjanje predvsem domače glasbe z glasbeno založbo, gradnja lastne stavbe s koncertno dvorano leta 1876 . Ob vsem tem je bila ena konstanta: prirejanje koncertov.

Po koncu prve svetovne vojne je bila na Hrvaškem finančna kriza, in tudi v Glasbenem zavodu je bila situacija težka. Vzdrževanje konservatorija je postala velika finančna obremenitev za to zasebno glasbeno društvo. Končno je leta 1920 konservatorij postal državna ustanova, in kmalu je bil preimenovan v Glasbeno akademijo (Muzička akademija). Rešen te velike skrbi, je Zavod z novim elanom vstopil v svoje zlato obdobje. Za takšne prelomne čase so potrebni izredni ljudje, v tem primeru je bil to Artur Schneider, Zagrebčan z nemškim imenom.'

1 Več o Schneiderju glej: Ladislav Šaban, »Artur Schneider i glazba«, Peristil, 23 (1980): 63-66; Nada Bezić, "Artur Schneider i glazba - tragom Ladislava Šabana«, v Artur Schneider 1879.-1946. Zbornik radova znanstveno-stručnog skupa Hrvatski povjesničari umjetnosti (Zagreb: Društvo povjesničara umjetnosti Hrvatske, 2016), 81-96. 
Schneider je bil človek, ki je s svojo posvečenostjo delu in marljivostjo dal pečat celemu obdobju, ne samo $v$ eni instituciji. Bil je profesor umetnostne zgodovine na Filozofski fakulteti, vodja Grafične zbirke Nacionalne in univerzitetne knjižnice in ravnatelj Strossmayerjeve galerije Hrvaške akademije znanosti in umetnosti. Leta 1919 je postal tajnik Glasbenega zavoda in ostal na tej poziciji do svoje smrti leta 1946. Organiziranje koncertnih ciklusov je bilo eno izmed njegovih prvih dejanj.

Upravičeno lahko rečemo, da so Jutranji koncerti in Intimni glasbeni večeri zaznamovali glasbeno življenje Zagreba v obdobju med dvema svetovnim vojnama. Do danes ni presežena njihova kombinacija kakovosti izbire izvajalcev in repertoarja, sledenja sodobnim glasbenim tokovom in skrbno sestavljenih programov. Sicer pa je treba povedati, da je imel Schneider za svoje cikluse vzor. Med letoma 1897 in 1918 je deloval Odbor za napredek komorne glasbe $\mathrm{v}$ Zagrebu (Odbor za unapređenje komorne muzike $\mathrm{u}$ Zagrebu), ki je organiziral koncerte $\mathrm{z}$ zanimivimi programi in številnimi tuji umetniki.

Schneiderjevi ciklusi so se v Glasbenem zavodu začeli januarja 1921 in trajali do konca sezone 1927/28, torej je bilo 7,5 koncertnih sezon, skupaj 148 koncertov. Sodeč po koncepciji in umetnikih, ki so nastopali, gre pravzaprav za en ciklus z dvema imenoma (kasneje se je sicer izgubila prva beseda, »Intimne«, in je ostalo le »Muzičke večeri«), edina razlika so bili termini koncertov: najprej so bile nedeljske matineje ob 11.0o, kasneje pa so bili koncerti v petek ob osmih. Vendar pa so tisto, kar je postalo pojem v zgodovini Glasbenega zavoda, bili Intimni glasbeni večeri, med letoma 1923 in 1926, ko je bilo več kot pol vseh koncertov. Intimni glasbeni večeri so tako pomembni, da o njih beremo ne samo v leksikonskih člankih o Glasbenom zavodu, ampak tudi v člankih o posameznih umetnikih (na primer: »...nastopal je na Intimnih glasbenih večerih «). ${ }^{2}$

Najštevilčnejšna, in $\mathrm{v}$ mnogih pogledih tudi najpomembnejša, je bila sezona 1923/24, ko je bilo kar 32 koncertov - neverjetna številka tudi za današnje čase, kaj šele za tedanji, štirikrat manjši Zagreb, s 170.000 prebivalcev. Za primerjavo podatek iz današnjega časa: Hrvaški glasbeni zavod je v prejšnih dveh letih organiziral samo 24 koncertov, ki so bili glede organizacije neprimerno manj zahtevni.

Repertoar ciklusov lahko razdelimo na standardni, domači in sodobni. Standardni koncertni repertoar, kot so pesmi Schuberta, Schumannove

2 [S. n.], »Hugo Mihalović, pijanist", Leksikon jugoslavenske muzike, zv. 2 (Zagreb: Jugoslavenski leksikografski zavod, 1984), 6. 
klavirske miniature ali Dvořákova komorna glasba, je zavzemal najmanjši del celega repertoarja. Lahko bi celo rekli, da je bila ta glasba vključena verjetno tudi zato, da lahko poslušalci uživajo v njim znani glasbi in da se odpočijejo od prevladajoče sodobne glasbe.

Jim Samson v svoji knjigi Music in the Balkans piše, da je leta 1918 Glasbeni zavod preživel krizo, in da so njegovi Intimni glasbeni večeri imeli za cilj "promocijo jugoslovanske glasbe «. ${ }^{3}$ Moramo sprejeti tedanji izraz $» j u-$ goslovanski«, čeprav je bil izraz »domača glasba« tudi pogosto rabljen za hrvaške, srbske in slovenske skladbe. Od 148 koncertov jih je 27 imelo povsem domači repertoar, kar je $18 \%$. Ob tem je bilo 17 koncertov domače glasbe kombiniranih z evropsko. Sodeč po informaciji na programih, je imelo svoje praizvedbe v tem ciklusu 11 skladb hrvaških skladateljev.

$\mathrm{V}$ spremljanju sodobnih tokov glasbe Intimni glasbeni večeri nimajo konkurence v dotedanjem glasbenem življenju Zagreba. Hrvaški glasbeni zavod je zagrebškemu občinstvu prvi predstavil skladbe najbolj pomembnih skladateljev 20. stoletja, kot sta Schönberg ali Bartók. Organizator Artur Schneider je imel smisel za sodobno glasbo, saj je bil od leta 1925 do 1932 tudi tajnik jugoslovanske sekcije Mednarodnega društva za sodobno glasbo (ISCM). Ko je Schneider poročal o teh ciklusih na skupščini ISCM-a v Zürichu, je skupščina sprejela sklep, da je »Glasbeni zavod verjetno edina institucija v Evropi, ki promovira sodobno glasbo v takšni meri kljub finančnim težavam «. ${ }^{+}$

Seznam vseh skladb kaže, da je bilo zastopanih 143 še živečih skladateljev, od najstarejšega, švicarskega skladatelja Friedricha Hegarja, rojenega leta 1841 (tedaj 8o-letnika) do najmlajšega, hrvaškega skladatelja Borisa Papandopula, rojenega 1906. V odnosu do vseh skladateljev je to okrog $70 \%$. Zemljepisno gledano so bili zastopani vsi najbolj pomembni evropski glasbeni narodi, pa tudi»nestandardni«, kot so Nizozemci, namreč, pred go leti smo imeli v Zagrebu večer tedaj sodobne nizozemske glasbe. Od tujih je bilo največ čeških skladateljev, predvsem pa skladb Vítězslava Nováka, čigar študenti so bili tudi nekateri tedaj vodilni hrvaški skladatelji, kot sta Antun Dobronić in Josip Štolcer Slavenski.

3 "Designed to promote Yugoslav music", Jim Samson, Music in the Balkans (Leiden, Boston: Brill, 2013), 339 .

4 »[D]a je HGZ zacijelo jedina evropska muzička ustanova koja bez obzira na materijalne žrtva propagira u tolikoj obilnoj mjeri savremenu muzičku tvorbu«, cit. v: Ladislav Šaban, 150 godina Hrvatskog glazbenog zavoda (Zagreb: Hrvatski glazbeni zavod, 1982), 120-121. 
Ob že omenjenih Bartóku in Schönbergu so bili zastopani, med drugimi tudi:

- $\quad$ angleški skladatelj Arthur Bliss, v svoji zgodnji fazi, ko je sledil Stravinskemu in Schönbergu;

- močno zastopana je bila skupina italijanskih skladateljev: Malipiero, Casella, Castelnuovo-Tedesco;

- mladi Hindemith, ki je v začetku 1920-ih let tudi nastopal v Zagrebu s svojim Amar-Hindemith kvartetom;

- Satie, Ibert in dva iz skupine »šestih«: Milhaud in Poulenc.

Skladatelj Eugene Goossens je pomemben, ker je kot dirigent s svojim orkestrom po letu $1921 \mathrm{v}$ Londonu predstavil skladbe Milhauda, Poulenca in Schönberga. Wilhelm Grosz, avstrijski skladatelj in pianist, je nastopal v Zagrebu leta 1926, in igral svoje skladbe, deset let kasneje pa je kot židovski emigrant v Angliji komponiral šlager Harbour Lights. Posebej je zanimivo, da je bila že leto dni po nastanku v Zagrebu igrana skladba Jazz o Danielu ameriškega skladatelja Louisa Gruenberga, pisana v njegovem t. i. »ameriškem stilu «, navdahnjenem $\mathrm{z}$ jazzom.

Če se vrnemo na kriterij »domači« skladatelji in ga kombiniramo s "sodobni«, dobimo naslednje: od treh največjih narodov tedanje države, Kraljevine S.H.S., je bilo seveda največ hrvaških skladateljev, 26, srbskih je bilo sedem, slovenskih pa osem: Emil Adamič, Oskar Dev, Franc Kimovec, Marij Kogoj, Anton Lajovic, Josip Pavčič, Janko Ravnik in Lucijan Marija Škerjanc. Slednji so bili tedaj - med letoma 1922 in 1924 - večinoma predstavniki srednje generacije, najmlajši pa je bil Škerjanc. Njihove skladbe so bili predvsem zbori in samospevi, ter en godalni kvartet. Nekatere skladbe Kogoja, Ravnika in Škerjanca so bile tedaj relativno nove, stare komaj nekaj let ali objavljene le nekaj let pred izvedbo na koncertih v Zagrebu.

In kako je bilo s sodobno hrvaško glasbo tistega časa? Seznam kaže, da je Schneider sledil tedanjemu trendu t. i. nacionalnega stila, kar se kaže predvsem v velikem številu skladb vodilnega skladatelja tega stila, Antuna Dobronića. Občinstvu so se predstavili tudi tedaj najmlajši skladatelji, v svojih 2o-ih letih: Zlatko Grgošević, Rudolf Matz, Boris Papandopulo, Mladen Pozajić in Marko Tajčević. Njihov profesor kompozicije Blagoje Bersa, najbolj pomemben predstavnik moderne na Hrvaškem, je bil v celotnem obdobju predstavljen le z eno skladbo. Imeli so ga pač za »obstranca« in eklektika, daleč od najbolj aktualne nacionalne smeri. Res je, da ni bila vsa hrvaška glasba pisana v nacionalnem stilu, najboljši primer so skladbe mlade- 
ga Josipa Štolcerja Slavenskega, ki je s svojim Godalnim kvartetom leta 1924 dobil prvo nagrado na festivalu v Donaueschingenu.

Seznam umetnikov, ki so nastopali, kaže sicer raznolikost, a večinoma so bili iz Zagreba. Tedaj novi ansambli, kot sta bila Zagrebška filharmonija ali Zagrebški kvartet, so dokaz, da je glasbeno življenje v Zagrebu zaživelo po letu 1918.

Težko je verjeti, da organizator Schneider v tako skrbno načrtovanem ciklusu koncertov občinstva ni seznanil $\mathrm{z}$ osnovnimi podatki o poustvarjalnih umetnikih. Npr. biografija pijanista Jenőja Takacsa je bila objavljena le zato, ker je bil v Zagrebu tudi v vlogi skladatelja.

Lahko rečemo, da sta bila zvezdi Glasbenih večerov hrvaška sopranistka Maja Strozzi-Pečić in njen soprog, pianist Bela Pečić. Nastopala sta na 12 koncertih, kaj je skoraj $10 \%$ vseh koncertov, vedno s skrbno sestavljenim programom. Celo dva koncerta sta bila posvečena skladbam njunega prijatelja, Igorja Stravinskega, ki je Maji Strozzi posvetil svoje Štiri pesmi. Na koncertu v ciklusu Glasbenih večerov je par Strozzi - Pečić med drugim igral tudi ciklus Tri lahke skladbe za klavir štiriročno Stravinskega, skladan leta 1917. To je zanimivo, ker je bila Maja Strozzi slavna primadona (celo Thomas Mann jo je občudoval) in do zdaj ni bilo znano da je znala tako dobro igrati klavir. Nekaj let pred nastopom v Zagrebu je Bela Pečić igral ta ciklus skupaj s Stravinskim v Švici, na koncertu v Laussani. V fondu Strozzi-Pečić v Hrvaškem glasbenem zavodu je shranjena notna izdaja, iz katere sta igrala, $z$ lastoročnim posvetilom Stravinskega Beli Pečiću.

Danes so v knjižnici Glasbenega zavoda zanimive notne izdaje, ki jih je Schneider nabavljal za koncertne cikluse. Natalija Sergejevna Gončarova, ruska slikarka in grafičarka, je oblikovala izdajo skladbe za klavir Le poisson d'or (Zlata ribica), skladatelja lorda Bernersa, znanega tudi kot »angleški Satie«. Skladba je bila objavljena 1919, ter izvajana na koncertu v Zagrebu leta 1923. Na naslovnici se vidi, da je ime Gončarove pisano s skoraj tako velikimi črkami kot ime skladatelja. Zanimivo pa je, da tudi članek o lordu Bernersu v enciklopediji Grove's Dictionary omenja, da je to izdajo oblikovala Gončarova.

5 »Berners' earliest mature works were for the piano - Le poisson d'or, dedicated to Stravinsky and published with designs by Natal'ya Goncharova of the Ballets Russes«, Peter Dickinson, »Berners, Lord [Tyrwhitt-Wilson, Sir Gerald Hugh, Baronet] «, Grove Music Online, obiskano oktobra 2017, http://www.oxfordmusiconline.com/ subscriber/article/grove/music/02872?q=berners\&search=quick\&pos=1\&_start=1\#firsthit. 
Za organizacijo vsakotedenskega novega koncerta je moral Artur Schneider najti dodatno finančno podporo. Posrečilo se mu je pridobiti pomoč od zagrebškega Francoskega inštituta, odprtega leta 1922. Že januarja naslednje leto piše na enem izmed koncertnih programov, da je Francoski inštitut pomagal pri nabavljanju partitur Gabriela Fauréja, tedaj še živega starega mojstra. Drugi je vir bila založba Chester iz Londona, ki je tedaj objavljala skladbe Stravinskega, de Falle, Poulenca in že omenjenega Lorda Bernersa. Kot zahvalo za note, ki jih je dobil od založbe, je Schneider večkrat objavil v koncertnih programih oglas za The Chesterian, glasbeni časopis hiše Chester.

Programi za Intimne glasbene večere so zaradi objavljenih portretov glasbenikov (fotografije in slike) med drugim tudi dragocen vir za glasbeno ikonografijo. Kot piše Schneider v enem od poročil, je bilo v sezoni 1923/24 v programih objavljeno kar 144 strani teksta. Verzi so bili vedno objavljeni v originalnem jeziku, celo v originalni pisavi (npr. v ruski cirilici). Zanimivo je, da nemške pesmi niso bile nikoli prevedene, verjetno zaradi dolge tradicije nemškega jezika $v$ Zagrebu in predpostavke, da koncertno občinstvo razume nemščino.

In na koncu, če imamo danes te cikluse za ponos Glasbenega zavoda, a je bilo tako tudi v Schneiderjevem času? Seveda ne, saj sodobne glasbe ni bilo lahko »udomačiti« v Zagrebu. Napadi na Schneiderja v časopisih so šli celo tako daleč, da je on vodstvu Zavoda na koncu leta 1923 ponudil svoj odstop. K sreči je od vodstva dobil brezpogojno podporo in ciklusi so se lahko nadaljevali.

Schneider je umrl leta 1946, na začetku povsem novega političnega in kulturnega obdobja, ki je narekovalo drugačno umetnost. Sodobna glasba je prodrla v Zagreb v večji meri šele leta 1961, ko se je začel znameniti festival Muzički biennale Zagreb. Tedaj, leta 1963, Stravinski ni prišel v Zagreb kot prijatelj para Strozzi-Pečić, ampak kot živa legenda.

Za zaključek vprašanje: Kako je institucija, kot je bil Glasbeni zavod, kritizirana že od 1860-ih letih naprej, da je zastarelih nazorov in progermansko usmerjena ter premalo narodno zavedna, naenkrat postala tako napredna, odprta za nacionalno in sodobno glasbo? To je bila seveda tudi posledica vzdušja po prvi svetovni vojni, pa tudi v samem Glasbenem zavodu, kjer je predsednik postal Robert Siebenschein, oče Dragana Plamenca, mladega ekspresionističnega skladatelja in kasneje svetovno znanega muzikologa. Plamenac je leta 1935 priredil prvi koncert hrvaške renesančne in baročne glasbe, s čimerje odprl še ena vrata, tista v zgodovino hrvaške glasbe. 


\section{Repertoar sodobne glasbe na koncertih - slovenski, hrvaški in srbski skladatelji}

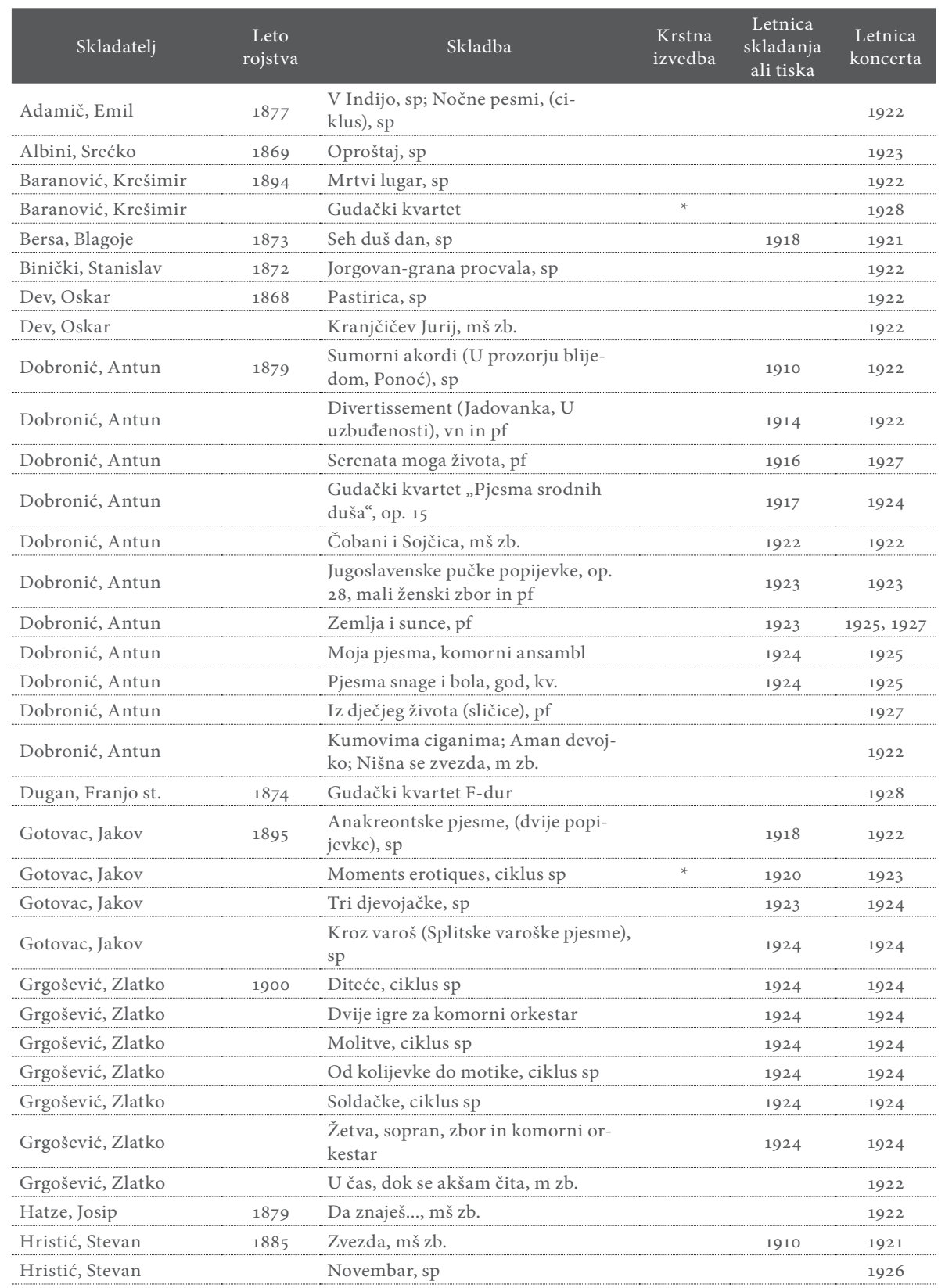




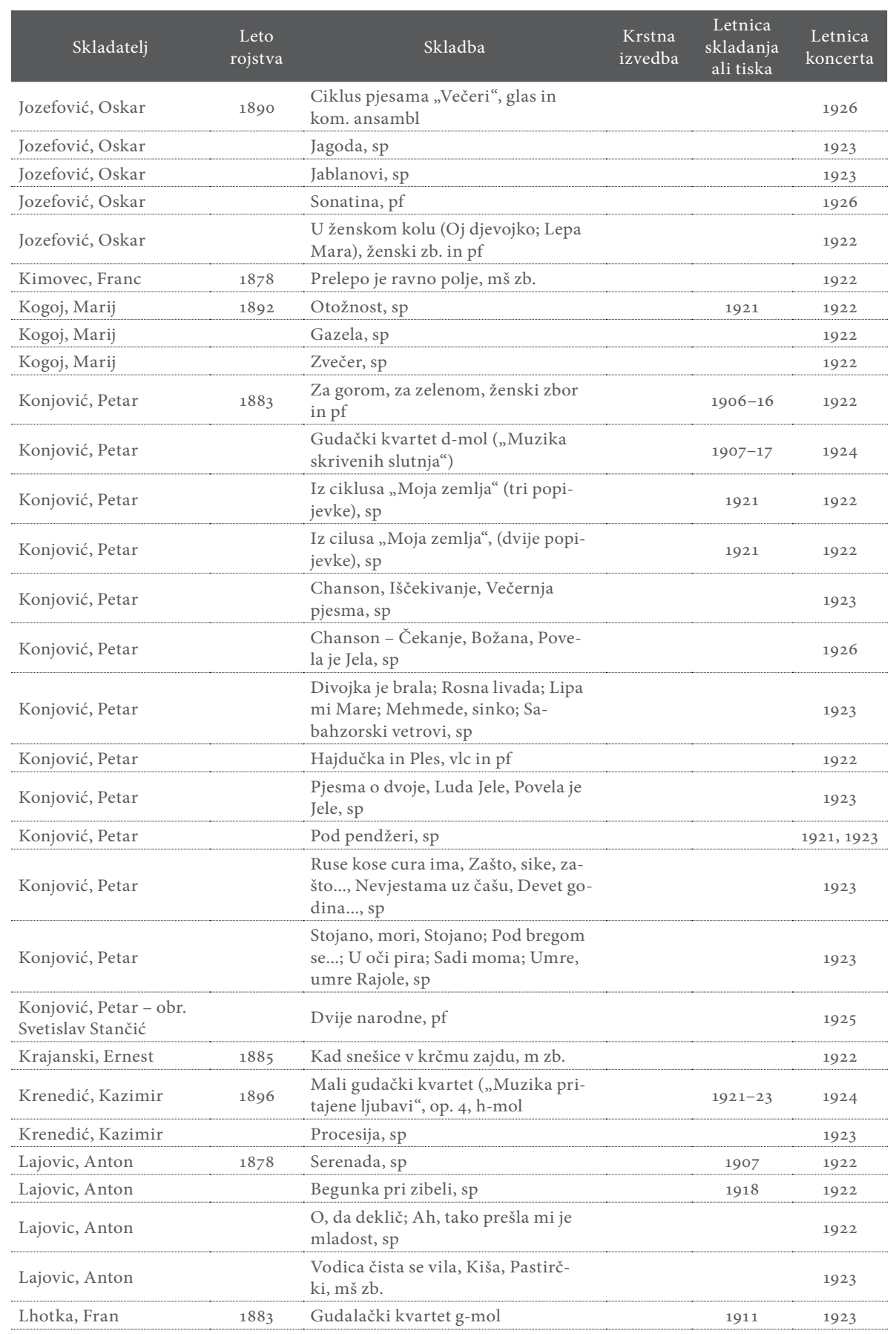




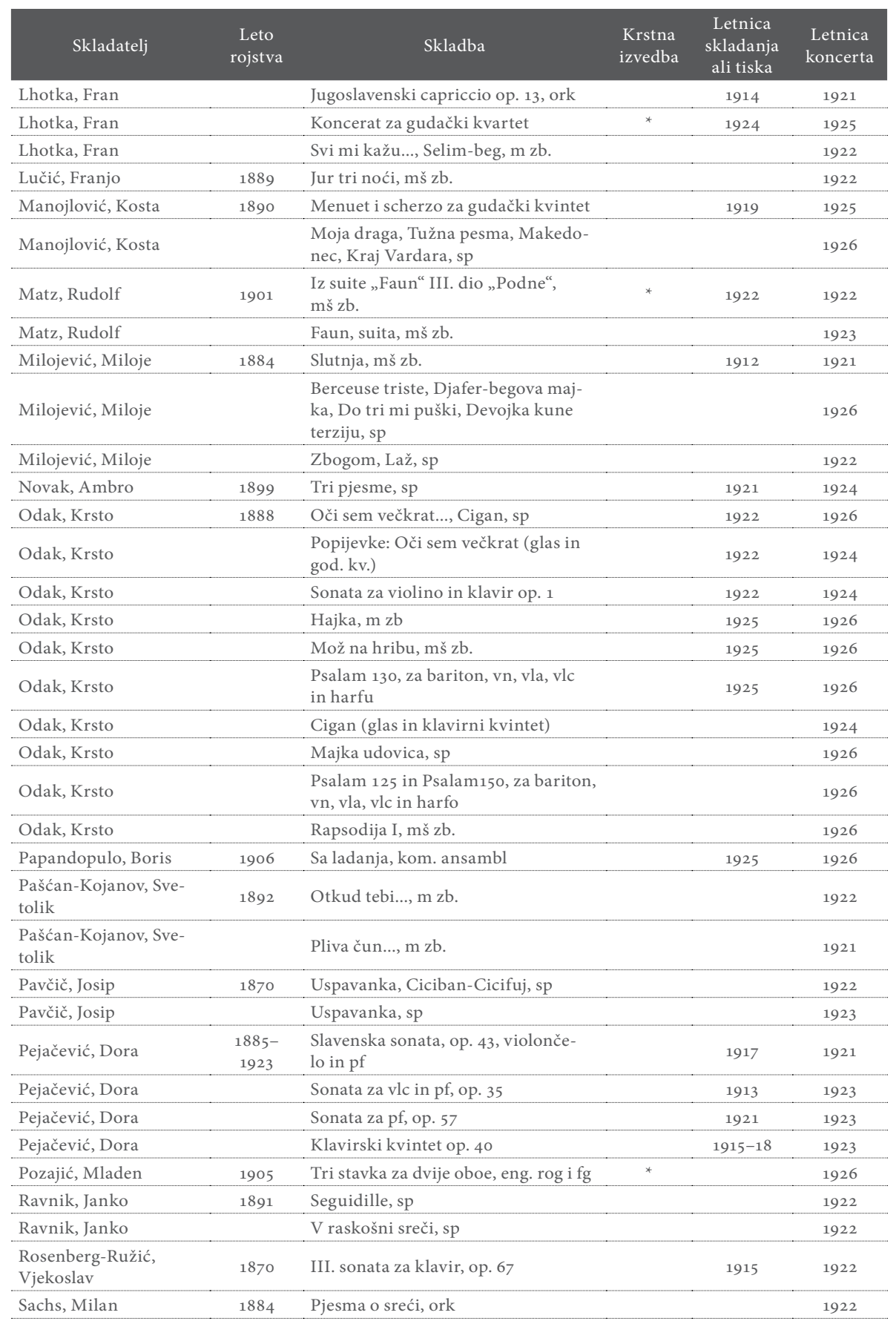




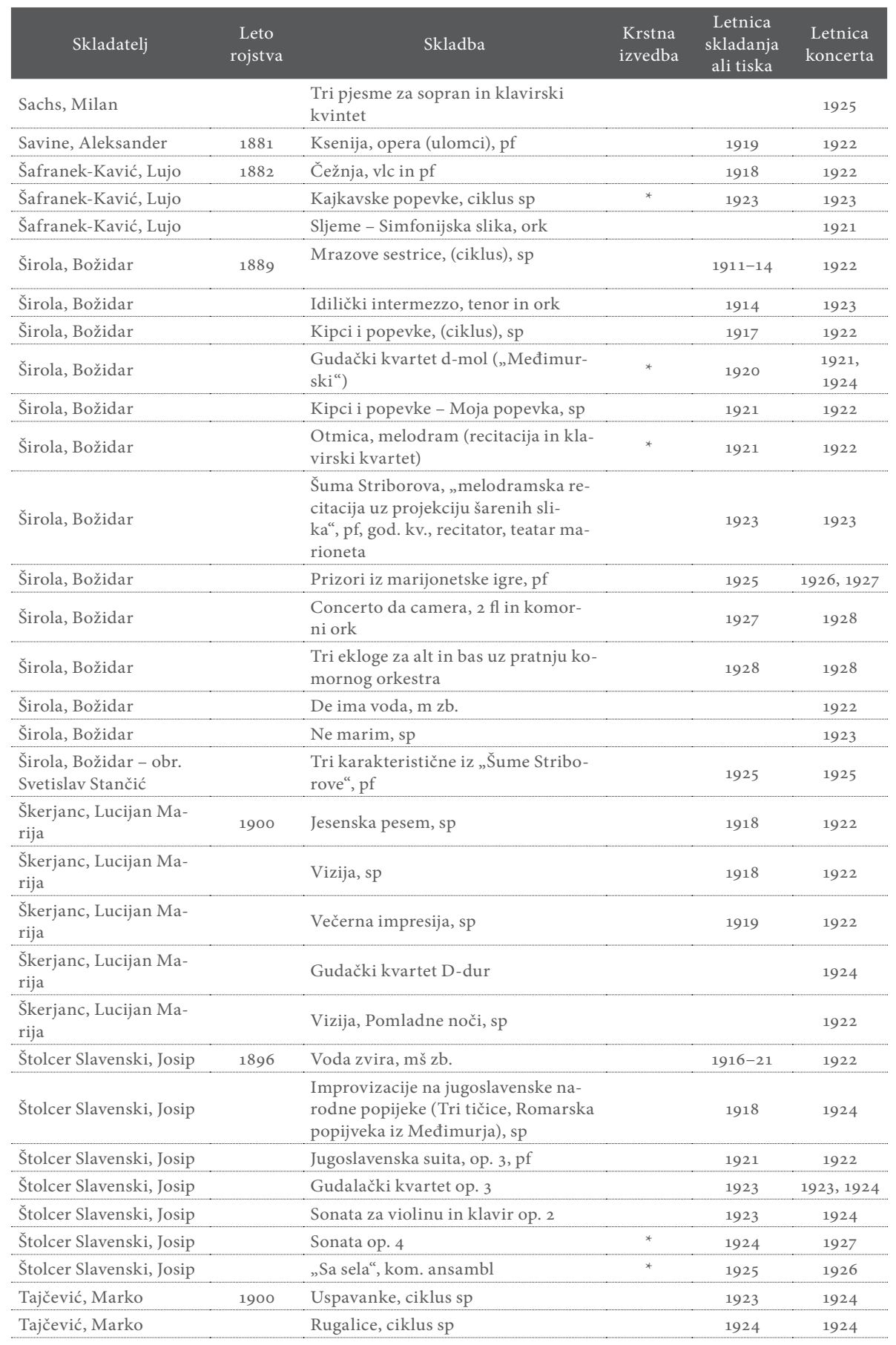




\begin{tabular}{|c|c|c|c|c|c|}
\hline Skladatelj & $\begin{array}{l}\text { Leto } \\
\text { rojstva }\end{array}$ & Skladba & $\begin{array}{l}\text { Krstna } \\
\text { izvedba }\end{array}$ & $\begin{array}{c}\text { Letnica } \\
\text { skladanja } \\
\text { ali tiska }\end{array}$ & $\begin{array}{l}\text { Letnica } \\
\text { koncerta }\end{array}$ \\
\hline Tajčević, Marko & & Vračaruše, ciklus sp & & 1924 & 1924 \\
\hline Tajčević, Marko & & Sedam balkanskih igara, pf & * & 1927 & 1927 \\
\hline Žganec, Vinko & 1890 & $\begin{array}{l}\text { Janica je fajn snešica; } \\
\text { Vu mleki se hmivam, mš zb. }\end{array}$ & & & 1922 \\
\hline
\end{tabular}

\section{Repertoar sodobne glasbe na koncertih}

- slovenski, hrvaški in srbski skladatelji

Upoštevani so skladatelji, ki so še živeli, ko so v Zagrebu igrali njihove skladbe. Izjema je Claude Debussy, toda ker je umrl samo nekaj let pred začetkom ciklusov in zaradi številnih različnih njegovih skladb, zasluži svoje mesto v repertoarju. Podatki o rojstnih letih in letnicah skladanja so prevzeti iz relevantnih leksikografskih publikacij, le v nekaj primerih je bilo treba prevzeti od drugod (označeno z opombo ali kratico).

Kratice:

$\mathrm{cl}=\mathrm{klarinet}$

$\mathrm{ctb}=$ kontrabas

$\mathrm{fg}=$ fagot

$\mathrm{fl}=$ flavta

god. kv. = godalni kvartet

kom. $=$ komorni

$\mathrm{m} \mathrm{zb} .=$ moški zbor

mš zb. = mešani zbor

$\mathrm{ob}=\mathrm{oboa}$

ork. $=$ orkester

$\mathrm{pf}=$ klavir

$\mathrm{sp}=$ samospev

vla $=$ viola

$\mathrm{vlc}=$ violončelo

$\mathrm{vn}=$ violina 


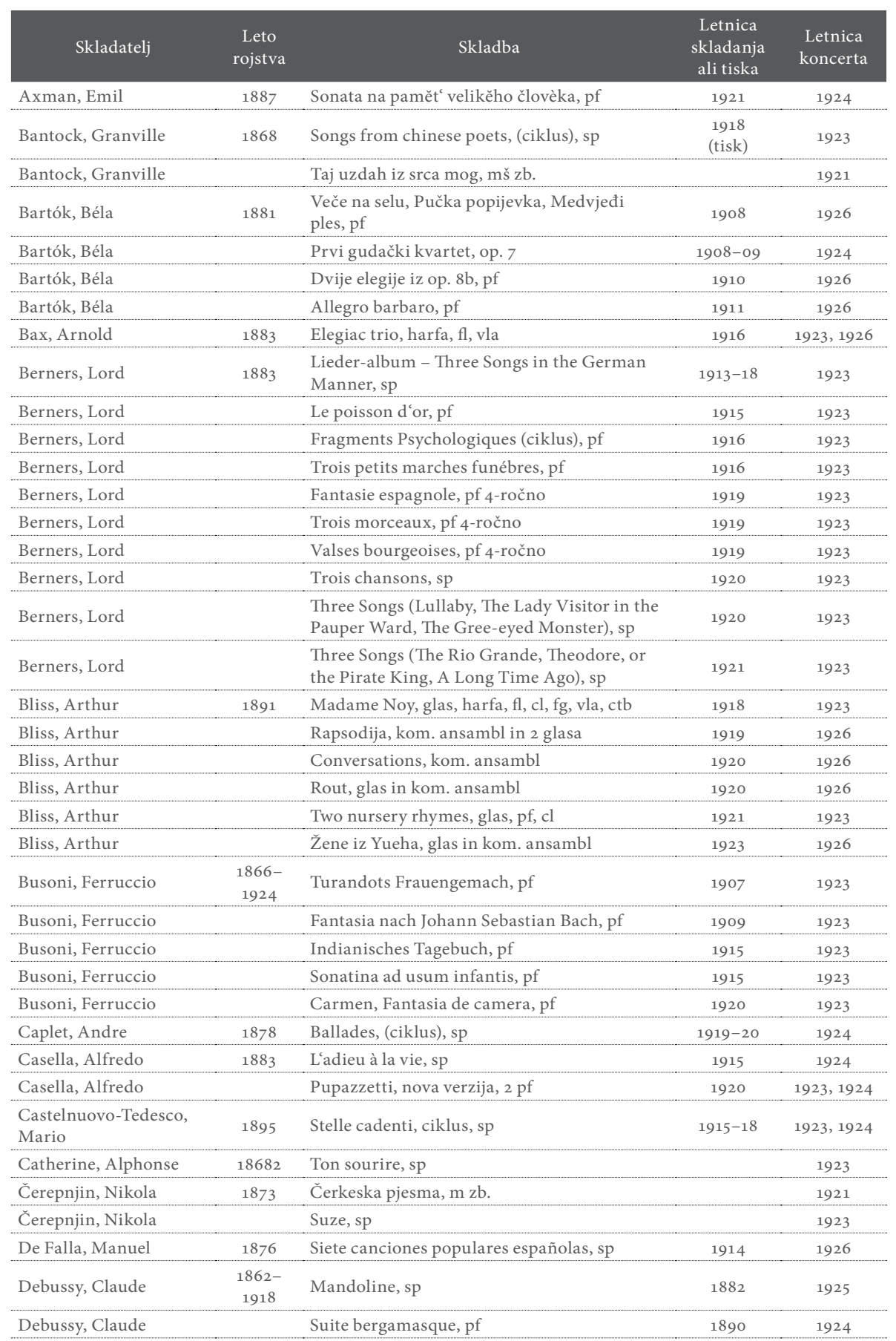




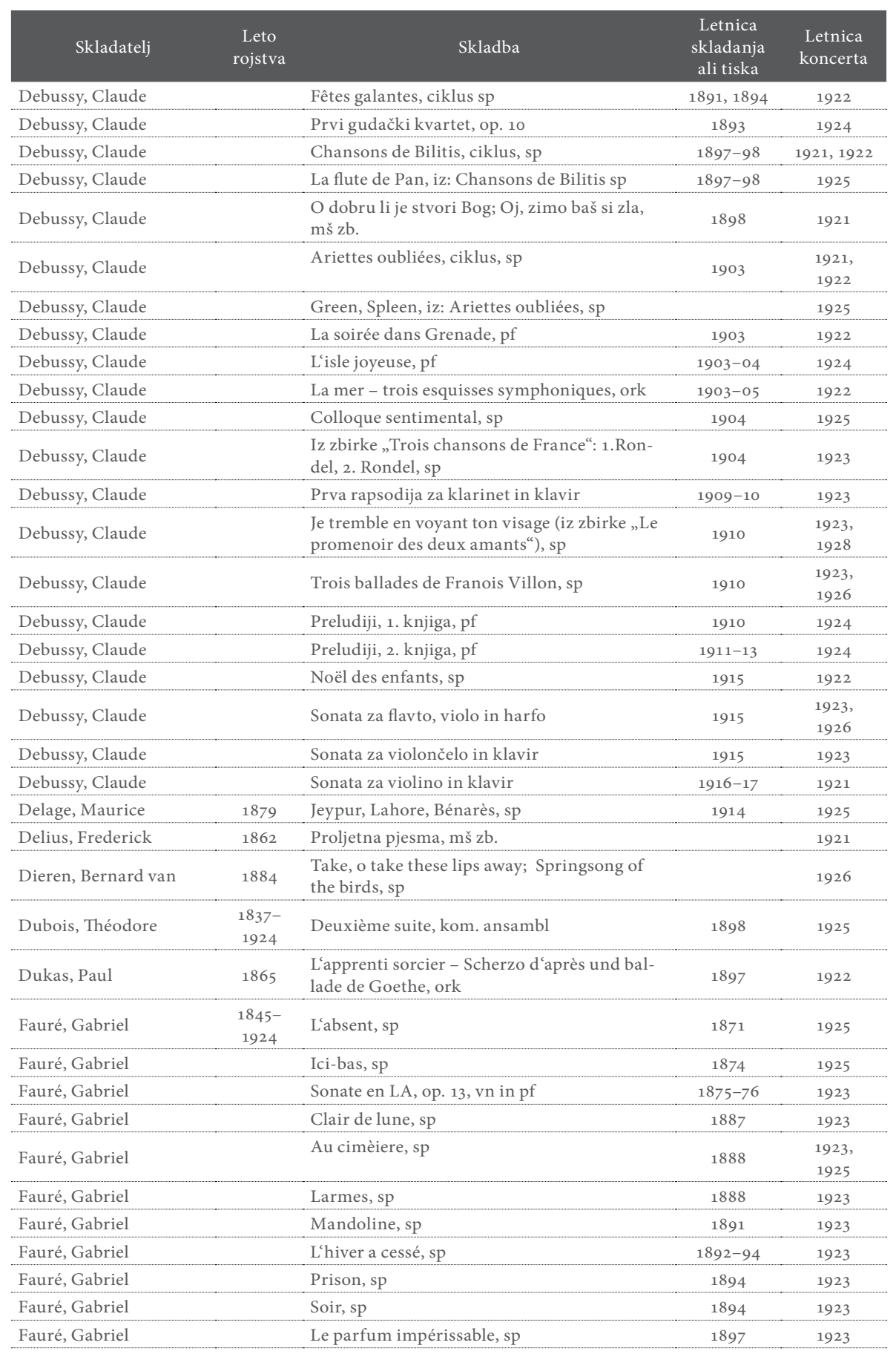




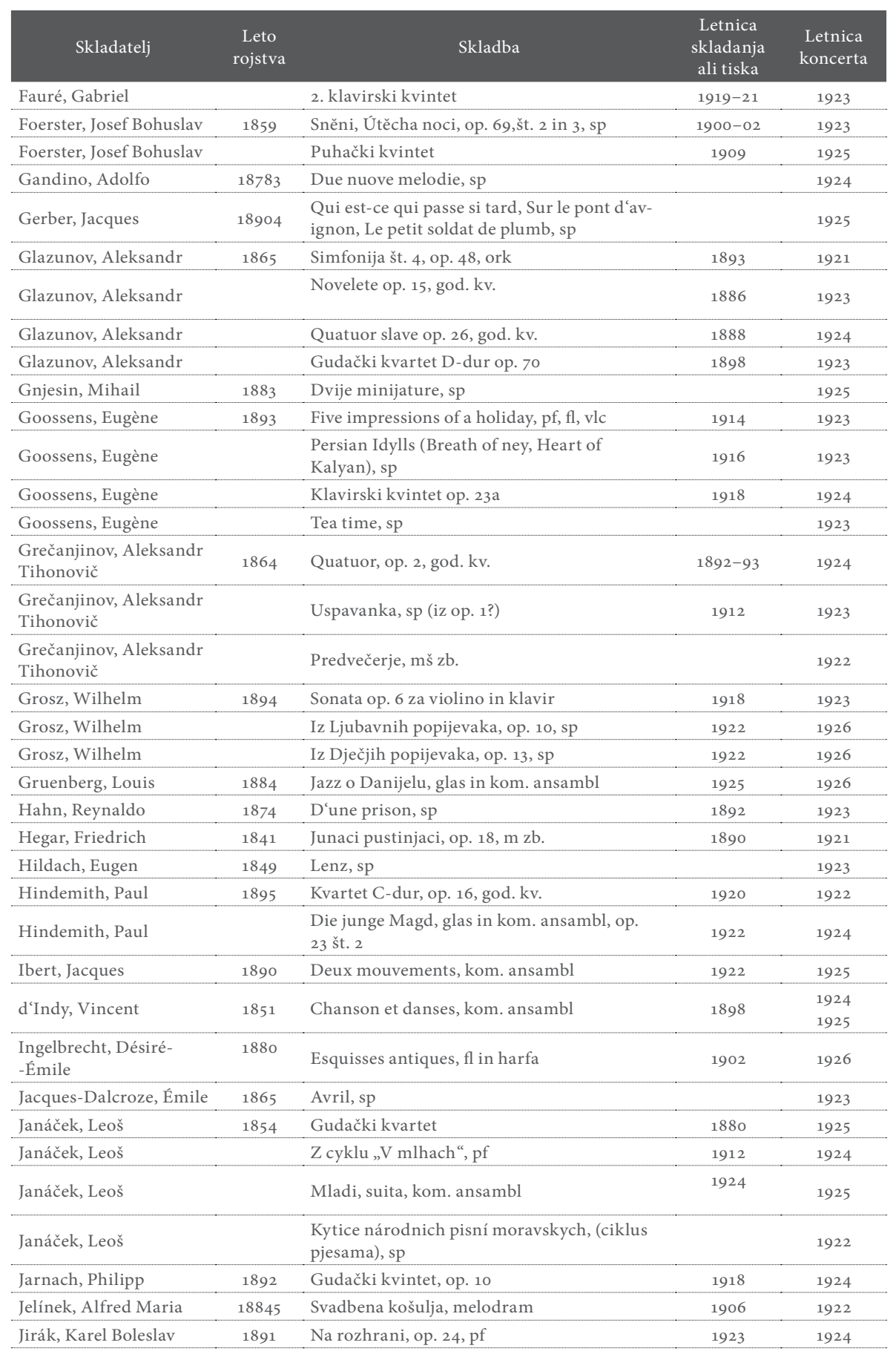




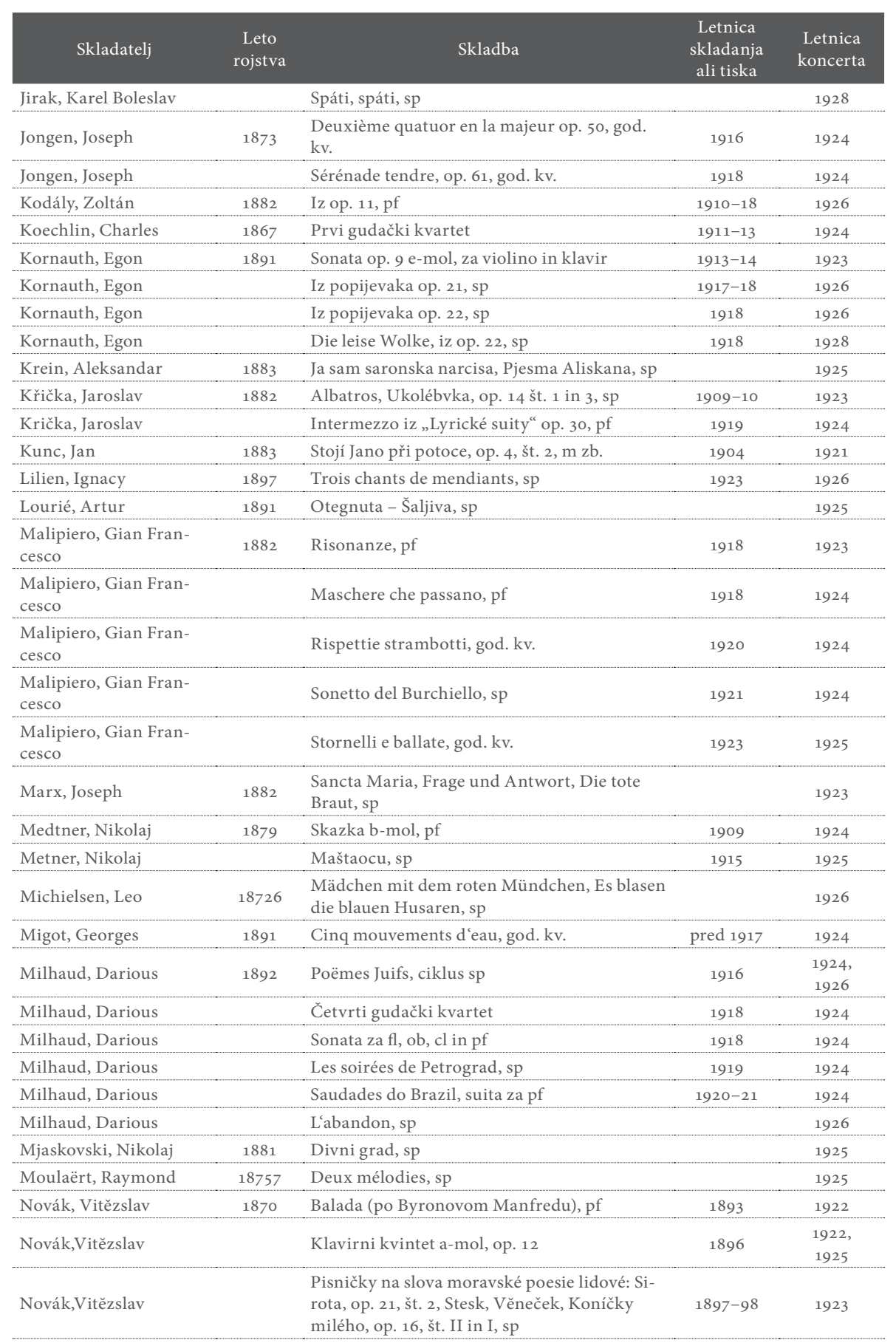




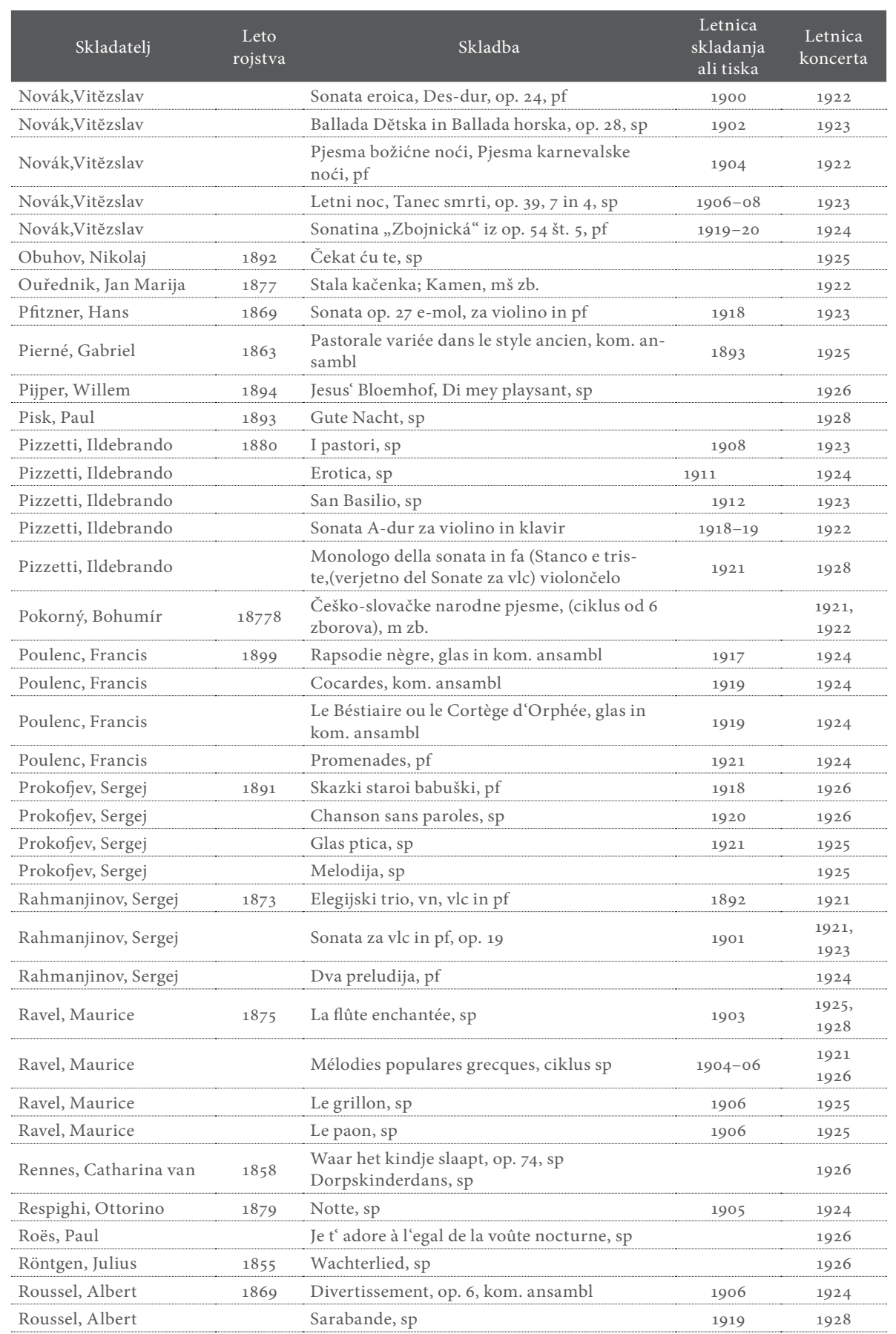




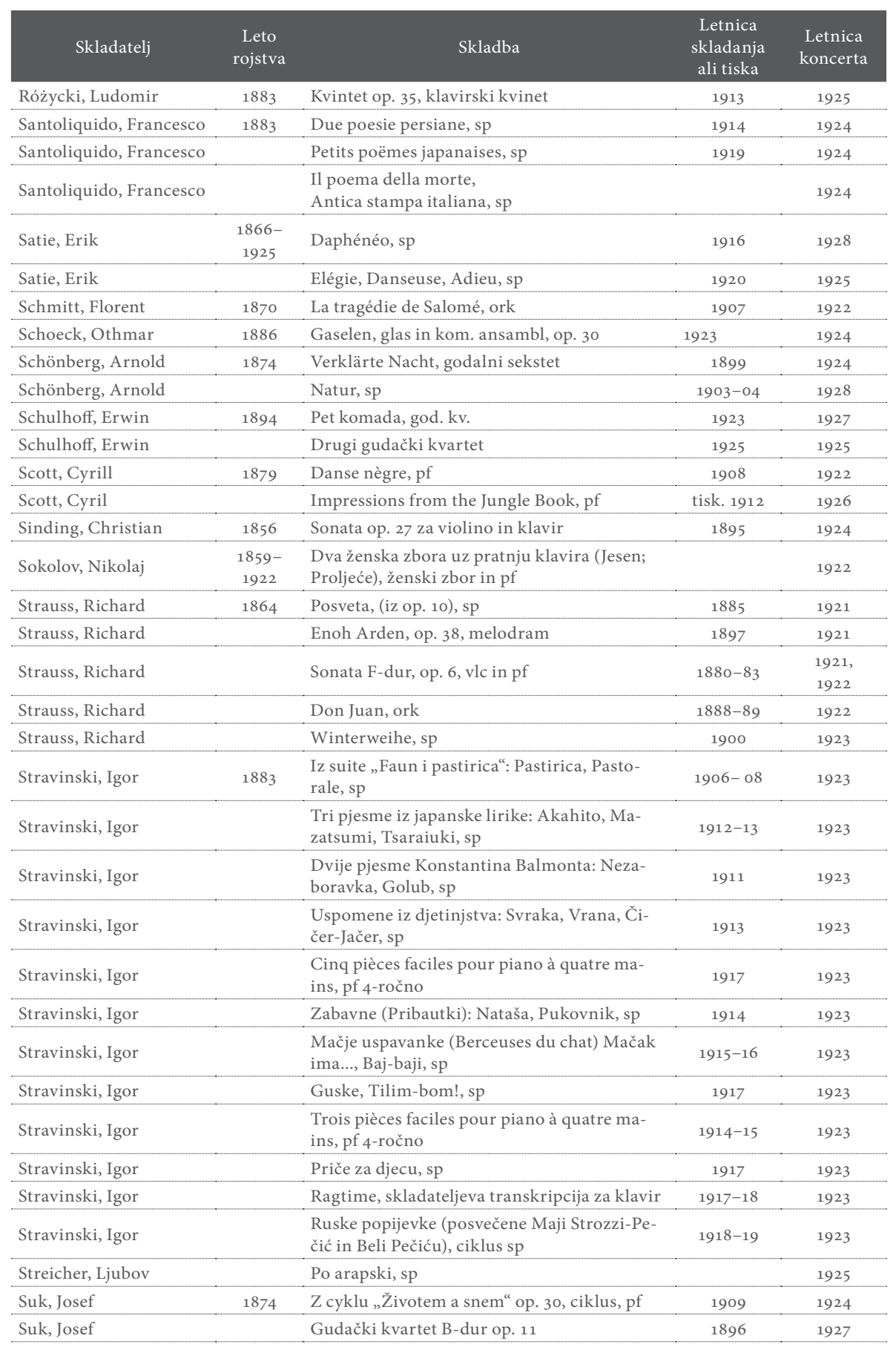




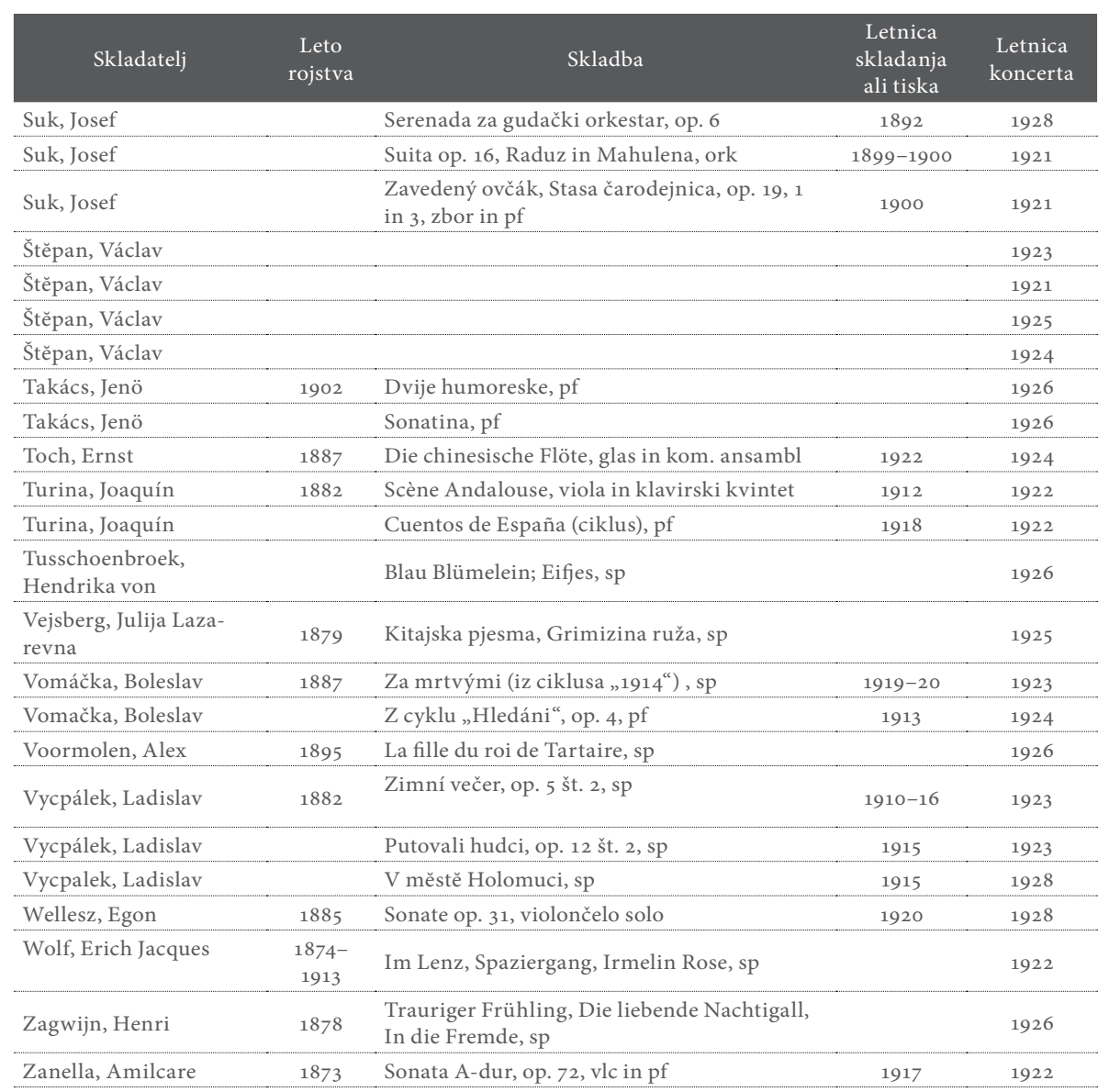

I Český hudební slovník, http://www.ceskyhudebnislovnik.cz/.

2 Petrucci Music Library, http://imslp.org/wiki/Category:Catherine\%2C_Alphonse.

3 Petrucci Music Library, http://imslp.org/wiki/Category:Gandino\%2C_Adolfo.

4 http://www.lieder.net/lieder/get_settings.html?COmposerld=24386.

5 Ceský hudební slovník, http://www.ceskyhudebnislovnik.cz/.

6 Wikipedija.

7 Petrucci Music Library, http://imslp.org/wiki/Category:Moulaert\%2C_Raymond.

$8 \quad$ Wikipedija. 


\section{Bibliografija}

Bezić, Nada. »Artur Schneider i glazba - tragom Ladislava Šabana«. V:Artur Schneider 1879.-1946. Zbornik radova znanstveno-stručnog skupa Hrvatski povjesničari umjetnosti. Zagreb: Društvo povjesničara umjetnosti $\mathrm{Hr}-$ vatske, 2016, 81-96.

Dickinson, Peter. »Berners, Lord [Tyrwhitt-Wilson, Sir Gerald Hugh, Baronet]«, Grove Music Online. Obiskano oktobra 2017, http://www.oxfordmusiconline.com/subscriber/article/grove/ music/02872?q=berners\&search=quick\&pos=1\&_start=1\#firsthit.

[S. n.]. »Mihalović, Hugo, pijanist«. Leksikon jugoslavenske muzike, zv. 2. Zagreb: Jugoslavenski leksikografski zavod, 1984, 6.

Samson, Jim. Music in the Balkans. Leiden, Boston: Brill, 2013, 339.

Šaban, Ladislav. »Artur Schneider i glazba«. Peristil, 23 (1980): 63-66.

Šaban, Ladislav. 150 godina Hrvatskog glazbenog zavoda. Zagreb: Hrvatski glazbeni zavod, 1982. 



\title{
Anton Dolinar kot doktorski študent Guida Adlerja
}

\author{
Matjaž Barbo \\ Univerza v Ljubljani \\ University of Ljubljana
}

Anton Dolinar je v obdobju med obema vojnama veljal za nesporno avtoriteto na glasbenem področju. Njegovo delovanje se je širilo vse od zvestega in požrtvovalnega pionirskega urednikovanja na ljubljanskem radiu, do dirigiranja, širšega kulturnega in organizacijskega dela, publicistike ter poučevanja. In četudi gre za enega sploh prvih slovenskih muzikologov z obranjenim doktoratom pri slovitem Guidu Adlerju na Dunaju, njegovo strokovno delo doslej žal ni bilo deležno posebne pozornosti in je celo v muzikološki literaturi obravnavano pičlo ali pa je sploh prezrto. Med redkimi zapisi o njem najdemo krajšo notico ob njegovi smrti ${ }^{1}$ ter mestoma nepopolne leksikografske zapise. ${ }^{2}$ Sicer so omembe njegovega imena in delovanja doslej praviloma obrobne in sporadične, ${ }^{3}$ pogosto pa njegovega imena strokovna literatura niti ne omenja.

Ob zagovoru svoje doktorske disertacije je Dolinar rigorosnim aktom priložil tudi življenjepis, ki dokaj natančno, seveda pa predvsem iz prve

1 Edo Škulj, »Anton Dolinar (1894-1953): Ob petdesetletnici smrti«, Cerkveni glasbenik 96, 7-8 (2003): 10.

2 "Dolinar, Anton«, v Slovenski bijografski leksikon, 1. zv.: Abraham-Erberg, ur. Izidor Cankar et al. (Ljubljana: Zadružna gospodarska banka, 1925), 141; Jože Sivec, »Dolinar, Anton«, Enciklopedija Slovenije, 2. zv. Ce-Ed., ur. Marjan Javornik (Ljubljana: Mladinska knjiga, 1988), 299.

3 Prim. Edo Škulj, Letopis slovenskega glasbenega življenja v Argentini: ob 5o. obletnici vélikega izhoda (Celje: Mohorjeva družba; Celovec: Krščanska kulturna zveza; [s. 1.]: Izseljensko društvo Slovenija v svetu, 1995), 42-43; Nataša Cigoj Krstulović, Zgodovina, spomin, dediščina: Ljubljanska Glasbena matica do konca druge svetovne vojne (Ljubljana: Založba ZRC, ZRC SAZU, 2015). 
roke in zato zanesljivo predstavlja nekaj podatkov o njegovem življenju. Nekaj podobnih podatkov je mogoče povzeti tudi iz pičle literature, ki je o tem skladatelju, dirigentu, uredniku in duhovniku sicer na voljo. Da je $\mathrm{v}$ domovini spomin nanj precej obledel, je nedvomno krivo dejstvo, da je kot politični emigrant po drugi svetovni vojni odšel v Združene države Amerike in tudi tako delil usodo nekaterih vsaj delno zamolčanih in postopno pozabljenih imen slovenske povojne emigracije. Pa vendar gre za enega najbolj pomembnih ustvarjalcev radijskega programa $\mathrm{v}$ začetnih desetletjih oddajanja Radia Ljubljana ter ne nazadnje enega muzikološko najbolj široko razgledanih glasbenikov, saj je svoj študij glasbe zaključil z doktoratom pri slovitem Guidu Adlerju na Dunaju. Prav temu njegovemu študiju in Adlerjevem vplivu na Dolinarja, s tem pa posredno na razvoj slovenske muzikologije je posvečen pričujoči prispevek.

Anton Dolinar je bil rojen 13. januarja 1894 v Trati nad Škofjo Loko, kjer je končal tudi osnovno šolanje, kot pravi sam v omenjenem življenjepisu. Gimnazijo je končal leta 1913 v eni prvih generacij maturantov na škofovih zavodih v Šentvidu nad Ljubljano (ustanovljeni 1905), tedaj edini popolnoma slovenski gimnaziji pri nas. Njegov glasbeni učitelj na gimnaziji je bil Vojteh Hybašek (1873-1947), češki duhovnik, literat in glasbenik, ki je pri nas vzgojil vrsto poznejših glasbenikov. ${ }^{4}$ Hybašek je bil nedvomno močno vplival na Dolinarja in mu dal »temeljito osnovno glasbeno izobrazbo «.'

Po gimnaziji je vpisal na ljubljanski Teološki fakulteti študij teologije (1913-17) in bil 8. junija 1917 posvečen $\mathrm{v}$ duhovnika.

Škof Jeglič, ustanovitelj šentviške gimnazije ter njen skrbni in premišljeni voditelj je želel nastaviti za glasbenega učitelja dobrega glasbenika, široko razgledanega, intelektualno močnega in človeško zanesljivega, ki si ga je izbiral iz duhovniških vrst. Na voljo je imel kar nekaj kandidatov. Eden od teh je bil Ludvik Puš (1896-1989), ki se je že v semenišču izkazal kot dober

4 Hybašek je bil izvrsten učitelj, ki je dobrih trideset let, od 1906 do upokojitve leta 1937, deloval kot glasbeni učitelj na Knezoškofijski klasični gimnaziji. Poučeval je violino, klavir, orgle, harmonij, pihala in trobila. Vzgojil je vrsto zavodskih gojencev, ki so se pozneje v veliki meri posvetili glasbi ter oblikovali kar t.i. »Hybaškovo šolo«. Mednje so sodili: Anton Dolinar, Matija Tomc, Alojzij Mav, Vilko Ukmar in Venčeslav Snoj. Prim. Stanko Premrl, »Hybášek, Vojteh (1873-1947)«, v Slovenski bijografski leksikon: 3. $z v$. Hintner - Kocen, ur. Izidor Cankar et al. (Ljubljana, Zadružna gospodarska banka, 1928), 360; Matjaž Ambrožič, »Profesorski zbor«, v Sto let Zavoda sv. Stanislava, ur. France M. Dolinar (Ljubljana : Družina, 2005), 439-440; Venceslav Snoj, »Prof. V. Hybašek«, v Letno poročilo 1937/38 (Št. Vid nad Ljubljano: Zavod sv. Stanislava, 1938), 10-11. 
glasbenik, a je moral po dveh letih in pol odstopiti zaradi jetike (vendarle je pozneje doktoriral na Filozofski fakulteti in bil dejaven pri Pevski zvezi). Med bogoslovci je kot glasbenik velik ugled užival tudi Lojze Mav (1898-1977), ki pa je po novi maši stopil $\mathrm{k}$ lazaristom in zato ravno tako ni bil povsem primeren kandidat za Jegliča. Jože Klemenčič (1892-1969) je kot najstarejši nekako samoumevno pričakoval, da ga bo škof poslal na študij, vendar mu Jeglič ni preveč zaupal, kar je pozneje zanetilo pravi spor med obema.

$\mathrm{V}$ enem zadnjih pisem (3. maja 1982), ki jih je v bogati korespondenci na uredništvo Cerkvenega glasbenika naslovil Matija Tomc (1899-1986), se je le-ta med drugim obširneje razpisal o skladatelju Jožetu Klemenčiču in $\mathrm{v}$ tem kontekstu predstavil tudi okoliščine izbire kandidata za študij na Dunaju:

"Ko je Zavod $v$ Šentvidu rabil novo moč za pouk glasbe, je menda Klemenčič pričakoval, da bo šel on študirat. Izbrali pa so Dolinarja in je Klemenčič tako izpadel. [...] Nadškof Jeglič je navadno izbral nove profesorje, ki so bili prej gojenci zavoda (če je to le šlo). Drugi profesorji so tako novega profesorja že od prej poznali; bil je tudi navajen od prej na zavodski redi in disciplino. Dolinar je bil med prvimi zavodskimi maturanti in je gotovo že / zaradi tega imel prednost pred Klemenčičem, ki ga je stari profesorski zbor verjetno bolj malo poznal, bodisi po glasbeni ali tudi po človeški strani.« ${ }^{6}$

Študij muzikologije na dunajski univerzi je Dolinar vzporedno dopolnjeval s študijem praktičnih disciplin na Oddelku za cerkveno glasbo na dunajskem konservatoriju. Tako je v zimskem semestru 1921-22 vpisal tudi študij na dunajskem glasbenem konservatoriju, kjer je leta 1923 končal oddelek za cerkveno glasbo. Sam je v omenjenem življenjepisu, ki ga je predložil ob obrambi disertacije, zapisal, da je »dve leti obiskoval Oddelek ta cerkveno glasbo dunajske glasbene akademije» (»2 Jahre die Abteilung für Kirchenmusik an der Wiener Musik-Akademie besuchte«). V omenjenem življenjepisu je zapisal, da je poleg tega harmonijo, kontrapunkt in oblikoslovje dodatno privatno študiral pri Karlu Weiglu (»Harmonie, Kontrapunkt und Formenlehre studierte ich dazu noch privat bei Dr. Karl Weigl«). Karl Weigl (1881-1949) je tedaj veljal za enega najbolj cenjenih glasbenikov na Dunaju. Široko razgledan (študiral je tako na konservatoriju kot pozneje na univerzi pri Adlerju) in tudi prijateljsko povezan z najvidnejšimi glas-

6 Edo Škulj, »Tomčeva pisma«, v Tomčev zbornik, ur. Edo Škulj (Ljubljana: Družina, 1997), 193-194. 
benimi osebnostmi svojega časa (Gustav Mahler, Richard Strauss, Bruno Walter, Alexander Zemlinsky, Arnold Schönberg, Anton Webern in številni drugi) je zagotovo predstavljal tudi mlademu Dolinarju posebno privlačen zgled, nedvomno pa mu je lahko nudil več kot dragoceno mentorsko pomoč.

Središče Dolinarjevega dunajskega študija je predstavljalo obiskovanje predavanj iz muzikologije na Filozofski fakulteti dunajske univerze na oddelku slovitega Guida Adlerja. Kako visoko je Dolinar cenil dunajski muzikološki oddelek, izpričuje njegov zapis iz leta 1923 znotraj prispevka, v katerem se sicer posveča analizi tamkajšnjega glasbenega življenja:

"Za splošno razumevanje glasbe stori veliko dunajska filozofična fakulteta s svojim oddelkom: , Musikhistorisches Institut'. Izmed seminarjev na tej fakulteti je bil ta lansko leto najmočnejši." "T

Kot je razvidno iz gradiva, hranjenega $\mathrm{v}$ dunajskem Univerzitetnem arhivu, je Dolinar vpisal šest semestrov študija, vse od zimskega semestra 1921-22 do letnega semestra 1924.

V vpisnicah posameznih vpisanih študijskih semestrov (Nationale), ki so hranjene $\mathrm{v}$ univerzitetnem arhivu dunajske univerze, se je Dolinar opredeljeval kot jugoslovanski državljan (od zimskega semestra 1922-23 kot državljan SHS), rojen na Jesenicah (spet pozneje natančneje določeno: »Trata - Slowenien«). Vsakič je v vpisnicah označena slovenščina kot njegov materni jezik in rimokatoliška veroizpoved. Označil je tudi ime očeta in njegov poklic: Gregor, »posestnik (»Grundbesitzer« - v letnem semestru 1923 kratko označen kot »kmet«, »Bauer«). Dolinar je kot duhovnik glede na vpisnico ves čas študija na Dunaju stanoval na naslovu Habsburgergasse 7, Wien I, kjer je tudi še danes katoliški študentski dom (Tomažev kolegij).

Predavanja, ki jih je Dolinar izbiral in obiskoval na Dunaju, že dokaj nakazujejo krog njegovih tudi poznejših glavnih strokovnih interesov. Pri tem je seveda nekaj predavanj vzel iz ponudbe muzikološkega oddelka, nekaj pa tudi med ponujenimi predmeti drugih oddelkov Filozofske fakultete.

V prvem vpisanem semestru (zimski semester 1921-22) je Dolinar tako poslušal dvoje predavanj o glasbeni drami profesorja Roberta Lacha (18741958; Das Musikdrama Richard Wagners, 2st. in Ursprung u. Entwicklungd. musikal. Dramas, 2 uri) ter Lachovo predavanje o Psihologiji glasbenega izraza (Die Psychologie d. musikal. Ausdruckes, 1 ura). Poleg tega je obiskoval znotraj muzikološkega oddelka še predavanje o Josephu Haydnu tedaj 
docenta Wilhelma Fischerja (1886-1962), ki je bil pozneje zaradi svojega judovskega porekla deležen nacističnega preganjanja. Zunaj oddelka za muzikologijo si je izbral filozofsko pregledno predavanje profesorja Roberta Reiningerja (1969-1955) o nacionalizmu in razsvetljenski filozofiji (Nationalismus u. Aufklarungsphilosophie von Beginn der Neuzeit bis Kant, 4 ure). Že zgodaj je tako mogoče iz tega zaslutiti Dolinarjevo poznejše strokovno angažiranje na področju glasbene filozofije, estetike in ne nazadnje narodnostnih vprašanj.

Zanimivo je, da Dolinar v prvem semestru študija muzikologije ni izbral nobenega od Adlerjevih dveh razpisanih predavanj. Tedaj je Adler namreč pripravil predavanja iz »Razlage in opredelitve umetniških del« (Erklären u. Bestimmen von Kunstwerken, 2 uri) ter "Vaje na glasbenozgodovinskem institutu " (Übungen im musikhistorischen Institut, 2 uri). Prav tako se ni odločil za predavanja Maxa Dietza (Führer und Bahnbrecher der neuromantischen Tonkunst in Sinfonik, im Oratorium und in der Oper; $m$. vielen Musikbeispielen, 3 ure), Egona Wellesza (Die Entwicklung d. großen sinfonischen Form u. d. Orchesters i. 19. Jahrh., 1 ura) in W. Fischerja (Allgemeine Musikgeschichte, 4 ure; ter Die Mensuralnotation d. 15. u. 16. Jahrh., 2 uri).

Prvič je Adlerjeva predavanja izbral vletnem semestru 1922, in sicer obe predavanji, razpisani za ta semester: Vaje iz glasbene zgodovine (Übungen im musik-hist. Inst., $2 \frac{1}{2}$ ure) ter razlaga in opredelitev umetniških del (Erklären und Bestimmen von Kunstwerken, $2 \frac{1}{2} 2$ ure). Znova je izbral tudi Lacha, tokrat s predavanji o psihologiji in estetiki sodobne glasbe (Psychologie u. Ästhetik d. Musik d. Gegenwart, 2 uri), ter Fischerja z uvodom v glasbenozgodovinsko literaturo (Einführung i. d. musikgeschichtl. Literatur, 2 uri). Poleg tega je zunaj oddelka izbral tudi uvod v latinsko paleografijo (3 ure).

Pri tem je zanimivo, da se med razpisanimi predavanji Dolinar ni odločil tokrat za dve Lachovi predavanji, pa tudi ne za Dietzev pregled klasične glasbene drame, za Fischerjeva predavanja (posvečena splošni glasbeni zgodovini in menzuralni notaciji) ter za predavanja Alfreda Orla (18891967, o glasbeni liturgiki in variacijskem principu).

V zimskem semestru 1922-23 je Dolinar znova poslušal obe Adlerjevi temeljni glasbenozgodovinski predavanji (Erklären u. Bestimmen von Kunstwerken, 2 uri; Übungen im musikhistorischen Institut, 2 uri), zato pa ne Adlerjevo specialko o Beethovnu. Prvič si je izbral tudi Orla in njegova predavanja o Antonu Brucknerju (2 uri) in gregorijanskem koralu (Einführung in den gregorianischen Choral, 1 ura). Spet je poslušal tudi Fischerja, tokrat 
o zgodovini instrumentalne glasbe (Geschichte der Instrumentalmusik, 2 uri). Zanimivo je, da si je izbral tudi cikel arheoloških predavanj o Pompejih, ki jih je pripravil rojak iz Podsrede, Arnold Schober (1886-1959; Pompeji, Entwicklung eines h. r. Stadtbildes, 1 ura), čigar mati Emma, r. Kopatsch je bila glasbeno izobražena in je izhajala iz celjske meščanske družine.

Znova v tem semestru ni vpisal nobenega od Lachovih predavanj (Dramaturgie und Ästhetik des altgriechischen Musikdramas; Allgemeine musikalische Entwicklungsgeschichte; Die musik der, orientalischen Kulturvöl$k e r$ ), prav tako pa tudi ne predavanje Egona Wellesza (o dunajski baročni operi) in W. Fischerja (o menzuralni notaciji).

V letnem semestru 1923 si je Dolinar izbral spet obe Adlerjevi temeljni predavanji (Übungen im musik-hist. Inst., $2 \frac{1}{2} 2$ ure; Eklären und Bestimmen von Kunstwerken, $2 \frac{1}{2}$ ure) ter vsa Orlova predavanja (poleg nadaljevanja predavanj o Brucknerju, 2 uri; še Die Frühzeit der Mehrstimmigkeit, 1 ura in Die Meßkomposition vom 17. Jahrhundert bis zu A. Bruckner, 2 uri). Poleg tega je vpisal še predavanja avstrijskega kulturnega filozofa Karla Roretza (1881-1967) o zgodovini novoveške psihologije (Geschichte der Psychologie der Neuzeit, 1 ura).

Orlova predavanja so očitno na Dolinarja naredila močan vtis, saj se je nedvomno prav pod njihovim vtisom lotil obsežnejšega portreta Antona Brucknerja, ki ga je objavil v Cerkvenem glasbeniku leta 1924 ob stoletnici skladateljevega rojstva. ${ }^{8} \mathrm{~S}$ tem se je poklonil velikemu skladatelju, ki je bil sicer v svojem času po Dolinarjevem mnenju deležen krivice: „Vendar, kar zakrivi sodobnost, popravi poznejša zgodovina; ona možem, ki izobrazbo svojega časa dosežejo in na podlagi te stremijo po napredku, iščejo novih potov, vódeni po neki notranji sili, popravi storjeno krivico in njihovo poslanstvo docela odkrije in razjasni.« (s. 2) Sam Dolinar je sicer v članku zapisal, da je podatke o Brucknerjevem življenju črpal iz monografije Maxa Auerja (1923), pa vendar lahko upravičeno domnevamo, da so na njegovo širšo interpretacijo skladatelja vplivala tudi Orlova predavanja.

Dolinar v interpretaciji Brucknerja poudarja nasprotje med obliko in vsebino ter $s$ tem izpeljuje splošne estetske principe, ki so tudi prek njegovega pisanja zaznamovali poznejše pisanje o glasbi pri nas, sam pa jih je, kot bomo videli tudi v nadaljevanju, prevzemal tudi pri Adlerju. Značilen v tem smislu je odlomek iz omenjenega članka o Brucknerju, v katerem lahko prepoznamo tako ideje Adlerja kot pozneje nekaterih Dolinarjevih mlajših sodobnikov, med njimi S. Vurnika in V. Ukmarja: 
"Oblika sama že pripomore k temu, da pravimo: ta in ta skladba je lepa, toda ne ona sama; oblika je le okvir, posoda duševne vsebine in ta vsebina je merodajna pri sodbi, katera glasba je lepa in katera ni. Glasba je govor, ki sicer ne deluje s tako gotovimi in določnimi pojmi, ki pa slika čustva tako globoko in razpoloženje (občutje) tako neposredno kot nobena druga umetnost."?

Tudi v tem semestru se Dolinar spet ni odločil za Lachova predavanja (Musik und Vogelgesang, 2 uri; Methoden und Probleme der vergleichenden Musikwissenschaft, 2 uri; Entwicklungsgeschichte des europäischen Gesellschaftstanzes, 1 ura) in za predavanja W. Fischerja (Geschichte der Instrumentalmusik II, 4 ure; Die Mensuralnotation des 15. und 16. Jahrh. (Forts.), 2 uri; Übungen zur Geschichte der Instrumentalmusik, 2 uri). Prav tako pa ni vpisal predavanj E. Wellesza (Die Musik im 2o. Jahrhundert, 1 ura) in M. Dietza (Die geschichtliche Entwicklung der Sinfonie und verwandter instrumentaler Kunstformen (mit vielen Musikbeispielen), 3 ure).

$\mathrm{V}$ tem semestru je torej Dolinar izbral na muzikološkem oddelku le dva predavatelja, Adlerja in Orla; pri obeh pa vse cikle predavanj, ki sta ju razpisala. Iz seznama izbranih predavanj je tudi razbrati, da Dolinarja izrazito niso zanimale etnomuzikološke in podobne "primerjalne« muzikološke discipline.

V zimskem semestru 1923-24 je Dolinar izbral le eno od treh ponujenih Adlerjevih predavanj (znova Übungen im musikhistorischen Institut, 2 uri; zato pa tokrat ne Erklären und Bestimmen von Kunstwerken, 2 uri, prav tako tudi ne Stilperioden der Musikgeschichte, 1 ura). Znova je poslušal tudi Lachovo glasbeno estetiko (Die Hauptprobleme der Musikästhetik, 2 uri), pa spet ne dveh drugih njegovih predavanj (Entwicklung der musikalischen Instrumente und Instrumentation, 2 uri; Ibsens »Peer Gynt « und Griegs Musik, 1 ura). Poleg tega je izbral prvič predavanje o notaciji (W. Fischer: Die Mensuralnotation d. 15. und 16. Jahrhunderts, 4 ure) ter prvič kot predavatelja Egona Wellesza (1885-1974) s ciklom predavanj o opernih začetkih (Die Anfänge der Oper, 1 ura).

Med zunanjimi predavatelji je izbral Uvod v etiko (Einführungen die Ethik, 3 ure) enega vodilnih predstavnikov dunajskega logičnega empirizma, Friedricha Alberta Moritza Schlicka (1882-1936) ter predavanje Han- 
sa Uebersbergerja o ruski državi in družbi (Staat. Gesellschaft in Rußland, 3 ure), ki ga je leto pozneje poslušal še en slovenski študent, Bratko Kreft. ${ }^{10}$

Zanimivo je, da v zimskem semestru 1923-24 Dolinar ni vzel niti enega od treh razpisanih Orlovih predavanj (Das rhythmische Problem in der Entwicklung der Notation, 1 ura, Übungen an Werken der Wiener Moderne, 2 uri; Die mehrstimmige Musik des späteren Mittelalter, 1 ura). Prav tako je nekoliko zanemaril izrazitejše muzikološke predmete - poleg navedenih še Dietzova predavanja o glasbeni romantiki (Anbruch und Blüte der musikalischen Romantik (mit vielen Musikbeispielen), 3 ure), Fischerjevo o Bachu (4 ure) ter Haasovo predavanje o zgodovini opere v 18. stoletju (Geschichte der Oper im 18. Jahrhundert, 2 uri). Vse to se umakne Dolinarjevemu očitnemu zanimanju za teme, ki načenjajo splošna družbena vprašanja, Slovanstvo ipd.

Omenjeno tendenco je zaznati tudi v naslednjem, letnem semestru 1924. Adlerjeva temeljna predmeta (Übungen im musik-hist. Institut, 2 1/2 ure; in Erklären und Bestimmen von Kunstwerken, $2 \frac{1}{2} 2$ ure) je Dolinar dopolnil z Lachovimi predavanji o razvoju sodobnega orkestra in instrumentacije po 17. stoletju (Entwicklungdes modernen Orchesters und der Instrumentation seit dem XVII. Jhdt., 2 uri) ter očitno bolj filozofsko naravnanim predavanjem iz glasbene estetike (Die Hauptprobleme der Musikästhetik II: Form und Inhalt, 2 uri) ter filozofije glasbene zgodovine (Philosophie der Musikgeschichte, 1 ura). Poleg tega je poslušal še nadaljevanje Fischerjevih predavanj o menzuralni notaciji (Die Mensuralnotation der 15. und 16. Jahrh. (Forts.), 4 ure) ter predavanje o zgodnjem razvoju opere (Vorstufen der Operngeschichte, 2 uri) Roberta Haasa (1886-1960).

Spet si je zunaj muzikološkega oddelka izbral predavanja H. Uebersbergerja o državni cerkvi in sektah v Rusiji (Die Staatskirche und Sekten in Rußland, 2 uri) ter Rüblerjev uvodni kurs iz psihologije (Einführungskurs in die Psych., 2 uri).

Tokrat se Dolinar znova ni odločil za nobenega od Orlovih predavanj (Die Musik der Troubadours und Minnesänger, 1 ura; Das Vorspiel zu R. Wagners "Tristan und Isolde«, 2 uri; Die mehrstimmige Musik des späteren Mittelalters »«, 1 ura), pa tudi ne za Welleszovo predstavitev opere v 17. stoletju (Die Oper im 17. Jahrh., 1 ura), Fischerjeva predavanja o Bachu (4 ure) in Dietzovo analizo nove romantike (Die Neuromantik in der

10 Tone Smolej, "Kaj večega poskusiti in postati«. Slovenski pisatelji dunajski študentje (1850-1926) (Ljubljana: Založba ZRC/Znanstvena založba Filozofske fakultete, 2015), 143. 
Tonkunst hohen Stils, ihre Ideale und ihre Führer (mit vielen Musikbeispielen), 3 ure)

Za postopno spremembo težišča njegovega širšega strokovnega interesa, kot se kaže v razpisanih predavanjih, je torej značilno, da se je Dolinar vse bolj usmerjal v vprašanja ruske oz. splošne slovanske kulturne zgodovine, poleg tega pa se je znova posvetil obči psihologiji.

$\mathrm{S}$ šestim absolviranim semestrom se je Dolinarjev redni študij na dunajski univerzi končal. Dolinar je sicer svoj dunajski študij videl tudi v smislu širšega konteksta celovitega življenjskega in predvsem glasbenega izpopolnjevanja. Zanimivo, čeprav posredno, je to moč zaznati iz njegovega prispevka ob 6o-letnici Josipa Čerina, še enega dunajskega študenta pri Adlerju. Lahko domnevamo, da opis Čerinovega dunajskega študija pravzaprav posredno razkriva lasten Dolinarjev pogled na to:

»Po dovršenem konservatoriju se je [Čerin] vpisal na filozofsko fakulteto dunajske univerze in dosegel doktorat iz glasboslovja, da je bil tehnično in estetsko kar najbolj pripravljen; poleg tega je pa živel na Dunaju bil v stalnem stiku s svetovnim glasbenim tokom, da je bila tako vsaka enostranost izključena. " ${ }^{\text {II }}$

Lahko bi torej rekli, da je študij, ki ga je pozneje prav tako kot Čerin zaključil z doktoratom, Dolinarju pomenil »tehnično in estetsko izpopolnitev«, samo bivanje na Dunaju pa mu je omogočilo najbolj širok vpogled v sodobna glasbena snovanja. Svoja spoznanja in doživetja bogatega dogajanja $\mathrm{v}$ tej glasbeni prestolnici je delil tudi s slovenskimi bralci in tako poročal o dunajskem glasbenem življenju v Cerkveni glasbenik (s. 8). Njegovi zapisi kažejo, kako si je prizadeval, da bi poleg študijskega izpopolnjevanja izkoristil možnosti, ki mu jih je Dunaj s svojim bogatim koncertnim in širšim kulturnim utripom ponujal.

Ob koncu študija, ko naj bi Dolinar nastopil mesto učitelja glasbe v šentviški gimnaziji, zaradi česar so ga predstojniki poslali na Dunaj, pa se je Dolinar pedagoškemu delu odrekel. „Kot vemo, je pa Dolinar, ko je že skoraj končal študije na Dunaju, izjavil, da nima veselja za pedagoško delo v zavodu, kar je bil vsekakor hud udarec za vse odločujoče, ki so nanj računali, « ${ }^{\mathrm{I}}$ se tega spominja $M$. Tomc, ki ga je škof Jeglič pozneje izbral za 
predvidenega učitelja glasbe $\mathrm{v}$ šentviški gimnaziji ter ga s tem namenom podobno kot Dolinarja poslal študirat na Dunaj. ${ }^{13}$

Po zaključenem rednem študiju leta 1924 je tako škof Dolinarja poklical nazaj v domovino v dušno pastirstvo in mu naložil kaplansko delo najbrže še nekoliko nejevoljen nad njegovo odločitvijo - bolj na obrobju škofije. Znova o tem plastično pripoveduje Tomc: „Vemo pa, da se je to [namreč odklonitev gimnazijske profesure] Dolinarju otepalo! Poslali so ga na razne kraje za kaplana, celo v Stari trg ob Kolpi (ki je, rekel bi, kar Bogu za hrbtom. Jaz kot Belokranjec nisem bil še nikoli tam, je res preveč od rok). Tako je Dolinar promoviral šele takrat, ko sem bil že jaz na Dunaju. ${ }^{14}$

Dolinar je tako kot kaplan služboval v Starem Trgu na Kolpi, pozneje pa še v Borovnici, Tržiču, na Jesenicah in pri svetem Jakobu v Ljubljani.

Za dokončanje študija je škof nato leta 1926 odobril Dolinarju 3 mesece dopusta, leta 1927 pa nato še 2 meseca za dokončanje disertacije. Junija 1927 je tako obranil pod Adlerjevim mentorstvom doktorsko disertacijo z naslovom Die Behandlung der Kirchentöne bei Palestrina.

\section{Vpliv Adlerja na Dolinarjevo glasbeno-zgodovinsko delo}

Leta 1926, torej še pred oddajo in obrambo svoje disertacije, je Dolinar objavil oceno tedaj slovitega zgodovinskega pregleda $\mathrm{z}$ naslovom Handbuch der Musikgeschichte. Z njim je Adler kot urednik povezal 32 strokovnjakov za posamezna področja, nato pa delo vsebinsko in slogovno poenotil. Med številnimi sodelavci razumljivo najdemo številne Adlerjeve dunajske kolege, ki jih je v času svojega študija spoznal seveda tudi Dolinar, saj gre za delo, ki je nastajalo prav v času Dolinarjevega študija na Dunaju (Adler predgovor k prvi izdaji opremi z datumom »april 1924«).

Razumljivo je, da je Adlerjeva glasbeno-zgodovinska šola močno zaznamovala tudi Dolinarjevo mišljenje. In morda prav ta zapis posredno jasno kaže, kako se je v svojem razumevanju zgodovinskega razvoja Dolinar neposredno opiral na Adlerjeva spoznanja. Glasbeni zgodovinar naj išče notranje vezi med posameznimi dogodki v času:

"Ne mislim podrobno govoriti o tem delu, poudariti hočem le nekaj dejstev. Kdor se je za tovrstna vprašanja zanimal, je ravno pri

13 Zanimivo je, da je pozneje Dolinarjeva sestra, Lojzka Dolinar, gospodinjila pri istem Matiji Tomcu, ko je župnikoval v Domžalah, kot je razvidno iz ohranjenih Dolinarjevih dokumentov v mapi Kronika v Glasbeni zbirki Narodne in univerzitetne knjižnice v Ljubljani. 
izbiri primerne knjige prišel vedno $v$ zadrego, vse knjige so se le bolj omejevale $v$ naštevanju zunanjih okolnosti (življenjska data skladateljev, naštevanje njihovih del i. t. d.), toda da bi se iskale one notranje sile, ki so tičale na dnu raznim kulturnim dobam in jim dajale svoj poseben značaj, da bi motrile, kako so se iste časovne ideje različno oblikovale $v$ vseh raznih umetnostnih panogah - take glasbeno-zgodovinske je manjkalo. " ${ }^{\text {15 }}$

Temeljna naloga glasbenega zgodovinarja torej ni naštevanje zgodovinskih dejstev, ampak iskanje njihove notranje povezave, razbiranje povezovalnih sil med različnimi umetnostmi, saj izražajo istega duha, so odraz istih »časovnih idej«.

V zapisu ob stoletnici Beethovnove smrti v Pevcu istega leta 1926 to Dolinar zgoščeno izrazi:

"Če bi hoteli dosedanji zgodovinski razvoj glasbene umetnosti po glavnih osebnostih na kratko označiti, bi poudarili imena: Gregor Veliki, Palestrina, Beethoven, Wagner. [...] Razvoj vsaktere umetniške osebnosti je odvisen najprej od časovnih razmer, $v$ katerih dotičnik dozoreva, in potem od bolj ali manj izrazite umetniške individualnosti. Ta dva činitelja se dasta $v$ življenju vsakogar jasno ločiti in njuno spoznanje je najboljši ključ za razumevanje celotnega umetniškega stvarjanja, kot tudi posameznih večjih del. ${ }^{16}$

Podobno lahko beremo pri G. Adlerju:

"Nebst der Erörterung das eigentlich musikalischen Entwicklungsganges ist entsprechend den Erfordernissen höherer Stilkritik auch das kulturhistorische Moment und die Biographistik berücksichtigt, die Abhängigkeit und der Zusammenhang der Tonkunst und ihrer Meister von und mit den Geistes- und Gefühlsströmungen der betreffenden Zeiten. « ${ }^{17}$

G. Adler se je izčrpneje posvečal vprašanjem slogovnega soodvisnosti med umetnostmi in izdelal koncept znanosti, ki je temeljil na teh premisah, tudi v drugih razpravah, ki so nastajale v času Dolinarjevega študija pri njem, med katerimi poleg Handbuch der Musikgeschichte izstopata vsaj Der Stil in der Musik in Die Methode der Musikgeschichte. Obe deli v

15 Anton Dolinar, »Handbuch der Musikgeschichte«, Pevec 6, 5-6 (1926): 34-35.

16 Anton Dolinar, »Ob stoletnici Beethovnove smrti«, Pevec 6, 3-4 (1926): 9.

17 Guido Adler, ur., Handbuch der Musikgeschichte (Tutzing: Hans Schneider, 1961), V. 
izdajah Breitkopfa in Härtla iz leta 1911 Dolinar med viri tudi navaja v svoji disertaciji.

Dolinar kot enega prvih muzikologov, ki so glasbeno zgodovinopisje zaznamovali s tako usmerjenim pogledom, v omenjeni oceni Adlerjevega dela navaja Huga Riemanna (1849-1919), leipziškega učitelja prvega muzikološkega doktoranda s Kranjske, Antona Krisperja (1858-1914). Kot poudarja Dolinar, je bil Riemann začetnik glasbenozgodovinskega univerzitetnega študija: »in treba je bilo prav veliko podrobnega dela, da so se mogli pokazati prvi sadovi in uspehi «. ${ }^{18}$

Dolinar je v omenjeni oceni Adlerjeve zgodovine menil, da se je po Riemannu pokazalo, kako nujno je povezovalno delo različnih strokovnjakov. Celotna zgodovina predstavlja namreč preprosto preobsežno snov za enega samega raziskovalca, zato je pozdravil Adlerjev uredniški projekt.

Zanimivo pri tem je, da je bil Dolinar v svoji oceni Adlerjeve zgodovine vendarle tudi kritičen; in sicer do dejstva, da v njej niso omenjeni Južni Slovani:

»K razpravi o novejši (moderni) glasbi so pritegnjeni vsi evropski narodi (izmed Slovanov Rusi, Poljaki, Čehoslovaki). Le o glasbi južnih Slovanov knjiga molči, kar celotni knjigi škoduje. Upajmo, da se to popravi v drugi izdaji." ${ }^{19}$

Očitno se je Adler zavedal utemeljenosti navedene kritike - in prav mogoče bi bilo, da bi mu jo neposredno izrazil tudi Dolinar sam, denimo $\mathrm{v}$ času priprave na zagovor disertacije. Adler se je vsekakor pozneje odločil zgodovinski pregled razširiti in dopolniti. Tako je v predgovoru k drugi izdaji zapisal:

"Dem mehrfach geäußerten Wunsch nach Teilung in 2 Bände wurde entsprochen - zumal da einige Abschnitte neu eingefügt, andere ergänzt wurden. ${ }^{20}$

Kot da bi prisluhnil Dolinarjevi kritiki, je Adler v drugo izdajo zbornika nanovo vključil tudi poglavje o južnoslovanski glasbi, ki ga je prispeval Adlerjev dober znanec iz njegovih dunajskih let, še en Kranjec, Josip Mantuani.

18 Dolinar, »Handbuch der Musikgeschichte«, 34.

19 Prav tam, 35.

20 Adler, Handbuch der Musikgeschichte, VII. 
Kako je Dolinar tudi pozneje sledil Adlerjevim glasbenozgodovinopisnim nazorom, kaže vrsta njegovih zapisov tudi iz poznejših let. Med njimi izstopa nekoliko obsežnejša razprava »Iz glasbenega razvoja, « ki jo je objavil v Cerkvenem glasbeniku leta $1932 .{ }^{21}$ Besedilo znova odpre programatski zapis:

"V celotnem zgodovinskem dogajanju vidimo dejstva največjega pomena, ki zaključujejo večstoletne razvojne dobe in hkrati tvorijo osnove enako dolgim razdobjem; vmes med temi najdemo zopet manjše dogodke, ki se razvijejo v okviru teh večjih in pomembnejših dogodkov, ki so v svoji vrsti tudi enako važni in tehtni, vendar manjše časovne dobe obsegajoči. [...] Taka silna razdobja bi mogli primerjati onim silnim morskim valovom, ki se pojavijo le v najvišjem viharnem razburkanju, ki se pa dele in nosijo s seboj toliko in toliko manjših valov. Vsi ti silnejši in manjši dogodki vtisnejo pečat tudi vsemu duhovnemu življenju, ki vsa ona gibanja silhuetno na sebi očituje. [...] Najsibo umetnina še tako v osebni ustvarljiteljevi noti zasidrana, bo vkljub temu nosila duševni pečat dobe, iz katere izvira: $k$ vsemu temu pa pridejo še nehote vpoštev posebne značilnosti posameznih narodnosti - in to brez ozira na katerokoli dobo - da Npr. ni vseeno, ali je delo nastalo v Rimu ali Antwerpnu - seveda istočasno mišljeno. ${ }^{22}$

Poleg tega najdemo tudi za ta čas značilno poudarjanje antagonizma med obliko in vsebino, ki ga Dolinar neposredno ponazori kar z Adlerjevim citatom:

"Zunanja oblika pa tako $v$ arhitekturi kot tudi $v$ glasbi le tedaj nekam oživi in se kot umetnost prikazuje, če se kot nujen estetski zakon kar vtelesi in $v$ tem estetskem zakonu umetnik svojo vizijo tako rekoč pred seboj doživlja."«3

Za splošno poznavanje izsledkov Dolinarjeve disertacije pa je seveda ključnega pomena objava članka, ki je v nadaljevanju izhajal v Cerkvenem glasbeniku leta 1930. Prispevek z naslovom »Iz uvoda k razpravi: Cerkveni toni v večglasju« Dolinar sam predstavi kot slovensko reproduciranje uvo-

21 Anton Dolinar, »Iz glasbenega razvoja«, Cerkveni glasbenik 55 (1932): 14-17, 50-53, $113-115$.

22 Prav tam, 14.

23 Adler, Handbuch der Musikgeschichte, 694; cit. po: Dolinar, "Iz glasbenega razvoja," 15 . 
da k svoji disertaciji z uvodno pripombo: »Oficialni naslov se glasi: Die mehrstimmige Behandlung der Kirchtöne bei Palestrina. ${ }^{24}$

V Dolinarjevi razpravi se splošna obravnava glasbene preteklosti prepleta $\mathrm{z}$ glasbeno estetiko, ta pa s filozofijo zgodovine. Vse to smo lahko zaslutili ne nazadnje tudi iz izbora vpisanih predavanj na dunajski univerzi. Čeprav gre torej za značilno zgodovinsko temo, jo avtor osvetljuje v luči sodobnih glasbeno-estetskih poudarkov.

Tako tudi stare cerkvene tonovske načine kot osrednji predmet svojega preučevanja razume in razlaga $\mathrm{v}$ kontekstu glasbe svojega časa.

V osnovi se Dolinar osredotoča na tonovske načine in njihovo mesto zlasti v kontekstu prehoda iz 16. v 17. stoletje:

„Če bi celotni tonski sistem primerjali solnčnemu žarišču, bi mogli cerkvene tone -, ki so iz tega žarišča izhajali in $v$ njem svojo eksistenčno upravičenost dobivali - prispodabljati žarkom iz tega centra se porajajočim: in ravno za te (cerkvene tone) pomeni čas okrog l. 16oo. naravnost dobo za obstanek, prav za prav neke vrste revolucionarno dobo. Omenjeni cerkveni toni, ki so bili $v$ rabi $v$ dobi vokalne polifonije, tvorijo $v$ celotnem razvoju oblikovnega muzikalnega materiala važen člen in ta razvoj sega daleč nazaj. Neposredno se naslanjajo nazaj na tonovske načine koralnega enoglasja; ti so pa zopet po imenu in tudi stvarno $v$ sorodu $z$ antičnimi tonskimi sistemi, katere sta pa grški in pozneje latinski srednji vek tako preoblikovala, da so dobili v koralu novo, njegovemu bistvu primerno izklesanost in uravnanost. ${ }^{25}$

Zgodovinski pogled pa obrne na sočasne razmere:

"In isti boj, ki je bil začetkom 17. stoletja napovedan sistemu cerkvenih tonov, velja že nekaj desetletij sem obema: duru in molu. Za dobo raznih-izmov (impresionizma, ekspresionizma, futurizma) se zdita oba - dur in mol - prešibka, da bi mogla povsem zadovoljiti vsej skali notranjega občutenja novodobnega človeka. In stalno so vedno bolj pogostni glasovi, ki podirajo temelje durmolski heptatoniki in napovedujejo celotonski, četrttonski, atonalni itd. sistem:

24 Anton Dolinar, »Iz uvoda k razpravi: Cerkveni toni v večglasju«, Cerkveni glasbenik 53 (1930): 1-3, 33-35, 65-68, 97-100, 129-133, 169-172. 
isti razvojni proces se $v$ živem organizmu glasbene umetnosti javlja in ponavlja vedno znova. ${ }^{26}$

Dolinar predstavi tudi ključen problem disertacije, ki je v razumevanju preobrazbe cerkvenih tonovskih načinov pri njihovi rabi v obdobju vokalne polifonije ter nato njihovo preoblikovanje v dur-molovsko tonaliteto.

Kot glavno avtoriteto na področju korala izpostavlja Dolinar v svoji disertaciji zlasti Petra Wagnerja, ki ga k svoji zgodovini pritegne tudi Alder. Poleg tega izpostavlja še Petra Mortimerja, A. Oberländerja in Jurija Arnolda (1811-1898) - zlasti slednji je bil za Dolinarja razumljivo posebno zanimiv kot ruski muzikolog, ki se je s svojim pisanjem, odmevnim tudi na zahodu, ukvarjal obsežno $\mathrm{z}$ vplivom cerkvenih tonovskih načinov na rusko cerkveno glasbo.

Prav tako Dolinar pogosto vpleta navedke Weinmanna, pa tudi nekaterih svojih učiteljev - poleg Adlerja zlasti Alfreda Orla.

Dolinar v članku navaja za slovensko bralstvo zanimivo in v veliki meri bržkone manj znano muzikološko literaturo in izpostavlja ključne publikacije s tega področja, tudi Adlerjeve, ki jim v okviru izvirne disertacije sicer razumljivo ne namenja tako izrazito poudarjenega prostora in širše razlage. Prav tako za slovensko bralstvo nekoliko razširi odlomek, $\mathrm{v}$ katerem splošen prikaz razvoja cecilijanskega gibanja dopolni z vpogledom v slovenske razmere. Dejansko se Dolinar cecilijanskemu gibanju in njegovi zgodovini v slovenski verziji teksta daleč izčrpneje posveti kot $\mathrm{v}$ nemškem izvirniku, kar kaže na to, kako je svoje besedilo v nadaljevanju vse bolj izrazito oblikoval po meri slovenskega bralca, tudi če se je tako povsem oddaljil od nemške predloge. Zdi se, kot da bi se s tem Dolinar delno poklonil okviru svoje objave znotraj Cerkvenega glasbenika kot publikacije slovenskega Cecilijinega društva, posredno pa je morda tudi reagiral na razpravo $\mathrm{z}$ naslovom »Zgodovina cerkvene glasbe« J. Mantuanija, ki ga je uredništvo Cerkvenega glasbenika objavljalo v nadaljevanjih vzporedno $\mathrm{z}$ Dolinarjevim besedilom, sam Dolinar pa ga je po Mantuanijevi smrti $z$ naslovom »Zgodovina katoliške cerkvene glasbe « tudi nadaljeval. Pozneje je razprava izšla tudi v obliki separata. ${ }^{27}$

V slovenski verziji Dolinar tudi ni označil nekaterih virov svojih navedkov (tako že takoj na začetku citat P. Wagnerja). Poleg tega se je nekoliko nerodno v slovenskem prevodu celo skliceval na nadaljevanje svo-

26 Prav tam, 2.

27 Josip Mantuani in Anton Dolinar, Zgodovina katoliške cerkvene glasbe (Ljubljana: Cecilijino društvo, 1938). 
je disertacije (dobesedno denimo: $॥$ v drugem delu razprave motrimo ... $\aleph^{28}$ ). Tovrstno opozorilo, ki je v izvirniku razumljivo, saj gre za napotek na besedilo, ki sledi predstavljenemu uvodu, v slovenski skrajšani verziji z zgolj uvodnim poglavjem disertacije seveda nima pravega smisla.

Vsaj na začetku skrbno zastavljen prevod uvoda $\mathrm{v}$ disertacijo se $\mathrm{v}$ nadaljevanju oddaljuje od svojega izvirnika in postaja samostojna razprava, namenjena širšemu slovenskemu bralstvu in konkretnemu zgodovinskemu trenutku.

Avtor se tudi sicer že v samem uvodu v disertacijo oddaljuje od glavne tematike, začrtane $\mathrm{v}$ njenem naslovu. Poleg omenjene obravnave cecilijanizma se tako posveti tudi vprašanju »cerkvenosti« glasbe. Prav tako razpravo zasnuje $\mathrm{z}$ mislijo na konkretne sodobne glasbeno-estetske dileme. Tako se ob koncu objavljene razprave znova vrne $\mathrm{k}$ izhodiščnim tezam in poudarja, kako sodobna glasba oživlja nekatere vidike, ki jih nakazuje »klasična a cappela glasba «" ${ }^{29}$, kot to imenuje Dolinar: sproščen ritem, ki se oddaljuje od »tiranije enakomernega taktovega ritma « ${ }^{30}$, in zavračanje dur-molovske tonalitete, kar da v sodobni glasbi »kaže, da se vračamo zopet na posodo $\mathrm{k}$ starim cerkvenim tonovim načinom, ko npr. med posameznimi lestvicami ni bilo posebnih bistvenih ločitvenih znakov. ${ }^{31} \mathrm{Ne}$ glede na vprašanje utemeljenosti njegovih postavk pa je soočanje zgodovinske teme s premislekom in estetskim utemeljevanjem sočasne stvarnosti seveda še danes zanimivo.

Dolinar se je očitno že kot študent muzikologije navduševal nad temi idejami, kot lahko razberemo tudi iz poročila o dunajski koncertni sezoni, objavljenega leta $1924 \mathrm{v}$ Slovencu. V izpostavljanju ruskih glasbenih del in navduševanju zanje celo med dunajsko publiko, ki je bila sicer zlasti po koncu svetovne vojne zadržana do nenemške ustvarjalnosti, vidi jasno izražen estetski normativ svojega časa, po katerem se je prelom dur-molovskih okvirov dopolnjeval z iskanjem »neomadeževanih« tradicij:

"Razmeroma zelo veliko je bilo slišati letos ruskih glasbenih del. Splošno dejstvo je, da zanimanje ravno za te proizvode zelo raste in da se vedno povdarja, da je tam še polno nedvignjenih zakladom zakopanih, ki bi bili zmožni doprinesti celotnemu toku prav mnogo novih razvojnih možnosti. [...] Poznejša dur in mol sta te sledo- 
ve popolnoma izbirsala, kar nikakor ne moremo kot posben [sic!] napredek beležiti, če pomislimo, da je cilj današnjega časa zopet na tem, da se izmota iz tega omejenega naročja, in nehote prihajajo stari tonovi načini zopet do veljave - pri katerih sta dur in mol tudi že obstojala (jonski aeolski tonov način), toda nista bila izključno merodajna in se je poleg teh obeh nahajalo še več vmesnih stopenj (frigični tonov način) med obema sklajnima poloma. Ta proces ločitve $v$ dur in mol se je izvršil koncem 17. stoletja, toda največji povdarek je dobil potem $v$ 18. stol. pri dunajskih klasikih, osobito pri Beethovnu. Vse kulture, ki so bile kolikor toliko v zvezi oziroma bolj ali manj odvisni od nemške, so to ločitev sprejele in če ruska kultura temu ni popolnoma podlegla, je iskati vzroka le $v$ veliki oddaljenosti od srednjeevropskega ozemlja. «2

Kot lahko pokaže analiza Dolinarjeve disertacije, ki jo kot tipkopis hrani danes knjižnica dunajske univerze, ${ }^{33}$ je premislek, ki je temeljil na povezovanju preteklih glasbenih sistemov s sodobnimi kompozicijskimi in estetskimi načeli, vendarle lahko vodil tudi v nekatere problematične metodološke principe in s tem povezane sklepe. $\mathrm{V}$ tem smislu izstopa analiziranje renesančne vokalne polifonije s pomočjo analitične optike, razvite ob dur-molovski funkcijski harmoniji. Prav to namreč tvori pomemben del Dolinarjeve disertacije, osredotočene na prelom v funkcijsko dur-molovsko harmonijo, ki naj bi se uresničil v času Palestrine.

Brez dvoma so občudovanja vredne Dolinarjeve obsežne in natančne statistične obdelave Palestrinovega opusa, pri čemer avtor disertacije precizno določa najrazličnejše parametre glasbe, ki jih uredi v številne pregledne tabele. Tako lahko $v$ tekstu sledimo denimo skrbnemu popisu cerkvenih tonovskih načinov, kot se pojavljajo $\mathrm{v}$ različnih zvrsteh in posameznih zbirkah. Avtor tudi ponazori, kakšen ambitus ima v skladbah vsak posamezni glas in kakšen interval ti glasovi obsegajo. V nadaljevanju opiše značilnosti melodije $\mathrm{v}$ primerjavi s koralnimi načini tvorjenja melodije in obravnava tipe melizmov. Pogleda in našteje tudi različne modele začetkov in sklepov skladb ter jih celo označi s pomočjo funkcijske teorije. Funkcijski analizi podvrže tudi analizo širših harmonskih zvez v posameznih skladbah. Sicer je pri tem v osnovi nekoliko zadržan in opozarja, da so

32 Anton Dolinar, "Nekaj zanimivosti dunajske koncertne sezone. Slovanska glasba«, Slovenec 52 (1924), 152 (6. 7.): 6.

33 Anton Dolinar, Die mehrstimmige Behandlung der Kirchtöne bei Palestrina (doktorska disertacija, Universität Wien, 1927). 
akordske tvorbe pogosto naključen rezultat vodenja linij (»es werden zwar Akkorde gebildet, jedoch diese Bildung ist nur ein zufälliges Resultat geführter Einzelstimmen ${ }^{34}$ ). Pa vendar v nadaljevanju iz tega izpelje sklepe, v kolikšni meri pride tudi pri Palestrini do osnovnih harmonskih tonalnih funkcij: »Selbstverständlich werden wir nachsuchen, ob und wie grossem Masse die Funktionen der Tonika, Dominante, Subdominante auch in der palestrinänsischen Mehrstimmigkeit zur Geltung kommen, und wie ihre Äusserung dort Platz ergreift..135 $\mathrm{V}$ tej zvezi govori celo o modulacijah, sredstvih za moduliranje, kadenčnih zvezah ipd.

Tako pride ob sklepu disertacije do ključnih treh sklepnih vprašanj (resultierende Fragen):

1. Značilnosti tonskih načinov« (Die Charakteristik der Tonarten)

2. $» N a$ kateri stopnji pride pri Palestrini do preloma s cerkvenimi tonovskimi načini ter njihove izostritve v dur in mol?« (In welchem Stadium befindet sich bei Palestrina der Durchbruch der Kirchentöne und deren Zuspitzung in 1 Dur in 1 Moll?)

3. „Razlike pri obravnavi posameznih cerkvenih tonovskih načinov« (Die Verschiedenheiten in der Behandlung einzelner Kirchentöne)

V disertaciji se torej Dolinar kaže kot izjemno natančen, skrben in sistematičen analitik, ki pa vendar zaradi danes nekoliko spornih metodoloških konceptov privede bralca do nekoliko problematičnih sklepov.

V svoji oceni disertacije $\mathrm{z}$ dne 24 . junija 1927, ki jo danes hrani dunajski univerzitetni arhiv, je bil nekoliko zadržan tudi G. Adler. Sicer je pohvalil marljivo Dolinarjevo delo, a je bil do njega tudi kritičen: »Disertacija je bleščeče izdelana, vendar pravzaprav ni pripeljana do konca." (Die Dissertation ist glanzig gearbeitet, aber eigentlich nicht zum Abschluss gebracht.) Adler je izpostavil »koristno" rabo statistike (Das Hilfsmittel der Statistik braucht er mit Vorteil) in harmonsko analizo. Kritičen pa je bil izrazito do rabe dolgih citatov, ki so po njem pogosto v nasprotju z Dolinarjevimi lastnimi stališči. Prav tako je opozoril na nejasno delitev med »modulacijo" (Modulation) in »izmikom« (Ausweichung). Opozoril je tudi na »zastarelo literaturo" (überholte Literatur) ter jezikovne pomanjkljivosti, pri čemer je izpostavil dejstvo, da je avtor disertacije Slovenec. Tako je v sklepu zapisal: »Delo potrebuje za morebitno objavo (brez dvoma vredno) izboljšave in dodatni študij. Vendar tudi na tej stopnji je kot disertacija popolnoma

34 Dolinar, Die mehrstimmige Behandlung, 104.

35 Prav tam, 107. 
zadostna." (Die Arbeit benotigt für eventuelle Veröffentlichung (ruerthens wert) der Stochbesserung und ergänzender Studien. Aber auch in dem gegenwärtigen Stadium ist sie als Dissertation vollgenügend.)

Profesor Robert Lach se je kot koreferent 25. junija 1927 skopo pridružil Adlerjevi oceni.

Žal kljub Adlerjevemu priporočilu do natisa disertacije ni prišlo, samo besedilo pa je bilo močno okrjeno širši javnosti dostopno le prek objave omenjenega slovenskega prevoda in predelave uvodnega poglavja, posredno pa so osrednje teze razprave prosevale še $\mathrm{v}$ nekaterih drugih avtorjevih zapisih zlasti glasbeno-estetskega značaja. Poleg tega bi lahko sklepali, da je seveda svoje ideje Dolinar posredoval javnosti tudi prek številnih drugih javnih nastopov, zlasti v okviru novoustanovljenega Radija Ljubljana, v delo katerega se je aktivneje vključeval.

Po disertaciji se je namreč Dolinar postal vse bolj viden del slovenskega kulturnega življenja. Že kot kaplan v Tržiču, pred zagovorom disertacije, se je udejstvoval na področju cerkvene glasbe in skrbel za vzgojo tudi duhovnikov. Ob duhovniški konferenci leta 1926 je tako pripravil

"referat o pomenu in stalǐ̌ču, ki ga zavzema glasba o cerkveni liturgiji, in o dolžnostih, ki jih ima duhovnik, kot vršilec liturgičnih opravil do nje. $\mathbb{1}^{36}$

Istega leta je Dolinar postal tudi urednik glasbene revije Pevec. Marko Bajuk je o tem v svojem poročilu na Občnem zboru Pevske zveze leta 1926 zapisal: »Letos je prevzel uredništvo prvotno predsednik Dolinar. Ker pa nam ga usoda ni hotela dati v Ljubljano, sem moral prevzeti odgovorno uredništvo sam. Delila sva si delo tako, da je urejal on priloge, jaz pa list..137 Z Markom Bajukom sta urejala tudi pesmarice Pevske zveze.

$\mathrm{V}$ istem obdobju je postal Dolinar predsednik Pevske zveze ter v tem okviru pripravil nekaj predavanj z glasbeno-estetsko tematiko, s katero se je intenzivneje ukvarjal tudi $\mathrm{v}$ času dunajskega študija muzikologije. $\mathrm{Na}$ podlagi predavanj, ki jih je imel Dolinar na tečajih Pevske zveze leta 1926, je nastal razmeroma obsežnejši članek v $P e v c u^{38}, \mathrm{ki}$ ob še nekaterih drugih zapisih $^{39}$ estetskega značaja po svoji tehtnosti nedvomno izstopa.

36 Anton Dolinar, »Tržič«, Cerkveni glasbenik 49 (1926): 22.

37 Marko Bajuk, »Občni zbor Pevske zveze«, Pevec 6, 9-10 (1926): 51-52.

38 Anton Dolinar, »Donesek h glasbeni estetiki«, Pevec 6 (1926), 37-38, 49-51.

39 Anton Dolinar, »Donesek h glasbeni kritiki«, Cerkveni glasbenik 48, 11-12 (1925): 125-129. 
Poleg tega je nekaj let vodil pevski zbor Ljubljana, kjer je nasledil Franca Kimovca, in bil dirigent Glasbenega društva Ljubljana.

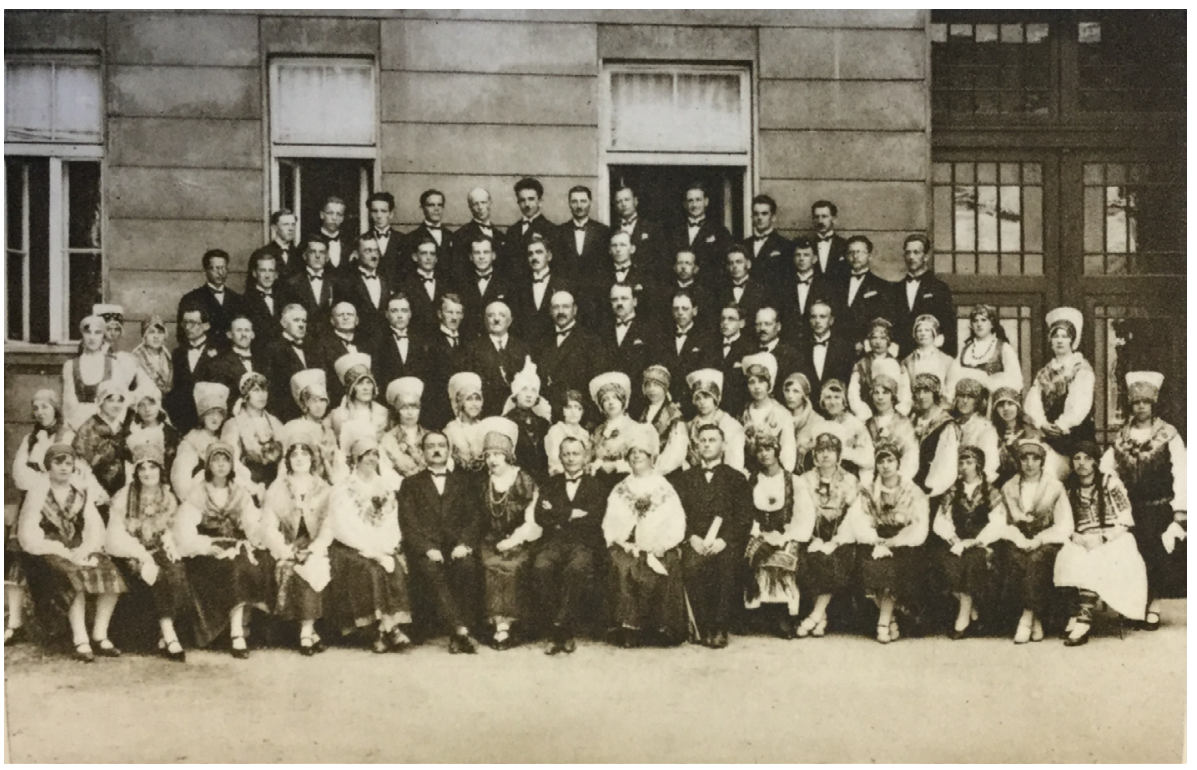

Slika ı: Zbor glasbenega društva Ljubljana z dirigentom Antonom Dolinarjem l. 1929; fotografija je objavljena v dvojezičnem koncertnem listu v slovenščini in češčini, natisnjenem ob gostovanju zbora 1.-10. 7. 1929; mapa Dolinar, Anton, Kronika, Glasbena zbirka NUK, z dovoljenjem.

Dolinar je občasno dirigiral Orkestralnemu društvu Glasbene matice. V njem so igrali študenti konservatorija in poklicni glasbeniki, orkester pa je včasih sodeloval z zbori ljubljanske in mariborske Glasbene matice ter $\mathrm{z}$ zborom Ljubljana (ki ga je vodil Dolinar) in Ljubljanskim zborom. Poleg tega je orkester povprečno enkrat do dvakrat letno snemal za Radio Ljubljana. $^{4 \circ}$

Posebej pomembno pa je bilo nedvomno Dolinarjevo sodelovanje $\mathrm{z}$ Radiom Ljubljana, pri katerem je deloval vse od leta 1928, ko je radijska postaja začela delovati. Bil je urednik oz. referent Radia Ljubljana ter eden najbolj konstantnih radijskih sodelavcev ves čas v obdobju 1928-1945. Ko so leta 1928 so pri Prosvetni zvezi ustanovili radijski odsek, ki je poskrbel za ustanovitev radija, so imenovali tudi širši programski odbor. V njem so so40 Cigoj Krstulović, Zgodovina, spomin, dediščina, 180. 
delovali: Anton Dolinar kot referent za glasbo, referent za prosveto je postal Vinko Zor, referent za propagando Ivan Martelanc. Pozneje, leta 1929, se jim je pridružil še France Koblar kot dramski in kulturni referent, od 1932 pa še Niko Kuret kot referent za šolske in mladinske oddaje. ${ }^{41}$ Leta 1937 so ustanovili pri radijski postaji samostojni komorni zbor, njegov dirigent pa je postal prav Dolinar.

Dolinar se kljub svojemu nasprotnemu stališču po zaključku dunajskega študija vendarle ni povsem odrekel pedagoškemu delu. Tako je nekaj časa deloval tudi kot profesor na ljubljanskem Liceju in na Orglarski šoli.

Po vojni je leta 1945 odšel najprej v Italijo, od tam pa se je nato odselil v ZDA, kjer je živel v zvezni državi Minnesota. Umrl je 1. avgusta 1953 v St. Cloud, ZDA v prometni nesreči v Yates Centru v državi Kansas.

Čeprav je Dolinar bil v svojem času nedvomno eden najbolj razgledanih glasbenih intelektualcev, široko dejaven na najrazličnejših področjih, pri čemer je zlasti izjemno pomembno njegovo dolgoletno zvesto delovanje $\mathrm{v}$ novoustanovljenem ljubljanskem radiu, pa je po vojni kot duhovnik in del politične emigracije postopoma žal njegovo delo po krivici v veliki meri utonilo $\mathrm{v}$ pozabo.

\section{Bibliografija}

Adler, Guido, ur. Handbuch der Musikgeschichte. Tutzing: Hans Schneider, 1961.

Ambrožič, Matjaž. »Profesorski zbor«. V Sto let Zavoda sv. Stanislava. France M. Dolinar, ur.. Ljubljana: Družina, 2005, 439-440.

Auer, Max. Anton Bruckner: sein Leben und Werk. Zürich/Leipzig/Wien: Amalthea 1923.

Bajuk, Marko. »Občni zbor Pevske zveze«. Pevec 6, 9-10 (1926): 51-52.

Brojan, Matevž. Začetki radia na Slovenskem. Ljubljana: Modrijan/Radio Slovenija, 1999.

Cigoj Krstulović, Nataša. Zgodovina, spomin, dediščina: Ljubljanska Glasbena matica do konca druge svetovne vojne. Ljubljana: Založba ZRC, ZRC SAZU, 2015.

Dolinar, Anton. »Anton Bruckner«. Cerkveni glasbenik 47 (1924): 1-4, 27-31, $48-49$.

Dolinar, Anton. »Današnji glasbeni Dunaj«. Cerkveni glasbenik 46 (1923): 102-105.

41 Matevž Brojan, Začetki radia na Slovenskem (Ljubljana: Modrijan / Radio Slovenija, 1999), 22 
Dolinar, Anton. Die mehrstimmige Behandlung der Kirchtöne bei Palestrina, doktorska disertacija, Universität Wien, 1927.

Dolinar, Anton. »Donesek h glasbeni estetiki«. Pevec 6 (1926): 37-38, 49-51.

Dolinar, Anton. »Donesek h glasbeni kritiki«. Cerkveni glasbenik 48, 11-12 (1925): 125-129.

Dolinar, Anton. »Dr. Josip Čerin - 6o letnik«. Pevec 7, 3-4 (1927): 15.

Dolinar, Anton. »Handbuch der Musikgeschichte«. Pevec 6 (1926): 34-35.

Dolinar, Anton. »Iz glasbenega razvoja«. Cerkveni glasbenik 55 (1932): 14-17, 50$53,113-115$.

Dolinar, Anton. »Iz uvoda k razpravi: Cerkveni toni v večglasju«. Cerkveni glasbenik 53 (1930): 1-3, 33-35, 65-68, 97-100, 129-133, 169-172.

Dolinar, Anton. „Nekaj zanimivosti dunajske koncertne sezone. Slovanska glasba«. Slovenec 52 (1924), 152 (6. 7.): 6.

Dolinar, Anton. »'Novi Akordi' (1901-1914)«. Zbori 2, 1-2 (1926): 2-3.

Dolinar, Anton. »Ob stoletnici Beethovnove smrti«. Pevec 7, 3-4 (1927): 9-10.

Dolinar, Anton. »Petletnica PZ«. Pevec 6 (1926): 30-31.

Dolinar, Anton. »Tržič«. Cerkveni glasbenik 49 (1926): 22-23.

Mantuani, Josip in Dolinar, Anton. Zgodovina katoliške cerkvene glasbe. Ljubljana: Cecilijino društvo, 1938.

Sivec, Jože. »Dolinar, Anton«. Enciklopedija Slovenije. 2. zv. Ljubljana: Mladinska knjiga, 1988, 299.

Smolej, Tone. "Kaj večega poskusiti in postati«. Slovenski pisatelji dunajski študentje (1850-1926). Ljubljana: Založba ZRC/Znanstvena založba Filozofske fakultete, 2015.

Snoj, Venceslav. »Prof. V. Hybašek«. V Letno poročilo 1937/1938. Ljubljana: Zavod sv. Stanislava, 10-11.

Premrl, Stanko. »Hybášek, Vojteh (1873-1947)«. V Slovenski bijografski leksikon: 3. zv. Hintner - Kocen. Izidor Cankar, ur., et al. Ljubljana: Zadružna gospodarska banka, 1928, 360 .

Škulj, Edo. »Anton Dolinar (1894-1953): Ob petdesetletnici smrti«. Cerkveni glasbenik 96, 7-8 (2003): 10. žŠkulj, Edo. Letopis slovenskega glasbenega življenja v Argentini: ob 5o. obletnici vélikega izhoda. Celje: Mohorjeva družba; Celovec: Krščanska kulturna zveza; [s. 1.]: Izseljensko društvo Slovenija v svetu, 1995, 42-43.

Škulj, Edo. »Matija Tomc (1899-1986)«. Cerkveni glasbenik 92, 10-12 (1999): $73-80$. 
Škulj, Edo. »Tomčeva pisma«. V Tomčev zbornik. Edo Škulj, ur.. Ljubljana: Družina, 1997, 111-198.

»Dolinar, Anton«. Slovenski bijografski leksikon: 1. zv.: Abraham-Erberg. Izidor Cankar, ur., et al. Ljubljana: Zadružna gospodarska banka, 1925: 141. ${ }^{42}$

42 Poglavje je nastalo kot del projekta J6-7180, ki ga je sofinancirala Agencija za raziskovalno dejavnost Republike Slovenije.

This chapter is part of the project J6-7180 funded by Slovenian research agency ARRS. 



\title{
Misel o glasbi v spisih treh slovenskih medvojnih glasbenih esejistov
}

\author{
Jurij Snoj \\ Znanstvenoraziskovalni center SAZU \\ Research Centre of the Slovenian Academy of Sciences and Arts
}

$\mathrm{V}$ času med obema vojnama je bilo slovensko pisanje o glasbi raznovrstno in raznoliko: Dnevno časopisje in kulturne revije so v obliki kritik redno spremljale glasbeno življenje; objavljali so se kritični pregledi koncertnih in opernih sezon; nekateri pisci so pisali kolumne $\mathrm{z}$ aktualno glasbeno vsebino; potekale so polemike o glasbenoorganizacijskih vprašanjih. V vsem tem, sprotno glasbeno življenje spremljajočem pisanju je mogoče prepoznavati miselna in estetska izhodišča, kot so jih imeli posamezni pisci. Poleg tega so nastajale glasbenozgovinske študije, ki so se raziskovalno posvečale temam iz slovenske glasbene zgodovine, kot tudi razni pregledi posameznih segmentov evropske glasbene zgodovine. Nenazadnje so nekateri glasbeniki in intelektualci snovali daljša esejistična besedila, ki so se lotevala estetskih vprašanj o glasbi, ne da bi bila ta neposredno vezana na sprotno glasbeno dogajanje.

Ljudi, ki so tako ali drugače pisali o glasbi, ni bilo malo, in kar so zapustili, je mogoče obravnavati iz različnih zornih kotov. Če se omejimo na glasbene esejiste, je bilo že pred časom imlicitno nakazano, da so bili med njimi najpomembnejši trije: skladatelj Anton Lajovic, skladatelj Marij Kogoj in umetnostni zgodovinar Stanko Vurnik. ${ }^{1} \mathrm{Ne}$ le, da so zapustili razmeroma obsežen glasbenoesejistični opus; v svojih spisih so razvijali misel o glasbi, ki je zanimiva tako v svojem zgodovinskem kontekstu kot tudi sama po sebi.

1 Primož Kuret, Umetnik in družba. Slovenska glasbena misel po prvi vojni. Lajovic, Kogoj, Vurnik (Ljubljana: Državna založba Slovenije, 1988). 
Teme, ki so se jih lotevali Lajovic, Kogoj in Vurnik, so bile raznovrstne. Po eni strani so se odzivali na sprotno glasbeno življenje in reševali kulturnopolitična vprašanja - slednje zlasti Lajovic; hkrati so razvijali misel o glasbi sami; Vurnik se je poleg tega v povezavi z estetskimi vprašanji ukvarjal tudi z zgodovino glasbe. Njihovo pisanje je bilo že večkrat predmet muzikoloških obravnav in raznih komentarjev. Prvo daljšo študijo o njihovem publicističnem in esejističnem delu je prispeval izdajatelj njihovih spisov P. Kuret. ${ }^{2}$

Pisanje omenjenih treh esejistov je odprto za razna vprašanja; zlasti se postavlja vprašanje izvora njihovih misli ter vprašanje, kako so bile povezane s siceršnjimi miselnimi tokovi na Slovenskem in v srednji Evropi. To besedilo opazuje njihov esejistični opus iz specifičnega zornega kota: sprašuje se, kako so omenjeni trije pojmovali glasbo kot umetnost in kako so pojmovali njeno mesto in vlogo $\mathrm{v}$ družbi. $Z$ drugimi besedami želi prikazati, kako so bodisi neposredno ali implicitno odgovarjali na vprašanja: Kaj je glasba, kako nastaja, kaj je pri nastajanju nove glasbe odločilno, kaj je njen smisel.

Preden se lotimo obravnave, je potreben metodološki premislek. Upoštevati je treba, da spisi imenovanih treh piscev niso istovrstni: Kogoj je bil prvenstveno umetnik, ki ni bil razgledan po glasbenoestetski literaturi; svoje glavne misli je temu ustrezno zbral v eseju, spisanem na umetniško prosti način. Lajovic se je kot poklicni pravnik zanimal za sociološka vprašanja in njegovi esejistični spisi so nastajali predvsem $\mathrm{v}$ zvezi $\mathrm{z}$ aktualnimi kulturnimi dilemami časa. Lajovičevi in Kogojevi spisi že po svojem žanru niso taki, da bi sistematično obravnavali glasbenoestetska vprašanja (kot si jih zastavlja ta spis). Vurnik je bil umetnostni zgodovinar in se je z vprašanji umetnosti ukvarjal poklicno, vendar je bil tudi on pogosto esejistično prost. Za sodobnega bralca to pomeni, da mora misli imenovanih treh esejistov na neki način izpeljati iz njihovih spisov in jih na osnovi vzporedno primerjalnega branja mestoma tudi rekonstruirati; da bi bile prav razumljive in medsebojno primerljive, jih je treba obnoviti v sodobnem jezi$\mathrm{ku}$, večkrat tudi z drugimi izrazi, kot so jih uporabljali omenjeni trije sami.

I

Začnimo z najstarejšim od treh, s skladateljem Antonom Lajovicem (18781960), ki ga slovensko glasbeno zgodovinopisje prepoznava kot enega od

2 Primož Kuret, »Slovenska glasbena misel po prvi vojni«, v: Primož Kuret, Umetnik in družba, 7-79. 
predstavnikov slovenske glasbene moderne..$^{3}$ Lajovic, ki je doraščal in študiral za časa monarhije, je bil v medvojnem obdobju v svojih zrelih letih. Njegovi pogledi so bili že večkrat analizirani in komentirani. ${ }^{4}$

Lajovic je glasbeno kulturo primerjal $\mathrm{z}$ jezikom in jo razumeval podobno kot literaturo, v tem smislu: Kot ima vsak narod svoj jezik, v katerem se sporazumeva, tako ima tudi svojo umetnost in svojo glasbo. Jezik je Lajovic razumel kot pristni izraz naroda; tako naj bi bila tudi glasba nekega naroda njegov pristni izraz. 5 to glasbo ni mislil le ljudske glasbe; bolj kot to si je predstavljal, da mora biti pristni izraz narodne skupnosti tisto, kar nastaja na novo, se pravi glasba skladateljev, delujočih $\mathrm{v}$ dani narodni skupnosti. Zdelo se mu je, da je glasba, ki nastaja znotraj določene narodne skupnosti, res razumljiva le njej, podobno kot zares razumejo jezik le tisti, ki se v njem sporazumevajo.

Lajovic je bil velik občudovalec nekaterih skladateljev, zlasti čeških in ruskih; kljub temu pa je bil - skladno s predstavljenimi mislimi - zadržan in skeptičen do tega, da bi skladatelji enega naroda slepo posnemali glasbo skladateljev drugih narodov: da bi se npr. Čehi zgledovali pri Nemcih in komponirali tako kot nemški skladatelji, ali pa da bi to delali slovenski skladatelji. ${ }^{6} \mathrm{~V}$ tem smislu je odklanjal internacionalizem. Sumničil je, da je internacionalizem zgolj pretveza za prevlado ene nacionalne kulture nad drugo in pretveza za to, da se nacionalna kultura enega naroda omeji ali celo zatre. Odklanjal je mnenje, da je lepota glasbenih del, npr. Bachovih, Beethovnovih, Wagnerjevih, nekaj absolutnega in da obstoji sama zase neodvisno od kulture narodne skupnosti, znotraj katere so nastala. ${ }^{7}$ Nasprotno temu, da bi skladatelji danega naroda posnemali glasbo drugih glasbenih kultur, je bil prepričan, da morajo poiskati, najti, ustvariti nekaj, kar ne bi bilo posnemanje nečesa že obstoječega, pač pa bi kot nekaj novega izšlo iz lastnega naroda, iz življenja njihove lastne narodnostne skupnosti. Ta narodna skupnost bi v tem smislu nastalo novo glasbo po njegovem mnenju lahko tudi razumela in sprejela za svojo, jo recipirala.

3 Gregor Pompe, »Glasba slovenske povojne moderne«, De musica disserenda 12, št. 2 (2016): 27 .

4 Dragotin Cvetko, Glasbeni svet Antona Lajovca (Ljubljana: SAZU, 1985), 48-60, 6794. Kuret, »Slovenska glasbena misel po prvi vojni«, 14-38.

5 Anton Lajovic, »O večnih krasotah in o strupu Beethovnovih, Bachovih in Wagnerjevih del«, v: Kuret, Umetnik in družba, 124. Anton Lajovic, »Misli o umetnostni politiki«, v: Kuret, Umetnik in družba, 173.

6 Lajovic, »O večnih krasotah in o strupu Beethovnovih, Bachovih in Wagnerjevih del $\ll, 125$.

$7 \quad$ Prav tam, 127 
Glede vprašanja, kako naj bi se to dogajalo, kako naj bi skladatelj ustvarjal novo glasbo kot del lastnega naroda, je šel Lajovic še korak dlje. Iz lastne skladateljske izkušnje je vedel, da je nastanek umetniškega dela težko razložljiv in tudi misteriozen proces. Tisto, kar vodi umetnika pri njegovem delu, kar ga usmerja, je sam imenoval z izrazom »ideal«, pri čemer se je zavedal, da to ni najboljši izraz. Iz celotnega konteksta njegovih misli je mogoče razbrati, da si je $\mathrm{z}$ »idealom « predstavljal neko vodilo, ki ga ima ustvarjajoči skladatelj pred svojimi očmi, čemur skuša slediti in z ozirom na kar se iz trenutka $v$ trenutek odloča; izostreno bi lahko rekli, da je njegov »ideal« nekaj, kar naj bi se preko skladateljeve osebnosti uresničevalo kot nova kompozicija. Lajovic se ni natančneje spraševal, kaj je ta »ideal«, ali o tem vsaj ni pisal, prepričan pa je bil, da »ideal« ni skladateljeva zasebna zadeva, pač pa nekaj, kar je povezano z njegovim narodom. S tem, ko skladatelj uresničuje »ideal«, se uresničuje nekaj, kar obstoji v narodu; če skladatelju uspe uresničiti »ideal«, pride do »resonance« med novim umetniškim delom in narodno skupnostjo, kar pomeni, da narodna skupnost novo umetniško delo razume in sprejme.

Zastavlja se vprašanje, kako je Lajovic razlagal in opravičeval dejstvo, da obstoji sočasno veliko število nacionalnih glasbenih kultur, ki so, sledeč njegovim izvajanjem, prav razumljive le pripadnikom vsakokratne narodnostne skupnosti. Iz odlomka $v$ nekem njegovem spisu je razvidno, da se mu je to stanje zdelo naravno in samoumevno; samoumevno se mu je zdelo tudi to, da si vsaka nacionalna kultura prizadeva za svoj obstoj in da se za svoj obstoj in svojo rast tudi bori. Soobstoj različnih nacionalnih kultur, večjih in manjših, močnejših in šibkejših, od katerih si vsaka prizadeva za svoj prostor pod soncem, se mu je zdel nekaj naravnega. Še več: to, da si posamezne kulture prizadevajo za svoj obstoj, četudi so majhne, je nujno za obstoj katere koli kulture, tudi velike; če nacionalne kulture v medsebojnem odnosu ne bi imele trdožive volje po obstoju in rasti, bi propadle, kar bi privedlo do propada kulture nasploh. ${ }^{9}$

V luči takega, darwinistično obarvanega gledanja na kulturo je treba razumeti Lajovičev odpor do prevlade nemških skladateljev na slovenskih koncertnih programih. Nemška obarvanost slovenskega glasbenega življenja je bila zanj znak poraza slovenske glasbene kulture, njena predaja. $\mathrm{Na}$ Slovenskem bi se morala po njegovem mnenju razcveteti slovenska glasba,

8 Lajovic, »O večnih krasotah in o strupu Beethovnovih, Bachovih in Wagnerjevih del«, 124 . 
glasba tu živečih ljudi; le tako bo slovenska glasbena kultura lahko obstala, se vključila $\mathrm{v}$ sicer neenakovredni boj za svoje mesto pod soncem in prispevala svoj delež $\mathrm{k}$ soobstoju različnih nacionalnih glasbenih kultur. To, da se na Slovenskem izvajajo in občudujejo nemški umetniki, se mu je zdela pot k izginotju slovenske kulture. ${ }^{10}$

Lajovičeva gledanja je mogoče razlagati zgodovinsko: Živel je v času, ko so si narodi monarhije prizadevali za samostojnost in se skušali osvoboditi premoči nemške kulture. Sam je bil priča tega, kako se je moč nemške kulture v primerjavi s slovensko porabljala kot ideologija v službi konkretnih političnih ciljev. Protinemška in proslovanska črta sta $v$ njegovem pisanju dobro vidni. ${ }^{I I}$ Vendar lahko v njegovi misli, če jo gledamo zunaj konkretnih zgodovinskih okoliščin, $v$ katerih je nastala, sprevidimo še nekaj drugega: Lajovic se je zavedal, da glasba ni nekaj, kar bi bilo univerzalno razumljivo; da novonastalo glasbeno delo ne more biti razumljivo kjer koli in komur koli; da ima območje, znotraj katerega se lahko novo glasbeno delo recipira, težko premostljive meje. Najbrž ni nenavadno, da je kot območje, znotraj katerega se novo glasbeno delo lahko recipira, prepoznal narodno skupnost.

\section{II}

Če se od Lajovica preselimo k poldrugo desetletje mlajšemu Mariju Kogoju (1892-1956), se srečamo s povsem drugačnim pogledom na umetnost. Kogoj je bil umetnik, predan svojemu umetništvu in zagledan vanj; v svojem času ni bil zmeraj razumljen in tudi danes se njegova glasba različno presoja. Bil je tudi glasbeni kritik in pisec, ${ }^{12}$ in kot je dobro znano, je svoje poglede na umetnost razvil v eseju O umetnosti, posebno glasbeni, objavljenem v reviji Dom in svet v letih 1918/19, ko še ni dopolnil trideset let. ${ }^{13}$

Preden se posvetimo Kogojevi misli, velja opozoriti na naravo njegovega pisanja. Tudi kot pisec esejist je bil Kogoj bolj umetnik kot mislec; bolj kot da bi sistematično razvijal svoje misli, se je predajal pesniško zanesenim besedam o umetnosti in njeni naravi. Tok njegovih misli, kot si sledijo od stavka do stavka in od odstavka do odstavka, ni zmeraj razviden in vča-

A. Lajovic, »Misli o kulturnem tipu germaniziranega Slovenca«, v: Kuret, Umetnik in družba, 115-116.

11 Lajovic, "Misli o kulturnem tipu germaniziranega Slovenca«, 112-114.

12 Borut Loparnik, Zoran Krstulović, »Bibliografija objavljenih besedil Marija Kogoja«, v: Borut Loparnik, Zoran Krstulović, Moja notranjost sem (Ljubljana: NUK, 1992), $38-43$.
} 
sih se približuje prostemu nizanju izjav o umetnosti v obliki maksim. $\mathrm{Ob}$ tem se večkrat zazdi, da si izjave nasprotujejo. Začetne strani Kogojevega eseja kažejo očitni vpliv Ivana Cankarja: Kogoj je po njem povzel slog pisanja, evlogistično opevanje lepote, pa tudi svetobolno podobo umetnika, ki ga družba, ki umetnika sicer potrebuje, ne razume in ne ceni, čeravno jo umetnik močno prekaša. Vse to pomeni, da je treba Kogojeve izjave na neki način prevesti v nepesniški in slogovno nevtralni jezik glasbene estetike.

Kogoj je izhajal iz prepričanja, ki ima v njegovem pisanju močan osebni nadih, da ima umetnost svoj izvor v umetniku kot izjemni osebnosti, ki močno prekaša okolje, v katerem živi. Umetnost izvira izključno iz njegove notranjosti. Umetnik je le to, kar je v njegovi notranjosti. Kogojeva formulacija te misli je: »Moja notranjost sem $« .{ }^{14}$ Misel, da ima umetnost izvor v umetnikovi notranjosti, velja po Kogoju še posebej za glasbo, ki za razliko od drugih umetnosti ne posnema zunanjega sveta. Ker ne posnema zunanjega sveta, lahko posnema ali manifestira le tisto, kar je v umetnikovi notranjosti. ${ }^{\text {is }}$

Postavlja se vprašanje, kaj je ta notranjost, ki se manifestira preko glasbe. V tej zvezi govori Kogoj o lepoti, ki jo umetnik vidi in kateri se želi približati, na nekem mestu pa pravi, da je vsebina umetniškega dela le umetnikovo "čustvo, zgolj estetično čustvo«. ${ }^{16} \mathrm{Z}$ izrazom »čustvo«, kot ga rabi Kogoj, ne gre razumeti česa takega kot človekova vsakodnevna razpoloženja; iz celotnega konteksta njegovega pisanja je razvidno, da je s čustvi pojmoval nekaj mnogo širšega: človekovo notranje življenje ali dinamiko umetnikove notranjosti, ki ga sili proti nekemu nedoločljivemu in nejasnemu cilju, ki ga umetnik sam ne pozna in ne razume. Preko približevanja temu nejasnemu cilju se umetnik uresničuje.

Na prvi pogled so Kogojeve misli o vsebini glasbe protislovne. Na nekem mestu trdi: »Na tem svetu ni ničesar, kar bi moglo biti vzor glasbeno umetniškega snovanja. Ne narava, ne naravni svet. $^{17}$ Malo dalje pravi: „Glasba izraža vse, kar spada v čas in nosi vse lastnosti značajev, vsako stanje ...« V nadaljevanju tega odstavka našteje vrsto duševnih stanj, čustev v ožjem pomenu besede, pa tudi vrsto lastnosti, ki jih imajo predmeti, kot sta barva in vonj. ${ }^{18}$ Spet nadalje beremo: »Kdor hoče slišati glasbo,

\footnotetext{
14 Kogoj, »O umetnosti, posebno glasbeni«, 296.

15 Prav tam, 296.

16 Prav tam, 297.

17 Prav tam, 296.

18 Prav tam, 297.
} 
mora zavrniti program, kajti programsko poslušanje ubija glasbo. ${ }^{19}$ Vse te, na ravni ubeseditve težko uskladljive misli bi bilo mogoče razumeti takole: Kogoj si je morda predstavljal, da kot romanopisec ali slikar nista neodvisna od zunanjega sveta - dogajanja v človeku, družbi, naravi -, tako tudi glasbenik ni neodvisen od tistega, kar vidi, čuti, doživlja; in kot je realnost lahko izvor romanopisja ali slikarstva, tako je lahko tudi izvor glasbe; vendar pa skladatelj - za razliko od romanopisca - pretvarja realnost v vsebino svojega glasbenega dela na strogo enosmerni način, tako, da je kakršna koli vzvratna povezava med glasbenim delom in realnostjo, na osnovi katere je glasbeno delo nastalo, za zmeraj zaprta, tudi za skladatelja samega. Glasbeno delo tako ne more izražati drugega kot »čustva« v pravkar pojasnjenem smislu.

A čeprav izvira umetnost le iz umetnikove notranjosti, po Kogoju ni le stvar umetnika. Podobno kot I. Cankar tudi Kogoj na nekaj mestih trpko omenja, kako družba umetnika ne razume, kako jo moti, da si umetnika ne more podrediti, in kako išče $\mathrm{v}$ umetnosti le zabave in udobja $;^{2 \circ}$ vendar pa družba slednjič mora sprevideti pomen in vrednost umetnikovega dela in ga prizna. ${ }^{21}$ Očitno je, da je Kogoj ločil med zunanjim življenjem vsakokratne sodobne družbe, ki umetnika ne razume, in med nekim drugim, globljim življenjem človeštva. Ne da bi bila kje izrecno izražena, se nakazuje misel, da si je predstavljal, da se preko umetnosti in glasbe, ki jo snuje umetnik v pravkar prikazanem smislu, uresničuje še neki zakriti in globlji smisel družbe in človeštva.

Iz takih izhodišč je Kogoj presojal vse ostalo: Razvoj glasbe je po njegovem prepričanju delo velikih osebnosti, ki jih posnemajo epigoni. ${ }^{22}$ Sloga, ki bi ga ustvarila skupina ljudi ali doba, ni; slog je delo posameznika. ${ }^{23}$ Umetnik je pri svojem delu svoboden $\mathrm{v}$ absolutnem smislu: $\mathrm{s}$ toni dela kar koli; ne ovirajo ga ne uveljavljene tehnike ne okus dobe; ${ }^{24} \mathrm{v}$ harmonskem pogledu to pomeni, da povsem prosto sestavlja akorde iz dvanajstih tonov; katera koli kombinacija je možna. ${ }^{25}$

$\mathrm{Ni}$ mogoče spregledati, da ima $\mathrm{v}$ Kogojevem pogledu na umetnost ključno vlogo umetnik, ki mu Kogoj pripisuje neke vrste duhovniško vlo-

\footnotetext{
19 Prav tam, 298.

20 Prav tam, 293, 303-304.

21 Prav tam, 295, 302.

22 Prav tam, 294-295.

23 Prav tam, 305.

24 Prav tam, 307.

25 Prav tam, 310.
} 
go. ${ }^{26}$ Podoben kult umetnika bi lahko v različnih variantah iskali pri številnih piscih poznega 19. in zgodnjega 20. stol. Dejstvo, da ima tudi v Kogojevem pogledu tako pomembno mesto, je možno razlagati s stališča njegovega osebnega položaja: Kot napredni umetnik svojega časa je najbrž čutil potrebo, da se nasloni na estetiko, ki je glasbi kot delu umetnikov pripisala metafizične razsežnosti.

\section{III}

V pisanju Stanka Vurnika (1898-1932) se srečamo s povsem drugačnim pristopom k umetnosti. Sin organista in skladatelja Mateja Vurnika je bil prvenstveno umetnostni zgodovinar. Na Univerzi v Ljubljani je doktoriral pri Izidorju Cankarju, ki je bil sam učenec Maxa Dvořaka na Dunaju, in sicer z disertacijo o slikarju Janezu Valentinu Metzingerju. Poleg umetnostne zgodovine se je posvečal etnologiji in glasbi. ${ }^{27}$ Čeprav je umrl mlad, je zapustil velik opus raznovrstnih spisov; če se omejimo na umetno glasbo, so to časopisne kritike, ocene glasbenih sezon, polemični prispevki ${ }^{28}$ in dve razpravi: Uvod v glasbo. I. Sistematični del ${ }^{29}$ in Stil $v$ zgodovini glasbe; ${ }^{30}$ slednja naj bi bila kot stilna zgodovina glasbe smiselno dopolnilo Uvoda, vendar je Vurnik uspel dokončati le poglavje o glasbi antične Grčije. Vurnikova misel o glasbi je bila doslej le nekajkrat predmet temeljitejšega muzikološkega razpravljanja. ${ }^{31}$

26 Prav tam, 293.

27 Vilko Novak, Peter Krečič, Kristijan Ukmar, »Vurnik, Stanko«, Slovenska biografija (splet).

28 Izbor pomembnejših Vurnikovih časopisnih prispevkov je objavil Kuret, Umetnik in družba, 337-476.

29 Stanko Vurnik, Uvod v glasbo. I. Sistematični del (Ljubljana: Nova založba, 1929). Pred tem je besedilo v nadaljevanjih izhajalo v reviji Dom in svet 41 (1928). Kot pravi v uvodu, je Vurnik za knjižno izdajo besedilo preuredil. Podnaslov dela in oštevilčenje napovedujeta nedokončani Stil v zgodovini glasbe. - Zunanje okoliščine nastanka Uvoda in Stila so prikazane v delu: Kristijan Ukmar, »Problem stila v interpretaciji Stanka Vurnika«, Muzikološki zbornik 3 (1967): 78.

30 Dom in svet 44, št. 3/4-10 (1931).

31 Ukmar, »Problem stila«, 77-87. Kuret, »Slovenska glasbena misel po prvi vojni«, 7-79. Omeniti velja še dve diplomski nalogi: Kristijan Ukmar, Stanko Vurnik: življenje in delo (Ljubljana: Filozofska fakulteta, 1964); Karmen Salmič Kovačič, Vpliv estetske misli Franceta Vebra na Uvod v glasbo Stanka Vurnika (Ljubljana: Filozofska fakulteta, 1990). - Tisti, ki smo poslušali predavanja Vilka Ukmarja, lahko ob branju Vurnikovega Uvoda ugotavljamo, da je bil glavni vir Ukmarjevega razpravljanja prav Vurnik. V Uvodu skorajda ni mesta, ki ne bi imelo v Ukmarjevih predavanjih nekega odmeva. Ukmar je sooblikoval pogled na glasbo številnim generacijam slovenskih 
Vurnikovo pisanje ni neproblematično. Čeprav je njegova misel v glavnih obrisih lahko razpoznavna, je mestoma nejasna: Morda je ponekod premalo natančno obrazložil, kaj pravzaprav misli; tovrstna mesta so še zlasti težko razumljiva, če jih beremo s skoraj stoletne časovne razdalje. Mestoma naletimo na odlomke, ki so $\mathrm{v}$ kompilativnem smislu navrženi brez prave zveze z glavnim tokom misli ali pa jih ni mogoče uskladiti s celoto. Tudi pri rabi pojmov je puščal bralca $\mathrm{v}$ dvomu; zelo pogosto se pri njem pojavi izraz »čutno«, ki ima nasploh zelo širok pomenski obseg. Vurnik nikjer ne obrazloži, kaj točno pomeni: ali to, da vzbuja glasbeno delo določene občutke in čustva, ali moralno vprašljivi hedonizem ali še kaj drugega.

Razlog za prikazano naravo Vurnikovega pisanja je mogoče videti $\mathrm{v}$ dvojem: (1) Svoj pogled na umetnost in glasbo si je Vurnik pridobival z branjem ustrezne literature. ${ }^{32} \mathrm{Zdi}$ se, da so njegovi spisi nastajali kot kompilacija tistega, kar je bral, pri čemer je prebrano vsebino na neki način prilagajal in predelaval. Vendar je bil pri kompiliranju svojih spisov premalo samokritičen; za področje, ki se ga je loteval, za eksaktno področje glasbene estetike, ni razvil ustrezne miselne discipline. (2) Vurnik ni ločeval med zgodovinskimi in glasbenoestetskimi spoznanji; interpretacije glasbenozgodovinskih dejstev, glasbe nasploh in posameznih skladb, interpretacije, ki so veljavne le znotraj določenega miselnega sistema, je imel za zgodovinska dejstva. Ker so misli, ki jih je kompilativno sprejemal kot dejstva, izhajale iz različnih smeri, je tok njegovega pisanja nujno večkrat neusklajen; v njegovih spisih so tako mesta, ki bralcu zamegljujejo pogled na celoto, ki niso niti izdelana niti jim ni mogoče najti ustreznega mesta v vsebinskem toku celote.

Vurnikovo pisanje se bere danes precej drugače kot $\mathrm{v}$ njegovem času, še zlasti, če pomislimo, da je bil pogled na zgodovino glasbe pred stoletjem bistveno drugačen od današnjega, in da je bila estetska in filozofska misel o glasbi v slovenskem kulturnem prostoru med obema vojnama nekaj novega. Sodobno branje Vurnikovih spisov je branje s stališča drugega miselnega okolja. Če hočemo obrise Vurnikove misli prav spoznati, je nujno, da jih predstavimo, tako kot $\mathrm{v}$ Lajovičevem in Kogojevem primeru, v sodobnem jeziku in s sodobno terminologijo; pri tem je treba mestoma razločno izraziti tudi tisto, kar Vurnikovo pisanje implicira, ne da bi bilo izrecno zapisano. Ker Vurnikovo pisanje ni povsem usklajeno, je razumljivo, da lahko tako postopanje privede tudi do nasprotujočih si zaključkov.

glasbenikov in muzikologov; Vurnikove misli o glasbi predstavljajo tako pomemben segment slovenske kulturne zgodovine.

32 Vurnik redko navaja kako literaturo. Katera dela s področja glasbe je poznal in uporabljal, je skušal dognati K. Ukmar, »Problem stila«, 78-79. 
Oglejmo si zdaj obrise Vurnikove misli. ${ }^{33}$ Vurnik je bil umetnostni zgodovinar in zato je bil njegov pristop h glasbi kot predmetu misli bistveno drugačen od Kogojevega, ki je glasbo razumel le kot delo umetnika. Vurnik je glasbo gledal kot družbeno danost in širok zgodovinski pojav, ki presega posameznika. S tega zornega kota - zornega kota zgodovinarja - je presojal obdobja, posamezne umetnike in posamezna glasbena dela.

V predgovoru v svoj Uvod Vurnik pove, da skuša odgovoriti na vprašanje, kaj je »umetnostna vsebina glasbe«, kaj njen "pomen«, zaprt v »formo.$^{34} \mathrm{~V}$ tem se nakazuje misel, ki pogosto zaveje iz njegovega pisanja, misel, da pomen glasbenega dela ni v glasbi sami, pač pa v ideji kot ubesedljivi misli, ki jo lahko prepoznamo v glasbi.

Kot je razvidno iz nadaljevanja, je bil Vurnik prepričan, da je umetnost povezana s svojim okoljem na racionalno spoznavni in razložljivi način. Predstavljal si je, da umetnost dobe, zgodovinskega okolja in umetnost posameznika v njem nujno izraža prevladujoči svetovni nazor svoje dobe ali zgodovinskega okolja: svetovni nazor, ki se da izraziti $z$ besedami kot določeni pogled na svet in človeka $\mathrm{v}$ njem. Za kateri koli svetovni nazor je menil, da ga je možno določiti z mestom na enodimenzionalni premici, na katere enem koncu je skrajni idealizem, ki priznava le obstoj duhovnega, na drugi pa skrajni materializem, imenovan pri njem tudi naturalizem, ki priznava le obstoj materialnega; med obema skrajnostma je po Vurniku realizem, ki priznava oboje. ${ }^{35}$ Kateri koli svetovni nazor je bodisi bliže idealizmu ali pa bliže materializmu. V tem smislu se je posluževal oznak kot »idealistični realizem «, "naturalistični realizem $\aleph^{36} \mathrm{ipd}$.

Vsaka doba naj bi imela po Vurniku svoj značilni in prevladujoči svetovni nazor, znotraj katerega so sicer obstajale na prostor ali na kaj drugega vezane različice. Srednji vek naj bi bil izazito idealističen, sledeče obdobje renesanse naturalistično. ${ }^{37}$ Prevladujoči svetovni nazor naj bi bil, kot je bilo omenjeno, razviden tudi v prevladujočem slogu dobe, $v$ tem smislu, da se svetovni nazor izraža preko sloga.$^{38} \mathrm{~V}$ zgodovini se iz obdobja v obdobje menja svetovni nazor, pogled na svet, občutevanje sveta, način življenja, in obenem s tem se iz obdobja v obdobje menja tudi slog. Zmeraj se uvelja-

33 Vurnik je osnovni pogled na umetnost prevzel po svojem učitelju Izidorju Cankarju. Ukmar, »Problem stila«, 78-79 in na več nadaljnjih mestih.

34 Vurnik, Uvod, 5.

35 Prav tam, 129.

36 Prav tam, 85.

37 Prav tam, 153.

38 Prav tam, 146. 
vi tisti novi umetnostni slog, ki ustreza svoji dobi, njeni miselnosti, načinu življenja, slog, ki izraža novi svetovni nazor dobe. Gledano s tega zornega kota se je Vurniku zdela zgodovina umetnosti zelo zanimiva: primerjal jo je s polifonim tokom, v katerem je zmeraj nekaj novega. Spričo povezave umetnostnega sloga s svetovnim nazorom si je predstavljal, da je preko spoznavanja umetniških del mogoče spoznavati zgodovino in tisto, kar se je miselnega, svetovnonazorskega dogajalo v njej. ${ }^{39}$

Če se ustavimo ob Vurnikovem pojmovanju sloga, lahko opozorimo na dvoje:

1) Za Vurnika je slog nekaj, kar je nad posameznimi umetnostmi: isti značilni slog dobe, ki obvladuje slikarstvo, je prisoten tudi v sočasni literaturi, glasbi itd.

2) Glede razmerja med svetovnim nazorom in slogom velja opomniti, da ima v Vurnikovi misli prvenstvo svetovni nazor, ki je pred slogom, če že ne časovno pa gotovo pomensko.

Kako natančneje nastane novi slog, je Vurnik nakazal v nekem drugem spisu: Predstavljal si je, da obstojijo določeni družbeni krogi, »vplivne sfere«, in znotraj njih »umetnostnomerodajni krogi«, kot jih je imenoval, s čimer si lahko predstavljamo ustvarjajoče umetnike. V vplivnih družbenih krogih nastajajo predispozicije, izhodišča, iz katerih lahko ustvarjajoči umetniki ustvarjajo nova dela in razvijejo novi slog, ki se razširi povsod tam, kjer obstojijo ustrezne miselne predispozicije zanj. Predispozicije, iz katerih nastane nova umetnost, niso glasbene; so splošne duhovne, miselne danosti, svetovni nazor dobe. Novi slog se uveljavi, če je v skladu s celotno duhovno atmosfero svojega časa in prostora. ${ }^{40}$

S temi mislimi je določena tudi vloga umetnika: Novo umetniško delo mora biti v skladu s predispozicijami, kot se oblikujejo v "vplivnih sferah«. Le v tem primeru lahko družbeno okolje novo umetniško delo sprejme. To pomeni, da umetnik ne ustvarja iz sebe, iz svoje notranjosti; pravi vir njegove umetnosti je okolje, v katerem živi. ${ }^{41}$ Novi slog vpelje genialna osebnost, ki prepozna značilnosti dobe, njenega duha, njen nazor, vse to na neki način vsrka, in izhajajoč iz tega ustvari novi slog, ki ustreza času. Geniju sledi plejada epigonov, ki razširijo in napravijo vsesplošno tisto, kar je

39 Prav tam, 163-164.

40 Stanko Vurnik, »Umetnost in družba ter umetnostna politika«, v: Kuret, Umetnik in družba, 365,367 .

41 Stanko Vurnik, »O glasbi sploh in o moderni glasbi posebej«, v: Kuret, Umetnik in družba, 395. 
odkril genij, dokler se spet ne spremeni duh dobe in se pojavi novi genij. ${ }^{42}$ Vlogo umetnika je Vurnik podal s primero: zgodovinski tok je kot polifonija, odločilni umetniki, tvorci novega sloga, so njen ritem. ${ }^{43} \mathrm{~V}$ smislu tega gledanja je bil Vurniku umetniški individualizem sumljiv; to, da umetnik ustvarja le iz sebe, se mu je zdelo toliko, kot da bi ustvarjal le zase. Po Vurniku se tak umetnik izloči iz družbe, saj je razumljiv le samemu sebi. ${ }^{44}$

Okolje, v katerem nastane novi slog, po Vurniku nikakor ni istovetno $\mathrm{z}$ narodnostno skupnostjo. Prav nasprotno. Vurnik je duhovno atmosfero katerega koli časa, znotraj katere nastane ustrezni slog, videl kot nekaj, kar obstoji mimo narodnostnih meja. Da je tako, mu je po eni strani kazala zgodovina umetnosti, po drugi pa tudi številni primeri iz sodobnega življenja. Vurnik si je sicer predstavljal, da lahko hkrati obstoji več okolij, znotraj katerih se generirajo novi slogi, vendar se ta okolja v njegovi misli nikakor ne pokrivajo $\mathrm{z}$ nacionalnimi mejami: slogi nastajajo, obstojijo in se razvijajo mimo narodnostnih meja. Umetniško snovanje je bilo za Vurnika izrazito nenacionalna, nacionalno spregledujoča dejavnost. ${ }^{45}$ Misel je še izostril: Bolj ko je umetnost nacionalna, bolj je individualistična, bolj zaprta, s tem pa v vse manjši meri tisto, kar bi kot umetnost morala biti. ${ }^{46}$

Vurnikovo razpravljanje ne bi bilo razpravljanje o glasbi, če ne bi teh misli apliciral na glasbo. Kot je razvidno že iz naslovov poglavij v njegovem Uvodu, je v glasbi ločil troje vsebin, kot jih je imenoval: Prva, »formalna vsebina « je vse tisto, kar je v glasbi zgolj glasbenega, tisto, kar more s svojim glasbenoteoretičnim aparatom prepoznati glasbena analiza. Druga, "predmetna vsebina« glasbe je tisto, kar je v glasbi zunajglasbenega in se da opisati $z$ besedami. $Z$ ozirom na predmetno vsebino se vsaka kompozicija uvršča med dve skrajnosti: na eni strani je glasba brez predmetne vsebine, pri kateri je vsa vsebina v njeni obliki - primer bi bil lahko kaka abstraktna fuga -, na drugi programsko deskriptivna glasba. Beethovnove kompozicije so nekako na sredi: očitno je, da pripovedujejo nekaj, kar bi se dalo izraziti v obliki zgodbe, vendar pa noben poskus določitve predmetne vsebine Beethovnovih skladb ni zanesljiv. Zdi se, da je Vurnik verjel, da predmetne vsebine Beethovnovih kompozicij objektivno obstojijo, le odkriti jih ni mogoče. ${ }^{47}$

42 Vurnik, Uvod, 159-160.

43 Vurnik, Uvod, 162.

44 Vurnik, »O glasbi sploh in o moderni glasbi posebej«, 396.

45 Vurnik, »Umetnost in družba«, 365.

46 Prav tam, 366. Stanko Vurnik, »Nova muzika«, v: Kuret, Umetnik in družba, 394.

47 Vurnik, Uvod, 104. 
Tretja vsebina glasbe je »estetska vsebina«; $\mathrm{z}$ ozirom na to je glasba lahko le lepa ali grda. Ni jasno, kot kaj si je Vurnik predstavljal estetsko vsebino. Poglavje o estetski vsebini govori namreč predvsem o svetovnem nazoru in o tem, kako se le-ta izraža v glasbi. Domnevno si je Vurnik predstavljal, da je glasba lepa, če se v njej idealno skladata formalna in predmetna vsebina, in se hkrati preko njenega sloga razločno izraža tudi določeni svetovni nazor. ${ }^{48}$

Ko v poglavju o estetski vsebini Vurnik razmišlja o tem, kako naj bi se svetovni nazor izražal v glasbi, kaj naj bi bila njena svetovnonazorska vsebina, glasbe ne razumeva $\mathrm{v}$ njenem glasbenoestetskem bistvu, pač pa skuša slog in svetovni nazor, iz katerega izhaja, razbrati v samem glasbenem in kompozicijskem gradivu, $v$ tistem, kar je sam imenoval formalna vsebina, tj. v glasbenih teoremih, abstrahiranih iz same glasbe, in $\mathrm{v}$ abstrahiranih kompozicijskih tehnikah in postopkih. Temu je pripisoval slogovno vrednost, s tem pa implicitno tudi to, da so izraz določenega svetovnega nazora. Tako naj bi bilo po njegovem mnenju srednjeveško koralno enoglasje izraz idealizma, zato, ker nima možnosti čutnega učinkovanja; polifona umetnost 15. in 16. stol., ki sestoji sicer iz nečutnih melodij, vendar ima njihov preplet nekaj čutnega, naj bi bila izraz realizma; homofonija - prevlada ene, $\mathrm{v}$ smislu funkcijske harmonije zasnovane in razumljene melodije pa naj bi bila izraz naturalizma, saj učinkuje predvsem čutno. ${ }^{49}$

Iz takih interpretacij je možno izpeljati Vurnikovo gledanje na kompozicijsko tehniko. Vurnik večkrat poudari, da je gonilo razvoja človeški duh, ne pa razvoj kompozicijske tehnike. ${ }^{50}$ To pomeni, da je vse tisto, kar je sam imenoval formalna vsebine, tj. kompozicijski postopki, zgolj sredstvo, preko katerega se izraža določena ideja, določeni svetovni nazor. Posledično se na več mestih njegovega pisanja ustvarja vtis, da si je predstavljal, da obstojijo glasbeni teoremi in kompozicijske tehnike ločeno od skladateljev, da so apriorno dani, da so celo zunaj zgodovinskega razvoja, in da se jih skladatelji poslužujejo z ozirom na svoj od svetovnega nazora odvisni slog. Srednjeveški koral je torej enoglasen zaradi idealizma, ki naj bi obvladoval celotni srednji vek; tvorci korala bi po Vurnikovem mnenju lahko komponirali tudi večglasno, če ne bi bili usmerjeni tako strogo idealistično.

Ob tem, ko je Vurnik na prikazani način abstraktom kompozicijskih postopkov skušal pripisati slogovne in nazorske vrednosti, je nujno zašel

48 Prav tam, 131-132.

49 Prav tam, 130-131.

50 Prav tam, 128, 156. 
$\mathrm{v}$ težave. Interpretiranje obdobij, smeri, skladateljev in njihovih del $\mathrm{v}$ tem smislu ga je privedlo do težko razumljivih trditev in $\mathrm{v}$ isti skupini so se znašle močno različne stvari. Za primer lahko vzamemo Vurnikove ponazoritve naturalizma: programska instrumentalna glasba, kot npr. Smetanova Domovina, je po njegovem naturalistična; ${ }^{51}$ a tudi čista instrumentalna glasba, ki razen svoje oblike nima nobene vsebine, je znak »čutno - materialističnega časa«; taka glasba je zgolj »igračkanje s formami« brez vsake vsebine; ${ }^{52}$ za primere take glasbe daje Vurnik tudi Bachove fuge, katerih teme so "plitev nič «; $;$ hkrati je odraz naturalizma tudi vsa plesna glasba vključno z Dvořakovimi Slovanskimi plesi, saj ples s svojim poudarjeno ritmičnim impulzom učinkuje predvsem na čute in nima nobene druge vsebine. ${ }^{54} \mathrm{Vu}-$ rnikovo razpravljanje o tem, kako se svetovni nazor odraža $v$ formalni vsebini, ni ne razumljivo ne obnovljivo.

Kot je bilo omenjeno na začetku prikaza Vurnikove misli, si je predstavljal, da mora biti tisto, kar kompozicija izraža, kar po svojem bistvu je, njen svetovni nazor torej, takšne vrste, da se ga da izraziti kot ubesedljivo idejo. Ta pogled je morda najbolj razločno izražen v njegovi analizi koralnega introita Statuit ei Dominus. .5 Glasba je tu po Vurnikovem mnenju omejena na to, da nosi besedilo, podčrtuje njegovo vsebino, ki je izraz krščansko-idealističnega pogleda na svet. Učinek same glasbe je pri tem ničen; celotni introit kot spev izraža torej le tisto, kar izraža njegovo besedilo. Nasprotni pol taki glasbi predstavlja glasba kot »igračkanje s formami« brez vsebine, kjer gre zgolj za glasbeno umetnijo brez čustev in idej. ${ }^{56}$ Kot omenjeno, sodijo po Vurniku v to skupino tudi Bachove fuge.

Ob koncu tega pregleda lahko opozorimo na nekaj dilem. Misli, ki so jih razvili Lajovic, Kogoj in Vurnik, gotovo niso bile samo njihove. V raznih variantah bi jih lahko našli v številnih spisih o glasbi, zlasti nemških, s konca 19. in začetka 20. stol. Poznavalci glasbene estetike bi v njih težko prepoznali kaj novega. Vendar pa to ne pomeni, da so bili Lajovic, Kogoj in Vurnik zgolj eklektični epigoni brez osebnostnih potez. Najmanj, kar je v tej zvezi

51 Prav tam, 101.

52 Vurnik, »O glasbi sploh in o moderni glasbi posebej«, 395.

53 Vurnik, Uvod, 122.

54 Prav tam, 124-125. O Vurnikovih zagatah gl. tudi Ukmar, »Problem stila«, 83-84.

55 Vurnik, Uvod, 61-64.

56 Vurnik, »O glasbi sploh in o moderni glasbi posebej«, 395. 
možno reči, je, da so si svoje poglede oblikovali na ozadju širše sočasne ali polpretekle misli o umetnosti in glasbi, bodisi da so jo poznali iz primarnih virov ali preko takega ali drugačnega posredništva.

Kot je bilo že nakazano, je misli vsakega od treh predstavljenih esejistov mogoče interpretirati s stališča njegove življenjske poti: Lajovic je bil otrok časa, ko je slovenska skupnost stremela h kulturni samostojnosti, in razumljivo je, da se je zavzemal za slovensko glasbo; Kogoj je bil umetnik, ki bi potreboval brezpogojno družbeno priznanje umetniškega delovanja; Vurnik je bil umetnostni zgodovinar, ki je ideje svojega učitelja skušal prenesti na glasbo. Zastavlja se vprašanje, ali ta dejstva omejujejo veljavnost njihovih pogledov ali pa so le-ti s tem, da so $\mathrm{v}$ odvisnostni povezavi $\mathrm{z}$ življenjskimi potmi njihovih nosilcev, pravi odraz razmer in časa, $v$ katerem so imenovani trije živeli.

Vsak od treh predstavljenih esejistov si je ustvaril lastni pogled na glasbo. Razlike med njimi so bile v času njihovega delovanja opazne, nemalokrat so imele tudi polemični značaj, saj je Lajovic javno polemiziral tako s Kogojem kot z Vurnikom. Tudi danes ni mogoče spregledati različnosti njihovih izhodišč in pogledov, čeravno se s skoraj stoletne zgodovinske perspektive njihova razmišljanja kažejo kot del istega kulturnega sveta. Sprašujemo se lahko, ali je prikaz njihovih misli hkrati tudi prikaz slovenske medvojne misli o glasbi ali pa je treba Lajovica, Kogoja in Vurnika gledati kot tri individualne osebnosti z različnimi pogledi na bistvena vprašanja $\mathrm{v}$ zvezi z glasbo.

\section{Bibliografija}

Barbo, Matjaž. Uvod v muzikologijo. Ljubljana: Znanstvena založba Filozofske fakultete, 2016.

Cvetko, Dragotin. Glasbeni svet Antona Lajovca. Ljubljana: SAZU, 1985.

Kogoj, Marij. »O umetnosti, posebno glasbeni«. V: Kuret, Primož. Umetnik in družba. Ljubljana: Državna založba Slovenije, 1988, 291-311.

Koter, Darja. Slovenska glasba 1918-1991. Ljubljana: Študentska založba, 2012.

Kuret, Primož. »Slovenska glasbena misel po prvi vojni«. V: Kuret, Primož. Umetnik in družba. Ljubljana: Državna založba Slovenije, 1988, 7-79.

Kuret, Primož. Umetnik in družba. Slovenska glasbena misel po prvi vojni. Lajovic, Kogoj, Vurnik. Ljubljana: Državna založba Slovenije, 1988.

Lajovic, Anton. »Misli o kulturnem tipu germaniziranega Slovenca«. V: Kuret, Primož. Umetnik in družba. Ljubljana: Državna založba Slovenije, 1988, 112-116. 
Lajovic, Anton. »Misli o umetnostni politiki«. V: Kuret, Primož. Umetnik in družba. Ljubljana: Državna založba Slovenije, 1988, 171-185.

Lajovic, Anton. »O nacionalnosti v umetnosti«. V: Kuret, Primož. Umetnik in družba. Ljubljana: Državna založba Slovenije, 1988, 133-135.

Lajovic, Anton. „O večnih krasotah in o strupu Beethovnovih, Bachovih in Wagnerjevih del«. V: Kuret, Primož. Umetnik in družba. Ljubljana: Državna založba Slovenije, 1988, 124-127.

Loparnik, Borut, in Krstulović, Zoran. »Bibliografija objavljenih besedil Marija Kogoja«. V: Loparnik, Borut, in Krstulović, Zoran. Moja notranjost sem. Ljubljana: NUK, 1992, 38-43.

Novak, Vilko, Krečič, Peter in Ukmar, Kristijan. »Vurnik, Stanko«. Slovenska biografija (splet).

Pompe, Gregor. »Glasba slovenske povojne moderne«. De musica disserenda 12, št. 2 (2016): 23-46.

Salmič Kovačič, Karmen. Vpliv estetske misli Franceta Vebra na Uvod v glasbo Stanka Vurnika. Ljubljana: Filozofska fakulteta, 1990 (diplomsko delo).

Škerjanc, Lucijan Marija. Anton Lajovic. Ljubljana: SAZU, 1985.

Ukmar, Kristijan. »Problem stila v interpretaciji Stanka Vurnika«. Muzikološki zbornik 3 (1967): 77-88.

Ukmar, Kristijan. Stanko Vurnik: življenje in delo. Ljubljana: Filozofska fakulteta, 1964 (diplomsko delo).

Vurnik, Stanko. »Nova muzika«. V: Kuret, Primož. Umetnik in družba. Ljubljana: Državna založba Slovenije, 1988, 392-394.

Vurnik, Stanko. »O glasbi sploh in o moderni glasbi posebej«. V: Kuret, Primož. Umetnik in družba. Ljubljana: Državna založba Slovenije, 1988, 394-397.

Vurnik, Stanko. »Stil v zgodovini glasbe«. Dom in svet 44, št. 3/4-10 (1931).

Vurnik, Stanko. »Umetnost in družba ter umetnostna politika«. V: Kuret, Primož. Umetnik in družba. Ljubljana: Državna založba Slovenije, 1988, 364-370.

Vurnik, Stanko. Uvod v glasbo. Ljubljana: Nova založba, 1929. ${ }^{57}$

57 Poglavje je nastalo kot del projekta J6-7180, ki ga je sofinancirala Agencija za raziskovalno dejavnost Republike Slovenije.

This chapter is part of the project J6-7180 funded by Slovenian research agency ARRS, 


\title{
Slavko Osterc's Compositional Journey and his Assimilation of New Techniques
}

\author{
Niall O'Loughlin \\ Univerza v Loughboroughu \\ Loughborough University
}

\section{Introduction}

The composing career of the leading Slovene composer Slavko Osterc (18951941) spanned the twenty years from 1921 to 1941. During this time his style developed in stages from a late Romantic idiom through various modifications to a well developed approach that incorporated numerous new musical techniques, many of which were passed on to his numerous Slovene composition pupils.

\section{Early Years 1921-1925}

There are some forty compositions of his dating from before his departure for Prague. ${ }^{I}$ Andrej Rijavec is dismissive of the simplistic view that they were somewhat immature, with a more or less romantic expression. ${ }^{2} \mathrm{He}$ notes in two selected chamber music works an interesting harmonic language which extends to the use of parallel chords, the loosening of the traditional progression of chords and the increasing 'indefinability' of chords by the supersaturation of seconds. The lucidity of form is attributed to his use of 'horizontal thought, whether a simple figure, a small motif, or a theme, even with melodic qualities." One substantial orchestral work from

$1 \quad$ Andrej Rijavec, "Komorno kompozicijsko snovanje Slavka Osterca pred njegovim odhodom v Prago," Muzikološki zbornik 5 (1969): 92-10o.

2 Ibid., 100.

3 Ibid., 100 . 
this period, the Symphony in C major of 1922, subtitled Ideali ('Ideals'), is traditional in its form and techniques. ${ }^{4}$ The last work of any substance from this time is his first opera Krst pri Savici ('Baptism at the Savica') with a story that has roots in Slovene history and mythology. It is through composed, but it is possible to identify traditional set-pieces such as arias, duets and ensembles. This technique of having the best of both worlds is something that he also used in his later opera, Krog s kredo.

\section{Prague Years 1925-27}

The years in Prague were used by Osterc to extend his style and study new techniques. He was able to expand his horizons considerably and learn to use new techniques to embrace those of his teachers, establishing a very good relationship with them, but taking from each of them only what he wanted. He gained a good grounding in new techniques from Karel Boleslav Jirák, but also developed an adventurous side from Alois Hába. Although there is no evidence that Osterc had any dealings with Alexander Zemlinsky who was living in Prague at the time, it is quite possible that he was able to encounter some of his work while he was studying in that city. The fact that both Osterc and Zemlinsky used the play Der Kreidekreis by Klabund as librettos for operas in the next few years may not be the coincidence that it initially seems. At the same time, there is also another side to his musical experience: that his fondness for using the folk music of his native land could be integrated into his modernist tendencies.

\section{Experimental Ljubljana 1927-30}

After returning from his studies in Prague to Ljubljana, Osterc became very active in three main ways. The first of course was the composition of his new music, which he hoped would be widely performed. Secondly, he worked extensively with the International Society for Contemporary $\mathrm{Mu}$ -

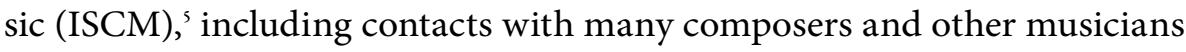
in the different republics of what was then Yugoslavia and further afield in numerous countries of Europe. The third important activity was his teaching of a significant number of composition pupils, whom he was able to en-

4 See the study Zoran Krstulović, "Kompozijski stavek Simfonije v C-duru ('Ideali') Slavka Osterca," Muzikološki zbornik 31 (1995): 53-62.

5 Normally referred to in continental Europe by its French name, Société internationale de la musique contemporaine (SIMC). 
courage technically and stylistically. Thus his influence operated on a number of different levels.

One of his pupils, the distinguished musicologist, Dragotin Cvetko (1911-1993), held Osterc in very high regard, pointing to the great significance of his compositions which dated from the last years of the 1920 in comparison with those of his contemporary Marij Kogoj (1892-1956):

"During the last years of the third decade of the 2oth century, it was Osterc who changed Slovene music, rather than Kogoj. Drawing intensively away from tradition in his ideas, he revolutionized the music of his time, though within the Slovene space and scale, not the European one. This is demonstrated by his works written during the years 1927-1930, which are different from those of his contemporaries and even from those of Kogoj, whose modernist inclination lay elsewhere. Even the first works written by the former [i.e. Osterc] foretold an even more radical grasp of the new style when compared to those by Kogoj.'

An examination of some of the music of these years is the key to the full understanding of the meaning of Cvetko's remarks. Osterc's main achievements in 1927-30 were in the fields of chamber music and opera. Much of the chamber music is small-scale in conception, with works divided into a number of separate short movements, often written for wind instruments. Štiri karikature ('Four Caricatures') for piccolo, clarinet and bassoon uses the widely spaced registers of the chosen instruments for clarity of texture, particularly in contrapuntal passages and in the sharply etched rhythms. There is an affinity with some music of Stravinsky in the clear colours of the Preludio, while the Fughetta finale is one of Osterc's distinctive character pieces of this period, with its playful contrapuntal character. Overall there is a feeling of humour and parody, especially in the Valse movement, with its sense of pastiche, precise rhythms and the use of widely differing wind instruments to mark out the clear-cut melodic lines. One finds the use of traditional dance forms from the baroque in his Silhuete ('Silhouettes') for string quartet of 1928. The longest of these five pieces is barely two minutes in duration while the shortest lasts a mere 30 seconds. The epigrammatic forms embrace a range of harmonic tension and discord that is rare in Slovene music of the period. Of the works using miniature forms, the delight-

6 Dragotin Cvetko, Fragment glasbene moderne iz pisem Slavku Ostercu - A Fragment of Musical Modernism from Letters to Slavko Osterc (Ljubljana: Slovenska akademija znanosti in umetnosti, 1988), 12 
fully entertaining Sonatina for two clarinets of 1929, with its contrapuntal textural variety of register differentiation, hides a range of discordant juxtapositions that is amazingly forward-looking. Also using short movements, but suggesting the possibility of longer paragraphs is the Suite of 1928, scored for a distinctive group of eight instruments, four woodwind, three brass and timpani. The first two movements have a more romantic feel, but the Tempo di Valse, the stern march-like Grave and the Vivo fughetta finale return to the lighter humour of the other pieces. Two more extended instrumental works also come from this time: the Koncert $z a$ violino in 7 instrumentov ('Concerto for violin and seven instruments') of 1927-28 and the Suite for orchestra of 1929, both with suggestions of Hindemith and Honegger. The Violin Concerto is cast in a single movement and scored for two woodwind, two brass, timpani and two strings in addition to the solo instrument. The way that Osterc planned the concerto's structure gives a clue to the single-movement forms that were soon to follow, while the orchestral Suite shows how the terse chamber-music miniatures could be extended. As a postscript to his time in Prague we note that the studies with Alois Hába resulted in only a small number of works that used his teacher's quarter-tone system, ones that had little bearing on Osterc's later development or on his influence on others.?

\section{New Operas 1928-29}

This period was one in which Osterc was also active as a vocal composer. There are a number of choruses which are less indicative of his more adventurous ideas, but ones in which the composer was able to keep a contact with his audiences and with Slovene traditional choral singing. More important for the development of newer techniques are solo songs and operas. The most impressive solo vocal work must be Štiri Gradnikove pesmi ('Four Songs to words of Alojz Gradnik') for alto and string quartet of 1929. Here there is none of the light and almost sarcastic sound of the wind instruments, but the brooding sounds of intense romanticism, the other side of Osterc's style. This movement between the romantic and the neo-classical is

7 The most important works are: Tri skladbe za četrttonski klavir, ca 1927, Štiri Heinejeve pesmi za višji glas in godalni kvartet $v$ četrttonskem sestavu, 1931 and Cvetoči bezeg, cantata 1936. A discussion of the importance and the extent of the influence of Hába on Osterc is discussed by Leon Stefanija in "Osterc in Hába," Muzikološki zbornik 31 (1995): 33-41. See also the paper by Jernej Weiss, "Alois Hába and Slovene students of composition at the State Conservatory in Prague," included in this volume. 
very much a part of his compositional activity of this period, ${ }^{8}$ which included the creation of no less than five operas. Admittedly four were only brief works, miniature dramas cast in a single act: his short operas Iz komične opere ('From the Opéra comique') of 1927 and the parody Saloma ('Salome') of 1929-30 caused great interest,' as did his Medea and Dandin v vicah ('Dandin in Purgatory'), both of 1930. Dandin v vicah is described as 'operna groteska', while Saloma is called 'minutna opera-parodija'. The latter in fact lasts a mere 11 minutes. ${ }^{10}$ It uses many of the features of the instrumental music to dramatic effect. Particularly notable is the wry and sardonic tone of the instrumental writing which supports the parodistic character of the story. Unlike in the traditional story of Salome, Herod is bored with Salome's dancing and calls for her to stop. Strauss's famous Dance of the Seven Veils is replaced, almost in cabaret fashion, by a rather tired waltz.

Moving on to consider the major opera of this period, Krog s kredo ('The Chalk Circle'), composed in the years 1928-29, one can imagine that Osterc was taking a somewhat cynical view of the subject and using all his musical resources to reinforce this idea in a full-length opera of imposing character. It showed a remarkable assurance in handling the operatic medium, but, like the instrumental works of the same period, also gave a clear indication of the techniques of some of the works to follow in the next decade.

The Chalk Circle play ${ }^{11}$ was originally Chinese, a story of rampant corruption, involving a magic method of deciding the truth between two disputants, something akin to the Judgement of Solomon as related in the Bible. ${ }^{12}$ In the early 1920s, the German poet and dramatist Klabund (the nom de plume of Alfred Henschke) rewrote a French translation of the play as

8 This dichotomy was explored in some detail by Ivan Klemenčič, "Slavko Osterc Composing Between Neoclassicism and Expressionism,” in: Primož Kuret, ed., Glasba med obema vojnama in Slavko Osterc (Ljubljana: Festival Ljubljana, 1995), 49-63 [Full English text with Slovene summary] and "Slavko Osterc med neoklasicizmom in ekspresionizmom," Muzikološki zbornik 31 (1995): 11-23 [in Slovene with English summary].

Jože Sivec, Dvesto let slovenske opere - Two Hundred Years of the Slovene Opera (1780-1980) (Ljubljana: Opera in Balet, 1981), 37-38, 91; Peter Andraschke, "Minutna opera 'Saloma' Slavka Osterca - Die Minutenoper 'Salome' von Slavko Osterc," in: Primož Kuret, ed., Slovenska glasba v preteklosti in sedanjosti - Slowenische Musik in vergangenheit und Gegenwart (Ljubljana: Kres, 1992), 204-15.

10 This length is an estimate derived from playing the score. Andraschke, op.cit. also gives this length, but the DSS catalogue surprisingly gives the duration as 20 minutes.

11 Hui-lan-chi or History of the Circle of Chalk, translated by Stanislas Julien as Le Cercle de Craie (London: John Murray, 1832). 
Der Kreidekreis with new characters and additional dramatic features, and published it in Berlin in $1925 .{ }^{13}$ Klabund's play soon became very popular all over Central Europe, with two operatic settings appearing in quick succession, the first by Osterc in a Slovene translation and the second by Alexander Zemlinsky completed in 1931 (Der Kreidekreis). ${ }^{14}$ Brecht later modified the story for his play The Caucasian Chalk Circle."

Osterc's opera presents a wide-ranging synthesis of his then current stylistic traits. Some notable features can be listed:

1. It is through composed, superficially abandoning the traditional separation of individual 'numbers'.

2. There are passages, however, in which traditional set-pieces such as arias, recitatives and choruses can be recognised, a feature that gives Osterc a foothold in the past. He composed transitions from one section to the next which maintained dramatic continuity, but which allowed him to set his words effectively.

3. The words of the strophic parts of the libretto are set almost as arias with uncomplicated melodies and flexible rhythms.

4. The prose parts of the text are set to flexible recitative-like vocal lines.

5. Orchestral counterpoints support and blend with the freely sung vocal parts without detracting from their interest and without disguising the words.

6. Recurrent musical motifs appear, some associated with the evil characters, as well as some related to the chalk circle itself, an effective dramatic device that was well known in many previous operas. There is no comprehensive system of Leitmotifs of a Wagnerian type.

7. The harmonies that Osterc used often contradict the possible tonal-harmonic implications of many of the vocal lines. There is a

13 Klabund [Alfred Henschke]: Der Kreidekreis (Berlin: J.M. Spaeth, 1925); Klabund: The Circle of Chalk, translated by James Laver (London: William Heinemann, 1929).

14 See Alfred Clayton, "Zemlinsky, Alexander," The New Grove Dictionary of Opera (London: Macmillan, 1992), vol.4, 1225-26 and "Kreidekreis, Der," Ibid., vol.2, 1043.

15 This was published as Der kaukasische Kreidekreis (Berlin: Suhrkamp Verlag, 1955) and in its English version by James and Tanya Stern with W. H. Auden as The Caucasian Chalk Circle (London: Methuen, 1960; revised version, London: Eyre Methuen, 1976). The latter replaced Eric Bentley's English version used in the first American production. 
feeling in the sound that Osterc wanted to write a romantic opera and produced the appropriate melodic lines, but at the same time concealed this impression by using harmonies that made the opera a much more 'modern' work.

8. The kaleidoscopic orchestration is allowed to transform itself from one section to the next with seamless transitions of the type which are found later in the Mouvement symphonique of 1936.

9. There are numerous unorthodox instrumental juxtapositions.

10. The scoring of the work makes full use of wind instruments in a most imaginative and unusual way, both in the contrapuntal webs that are spun around the vocal lines and in the bold homophonic instrumental interludes, which reveal harsh added-note harmonies.

The Chalk Circle was never performed in the composer's lifetime and the score was very nearly destroyed in a bombing raid. After the composer's death in 1941, the manuscript disappeared and for many years the score was considered lost. ${ }^{16}$ It re-emerged in the early 1990 s in time for performing material to be prepared at last for a production. The set of orchestral parts is preserved in the archives of Slovene National Opera in the Ljubljana Opera House, ${ }^{17}$ while the score is kept in the National and University Library in Ljubljana. Eventually it was first performed in 1995, the centenary of the composer's birth and some 60 years after his death, in Maribor, not far from the composer's birthplace in Veržej..$^{18}$ Its stature and importance have now been revealed.

\section{New Forms 1930-41}

It can now be seen that the groundwork of Osterc's modernism was fully established by 1930. We do not find him using fully atonal or 12-note tech-

16 In 1969, it was listed as "lost" by Danilo Pokorn, "Bibliografski pregled kompozicij Slavka Osterca," Muzikološki zbornik 6 (1969): 76. Apparently after the composer's death the score was passed by the composer's widow to Demetrij Žebrè and later to Uroš Lajovic before being used for producing the material for the Maribor production of 1995.

17 My thanks to Andrej Rijavec for help in tracing the orchestral parts in the Ljubljana Opera House archives in April 1994 and for recovering a copy of the full score for study purposes.

18 By the Slovene National Opera conducted by Simon Robinson in Maribor Opera House on 7 April 1995. The composer was born in Veržej in the Ljutomer region of Slovenia on 17 June, 1895. For more details of the opera see Niall O'Loughlin, "The Chalk Circle Operas of Osterc and Zemlinsky: a comparative Analysis," in: Primož Kuret, ed., Glasba med obema vojnama in Slavko Osterc - Musik zwischen beiden Weltkriegen und Slavko Osterc (Ljubljana: Festival Ljubljana, 1996), 64-76. 
niques ${ }^{19}$ nor do we find that his melodic, harmonic or contrapuntal techniques were as advanced as those of Schönberg, Berg or Webern. What we do discover that is new is a far-reaching development of formal construction, which can be seen in many of his works of the period. Even the light-hearted chamber works for wind instruments, the Kvintet za pihala ('Wind Quintet') and the Trio for flute, clarinet and bassoon, which are divided into a number of separate movements, show a fascinating involvement in methods of manipulating form by combining or juxtaposing tempos. The String Quartet No.2 ${ }^{20}$ and the Nonet, both cast in two movements, display to a remarkable extent a brilliant juggling of different tempos as a means of creating dramatic contrasts and tensions. Two of the major Sonatas for solo instrument and piano from this period, those for saxophone and for cello, are good examples of how Osterc created transitions between the sections in a seamless way. The former does this over two multi-tempo movements, while the latter, nominally in five separate movements, is played attacca, without a break and with expertly composed transitions and links between the movements. In orchestral works such as the Passacaglia in koral of 1934, the Mouvement symphonique of 1936 and the symphonic poem Mati of 1940 brief neoclassical miniatures are gone and in their place are developmental, monolithic structures that have their roots in the Koncert za violino in 7 instrumentov and the opera Krog s kredo. This breaking down of the traditional structures is an important aspect of Osterc's legacy to Slovene music.

\section{SIMC/ISCM}

Osterc's involvement with the ISCM (SIMC) was in the first place concerned with getting his music performed abroad among sympathetic audiences. This worked well for him with the performances of Štiri Gradnikove pesmi in Florence in 1932, the Concerto for piano and wind in 1935 in Prague, the Mouvement symphonique in London in 1938 and the Passacaglia in koral in Warsaw in 1939. Inevitably he was additionally drawn into correspondence, almost exclusively from 1930, with numerous musicians many of whose let-

19 Andrej Rijavec, "K vprašanju tonalnosti in verticale v skladbah Slavka Osterca," Muzikološki zbornik 6 (1970): 53

20 A full discussion of the extent of Osterc's 'avant-gardism' in this work is discussed by Marija Bergamo in “Osterčeva 'avantgardnost' v luči Drugega godalnega kvarteta (1934),” Muzikološki zbornik 31 (1995): 63-69. 
ters received by Osterc have been preserved. ${ }^{21}$ These give a fascinating picture of Osterc's activities, not only in promoting his own music, but also in the way that he encouraged the adoption of modernism in one form or another in new music. The list of composers with whom he corresponded was extensive. From outside Yugoslavia there were Luigi Dallapiccola, Karl Amadeus Hartmann, Arthur Honegger, Alois Hába, and Karel Boleslav Jirák. Within Yugoslavia but outside Slovenia, Osterc received letters from the composers Krešimir Baranović, Petar Bingulac, Dragutin Čolić, Jakov Gotovac, Fran Lhotka, Ljubica Marić, Miloje Milojević, ${ }^{22}$ Krsto Odak, Boris Papandopulo, Milan Ristić, Josip Slavenski, ${ }^{23}$ and Vojislav Vučković. Within Slovenia itself he corresponded with Marjan Kozina, Gojmir Krek, Bogo Leskovic, Marjan Lipovšek, Karol Pahor, Risto Savin, Pavel Šivic, Lucijan Marija Škerjanc, Franc Šturm, Danilo Švara and Demetrij Žebre. There are many more performing musicians, conductors especially, and some musicologists with whom he had significant contact. In all these letters it is clear that Osterc was fully conversant with new developments all over Europe and was very keen to encourage them wherever he could, but especially in his native Slovenia. The dedicatees of his works also give an indication of his contacts; the important ones are Prokofiev for the ballet Illusions (1937-41), Hába for the Concerto for piano and wind instruments of 1933, Hermann Scherchen for Plesi ('Dances') for orchestra of 1935, Karel Boleslav Jirák for Mouvement symphonique of 1936 and Arthur Honegger for the Nonet of 1937.

\section{Conclusion}

Finally, while Osterc did encounter opposition to his music from some quarters, he did not become estranged from the Slovene musical centre ground. He made many musical friends in Slovenia, in the rest of what was then Yugoslavia, as well as abroad to help his cause and was able to influence a number of his pupils to adopt an adventurous line of composition.

21 See the definitive collection of the most important letters in Dragotin Cvetko: Fragment glasbene moderne iz pisem Slavku Ostercu - A Fragment of Musical Modernism from Letters to Slavko Osterc (Ljubljana: Slovenska akademija znanosti in umetnosti, 1988).

22 The correspondence is fully documented by Dragotin Cvetko, "Kontakti Slavka Osterca z Milojem Milojevićem," Muzikološki zbornik 22 (1986): 39-52 and "Kontakti Slavka Osterca z Milojem Milojevićem," in Miloje Milojević kompozitor i muzikolog (Belgrade: Udruženje kompozitora Srbije, 1986), 173-203.

23 See Dragotin Cvetko's article "Veze Josipa Slavenskog sa Slavkom Ostercom," Arti Musices 3 (1972): 63-76. 
More recently, however, the perspective on his work has changed: Osterc's music today is not considered advanced according to Western European criteria, even if much of his music is still relatively little known. His music explored new formal workings and a harmonic idiom that verged on atonality and twelve-note working rather than strict serial technique. It is now understood and appreciated on its own terms, that is, without too much reference to the ideas of modernism. In all ways, however, Slovene music developed enormously under his influence.

\section{Bibliography}

Anon.. Hui-lan-chi or History of the Circle of Chalk. Translated into French by Stanislas Julien as Le Cercle de Craie. London: John Murray, 1832.

The Old Testament of the Bible, I Kings, 3, verses 16-28.

Andraschke, Peter. "Minutna opera 'Saloma' Slavka Osterca - Die Minutenoper 'Salome' von Slavko Osterc.” Kuret, Primož, ed.. Slovenska glasba $v$ preteklosti in sedanjosti - Slowenische Musik in vergangenheit und Gegenwart. Ljubljana: Kres, 1992, 204-15.

Bergamo, Marija. “Osterčeva 'avantgardnost' v luči Drugega godalnega kvarteta (1934).” Muzikološki zbornik 31 (1995): 63-69.

Brecht, Bertolt. Der kaukasische Kreidekreis. Berlin: Suhrkamp Verlag, 1955.

Brecht, Bertolt. (translated James and Tanya Stern with W.H. Auden). The Caucasian Chalk Circle. London: Methuen, 1960; revised, London: Eyre Methuen, 1976.

Clayton, Alfred. "Zemlinsky, Alexander.” The New Grove Dictionary of Opera. London: Macmillan, 1992, vol. 4, 1225-26.

Clayton, Alfred. "Kreidekreis, Der." The New Grove Dictionary of Opera. London: Macmillan, 1992, vol. 2, 1043.

Cvetko, Dragotin. Fragment glasbene moderne iz pisem Slavku Ostercu - A Fragment of Musical Modernism from Letters to Slavko Osterc. Ljubljana: Slovenska akademija znanosti in umetnosti, 1988.

Cvetko, Dragotin. “Kontakti Slavka Osterca z Milojem Milojevićem.” Muzikološki zbornik 22 (1986): 39-52.

Cvetko, Dragotin. “Kontakti Slavka Osterca z Milojem Milojevićem.” In Miloje Milojević kompozitor i muzikolog. Belgrade: Udruženje kompozitora Srbije, 1986, 173-203.

Cvetko, Dragotin. "Veze Josipa Slavenskog sa Slavkom Ostercom.” Arti Musices 3 (1972): 63-76. 
Klabund [Alfred Henschke]. Der Kreidekreis. Berlin: J. M. Spaeth, 1925.

Klabund (translated James Laver). The Circle of Chalk. London: William Heinemann, 1929.

Klemenčič, Ivan. "Slavko Osterc Composing Between Neoclassicism and Expressionism.” In: Kuret, Primož, ed.. Glasba med obema vojnama in Slavko Osterc. Ljubljana: Festival Ljubljana, 1995, 49-63 [Full English text with Slovene summary].

Klemenčič, Ivan. "Slavko Osterc med neoklasicizmom in ekspresionizmom." Muzikološki zbornik 31 (1995): 11-23 [in Slovene with English summary].

Krstulović, Zoran. “Kompozijski stavek Simfonije v C-duru ('Ideali') Slavka Osterca.” Muzikološki zbornik 31 (1995): 53-62.

O’Loughlin, Niall. “The Chalk Circle Operas of Osterc and Zemlinsky: a comparative Analysis." In: Kuret, Primož, ed.. Glasba med obema vojnama in Slavko Osterc - Musik zwischen beiden Weltkriegen und Slavko Osterc. Ljubljana: Festival Ljubljana, 1996, 64-76.

Pokorn, Danilo. "Bibliografski pregled kompozicij Slavka Osterca." Muzikološki zbornik 6 (1969): 76.

Rijavec, Andrej. "Komorno kompozicijsko snovanje Slavka Osterca pred njegovim odhodom v Prago.” Muzikološki zbornik 5 (1969): 92-10o.

Rijavec, Andrej. “K vprašanju tonalnosti in verticale v skladbah Slavka Osterca.” Muzikološki zbornik 6 (1970): 53.

Sivec, Jože. Dvesto let slovenske opere - Two Hundred Years of the Slovene Opera (1780-1980). Ljubljana: Opera in Balet, 1981, 37-38, 91.

Stefanija, Leon. “Osterc in Hába.” Muzikološki zbornik 31 (1995): 33-41. 



\title{
Slavko Osterc in Lucijan Marija Škerjanc: estetski razkol in poetsko bratstvo
}

\author{
Gregor Pompe \\ Univerza v Ljubljani \\ University of Ljubljana
}

Lucijana Marijo Škerjanca in Slavka Osterca pogosto razumemo kot antagonistični dvojec, ki naj bi v temelju zaznamoval slovensko glasbo najprej med obema vojnama, razlike med obema "šolama« - oba sta bila tudi pomembna učitelja oz. profesorja kompozicije - pa naj bi odmevale še v sodobnem času. Tako že Marijan Lipovšek izpostavlja Škerjanca kot "protipol« Ostercu, češ da sta si oba skladatelja »nasprotna do zadnjega kotička«, Dragotin Cvetko govori o tem, da je bila med Ostercem in Škerjancem »vidna napetost, gotovo zavoljo različnih umetnostnih nazorov «, ${ }^{2}$ Darja Koter trdi, da sta bila »Škerjanc kot tradicionalist in Osterc kot avantgardist [...] večna rivala ${ }^{3}$, o nasprotujočih osebnostnih in estetikah ter celo dveh »kompozicijskih šolah" pa govori tudi Katarina Bogunović Hočevar. ${ }^{4}$

Osrednje razlike je najlažje razkriti na estetski ravni, pri čemer je poenostavljeno rečeno Škerjanca moč razumeti kot tradicionalista ${ }^{5}$ in Osterca kot doslednega zagovornika novega. Svojo tradicionalistični držo Škerjanc izpostavlja zelo jasno, ko trdi, da »doslej ni bil izrabljen niti odstotek vseh

1 Marijan Lipovšek, »Naša glasbena produkcija«, Ljubljanski zvon 55, 10-11 (1935): 577.

2 Dragotin Cvetko, Osebnost skladatelja Slavka Osterca (Ljubljana: Cankarjeva založba, 1993), 117.

3 Darja Koter, Slovenska glasba. 1918-1991 (Ljubljana: Študentska založba, 2012), 143.

4 Katarina Bogunović Hočevar, »Ravnikovi glasbenoestetski nazori v kontekstu dveh kompozicijskih šol«, De musica disserenda 6, 2 (2010), 87.

5 Prim.: Monika Kartin, Simfonije Lucijana Marije Škerjanca, magistrsko delo (Ljubljana: Filozofska fakulteta, 1982), 125. 
možnih zvočnih kombinacij [in zato] ni nobene potrebe po novih tonskih sistemih «. ${ }^{6}$ Seveda pa je mogoče iti v razpiranju razlik še globlje, pri čemer je Škerjančeva tradicionalnost jasno povezana $\mathrm{z}$ njegovim osrednjim prepričanjem o subjektivnosti umetniškega ustvarjanja, ki je pripeto na močno čustvovanje in instinkt tako avtorja kot sprejemnikov. Tako je prepričan, da je "glasba individualno in množično prilagodljiva ter pripravna za ponazarjanje najrazličnejših odtenkov čustev «, ${ }^{7}$ hkrati pa je prepričljivost umetnine »funkcija notranjega zanosa, ki je preveval umetnika-ustvaritelja ob delu in čigar odsev je - bolj ali manj popolno - znal položiti v umetnino samo«. ${ }^{8}$ Umetnina nosi vse značilnosti ustvarjalnega subjekta, zato tudi sama ni objekt, ampak v resnici umetniški subjekt: ${ }^{9}$ „Edino v umetnosti možno in upravičeno geslo je iskrenost. ॥ $^{10}$ Seveda so takšnim prepričanjem Osterčevi pogledi skoraj diametralno nasprotni. V tem smislu je mogoče razumeti že njegovo nedvoumno priznanje: "Fanatično odklanjam tradicijo. «" Odmika se od romantičnega poudarjanja moči subjekta in s tem iracionalnega ter poudarja pomen racionalnega. Prepričan je, da ima »vsaka umetniška tvorba svoje intelektualno ozadje «, ${ }^{\text {I2 }}$ zato "zahtevamo intelekt pri komponistih! « ${ }^{13}$ Tako ne preseneča, da je »dostikrat namerno prezrl emocijo ${ }^{\mathrm{I} 4}$ in bil nasploh nasprotnik sentimentalizma in romantike. ${ }^{\mathrm{IS}}$

Takšne razlike v osnovni estetski drži so nato logično odmevale tudi v zasnovi glasbenega stavka, ki je pri Škerjancu slonel na tradicionalnih izhodiščih, medtem ko je Osterc zaupal raznolikim sodobnim vzpodbudam. $\mathrm{Ni}$ čudno, da je bil kot dedič 19. stoletja in moderne, Škerjanc »izrazit akordik«. ${ }^{16}$ Harmonija je zanj »konstruktivna in oblikovalna sila, brez katere bi

6 Lucijan Marija Škerjanc, »Vrednotenja«, Sodobnost 9, 2 (1933): 57.

7 Lucijan Marija Škerjanc, »Apologia musicae artis«, Sodobnost 1 (1953): 172.

8 Prav tam, 178.

9 Lucijan Marija Škerjanc, »Moji umetnostni nazori«, Sodobnost 8, 5 (1940): 204.

10 Škerjanc, »Vrednotenja«, 58.

11 Slavko Osterc cit. po Katarina Bedina, »Nazori Slavka Osterca o tradiciji v glasbi in o glasbenem nacionalizmu«, Muzikološki zbornik 3 (1967): 90.

12 Slavko Osterc, »Čustvo in razum v glasbi«, Žena 6, 4 (1935): 95.

13 Slavko Osterc, »Muzika u zemlji«, Zvuk 2, 3 (1933): 104.

14 Cvetko, Osebnost skladatelja Slavka Osterca, 185.

15 Bratko Kreft, »Spomini na Slavka Osterca in še marsikaj«, v Varia musicologica 2. Slavko Osterc, ur. Katarina Bedina (Ljubljana: Slovensko muzikološko društvo, 1995), 256.

16 Monika Kartin, »Peta simfonija Lucijana Marije Škerjanca«, Muzikološki zbornik 19 (1983): 67 . 
ostale višje formalne težnje neizpolnljive «, ${ }^{17}$ obenem pa je prepričan, da je polifonija, torej

»kombinacija več sočasnih melodij [...] bolj spekulativna tvorba kot pa neposreden izraz ustvarjalne potrebe. Dejansko ni mogoče enakovredno in enako pozorno dojemati več sočasno odvijajočih se melodij in vselej dajemo prednost eni pred drugo. ${ }^{18}$

Povsem drugačne poudarke je vnesel v svojo hierarhijo glasbenih parametrov Osterc, ki je prostodušno priznal, da

"je harmonija precej postranska zadeva, prepričan sem celo, da harmonično mnogo novega ne bo produciral ne ta ne oni. Tudi sem mnenja, da je harmonija najmanj bistven del invencije ter jo prištevam $k$ tisti neizogibni tehniki, brez katere ne more nastati nobeno mojstrsko delo. ${ }^{19}$

Osterčevo kompozicijsko snovanje sloni na linearnemu vodenju glasov, pri čemer »horizontalna misel [...] predstavlja enega od bistvenih elementov skladateljevega glasbenega mišljenja«. ${ }^{20}$ Toda Osterc sam je hierarhijo parametrov razumel še drugače:

»Vedno sem pri glasbi ritmu dajal prednost pred harmonijo in polifonijo. [...] V ritmu vidim največji kos originalnosti, [...] življenje, radost, komiko. ${ }^{21}$

To misel je najbrž potrebno brati tudi v kontekstu Škerjančevih sicer redkih, a odločnih kritik novih struj, ki jih je v slovensko glasbo vpeljeval Osterc - tako naj bi po pričevanju Lipovška v eni izmed njih zapisal, da »je ta muzika [...] prišla do edine ostale prvine, do ritma, se pravi, do bobna in bo tudi prišla na boben «, ${ }^{22}$ a vendarle si težje predstavljamo večjo razpetost, kot je veljala med skladateljema $\mathrm{v}$ dojemanju pomembnosti prvin glasbenega stavka. Zato najbrž niso odveč misli, da sta se morala sklada-

17 Škerjanc, »Apologia musicae artis«, 543.

18 Prav tam, 432.

19 Slavko Osterc, "Glavne struje sodobne glasbe in njih eksistenčna upravičenost«, Nova muzika 1 (1928): 3.

20 Andrej Rijavec, Kompozicijski stavek komornih instrumentalnih del Slavka Osterca (Ljubljana: Slovenska akademija znanosti in umetnosti,1972), 8.

21 Slavko Osterc cit. po Katarina Bedina, „Novo v mladinskih zborih Slavka Osterca«, $M u$ zikološki zbornik 11 (1975): 98.

22 Cit. po Bogunović Hočevar, »Ravnikovi glasbenoestetski nazori v kontekstu dveh kompozicijskih šol«, 89 . 
telja močno razlikovati tudi $\mathrm{v}$ osebnostnem pogledu in ne le $\mathrm{v}$ estetskih prepričanjih, kar nenazadnje potrjuje tudi njuna svetovnonazorska orientacija. Medtem ko je bil Osterc »izrazito v levo usmerjen intelektuale ${ }^{23}{ }^{23}$ in se je leta 1940 znašel med ustanovitelji Društva prijateljev Sovjetske zveze, ${ }^{24}$ pa Škerjanc ni imel tako jasno izdelanih politično-nazorskih stališč, a se je znal predvsem zelo dobro prilagoditi vsem spremembam oblasti, tako stari jugoslovanski s kantato Ujedinjenje, po nekaterih navedbah tudi italijanski fašistični med okupacijo ter v povojnih časih, ${ }^{25}$ ko ga je rešilo predvsem visoko mnenje, ki ga je imel o njegovi glasbi glavni kulturni usmerjevalec Josip Vidmar.

Škerjanc je tako predvsem po drugi svetovni vojni postal pomemben »igralec« na slovenski glasbeni sceni, kar priča njegova dolgoletna profesura na Akademiji za glasbo, članstvo v Akademiji znanosti in umetnosti ter upravništvo Slovenske filharmonije. Številne generacije skladateljev so šle skozi njegovo kompozicijsko šolo in čeprav ni bil posebej predan univerzitetni učitelj, ${ }^{26}$ je s svojo estetsko mislijo vendarle zaznamoval številne skladatelje, medtem ko je bil pred vojno kot učitelj na konservatoriju in srednji šoli Glasbene akademije pomemben tudi Osterc, ki si je s svojo jasno mislijo in prepričljivostjo kmalu priboril četo soborcev in sledilcev v novo glas$b o$, toda pomembneje je, da si je prek članstva v Mednarodnem združenju za sodobno glasbo izboril tudi pomembno mesto na mednarodni skladateljski sceni, kar ni mogoče trditi o Škerjancu.

Toda kljub vsem tem očitnim razlikam sta si bila Škerjanc in Osterc na poetološki ravni vendarle bistveno bolj podobna, kot bi si lahko mislili. Njuna osnovna prepričanja so bila res močno vsaksebi, toda ko sta se do njih dokopala, zanimivo oba okoli leta 1927 (Osterc se takrat vrne s svojih študijev v Pragi, Škerjanc pa doživi svojo najbolj radikalno sodobno fazo, po kateri se »vrne« v bolj utečene tire tradicionalnega izraza), sta trdno vztrajala v svojih kompozicijskih izhodiščih, ki sta jih mestoma celo šablonizirala v lahko prepoznavne vzorce, ki so omogočali precej bogato produkcijo, kakršne slovenska glasba, če izvzamemo nekoliko starejšega Emila Adamiča, praktično ni poznala - Škerjanc je v vojnem času napisal štiri od svojih petih simfonij $(1931,1940,1942,1943,1944)$, pet godalnih kvarte-

23 Danilo Pokorn, "Slavko Osterc. Prispevek za biografijo«, Muzikološki zbornik 5 (1969): 91.

24 Prav tam.

25 Ivan Klemenčič, Slovenski skladatelji akademiki (Ljubljana: Slovenska akademija znanosti in umetnosti, 2003), 47.

26 Jurij Snoj, Portret skladatelja Janeza Matičiča (Ljubljana: Slovenska matica, 2012), 91. 
tov, nato pa poleg dveh širokopoteznih kantat (Ujedinjenje, 1936, Sonetni ve$n e c, 1949)$ ob razvejanem komornem in klavirskem opusu še celo vrsto koncertov - dva za violino $(1927,1944)$ in po enega za klavir (1940), violončelo (1947), harfo (1954), fagot (1956), klarinet (1958), violo (1959) in flavto (1962) -, medtem ko je Osterc snoval operni opus (Iz komične opere, 1928, Krog s kredo, 1929, Saloma, 1929, Dandin v vicah, 1930, Medea, 1930), številna komorna dela (sonate za violo in klavir, saksofon in klavir, violončelo in klavir), suite in klavirske kompozicije. Škerjanc je plodovitost celo posebej izpostavil kot kvaliteto izstopajočih skladateljev, ki jih ne odlikuje

"samo kakovost del, temveč tudi izredna plodnost, ki jim ni dovoljevala daljših odmorov. [...] To edino jim je tudi omogočilo, da so se povzpeli iznad sorojakov«, ${ }^{27}$

delavnost in hitro ustvarjanje pa je izpostavljal tudi Osterc, ki se na posameznostih »ni zaustavljal, ne brusil zapisanih idej $\aleph^{28}$ in je celo zapovedoval: "Delajmo in študirajmo brez počitka, da nas čas ne prehiti! «" ${ }^{29}$

Tudi njun kompozicijski »jezik« ni povsem osebno izviren, temveč vedno nabran in povzet po vabečih in izstopajočih tujih zgledih, hkrati pa v svoji izpopolnitvi tudi ni estetsko radikaliziran. Tako je Škerjanc kot osemnajstletnik stopil s koncertom svojih samospevov na slovensko glasbeno sceno kot tipični predstavnik moderne, razpete med izrazno estetiko 19. stoletja in kromatične harmonske premike 2o. stoletja, ki jih je nato pobarval še z impresionističnimi barvnimi izmiki. To je ostala osnova njegovega kompozicijskega jezika tudi v tridesetih letih, torej ko je končal vsa svoja šolanja v tujini in ko se je estetsko ustalil po krajši epizodi bolj eksperimentalno-ekspresionističnih poizkusov, ki jih lahko razberemo iz skladb nastalih v letih 1926 in 1927. Toda Škerjanc vendarle ni enostransko zavrnil sodobnih tokov, ki se jim je povsem približal s svojim enostavčnim Koncertom $z a$ violino in orkester (1927), temveč je premišljeno sprejemal nove vplive ter se $s$ tem nekako skušal postavljati ob bok Ostercu, ki se je prav v tem času vrnil iz študija v Pragi. Tako ne moremo spregledati, da je v mnoga dela iz tridesetih let Škerjanc prevzel neoklasicistične in neobaročne elemente: Preludij, arija in finale za godala (1933) prinaša neobaročno monotematsko motoričnost in kontrapunktično razpredanje, ki spominja na Hindemit-

27 Lucijan Marija Škerjanc, »Nezanimivost slovenske glasbe«, Sodobnost 8, 9 (1940): 398.

28 Katarina Bedina, »O glasbeni poetiki in prozi Slavka Osterca«, Muzikološki zbornik 25 (1989): 12. 
ha, medtem ko je Suita $v$ starem slogu (1934) zasnovana kot nekakšen concerto grosso, v katerem je mogoče godalni kvartet razumeti kot concertino, ki agira proti celotni godalni skupini kot ripieno, obsežni sonati za violončelo (1935) in violo (1936) pa bi zaradi nizanja baročnih form lahko razumeli kot posvetilo Bachovim partitam. Lahko bi celo trdili, da je $\mathrm{z}$ vsakim letom in $\mathrm{z}$ vsakim novim slogovnim impulzom Škerjančev opus postajal bolj eklektičen, kar pomeni, da je vendarle dvomil, da je preizkušal, vendar vedno previdno, tako da se je novih slogov in tehnik lotil šele takrat, ko so se zdele že "udomačene«, preizkušene in takorekoč »klasične«, kar velja tudi za dodekafonijo, s katero se je preizkušal $\mathrm{v}$ poznih petdesetih letih.

Na prvi pogled se zdi, da je bil Osterc mnogo manj "previden« kot Škerjanc in zavezanem vsemu novemu. Res se je iz študija v Pragi vrnil pod vtisom takrat najnovejših struj: neobaroka, neoklasicizma, nove stvarnosti, poznal je tudi ekspresionizem druge dunajske šole. Toda kljub temu, da je bil Osterc strasten in glasen zagovornik atonikalne in atematične glasbe, da se je postavljal zoper programsko glasbo in tonsko slikanje ter opozarjal na preživelost dur-molovega tonskega sistema, ${ }^{30}$ je bil hkrati prepričan, da »tradicija ni ovira pri ustvarjanju novih vrednot, ampak pripomoček «, ${ }^{31}$ zato ne preseneča ugotovitev Andreja Rijavca, da se ni "nikoli popolnoma odpovedal tradicionalnim funkcijskim harmonskim odnosom «. ${ }^{32}$ Tako lahko Osterčevo osnovno vodilo razumemo podobno kot pri Škerjancu v nekakšnem povzemajočem smislu, v njegovem delu je razvidna »svojevrstna zmes takratnih glasbenih poetik « ${ }^{33}$ od Busonija prek Stravinskega in Hindemitha do druge dunajske šole, torej cela pahljača, ki razpira precej raznolike estetske poudarke, Rijavec pa govori celo o »slogovnem trikotniku«, razpetem med neoklasicizem, ekspresionizem in novo stvarnost. ${ }^{34}$ Tako je Osterc postavljal pod vprašaj tradicionalno zvrstno mrežo, predvsem s svojimi uspelimi deli za komorne zasedbe, a je hkrati vendarle ustvaril sonate, godalne kvartete, klavirski trio in pihalni trio, bil je proti programski glasbi, a ustvaril operni opus, se navidez ni zanimal za harmonijo, a je vendarle izhajal iz funkcijskih odnosov, ki jih je največkrat zakril

30 Katarina Bedina, »K vprašanju o kompozicijskih nazorih Slavka Osterca«, Muzikološki zbornik 4 (1968): 114 in 116.

31 Slavko Osterc, »Gledališki pregled. Opera. Matija Bravničar: Pohujšanje v dolini šentflorjanski«, Ljubljanski zvon 50, 6 (1930): 377.

32 Andrej Rijavec, »K vprašanju tonalnosti in vertikale v skladbah Slavka Osterca«, Muzikološki zbornik 6 (1970): 39.

33 Bedina, "O glasbeni poetiki in prozi «, 9 .

34 Andrej Rijavec, "Slavko Osterc - an expressionist?«, Muzikološki zbornik 20 (1984): 53 . 
s harmonsko tujimi toni (priključene sekunde), povsem dosleden pa ni bil tudi v atematskosti. Vse to pomeni, da je podobno kot Škerjanc izbiral in ni bil do konca slepo zvest modnim trendom.

V tem pogledu sta si bila Škerjanc in Osterc podobna, imela sta najbrž tudi skupnega vzornika, Stravinskega, kar kaže predvsem Škerjančev omenjeni prvi Koncert za violino z gosto orkestracijo, ki na mnogih mestih izkazuje prvenstveno vlogo orkestrskih barvnih tekstur, česar se je moral skladatelj naučiti iz partiture Ognjena ptiča, medtem ko je Osterc sam priznal, da ga je »ravno Petruška pripeljal v tabor hipermoderne «. ${ }^{35}$ Navdušenje do Stravinskega pa sta Škerjanc in Osterc delila tudi s starejšo generacijo slovenskih skladatelj, o čemer priča navdušeno poročilo Antona Lajovica iz Festivala slovanske glasbe v Zagrebu, v katerem je izrazito pohvalil Stravinskega, ${ }^{36} \mathrm{kar}$ pomeni, da sta Škerjanc in Osterc ohranjala vez s starejšo generacijo. Seveda pa je šel Osterc tudi korak dlje, ko je izpostavljal kot edinega nekompromisnega skladatelja svojega časa Schönberga, kateremu je ob bok postavil tudi svojega učitelja Hábo, ${ }^{37}$ in se v tem pogledu jasno odlepil od generacij Novih akordov. Toda kljub takšnemu navduševanju nad delom druge dunajske šole, je bil Osterčev odnos do dodekafonije precej soroden Škerjančevemu. Tako Škerjanc v Sedmih dvanajsttonskih fragmentih (1958) in Treh skladbah za violino in klavir (1959) dvanajsttonske vrste uporablja v smislu tematskega gradiva - je nekaj namigov na inverzije in rakove obrate, toda Škerjanc ne prevzema sistema $\mathrm{v}$ celoti in obravnava vrste kot melodije, pri čemer se izogiba gostemu kontrapunktu ali zahtevnejšim izpeljavam. Osterc se je z dodekafonijo spoprijel že prej, sredi tridesetih leti, vendar podobno kot Škerjanc ni sprejel celotne Schönbergove sistematike, temveč le idejo nizanja različnih dvanajsttonskih zaporedij, katerega rezultat je popolna kromatičnost, kot je to razvidno iz skladb Mouvement symphonique (1936), Fantaisie chromatique (1940), Mati (1940) in Six petites morceaux (1940).

Še bolj pomembno kot zgornje stične točke pa je izpostaviti, da sta oba skladatelja nekatere izmed svojih postopkov kmalu šablonizirala, da nista več v temelju premišljala svojih estetskih in kompozicijsko-tehničnih izhodišč, temveč sta se zavezala predvsem širitvi svojih opusov in izpolnjevanja žanrskih »lukenj«, ki so še pestile slovensko glasbo.

35 Slavko Osterc, »Muzika u zemlji. Ljubljana«, Zvuk 3, 6 (1935): 229.

36 Primož Kuret, Umetnik in družba (Ljubljana: Državna založba Slovenije, 1988), 121. Lajovic Stravinskega ni imel zgolj za vodilnega ruskega skladatelja, temveč za najpomembnejšega svetovnega avtorja (prav tam, 168).

37 Ivan Klemenčič, »Slavko Osterc med neoklasicizmom in ekspresionizmom«, Muzikološki zbornik 31 (1995): 13 . 
Eno izmed tipičnih Škerjančevih šablon, skorajda škerjančevski topos bi lahko poimenovali »trepetajoča predstavitev večne melodije«. Skladatelj najprej zariše harmonsko okolje $\mathrm{z}$ značilnimi nerazvezanimi štirizvoki, ki so pogosto orkestracijsko ali inštrumentalno razgibani (tremolo v godalih, razloženi akordi v klavirju), čez njih pa se oglasi dolgo razpeta melodična linija. Takšno teksturo uporabi Škerjanc že v prvem izmed svojih Sedmih nokturnov (1935), ko klavirska figuracija združuje dva štirizvoka, nad takšno harmonsko osnovo pa se napenja blodeča melodična misel, sestavljena iz fragmentarnih vzgibov, zelo podobno pa je zasnovana tudi Lirična bagatela (1941), v kateri je le nekoliko drugače domišljena ritmična podoba trepetajoče akordske spremljave, nad katero se podobno sestavlja dolga melodična misel. Le nekoliko drugačna sta primera iz Četrtega in Petega godalnega kvarteta, kjer akordska spremljava ni značilno »trepetajoča«, pa vendar je nad akorde razpeta daljša melodična misel, ki črpa iz kratkih motivičnih drobcev, ki se združujejo v nekakšno »večno « melodijo - v začetku Četrtega godalnega kvarteta je takšna spremljava še večinoma homofona, iz melodičnega glasu je jasno razvidno motivično delo, medtem ko je $\mathrm{v}$ začetku drugega stavka Petega godalnega kvarteta tekstura bolj polifono razgibana, melodični glas pa je z izjemo sekvenčnega niza zasnovan bolj rapsodično.

Osterčeve šablone so bile bolj jasno povezane s sprejemanjem žanrskih obrazcev - tako v njegovih skladbah pogosto srečamo passacaglie, kanone, atonikalne fuge, korale in koračnice, pri čemer sta bolj zanimiva zadnja, "čista" glasbena žanra, katerih značilnosti niso povezane s kompozicijsko tehniko. Posebej v povezavi s koralom bi lahko govorili o Osterčevem tipu korala, o nekakšnem »koralu sekund«. Skladatelj je prevzel idejo enakomernega počasnega melodičnega gibanja $\mathrm{v}$ majhnih intervalnih korakih iz protestantskega korala, podobno je posneta tudi ideja popolne homofonije, le da je Osterc akorde pogosto močno obložil z dodanimi sekundami, ki zakrivajo funkcijske zveze in dajejo občutek disonantnih trkov. Najbolj »čiste« primere takšnih »koralov sekund « lahko razpoznamo v četrti izmed skladateljevih Bagatel (1933), v zadnji izmed Štirih miniatur (1938) za klavir, Koralu in fugi (1942), $\mathrm{v} »$ Pravljici in resnici o svetovnem miru « iz zbirke Pravliice ter Klavirskemu triu (1939), ki je zasnovan kot niz med seboj povezanih epizod, med katerimi je poslednja zasnovana kot koral. Takšen koralni idiom je Osterc uporabil tudi v simfoničnih delih - tako se že drugi stavek Koncerta za orkester (1932) prične z značilnim koralom, »Toccata« iz Štirih simfoničnih skladb (1939) se zaključuje z odsekom »Maestoso«, v katerem lahko prepoznamo sledi koralne polifonije, zelo podobno zasnovani odseki 

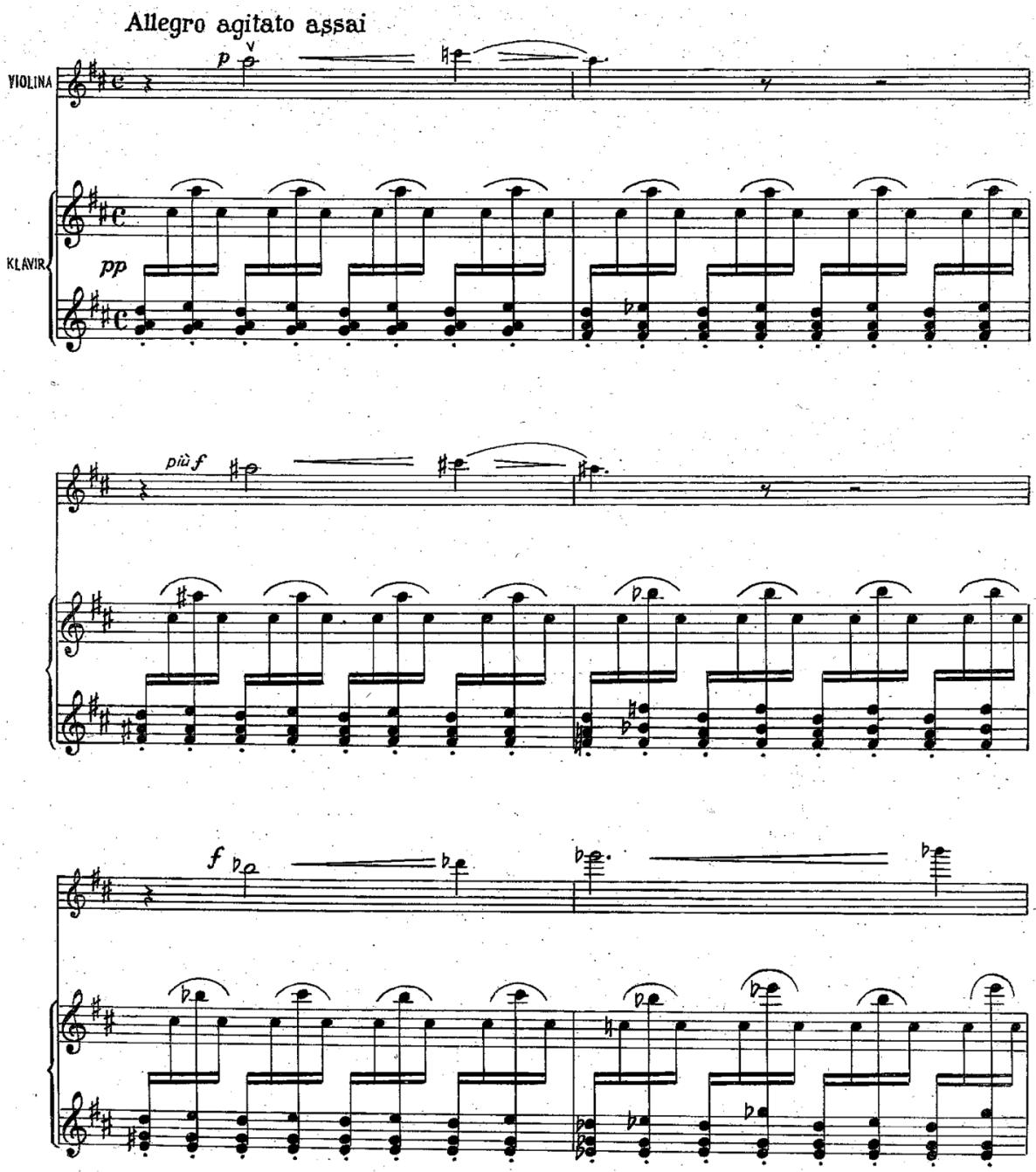

Notni primer I: Začetek Škerjančeve Lirične bagatele. 

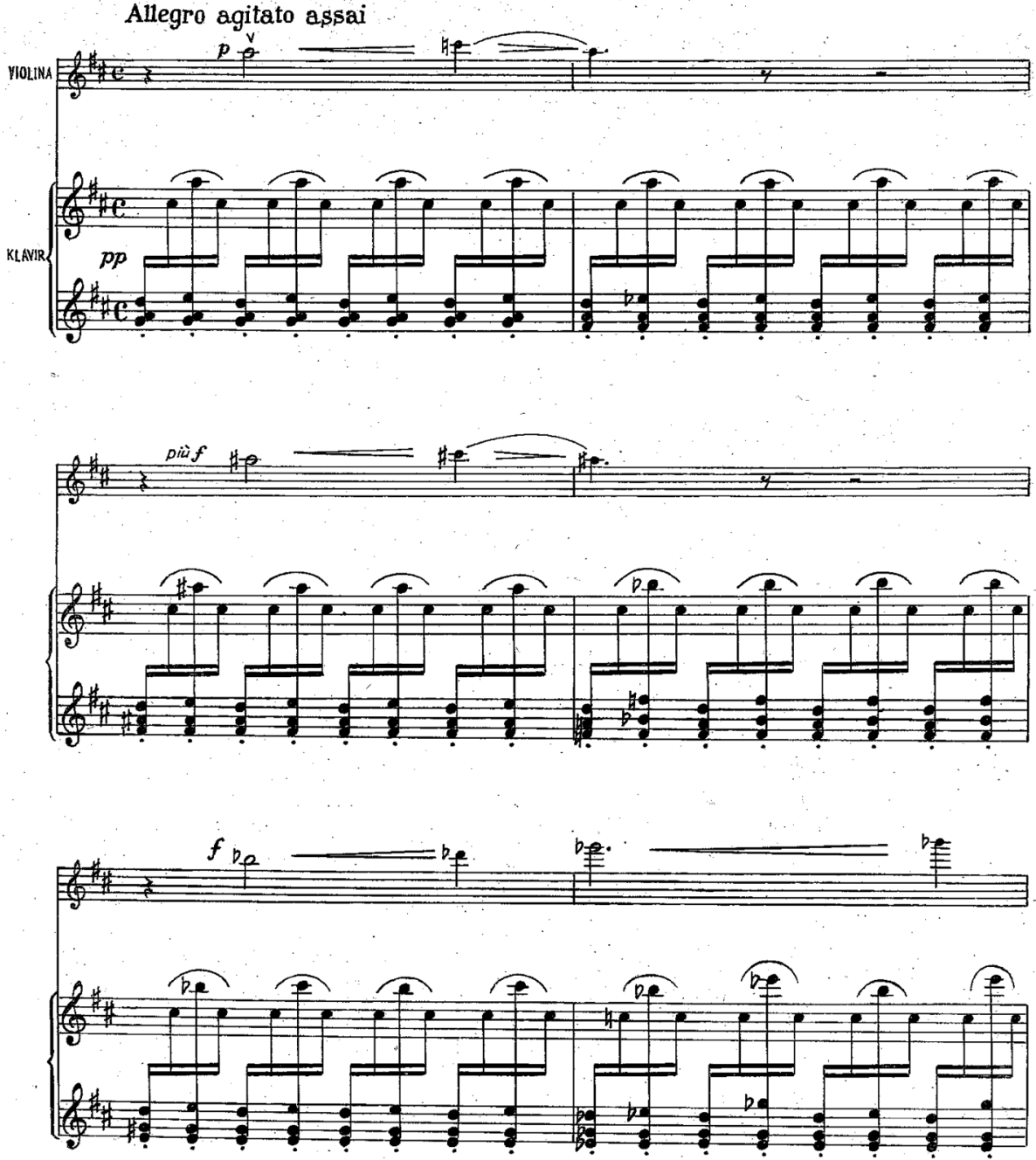

Notni primer 2: Začetek Škerjančeve Lirične bagatele.

pa zaznamujejo tudi odlomek iz prvega in tretjega stavka Koncerta za klavir in pihala (1933).

Osnovno estetsko polarno razmerje med obema skladateljema postaja ob poetoloških sorodnostih zmeraj bolj relativno. Izkaže se, da sta oba skladatelja v svojih estetskih proklamacijah - Osterc se zdi namenoma bojevit in provocira, medtem ko se v svojih zapisih Škerjanc predvsem cinično brani - še radikalna, pa vendar tega njune končne stvaritve ne potrjuje- 
Choral. Lento
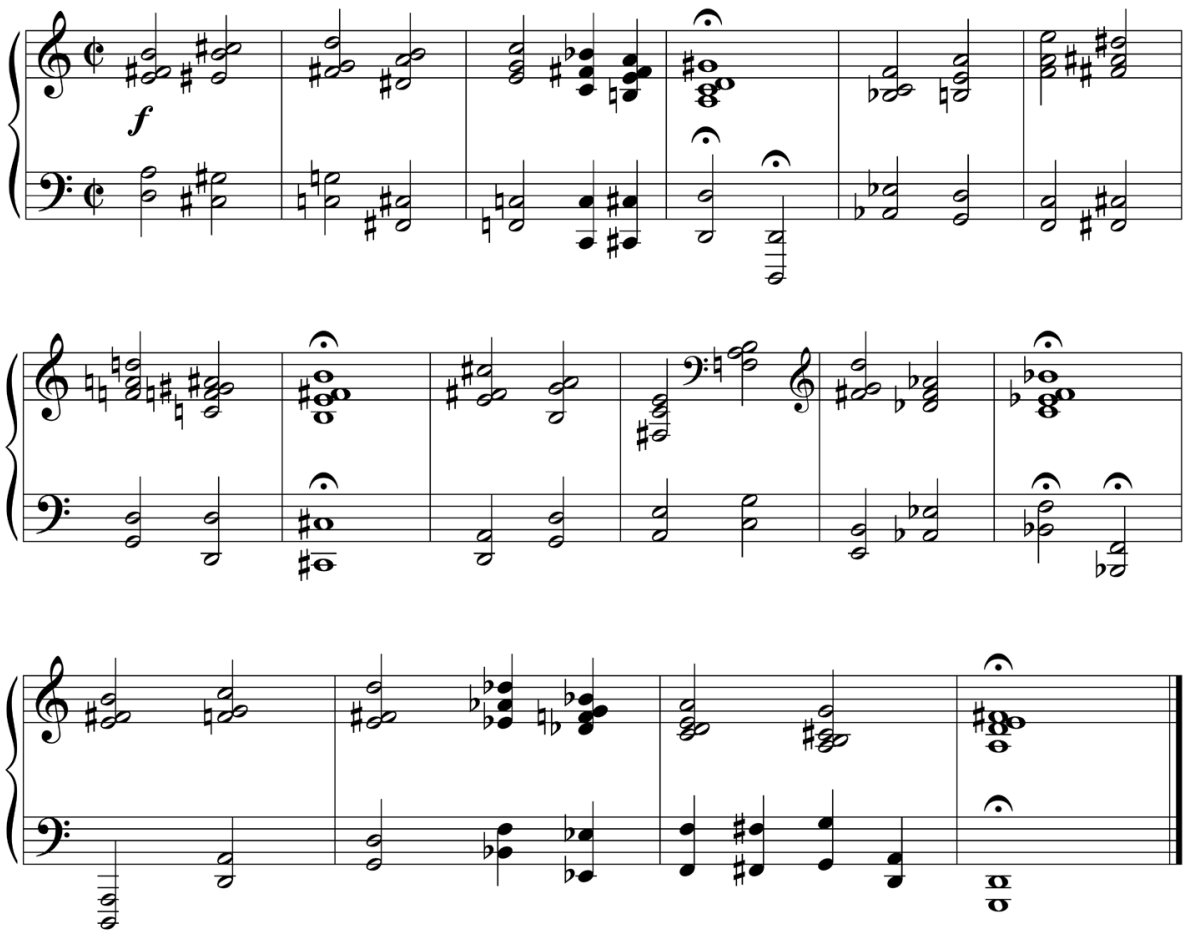

Notni primer 3: Koral iz Osterčevih Štirih miniatur.

jo. Skupaj predstavljata dva pola, morda celo tipa - tradicionalističnega in modernističnega -, toda nobeden ni domišljen povsem dosledno, radikalno in izvirno. Kljub temu pa lahko obema skladateljema pripisujemo odločilno vlogo pri oblikovanju sledečih skladateljskih generacij med obema vojnama, kar kaže predvsem na splošen nivo slovenske glasbe tistega časa, ki je s Škerjancem in Ostercem v prvi vrsti dobila dva tehnično popolnoma verzirana skladatelja. Oba sta svoje okolje, v katerega sta vstopila $\mathrm{z}$ vso močjo konec dvajsetih letih, presegala v obrtniški popolnosti, ki jima je omogočala (pre)hitro ustvarjanje in s tem obsežna opusa, oba sta delovala kot poklicna glasbenika (za generacijo Novih akordov je bilo to še nepredstavljivo) in oba sta se izšolala $v$ tujini, kjer sta prišla $v$ aktivni stik s sodobnimi tokovi, ki pa sta jih prekvasila vsak na svoj način in spremenila v tipološki odnos do tradicionalnega in sodobnega, ki v marsičem zaznamuje slovensko glasbeno ustvarjalnost še danes. Tako lahko imamo Škerjanca in Osterca za dva obraza iste kulture $\mathrm{v}$ isti dobi in ne dva povsem raznorodna pojava, 
ki bi kulturno okolje povsem razdelila: $v$ resnici enega ni brez drugega, kar potrjujejo njuni ambivalentni odnosi. Tako Dragotin Cvetko piše o tem, da nista bila velika prijatelja, a sta se med seboj »umetniško vendarle spoštovala, jasno jima je bilo, kaj kdo od njiju pomeni. Njun odnos je označevala korektnost, ne pa nestrpna napadalnost, $\ll^{38}$ kasneje vendarle tudi prizna, da je bila med Ostercem in Škerjancem "vidna napetost, gotovo zavoljo različnih umetnostnih nazorov ter Škerjančevega nasprotovanja moderni. «" $\mathrm{Za}$ svojo negacijo sodobnega je Škerjanc tako potreboval navidezni protipol, Osterca in njegove učence, temu ustrezno pa je tudi Osterc za svoj boj proti okostenelemu tradicionalizmu potreboval simboličnega sovražnika, ki ga je dobil v Škerjancu. A kot je Škerjanc mestoma dvomil v tradicionalna izhodišča in jih je dopolnjeval s sodobnejšimi impulzi, tako tudi Osterc ni dosledno zaupal zgolj najnovejšim vzpodbudam in $\mathrm{v}$ takem prečiščevalnem relativizmu lahko nedvomno zagledano skupno točko, ki hkrati ne pojasnjuje zgolj razmerja med skladateljema, temveč kaže širšo sliko slovenske glasbe med svetovnima vojnama.

\section{Bibliografija}

Bedina, Katarina. "Nazori Slavka Osterca o tradiciji v glasbi in o glasbenem nacionalizmu«. Muzikološki zbornik 3 (1967): 89-94.

Bedina, Katarina. „K vprašanju o kompozicijskih nazorih Slavka Osterca«. Muzikološki zbornik 4 (1968): 114-119.

Bedina, Katarina. »Novo v mladinskih zborih Slavka Osterca«. Muzikološki zbornik 11 (1975): 93-100.

Bedina, Katarina. »O glasbeni poetiki in prozi Slavka Osterca«. Muzikološki zbornik 25 (1989): 7-14.

Bogunović Hočevar, Katarina. »Ravnikovi glasbenoestetski nazori v kontekstu dveh kompozicijskih šol«. De musica disserenda 6, 2 (2010): 85-99.

Cvetko, Dragotin. Osebnost skladatelja Slavka Osterca. Ljubljana: Cankarjeva založba, 1993.

Kartin, Monika. Simfonije Lucijana Marije Škerjanca, magistrsko delo. Ljubljana: Filozofska fakulteta, 1982.

Kartin, Monika. »Peta simfonija Lucijana Marije Škerjanca«. Muzikološki zbornik 19 (1983): 51-70.

Klemenčič, Ivan. »Slavko Osterc med neoklasicizmom in ekspresionizmom«. Muzikološki zbornik 31 (1995): 11-31.

38 Dragotin Cvetko, Fragment glasbene moderne. Iz pisem Slavku Ostercu (Ljubljana: Slovenska akademija znanosti in umetnosti, 1988), 128. 
Klemenčič, Ivan. Slovenski skladatelji akademiki. Ljubljana: Slovenska akademija znanosti in umetnosti, 2003.

Koter, Darja. Slovenska glasba. 1918-1991. Ljubljana: Študentska založba, 2012. Kreft, Bratko. »Spomini na Slavka Osterca in še marsikaj«. V Varia musicologica 2. Slavko Osterc, ur. Katarina Bedina. Ljubljana: Slovensko muzikološko društvo, 1995, 255-259.

Kuret, Primož. Umetnik in družba. Ljubljana: Državna založba Slovenije, 1988. Lipovšek, Marijan. »Naša glasbena produkcija«. Ljubljanski zvon 55, 10-11 (1935): 573-577.

Osterc, Slavko. »Glavne struje sodobne glasbe in njih eksistenčna upravičenost«. Nova muzika 1 (1928): 2-3.

Osterc, Slavko. »Gledališki pregled. Opera. Matija Bravničar: Pohujšanje v dolini šentflorjanski«. Ljubljanski zvon 50, 6 (1930): 377-378.

Osterc, Slavko. »Muzika u zemlji«. Zvuk 2, 3 (1933): 103-105.

Osterc, Slavko. »Čustvo in razum v glasbi«. Žena 6, 4 (1935): 94-95.

Osterc, Slavko. »Muzika u zemlji. Ljubljana«. Zvuk 3, 6 (1935): 228-230.

Pokorn, Danilo. »Slavko Osterc. Prispevek za biografijo«. Muzikološki zbornik 5 (1969): 83-91.

Rijavec, Andrej. »K vprašanju tonalnosti in vertikale v skladbah Slavka Osterca«. Muzikološki zbornik 6 (1970): 38-53.

Rijavec, Andrej. Kompozicijski stavek komornih instrumentalnih del Slavka Osterca. Ljubljana: Slovenska akademija znanosti in umetnosti, 1972.

Rijavec, Andrej. »Slavko Osterc - an expressionist?«. Muzikološki zbornik 20 (1984): 47-54.

Snoj, Jurij. Portret skladatelja Janeza Matičiča. Ljubljana: Slovenska matica, 2012.

Škerjanc, Lucijan Marija. »Vrednotenja«. Sodobnost 9, 2 (1933): 55-59.

Škerjanc, Lucijan Marija. »Moji umetnostni nazori«. Sodobnost 8, 5 (1940): 203-211.

Škerjanc, Lucijan Marija. »Nezanimivost slovenske glasbe«. Sodobnost 8, 9 (1940): 395-403.

Škerjanc, Lucijan Marija. »Apologia musicae artis«. Sodobnost 1 (1953): $170-182 .^{40}$

40 Poglavje je nastalo kot del projekta J6-7180, ki ga je sofinancirala Agencija za raziskovalno dejavnost Republike Slovenije.

This chapter is part of the project J6-7180 funded by Slovenian research agency ARRS. 

Alois Hába and Slovene Students of Composition at the State Conservatory in Prague

Jernej Weiss

Univerza v Ljubljani/Univerza v Mariboru

University of Ljubljana/University of Maribor

In the immediate aftermath of the First World War, with Czech-Slovene cultural and political connections having grown increasingly strong over the course of the nineteenth and early twentieth centuries, Prague became the most important centre of university education for Slovenes. ${ }^{\mathrm{I}}$ A consequence of this was that the State Conservatory in Prague, an institution founded more than a century earlier, also became increasingly attractive to Slovene students in the new cultural and political reality of the Little Entente, despite the fact that this same period saw the establishment of the conservatory of the Glasbena matica music society in Ljubljana (in 1919). ${ }^{2}$

For students from Slovenia, the names of illustrious teachers such as Josef Bohuslav Foerster, Vítězslav Novák, Josef Suk and Václav Talich represented a guarantee of a good musical education, while they saw greater opportunities for practical music-making in Prague, at that time unquestionably a musically more stimulating environment. Annual reports for individual academic years show that students from southern and eastern European countries predominated at the State Conservatory in Prague in the interwar period. Students came from Ukraine, Lithuania, Latvia, Bulgaria,

1 Vasilij Melik, “Češko-slovenski odnosi," in Enciklopedija Slovenije, ed. Dušan Voglar (Ljubljana: Založba Mladinska knjiga, 1988), 126.

2 Tatjana Dekleva, "Ljubljanska univerza od ustanovitve do začetka devetdesetih let," in 9o. let Univerze v Ljubljani: med tradicijo in izzivi časa, ed. Jože Ciperle (Ljubljana: Univerza v Ljubljani, 2009), 36-39. 
Romania, Italy, Hungary, Turkey, the Kingdom of Serbs, Croats and Slovenes (later known as Yugoslavia) and of course Czechoslovakia. ${ }^{3}$

If we disregard a few individuals such as Fran Gerbič, it is not until shortly before the outbreak of the First World War that we find the first Slovene students enrolled at the State Conservatory in Prague. One of the first female Slovene concert pianists, Dana Kobler, studied at the conservatory between 1910 and 1915. Three members of the Ravnik family (Janko, Anton and Bonita) studied piano there with Josef Jiránek in roughly the same period. The names of a number of other Slovene musicians appear on the roll of the Prague conservatory during and directly after the First World War. ${ }^{4}$ Notable among them are the violinists Taras Poljanec and Leon Pfeifer the latter would later become a professor of violin at the conservatory in Ljubljana. Slovene students increasingly began to be drawn to the study of composition alongside other musical disciplines.

The first Slovene composer to study at the State Conservatory was Slavko Osterc, who in the decade or so following his return from Prague acted as a "bridge" between the Slovene and Czech capitals for the next generation of important Slovene composers. On arriving in Prague, he was admitted to the third (penultimate) year of the intermediate level of the State Conservatory. He was taught composition by Karel Boleslav Jirák, instrumentation by Vítězslav Novák, musical form by Jaroslav Křička, conducting by Otakar Ostrčil, aesthetics by Václav Štěpan, and so on. ${ }^{5}$ In other words by some of the leading composers of the Czech Moderna. From Jirák in particular, Osterc acquired a thorough grounding in compositional technique that covered a great diversity of styles. In terms of ideas, there is no doubt that Alois Hába was the biggest influence during the period of his studies.

Like almost all composers of the interwar period, Hába resists easy classification when it comes to discussing his artistic focus or "poetics". Nevertheless, he is remembered above all as a pioneer of microtonal mu-

3 Vlastimil Blažek, ed., Sborník na pamét’ 125 let Konzervatoře hudby v Praze (Prague: Vyšehrad, 1936).

4 Josef Šebesta, "Slowenische Studenten am Prager Konservatorium in der Zeit der ersten Tschechoslowakischen Republik 1918-1938," in Stoletja glasbe na Slovenskem, ed. Primož Kuret (Ljubljana: Festival Ljubljana, 2006), 168-179.

5 Danilo Pokorn, "Slavko Osterc (Prispevek za biografijo)," in Varia musicologica, ed. Katarina Bedina (Ljubljana: Oddelek za muzikologijo Filozofske fakultete in Slovensko muzikološko društvo, 1995), 133. 
sic. The beginnings of Osterc's acquaintance with Hába coincided with the period of the latter's affirmation as a composer, when together with the pianist Erwin Schulhoff (and with the considerable assistance of the Förster company, one of the first piano makers in Czechoslovakia to build a quarter-tone piano), he gave concerts of quarter-tone music in Prague. ${ }^{6}$ In the early 1920 Hába was considered a relatively marginal avant-garde figure, whose propagation of athematic music free of motivic and thematic repetitions should, in theory, have set him far apart from the compositional approaches of the leading Czech composers of the day - Janáček, Suk, Novák and, increasingly, Martinů. ${ }^{7}$ Despite this, his ideas were slowly gaining increasing attention. In 1920 he completed his first microtonal composition, the String Quartet No 2 (op. 7), which received its premiere performance on 28 November 1922 at the Hochschule für Musik in Berlin. Hába returned to Prague in 1923, his head full of the ideas of Schreker and Busoni, and in September 1924 began to teach a course in quarter-tone and six-tone composition at the State Conservatory. As Lubomír Spurný notes in his foreword to the catalogue of Hába's music and writings, Hába had already published Harmonické základy čtvrttónové soustavy (The harmonic principles of the quarter-tone system) in Prague in 1922. This work represented the theoretical basis for his most influential work, the harmony textbook Neue Harmonielehre des diatonischen-, chromatischen-, Viertel-, Drittel, Sechstel- und Zwölften-Tonsystems (A new theory of harmony of the diatonic, chromatic, quarter-tone, third tone, sixth tone, and twelfth tone systems) published in Leipzig in $1927 .{ }^{8}$ Osterc was thus one of Hába's first pupils, attending his quarter-tone composition course in as early as 1926 and 1927, in other words even before Hába was appointed a professor at the conservatory in 1934, the moment that marked the official opening of his composition class, which then continued until 1949. It would thus appear that Osterc did not have the opportunity to get to know Hába's harmony textbook during his time in Prague, and was only acquainted with it later, via his own pupils. It was a similar story with the musical poetics of Josef Suk, with whom Osterc never studied, unlike his pupils.

6 Horst-Peter Hesse, ed., Alois Hába. Harmonielehre des diatonischen, chromatischen, Viertel-, Drittel-, Sechstel- und Zwölftel-Tonsystems (1942-1943) (Nordstedt, 2007), 557-558.

7 The apparent polarisation between these composers and Hába is dicussed in 1923 by the Czech musicologist Zdeněk Nejedlý. Zdeněk Nejedlý, "O čtvrttónové hudbě," Smetana 13 (1923): 17-20.

8 Lubomír Spurný and Jiří Vysloužil, Alois Hába: A Catalogue of the Music and Writings (Prague: Koniasch Latin Press, 2010), XI. 
Hába never studied with Schönberg either, although he was certainly influenced by the latter's ideas. Although in his teachings Hába constantly stressed the importance of independence, like Schönberg he developed his own micro-intervallic systems exclusively in order to develop and expand his range of expression, and in doing so "strove for the maximum and most appropriate use of the expressive possibilities of different tone systems." He therefore went a step further in the development of the semitone system, to which he added quarter-tone, fifth-tone and sixth-tone intervals. Jiři Vysloužil explains that the period in which Arnold Schönberg and his pupils were losing the right of domicile in Austria and Germany coincided with the arrival of their music in Prague. ${ }^{10}$ It could be heard at concerts and on the radio. Thanks to Hába, it was also discovered by students at the conservatory. Hába's lessons soon gained an international dimension and reputation, since as well as Osterc his students included a number of other soon-to-be highly influential composers: the Czechs Karel Reiner, Jaroslav Ježek and Karel Ančerl, the Serbs Milan Ristić, Ljubica Marić, Vojislav Vučković and Stanojlo Rajičić and the Bulgarian Konstantin Iliev. These and many other attendees of Hába's course went on to form some of the leading avant-garde movements around Europe.

In this connection, it is worth highlighting Hába's particular fondness for his Yugoslav colleagues, a fondness that was in fact shared by the majority of the Czech cultural and political community in this period. A special issue of music periodical Tempo, formerly Listy Hudební matice (produced by the Hudební Matice music publishing company) dated 16 October 1927 was entirely devoted to the music scene in Yugoslavia and included a Slavophile poem by Aleksa Šantić entitled Nové pokolení (New Generation). ${ }^{\text {II }}$ The same issue also included a brief report on the most important Slovene composers working at that time, among them Anton Lajovic. The report ends with a mention of the fresh creative potential of Slavko Osterc, a student at the Prague conservatory. It was Lajovic, the true spiritus agens of Slovene music in the immediate post-war years, who intervened with Václav Talich - the first conductor of the Slovenian Philharmonic Orchestra - regarding Osterc's enrolment at the conservatory in Prague (where Talich taught).

In contrast to Osterc, who in the late 1920 s was just beginning his career as a professional music teacher at the conservatory of the Glasbena

Jiř́ Vysloužil, “Alois Hába Heute,” Muzikološki zbornik 20 (1984): 62.

10 Ibid., 57.

11 Aleksa Šantić, “Nové pokolení,” Tempo - Listy Hudební matice 7, no. 2 (1927-28): 5556. 
matica in Ljubljana, Hába was increasingly establishing himself as one of the leading representatives of the Czech interwar avant-garde. He was the head of the Czech section of the International Society for Contemporary Music (ISCM) with a wide network of influential composer friends. He was also the head of the music society Prítomnost (The Present), which had taken the place of Novák's earlier Spolek pro moderní hudbu (Society for Modern Music), and an active writer who, with an enthusiasm that matched that of Osterc, wrote about the need for new musical perspectives in Prague periodicals such as Tempo and Klíč (Clew).

In the field of music education, too, Hába successfully presented a thoroughly grounded new view of old, historical facts in the textbook mentioned earlier, Neue Harmonielehre. This was almost literally compiled from the findings of a range of theorists. Hába believed, and admitted with total frankness, that his most important contribution lay in the "synthesis and expansion of their findings." $\mathrm{He}$ was, then, as capable and fruitful a theorist as he was a composer - something we could not claim for Osterc. In as early as 1936 Vladimír Helfert was able to talk, with justification, about a "Hába School"13 in his essay Česká moderní hudba (Czech Modern Music), although it should be emphasised that as a teacher Hába allowed his students considerable creative freedom, and did not impose his own views of compositional technique on them. The concept of a "Hába School" may be taken on the one hand to mean a set of guiding principles of compositional technique supported by theoretical considerations, and on the other, aesthetic and ideological perspectives supported by more or less specific compositional solutions. Both were available to Hába's students - among whom, interestingly, he considered Osterc one of the most important, alongside Dragutin Čolić and Vojislav Vučković - even before the department for quarter-tone composition at the Prague conservatory officially opened in 1934. Hába's ideas about composition received particular international attention on 17 May 1931 following the Munich premiere of his quarter-tone opera Matka (The Mother), conducted by Hermann Scherchen. ${ }^{14}$ Just three weeks later the Society for Modern Music organised a concert of quarter-tone music in Prague, at which the pianist Karel Reiner

12 Alois Hába, Neue Harmonielehre des Diatonischen, Chromatischen, Viertel-, Drittel-, Sechstel und Zwölftel-Tonsystems (Leipzig: F. Kistner \& C.F.W. Siegel, 1927), 12.

13 Vladimír Helfert, Česká moderní hudba: Studie o české hudební tvořivosti (Olomouc: Index, 1936), 155-158.

14 Vlasta Reittererová and Lubomír Spurný, “»Musik am Rande«. Einige Bemerkungen zur Typologie der Musik von Alois Hába,” Muzikološki zbornik 47, no. 1 (2011): 161. 
performed Osterc's Preludij za četrttonski klavir (Prelude for quarter-tone piano), among other works. ${ }^{\text {Is }}$ An indication that quarter-tone composition was never at the forefront of Osterc's compositional endeavours but was instead a more or less academic or occasional pursuit, much as it was with other composers of quarter-tone music, comes from the fact that Osterc only composed two other works using this system: Štiri Heinejeve pesmi za glas in godalni kvartet (Four Poems by Heine for voice and string quartet, 1931) and the cantata Cvetoči bezeg za alt, zbor in devet instrumentov (The Blossoming Elder for alto, choir and nine instruments, 1936).

Despite the increasingly evident honing of his compositional style following his return from Prague, where it was "Hába who played a decisive role in the final stylistic transformation of Osterc the modernist, ${ }^{316}$ we could analyse in detail practically any of Osterc's constructs from his Ljubljana period, including the most radical, namely the central movement of his Koncert za klavir in pihala (Concerto for piano and wind instruments), written in 1933 and dedicated to Hába, and discover in every case that in compositional terms he was building from what we might call consistent inconsistency. Although Hába praises Osterc for the "fine concerto", which he listened to and which was even analysed at school, he simultaneously exhorts him to write sequences in an athematic style and advises him to compose a uniformly atonal and athematic piece of a kind he has not yet written, but which he is capable of writing. ${ }^{17}$ Yet even Osterc's works continued to show, rather than a consistent athematic and atonal style, a tension between neoclassicist technique and expressionist language that became quite typical of his work in the 1930s. For this reason, many researchers draw attention to the composer's inability to "elaborate a solid compositional system" ${ }^{18}$ From this point of view, it would therefore be difficult to credit him with having attended the "Hába School". Even as a teacher or music theorist, he limited himself to merely indicating certain new developments, for example in his correspondence school with Pahor or in his unpublished Kromatika in modulacija (Chromatics and Modulation), despite the fact

15 The original title of the work was Tri skladbe za četrttonski klavir (Three pieces for quarter-tone piano). Osterc then renamed it Preludij in fuga (Prelude and Fugue) but never completed it, with the exception of the prelude. NUK, Glasbena zbirka [National and University Library, Music Collection].

Gregor Pompe, "Glasba slovenske povojne moderne (1918-1927)," De musica disserenda 12, no. 2 (2016): 42.

17 Dragotin Cvetko, Fragment glasbene moderne: iz pisem Slavku Ostercu (Ljubljana: Slovenska akademija znanosti in umetnosti, 1988), 189.

18 Leon Stefanija, “Osterc in Hába," Muzikološki zbornik 31 (1995): 33. 
that his conception of study was as free as possible. The syllabus and traditional forms were, for him, merely a framework which he filled in with his own judgements. He did not even teach his students detailed rules of composition, preferring to give free rein to their individual creative fantasy.

It is the systematic nature of justification that thus appears to be one of the principal differences between Hába and Osterc, reflected both in their compositions and in their writings. Hába was not, of course, Osterc's only model. Even after his return from Prague, Osterc frequently emphasised his ideological orientation based on "creative intuitions" or "free expression" that would not allow him to follow any kind of authority: "Now it is the duty of the young generation to break with Petrushka, when the ideology of Schönberg, Berg and Hába is already getting old, and it is the duty of the youngest to break with Schönberg and the others." And further: "Music has even greater possibilities of development!"' It is evident from these quotations that for Osterc the most important signpost in creative work was the retreat from the existing or the "new", although he never succeeded in defining it entirely unambiguously, either compositionally or theoretically. He was thus above all someone who spoke about the new, and less a creator of the new - something pointed out by Leon Stefanija in his article Osterc in Hába (Osterc and Hába). ${ }^{20}$

Shortly after his return from Prague in 1927, Osterc succeeded in gathering around himself a generation of younger composers who, as a result of his later contacts with Hába, would go on to study in Prague. They have become known as the "Osterc School", although apart from a commitment to predominantly instrumental music, it would be difficult to attribute a common artistic focus to them.

Osterc's first successor in Prague was Srečko Koporc, who graduated in composition under Rudolf Karel, a former student of Dvořák's, in 1929. Although Koporc did not compose even a single quarter-tone piece, he clearly became very familiar with Hába's teachings in Prague, as demonstrated by his exact description of Hába’s teaching in an article entitled Alois Hába in njegova četrttonska teorija (Alois Hába and his quarter-tone theory) published in Cerkveni glasbenik (Church Musician) in $1928 .{ }^{21}$ It is interesting to note that, following his return from the Czech capital, Koporc produced a

19 Slavko Osterc, Zvuk 3, no. 6 (1935): 191.

20 Stefanija, “Osterc in Hába," 33-41.

21 Srečko Koporc, "Alois Hába in njegova četrttonska teorija (Črtica ob priliki izdane knjige: Neue Harmonielehre)," Cerkveni glasbenik 51, no. 7-8 (1928): 111-112. 
considerable body of theoretical writings based on his studies in Prague. Among other things this includes notes on dodecaphonic composition under the significant title Skrivnost dvanajstih tonov (The secret of the twelve notes), ${ }^{22}$ which demonstrates Koporc's familiarity with the most modern foreign music theory literature of the day. In these notes Koporc even cites Hába's Neue Harmonielehre, despite having been quite critical of it in his earlier Cerkveni glasbenik article, published immediately after completing his studies in Prague, in which he describes Hába's theory as "primitive" Though he provides no argument at all to support this label, Koporc's rich legacy of writings on music theory is evidence that - thanks to his studies in Prague - he was among the more broad-minded Slovene authors working in the field of music theory in the period between the wars.

Marijan Kozina studied at the conservatory in Prague in almost the same period as Koporc, although unlike the composers mentioned earlier, he did not attend Hába's course. Predominantly bound to the Romantic tradition, Kozina studied composition with Josef Suk from 1930 to $1932 .{ }^{24}$ Alongside Hába, Suk was the biggest influence on Slovene students of composition in Prague. All Osterc's later students studied with Suk, who - unlike Osterc - put the artistic value of a work ahead of everything else. This, of course, contrasted with Osterc's avant-garde endeavours advocating the radically new in the composition without logical connection and coherence. Suk's teaching and theoretical work deserve more attention if we are to obtain a more complete picture of the influences of the "Prague School" in terms of ideas and compositional techniques.

One of the first students to attend Hába's course in quarter-tone composition at the State Conservatory in Prague was the pianist and composer Marijan Lipovšek, who enrolled in the master's course at the conservatory in 1932, studying composition with Josef Suk and piano with Vilém Kurz (as a private student), at the same time as attending Hába's lessons on quarter-tone composition and reporting on them periodically to Osterc. It is worth emphasising that Lipovšek, after completing his single year of studies in Prague, did not adopt the ideological views of the "Hába School" as

22 Srečko Koporc, Skrivnost dvanajstih tonov (Ljubljana: ms., 1957), NUK, Glasbena zbirka [National and University Library, Music Collection].

23 Koporc, “Alois Hába in njegova četrttonska teorija”, 111.

24 For the diploma examination, he submitted his Suita za veliki orkester (Suite for large orchestra). He did not, however, officially complete his training at the conservatory and too many absences meant that he had to leave. Šebesta, "Slowenische Studenten am Prager Konservatorium," 176. 
Osterc's later students did, nor did these cause significant stylistic changes in his work following his return to Ljubljana. ${ }^{25}$

One composer who more closely approached Hába's views in some of his post-Prague works was Osterc's first graduate, Pavel Šivic. Šivic was said to have "adopted expression in Prague", ${ }^{26}$ where he studied between 1931 and 1933. Certain structural changes in Šivic's compositional style following his studies in Prague would appear to confirm this thesis. Another consequence of his Prague studies would appear to be what, in the Slovene music of the time, was a more or less isolated example of the use of the dodecaphonic technique in the form of a series of twelve-note studies entitled Mala klavirska suita (Little Piano Suite), written in 1937. Even here, however, we can only really talk about an attempt at twelve-note composition. The work that most recalls the twelve-note approach, albeit somewhat ironically, is his Romantična fantazija (Romantic Fantasia) for piano. It seems important to underline the fact that in 1933, as well as attending Hába's course, Šivic also completed his composition studies with Josef Suk ${ }^{27}$ and his piano studies with Vilém Kurz. ${ }^{28}$

Osterc's "favourite" student Franc Šturm also studied with Josef Suk and Alois Hába at the conservatory in Prague from 1933 to 1935, following three years of study with Osterc. He was the only Slovene composer who continued to apply Hába's quarter-tone solutions in his own compositions following his return from Prague. Šturm's work in fact reveals a new kind of creative desire, already evident in his 1934 Fantazija za orgle (Fantasia for organ) and supported by a series of works composed during his two years in Prague, several of them written using the quarter-tone system. These early works of Šturm's are characterised by athematism and an atonality that is more consistent than Osterc's. Even in the Fantasia for organ, which begins with a veritable explosion in the form of eleven different notes (with repetitions) over a dissonant chord, he uses the characteristic technique of adding an accidental for each note as it occurs, without natural signs. It is, then, a kind of attempt at a dissonant honing with a filling of the chromatic

25 Lipovšek is described as being "focused on the objectivity of neoclassicism and, initially, even a narrower neo-baroque" right up until the start of the Second World War. Ivan Klemenčič, Slovenski glasbeni ekspresionizem (Ljubljana: Cankarjeva založba, 1988), 119.

26 Ibid., 145.

27 For the diploma examination, he submitted his Godalni kvartet (String Quartet). Šebesta, "Slowenische Studenten am Prager Konservatorium", 171.

28 For the diploma examination, he performed Liszt's Piano Concerto No 2 in A major. Ibid. 
space, although again without Schönberg's dodecaphonic system. In a letter to Osterc dated 25 March 1934 Šturm himself writes: "Hába said that I have [...] arrived at a composition that resounds, and that I am to be congratulated. ${ }^{229} \mathrm{He}$ admits that he struggled for an entire year with this composition, without achieving much else. Hába's influence is also evident in numerous quarter-tone compositions, among them the Četrttonski godalni kvartet (Quarter-tone String Quartet) that he submitted for his diploma examination..$^{30}$ Another interesting work written in Prague is his suite in four movements for quarter-tone piano entitled Luftballon, to which he gave the opus number 3. In Šturm's case, just as with Osterc, it is possible to detect an intention to renounce his pre-Prague works.

Another factor that seems extremely important with regard to the continuity of Šturm's later focuses as a composer is that his creative ideals were more or less clearly developed during his time in Prague. If in the aforementioned letter to Osterc he had expressed a negative view of the neoclassicism he previously espoused, in the article Glasba kot socialni činitelj (Music as a social factor), which appeared in Sodobnost (Modernity) in 1935, he is an adherent of anthroposophy - something Hába had constantly promoted - and claims, with the system's founder Rudolf Steiner: "Music is the inner image of man." ${ }^{\text {'I }}$ Thus he accepts the view of living and organic music that the listener primarily experiences at the emotional level, where it "configures his soul". ${ }^{2}$ Like Steiner, he is aware that all social, existential and spiritual processes of the age are reflected in art, so the social aspect is important to him - hence the need for such music to be addressed to "the broad masses". ${ }^{33}$ In accordance with his left-wing views, which were incidentally shared by Osterc, he aimed at a working-class audience, while the bourgeois audience was considered less than ideal in that it was "burdened by the partial, frequently inadequate knowledge of music theory and [...] a mass of personal prejudices." ${ }^{\prime 34}$ Subjectivism is thus no longer the exclusive basic emotion. Here Šturm distances himself from Schönberg, in whom the idea and execution of a composition was a matter of intuition and inspira-

29 Cvetko, Fragment glasbene moderne, 337.

30 At the end of the year he was given the overall assessment "highly capable". Šebesta,

"Slowenische Studenten am Prager Konservatorium," 171.

31 Franc Šturm, "Glasba kot socialni činitelj," Sodobnost 3, no. 11-12 (1935): 581.

32 Ibid., 582.

33 Ibid.

34 Ibid. 
tion, and only realised with the help of compositional technique as a craft and a mental process.

Hába's views were presented more comprehensively to the Slovene public in 1935 by Ivan Pučnik, at that time a student of Hába's, in a special interview with the composer published in the newspaper Jutro (Morning). ${ }^{35}$ He portrayed Hába as an advocate of the radically new and, at the same time, as a sensitive artist who, as such, was aware of his special task. Almost entirely overlooked in writings on the history of Slovene music, Pučnik is today better known as an agitator than as a composer. Unlike his fellow composers in Prague, Pučnik had received no formal musical training, and was thus unable to enrol in Osterc's composition class. Having enrolled as a law student in Prague in 1934, he later studied composition with Alois Hába, who had previously prepared him privately for the conservatory entrance exam. As he writes in one of his letters to Šturm: "I tell you frankly that I hate all schools and the only thing that is keeping me in Prague and at the conservatory is Hába, who gives me something immense with every lesson. ${ }^{336}$ During his years in Prague he formed close friendships with Franc Šturm and Demetrij Žebre, both of whom were studying there in the same period. Despite the reverence he had for Osterc, he believed that the time had come for radical changes. Together with Šturm he even planned to found an independent group of composers that would mark a new direction and stir up the Slovene music scene.

Pučnik completed several compositions while studying in Prague, including settings of three poems from Kocbek's first poetry collection Zemlja (Earth). In 1936 he completed a fantasia for chamber orchestra entitled Živim z zemljo (I live with the Earth) in a more or less consistently atonal style. He is also believed to have written his Četrttonski kvartet s sopranom (Quarter-tone Quartet with soprano) and Šestinotonska fantazija za solo violo (Sixth-tone Fantasia for solo viola) in this period. ${ }^{37}$ Unfortunately, the fate of the remainder of the composer's legacy is unknown. The years of Pučnik's big musical plans and revolutionary ideas were eventually substituted, at the instigation of his parents, by medical studies in Zagreb, after which he enjoyed an enviable career as a pulmonologist at Golnik Hospital.

35 Ivan Pučnik, "Alois Hába," Jutro, no. 135 (13. 6. 1935): 7.

36 Katarina Bedina, "Nova najdba iz pisem Francu Šturmu," Muzikološki zbornik 21 (1985): 93 
The last of Osterc's students to go on to study at the master's level at the State Conservatory in Prague was Demetrij Žebre. Interestingly, Žebre arrived at his short-lived but surprisingly early and radical beginnings in a distinctively expressionist style in 1928, a full year before he began studying with Osterc. Where he found the inspiration for such a highly contemporary sound world characterised by harsh dissonance and extratonal effects, for example in early songs such as Tepežnica (Holy Innocents' Day), written in 1928, and Trije samospevi (Three Lieder), settings of texts by Župančič written a year later, remains an open question. Few of Žebre's works, however, are susceptible to easy stylistic definition, even if we know that he studied with Slavko Osterc (1929-1934), Josef Suk (1934-1935) ${ }^{38}$ and Alois Hába $^{39}$, while also studying conducting with Václav Talich. Uniformity of style may most easily be identified in his predominantly expressionistically conceived quarter-tone compositions, lieder and chamber works, and in the clearly impressionistic Tri vizije za simfonični orkester (Three Visions for symphony orchestra).

One of the two central branches of the Slovene avant-garde movement between the wars was thus far from being clearly categorisable, either in compositional terms or in terms of ideas. Lipovšek can certainly not be included in it. Šturm and Pučnik, influenced by Hába's most advanced ideas, later wished to liberate themselves from Osterc, the movement's central figure, to form an independently functioning group, although because of Šturm's reservations this did not actually happen. ${ }^{40}$ On the other hand Marijan Lipovšek, Pavel Šivic, Franc Šturm and Demetrij Žebre all studied with Osterc when the latter was still largely oriented towards the neo-baroque, neoclassicism and new objectivity. This means that more decisive artistic and technical stimulations can only have come from their studies in Prague, particularly with Hába, who, like Osterc, allowed his students a relatively large degree of creative freedom.

It is worth emphasising here that the majority of compositions written by Slovene students in Prague do not use the quarter-tone system, although a gradual sharpening of musical language is nevertheless observable in

38 For his diploma, he submitted his Godalni kvartet (String Quartet) to Suk. Šebesta, "Slowenische Studenten am Prager Konservatorium," 171.

39 He is thought to have submitted one of his quarter-tone compositions to Hába for his diploma examination. At the end of the year he was given the overall assessment "highly capable". Ibid., 172. 
them. Musical composition thus arrives at the limit of traditional means of expression, which are intensified to their extreme point, although it rarely crosses the threshold of atonality and hardly ever subordinates itself to consistent constructivist logic. Like the majority of their contemporaries, Slovene composers adapted constructivist procedures in a fairly original manner, and like them did not feel the need for a consistent use of atonality. Accordingly, it was perhaps above all Josef Suk's extremely liberal "systematic openness" that influenced the still prevailing polystylistic synthesis with various characteristic emphases. The fact that Suk's composition class, unlike Hába's optional one-year course in quarter-tone composition, took place at the master's level of the conservatory, which all of Osterc's former students with the exception of Pučnik attended for least two years, should certainly not be overlooked. The possibility of other influences, in terms of ideas and techniques, on the creation of individual works should certainly also be admitted. One less known and certainly overlooked influence is the composition by Karel Boleslav Jirák and Otakar Šín, with which Slovene students in Prague were undoubtedly very familiar, like practically all students of composition. Whatever label we might be tempted to give to individual compositions by Slovene students in Prague, it would probably soon become apparent that when describing their compositions we need to treat individual structural elements separately, since they are usually a combination of diverse elements of compositional technique and only contribute to a single whole when put together.

To what extent, then, when considering later works by Slovene composers who studied composition in Prague, is it even possible to talk about a "Hába School"? In what aspect of these works is this apparent? Or is this not perhaps something that only really exists on paper, even when it comes to the works of some of Hába's other students, as Lubomír Spurný demonstrates in his article Hába School - Reality or Myth $?^{41}$ Be that as it may, it would be hard to deny that a certain influence of Hába is perceptible in individual post-Prague works by Slovene students from the State Conservatory in Prague, an influence that is apparent above all in the more or less consistent athematism and atonality of individual compositions - as well as in the honing of ideological views and in individual studies and other occasional works using the quarter-tone system.

41 Lubomír Spurný, “Hába School - Reality or Myth?," in Spaces of Modernism: Ljubica Marić in Context, ed. Dejan Despić and Melita Milin (Belgrade: Serbian Academy of Sciences and the Arts, 2010), 135-142. 
Only with the help of a more precise definition of the individual structural elements and techniques that condition the style of the compositions in question (and not vice versa), the emphases of which then changed following the return of their composers from Prague, under the influence of time and environment, will we succeed in arriving at some more relevant conclusions. Until then, discussion of the works of the composers in question will probably continue to be dominated by unhelpful stylistic generalisations and comparisons with more or less incomparable or even non-existent pinnacles of contemporary European musical creativity which are the origin of that myth - so characteristic of Slovene musical historiography - of the eternal backwardness or reactionary nature of musical creativity in Slovenia.

\section{Bibliography}

Bedina, Katarina. “Nova najdba iz pisem Francu Šturmu.” Muzikološki zbornik, 21 (1985): 87-95.

Blažek, Vlastimil, ed.. Sborník na pamět’ 125 let Konzervatoře hudby v Praze. Praha: Vyšehrad, 1936.

Cvetko, Dragotin. Fragment glasbene moderne: iz pisem Slavku Ostercu. Ljubljana: Slovenska akademija znanosti in umetnosti, 1988.

Dekleva, Tatjana. "Ljubljanska univerza od ustanovitve do začetka devetdesetih let.” 9o. let Univerze v Ljubljani: med tradicijo in izzivi časa. Jože Ciperle, ed.. Ljubljana: Univerza v Ljubljani, 2009, 36-39.

Hába, Alois. Neue Harmonielehre des Diatonischen, Chromatischen, Viertel-, Drittel-, Sechstel und Zwölftel-Tonsystems. Leipzig: F. Kistner \& C.F.W. Siegel, 1927.

Helfert, Vladimír. Česká moderní hudba: Studie o české hudební tvořivosti. Olomouc: Index, 1936.

Hesse, Horst-Peter, ed.. Alois Hába. Harmonielehre des diatonischen, chromatischen, Viertel-, Drittel-, Sechstel- und Zwölftel-Tonsystems (1942-1943). Nordstedt: 2007.

Klemenčič, Ivan. Slovenski glasbeni ekspresionizem. Ljubljana: Cankarjeva založba, 1988.

Koporc, Srečko. “Alois Hába in njegova četrttonska teorija (Črtica ob priliki izdane knjige: Neue Harmonielehre)." Cerkveni glasbenik, 51, no. 7-8 (1928): 111-112.

Koporc, Srečko. Skrivnost dvanajstih tonov. Ljubljana: ms., 1957. 
Melik, Vasilij. “Češko-slovenski odnosi.” Enciklopedija Slovenije, 2 (1988): 115-126.

Nejedlý, Zdeněk. “O čtvrttónové hudbě.” Smetana, 13 (1923): 17-20.

Osterc, Slavko. Zvuk, 3, no. 6 (1935): 191.

Pokorn, Danilo. “Slavko Osterc (Prispevek za biografijo)." Varia musicologica. Katarina Bedina, ed.. Ljubljana: Oddelek za muzikologijo Filozofske fakultete in Slovensko muzikološko društvo, 1995, 127-137.

Pompe, Gregor. "Glasba slovenske povojne moderne (1918-1927).” De musica disserenda, 12, no. 2 (2016): 23-46.

Pučnik, Ivan. “Alois Hába.” Jutro, no. 135 (1935): 7.

Reittererová, Vlasta, and Lubomír Spurný. “»Musik am Rande«. Einige Bemerkungen zur Typologie der Musik von Alois Hába.” Muzikološki zbornik, 47, no. 1 (2011): 153-165.

Spurný, Lubomír, and Jiří Vysloužil. Alois Hába: A Catalogue of the Music and Writings. Prague: Koniasch Latin Press, 2010.

Spurný, Lubomír. “Hába School - Reality or Myth?” Spaces of Modernism: Ljubica Marić in Context, Dejan Despić and Melita Milin, ed.. Belgrade: Serbian Academy of Sciences and the Arts, 2010, 135-142.

Stefanija, Leon. “Osterc in Hába.” Muzikološki zbornik, 31 (1995): 33-41.

Šantić, Aleksa. "Nové pokolení." Tempo - Listy Hudební matice, 7, no. 2 (192728): 55-56.

Šebesta, Josef. "Slowenische Studenten am Prager Konservatorium in der Zeit der ersten Tschechoslowakischen Republik 1918-1938." Stoletja glasbe na Slovenskem. Primož Kuret, ed.. Ljubljana: Festival Ljubljana, 2006, 168-179.

Šturm, Franc. "Glasba kot socialni činitelj." Sodobnost, 3, no. 11-12 (1935): 581-583.

Vysloužil, Jiří. “Alois Hába Heute.” Muzikološki zbornik, 20 (1984): 55-64. ${ }^{42}$

42 Poglavje je nastalo kot del projekta J6-7180, ki ga je sofinancirala Agencija za raziskovalno dejavnost Republike Slovenije.

This chapter is part of the project J6-7180 funded by Slovenian research agency ARRS. 



\title{
O polislogovnosti klasicističnega modernizma
} po razkritju »adornovske zmote « - na primerih iz opusa Demetrija Žebreta

\author{
Karmen Salmič Kovačič \\ Univerza v Mariboru, Univerzitetna knjižnica Maribor \\ University of Maribor, University of Maribor Library
}

Na začetku si bomo zastavili vprašanje, ki se porodi pri poskusu slogovnega opredeljevanja posamezne skladbe $v$ dvajsetem stoletju: ali je mogoče, da glasbeno delo z zmerno modernistično obravnavo melodike, harmonije in teksture $\mathrm{v}$ klasicistični formi in $\mathrm{z}$ vključevanjem nekaterih elementov tonalnega sistema zveni mestoma romantično? Besedi romantično in tonalno, namreč, asociirata vse prej kot modernistično delo oziroma sodita med tiste etikete, ki se pri črno-belem in poenostavljenem razumevanju tovrstne glasbe prepogosto povezujejo s tradicijo, tudi pri glasbenih strokovnjakih. Takšno stereotipno sklepanje, zreducirano na nekaj skrajno abstraktnih kategorij oziroma opornih točk, lahko sproži pri bralcu popolnoma napačno predstavo o delih in opusih skladateljev. Lahko bi jim rekli predsodki, ki ne držijo in so, kot vse bolj ugotavljajo tuji raziskovalci, posledica nacionalno in ideološko pogojenega konstrukta $v$ glasbeni historiografiji. Poimenovali smo ga »adornovska zmota«, če uporabimo najmilejšo oznako njegove vsebine.

Naslednje vprašanje, ki se zastavlja ob analizah del slovenskih skladateljev iz časa med obema vojnama, je, kako razumeti polislogovno sintezo tehnik in izraznosti pri modernističnem skladatelju v eni sami skladbi - denimo impresionizma, ekspresionizma, neoklasicizma in romantizma? Ali gre zgolj za skladateljev individualni slog, za zapolnjevanje vrzeli v nacionalni glasbeni tradiciji ali za splošno razširjen glasbenoestetski fenomen? Vprašati se je, ali ne gre morda pri vrednotenju in predstavljanju slo- 
venskih glasbenih del za domala pretiran občutek zaostajanja, posnemanja in dohitevanja, če vemo, da so se naši skladatelji iz prve polovice 2o. stoletja, izpopolnjevali pri največjih, tudi avantgardistično usmerjenih skladateljih?

Po zaslugi Hermanna Danuserja lahko gledamo na takšno glasbo danes že kot na splošno razširjen pojav, ki je del širšega modernističnega toka med obema vojnama po radikalnem prelomu s tonalnostjo v novodunajski šoli. Žal do nedavna ni imel svojega poimenovanja in definiranih kriterijev, zato predlaga Hermann Danuser uvedbo izraza klasicistični modernizem oz. modernistični klasicizem - kot najprimernejša označevalca kompozicije, v katerem se staro druži z novim na sodoben način. Da ima množica raznolikih tehnik za svojo logično posledico tudi polislogovno sintezo oz. slogovni pluralizem, ki je $\mathrm{v}$ takšni glasbi prej determinanta kot diskvalifikator, pa lahko ugotovimo neposredno iz izraznosti posameznih, v našem primeru, Žebretovih skladb.

\section{$\mathrm{O}$ »adornovski zmoti«}

Ker smo o kritiki adornovske miselnosti več zapisali v Muzikološkem zbor$n i k u,{ }^{1}$ na kratko povzemimo le bistveno, saj se nanjo navezuje tudi prenovljeno pojmovanje glasbenega modernizma, neoklasicizma in modernističnega klasicizma oz. klasicističnega modernizma. Zaradi pomembnosti njene razlage se bomo težko izognili ponovljenemu citiranju nekaterih avtorjev tudi v tem prispevku.

Ideološko in nacionalistično motivirano glasbenozgodovinsko tezo o avantgardnih dosežkih dunajskega ekspresionizma v glasbi 2o. stoletja kot edinem generatorju glasbenega modernizma smo poimenovali kot "adornovska zmota zato, ker je imel Theodor W. Adorno ključno vlogo pri njenem utemeljevanju in širjenju. Manipulativnost njene vsebine dokazuje $i z$ ključevanje ostalih sočasnih modernističnih smeri, gibanj in avantgard $\mathrm{s}$ strani njegovih pristašev, pojasnjuje Markus Bandur. Navaja ironično posmehovanje Arnolda Schönberga iz neoklasicizma in novih pojavov v dvajsetih letih (folklorizma, vitalne ritmike, antiromantike, nove stvarnosti), Webernovo označevanje neoklasicizma s »kopijo stila«, podobno Adornovo uporaba izraza v njegovih številnih kritikah po letu 1925 ... Konec dvajsetih let je slednji prvič poskušal zaokrožiti teorijo o moderni glasbi, ko je okrog pojmov neoklasicizem in klasicizem ustvaril sociološko, kulturno, poli-

Karmen Salmič Kovačič, »Donedavno pojmovanje glasbenega modernizma 'adornovska zmota'?«, Muzikološki zbornik 53, 1 (2017): 121-141. 
tično in glasbeno nadvse zapleteno pomensko polje, za moderno glasbo pa označil le Schönbergov krog. ${ }^{2}$

Posledice adornovske miselnosti so zaznavne v pojmovanju glasbenega modernizma, tradicionalizma, glasbene avantgarde, neoklasicizma, nove tonalnosti, atonalnosti ipd. Zato nanjo vse bolj opozarjajo številni raziskovalci. »Standardno historično paradigmo in zgodbo o novodunajski šoli, ki pa se je $\mathrm{v}$ času postmodernizma in neoromantizma začela postavljati pod vprašaj «, obravnava Leon Botstein v Grove music online pod geslom o glasbenem modernizmu, ${ }^{3}$ prenovljeno kritičen pogled na zgodovinopisno preteklost pa prežema, med drugim, tudi prispevke več avtorjev, ki obravnavajo glasbo prve polovice 20. stoletja $\mathrm{v}$ The Cambridge history of twentieth-century music ${ }^{4}$. Christopher Butler, denimo, je prepričan, da je bilo veliko različnih vrst avantgardnih skladateljev, ki so odprli široko zasnovano in pluralistično konverzacijo o novih smereh glasbe tega časa, zato ne morejo biti zreducurani po Adornovih marksističnih principih na najožji krog. ${ }^{5}$ Andrew Timms vidi kot posledico in problem "umišljene konstrukcije glasbene zgodovine « v tem, da se modernizem še vedno prepogosto povezuje $\mathrm{z}$ enim samim aspektom glasbe - atonalnostjo. ${ }^{6}$ Podobno ugotavlja Peter Franklin, ki priznava, da je bila regresivnost glasbe $\mathrm{z}$ elementi tonalnosti nasproti progresivni uporabi disonance in atonalnosti najpogosteje uporabljena formula in da nas je šele postmodernistična historiografija opogumila, da ponovno razmislimo o tem. ${ }^{7}$ Timms tudi meni, da je določena sinhrona logika tistih, ki so enačili glasbeni modernizem $\mathrm{z}$ atonalnostjo, dodekafonijo pa s koncem zgodovine tonalnosti, odrinjala in pripeljala do razporejanja ostalih slogov ter gibanj (kot sta npr. neoklasicizem in surrealizem) okrog samooklicanega mainstreama. Zanj je organski mo-

2 Markus Bandur, »Neoklassizismus«, v Handwörterbuch der Musikalischen Terminologie. Ordner IV: M-O, ur. Heins Heinrich Eggebrecht in Albrecht Riethmüller (Wiesbaden: Franz Steiner Verlag, 1994), 19-20.

3 Leon Botstein, »Modernism«, v Oxford music online - Grove music online (Oxford: Oxford University Press), 2007-2016.

4 Nicholas Cook in Anthony Pople, ur., The Cambridge history of twentieth-century music (Cambridge etc.: Cambridge University Press, 2004).

5 Christopher Butler, "Innovation and the avant-garde, 1900-20«, v The Cambridge history of twentieth-century music, ur. Nicholas Cook in Anthony Pople (Cambridge etc.: Cambridge University Press, 2004), 87.

6 Andrew Timms, »Modernism's moment of plenitude«, $\mathrm{v}$ The modernist legacy: essays on new music, ur. Björn Heile (Farnham, Surrey: Ashgate, 2009), 13.

7 Peter Franklin, "Between the wars: traditions, modernisms, and the 'little people from the suburbs' «, v The Cambridge history of twentieth-century music, ur. Nicholas Cook in Anthony Pople (Cambridge etc.: Cambridge University Press, 2004), 187. 
del glasbene zgodovine $\mathrm{z}$ razvojem tonalnosti in njenim koncem izmišljena zgodba, ki nima osnove v realnosti. Izkazalo se je, da je tonalnost kljub svojim »padcem « in »vzponom « ostala osrednja urejevalna moč v glasbi, kombinacija tonalnosti in modernosti pa gravitacijsko središče zgodovine glasbe, trdi. Povezovanje modernizma $\mathrm{z}$ atonalnostjo je po njegovem mnenju "omejeno" - ne le zato, ker ignorira potencialno historično raznovrstnost glasbe, ampak tudi zato, ker nas prepričuje, da modernizem naznanja konec njene zgodovine, $v$ bistvu pa gre le za problematično pot filozofije njene historiografije $\mathrm{z}$ bolečim koncem. ${ }^{8}$

\section{"Adornovska zmota«, neoklasicizem in klasicistični modernizem}

$\mathrm{Na}$ kritiko adornovske miselnosti naletimo tudi pri obravnavi neoklasicizma in modernističnega klasicizma - pojma, ki ga vpeljuje Danuser, kot rečeno, prav zaradi omenjenega pojava. Prepričan je, da je bil klasicistični modernizem (med tem in modernističnim klasicizmom ne vidi vsebinskih razlik), eden najbolj vplivnih fenomenov glasbene zgodovine $\mathrm{v}$ prvi polovici 20. stoletja, po krivici odrinjen kot nasprotni pol radikalnega modernizma s pejorativno oznako neoklasicizem, in se sprašuje, če ni bil celo del tega ter poziva k ponovni definiciji. ${ }^{9}$ Vrednotenje $\mathrm{v}$ okviru predsodka o dveh antagonističnih vrednostih - čistega klasičnega ideala na eni strani in čistega modernističnega na drugi strani ne vzdrži več, meni. ${ }^{10}$

Tudi Markus Bandur ugotavlja, da je Adorno z izrazom neoklasicizem označeval predvsem restavrativen in reakcionaren glasbenoizrazni koncept. ${ }^{\text {II }}$ Anahronistično pojmovanje neoklasicizma kot klasičnega pomeni za Timmsa posvetiti pozornost le končni točki historične sheme, v kateri se tonalnost $\mathrm{z}$ »najvišje« razvojne točke premakne do »krizne«, predstavlja pa tveganje, da spregledamo osupljiv način, kako je ta najvišja točka oblikovana. ${ }^{\text {I2 }}$

8 Timms, »Modernism's moment of plenitude«, 15, 22-24.

9 Hermann Danuser, »Rewriting the past: classicisms of the inter-war period «, v The Cambridge history of twentieth-century music, ur. Nicholas Cook in Anthony Pople (Cambridge etc.: Cambridge University Press, 2004), 282-283.

»'Classicism' needs to be prised away from the prejudices that have crushed it under the mutually antagonistic values of a pure classical ideal on the one hand, and a pure modernist one the other. [...] These evaluations, which on both side are developed from 'pure' stances, do not stand up any more." Prav tam, 282.

11 Bandur, »Neoklassizismus«, 2.

12 Timms, »Modernism's moment of plenitude«, 19. 
Posodobljen pogled na neoklasicizem ponuja Oxford music online izpod peresa Arnolda Whittalla. Neoklasicizem definira kot slogovno gibanje v nekaterih delih skladateljev 20. stoletja, ki so, zlasti v obdobju med obema vojnama, oživili uravnotežene oblike in jasno prepoznavne tematske procese zgodnejših slogov, $\mathrm{v}$ nasprotju s pretiravanjem $\mathrm{v}$ dimenzijah in umanjkanjem oblikovnega reda poznega romantizma. Kot splošni pojem za specifična slogovna načela je zanj izraz neoklasicističen nenatančen in nikoli ni bil razumljen kot da bi se nanašal izključno na obuditev tehnik in oblik Haydna, Mozarta in Beethovna. Kot gibanje si je neoklasicizem izbral slogan »nazaj k Bachu«, čeprav je bilo zanj manj značilno oživljanje tradicionalnih postopkov kot pa reakcija na romantizem ali ekspresionizem. Vendar njegov cilj ni bil eliminirati vse ekspresivnosti, ampak jo le oklestiti in kontrolirati, meni. ${ }^{13}$ Izraz se je najprej nanašal na Stravinskega v letu 1923 in veljal zlasti za njegovo glasbo od Pulcinelle (1919-20) do Razuzdančevega življenja (1947-51), čeprav so dela skladateljev kot so Prokofjev (Klasična simfonija, 1916-17) in Satie (Birokratična sonatina, $1917 \mathrm{z}$ uporabo glasbe Clementija) že pokazala domiselnost, ekonomijo sredstev in aluzijo na oz. citiranje predromantičnih skladateljev, kar je najpogostejši prepoznaven znak neoklasicizma. Whittall imenuje neoklasicizem »historični performens « in ga primerja s »tendencioznim potovanjem nazaj - tja, kjer še nismo bili«. ${ }^{14}$ Označitev dejansko celotne vidnejše kompozicijske produkcije iz obdobja med 1918 in 1945 (Varèse je morda osrednja izjema) kot "neoklasicistične« je skupna vsem sodobnejšim piscem, ki verjamejo, da je bila pred letom 1945 storjena napaka, ki ji ni mogel ubežati niti pozni Webern - okoriščanje s skrajnimi inovacijami ekspresionizma, pojasnjuje. ${ }^{\text {I5 }} \mathrm{V}$ Pogovorih Stravinski-Craft je označil Stravinski neoklasicizem kot »obdobje formulacije «, ki je sledilo »obdobju raziskovanja« z viškom v letu 1912. Zanimivo je, da je slednji identificiral tudi tri neoklasicistične "šole": svojo, Hindemithovo in Schönbergovo, vključno s tistimi dvanajsttonskimi deli, ki so kljub atonalni klasifikaciji povezana $\mathrm{z}$ baročnim in klasicističnim obdobjem prek teksture in formalnega načrta. Še bolj presenetljivo pa je Boulezovo prepričanje, ki ga navaja isti pisec, da se poti Stravinskega in Schönberga do neoklasicizma razlikujejo v bistvu le v tem, da je ena diatonična, druga pa kromatična in da sta oba skladatelja "posvojila mrtve oblike ter bila

13 Arnold Whittall, »Neo-classicism«, v Oxford music online - Grove music online (Oxford: Oxford Univeristy Press, 2007-2016).

14 Prav tam.

15 Prav tam. 
tako obsedena z njimi, da sta jim dopustila, da transformirajo njune glasbene ideje vse do izumrtja. ${ }^{16}$

$\mathrm{Na}$ kratko še o najnovejših spoznanjih in pogledih na to slogovno smer, ki jih razkriva Hermann Danuser v že omenjeni dvanajst let stari zgodovini glasbe 2o. stoletja, ki je izšla v Cambridgeu. Po eni strani »obrača na glavo « tudi dolgoletno historiografsko tradicijo, ki je bila očitno ideološko-nacionalni konstrukt, po drugi strani pa jo primerneje definira oziroma postavlja na pravilnejše temelje. Obširneje razloži tudi začetke neoklasicizma, zgodovino njegove percepcije in kje je bil storjen »izvirni greh « za njegovo »izkrivljeno« pojmovanje. Pravi, da so morali biti v danem zgodovinskem trenutku izpolnjeni trije pogoji, da se je neoklasicizem mogel izviti iz raznotere predhodne faze oziroma oscilacije med klasicizmom in dunajskim modernizmom ter postal prevladujoča sila v sodobni glasbi. Prvi pogoj je bil ta, da je ekspresionistični modernizem zaključil svoj krog; drugi, da je avantgardno eksperimentiranje začelo izgubljati umetniško atraktivnost in socialno legitimiteto; tretji pa, da se je morala pojaviti oblika sodobne glasbe, ki je bila dojemljivejša za širšo publiko z vrnitvijo k bolj znanim (tradicionalnim) slogovnim sredstvom in oblikam. ${ }^{17}$

Meni, da sta se oba, Stravinski in Schönberg, v dvajsetih letih, čeprav na različen in antagonističen način, vrnila k preteklosti, ko sta postavila vzore za novo tonalnost na eni in dodekafonijo na drugi strani za nekaj desetletij ter da v tem smislu razlike med njima ne bi smeli videti kot strogo antitetične. Tri šole neoklasicizma, ki jih je omenjal Stravinski (Schönbergovo, Hindemithovo in svojo), so potem določale smeri glasbene zgodovine med letoma 1930 in $1945 .{ }^{18}$ Po srečanju Mednarodnega združenja za sodobno glasbo v Benetkah leta 1925 so se začele razlike med njihovimi predstavniki, ki so bile do tega "premirja« še fleksibilne, zaostrovati, razlaga Danuser. V estetiki in kompozicijski tehniki je nastala polarizacija med dodekafonsko

16 Prav tam.

17 "The historical moment when neoclassicism was able to emerge from a many-faceted preliminary phase or oscillation between traditional classicism and modernism and become the predominant force in contemporary music was, however, not reached until three conditions were met: expressionist modernism had to run its cycle; avant-garde experimentation had to start losing its artistic attractions and social legitimacy; and there had to emerge the possibility of a form of contemporary music that would be accessibe to wider segments of the public thanks to its recourse to familiar stylistic means and forms."Danuser, "Rewriting the past: classicisms of the inter-war period", 264 .

18 Igor Stravinsky in Robert Craft, Memories and Commentaries (London, 1981), 122. Cit. po: prav tam, 264-265. 
atonalnostjo, ki ohranja romantične principe ekspresivnosti na eni strani in novo tonalnostjo (»neotonality«), ki teži k objektivizaciji in zavračanju vse subjektivne izraznosti, na drugi. Prav zato splošna javnost dolgo ni vedela, da je bil Schönberg $\mathrm{z}$ razrešitvijo formalnih problemov svoje dvanajsttonske glasbe $\mathrm{v}$ prvi vrsti klasicist, je prepričan. Zmotna polarizacija je dobila na veljavi tedaj, ko je Adorno leta 1949 pisal le iz Schönbergovega zornega kota in razvil filozofijo nove glasbe, ki si je izposodila iz intelektualne zgodovine koncept razvoja nasproti restavraciji. Dejstvo je, da je neoklasicizem, zlasti tisti iz 20-ih let, ne glede na velike razlike v estetiki in kompozicijski tehniki, mogoče razumeti kot močno stremljenje k novi spojitvi klasicizma in modernosti (»new unity between classicism and modernity«) $\mathrm{v}$ glasbi $z$ vrnitvijo $k$ preteklosti. To gibanje je zajelo vse pomembnejše skladatelje, vključno s Hindemithom, ugotavlja Danuser. ${ }^{19}$

Kljub številnih delom po vzoru preteklosti ${ }^{20}$ se nova epoha po njegovem mnenju ni začela, dokler Stravinski ni razvil svojega načina predelave izvirnega gradiva $\mathrm{z}$ miksturami harmonskih popačenj, nerazvezanih disonanc oz. značilne instrumentacije. Primeri adaptacije predhodne glasbe $\mathrm{v}$ baletni obliki so sicer že nekaj časa obstajale, vendar je prav Stravinski prvi doumel možnosti njene neoklasicistične parodije. ${ }^{21}$ Po preselitvi v ZDA je tudi prvi prispeval $\mathrm{k}$ formiranju univerzalne neoklasicistične teorije $\mathrm{v}$ glasbi, ki jo je predstavil leta 1939 v Poetiki glasbe ter temelji zlasti na konceptu reda in oblike. ${ }^{22}$ Nacionalni klasicizmi so se po njegovem razvili približno v istem času, ozirajoč se $\mathrm{k}$ nacionalnim slogom preteklosti kot svoji osnovi, $\mathrm{z}$ željo, kot denimo v Italiji in Španiji, prispevati k občutku nacionalne identitete. ${ }^{23}$ Vplivna interpretacija neoklasicizma Stravinskega pa se je pojavila na temelju ruske formalistične teorije, ki so jo v prvi dekadi 2o. stoletja razvili Viktor Šklovski, Jurij Tinjanov in drugi. ${ }^{24}$ Prednost takšnega pristopa

19 Prav tam, 264-265.

20 Casella, Pupazzetti, 1915, Vinzenco Tommasini, Le donne di buon amore, 1917 po D. Scarlattiju, Ottorino Respighi - La boutique fantastique po Rossiniju, 1919 itd.

21 Opera Mavra, 1921-22 (Puškin, po zgledu Glinke), balet Vilin poljub, 1928 (po zgledu Čajkovskega) predstavljata »ruski neoklasicizem«. Prav tam, 266.

22 Pojavlja se v izzivalno suhoparnem aksiomu, pravi Danuser, ko citira besede Stravinskega: „Composing, for me, is putting into an order a certain number of these sounds accordnig to certain interval-relationships." Igor Stravinsky, Poetics of Music in the form of Six Lessons (tr. Arthur Kondel and Ingolf Dahl). Cambridge, MA, 6th edn, 1982, p. 37. Cit. po: prav tam, 266.

23 Prav tam, 267.

24 Viktor Erlich, Russischer Formalismus (Frankfurt am Maain, 1973), 189ff. Citirano po: prav tam, 268 , op. 14 . 
je bila v tem, da je branil avtentični neoklasicizem pred polemično obtožbo golega restavriranja starih slogov, vendar se še vedno v marsičem razlikuje od zmernega modernizma, ki se je iz njega razvil ter postal vplivna sila $\mathrm{v}$ tridesetih in štiridesetih letih 20. stoletja. Bistveni za ruski formalizem so koncepti parodije, deformacije in potujitve, pojasnjuje Danuser. Nanašajo se na tehnične postopke spreminjanja obstoječih struktur in oblik, s ciljem transformirati estetsko izkušnjo ter $\mathrm{z}$ njo povzročiti drugačen odziv publike. Ta je bil zares zelo buren, saj je bila navajena na sodobno glasbo, ki je bila izključno v okvirih poznoromantistične estetike. ${ }^{25}$ Po pravilnem predvidevanju ruskih formalistov vpliv tako ozko pojmovanega neoklasicizma ni bil širok: ostal je omejen predvsem na Stravinskega, zlasti na njegova dela do sredine tridesetih let. Principa parodije in potujitve sta bila okrnjena zaradi konstantnega stremljenja $\mathrm{k}$ inovaciji, znotraj katere so ostale historične reference ostale le eden od možnih slogov. S splošno averzijo do romantizma in 19. stoletja zaznamovana dela Nadie Boulanger in njenih učencev so tudi prispevala k določitvi zgodovine "neotonalne" glasbe v drugi četrtini 2o. stoletja.

V kolikšni meri so bili individualni neoklasicistični opusi oz. gibanja univerzalni (kot pri Stravinskem) ali nacionalni v orientaciji, ostaja zahtevno vprašanje za nadaljnje raziskovanje, meni Danuser. Po mnenju Erica Salzmana je bila ideja neoklasicizma, ki se je izkristalizirala v slog sintetizirane neotonalne glasbe, najbolj uspešna v tistih predelih, kjer je dobil klasicizem poznega 19. stoletja prizvok izumetničenega vsiljenega konstrukta, torej zunaj glasbene kulture centralne Evrope. ${ }^{26}$ Potrebno bi bilo opredeliti razlike $\mathrm{v}$ razvoju neoklasicizma v posameznih državah, pravi, saj gre za različne izvore, ki bodo pomagali pojasniti splošni trend neoklasicističnega gibanja. ${ }^{27}$

25 Prav tam, 267-268.

26 Eric Salzman, Twentieth-Century Music: An Introduction, 2nd edn (Englewood Cliffs, NJ, 1974), 43ff. Cit. po: prav tam, 269, op. 15.

27 Različne izvore neoklasicizma pri Italijanih, Francozih in Nemcih Danuser pojasni z besedami: "In 1920 Casella, Milhaud, and Hindemith set out from different points to make their contributions to the developement of music in Italy, France, and Germany before coming, a little later, exponents of neoclassicism. In Italy neoclassicism came from the rejecton of verismo opera and a desire to promote instrumental music; in France it sprang from a reaction to the primacy of German music's expressive aesthetic; in Germany itself it began with distaste for the expressive principles and formal canon of the classical and Romantic periods, including expressionism. Such a diversity of origins certainly provides some explanation for the general trend of developments in neoclassicism.«Prav tam, 269. 
Torej je pot raziskovanja izvora in oblik slovenskega neoklasicizma tudi še pred nami. Gotovo je to področje, ki je bilo doslej najmanj raziskano, zlasti zaradi njegove slabšalne obravnave $\mathrm{z}$ vidika in $\mathrm{v}$ luči adornovske mislenosti, zato je bil prav ta slogovni pojav večinoma tudi pri nas obravnavan kot regresiven in znotraj »vračanja $\mathrm{k}$ tradiciji«.

Da bi se zgodovinarji lahko izognili antagonističnemu pojmovanju preteklosti, zlasti slabšalni konotaciji izraza »neoklasicizem «, vpeljuje Danuser, kot rečeno, izraza »klasicistični modernizem« oziroma »modernistični klasicizem ${ }^{28}{ }^{28}$

Meni, da danes ideal (dunajskega) modernizma kot edinega dejavnika razvoja ni več kredibilen, kajti zelo dvomljiva je ideja o novi glasbi, ki bi naj zaključila svojo heroično fazo v dvajsetih letih, iz slepe ulice pa se zopet pojavila $\mathrm{z}$ razvojem serialne glasbe po drugi svetovni vojni. Neoklasicizem je po njegovi oceni prej del širše razumljenega in primerneje pojmovanega glasbenega modernizma. ${ }^{29}$

Meje med kreiranjem in prirejanjem, med invencijo in imitacijo so veliko bolj elastične, kot so pripravljeni priznati teoretiki estetike, ki fetižirajo izvirnost, ugotavlja..$^{\circ}$ Modnost del s končnico »-ana « je dosegla svoj višek med prvo svetovno vojno in sredino 20. stoletja. To je bil izraz "modernističnega klasicizma« (»modernist classicism«) - koncepta, ki se mu zdi bolj produktiven kot Adornova negativna ideja "neoklasicizma (ta jo je formuliral šele, ko je bilo gibanje že izčrpano), ker ne zagovarja restavracije, ampak modernost. Center tega razvoja je bila Italija: »-ana « dela so napisali Alfredo Casella, Gian Francesco Malipiero in Ottorino Respighi, skladatelji rojeni okrog 188o. Tudi malo mlajši Luigi Dallapiccola je prispeval k temu žanru, čeprav na svoj način. ${ }^{31}$

28 "But if historians are to avoid making antagonismus of the past the basis of their own understanding, what initially appears to be the oxymoronic notion of 'modernist classicism' or 'classical modernism' can be helpful. Simply at the level of terminology, it signals an endeavour to revaluate the phenomenon that has generally been treated in German-language musical historiohraphy under the negative title of 'neoclassicism'." Prav tam, 282-283.

29 "Today the ideal of modernism as a single-minded drive for progess is no longer credible: there is scepticism about the idea that new music ended its heroic phase in the 1920s, emerging from a blind alley only with the development of serialism after the Second World War. Neoclassicism is rather part of a more comprehensively and adequately understood musical modernism. « Prav tam, 282-283.

30 Prav tam, 270.

31 Tovrstna orkestralna dela so napisali, denimo, Malipiero - Cimarosiana, 1921, Vivaldiana, 1952, Gabreliana, 1971; Respighi - Rossiniana, 1925; Casella - Scarlattiana, 1926. 
Takšna »-ana« dela, kot denimo Rossiniana, so del širšega zgodovinskega konteksta, skupaj s skladbami brez »-ana" v naslovih, pojasnjuje Danuser. $^{32}$ Tudi Pulcinella od Stravinskega (1920), ki jo imamo za izvor neoklasicizma in pionirsko delo v modernizaciji zgodovinskega gradiva, je dejansko del istega splošnega razvoja, pravi. ${ }^{33} \mathrm{~V}$ Italiji se je modernistični klasicizem manifestiral v nacionalni tendenci vrnitve $\mathrm{v}$ slavno dobo italijanske glasbene zgodovine. Čeprav se tovrstna dela precej razlikujejo v rabi raznolikosti virov, je ta glasba predstavljala odklon od prevlade germanskega romantizma. »-Ana« dela na splošno predstavljajo le eno od možnosti kreativnega priziva že obstoječe glasbe in so le eno od klasicističnih idej in praks. Npr. z Bachianas brasileiras (1930) se je Heitor Villa-Lobos z obračanjem k Bachu priključil predvsem ključnemu trendu v evropskem modernističnem klasicizmu, v katerem so se "priredbe « Bacha izpod peresa Weberna, Schönberga, Stravinskega in mnogih drugih, denimo Hindemitha (Ragtime wohltemperiert in Ludus tonalis) uveljavile kot prevladujoč slogovni vpliv. ${ }^{34}$

Glasbeno retuširanje (»musical retouching») obsega najrazličnejše aspekte zgodovinskega teksta: tonaliteto, melodične linije, zvočne vzorce, obliko in ostale elemente glasbe, posamezno ali kombinirano. Gre za ambivalenten zgodovinski značaj klasicističnega modernizma oz. modernističnega klasicizma, ki je kombinacija preteklosti in sedanjosti, zgodovine in današnjega dne. ${ }^{35}$

Slogovno predstavlja klasicistični modernizem (izraz nam je ljubši zaradi samostalniške besede) oddaljitev od glasbenega modernizma s preloma stoletja, gre za razvoj, ki ga je povzročila kriza nove glasbe okrog leta 1910, pojasnjuje Danuser. V širšem smislu predstavlja obenem odklon od dveh glavnih paradigem 19. stoletja - nemške instrumentalne glasbe in italijanske opere, ki sta postali med elitami vsakdanjost univerzalne vrednosti, kljub različnim nacionalnim in kulturnim vidikom. Tudi $v$ 2o. stoletju so imele kljub internacionalnemu vplivu celo radikalne skladbe kot npr. Schönbergov Pierrot Lunaire in Stravinskega Pomladno obredje svoj izvor $\mathrm{v}$ elementih nacionalnega, če ne regionalnega. Klasicistični modernizem se zato po Danuserju, kot vsak estetski koncept, upira omejitvam slogovne definicije. O tem priča način, kako so glasbeni zgodovinarji "zapakirali« različne fenomene klasicizma (različne »tonalne« eksperimente Stravinske-

\footnotetext{
32 Prav tam, 272.

33 Prav tam, 273.

34 Prav tam, 273-274.

35 Prav tam, 275.
} 
ga, Hindemitha in Bartóka, dodekafonsko atonalnost Schönberga) v isto kategorijo. Dejstvo je, pravi, da so bili vsi ti fenomeni izvorno povezani $s$ skupno averzijo do estetike, ki je okrog stoletja, povzdignila ideal absolutne glasbe v estetsko religijo glasbene metafizike. ${ }^{36}$

S Stravinskim je slogovni obrat pridobil univerzalno kakovost. Hindemith, Bartók in ostali skladatelji so uvedli principe 18. stoletja v svoja dela na inovativen način, brez ozira na nacionalne slogovne kategorije. Poskušali so se izogniti vsemu, kar bi spominjalo na simfonično tradicijo 19. stoletja (denimo postopku »organskega« razvoja motivov), čeprav se je zgodovinsko tudi ta gradbeni princip izkazal za ambivalentnega, saj so se v istem času pojavile nacionalne zahteve. Okrog leta 1930 se je zdelo manj neobhodno potegniti jasno ločnico z estetskimi ideali 19. stoletja in tako so dela iz te dobe (kot simfonije, obsežni koncerti, simfonične pesnitve) dobile $a b$ novljen pomen. S Klavirskim koncertom iz leta 1942 se je Schönberg ozrl nazaj k velikim romantičnim primerom oblike, namesto k skromnejšim baročnim modelom. To je izraz ponavljajočega se spreminjanja zgodovinske reference, ki je bistveni sestavni del internacionalne mreže povezav v klasicističnem modernizmu, pojasnjuje Danuser in meni, da univerzalni in nacionalni faktorji vsekakor vplivajo na slogovni in ideološki ravni, vendar se razmerje med njimi spreminja. ${ }^{37}$ Med letoma 1920 in 1950 je bila ideja o klasicističnem modernizmu povezana $\mathrm{z}$ nacionalnimi glasbenimi elementi, vendar je dandanašnji jasno, da je glasba, ki je nastala pod tem okriljem, črpala še iz vrste drugih virov, je prepričan. Niti nacionalna niti univerzalna orientacija ne zagotavljata uspešnosti glasbenega dela ali ga izključujeta, ugotavlja in povzema: »Modernistični klasicizem je ena od temeljnih kategorij v historiografiji umetnosti in glasbe, ki je ne moremo definirati kot golo prepisovanje preteklosti: poglobljen pregled Scotta Messinga, Wolfganga Ratherta, and Volkerja Scherliessa kaže izjemno zgodovinsko širino, ki jo ta kategorija obsega. ${ }^{38}$

Arnold Whittall pa meni, da "vseobsegajoča definicija sicer reši marsikateri problem, npr. potrebo po odločitvi, v kakšnem smislu je Prokofje-

36 Prav tam, 278.

37 Prav tam, 279.

38 Scott Messing, Neoclassicism in Music: From the Genesis of the Concept through the Schoenberg-Stravinsky Polemic, Ann Arbor, 1988; Wolfgang Rathert, "Vom Klassicismus zur Postmoderne: Anmerkungen zur Musikgeschichte des 19. und 20. Jahrhunderts«, in: Meyer, ed., Klassizistische Moderne, 1996, 40-59; Volker Scherliess, »Torniamo all'antico e sará un progresso « - »Creative Longing in Music«, in: Boehm, Mosch, and Schmidt, eds., Canto d'Amore, 39-62, and Neoklassizismus: Dialoge mit der Geschichte (Kassel: 1998). Cit. po: prav tam, 280. 
va Klasična simfonija neoklasicistična, njegovi Peta in Šesta simfonija pa ne. Saj je pri mnogih skladateljih, od Berga in Bartóka do Lutosławskega, Elliota Carterja in Daviesa iluzorno poskušati ločiti 'inovativno' (in nadaljevanje ekspresionizma) od bolj očitne 'tradicionalnosti'. In vedno obstaja možnost, da bomo skladatelja, ki ga imamo danes za radikalnega ekspresionista, imeli jutri za neoklasicista. «" Omenjene težave z definicijo povzročajo probleme, ki jih predstavlja neoklasicistična glasba za analitike, ocenjuje. Nevarnost neproduktivnega posploševanja je morda pri neoklasicizmu večja kot pri katerem koli drugem slogu, opozarja. Zanj je zaenkrat najprepričljivejši pristop takšnih analitikov, kot je Salzer, čigar pogosto zelo temeljite modifikacije Schenkerjevih postopkov lahko vsaj določijo, do kakšne mere je lahko posamezno delo definirano kot »tonalno « nasploh. ${ }^{4 \circ}$

Z Whittallovo bojaznijo o nerešljivosti analitičnih problemov v zvezi z neoklasicističnimi skladbami se težko popolnoma strinjamo. Dejstvo je, da so bili tudi analitiki žrtev »adornovske zmote«. Napačno se zdi že razmišljanje o določanju količine tonalnosti v nekem delu, če je to modernistično, posttonalno, zunajtonalno, kljub številnim jasno prepoznavnim elementom iz starega sistema, saj gre pogosto za drugačno teksturo (politeksturo), razširjen nabor tonskih vrst (ne le molovih in durovih), njihovo naslojevanje, kolažni pristop in podobno. Iskati tradicionalne elemente $\mathrm{v}$ modernističnem delu zato, da bi se ga označilo za tradicionalnega, je nesmisel in sestavni del manipulacije. Problem je bil torej povsem drugje: $v$ ignoranci do priznavanja modernosti sodobnemu glasbenemu jeziku, ki elemente tradicije kombinira in povezuje med seboj na nov, a manj radikalen način. Dokaz za to je neustrezna, dvoumna in nedorečena terminologija za poimenovanje fenomenov iz območja posttonalne glasbe, ki ni atonalna niti tonalna. Množico teoretičnih fenomenov iz skladb modernističnega klasicizma $\mathrm{v}$ posttonalni tonikalnosti bo potrebno zato terminološko definirati na novo.

\section{Polislogovnost v opusu Demetrija Žebreta}

Če navežemo obe pravkar predstavljeni ideji na opus Demetrija Žebreta (1912-1970), lahko rečemo, da analitični izsledki ${ }^{41}$ potrjujejo Danuserje-

Whittall, »Neo-classicism «.

Prav tam.

Analizam Žebretovih skladb sta bili posvečeni magistrsko in doktorsko delo avtorice prispevka na Oddelku za muzikologijo Filozofske fakultete Univerze v Ljubljani. Prim. Karmen Salmič Kovačič, Orkestralni opus Demetrija Žebreta, mag. delo (Ljubljana: samozal., 2006), 31-194, in Demetrij Žebrè in sodobne slogovne tendence slovenske glasbe, doktorska disertacija (Ljubljana: samozal., 2016), 115-178. 
vo teorijo. Namreč, le redko katero skladateljevo delo lahko slogovno enoznačno opredelimo, čeprav vemo, da je študiral pri Slavku Ostercu, Josefu Suku in Aloisu Hábi. Še najlaže izrazno prepoznamo njegove pretežno ekspresionistično zasnovane samospeve in komorna dela ter impresionistične (simbolistične) ${ }^{42}$ Tri vizije za simfonični orkester. Povsod drugod moremo govoriti o polislogovni sintezi in pri opisovanju precej jasno med seboj ločevati posamezne strukturne elemente, ki komaj skupaj učinkujejo kot učinkovita celota.

Kljub številčni skromnosti skladateljevega opusa lahko ugotovimo, da je ta nastajal premišljeno, konsistentno ter $\mathrm{z}$ dodelano glasbeno poetiko. Slednja se je sicer od najzgodnejših stvaritev iz leta 1925 do zadnje skladbe $\mathrm{v}$ letu 1949 spreminjala, pod vplivom in v skladu s sodobnimi slogovnimi tendencami časa ter okolja, $v$ katerem je živel. Kot večina slovenskih modernistov prve polovice 20 . stoletja, ki jih je pritegnila in zaznamovala ideja "napredka« oziroma »inovacije«, je v novem ter svobodnem zvočnem svetu po prelomu s tradicionalno tonalnostjo moral poiskati drugačne rešitve vezivnosti in artikulacije glasbena toka, kar je prej omogočal tonalni sistem sam po sebi.

Analize večine njegovih skladb, zlasti pa vseh orkestralnih, so pokazale, da je njegov opus večkrat doživel slogovne premene. Preseneča dejstvo, da je mladi ustvarjalec začel svojo kompozicijsko pot s precej radikalnimi novostmi za tisti čas $\mathrm{v}$ slovenski glasbi pod vplivom ekspresionističnih slogovnih tendenc pri nas in tudi že elementov nove stvarnosti. Kje je dobil spodbude za tako aktualen in disonančno zaostren zunajtonalni zvočni svet, denimo, v zgodnjih samospevih, kot so Tepežnica (1928) in Trije samospevi na Župančičeva besedila (1929), ostaja odprto vprašanje.

Skladbe iz časa študija pri Slavku Ostercu (v letih 1929-1934) kažejo med drugim vpliv Hindemitha, Stravinskega, Šostakoviča, nove stvarnosti, jazzovskih elementov ter ameriške plesne glasbe tistega časa. Zlasti opazen je parodično-humoren lahkotnejši in antiromantični izraz, značilen za predstavnike francosko-ruske osi znotraj širokega toka modernističnega klasicizma oziroma klasicističnega modernizma (Intermezzo saxofobico za saksofon in klavir, 1932, Burleska za violino in klavir, 1933, Pihalni trio za flavto, klavir in fagot, 1934 ter orkestralna Suita za mali orkester).

42 Čeprav je "glasbeni simbolizem" primernejša slogovna oznaka za glasbo Treh vi$z i j$, ki s »slikanjem" narave ali zunanjih pojavov nimajo nič skupnega, gre pri teh za kompozicijsko tehniko »impresionizma«, ki je najpogostejši in najbolj uveljavljen izraz za slog, denimo, Debussyjeve glasbe. 
Zanimivo je, da je skladatelj v svojih samospevih ter v večini svojih komornih in solističnih del ohranil ekspresionistični slog z elementi nove stvarnosti vse do zadnjih Treh samospevov na besedilo Mitje Šarabona leta 1944. To dokazujeta tudi denimo Scherzo (1925) in Nocturno (1944) za klavir oz. priredba slednjega za violino in klavir (1947), ki začenjajo ter zaključujejo njegov ekspresionistični lok izraznosti. Ta se še posebej vzpne med in po Žebretovem prihodu iz Prage v delih kot so Godalni kvartet (1935), Caprice (1935) in Preludij za violino in klavir (1936), Trije lirični poemi za violino in klavir (1937), komorne skladbe in otroški zbori v četrtonskem in šestinotonskem sistemu ter orkestralni skladbi Tek (1935) in Toccata (1936). Sodijo med »najradikalnejša"s slovenska ekspresionistična dela.

Leta 1938 začne Žebrè vključevati impresionistične tehnike v svoj kompozicijski slog in ustvari zaporedoma dve obsežni skladbi pod vplivom Clauda Debussyja. Polislogovni balet (simfonično sliko v treh stavkih) Dan oz. Bacchanale (1938-1942) ${ }^{43} \mathrm{z}$ elementi impresionizma, ekspresionizma, nove stvarnosti in postromantike zaključi štiri leta zatem. Njegova zamisel o izključno impresionistični skladbi pa se uresniči že prej. Leta 1939 nastane njegov prvi »impresionistični biser« z naslovom Vizija, ki se ji pridruži leta 1942 Tretja, imenovana tudi Prebujenje, in leta 1943 še Druga. Cikel Treh vi$z i j$ (sestavil ga je glede na glasbeno vsebino, ne po letnicah nastanka), je njegovo najbolj slogovno enovito delo in eno najboljših orkestralnih impresionističnih skladb na Slovenskem.

Nekatere impresionistične tehnike ostanejo v manjši meri del kompozicijskega stavka tudi v njegovih kasnejših orkestralnih skladbah, kljub njihovemu drugačnemu končnemu izraznemu učinku (figuralne teksturne plasti, za impresionizem značilne tonske vrste - pentatonika, celotonska lestvica ipd. ob daljših, tudi kromatičnih tonskih strukturah). Pod močnejšim vplivom impresionstičnega izraza in tehnike, ki ga združi z ekspresionističnem, pa ostaja le še Maja in morje za sopran in orkester (1944). Tendenci socialističnega realizma $\mathrm{z}$ večjim nagibom $\mathrm{k}$ tradicionalnim oblikovnim postopkom in diatoničnim strukturam je prilagodil skladatelj orkestralna dela Svobodi naproti (1944), Žalno glasbo v spomin Slavka Osterca (1945) in Allegro risoluto-marciale (1949), posebej veličastno polislogovno delo sodobnega klasicističnega modernizma pa je Concertino za klavir in orkester (1946).

43 Skladba je poznana pod naslovom Bacchanale, dokler se ni ugotovilo pravega naslova dela. Prim. Salmič Kovačič, Orkestralni opus Demetrija Žebreta, 59-72. 
Podrobneje poglejmo orkestralna dela, ki jih zaznamuje polislogovnost modernističnega klasicizma, razen Treh vizij, ki jih ne kaže razumeti drugače kot Žebretovo študijo impresionističnega sloga.

Suita za mali orkester (1932) v štirih stavkih (Koračnica, Valček, Tango, Blues) kaže slogovne vplive novega klasicizma, novega baroka, nove stvarnosti in jazzovske glasbe. Zaznamujejo jo punktirani ritmi, ritmična polimetrija v horizontali in vertikali, ostinatni ritmični utrip, novobaročni oblikovni postopki, svoboden posttonalni zvočni prostor - od razširjenih diatoničnih tonskih vrst do popolne kromatike, svobodna raba nefunkcionalno vezanih tonalnih in novih akordskih struktur (iz kvart, kvint) ter njihovo politeksturno naslojevanje. Neoklasicistična parodija s humornim učinkom je posledica "politonikalne« melodične linije v stilu Prokofjeva ali Šostakoviča in ostinatnih teksturnih plasti.

V dveh delih za veliki orkester iz časa praškega študija - v Teku (1935) in Toccati (1936) je Žebrè disonančno zaostril tonski prostor do skrajnih meja s popolnim zapolnjevanjem kromatičnega prostora, vendar brez Schönbergove dodekafonske sistematike, kar je bil brez dvoma Hábin zgled, razvijanje neskončne variacije motivičnega gradiva brez ponavljanja pa Hábin in Sukov vpliv. Skladba ima skrajno napeto, ekspresionistično, glasbeno dikcijo, z ekstremnimi dinamično in disonančno zaostrenimi viški. Redko ponavljanje tonov je prisotno zgolj v določenih, motorično-ritmičnih teksturnih plasteh, katerih ritmični utrip skladbo poenoti kot element nove stvarnosti, baroka in jazzovske glasbe. Pretežno atonalno (atonalitetno) in atematsko delo $\mathrm{z}$ ekspresionističnim izrazom je skladatelj objektiviziral $\mathrm{z}$ ritmičnim pulzom (ostinatom) glasbenega toka $\mathrm{v}$ eni od teksturnih plasti, ob gosti politeksturni ritmično-metrični "polifoniji«. To je bila njegova rešitev pri snovanju obsežnejših orkestralnih skladb v tistem času. Zaradi redke tonalne asociativnosti in bolj ali manj podobne teksturne zasnove skozi vse delo pa v njej vendarle pogrešamo več oblikovnih predahov.

Tri vizije so edino Žebretovo delo, ki ga je ustvaril izključno v impresionističnem slogu. Balet (simfonična slika) Dan oz. Bacchanale za veliki orkester in samospev Maja in morje za sopran in orkester pa sta polislogovni deli, pri katerih ima impresionistična izraznost sicer levji delež, vendar ni edina. V obeh je skladatelj ohranil precej impresionističnih tehnik - od orkestralne in harmonske barvitosti do figuralnih ostinatnih plasti, zvočnih ploskev in strukturne enovitosti tonskih polj. Za razliko od Vizij in skladbe Maja in morje se v baletu Dan (Bacchanale) je za glasbeno sintakso značilna epizodična struktura s hitro menjavo raznolikih odsekov, različnih po 
tonski kot ritmično-metrični vsebini. Izraznost se pne od lirične (romantične) zamaknjenosti do impresionistične barvitosti, od ekspresionistično disonančne zaostrenosti in napetosti do ritmično-metrične impulzivnosti in pregnantnosti nove stvarnosti. Hitra polislogovna in kalejdoskopska menjava raznolikih glasbenih bitnosti v »razrezani« sintaksi uvršča to stvaritev med najobsežnejša in najboljša baletna dela modernističnega klasicizma v najširšem pomenu besede.

Samospev za sopran in orkester Maja in morje (1944) na Gradnikovo besedilo je nastal sicer istega leta kot simfonična pesnitev Svobodi naproti (1944), vendar v precej drugačni tehniki in slogu. To dokazuje, kako se je Žebrè v Svobodi naproti prilagodil estetiki socialističnega realizma, ki je očitno vplivala na njegovo obrnitev k sintaksi, stavčni tehniki in oblikam klasicizma. Medtem ko je Maja in morje po slogu impresionistično-ekspresionistično delo, je Svobodi naproti oblika modernističnega klasicizma z razponom od romantičnega lirizma do dramatičnosti, ob koračniško poudarjenem ritmičnem toku. Ta dinamizem ekspresivnosti v slednji zelo dobro podpira sama sonatna oblika, ki jo je Žebrè znal preoblikovati na izviren način. Klasicistična sta tudi periodična struktura kratkofraznih tem in motivično-tematsko delo. Sicer povezuje vsa njegova orkestralna dela iz štiridesetih let poleg politeksturne zasnove tudi izbira bolj diatoničnih tonskih vrst v melodiki. Te skladatelj "politonikalno« razslojuje po različnih teksturnih komponentah, ki rezultirajo $\mathrm{v}$ disonančnosti stavčne vertikale. Podobnost med njegovimi orkestralnimi deli iz štiridesetih let je tudi v sukcesivni gradnji tonskih polj z različno domeno tonskih višin in vključitev ene ali več ostinatnih teksturnih plasti, ponavadi figuralnih, ki pripevajo $\mathrm{k}$ bogatejši barvitosti zvoka. Oboje je dediščina impresionističnih tehnik.

Pri omenjenem orkestralnem samospevu pa je drugačna tudi izraznost skladbe. Čeprav je stavčna tehnika impresionistična, zelo podobna tisti iz Vizij ali baleta Dan (Bacchanale), je izraz le mestoma impresionističen. Pogosteje je namreč ekspresionističen, $\mathrm{z}$ večjimi tonskimi skoki in dvigovanjem melodičnih linij do »kričečih" viškov. Gre za precej podobno napetostno "valovanje " glasbenega toka kot v Vizijah, le da je to v Vizijah prefinjeno v ustvarjanju lirično impresivnega vzdušja, pri samospevu pa se izraz konstantno stopnjuje do ekspresionistične skrajnosti po vmesnih sprostitvah. Napetostno nihanje je v samospevu torej veliko bolj dramatično in razgibano in je izraz nenehnega "tragičnega hrepenenja«, prispodobe razburkanega morja, ki do konca ne popusti. V njem ni romantičnega lirizma, ki preveva vse tri Vizije ob redkih dramatičnih vznemirjenih. Sicer je čle- 
njenje podobno kot v Vizijah - zaporedno nizanje dveh podobnih motivičnih fraz, ki se tretjič motivično spremenijo, daljših struktur (tem) pa nikoli ne razvijejo. V tem se obe skladbi razlikujeta od periodičnih klasicističnih struktur v delih, ki so nastala pod vplivom socialističnega realizma (Svobodi naproti, Žalna glasba in Allegro risoluto-marciale)

Raznolikost obeh skladb (Maja in morje, Svobodi naproti), ki sta nastali v istem letu, tudi dokazuje, da Žebrè ni omilil svojega sloga s transparentnejšimi klasicističnimi modeli in stavčno sintakso $\mathrm{v}$ glasbi za orkester $\mathrm{v}$ poznih štiridesetih letih zato, ker bi bil po naravi nagnjen $\mathrm{k}$ tradiciji, ampak že iz omenjenih razlogov. Našel je najmilejšo obliko modernizma, perceptibilno tudi za širše množice s prav določenim namenom. Orkestralni samospev Maja in morje ter Concertino za klavir in orkester (1946) ne izstopata od teh le po disonančni zaostrenosti in bolj kromatični tonski vsebini, ampak tudi po izrazu, še najbolj radikalno zunajtonalni (atonalni) in ekspresionistično izrazni pa so Trije samospevi za glas in klavir na besedilo Mitje Šarabona iz istega leta (1944), ki dodatno dokazujejo širok diapazon slogovne izraznosti v istem časovnem okviru skladatelja. Nasploh je ta ohranil ekspresionistični slog, kot rečeno, v zvrsti samospeva, komorne in solistične glasbe, vse od začetka do zadnje tovrstne skladbe. Orkestralni samospev Maja in morje je edina izjema. Le-tega je zasnoval polislogovno, pretežno pa $\mathrm{z}$ impresionističim in ekspresionističnim izraznim navdihom, kot smo ugotovili.

Concertino za klavir in orkester (1946) je edino skladateljevo instrumentalno koncertantno delo, s stavki Allegro con moto, Andantino in Allegro. Kljub skromni oznaki »concertino" gre za pol ure dolg klavirski koncert $\mathrm{z}$ veličastno težo (čeprav so vse njegove skladbe dodelane umetnine). Žal ga pri nas slabo poznamo, ker je zahteven za izvajanje. Sicer ga lahko postavimo ob bok koncertom največjih klasikov klasicističnega modernizma - Ravela, Bartóka, Šostakoviča, Prokofjeva in drugih.

Poleg tega, da je skladatelj klavir ob violini tudi dokaj dobro obvladal in poznal, ga je očitno izbral zato, ker je najprimernejši za »tolkalno" obravnavo (spomnimo na njegovo identično vlogo tudi v Suiti za mali orkester). $\mathrm{V}$ koncertu prevladuje tokatni element $\mathrm{z}$ jazzovskim pridihom. Še najlaže bi ga primerjali z Ravelovim koncertom v G-duru. Slogovno gre za modernistični klasicizem, ki se pogosto izrazno spreminja - od neoromantičnega lirizma in dramatike, impresionističnih segmentov, do parodije, nove stvarnosti in prevladujoče klasicistične zadržanosti. Od vseh strukturnih parametrov je najpomembnejši ritmično-metrični s svojo nenadno spre- 
membo, zaznavna pa je tudi politeksturna kombinatorika. Ritmično-metrična polifonija in variacija sta tako pestri v dogajanju, da ne moreta zanikati svojega izvora v jazzovski glasbi. Poleg tega je tokatni, zvočno suhi, kratki in odsekani ritmično-metrični pulz (v klavirju, pihalih itd.) pogosto tisti, ki prispeva $\mathrm{k}$ pregnantnosti in energetski razgibanosti dela, ob pogostem in raznolikem spreminjanju teksture. Motivično-tematsko delo je bolj podobno konstantni variaciji in nenehnemu izpeljevalnemu procesu. Teksturni, zvočni in izrazni kalejdoskop, ki je podprt $\mathrm{z}$ razgibano dinamiko in pestro zvočno barvitostjo, je s kolažno tehniko gradnje povezan v enkratno in razgibano celoto. Predstavlja odličen primer koncerta modernističnga klasicizma in posttonalne tonikalnosti s tipično polislogovno izraznostjo. Nova stvarnost se ga dotika $\mathrm{v}$ obliki energetsko razgibane in polnokrvne ritmike. Kljub naslonu na obrise sonatnega modela je sintaksa modernistična, stavek bolj disonančno zaostren in kromatičen. V tem se razlikuje tudi od treh socrealističnih orkestralnih skladb iz štiridesetih let.

Ostale tri orkestralne skladbe iz tega časa (Svobodi naproti, Žalna glasba v spomin Slavku Ostercu, Allegro risoluto-marciale), kot rečeno, temeljijo na klasicističnih sonatnih modelih, ki jih je Žebrè po svoje izvirno modificiral. Vse imajo periodično stavčno gradnjo, izbor tonskega gradiva pa je precej bolj diatoničen kot $\mathrm{v}$ koncertu, vendar svobodno tonikalen, ponekod temelji tudi na kromatičnih tonskih vrstah. Zvočni prostor je posttonalno razširjen. Modernistična ostaja $\mathrm{v}$ teh skladbah tudi tekstura, stavčna sintaksa pa je klasicistična in temelji na dramaturgiji nasprotja tem, njihovi izpeljavi in reprizi. Motivično-tematska enovitost mnogoterosti zagotavlja vsem skladbam koherentno strukturo, ki jo Žebrè razdela tudi na ravni orkestralnega zvoka oziroma zvočnobarvnega dinamizma glasbenega toka. Izraznost teh skladb pa je v precejšnji meri romantična, »čustveno« angažirana.

Če se vrnemo $\mathrm{k}$ polislogovnosti del klasicističnega modernizma, Žebretova glasba ni osamljen primer, zato bodo primerjave s skladateljivimi sodobniki predstavljale $\mathrm{v}$ prihodnosti še poseben izziv. Na tem mestu omenimo le nekaj od tega, kar Arnold Whittall, denimo, ugotavlja o Bartókovi glasbi:

"Nevertheless, Bartók was no slave to emotional neutrality, or to the purely architectural delights of formal manipulation and construction: variety of expression, the playing off of the dynamic aga- 
inst the lyrical, was essential if those largescale works were not to seem arid and formulaic. ${ }^{44}$

Ko ga primerja s Stravinskim, pa omeni tudi Bartókov modernistični klasicizem:

"This contrast of character and temperament can also be extended to a distinction between the confident iconoclasm of Stravinsky's neoclassicism, which preserves and even enchances the formal discontinuities of modernism - even if it also rejects the expressionistic manner with which modernism before 1920 was primarly associated - and the concern to validate and yet transform traditions characteristic of Bartók's modern classicism, in which stylistic allusions to Bach or Beethoven are, on the whole, less direct. " ${ }^{45}$

Socialistični realizem je pri nas in $\mathrm{v}$ drugih socialističnih deželah sovpadal z neoromantičnim valom (primer Anglija) na Zahodu, kjer so štirideseta leta že predstavljala dovolj velik časovni odmik od objektiviziranega neoklasicističnega izraza, da je izrazito odklanjanje estetike romantizma tedaj že izgubilo svoj najmočnejši vpliv. Zato je dokaj razumljivo, da se je modernistični klasicizem štiridesetih let 2o. stoletja manifestiral v obliki polislogovne sinteze, v kateri so se združevale vse slogovne silnice in kompozicijske tehnike prve polovice stoletja. Na ravni osebnih ustvarjalnih poetik so kulminirale kot skupek znanja, razgledanosti in izkušenj z že preizkušenimi »čistimi« rešitvami skladateljev, ki so bili sopotniki tega časa. Tisti, ki so se zavedali, da je estetska vrednost vendarle pomembnejša od »naprednosti« umetnine, še najbolj od vsega pa samobitnost ustvarjalca (tako sta učila tudi Suk in Hába), so izrazili svoja čustva in muzikalnost svobodno brez pridržkov. Ne nazadnje je bil to tudi čas, ko »lepa« (romantična) in »vedra, humorna« (klasicistična) čustva niso bila več "prepovedana« s strani zagovornikov radikalnega ekspresionizma, nasprotno, v okviru omejitev socialističnega realizma so bila celo zaželena.

$\mathrm{O}$ razliki med neoklasicizmom in modernističnim klasicizmom, $\mathrm{v}$ okviru katerega se najde mesto tudi za romantično izraznost, kar na neki način potrjuje našo tezo o polislogovnosti modernističnega klasicizma, pa tudi o dejstvu, da je predlagani Danuserjev izraz že dokaj uveljavljen, vsaj na univerzi v Cambridgeu, pričajo naslednje Whittallove besede:

44 Arnold Whittall, Exploring Twentieth-Century Music: Tradition and innovation (Cambridge, Cambridge University Press, 2003), 56. 
"There is another consequence of the distintion between neoclassicism and modern classicism: to the extend that neoclassicism depends on sudden shifts, conflicts and disorientating textural and stylistic effects, it is as much an outgrowth of late romanticism as of earlier, genuine classicism. $\aleph^{46}$

\section{Sklep}

Kot lahko ugotovimo, je večina Žebretovih orkestralnih del po izrazu in kompozicijski tehniki polislogovnih. Brez natančne analize in opredelitve posameznih strukturnih elementov določene skladbe sta njihova celovita predstavitev in razumevanje oteženi. Morda bo v luči postadornovske miselnosti in Danuserjevega klasicističnega modernizma olajšana analitično-slogovna obravnava tudi tistih skladb slovenskih skladateljev, ki so nas spravljale v zadrego pri poskusu slogovnega opredeljevanja. Če je v dosedanji »adornovski« perspektivi obstajalo samo »tradicionalno « (klasicistično, romantično) in "novo" (modernistično, avantgardno, ekspresionistično), bo potrebno, glede na najnovejše in vedno soglasnejše poglede različnih teoretikov na dosedanjo interpretacijo zgodovine in filozofije glasbe 20. stoletja, njene postulate temeljito prevetriti in jih postaviti na drugačna izhodišča. Vendar to ni bila ambicija niti namen pričujočega prispevka. Če smo $\mathrm{z}$ njim uspeli le opozoriti na določena, dolgo spregledana dejstva o kompozicijskih tokovih in tendencah glasbe $\mathrm{v}$ 1. polovici predhodnega stoletja, ki bodo spodbudila ponovno odpiranje vprašanj, je bil naš namen dosežen.

\section{Bibliografija}

Bandur, Markus. "Neoklassizismus«. V Handwörterbuch der Musikalischen Terminologie Ordner IV: M-O, ur. Heins Heinrich Eggebrecht, in Albrecht Riethmüller (po 1. 1999). Wiesbaden: Franz Steiner Verlag, 1994.

Botstein, Leon. »Modernism«. V Oxford music online - Grove music online. Oxford: Oxford University Press, 2007-2016. Obiskano 1. december 2015. http://www.oxfordmusiconline.com.ezproxy.lib.ukm.si/subscriber/article/grove/music/40625?source $=$ omo_gmo\&source $=$ omo_t237\&source $=$ omo_t114\&q=modernism \&article_section $=$ all\&search $=$ article\&pos=1\&_start=1\#firsthit.

Butler, Christopher. "Innovation and the avant-garde, 1900-20«. V The Cambridge history of twentieth-century music, ur. Nicholas Cook and 46 Prav tam. 
Anthony Pople, 69-89. Cambridge etc.: Cambridge University Press, 2004.

Cook, Nicholas and Anthony Pople, ur. The Cambridge history of twentieth-century music, Cambridge etc.: Cambridge University Press, 2004.

Danuser, Hermann. »Rewriting the past: classicisms of the inter-war period «. $\mathrm{V}$ The Cambridge history of twentieth-century music, ur. Nicholas Cook in Anthony Pople, 260-285. Cambridge etc.: Cambridge University Press, 2004.

Franklin, Peter. »Between the wars: traditions, modernisms, and the 'little people from the suburbs'«. V The Cambridge history of twentieth-century music. ur. Nicholas Cook in Anthony Pople, 186-209. Cambridge etc.: Cambridge University Press, 2004.

Salmič Kovačič, Karmen. Orkestralni opus Demetrija Žebreta. Magistrsko delo. Ljubljana, samozal., 2006.

Salmič Kovačič, Karmen. Demetrij Žebrè in sodobne slogovne tendence slovenske glasbe. Doktorska disertacija. Ljubljana, samozal., 2016.

Salmič Kovačič, Karmen. »Donedavno pojmovanje glasbenega modernizma 'adornovska zmota'?«. Muzikološki zbornik 53,1 (2017): 121-141.

Timms, Andrew. »Modernism's moment of plenitude«. V The modernist legacy: essays on new music, ur. Björn Heile, 13-24. Farnham, Surrey: Ashgate, 2009.

Whittall, Arnold. Exploring Twentieth-Century Music: Tradition and innovation. Cambridge, Cambridge University Press, 2003.

Whittall, Arnold. "Neo-classicism«. V Oxford music online - Grove music online. Oxford: Oxford University Press, 20072016. Obiskano 12. december 2015. http://www.oxfordmusiconline.com.ezproxy.lib.ukm.si/subscriber/article/grove/ music/19723?q=neoclassicism\&search=quick\&pos=1\&_start=1\#firsthit. 

Nekaj misli o slovenskem zborovskem skladanju med obema svetovnima vojnama

\author{
Andrej Misson \\ Univerza v Ljubljani \\ University of Ljubljana
}

Vse je ekstaza, ekstaza smrti!

Zlati stolpovi zapadne Evrope,

kupole bele - (vse je ekstaza!) -

vse tone $v$ žgočem, rdečem morju;

sonce zahaja in $v$ njem se opaja

tisočkrat mrtvi evropski človek.

- Vse je ekstaza, ekstaza smrti. -

Srečko Kosovel (1904-1926), Ekstaza smrti

Slovenci smo po stoletnem prizadevanju leta 1918 našli nov državni okvir, ki naj bi nam zagotovil tudi večji kulturni in umetniški razvoj. Nova država je nedvomno dala spodbudo naši kreativnosti. Zborovska ustvarjalnost je bila razpeta med prilagajanjem sposobnostim naših zborov in hotenjem skladateljev po sledenju modernim umetniškim dosežkom tedanje evropske glasbene ustvarjalnosti. To sledenje pa je po eni strani tudi problem, saj lahko izgubljamo svojo nacionalno glasbeno, umetniško in kulturno identiteto. $\mathrm{O}$ tem je tedaj pisal skladatelj Anton Lajovic. Naši starejši, na tujem in doma vzgojeni skladatelji (Hubad, Adamič, Premrl, Lajovic, Dev, Mirk, Pavčič, Sattner, Hochreiter in drugi), so vstopili v zrelo obdobje ustvarjanja. Skladatelji mlajših generacij, prav tako glasbeno izobraženi doma in na tujem (Kogoj, Prelovec, Osterc, Švara, Bučar, Kernjak, Mav, Marolt, Pahor, Pirnik, Ravnik, Breda Šček, Tomc, Ukmar in drugi), pa so iskali svojo »ars nova«. 


\section{Kratko o zgodovinskem okviru}

Takoj po prvi svetovni vojni je bilo gospodarsko stanje Slovencev težko. V novi državi, ki je izgubila precej ozemlja, poseljenega s Slovenci, je bilo potrebno nadaljevati družbeno urejenost, podedovano po Avstro-Ogrski. Po drugi strani pa uveljaviti nacionalno svobodo, ki smo jo pričakovali po združitvi z bratskima, južnoslovanskima, narodoma. Sprva sta bili med našimi predniki vzplamtela zadovoljstvo in lojalnost do nove skupnosti, oboje pa je kmalu začelo plahneti. Leta 1920 je tako v samozaložbi Luke Kramolca izšla zbirka domoljubnih pesmi, Narodni praznik, za meščanske osnovne in srednje šole, posvečena novi domovini. $\mathrm{V}$ zbirki so bile objavljene številne skladbe tedanjih uveljavljenih slovenskih skladateljev (Alojzij Mav, Vasilij Mirk, Ivan Ocvirk, Karol Pahor, Matija Tomc, Josip Klemenčič, Emil Adamič, Emil Hochreiter, Hugolin Sattner idr.).

O tem obdobju so tedanji izobraženci pripravili zanimivo delo, ki ga je uredil Josip Mal, Slovenci v desetletju 1918-1928. ${ }^{2} \mathrm{~V}$ njem so številni avtorji podali analizo družbenega, ekonomskega, kulturnega in umetniškega stanja Slovencev v tedanjem času.

O stanju tedanjega duha je zanimivo zapisal Francé Koblar v prispevku Slovenska književnost $v$ zadnjih desetih letih:

"Kakor hitro pa smo stopili v državno zvezo, kakršno je prinesel konec svetovne vojne, se je takoj pokazalo dvojno mišljenje in dvojna narodno politična usmerjenost: slovenstvo, vklenjeno $v$ južnoslovansko državnost na eni strani, na drugi pa jugoslovanska državna in narodna edinost s tendenco, da se razločki med posameznimi deli čimprej izravnajo in strnejo v narodnem "jugoslovanstvu«. [...] Tesnoba, ki je legla na Slovence ob izgubi naših meja, se je prelivala $v$ tesnobo radi notranjega nereda in nasilstva $v$ obliki materialističnega jugoslovanstva, ki narodno tradicijo taji in sklepa račune samo s politično močjo. Vsporedno z omalovaževanjem lastnega duhovnega bogastva in malodušnostjo je istočasno rasla slovenska individualna zavest. Deloma je to ogorčenje, deloma dovršavanje lastne kulturne stavbe $v$ tesnejši in smotrnejši organizaciji kulturnega življenja, deloma iskanje svoje globlje bitnosti. Osnovna črta pa je duhovna defenzivnost Slovenstva. [...] Svetovna vojna je pokopala pod seboj stari red in mladi rod, ki se je vračal domov in tis- 
ti, ki je ostal doma, ni zase našel nikjer trdnih opor za življenje. Literarna mladina je zavrela $v$ revoluciji, etični in formalni. Zgraditi nov svet, novega človeka nasproti lažnivemu formalističnemu meščanstvu, iskrenega in neposrednega, iz dna, je bila parola. O resničnosti tega hotenja ni dvomiti; mladina, ki gleda stari svet okoli sebe $v$ najgrši popačenosti, a nima na njegovo mesto postaviti niti približno zgrajenih temeljev, prerokuje nov razpad in podira dalje. Ves njen novi svet biva šele $v$ slutnji. Zato se je ta mladi rod dosledno izgubljal v simbolističnem epigonstvu, vizionarnih parafrazah, misleč, da oblikuje novo in na nov način."

Te misli, mutatis mutandis, veljajo tudi za skladatelje. Ti so tako v letu 1919 še pisali domoljubne, politično angažirane pesmi, kar pa je kmalu zamrlo. O čedalje večji stiski Slovencev v novi državi priča tudi zapis iz dnevnika škofa Antona Bonaventure Jegliča s konca leta 1929: »Sedaj skoraj verjamem in kar sem že večkrat slišal, da tudi kralj laže. $^{3}$

Sicer pa so se med jugoslovanskimi skladatelji spletle vezi, ki trajajo vse do danes. Skupaj bi morda lahko zgradili glasbeni prostor, ki bi v svetu imel kakšno težo. Žal ga danes ponovno, razmeroma neodmevno, gradimo sami. Vsekakor pa je zborovska umetnost vezana na besedilo. Slovenci smo želeli peti slovenske pesmi, drugi narodi pač pesmi v svojih jezikih. Na koncertnih programih slovenskih zborov so bila dela jugoslovanskih skladateljev, kako so bila naša dela zastopana po Jugoslaviji, pa ne vem. Zdi se mi, da smo se tedaj v zborovskih skladbah še bolj naslonili na slovensko literarno umetnost in ljudsko pesem ter strnili svoje skladateljske vrste. Naj kot primer tedanjih težkih povojnih gospodarskih razmer v Sloveniji, iz katerih je rastla tudi umetnost, navedem starega očeta Štefana Brezarja, ki se je leta 1926 iz Globodola pri Mirni Peči odpravil na delo v »Ameriko«. O njem sem našel zapis kanadske imigracijske službe, na katerem je zapisano, da so iz francoskega pristanišča Boulogne-sur-Mer odpluli 3. apr. 1926 in 14. apr. 1926 prispeli v kanadski Halifax. Sicer se, žal, staremu očetu ta izlet ekonomsko ni posrečil, domov se je vrnil kot revež.

Naj kot pričanje o tedanjem slovenskem zavedanju navedem še besede urednika Josipa Mala v predgovoru k delu Slovenci v desetletju 1918-1928:

"Naravno je zato, da se nismo mogli pri tem ozirati le na tisti del slovenskega narodnega telesa, ki mu je pred desetimi leti usoda do-

3 Blaž Otrin, Marija Čipić Rehar, ur., Jegličev dnevnik (Celje: Celjska Mohorjeva družba, 2015), 1035. 
volila, da je uresničil svoj sen in se $z$ brati združil pod eno državno streho. Ne, - naša pažnja in naša ljubav veljaj še prav posebno onim našim rojakom, $k i$ so jih diplomati iztrgali iz naročja prave, skupne domovine in jih žrtvovali tujemu, zemlje lačnemu pohlepju. Ravno tako pa tudi nismo smeli prezreti tistih, ki so - zapustivši naš kompaktno naseljeni etnografski teritorij - šli v široki tuji svet, da si tam poiščejo kruha ali si izboljšajo svoj življenski položaj.« ${ }^{4}$

Za delovanje na kulturnem in umetniškem področju ni bilo dobrih gospodarskih in družbenih pogojev. Vseeno je tedanjim generacijam v danih razmerah uspelo z mnogo truda doseči veliko več kot le preživetje. Področje glasbene umetnosti je bilo $\mathrm{v}$ rokah kolegov, ki so ga bili sposobni kakovostno graditi in razvijati. Izguba Primorske in Koroške je vodila v glasbene povezave ter koncertne izmenjave $\mathrm{z}$ obema deželama. Skladatelji so radi prirejali in izdajali koroške oziroma primorske ljudske pesmi. Zanimive so izdaje primorskih' in prekmurskih ${ }^{6}$ ljudskih pesmi Riharda Orla (18811966), pa zbiranje slovenskih ljudskih pesmi Franca Kramarja (1890-1959).

Naj kratko omenim še nekaj dejstev, ki se nanašajo na krog, v katerem nastane in kroži umetnina: skladatelji, zborovodje in zbori ter poslušalci.

\section{O skladateljih, izvajalcih in poslušalcih Skladatelji}

Prva svetovna vojna je bila precejšnja motnja v izobraževanju, tudi glasbenem. Glavno izobraževanje skladateljev na Slovenskem v medvojnem času je bilo v rokah Konservatorija Glasbene Matice in Orglarske šole. Številni nadarjeni glasbeniki pa so se izobraževali tudi v tujini. Izobraževanje je bilo na dovolj visoki ravni in primerljivo izobraževanju v državah s podobno družbeno situacijo. Stanko Vurnik (1898-1932), eden prvih slovenskih muzikologov, je v članku Slovensko glasbeno življenje izza prevrata, v prej omenjenem delu Slovenci $v$ desetletju 1918-19287, zapisal:

"Tolikih in tako številnih uspehov, kakor sta jih pokazala zadnjih 30 let naša literatura in slikarstvo, naše glasbeno življenje v istem

Josip Mal, ur., Slovenci v desetletju 1918-1928 (Ljubljana: Leonova družba, 1928).

Rihard Orel, Slovenske narodne pesmi iz Benečije (Ljubljana: Glasbena matica, 1921).

Rihard Orel, Slovenske narodne pesmi iz Prekmurja (Ljubljana: Glasbena matica, 1936).

Josip Mal, ur., Slovenci v desetletju 1918-1928 (Ljubljana: Leonova družba, 1928). 
času nima zaznamovati, dasiravno je bilo živahno. Moralo se je boriti $v$ našem malem narodu za trdo eksistenco, morda še bolj kakor ostala umetnost; rastlo je iz majhnih razmer in še danes ne more prodreti $v$ svet. [...] Nivo naše produkcije je primeroma visok. Lajovčevih, Adamičevih, Premrlovih skladb se ne ustrašimo pokazati velikemu svetu - baš letos so se vzdržale v Pragi, na Poljskem in na Dunaju, pa tudi v Švici - tudi mladi Ravnik, Kogoj, Škerjanec, Osterc, Bravničar, Ukmar, Železnik, Jobst, Klemenčič, Tomc itd. nam še mnogo obetajo. Mlajši goje radikalen impresionizem in ekspresionizem, zadnje čase pa smo že tudi stopili v ris novega realizma in polifonije, kateri utirajo pot Adamič, Kogoj, Osterc in najmlajši. [...] Vokalna reprodukcija je pri nas najživahnejša. V mestu in na deželi štejemo malone stotino zborov."

Slovenske skladatelje bi lahko razvrstili v dve skupini; na tiste, ki so skladali posvetne skladbe in tiste, ki so komponirali sakralno glasbo. Največ jih je pisalo oboje, le redki pa pretežno oz. izključno posvetne ali cerkvene. Prav tako lahko skladatelje slogovno splošno opredelimo kot tradicionaliste in moderniste $v$ najširšem pomenu. Tu pritrjujem kolegi Pompetu, da je pri uporabi slogovnih izrazov potrebna terminološka previdnost ${ }^{8}$. Na področju zborovskega skladanja pa v medvojnem obdobju ni pomembnejših slogovnih razlik. Pri vseh skladateljih je prisotno iskanje bogatejše, zanimivejše harmonije, in melodij. Modernisti pišejo še sodobnejša zborovska dela kot tradicionalisti. Zanje je značilna bogatejša harmonija, uporaba disonanc (ekspresionizem), označevanja ritma senza misura, parlato, stopnjevanje ritmične in melodične zahtevnosti; polifonija (prosta); melizmatično komponiranje ipd. Skladatelji radi izbirajo neromantične, sodobnejše vsebine pesmi. Skoraj vsi skladatelji so pragmatični, komponirajo tudi cerkvene pesmi, upoštevajo sposobnosti naših zborov pri pisanju po naročilu, vsi pa skladajo priredbe ljudskih pesmi. Najbolj modernistična sta skladatelja Slavko Osterc in Marij Kogoj, ki sta se od tradicionalističnih konceptov obdelave odmaknila tudi pri priredbah ljudskih pesmi.

Pri oblikovanju kompozicijskih slogov in tehnike posameznih skladateljev, ter morebitnem medsebojnem vplivu, bi nam prav prišli sociogrami in njihova analiza. Pri številnih skladateljih, predvsem starejših lahko zaznamo vpliv Stanka Premrla. Prav tako lahko ugotovimo, da sta vsak 
po svoje, na skladatelje vplivala tudi slogovno različna pedagoga Osterc in Škerjanc.

Delitev na tradicionaliste in moderniste je morda tudi razlog, da pogosto prisiljeno iščemo več elementov tradicije pri tradicionalistih in avantgarde pri avantgardistih kot bi bilo treba. V resnici pa so si, vsaj pri zborovskih skladbah, precej bliže, kot si običajno mislimo.

\begin{tabular}{|l|l|l|l|}
\hline \multirow{4}{*}{ Učitelji } & \multirow{4}{*}{ Robert Fuchs } & Vincent d'Indy & Karel Boleslav Jirak \\
\cline { 3 - 4 } & & Joseph Marx & Alois Haba \\
\cline { 3 - 4 } & & Stanko Premrl & Hinko Druzovič \\
\cline { 3 - 4 } & & Anton Lajovic & \multicolumn{1}{|c|}{ Emerik Beran } \\
\hline Učenci, učitelji & Stanko Premrl & Lucijan Marija Skerjanc & Slavko Osterc \\
\hline \multirow{5}{*}{ Učenci } & Alojzij Mav & Radovan Gobec & Pavel Sivic \\
\hline & Anton Jobst & Rado Simoniti & Marijan Lipovšek \\
\cline { 2 - 4 } & Matija Tomc & Zvonimir Ciglič & France Šturm \\
\cline { 2 - 4 } & Blaž Arnič & Uroš Krek & Karol Pahor \\
\cline { 2 - 4 } & $\ldots$ & $\ldots$ & $\ldots$ \\
\hline
\end{tabular}

Slika r: Skica sociograma naših treh med vojnih vodilnih skladateljev in pedagogov, ter verjetnem neposrednem in posrednem medsebojnem vplivu.

Dober skladatelj mora upoštevati psihosociološke lastnosti pevskega zbora in potencialnega kroga poslušalcev. Posledice kakršnekoli odločitve bo nosil skladatelj sam. Posnemanje raznih kompozicijskih slogov je priljubljen način iskanja uspeha, vendar predstavlja velik izziv - posnemovalec je vedno korak za vzornikom. Tako je skladatelj Lajovic leta 1926 zapisal v Ljubljanskem zvonu': "Glede Slovencev Npr. je moja diagnoza, da smo v vsem kulturnem življenju na vseh poljih pod izrazito fascinacijo nemške kulture, ki naravnost preplavlja vse naše mišljenje. Če je ta diagnoza pravilna, se mi zdi naravno, da je treba zapreti novi dotok nemške kulture. Razen tega s kritično analizo obstoječega mišljenja opozarjati, kaj je v našem mišljenju čisto nemškega.«

Stanko Vurnik, s katerim je Anton Lajovic sicer pogosto polemiziral, pa je svoj prispevek Slovensko glasbeno življenje izza prevrata v prej omenjenem delu Slovenci $v$ desetletju $1918-1928^{10}$ prispevku končal z besedami: "Želel bi naši glasbi, da bi se vzmahnila na nivo napredne Evrope in ne pogrevala vedno le starih, drugod že izumrlih okusov in miselnosti. Če bi dosegla na mednarodnem poprišču zasiguran položaj, bi nam politično i gospodarski koristila. Le v majhni meri se udeležujemo velikih duhovnih in

9 Anton Lajovic, »Misli o umetnostni politiki«, Ljubljanski zvon XLVI, 2 (1926).

10 Josip Mal, ur., Slovenci v desetletju 1918-1928 (Ljubljana: Leonova družba, 1928). 
umetnostnih pokretov velike Evrope - včasih zvemo o njih le iz časopisov, dosežejo nas pa vedno prepozno. Tako smo za Evropo vedno neaktualni in malo zanimivi. Toda upajmo! Bo čedalje boljše.«

Če oboje združimo: morda v Evropi moramo nastopiti s svojo avtonomno kulturo in skladbami, ki bodo umetniško aktualne, prepričljive in zanimive.

Skladatelji so svoje skladbe lahko izdajali tudi v treh revijah, Zbori (1925-1934, Pevsko društvo Ljubljanski zvon, Zorko Prelovec), Pevec (19211938) in dve leti tudi v reviji Nova muzika (1928-1929). Skladbe so lahko izdajali tudi v samostojnih edicijah, pri založbah kot npr. Glasbena matica,

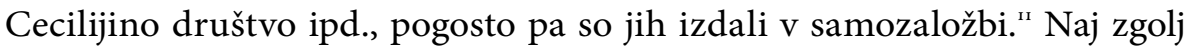
omenim, da so po prvi svetovni vojni oblikovali tudi že zakonodajo o avtorski zaščiti. ${ }^{12}$

Če bi želel sistematično prikazati zborovsko skladanje $\mathrm{v}$ medvojnem obdobju, bi moral skrbno pripraviti selekcijo skladateljev in njihovih skladb. Ena možnost je preprosto napraviti izbor najbolj odmevnih skladateljev in njihovih del. Vseeno predlagam še bolj natančno metodologijo obravnave izbranih skladateljev. Le-ti so v tem obdobju bili različno stari. Življenje skladatelja bi lahko morda delil na štiri ustvarjalna obdobja (oblikovano na temelju delitve obdobij psihosociološkega razvoja po Eriku Eriksonu):

1. Prvo obdobje od rojstva do konca osnovnega izobraževanja, do starosti 15 let.

2. Drugo obdobje je obdobje intenzivnega izobraževanja, ki lahko traja v širšem smislu do približno 3o. leta starosti.

3. Tretje, zrelo obdobje, pomeni obdobje poklicnega dela in samostojno glasbeno prakso.

4. Zadnje, četrto obdobje je tisto, ki ga živimo po upokojitvi oziroma 65. letu starosti.

V vsakem obdobju lahko skladamo nekoliko drugače, ali pa ne. Običajno se v prvih dveh obdobjih razvijamo, iščemo skladateljsko pot, v tretjem jo bolj ali manj živimo, v zadnjem obdobju pa jo zaokrožimo.

11 Glej Niko Kuret, ur., Slovenska knjiga (Ljubljana: Knjigarna Kleinmayr in Bamberg, 1939).

12 Anton Lajovic, »Naši umetniki in novo avtorsko pravo«, Ljubljanski zvon 39, 8 (1919). 


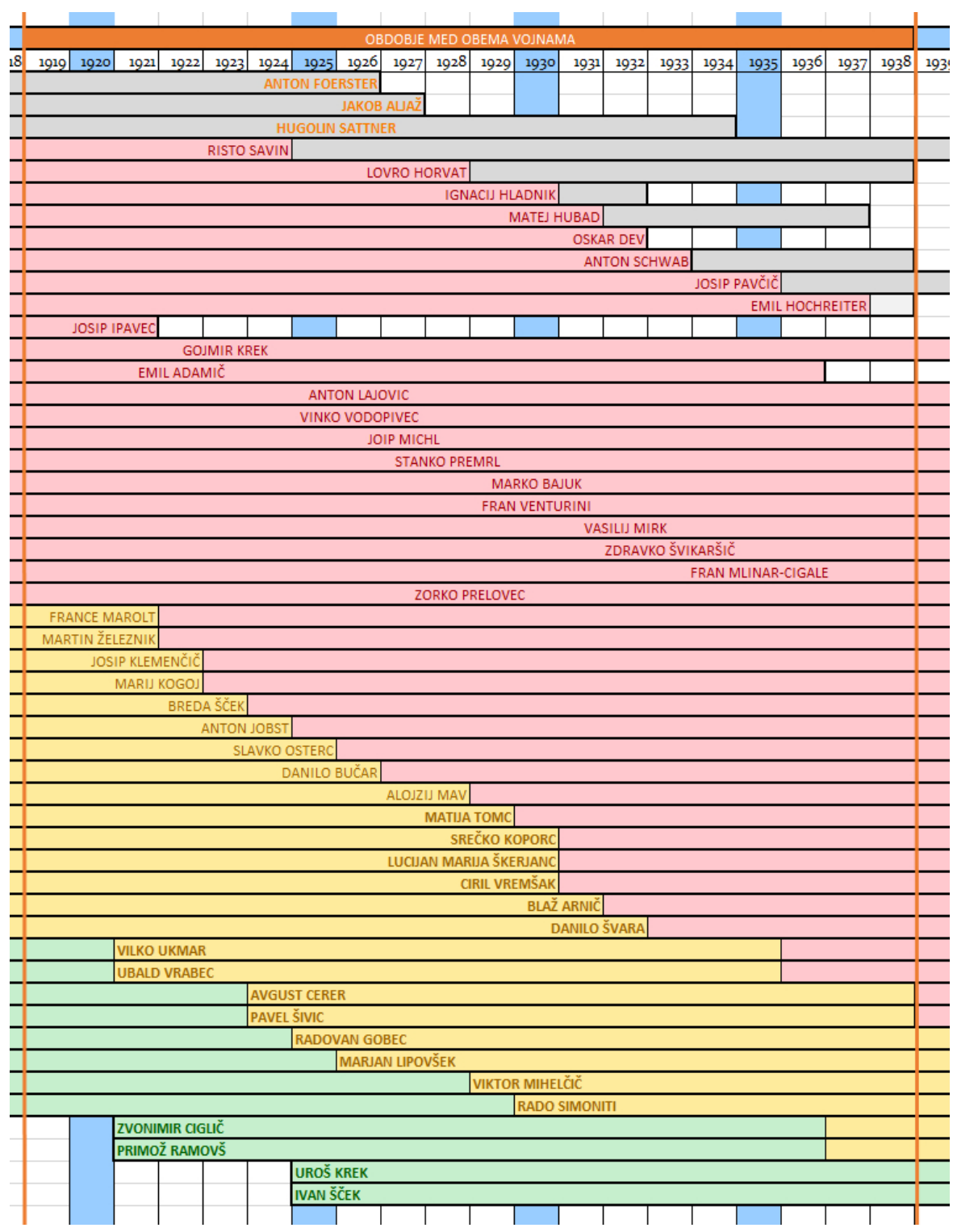

Slika 2: Izsek prikaza medvojnih skladateljev glede na starost in glasbeno kariero, zgoraj so najstarejši skladatelji, ki so ustvarjali v svojem zadnjem obdobju, npr. A. Foerster, spodaj so skladatelji v zrelih obdobjih, npr. S. Premrl, Z. Prelovec, E. Adamič, pod njimi so mlajši skladatelji, v intenzivnem obdobju pridobivanja znanja in iskalci novosti, npr. M. Kogoj, S. Osterc, L. M. Škerjanc, na dnu pa so najmlajši skladatelji, ki so šele vstopali v svet glasbe, npr. P. Ramovš, U. Krek. 


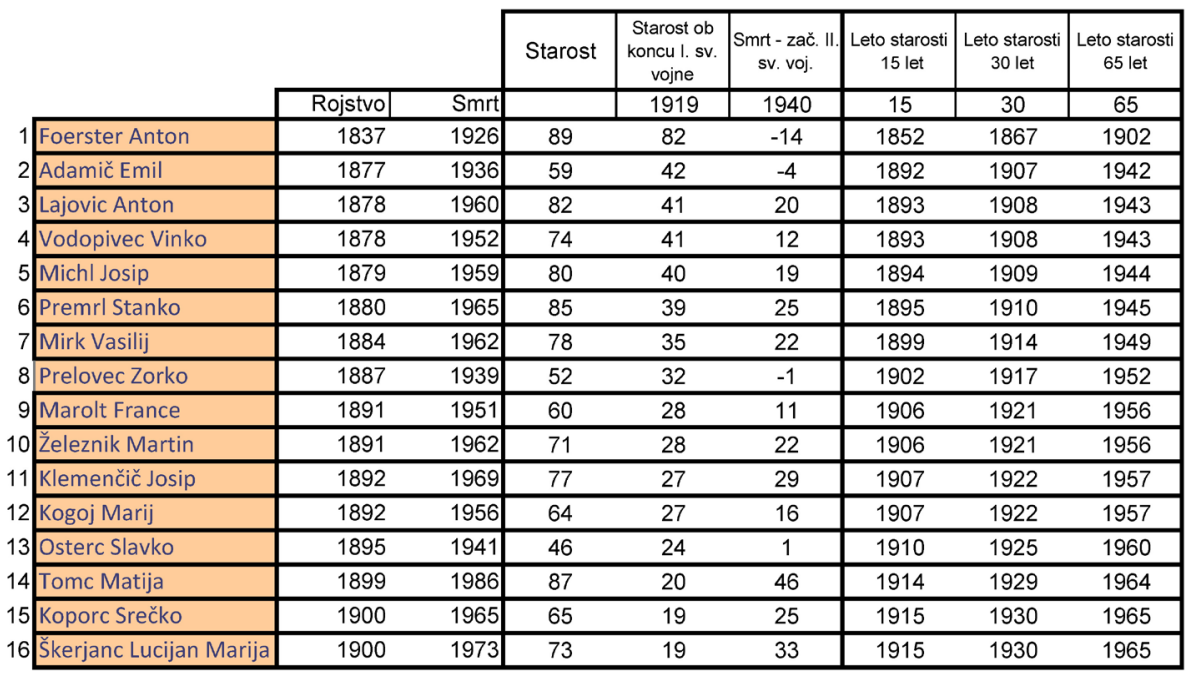

Slika 3: Nekaj podatkov izbranih skladateljev, ki so delovali med vojnama.

V prvo skupino bi uvrstil izbrane skladatelje, rojene do leta 1875 , ti so se med obema vojnama upokojili ali umrli, npr. Anton Foerster (1837-1926).

V naslednjo skupino uvrščam skladatelje, ki so se rodili do leta 1900, in so bili med obema vojnama aktivni, upokojili pa so se nekoliko pred drugo svetovno vojno, med njo ali kmalu po njej, npr.

1. Emil Adamič (1877-1936),

2. Anton Lajovic (1878-1960),

3. Vinko Vodopivec (1878-1952),

4. Josip Michl (1879-1959),

5. Stanko Premrl (1880-1965),

6. Vasilij Mirk (1884-1962),

7. Zorko Prelovec (1887-1939),

8. France Marolt (1891-1951),

9. Martin Železnik (1891-1982),

10. Josip Klemenčič (1892-1969),

11. Marij Kogoj (1892-1956),

12. Slavko Osterc (1895-1941). 
V tretjo skupino bi uvrstil avtorje, ki so bili rojeni okrog leta 1900, nekaj prej ali nekoliko kasneje. Ti so bili po prvi svetovni vojni v sredini ali ob koncu glasbenega izobraževanja in so vstopali v prostor kariere in službe, tvorili so skupino mlajših skladateljev, običajno so iskali naprednejše skladateljske poti. Npr.:

1. Karol Pahor (1894-1974)

2. Matija Tomc (1899-1986)

3. Srečko Koporc (1900-1965)

4. Lucijan Marija Škerjanc (1900-1973)

5. Danilo Švara (1902-1981)

Navedel sem nekaj najbolj odmevnih in pogosto izvajanih skladateljev. Tudi preostali skladatelji različnih generacij, delujoči med vojno, ki jih je več kot sto, so ustvarili zanimiva dela, npr. Jakob Aljaž, Hugolin Sattner, Ignacij Hladnik, Matej Hubad, Oskar Dev, Fran Venturini, Karlo Adamič, Breda Šček, Anton Dolinar, Danilo Bučar, Ludovik Puš, Alojzij Mav, Ciril Vremšak, Blaž Arnič, in najmlajši, rojeni po letu 1905, Vilko Ukmar, Ubald Vrabec, Avgust Cerer, Pavel Šivic, Radovan Gobec, Marijan Lipovšek idr.

\section{Zbori in zborovodje}

Naj kratko spregovorim še o zborih in zborovodjih, saj brez njih skladbe ostajajo neme. Zborovodje sestavljajo programe in s tem širijo naša dela, pri tem pa morajo skrbno upoštevati sposobnosti pevcev in percepcijske sposobnosti in želje poslušalcev. V medvojnem času je bilo nekaj vrhunskih zborov, ki so bili sposobni izvajati zahtevnejša dela, npr. mešani zbor Glasbene Matice, moški (zbor) Akademski pevski zbor Franceta Marolta, Učiteljski pevski zbor (zbor JUU), Trboveljski slavček in Stolni zbor.

Veliko je bilo tudi raznovrstnih zborov in pevskih društev, ki so bili sposobni odpeti kakšno zahtevnejšo skladbo, npr. kamniška Lira, kamniška Solidarnost idr.

Fran Erjavec v prej omenjenem delu Slovenci v desetletju 1918-1928 $8^{13}$ v prispevku Naše društveno življenje navaja, da je pod okriljem Prosvetne zveze delovala Pevska zveza, ki je v 12 okrožjih združevala 130 pevskih zborov z nad 2000 pevci. Delovala so tudi druga društva, npr. Zveza kulturnih društev, v katero je bilo vključenih okrog 100 zborov. Organizirani so bili 13 Josip Mal, ur., Slovenci v desetletju 1918-1928 (Ljubljana: Leonova družba, 1928). 
tudi cerkveni zbori. Najverjetneje je zbor imela vsaka večja župnija, le-ti pa so bili povezani v razna Cecilijanska društva.

O programih in organiziranosti koncertov lahko veliko izvemo iz koncertnih listov, ki so jih tiskali pomembnejši zbori, mdr. tudi kamniška Lira. $\mathrm{O}$ koncertih in glasbenem dogajanju so $\mathrm{v}$ tedanjih publikacijah, npr. Ljubljanski zvon, izhajala poročila, tudi kritična, znanih glasbenikov, če navedem nekaj znanih kot so Stanko Vurnik (1925), France Marolt (1926), Matija Tomc (1933/36) idr. Pozornost je veljala tudi izobraževanju pevcev; tako je France Marolt za Zvezo slovenskih pevskih zborov pripravil Pevsko vadnico, ki jo izdala in založila Glasbena Matica leta 1925.

Nazadnje bi veljalo nekaj zapisati tudi o tedanjih poslušalcih in njihovi recepciji zborovskih del. Tedanji kulturniki in umetniki so se zavedali problema vzgoje poslušalcev, saj so za obiskovalce svojih koncertov morali tekmovati z drugimi družbenimi skupnostmi (šport, kultura, ples ipd.). O recepciji s strani medijev priča sledeč odlomek anonimnega avtorja, objavljen v Zborih leta 1926 (Zbori, letnik II., 1926, št.5):

"Ako čitaš naše dnevnike, z začudenjem opaziš, da odmerjajo veliko več prostora športu kot umetnosti, kinu kot koncertom, umazanim korupcijskim aferam kot drami in operi. Na dolgo in široko opevajo športne klube, se navdušujejo za 'elegantno' ali pa 'sirovo' bičanje, prinašajo cele kolone dolge životopise filmskih zvezda, kino-programe iz vseh vetrov sveta in do podrobnosti opisujejo ugled naše mlade države uničujoče koritarske zgodbe. A o naših književnih dogodkih, o slikarskih in kiparskih razstavah in novih delih, o drami in naših igralcih cele države in sorodnih slovanskih narodov, o glasbi, o operi, o pevcih, o komponistih, dirigentih, o novih skladbah, sploh o lepih umetnostih iz vse naše države, iz Češkoslovaške, iz Poljske, iz Rusije pa bereš le ali zelo pičla poročila, ali do nerazumljivosti okrnjena ali pa jih sploh iščeš zaman. Važnejše je, kaj se igra na Dunaju, v Berlinu, kot v Pragi ali Varšavi, ali - čemu tako daleč hoditi - kot v Zagrebu in Beogradu."

Besede, ki bi jih lahko našli tudi v današnjem časopisju.

Pomembno vlogo pri širjenju zborovskega petja je imel tudi radio. Radio Ljubljana je že leta 1928 pričel oddajati redni program, leta 1937 je ustanovil tudi radijski Komorni zbor. Predvajanim zborovskim skladbam lahko sledimo po objavah v tedniku Radio Ljubljana, ki je izhajal od leta 1929 do leta 1941. 
Vendar pa so tedaj mnogi menili, da odnos radia do zborovskega petja ni ustrezen in da mu posveča premalo pozornosti dokaz česar je mnenje Ludovika Puša v reviji Pevec (1934, št. 1-2 in 3-4) v članku Naša pesem in radio.

\section{Nekaj primerov medvojnih zborov izbranih skladateljev}

Anton Foerster (1837-1926) je bil eden naših vodilnih skladateljev, glasbenikov, pedagogov, odličen poznavalec kompozicije in prav tako tudi izvrsten skladatelj. Zložil je več znamenitih skladb v tradicionalnem, romantičnem slogu. V mnogih zborovskih delih je bil domiseln. V 2o. stoletje je s seboj prinesel zavidljivo bero skladb, $s$ katerimi je vplival tudi na mlajše rodove skladateljev. Številne njegove skladbe so še danes priljubljene. Takole je v koncertnem listu Akademskega pevskega zbora ob koncertu, posvečenem skladatelju, zapisal France Marolt:

"Foerster je temeljna postava slovenske glasbe, one nujne, bitne kulturne sestavine našega naroda, ki umetno glasbo redno in stalno ustvarja in soustvarja, one trajne kulturne žiti, ki v narodnem snovanju tesno veže skladatelja-izvajalca s poslušalstvom. Foerster šele je postavil in zahteval te nujne in potrebne premise našega glasbenega življenja, jih programatično razširil in poglobil, sistematično utrdil ter s svojim velikim delom posvetil. Od svojega nastopa $v$ Slovencih do pojave Fr. Gerbiča in M. Hubada na polju svetne glasbe ter do nasledstva St. Premrla v cerkveni glasbi je Foerster prvi vsestransko oral našo glasbeno ledino in zlasti cerkveno, glasbo temeljito preobrazil. Foerster je veliki mojster - zdravnik naše glasbe: neustrašeno je začel trebiti tuji plevel z naše glasbene njive ter pobijati diletantsko prizadevanje starokopitnih glasbunov in zlaganih pevoskladnikov. ${ }^{14}$

Med njegovimi stvaritvami naj omenim zbor Spak (1910), ki je nastal že pred prvo svetovno vojno, in je vplivna, odmevna, vrhunska sodobna skladba. Spak je pomembno, vrhunsko zborovsko delo), s katero se lahko še danes trudim tekmovati. Stanko Premrl je o tem delu zapisal:

"Dandanašnji moderni glasbeniki sicer Foersterja ne štejejo več med svoje - zdi se jim namreč že nekoliko prestarinski; a naj rečejo moderni, kar hočejo, jaz sem tega mnenja, da bi od naših mo- 
dernih skladateljev težko kateri naslikal Aškerčevega „Spaka, bolj natančno in pa originalno kot je to storil ravno Foerster. « ${ }^{15}$

Priljubljena skladba pa je tudi Večerni ave za moški zbor (objavljena leta 1926).

Emil Adamič (1877-1936) je morda skladatelj $\mathrm{z}$ največ zborovskimi stvaritvami in mnoge njegove skladbe so izjemno priljubljene, če ne že ponarodele, npr. Kazen ali Završki fantje. Po drugi strani je v zborovsko ustvarjalnost Slovencev vnesel mnogo kompozicijskih novosti, predvsem s področja harmonije - »Novi akordi« so dejansko prinašali najbolj nove akorde. Adamič se je ob Kreku oprijel sodobnejših, novo- in postromantičnih kompozicijskih prijemov.

Neformalno se je izobraževal na različnih zborovskih, glasbenopedagoških in skladateljskih strokovnih srečanjih ter kongresih: Dunaj (1911), Moravska Ostrava, 1914; Donaueschingen, 1926; Sofija, 1928; Praga, $1936 .{ }^{16} \mathrm{~V}$ uvodu ene od številk Nove muzike, katere glavni ustanovni pobudnik je bil ravno Adamič sam, je zapisal:

"Stanje naše glasbe je bilo ob pričetku svetovne vojne tako ugodno, da smo občutili prenehanje »Novih akordov«kot silno težak udarec. Svetovni požar je vpepelil marsikatere naše načrte, želje in nade. Pod pepelom pa je žarelo dalje in po vojni so čimdalje pogosteje in silneje čuli klici po novih "Novih akordih«. Toda glasba je med tem krenila na nova pota, glasbene tendence novega časa so drugačne kot so bile nekdaj in nova glasba je postala važen duševni problem vseh narodov. Romantičnim "Novim akordom "sledi realna, sodobna »Nova muzika«. [...] Ne tarnajmo nad tem, kar se je za večno zrušilo! Pričnimo veselo in pogumno z novim delom! «"

Anton Lajovic (1878-1960) je bil glasbeno izvrstno izobražen, kompozicijo ga je na Dunaju učil Robert Fuchs. Bil je pomemben slovenski izobraženec in glasbeni pisec, ki je močno vplival na slovensko glasbo. Zanj je zrelo obdobje ustvarjanja nastopilo med obema vojnama. Številna njegova zborovska dela so v železnem repertoarju slovenskih del. Morda najbolj znamenita poznoromantična skladba je Lan, objavljena leta 1920.

Vinko Vodopivec (1878-1952) je bil duhovnik in pomemben tradicionalistični slovenski zborovski skladatelj. Skladba Žabe (natisnjena leta 1921,

15 Dom in svet 24, 6 (1911).

16 Emil Adamič (1877-1936), Slovenska biografija.

17 Emil Adamič, »Novi muziki na pot«, Nova muzika 1 (1928). 
najbrž nastala leta 1916) je morda najbolj svetovno znano slovensko delo iz tega obdobja, pri nas skoraj ponarodelo. Naj za primer navedem izvedbo z Londonskim waleškim moškim zborom, The London Welsh Male Voice Choir in kamniško Liro v Kamniku ter avstrijsko izvedbo zbora Steirischen Jägerchor. ${ }^{18}$

Josip Michl (1879-1959) je manj znan, a pomemben in zanimiv slovensko-češki skladatelj. Njegovo skladbo Atila in ribič (1909) je kamniška Lira med obema vojnama večkrat izvedla. Skladba je eno prvih slovenskih zborovskih del, ki ima parlato.

Stanko Premrl (1880-1965), odličen organist, zborovodja, pedagog, publicist, predvsem pa plodovit skladatelj, je eden vodilnih glasbenikov prve polovice 20. stoletja na Slovenskem. Čas njegovega osrednjega ustvarjanja na cerkvenem in tudi posvetnem področju sega prav v medvojno obdobje. Posebne omembe je vredna njegova skladbo Večerna, objavljena leta 1925.

Tudi skladatelj Vasilij Mirk (1884-1962) je pomemben glasbenik, pedagog in zborovodja ter avtor številnih priljubljenih zborovskih del. Pogosto izvajamo njegovi Kolo in $\mathrm{Na}$ trgu.

S številnimi deli zelo priljubljen je tudi skladatelj Zorko Prelovec (18871939). Naj omenim Oj, Doberdob in Sedem si rož porezala mi.

France Marolt (1891-1951) je pomemben zborovodja, glasbenik in pisec, kot skladatelj pa slovi po domiselnih priredbah ljudskih pesmi, npr. Kangalilejska ohcet in Ribniška.

V medvojnem obdobju sta delovala tudi pomembna skladatelja, znana bolj po sakralnih delih, Martin Železnik (1891-1982) in Josip Klemenčič (1892-1969).

Marij Kogoj (1892-1956) je eden najpomembnejših slovenskih modernističnih ekspresionističnih skladateljev. Več njegovih zborov je redno na koncertnih programih. V Ljubljanskem zvonu je napisal članek o sodobni zborovski produkciji pri Slovencih. ${ }^{19}$ Med drugim je zapisal tudi tole:

"Medtem ko je čitalniška soba ustvarila zbore s konkretno vsebino, medtem ko se je novoakordiška doba izživljala $v$ razpoloženjih, je mlada generacija začela izražati duhovno ekspresijo."

Modernistično, avantgardno je bil usmerjen tudi Slavko Osterc (18951941). Skladatelj je muzikološko dobro obdelan, o njegovem zborovskem

18 Viertelfinale »Große Chance der Chöre 2016«, ORF 1, Steirischen Jägerchor, obiskano oktobra 2017, https://www.youtube.com/watch?v=gzW2vic7ebQ.

19 Marij Kogoj, "Prosvetna zborovska produkcija pri Slovencih«, Ljubljanski zvon XLIX, XI (1929). 
stavku je pisal Tomaž Šegula. Osterc je bil tudi aktiven v mednarodnem društvu za sodobno glasbo (ISCM). Tako se je najbolj neposredno in temeljito seznanil s tedanjimi glasbenimi tokovi. V reviji Zbori je o sodobnih zborovskih skladbah leta 1928 zapisal tudi tole:

"Kar bom povedal, se mi dozdeva en možen način, kako pisati in naštudirati sodobne zbore. Mislim pa, da to ne bo edin način. Torej, kako pisati? Na vsak način tako, da bo stvar čim laže izvedliviv! In pri tem ostati sodoben? Vsekakor! Sodobne zbore piše Janaček, Hindemith in Berg (v operah), Kaminski (eden glavnih zborovskih komponistov sedanjosti, ki svoje glavne sile polaga $v$ zbore), med Čehi jih je vse polno in pri nas Adamič, Lajovic, Gotovac, Slavenski..20

Duhovnik Matija Tomc (1899-1986) je bil odličen skladatelj posvetnih in cerkvenih zborovskih skladb. S pisanjem je pričel že okrog leta 1920 in ustvarjal do konca življenja. Številna njegova dela so še danes priljubljena. Ob koncertu Akademskega pevskega zbora pod vodstvom Franceta Marolta v Ljubljani leta 1934, je kritik v reviji Dom in svet, skladatelj Ludovik Puš zapisal:

"Višek koncerta so pa dosegle značilne belokrajinske v Tomčevi priredbi. Odlikuje jih prelepa stilna ubranost, iskreno in pristno občutje in poglobljenje v ljudsko dušo, zraven pa kontrapunktično odlično speljana zgradba. Takšno pesem, kakršno nam je zapel APZ, pokažimo zunaj svojih meja! To je naše blago, ne pa brezizrazni proizvodi naših glasbenikov, ki so zgubili domala ves stik $z$ rodno grudo in njeno umetnostjo in plavajo $v$ mogočnem toku mednarodne muzike. Res so nekatere Tomčeve pesmi težke, napisane za zbore odličnih kvalitet in zato - žal - povprečnim zborom težko dostopne. Toda to ne zmanjša njihove umetniške vrednosti. Želimo le, da bi nam Matija Tomc napisal še kaj podobnega iz bogate belokrajinske zakladnice za naše povprečne zbore. Tam bo pokazal vso svojo umetniško silo, ko mu bodo izrazna sredstva bolj omejena, kakor so mu bila tu (saj je ponekod vodil glasove do skrajnih mej in pisal za petje izredno krhka mesta).."1

20 Slavko Osterc, »O sodobni smeri zborovskih skladb«, Zbori 4, 3 (1928).

21 Ludovik Puš, »Akademski pevski zbor; Slovenska narodna pesem«, Dom in svet 47, 6/7 (1934). 
Tudi Srečko Koporc (1900-1965), skladatelj mlajše generacije med obema vojna, je pomemben modernejši zborovski skladatelj.

Lucijan Marija Škerjanc (1900-1973) je bil eden najpomembnejših slovenskih glasbenikov, pedagogov in skladateljev. Pomemben je predvsem kot skladatelj instrumentalne in orkestralne glasbe, napisal pa je tudi nekaj zborovskih skladb. Predvsem je pomemben njegov vpliv na mlajše rodove slovenskih skladateljev.

\section{Sklep}

Življenje v času med obema vojnama je bilo za naše prednike polno izzivov, s katerimi so se spopadli po najboljših močeh. Dediščino Avstro-Ogrske je bilo treba uporabiti za novo, sorazmerno samostojno življenje. Tudi zborovska kultura $\mathrm{z}$ ustvarjanjem zborovskih skladb je bila del tega, čeprav imam občutek, da smo se, prej varno privezani na mogočno avstro-ogrsko ladjo, nenadoma znašli sami, v čolničku sredi razburkanega evropskega političnega in družbenega morja. $V$ tem času je kultura zborovskega ustvarjanja in poustvarjanja zrasla in postala primerljiva kulturi drugih narodov Evrope. Tudi pri nas so skladatelji ustvarjali raznovrstna dela. Skladateljsko smetano zborovskih ustvarjalcev so sestavljali tako pristaši tradicionalnega postromantičnega sloga kot modernističnega. Vendar razen Osterca ni bilo pomembnejših avtorjev naprednih zborovskih del. Zahtevnost tovrstnih del za pevce in poslušalce je prav gotovo eden glavnih razlogov za to. Najbrž pa je bil napredni slogovni izraz tudi izven želja in zaznavnih sposobnosti ljudi. A dela, ki se globlje dotaknejo poslušalcev, ostanejo, naj bodo moderna ali ne. Preostala pa ostanejo zgodovinska zanimivost, primerna za simpozije. Če bil dali obojna, tradicionalistična in modernistična dela na tehtnico, ki bi tehtala uspešnost in bolj pogosto izvajanje skladb, bi se tehtnica nagnila $\mathrm{k}$ tradicionalistom. Več njihovih del je pogosteje izvajanih in »zimzelenih« .

V času med obema vojnama so skladatelji ustvarili številna zborovska dela, ki so trajno ostala na našem izvajalskem repertoarju.

Pred kratkim smo praznovali dvestoletnico javnega glasbenega šolstva na Slovenskem. Tedaj sem svoj prispevek končal z mislimi Marija Kogoja in naj tako storim tudi tokrat. Sprejemanje, recepcija klasične glasbe ni bila lahka in enostavna nikoli; ne nekdaj, ne danes, ne v tradicionalistični ne modernistični glasbi. Usodo enega vodilnih slovenskih skladateljev, Marija Kogoja, je v svojem delu Obrazi pretresljivo opisal eden naših pomembnih izobražencev svojega časa, Josip Vidmar. Marij Kogoj je bil zanj pomemben 
obraz tedanje kulture in umetnosti, čeprav ga poslušalci, tudi izobraženi, niso najbolje sprejemali. Takole je zapisal Vidmar:

"Po svoji osnovni dispoziciji je bil Kogoj temperamenten in strasten in nič čudnega ni, da se je njegova osebnost v težkih in mučnih okoliščinah, kakršne si lahko predstavljamo, razvila v koleričen značaj, ki se je z vsemi močmi neugnano boril za svoj prostor na soncu. Če si hotel shajati $z$ njim, si moral brezpogojno verjeti v njegovo umetnost in njegov uspeh. Glede vere vase je bil neomajen, hkrati pa je bil nenavadno zahteven do svoje umetnosti."22

Morda je vse v tem, da smo do svoje umetnosti in do sebe zahtevni, ter da se borimo za svoj prostor pod soncem, ne samo kot posamezniki ampak tudi kot narod, in da vztrajamo, kot je zapisal nekoč sveti Pavel »bodi prilično ali neprilično ${ }^{23}$ «. In najbrž so danes za umetnost boljši časi, kot so bili kadar koli do sedaj, naj bodo še boljši, čeprav mi še vedno odzvanjajo besede Stanka Vurnika izpred slabih sto let, ki sem jih malo prej navedel: »Tako smo za Evropo vedno neaktualni in malo zanimivi. Toda upajmo! Bo čedalje boljše. ${ }^{24}$ Upajmo!

\section{Bibliografija}

Adamič, Emil (1877-1936). Slovenska biografija.

Adamič, Emil. »Novi muziki na pot«. Nova muzika 1 (1928).

Dom in svet 24, 6 (1911).

Kogoj, Marij. "Prosvetna zborovska produkcija pri Slovencih«. Ljubljanski zvon XLIX, XI (1929).

Kramolc, Luka. Narodni praznik. Ljubljana: Samozaložba, 1920.

Kuret, Niko, ur.. Slovenska knjiga. Ljubljana: Knjigarna Kleinmayr in Bamberg, 1939.

Lajovic, Anton. »Misli o umetnostni politiki«. Ljubljanski zvon XLVI, 2 (1926).

Lajovic, Anton. »Naši umetniki in novo avtorsko pravo«. Ljubljanski zvon 39, 8 (1919).

Mal, Josip, ur.. Slovenci v desetletju 1918-1928. Ljubljana: Leonova družba, 1928. Marolt, France. Spremno besedilo o Antonu Foersterju, Akademski pevski zbor v Ljubljani/Koncertni spored. Ljubljana, 1933.

22 Josip Vidmar, Obrazi (Ljubljana: Državna založba Slovenije in Založba Borec, 1985).

$232 \operatorname{Tim} 4,2$.

24 Josip Mal, ur., Slovenci v desetletju 1918-1928 (Ljubljana: Leonova družba, 1928). 
Orel, Rihard. Slovenske narodne pesmi iz Benečije. Ljubljana: Glasbena matica, 1921.

Orel, Rihard. Slovenske narodne pesmi iz Prekmurja. Ljubljana: Glasbena matica, 1936.

Osterc, Slavko. »O sodobni smeri zborovskih skladb«. Zbori 4, 3 (1928).

Otrin, Blaž in Čipić Rehar, Marija, ur.. Jegličev dnevnik. Celje: Celjska Mohorjeva družba, 2015, 1035.

Pompe, Gregor. »Glasba slovenske povojne moderne (1918-1927)«. De musica disserenda XII, 2 (2016)

Puš, Ludovik. "Akademski pevski zbor; Slovenska narodna pesem«. Dom in svet 47, 6/7 (1934).

Vidmar, Josip. Obrazi. Ljubljana: Državna založba Slovenije in Založba Borec, 1985.

Viertelfinale »Große Chance der Chöre 2016 «. ORF 1, Steirischen Jägerchor. Obiskano oktober 2017, https://www.youtube.com/watch?v=gzW2vic7ebQ. 


\title{
Idejna in umetniška identiteta mladinskih zborov med obema vojnama
}

\author{
Darja Koter \\ Univerza v Ljubljani \\ University of Ljubljana
}

Stanko Vurnik (1898-1932), vodilni ideolog slovenske glasbene umetnosti dvajsetih let 20. stoletja, se je kot poznavalec svetovnih in evropskih družbeno-političnih, duhovnih in umetnostnih gibanj kritično odzival na aktualne prelomnice človeštva. V svojih ostrih zapisih o šibki odzivnosti slovenskih kulturnikov in posebno glasbenikov na družbene in posledično umetnostne spremembe po prvi svetovni vojni, je poudarjal, da:

"Problemi nove kulturnosti ne morejo biti nič drugega kakor problemi novega človeka, nove duhovne smeri, kratko: novih svetovno-nazornih osnov. Te osnove so namreč tista osrednja os, ki oblikuje in giblje vse socialno, gospodarsko, politično, kulturno, religiozno in umetnostno življenje vsake dobe $v$ čudovito organičen sistem, katerega vsi sestavni deli enotno odžarevajo vsebino svojih osnov. "

Kot edino pravo pot, ki vodi k »novim« časom in »novi« umetnosti, je zagovarjal temeljno preobrazbo vsesplošne miselnosti, umetnostnih nazorov in glasbenih pojavov, stavil na odprtost v svet in glasbeno izobraževanje v »novem duhu « ter o tem zapisal:

"In vendar mora nov čas pokazati nove ljudi in preobraziti tudi naše glasbeno življenje prav do korenine. Na vseh poljih, na vseh panogah mora vzkliti najprej nova kulturna orientacija, z njo nov umetnostni nazor, našemu času potreben in primeren, potem šele 
bo konec te čudne stagnacije, iz katere ne moremo nikamor dalje. In vendar moramo Slovenci ravno z glasbo iskati svetovnega uveljavljenja, ker nam na drugih poljih ni tako lahko prodreti $v$ svet in koristiti svetovni kulturi ... Zato pa treba vzgojiti nove generacije glasbenikov v novem duhu .... ${ }^{2}$

Vurnik je kot privrženec Guida Adlerja je poznal slogovne novosti, ki so prežemale svet severno in zahodno od slovenskega prostora in se čutil dolžnega, da o tem razsvetli širšo slovensko glasbeno javnost. ${ }^{3}$ Ker se je zavedal ekspresionistične stvarnosti druge dunajske šole, nove glasbene arhitektonike, racionalnosti umetniškega izražanja in ne nazadnje nadnacionalnih pojavov, je širšo javnost nagovarjal k novemu. Čeprav ekspresionizma ni postavljal na piedestal, neobaročne oziroma neoklasicistične slogovne značilnosti pa je v svojem času šele slutil, je bil dovolj osveščen, da je kot predstavnike novosti izpostavljal osebnosti, kot so Busoni, Schönberg, Křenek, Hindemith, Stravinski.... Svojih misli zaradi prezgodnje smrti sicer ni uspel povsem razviti in utemeljiti, vendar je $\mathrm{z}$ opredelitvijo proti romantičnim in impresionističnim slogovnim značilnostim in poudarjanjem potreb po "novem« spodbujal sodobnejša razmišljanja ter tako tlakoval pot aktualnim glasbenim pojavom $\mathrm{v}$ kompoziciji in poustvarjalnih navadah, ki so jih drug za drugim sprejemali in razvijali nekateri najbolj osveščeni slovenski glasbeniki. Pot k sodobnejšim glasbenim tokovom zahodnega sveta je bila za slovenske glasbenike precej strma, večino je ovirala privrženost $\mathrm{k}$ tradicionalnemu in ne nazadnje je bilo zanje $\mathrm{v}$ omenjenem času še vedno malo možnosti izobraževanja na vodilnih evropskih glasbenih ustanovah. Družbene oziroma socialne okoliščine so bile tiste, ki so najbolj omejevale mlade glasbene talente pri uresničevanju njihovih poklicnih željah. Naj spomnimo, da je ljubljanski konservatorij, ustanovljen leta 1919, nudil izobraževanje na nižji in srednji stopnji. Eden temeljnih vzrokov, da ni bilo možnosti visokošolskega študija, je bilo pomanjkanje primerno izobraženih učiteljev z zaključeno visoko stopnjo izobrazbe na ustreznih evropskih ustanovah.

Za razmislek o tem, kaj je oviralo in spodbujalo približevanje slovenske glasbe k razvitejšim sredinam, so med drugimi povedni Vurnikovi zapisi, s katerimi se je odzival na koncertno in operno poustvarjalnost ak-

2 Stanko Vurnik, »Glasbeno življenje v Ljubljani 1. 1930«, Dom in svet 44, 1-2 (1931): 95.

3 Glej Vurnikovo najobsežnejše teoretično delo: Stanko Vurnik, Uvod v glasbo. I. Sistematični del (Ljubljana: Nova založba, 1929). 
tualnega časa, na dosežke posameznih skladateljev in delovanje takrat osrednjih izobraževalnih glasbenih ustanov, ljubljanske Glasbene matice in Konservatorija. Njegova poročila in kritiški zapisi odražajo stanje duha in glasbene prakse. Med velikimi pomanjkljivostmi desetletja po prvi vojni, ki so vplivale na slogovno in repertoarno raven glasbenega delovanja, je izpostavljal, da Ljubljana ni premogla pravega simfoničnega orkestra, da slovenski skladatelji niso bili sposobni napisati orkestralnih del večjega formata, da je bila ljubljanska Opera $\mathrm{z}$ redkimi izjemami vpeta $\mathrm{v}$ tradicionalni program ${ }^{4}$, da so koncertni podij v preveliki meri obvladovali skladatelji romantičnih in impresionističnih nazorov, ki mladih niso spodbujali $\mathrm{k}$ sodobnejšim kompozicijskim prijemom, da se je zbor ljubljanske Glasbene matice kot osrednji slovenski vokalni ansambel na svojih mednarodnih turnejah predstavljal s pretežno slogovno "zastarelim « programom in ne nazadnje je poudarjal zastarelost konservatorija, ki mu je očital preživete in $\mathrm{z}$ Evropo neprimerljive učne programe. ${ }^{5} \mathrm{~V}$ svojem umetnostnem manifestu, objavljenem v Ljubljanskem zvonu leta 1926, je opozoril, »da je naloga umetnostne politike pospeševati mednarodno umetnostno komunikacijo $z$ oddajanjem in sprejemanjem ... « ${ }^{6} \mathrm{~S}$ tem je apeliral na mednarodno uveljavljanje slovenskih skladateljev in poustvarjalcev, ki bi prineslo prepoznavnost slovenske glasbene umetnosti in večji pretok sodobnih slogovnih oziroma kompozicijskih idej.

Pregled slovenske glasbene poustvarjalnosti potrjuje številne Vurnikove ugotovitve, med drugim, da je bil največji repertoarni ter z njim slogovni in kompozicijsko-tehnični napredek na področju poustvarjanja vokalne glasbe, v čemer sta v letih 1927-1930 izstopala dva ansambla, v Ljubljani delujoča Pevski zbor slovenskih učiteljev pod vodstvom Srečka Kumarja in moški Akademski pevski zbor pod vodstvom Franceta Marolta. Oba sta v sezoni 1930 nastopala s pretežno novejšimi deli slovenskih oziroma jugoslovanskih avtorjev, v katerih je najti ekspresionističen izraz, ostrej-

$4 \quad$ Vurnik je nekatere poustvarjalne dosežke ljubljanske Opere pod vodstvom Mirka Poliča ob koncu 20. let, takrat aktualna dela Stravinskega, Šostakoviča, Křeneka in Prokofjeva ter med slovenskimi novitetami sodobnih slogovnih tokov dela Kogoja, Osterca in Bravničarja, prepoznal kot izjemne, hkrati pa ugotovil, da je nadaljnji razvoj Opere upočasnila in zavrla državna politika ter gospodarska kriza začetka 30. let. Prim: Stanko Vurnik, »H krizi naše Opere«, Dom in svet 43, 1-2 (1930): 58-59.

5 Vurnik je svoja opažanja strnil v letnih poročilih in jih objavljal v reviji Dom in svet 39, 1 (1926): 61-64; 40, 1 (1927): 47-50; 41, 6 (1928): 191-92; 42, 1-2 (1929): 62-64; 43, 1-2 (1930): 57-59; 44, 3-4(1931): 190-92.

6 Stanko Vurnik, »Umetnost in družba ter umetnostna politika«, Ljubljanski zvon 46, 4 (1926): 244. 
še melodične napetosti in rahljanje tonalitet, ter se uveljavljala na širši glasbeni sceni na območju takratne Jugoslavije in v nekaterih drugih evropskih slovanskih državah. Prvi je tega leta izvedel uspešno koncertno turnejo po Češkoslovaški, Akademski pa je s skladbami Marija Kogoja in Janka Ravnika nastopal v Beogradu.

Nedvomno so se avantgardni umetnostni pojavi na Slovenskem utrjevali počasi, v manjših, deloma celo v zaprtih umetniških krogih, saj je bila tradicija zelo zakoreninjena, novosti pa podvržene ostri netolerantni kritiki. Med najbolj napredno mislečimi je bila skupina v krogu Kluba mladih (ustanovljen leta 1920) pod vodstvom pesnikov Antona Podbevška in Mirana Jarca ter slikarjev Božidarja Jakca in Riharda Jakopiča, ki je s svojimi kulturnimi manifestacijami, znanimi kot "novomeška pomlad«, tlakovala pot prihajajočim generacijam umetnikov. To je bil čas, ko so se pojavljale vedno nove umetnostne smeri, futurizem, dadaizem, kubizem in konstruktivizem, Srednja Evropa pa se je najbolj ogrela za ekspresionizem. Slovenski mladi umetniki so izražali težnje po drugačnem, nematerialističnem svetu, ter $\mathrm{z}$ ekspresionističnimi in konstruktivističnimi deli stopali po poti nove stvarnosti oziroma novega realizma. ${ }^{8}$ Pomenljivo napredna sta bila gledališka režiserja Ferdo Delak in Bratko Kreft, medtem ko so bili med skladatelji sodobnih glasbenih tokov le tisti, kot pravi Matija Bravničar, "prežeti z željo ustvariti nekaj povsem novega, brez kompromisov, z zavestnim tveganjem in kljubovanjem «. ${ }^{9}$ Prvi med njimi je bil Marij Kogoj kot ekspresionist $z$ dunajskimi vzori Arnolda Schönberga in Franza Schrekerja, ki je leta 1927 dokončal za slovensko zgodovino epohalno opero Črne maske. Njegov vpliv je sooblikoval Matijo Bravničarja, ki je svojo prvo opero s socialno tematiko Pohujšanje $v$ dolini šentflorjanski (dokončana 1930) zasnoval v slogu operne farse. Med najnaprednejšimi pa je bil praški diplomant Slavko Osterc, privrženec ekspresionizma in kasneje neoekspresionizma ter zagovornik Hábovega četrttonskega sistema, ki je kot profesor kompozicije na ljubljanskem konservatoriju od leta 1927 bíl bitko z zastarelim učnim programom in njegovimi zagovorniki. S svojimi sodob-

Stanko Vurnik, »Glasbeno življenje v Ljubljani 1. 1930«, Dom in svet 44, 1-2 (1931): 95 . prazgodovine do danes, Stane Bernik et al. (Ljubljana: Mladinska knjiga, 1998): 26370.

9 Darja Koter, »Matija (Frane) Bravničar - prispevek k biografiji«, Matija Bravničar (1897-1977), Tematska številka Glasbeno-pedagoškega zbornika Akademije za glasbo, zv. 9, ur. Darja Koter (Ljubljana: Akademija za glasbo, 2008), 15. 
nimi umetnostnimi nazori je kot eden prvih skladateljev svojega časa zaznamoval več generacij mladih glasbenikov, ki so komponirali v sodobnem duhu, tudi v atonalnem slogu, ter se skupaj z njim uveljavljali na festivalih sodobne glasbe v okviru mednarodnega združenja SIMC (Société internationale de musique contemporaine). Prvi slovenski avantgardizem je dosegel vrhunec $\mathrm{z}$ revijo Tank (1927), katere pisci so o razvoju nove umetnosti razpravljali tudi v znani umetnostni reviji Der Sturm, ki je leta $1929 \mathrm{v}$ posebni številki objavila dejavnost avantgardnega, t. i. Novega odra Ferda Delaka, komentar h konstruktivistični razstavi slikarja Avgusta Černigoja in h glasbenemu opusu Marija Kogoja, sicer pretirano označenega za predstavnika atonalne glasbe. ${ }^{10}$ Med večje dosežke, ki so bili plod evropskih novih gibanj, smemo šteti tudi nekatere poustvaritve ljubljanske Opere pod vodstvom Mirka Poliča, ki je poleg Kogojevih Črnih mask (1929) izvedla nekaj zares aktualnih del širšega evropskega prostora, kot so bile Zaljubljen v tri oranže (1927) Sergeja Prokofjeva, Oedipus Rex (1928) Igorja Stravinskega in ne nazadnje Ernsta Křeneka Johnny spielt auf (nastala 1927, v Ljubljani 1928). Nujnosti pretoka sodobnejših idej v slovensko ustvarjalnost in poustvarjalnost se je začel zavedati tudi odbor Glasbene matice, ki je, ne brez turbulentnih dogovarjanj, podprl predlog Emila Adamiča o izdajanju sodobne glasbene revije Nova muzika. Njeno idejno usmeritev in vizijo $\mathrm{k}$ »novemu « so v uvodu prve številke leta 1928 predstavili tako urednik Adamič kot umetnostni ideolog Vurnik ter Osterc, ki je na tem mestu zapisal svoj umetniški manifest in ga zaokrožil z motom: »Delajmo in študi-

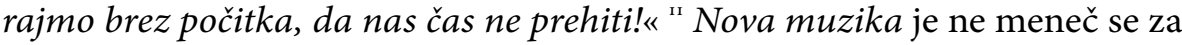
kritike uresničila marsikaj od zastavljenega, spodbujala je dela v slogu aktualnih evropskih gibanj, objavila vrsto novih skladb mlajših in najmlajših slovenskih skladateljev, pa tudi dela hrvaških, srbskih, čeških, poljskih in nekaterih drugih avtorjev, ter vseskozi sledila svojim ciljem - predstavljati sodobnejše kompozicijske prijeme. Med kompozicijsko najradikalnejšimi objavami so bila dela čeških skladateljev (Otakar Ostrčil, Rudolf Karel, Jaroslav Křička, Karel Boleslav Jirák, Alois Hába idr.), med slovenskimi pa Slavka Osterca, Demetrija Žebreta in Srečka Koporca. Žebre je predstavnik praške mojstrske šole Josefa Suka in Aloisa Hábe ter eden ključnih modernistov slovenskega prostora svojega časa, Koporc pa je bil dunajski študent Schönbergovega učenca Egona Lustgartna. Adamič je revijo uspešno distri-

10 Ervin Dolenc, »Avantgarda v umetnosti - konstruktivizem«, Slovenska kronika XX. stoletja (Ljubljana: Nova revija...), 307.

11 Slavko Osterc, "Glavne struje sodobne glasbe in njih eksistenčna upravičenost«, Nova muzika 1, 1 (1928): 1-2. 
buiral v nemške, češke in druge slovanske glasbene kroge, $s$ čimer je uresničeval idejo razširjanja mlade slovenske glasbe. Kljub aktualnosti, pretoku idej in dobri uredniški politiki revija zaradi nasprotovanj tradiciji zavezanih slovenskih krogov ni obstala in je po dveh letih prenehala izhajati. ${ }^{12} S$ tem so bile prekinjene nadvse pomembne ustvarjalne spodbude mladim skladateljem, ki jim je Nova muzika nudila oporo ter omogočala predstavitev v domačih in tujih glasbenih krogih. V naslednjih dveh desetletjih slovenska glasbena scena ni zmogla ustvariti podobno pomembne revije, ki bi zastopala širok spekter sodobne glasbene ustvarjalnosti.

Kljub številnim oviram, ki so v obravnavanem času vplivale na kulturno raven slovenske umetnosti, so $\mathrm{v}$ danih razmerah nastajali posamezni zbori, ki so presegli slovensko povprečje in se močno približali idealom razvitejših evropskih sredin. Odrasle in mladinske zbore je k "novemu« spodbudil že omenjeni Pevski zbor slovenskih učiteljev, ki je imel odlične vzore. To je bil izjemno odmeven, že pred prvo svetovno vojno mednarodno uveljavljen moški zbor Pevske zveze moravskih učiteljev, ki je deloval pod vodstvom Ferdinanda Vacha in se proslavil z odlično pevsko tehniko in izbornim programom. Decembra leta 1907 je nastopil v Ljubljani in Trstu ter vzbudil posnemanja vredno občudovanje. ${ }^{13}$ Njegov nastop je med slovenskimi učitelji in zborovodji odmeval več let in bil ponovno v ospredju leta 1922, ko je isti dirigent $\mathrm{v}$ Ljubljani nastopil z ženskim zborom društva, ki je veljal za edinstvenega. Pisec poročila o tem koncertu Josip Michl, po rodu Čeh, sicer pa vpliven učitelj goriškega učiteljišča, je zapisal, da sta oba zbora epohalna ter da je dirigent Vach rešitelj češke zborovske glasbe, ki je na začetku 2o. stoletja ob sicer velikem vzponu instrumentalne glasbe stagnirala. Ferdinand Vach, prej neznani učitelj petja na učiteljišču, je v okviru zveze učiteljskih društev zbral nekdanje učence in sestavil zbor visoko motiviranih pevcev, s katerimi je ob trdem delu kmalu dosegel odlično pevsko tehniko in zmožnost umetniškega poustvarjanja. Pevci so na vaje prihajali iz različnih krajev, pripravljeni na skupno delo. Zbor je kmalu dosegel zavidljive uspehe in mednarodno priznanje ter postal vzor drugim češkim zborovodjem in zborom. Število zborov je skokovito naraščalo, kvaliteta je bila vse višja. Ob tem Michl poudarja, da so češki skladatelji ob poslušanju obeh Vachovih zborov, njunem ubranem, intonančno čistem in umetniško prepričljivem petju začeli množično ustvarjati nove skladbe ter tako poskrbeli za ponov-

12 Darja Koter, "Glasbena revija Nova muzika - Adamič kot urednik«, Adamičev zbornik (2004): 63-75. 
ni vzpon zborovske literature in njeno kompozicijsko posodobitev. ${ }^{14}$ Uspeh Vachovih zborov je močno odmeval med slovenskimi učitelji, zborovodji in skladatelji, zato ne čudi, da so ga želeli posnemati. V tem duhu je leta $1920 \mathrm{v}$ okviru Zveze jugoslovanskih učiteljskih društev nastal Pevski zbor tržaškega učiteljskega društva pod vodstvom Srečka Kumarja. Kot pravi Karol Pahor, je idejo o tovrstnem zboru že pred prvo svetovno vojno na Tržaškem razširjal Emil Adamič, ${ }^{15}$ Ivan Grbec pa poudari, da se je porodila v času, ko so moravski učitelji nastopali "po naših krajih $«{ }^{16}$ kar je bilo prvič leta 1907.

Adamiča in Kumarja štejemo za najvplivnejša moža v procesih izobraževanja slovenskih zborovodij med obema vojnama ter ju poznamo kot zaslužna za nastanek novih, predvsem mladinskih zborov ter umetniško vredne, kompozicijsko raznolike, vendar modernistične literature zanje. Ideje o zborovski literaturi in izvajalski praksi, ki naj presežejo narodnobuditeljske težnje in stremijo $\mathrm{k}$ sodobnim umetniškim stvaritvam, sta negovala oba, kar ju je zbližalo že v njunem tržaškem obdobju pred prvo svetovno vojno. Emil Adamič (1877-1936), od mladih let predan učitelj in zborovodja ter mentor številnim zborom, se je $\mathrm{z}$ aktualnim glasbenim dogajanjem in novostmi seznanjal na zborovskih, glasbenopedagoških in skladateljskih strokovnih srečanjih in kongresih na Dunaju, v Nemčiji, na Češkem, v Bolgariji in drugod. ${ }^{17}$ Čeprav je bil kot skladatelj otroških in mladinskih zborov najbolj predan priredbam ljudskih pesmi, se je posebno od 2o. let posvetil razvoju mladinske literature ter ji vdihnil sodobnejši vsebinski in kompozicijski pečat. ${ }^{18}$ Srečko Kumar (1888-1954), najprej učitelj, nato pa kot pianist diplomant tržaškega konservatorija, je že v dijaških letih vodil zbor koprskega učiteljišča in nato pevce društva Zarja v Rojanu, s katerimi se je dokončno zapisal zborovstvu. Nase je opozoril kot zborovodja sodobnega repertoarja, kar je bila v slovenskem narodnozavednem okolju redkost. Kot pravi sam, ga je za sodobno glasbo še pred vojno navdušil učitelj Josef Michl kot pevovodja zbora Glasbene matice v Gorici, ki je med prvimi izvajal dela takrat mladega Antona Lajovca. ${ }^{19}$ Kumar se je aktualnih glasbenih

14 Josip Michl, »Iz koncertne dvorane«, Ljubljanski zvon 43, 1 (1923): 60-61.

15 Jože Zorn, »Učiteljski pevski zbori v ogledalih učiteljskih listov«, Petdeset let Učiteljskega pevskega zbora (Ljubljana: UPZ Emil Adamič, 1975), 10.

16 Zorn, »Učiteljski pevski zbori v ogledalih učiteljskih listov«, 11.

17 Darja Koter, »Emil Adamič«, Novi Slovenski biografski leksikon, obiskano 22. avgusta 2017, http://www.slovenska-biografija.si/oseba/sbi123724/.

18 Prav tam.

19 Albert Širok, »Srečko Kumar«, Petdeset let Učiteljskega pevskega zbora (Ljubljana: UPZ Emil Adamič, 1975), 29. 
gibanj navzel tudi v Leipzigu, kjer je že pred prvo svetovno vojno študiral klavir, gotovo pa tudi na Češkem, kjer je med vojno in po njej vodil pevske zbore. Leta 1919 se je vrnil v Trst in se predal vsestranskemu glasbenemu delovanju in bil med ustanovitelji učiteljskega pevskega zbora, s katerim je med leti 1922 in 1924 zelo uspešno nastopal na širšem Tržaškem, pa tudi v Gorici, Benetkah in Bologni ter prejemal odlične kritike. V naslednjih dveh letih je zbor zaradi vse hujših fašističnih pritiskov in ovir počasi usihal in sredi leta 1926 prenehal delovati. ${ }^{20}$ Zbor učiteljev širše Primorske, Goriške in Istre (Zbor učiteljske zveze za Primorsko) je nastal in deloval po vzorih moravskih učiteljev. Kumar je ansambel vsestransko glasbeno in pevsko izobraževal ter skrbel za tehten in sodoben repertoar, ki ga je pridobil tako, da se je obrnil na slovenske skladatelje in jih spodbudil $\mathrm{k}$ novim delom. $\mathrm{O}$ svojem delu je izjavil:

"Poskusil sem izluščiti glasbeni 'šund' s programov naših koncertov, propagiral sem modernejšo strujo pri nas, od vseh omalovaževano, animiral sem naše skladatelje, da so se vrgli na delo s še večjo vnemo. ${ }^{21}$

Med drugim je izvedel Antona Lajovca Pomladni spev, ki je postal zborov emblem, ter Emila Adamiča Kregata se baba in devojka. Kumrovi pobudi so se odzvali tudi drugi skladatelji, Ivan Grbec, Vasilij Mirk, Emil Komel, Stanko Premrl, Janko Ravnik in Vinko Vodopivec. ${ }^{22}$ Kumarjev učiteljski zbor je ob povedanem uresničeval tudi druge cilje, kot je glasbeno izpopolnjevanje pevcev za zborovodsko delovanje, kar je pomenilo, da je bil zbor ne le pevsko temveč tudi izobraževalno telo. Ta pomemben cilj je širši javnosti predstavil Karol Pahor:

»Naloga pevskega zbora bi bila: gojiti izmed zborovskih skladb (one) najboljše. [...] Lajovic, Ravnik, Kogoj, Foerster idr., ki so do sedaj dvignili umetno pesem najvišje. [...] ki jim zmore biti kos učitelj, ki je v splošnem glasbeno izobražen. Vsak učitelj je dobil na učiteljišču toliko glasbene izobrazbe in bo gotovo težkoče modernih skladateljev tudi zmogel. Nadalje se bodo tu centralizirale vse one učne moči, ki opravljajo po deželi že delo pevovodij, da si bodo po2017, www.slovenska-biografija.si/oseba/sbi309739/; Zorn, »Učiteljski pevski zbori v ogledalih učiteljskih listov«, 11-24.

21 Širok, »Srečko Kumar«, 27.

22 Zorn, »Učiteljski pevski zbori v ogledalih učiteljskih listov«, 11-12. 
tem potom predavanj pridobili na glasbenem polju širše obzorje in bodo mogli opravljati med ljudstvom svojo nalogo na umetniškoglasbenem polju .... $\aleph^{23}$

Hkrati z razvojem učiteljskega pevskega zbora se je pod idejnim vodstvom Srečka Kumarja na širšem Primorskem razgibalo tudi mladinsko petje, označeno kot novo glasbeno gibanje, ki je rojevalo sodobnejšo zborovsko literaturo. ${ }^{24} \mathrm{~V}$ šestdeset članskem učiteljskem zboru je bila kar polovica pevovodij, ki so na podeželju v šolah in društvih vzgajali pevski naraščaj. ${ }^{25}$ Kumarja lahko označimo za glasbenega vizionarja, saj se je zavedal preživelosti vsebinskih in glasbenih značilnosti skladb, ki so jih otroci običajno prepevali pri razrednem zborovskem petju. Bile so vsebinsko okorne ter daleč od otrokovega miselnega in čustvenega sveta. Po glasbeni plati so se opirale na ljudsko ali tujo umetno pesem, imele otrokom neprilagojen glasovni obseg, melodične, ritmične in druge glasbeno-tehnične nerodnosti in ne nazadnje so bile večinoma umetniško šibke. ${ }^{26}$ Vse to ga ja spodbudilo, da je nagovoril skladatelje in jih prepričal k snovanju sodobnejših in tehtnejših mladinskih skladb, pri katerih bi bilo potrebno upoštevati značilnosti otrokovega psihološkega in glasbenega razvoja ter izbirati primerna in tehtna besedila. Ne nazadnje si je prizadeval, da bi bila nova dela vsaj simbolni odsev tedanjega družbeno-političnega stanja primorskih Slovencev, ki so bíli neusmiljen boj s fašizmom. Da bi bile skladbe tudi vsebinsko in idejno primerne, je celo sam zbiral besedila in jih pošiljal skladateljem. ${ }^{27}$ Njihov odziv je bil več kot zadovoljiv: 49 del enajstih avtorjev je Kumar leta 1924 izdal v zbirki Otroške pesmi (E. Adamič, M. Kogoj, I. Grbec, A. Lajovic, K. Pahor, V. Vodopivec...). Zbirka je bila takoj opažena in označena kot izjemna novost in brez primere $\mathrm{v}$ širšem evropskem prostoru. Časopis Učiteljski tovariš je objavil recenzijsko poročilo, ki pravi:

"Končno je naša mladina v pričujoči zbirki dobila pesmarico, skakoršno se niti veliki narodi zlepa ne morejo ponašati. [...] poznam češke, ruske, nemške, ruske in italijanske, seveda tudi hrvaške in

23 Povzetek zapisa Karola Pahorja v učiteljskem časopisu Tržaški list II, 8 (1921), 16. 4. 1921, III.

24 Rafael Ajlec, "Za uvod", Slavček. Pesmarica mladinskih zborov, ur. A. Šuligoj (Ljubljana: Svet zveze Svobod in prosvetnih društev Slovenije, 1957), XII.

25 Širok, »Srečko Kumar«, 27.

26 Cvetko Budkovič, Razvoj slovenskega mladinskega zborovskega petja na Slovenskem: od začetkov do druge svetovne vojne (Ljubljana: Partizanska knjiga, 1983), 9-26. 
srbske, toda tozadevna literatura je skoraj povsodi tako uboga in neumetniška ....1 ${ }^{28}$

Pisec nato opozori, da so med objavljenimi pesmimi zahtevnejše, za bolj izobražene učitelje zborovodje, pa tudi lažje, a umetniško vredne, »ki bodo kaj kmalu izpodrinile brezsmiselno, dolgočasno prepevanje šablonskih, vse prej kot lepih pesmic. «9 $^{29}$ Besedila skladbic so večinoma dobro prilagojena otroški duši, predvsem pa so umetniško vredna in sledijo glasbenim spodobnostim mladih pevcev. Prevladujejo razpoloženjske, nekaj je predelanih narodnih in nabožnih besedil, posamezne pa so aktualne družbene prispodobe, vendar presenetljivo med njimi ni bilo skladb z izrazito socialno tematiko. Po glasbeni strukturi izstopajo dela Marija Kogoja, ki so tudi najštevilčnejša. ${ }^{30} \mathrm{O}$ Kogojevih delih, od katerih so mladinski zbori nastali prav na pobudo Srečka Kumarja, je le-ta tik pred izidom zbirke povedal:

"Kogoj pa je silen. Njegovo dosedanje ustvarjanje je vulkansko, vino $v$ vretju, ko se čisti. Čustvo je pri njem gigantsko močno, a preobloženo je z bogatim, mestoma prisiljenim in nenavadnim ritmom in z najekstremnejšo harmonijo, ki tonaliteto večkrat popolnoma ubije. Njegovi načrti so drzni kot njegov obraz. Zdi se, da je $v$ Kogoju večno živa želja napisati nekaj formalno popolnoma novega. [...] piše za zbor tako, da omaga pri skladbi celo orkester. Iz najglobljega trpljenja klijejo njegove stvari in vse njegove skladbe bi se dale strniti pod skupen naslov: himna trpljenja. Čeprav so njegove nove skladbe tako silne po čustvu, da prenesejo vso njegovo nečisto materijo, niso še cilj, so šele pot, so šele dragoceno izpričevalo njegovega razvoja, orglje, $k i$ se počasi kristalizira $v$ diamant. " $^{31}$

Kogojeva kompozicijska načela so temeljila na popolni osvoboditvi od preteklosti, romantike in impresionizma, in bila proti vsakršnim efektom, pri čemer se je zavzemal, da treba

»izvršiti popolno očiščenje in ustvariti objektivne vrednote, $k i$ bi bile vedno zmožne delovati na notranjost človeka [...]; izgnati iz N. N., »Otroške pesmi. Uredil Srečko Kumar«, Učiteljski tovariš, št. 21, 22. 5. 1924, 2. Prav tam.

30 Prim. Otroške pesmi, ur. S. Kumar (Trst: Zveza slovanskih učiteljskih društev v Italiji, 1924).

31 Širok, »Srečko Kumar«, 30. 
muzike vsako sentimentalnost in dobiti zdrav, močan izraz zdravemu, močnemu čustvu. $\aleph^{32}$

Svojih hotenj sicer ni povsem uresničil in ni zašel na področje atonalnosti. Svojemu prepričanju je sledil tudi v eno in dvoglasnih otroških pesmih, nastalih v enem zamahu leta 1922 ali 1923 . Zanje je skrbno zbiral besedila, se izogibal melodičnim stereotipom, nihal med modalnim in tonalnim, imitiral in ustvaril izviren ekspresionistični izraz, ki temelji na povednosti besedil, svojstvenih intervalnih razmerjih, subtilnih variacijah ter ne nazadnje na svobodnih ritmičnih in metričnih postopih..$^{33} \mathrm{Kmalu}$ po izidu Kumrove zbirke so njene skladbe zaživele v osnovnih šolah, kjer so petje vodili pevci Kumrovega učiteljskega zbora, ki so njegovo znanje ter ideje zborovskega petja prenašali na mlajše rodove. ${ }^{34}$ Med njimi je posebej izstopal Avgust Šuligoj, ki se je izkazal za odličnega mentorja otroškega oziroma mladinskega petja na različnih primorskih osnovnih šolah in nekaj kasneje postal spiritus agens mladinskega petja $\mathrm{v}$ osrednji Sloveniji.

Srečko Kumar se je leta 1924 kot gostujoči zborovodja Glasbene matice predstavil v Ljubljani, ${ }^{35}$ ko pa je bil dve leti kasneje zaradi fašizma primoran razpustiti svoj primorski učiteljski zbor, se je zatekel v Ljubljano ter se vključil v vseslovensko zborovsko gibanje. Njegovi akterji, med njimi Anton Lajovic, so si že od konca vojne prizadevali, da bi po moravskih vzorih ustanovili zbor vseslovenskega učiteljstva. Ideja je zorela v posameznih krajih, $v$ manjših sestavih učiteljev, do združenega pevskega zbora pa je prvič prišlo leta 1924, ko je Zveza slovenskih zborov v Ljubljani priredila koncert združenih zborov pod vodstvom Zorka Prelovca. ${ }^{36}$ Do končne uresničitve vseslovenskega pevskega zbora učiteljev je prišlo sredi leta 1925 na pobudo Društva učiteljev glasbe, katerega predsednik je bil Marko Bajuk, tajnik pa Adolf Gröbming. V pozivu k ustanovitvi ansambla je društvo zapisalo:

»Moderne zborovske skladbe zahtevajo glasbeno naobraženih pevcev, [...] najboljše pevce moremo iskati med učiteljstvom, [...] dokaz temu je zbor učiteljev v Južni Benečiji, ki se je v nekaj letih popolnoma uveljavil ne le pri rojakih, temveč tudi pri Italijanih sa-

32 Marij Kogoj, »Smer glasbe v zadnjem desetletju«, Ljubljanski zvon 43, 6 (1923): 324.

33 O teksturi Kogojevih otroških pesmih glej tudi: Borut Loparnik, »Prvine melodične dikcije Kogojevih otroških pesmih", Muzikološki zbornik 5 (1969): 54-70.

34 Ajlec, »Za uvod«, XIII.

35 Prim. Zorn, »Učiteljski pevski zbor med obema vojnama«, 35.

36 Prav tam. 
mih. [...] Kaj premore dobro organiziran zbor, priča tudi zbor moravskih učiteljev. Delovanje tega zbora je bilo tako uspešno, da je produktivno vplivalo na produktivno češko glasbeno umetnost. Odprl je skladateljem nove perspektive in nastale so mogočne širokopotezne skladbe ... Pri nas čaka nešteto krasnih skladb moderne koncepcije za izvajanje. Pretežke so za naše zbore, ne bi pa bile za zbor glasbeno naobraženih pevcev. Zato je dolžnost našega učiteljstva, da tu zastavi svoje moči in pomaga moderni slovenski pesmi na noge. «7

K uresničevanju ideje o pospeševanju nastajanja novih, sodobnejših skladb in višjega nivoja poustvarjalnosti sta dejavno pripomogla soustanovitelja zbora Emil Adamič in Srečko Kumar, ki je postal tudi dirigent s smelimi in večplastnimi cilji. Privabljali so učitelje širšega slovenskega ozemlja, tudi primorske Slovence, nekdanje Kumarjeve pevce. Od pevcev je bila pričakovana višja izobrazbena raven petja in usposabljanje za vodenje odraslih in šolskih zborov. $\mathrm{V}$ ta namen so organizirali večdnevne pevske tečaje in skupne vaje, kjer so se pevci urili v vokalni tehniki, glasbeni teoriji, dirigiranju ... Posledično je bilo pričakovati rast novih zborov ter tehnični in umetniški dvig otroškega in mladinskega petja. Kumar je tudi ta učiteljski zbor pojmoval kot "poligon« izobraževanja zborovodij, kar je pred leti uresničil na Tržaškem. Ker si je zadal, da bo ansambel poustvarjalno telo najnovejše zborovske glasbe, je skladatelje slovenskega in širšega jugoslovanskega prostora spodbujal k novim, kompozicijsko aktualnejšim skladbam, ki naj bi jih predstavljali tudi v mednarodnih okvirjih. Zaradi drugačnih družbeno-političnih razmer pa je nekoliko v ozadje stopila narodnobuditeljska nota, ki jo je nadomestila usmeritev k socialni problematiki in novim družbeno-političnim razmeram časa. Zastavljene cilje je ansambel pod Kumarjevim vodstvom ter idejni in strokovni podpori Adamiča uspešno uresničeval. V nekaj letih je zaživel kot umetniško telo $\mathrm{z}$ velikimi ambicija$\mathrm{mi}$ in izrazito sodobnim repertoarjem. Izvedel je številne novitete slovenskih in jugoslovanskih skladateljev aktualne dobe, $s$ katerimi se je predstavljal $v$ domačem in mednarodnem prostoru, iz njegovih vrst pa je izšla tudi vrsta dobrih zborovodij, ki so delovali v kulturnih društvih in šolah. ${ }^{38} \mathrm{Zbor}$

37 Marko Bajuk in Adolf Gröbming, »Ustanovimo učiteljski pevski zbor«, Učiteljski tovariš 63, 30 (1923), 23. 7. 1923, 2 .

38 Zorn, »Učiteljski pevski zbor med obema vojnama«, 38-54. Za sintezo razvoja zborovstva med obema vojnama glej: Darja Koter, Slovenska glasba 1918-1991 (Ljubljana: Študentska založba, 2012), 83-85. 
učiteljstva je užival vsestransko navdušenje in dobival pohvalne kritike. ${ }^{39}$ Njegove ideje, stremljenje k odličnosti ter sodobnemu repertoarju, so široko odmevale in posebno spodbudile razvoj mladinskih zborov po osnovnih šolah, kjer se je dotlej pretežno gojilo enoglasno razredno petje preprostih, vsebinsko in glasbeno-tehnično ne dovolj primernih pesmi. Ideja o potrebi po razvoju mladinskega petja $\mathrm{v}$ pevskem oziroma glasovnem in repertoarnem pogledu, je kmalu prinesla novo kvaliteto: učitelji zborovodje, Kumarjevi pevci, so spoznavali, da v okviru razrednega petja ni mogoče doseči zares ubranega petja in umetniške poustvarjalnosti, zato so drug za drugim ustanavljali šolske mladinske pevske zbore izbranih pevcev, jih pevsko izobraževali in posegali po zahtevnejših oziroma tehtnejših in sodobnejših skladbah.

Med prvimi, ki so sledili tej ideji, je bil Avgust Šuligoj, ki je od leta 1927 poučeval $\mathrm{v}$ osnovni in meščanski šoli Trbovlje-Vode in tam vodil tudi mladinski pevski zbor, kasneje preimenovan v Trboveljski slavček. Kot učitelj je bil osupel nad težkimi socialnimi razmerami tamkajšnjih otrok. Prišel je namreč v času velike gospodarske krize, ki je še posebno prizadela rudarje in njihove družine. Ob vsakodnevnem opazovanju težkih življenjskih pogojev bolehnih in slabotnih otrok pa je pri učencih zaznal izjemno pevsko nadarjenost, zato je začel iskati oblike, kako mladim olajšati mladost in razvijati njihove naravne danosti. Možnost omilitve duševnih stisk je videl v vsestransko ambicioznem pevskem zboru, ki bi pevcem omogočil lepše življenje. Ko je spoznaval socialne razmere, se je zavedal, da v novih časih, prežetih s številnimi drugimi grenkobami, narodnostna ideja ni več v ospredju. Zbor rudarskih otrok je zasnoval kot ansambel takrat revolucionarnih socialnih idej..$^{40} \mathrm{~V}$ ospredje je postavljal iskrene medsebojne odnose, »da predstavlja zborovska družina nekaljivo harmonijo in nedeljivo celoto $z$ enim hotenjem in eno voljo « in šele nato glasbeno izobrazbo in ambicijo dirigenta. ${ }^{41}$ Prav poglobljen in pristen odnos s pevci mu je prinesel sugestivno moč, s katero je z zborom dosegal dotlej na Slovenskem nezmožne umetniške presežke. Pot do slavnega Trboveljskega slavčka pa ni bila lahka. Šuligoj je v prvem letu z zborom sicer nastopil v trboveljskem Delavskem domu, vendar se je kmalu zavedal, da ima za uresničitev svojih idej pomanjkljivo izobrazbo in premalo izkušenj z metodami zborovskega dela. Šolsko delo

39 Jože Župančič, »Učiteljski pevski zbor v polnem razmahu«, Učiteljski tovariš 71, št. 41 (1931), 26. 11. 1931, 3.

40 O Šuligojevem življenju in ustvarjanju glej: Ajlec, »Za uvod«, XV.

41 Avgust Šuligoj, "Moja pot«, Slavček. Pesmarica mladinskih zborov, ur. A. Šuligoj (Ljubljana: Svet Zveze Svobod in prosvetnih društev Slovenije, 1957), XVIII. 
je za nekaj časa prekinil, se samoizobraževal ter študijsko potoval v Prago in na Dunaj, kjer se je seznanil z načini dela dveh slavnih zborov: z Bakulovo pevsko družino v Pragi ter z zborom Dunajskih dečkov. Nato se je še izčrpneje posvetil proučevanju življenjskih prilik trboveljskih rudarjev in njihovih otrok ter o tem objavil nekaj alarmantnih člankov. Bil je tako prodoren, da so mu oblasti nadaljnje objave prepovedale. ${ }^{42}$ Vse to pa mu ni preprečilo uresničiti ideje o stalnem mladinskem pevskem zboru, ki bi bil s poglobljenim vokalnim izobraževanjem in umetniškim poustvarjanjem sposoben izvajati najnovejša in zahtevna dela slovanskih avtorjev, tudi izven trboveljske kotline, $\mathrm{v}$ mednarodnem prostoru. Leta 1930 je $\mathrm{v}$ ta namen na deški in dekliški osnovni šoli Trbovlje-Vode zbral okrog sto pevcev in že čez nekaj mesecev z njimi izvedel samostojni koncert. Njegova pot je šla strmo navzgor, nastopi so se vrstili vse bliže Ljubljani, nato v drugih slovenskih krajih in kmalu tudi na Češkoslovaškem in na Dunaju. Kritiki so zbor in dirigenta slavili in kovali $\mathrm{v}$ zvezde. ${ }^{43} \mathrm{Ob}$ študiju izbrane pevske literature se je Šuligoj zavedal potreb po skladbah s socialno noto, ki jih skladatelji dotlej niso namenjali otrokom, zato se je povezal z nekaterimi pesniki in skladatelji. Prvo takšno pesem je zboru posvetil Emil Adamič na besedilo Vlada Klemenčiča in nosi pomenljiv naslov: Pesem rudarskih otrok (nastala avgusta 1931). Ta skladba je kmalu postala zborova himna, ki so jo na zahtevo občinstva redno prepevali na začetku in ob zaključku koncertov. ${ }^{44}$ Nič manj grenkobna ni bila Pesem beračev (bes. Oskar Hudales, izvirno Pesem ubožcev), ki jo je prav tako uglasbil Emil Adamič (1933), vendar je zaradi vsebine in sugestivne uglasbitve zbor ni smel izvajati (prva izvedba leta 1940). ${ }^{45}$ Še posebno pretresljiva je bila tožba za umrlim očetom Čaće moj Ivana Matetića-Ronjgova (nastala po tragični rudarski nesreči v Trbovljah leta 1932). Matečić je med prvimi pisal priredbe istrskih ljudskih pesmi in kljub zahtevnosti in posebnosti istrske lestvice jih je Šuligojev zbor uspešno izvajal, kar je skladatelja spodbudilo k nastanku tožeče pesmi Čaće moj, posvečene Slavčkom. Le-ti so jo večkrat prepevali z izjemnim uspehom, tudi na velikih mednarodnih shodih, kot je bil leta 1936 v Pragi ob prvem mednarodnem kongresu za sodobno glasbeno vzgojo, kjer so bili Trboveljski slavčki

\footnotetext{
42 Jože Skrinar, Trboveljski slavček od srca k srcu (Trbovlje: Mešani zbor Slavček, 1971), 10.

Nekaj udarnejših kritik je objavil Jože Skrinar v delu Trboveljski slavček od srca k srcu, 39-42.

44 Prav tam, $17-18$.

45 Prav tam, 18.
} 
posebni gostje. ${ }^{46}$ Šuligoj je imel pretanjen občutek za glasbeno literaturo in je znal zbrati najtehtnejše in kompozicijsko primerne skladbe, $s$ katerimi se je zbor izkazal tako po tehnični kot muzikalni plati, ne glede na to, ali so izvajali priredbe ljudskih ali umetne pesmi. Najprej se je naslonil na Emila Adamiča in Slavka Osterca, ki sta se njegovim sugestijam odzvala in pisala na ljudska in sodobna pesniška besedila ter postala velika prijatelja in pokrovitelja zbora. Številne pesmi sta zboru tudi posvetila. Osterc med drugimi tudi svoj znameniti Kvartet na satirično basensko besedilo ruskega pisatelja Ivana Krilova (1769-1844), s katerim je simbolično ošvrknil tedanjo jugoslovansko vlado, kot sokrivo za šibko socialno stanje rudarskih otrok. Skladbo je Osterc opredelil kot atonalno. ${ }^{47}$ Delo sicer kaže atonalne težnje, vendar vsebuje tudi tonalne centre in še danes velja za eno najzahtevnejših skladb mladinske literature medvojnega časa.

Do leta 1934, ob 100 koncertu, je imel Trboveljski slavček kot promotor slovenske in slovanske sodobne mladinske zborovske literature zaokroženo tehten repertoar, ki je večinoma obsegal modernistična dela Emila Adamiča, Marija Kogoja, Slavka Osterca, Zorka Prelovca, Karola Pahorja, Vasilija Mirka, Matije Bravničarja in drugih slovenskih avtorjev, med kompozicijami hrvaških in srbskih skladateljev pa so bile skladbe Zlatka Grgoševića, Marka Tajčevića, Ivana Matetića-Ronjgova, Miloja Milojevića, Petra Krstića, Mladena Pozajića, Stevana Mokranjca in ne nazadnje Borisa Papandopula. Vsi omenjeni so sodili med najvidnejše slovenske oziroma jugoslovanske skladatelje, njihova dela za Trboveljski slavček pa izstopajo po aktualnih besedilih in takrat sodobnih kompozicijskih prijemih, ki so zahtevali odlično pevsko tehniko, pretanjen posluh in zavzet odnos do povednosti besedil. Šuligoj je namreč kmalu izčrpal Kumarjevo zbirko Otroških pesmi iz leta 1924, predvsem pa je potreboval skladbe $\mathrm{z}$ drugačno vsebino, ideološko naravnane na družbene razmere, v katerih je deloval. Kot se je izkazalo, so prav pesmi s socialno noto poslušalce najbolj prepričale in ganile. Pregled priredb ljudskih pesmi kaže na to, da so bile izvirne predloge zgolj zvočno ogrodje za modernistične poteze in povsem nov pristop do predelav ljudskih motivov. V splošnem prevladuje iskanje novih sozvočij, menjavanje slogovnih značilnosti, uveljavljanje novih kompozicijskih tehnik, intervalno in harmonsko slikovita in pevsko zahtevna dela, ki segajo do roba ekspresivnosti in celo do atonalnosti. Ob tem se zdi povsem naravno, da so skladatelji premišljeno izbirali besedila, glasbeni stavek pa ostrili toliko, da je bil za otroško dojemanje glasbe muzikalno in tehnično sprejemljiv, ven-

46 Prav tam, 21.

47 Prav tam. 
dar so kmalu spoznali, da so Slavčki sposobni izvajati glasbeno-tehnično in izrazno najzahtevnejša dela. Slavčkov repertoar je po izvirnosti in aktualnosti presegel vsa društva, odrasle in mladinske zbore. $\mathrm{Z}$ njim se je rodilo pravo glasbeno gibanje, ki je spodbujalo nove in nove mladinske zbore, nastajanje številnih skladb in notnih zbirk, med pomembne vzgibe pa sodi tudi revija Grlica, ki sta jo med leti 1933 in 1935 v Zagrebu izdajala Ivan Grbec in Srečko Kumar. Njuna Grlica je postala osrednja revija za izdajanje sodobno naravnanih jugoslovanskih skladb za mladinske zbore, prinašala pa je tudi aktualne članke o vlogi in razvoju zborovskega petja in glasbenega pouka v osnovnih šolah.

Trboveljski slavčki so bili slavni doma in na tujem, kjer so jih primerjali z obema že omenjenima zboroma, praškim in dunajskim, nekateri pa so ga postavljali celo na piedestal pred vsemi. Številni koncerti so bili dobrodelni, v korist rudarskih otrok, pomoči najbolj potrebnim, pa tudi za gostovanja in letovanja na morju, kar je bila pevcem najlepša nagrada. Slavčkovo poslanstvo je tudi $z$ današnjimi očmi neizmerno: spodbujal je nove mladinske zbore, ki so zlagoma nadgradili nekoč prevladujoče šablonsko razredno petje, razvijali vokalno tehniko, izobraževali v glasbeni teoriji ter kot vrhunec stremeli k višji umetniški ravni poustvarjanja. Gibanje mladinskih zborov smemo šteti za pomemben dejavnik repertoarne tranzicije $\mathrm{k} »$ novemu«, Avgusta Šuligoja pa za najpomembnejšega akterja pri nastajanju in promoviranju mlade slovanske glasbene literature za mladinske zbore. Za njegov zbor je nastalo okrog 800 skladb, izvedenih na koncertih in radijskih postajah, kar je poslanstvo mladih pevcev še stopnjevalo. Za sistematični razvoj mladinskega poustvarjanja je bila zaslužna vrsta napredno mislečih učiteljev zborovodij, kot so Emil Adamič, Srečko Kumar, Avgust Šuligoj, Ivan Grbec, Ciril Pregelj, Makso Pirnik, Vasilij Mirk, Jurče Vreže in drugi, ki so v različnih slovenskih krajih delovali kot zborovodje, skladatelji in organizatorji pevskih koncertov. Posebej prelomno je bilo leto 1934, ko je bil v Ljubljani izveden prvi mladinski pevski festival. S svojo množično zasnovo je k sodelovanju privabil skoraj vse najvidnejše zborovodje in njihove sestave. Odmevna prireditev ni ostala brez dolgoročnih vplivov, med katerimi je potrebno izpostaviti rast novih mladinskih zborov, razširjanje umetniško in sodobno naravnanega programa ter poglobljenega pevskega izobraževanja. Čeprav je druga svetovna vojna razmah mladinskega zborovstva nasilno prekinila, je tradicija preživela in se nadaljevala po letu 1945. Novi časi so prinesli drugačne poglede na poslanstvo zborovskega petja, nove idejne poglede ter ideološko obarvane repertoarje, med kompozi- 
cijskimi načeli pa ni bilo prostora za moderniste predvojnega časa. Vse to je vplivalo na to, da je Trboveljski slavček, čeprav po vojni obujen, kmalu za$\mathrm{mrl}$ in ni imel pravih naslednikov. Zborovodje mladinskih zborov so hote ali nehote sledili idejnim zapovedim socializma, kjer pa ni bilo prostora za najnovejše kompozicijske tehnike zahodnega sveta.

\section{Bibliografija}

Bajuk, Marko in Gröbming, Adolf. »Ustanovimo učiteljski pevski zbor«. Učiteljski tovariš 63, št. 30 (1923), 23. 7. 1923, 2.

Budkovič, Cvetko. Razvoj slovenskega mladinskega zborovskega petja na Slovenskem: od začetkov do druge svetovne vojne. Ljubljana: Partizanska knjiga, 1983.

Dolenc, Ervin. »Avantgarda v umetnosti - konstruktivizem«. Slovenska kronika XX. stoletja, ur. M. Drnovšek in D. Bajt. Ljubljana: Nova revija, 1995, 307.

Dom in svet, leta 1926-1931.

Kogoj, Marij. »Smer glasbe v zadnjem desetletju«. Ljubljanski zvon 43, 6 (1923): 324.

Komelj, Milček. »Umetnost med obema vojnama«. Umetnost na Slovenskem Od prazgodovine do danes, Stane Bernik et al. Ljubljana: Mladinska knjiga, 1998, 263-70.

Koter, Darja. »Glasbena revija Nova muzika - Adamič kot urednik«. Adamičev zbornik. Ljubljana: Akademija za glasbo, 2004, 63-75.

Koter, Darja. »Matija (Frane) Bravničar - prispevek k biografiji«. Matija Bravničar: (1897-1977): tematska publikacija Glasbeno-pedagoškega zbornika Akademije za glasbo v Ljubljani, zv. 9, ur. D. Koter. Ljubljana: Akademija za glasbo, 2008, 7-24.

Koter, Darja. Slovenska glasba 1918-1991. Ljubljana: Študentska založba, 2012.

Koter, Darja. »Emil Adamič«. Novi Slovenski biografski leksikon. Obiskano 22. avgusta 2017. http://www.slovenska-biografija.si/oseba/sbi123724/.

Kumar, Srečko, ur.. Otroške pesmi. Trst: Zveza slovanskih učiteljskih društev v Italiji, 1924.

Loparnik, Borut. »Prvine melodične dikcije Kogojevih otroških pesmih«. Muzikološki zbornik 5 (1969): 54-70.

Michl, Josip. »Iz koncertne dvorane«. Ljubljanski zvon 43, 1 (1923): 60-61.

Osterc, Slavko. »Glavne struje sodobne glasbe in njih eksistenčna upravičenost«. Nova muzika 1, 1 (1928): 1-2. 
Premrl, Stanko. »Koncerti moravskih učiteljev«. Dom in svet 21, 3 (1908): 140.

Ajlec, Rafael. »Za uvod«. Slavček. Pesmarica mladinskih zborov, ur. A. Šuligoj. Ljubljana: Svet zveze Svobod in prosvetnih društev Slovenije, 1957, XII-XXIV.

Skrinar, Jože. Trboveljski slavček od srca k srcu. Trbovlje: Mešani zbor Slavček, 1971.

Širok, Albert. »Srečko Kumar«. Petdeset let Učiteljskega pevskega zbora. Ljubljana: UPZ Emil Adamič, 1975, 25-29.

Šuligoj, Avgust. Slavček. Pesmarica mladinskih zborov, ur. A. Šuligoj. Ljubljana: Svet Zveze Svobod in prosvetnih društev Slovenije, 1957.

Valentinčič, Emil. »Srečko Kumar«. Primorski biografski leksikon. Obiskano 6. marca 2017. www.slovenska-biografija.si/oseba/sbizo9739/.

Vurnik, Stanko. »Umetnost in družba ter umetnostna politika«. Ljubljanski zvon 46, 4 (1926): 244.

Vurnik, Stanko. Uvod v glasbo. I. Sistematični del. Ljubljana: Nova založba, 1929.

Vurnik, Stanko. »K problemu sodobne kulturnosti«. Dom in svet 43, 5/6 (1930): 1.

Vurnik, Stanko. »H krizi naše Opere«. Dom in svet 43, 1-2 (1930): 58-59.

Vurnik, Stanko. »Glasbeno življenje v Ljubljani 1. 1930«. Dom in svet 44, 1-2 (1931): 95 .

Zorn, Jože. »Učiteljski pevski zbori v ogledalih učiteljskih listov«. Petdeset let Učiteljskega pevskega zbora. Ljubljana: UPZ Emil Adamič, 1975, 10-24.

Župančič, Jože. »Učiteljski pevski zbor v polnem razmahu«. Učiteljski tovariš 71,41 (1931), 26.11.1931, 3. ${ }^{48}$

48 Poglavje je nastalo kot del projekta J6-718o, ki ga je sofinancirala Agencija za raziskovalno dejavnost Republike Slovenije.

This chapter is part of the project J6-7180 funded by Slovenian research agency ARRS. 


\title{
Radio Ljubljana v prvem desetletju svojega
} delovanja - medij, ideologija in inštitucija v luči glasbe

\author{
Katarina Bogunović Hočevar in Ana Vončina \\ Univerza v Ljubljani \\ University of Ljubljana
}

\section{Medij: izhodišča za razumevanje začetkov Radia Ljubljana}

Pričujoči prispevek ponuja vpogled v predvojni Radio Ljubljana in s stališča glasbenosti osvetljuje vpliv evropskega radijskega formata ter zlasti specifičnega lokalnega okolja in njegovih glasbenih danosti na začetke delovanja Radia Ljubljana.

Začetki radijskih postaj segajo nekako v prva leta dvajsetih let prejšnjega stoletja (ZDA 1920, Francija 1921, Nemčija 1923). Radio kot novi medij je bil prvotno zasnovan kot posredovalec političnih in gospodarskih poročil. Zasebne radijske postaje pa so kmalu začele odkrivati njegovo zabavno funkcijo, pri čemer je imela prav glasba precejšnji pomen - bila je glavni nosilec programa med pavzami poročil. ' Zaradi neustrezne tehnologije je bila uporaba gramofonskih plošč v prvih letih radijskih prenosov omejena, saj se je kvaliteta gramofonskega zvoka ob prenosu v nov medij (zaradi številnih tehničnih pomanjkljivosti aparatur) močno zmanjšala. Za pokrivanje dnevnih glasbenih potreb so denimo v Nemčiji leta 1924 nastali inštrumentalni ansambli radijskih postaj različnih velikosti in tudi z različnimi nalogami: radijski orkester, zbor, plesna kapela, radijski trio, ki se je kot mali ansambel izkazal za zelo uporabnega. ${ }^{2}$ Slednji je prav zaradi omejenega repertoarja igral pretežno priredbe. Pozneje so se pridružili še mali

1 Arnold Jacobshagen in Frieder Reininghaus, ur., Musik und Kulturbetrieb. Medien, Markte, Institutionen (Laaber: Laaber-Verlag, 2006), 47.

2 Prav tam, 48. 
radijski orkester (1930) in še radijski šramel orkestri, da bi izpolnili potrebo po zabavni oz. ljudski glasbi. ${ }^{3}$ Pogojev za dober prenos simfoničnega koncerta iz studija ni bilo, saj prvi mikrofoni masivnega zvoka orkestra niso reproducirali uspešno. Zabavna glasba je bila tako rekoč izhodišče in pomemben del glasbenega programa. $V$ realnosti se je delež glasbe $v$ programu nasploh postopno povečeval, to je veljalo zlasti za delež zabavne glasbe, ki so jo v prvi vrsti sestavljale večne melodije iz operet in drugih priljubljenih napevov. ${ }^{4}$ Poleg ljudske glasbe sta postajala priljubljena še plesna glasba in jazz. Radijski ansambli so $\mathrm{v}$ prvih letih delovanja izvajali pretežno lahko glasbo, nova glasba je le redko prišla v program..$^{5}$ Tako imenovana resna glasba je bila na Radiu v zelo občutljivem položaju: po eni strani ni bila razumljena širši publiki, po drugi pa se je zaradi takratnih tehničnih ovir ni moglo kakovostno predvajati. Specifični radijski ansambli so izkazovali potrebo po »specifično radijskem « repertoarju, ki je ustvaril povpraševanje po tovrstnih skladbah. Glasba na radiu je temeljila bodisi na glasbenih prenosih, bodisi na reproduciranju plošč. Delež slednjega se je z razvojem tehnologije plošč v tridesetih letih 20. stoletja povečeval.

V članku Radio na Švedskem iz leta 1947 opredeljuje Henrik Hahr tri tipe ureditve in delovanja Radiev v Evropi. ${ }^{6}$ Prvi tip povsem nadzoruje in vodi vlada; drugega nadzoruje vlada. Pri tretjem pa vlada vodi tehnični del (najbrž je mišljeno, da je lastnica infrastrukture), medtem ko program načrtujejo in vodijo zasebna ali pa polzasebna podjetja, ki so si pridobila koncesijo.? To je med drugim pomenilo tudi to, da so bile karkršnekoli tehnične težave prenosov predvsem problem izvajalca oz. koncesionarja in ne lastnika.

Delovanje Radia Ljubljana v času od ustanovitve do začetka druge svetovne vojne bi nekako najbolj ustrezalo zadnji kategoriji. Radijsko postajo v Ljubljani je v takratni Kraljevini Srbov Hrvatov in Slovencev leta 1928 dobila v 15-letno koncesijo Prosvetna zveza. ${ }^{8}$

\footnotetext{
Prav tam.

Prav tam, 54 .

Prav tam.

Henrik Hahr, »Radio Broadcasting in Sweden«, Hollywood Quarterly 1, 3 (Autumn, 1947): 11-14, obiskano 15. Februarja 2017, http://www.jstor.org/stable/1209627.

Prav tam, 11.

8 Arhivsko gradivo Radia Ljubljana se nahaja v Arhivu Slovenije. Glej: Fond Radiotelevizija Slovenije, AS 1215. Celotno gradivo tehničnih enot (škatel) ne sledi kronologiji, čeprav je le-ta sporadično prisotna znotraj posameznih zaporedij škatel. Podatke o delovanju Radia Ljubljana najdemo v t.e. 2 - 5, 8, 10, 54 - 57.
} 


\section{Ideologija: družbenopolitični kontekst RL}

Imetnike prvih radijskih aparatov v Kraljevni SHS najdemo že leta 1924. To so bili predvsem premožnejši ljudje, bankirji, direktorji, obrtniki, funkcionarji ipd. ${ }^{9} \mathrm{~V}$ istem času začnejo $\mathrm{v}$ Kraljevini delovati različni klubi radioamaterjev, za Slovenijo pa je bil še posebej pomemben poskus inženirja Marija Osane, ki je leta 1926 sestavil prvi radijski oddajnik. ${ }^{10}$
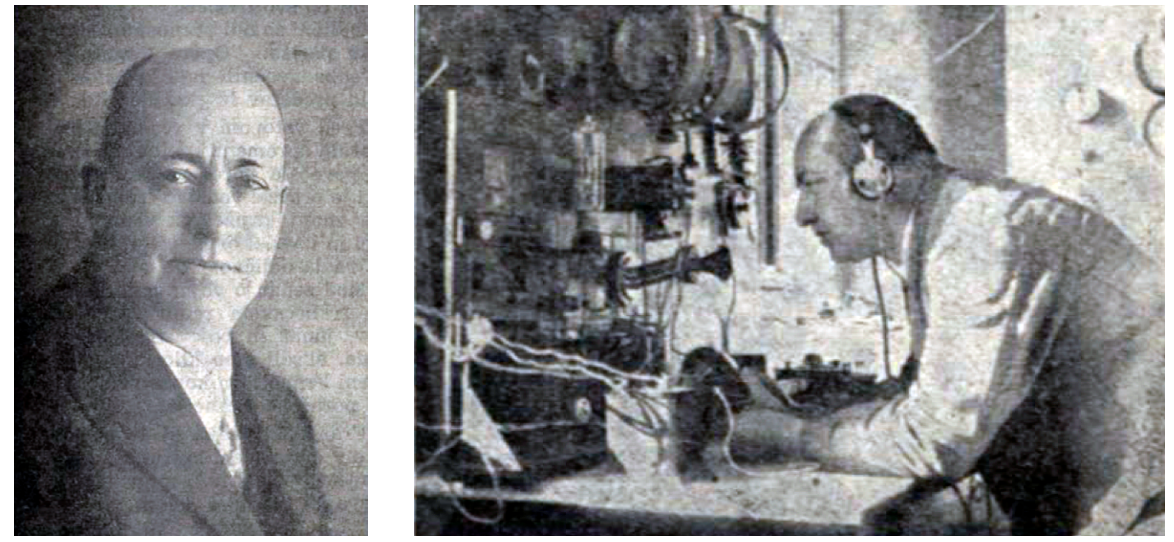

Slika I in 2: Marij Osana (Radio Ljubljana I2, št. 28 (1940), I.)

Prosvetna zveza, ki je bila krovna kulturna organizacija vseh katoliško usmerjenih društev, je prepoznala pomen novega medija in kot pripravo na ustanovitev in upravljanje radijske postaje, pod svojim okriljem ustanovila gospodarski oddelek in programski oddelek Radia Ljubljana.

Tone Sojar navaja, da je bila jugoslovanska vlada nezainteresirana za širitev novega komunikacijskega medija. Po eni strani ni želela radia vzeti v okrilje svoje administracije, po drugi pa se je upirala koncesijam. Pravi, da je bilo »prej mogoče pridobiti za to tehnično novost patriarha srbske pravoslavne cerkve kot pa ministre.$^{11}$

9 Knjiga prvih radijskih naročnikov se nahaja v Glasbeni zbirki NUK. Da je bil radio privilegij premožnih ne povedo zgolj imena prvih radijskih naročnikov temveč tudi njihovo število. Dvajseta so bil povojna leta, ko je bila domača industrija skromna in revna. Prav tako je bil radijski aparat določena moda, glede na visoke cene pa predvsem privilegij premožnih.

10 Prim. Arhiv Slovenije, AS 1215, Fond Radiotelevizija Slovenije, t.e. 2. Tehnična enota 2 vsebuje pretežno zapise o začetkih Radia pri nas.

11 Tone Sojar, »Iz zgodovine našega Radia«, str. 4-5, v: Arhiv Slovenije, AS 1215, Fond Radiotelevizija Slovenije, t.e. 2. 
Spremembe v političnem vrhu Kraljevine SHS leta 1928 so Prosvetni zvezi omogočile pridobitev koncesije (inženir Osana je bil načelnik v ministrstvu za Pošto telegraf in telefon v Beogradu). ${ }^{{ }^{2}} \mathrm{~V}$ radiofonskem pravilniku, ki ga je leta 1929 izdalo Ministrstvo za PTT v Beogradu, je pravilnik za radijske postaje določal, da so bile vse oddajne postaje pod neposredno kontrolo državne oblasti, ki naj bi ob nadzoru infrastrukture tudi redno nadzorovala oddajanje, trajanje oddaj in njihovo kakovost. ${ }^{13}$ Čeprav si je država pridrževala določene pravice nadzorstva nad postajami, ${ }^{14}$ se teh $\mathrm{v}$ praksi ni posluževala, saj so koncesionarji pri programski politiki postaj delovali povsem avtonomno.

Prosvetna zveza je, kot najmočnejša organizacija kulturnih društev na Slovenskem, delovala pod okriljem Slovenske ljudske stranke. ${ }^{\text {is }}$ Ob njej je, za primerjavo delovala še Zveza kulturnih društev, prav tako kulturna organizacija, ki pa je delovala pod okriljem liberalne stranke.

$\mathrm{O}$ vlogi političnih strank $\mathrm{v}$ kulturni zgodovina Slovencev pričajo poglobljene študije Ervina Dolenca, ki v ozadju različnih političnih prizadevanj in konfliktov prepoznava »stari kulturni boj med liberalizmom in političnim katolicizmom ${ }^{16}{ }^{16}$

Sledijo trije navedki Ervina Dolenca, ki osvetljujejo ozadje ob katerem je začel delovati in je deloval predvojni Radio Ljubljana:

- $\quad$ »Pomembna komponenta strankarske kulturne politike se je kazala v dejavnosti strankarsko ali vsaj ideološko opredeljenih kulturnih organizacij. $\aleph^{17}$

- $\quad$ NVečji del kulturnega boja v novi državi se je osredotočil na šolo, ker so oboji ocenili, da je to strateško najpomembnejši boj za prihodnje generacije. ${ }^{18}$

12 Prav tam, str. 6.

13 Jože Zorn, »Kronika Radia Ljubljana za leto 1928-1929«, 25, v: Arhiv Slovenije, AS 1215, Fond Radiotelevizija Slovenije, t.e. 56.

14 Sojar, »Iz zgodovine našega Radia«, 8.

15 Prim. Ervin Dolenc, Kulturni boj: slovenska kulturna politika v Kraljevini SHS 19181928 (Ljubljana: Cankarjeva založba, 1996). Isti, Med kulturo in politiko: kulturnopolitična razhajanja $v$ Sloveniji med svetovnima vojnama (Ljubljana: Inštitut za novejšo zgodovino, 2010).

16 Dolenc, Med kulturo in politiko, 94.

17 Ervin Dolenc, »Glavni problemi slovenske kulture v prvi Jugoslaviji«, v Preteklost sodobnosti: izbrana poglavja slovenske novejše zgodovine, ur. Zdenko Čepič (Ljubljana: Inštitut za novejšo zgodovino 1999), 92.

18 Ervin Dolenc, »Kulturni boj v Sloveniji«, Zgodovina v šoli 14, 1-2 (2005): 18. 
- $\quad$ V dvajsetih letih so se pomena dobre in množične, ne le politične organizacijske mreže zavedali vsi slovenski politiki. «19

Omenjene misli so še posebej pomenljive za razumevanje ozadja na katerega je bilo vpeto delovanje Radia Ljubljana.

Ko je Prosvetna zveza leta 1925 poslala Jugoslovanskemu klubu v Beograd osnutek za radio pravilnik, je zapisala, da naj bi bila radiofonija v Sloveniji namenjena bolj ljudskoprosvetnemu namenu, kakor pa zabavi. ${ }^{20}$ Poudarek na ljudskoprosvetnem je bil torej zgolj simptomatično nadaljevanje delovanja $\mathrm{PZ}$, ki je $\mathrm{v}$ šolah in izobraževanju prepoznala strateški pomen kulturne in ideološke moči.

Gospodarsko in programsko vodenje Radia je tako prevzel sam vrh zveze, ki je zasnoval širši programski odbor. Ta je dajal smernice za oblikovanje sporeda in skrbel za njegovo uresničitev. Za posamezna področja (za novinarstvo, literaturo, prosveto, šolstvo, zabavo in glasbo) je bila programska skrb dodeljena posameznim referentom, pri čemer je skrb za glasbo oziroma glasbeno uredništvo prevzel dr. Anton Dolinar. ${ }^{21}$

Vsebinsko zasnovo radia je programski odbor dojemal kot nadaljevanje idej Prosvetne zveze, ki je v želji po ustanavljanju Ljudske univerze videla eno svojih pomembnih nalog.

19 Dolenc, »Glavni problemi slovenske kulture v prvi Jugoslaviji«, 93.

20 Zorn, "Kronika Radia Ljubljana za leto 1927-1928«, 10. Zorn navaja: »Iz raznih listin, zapisov in izjav izhaja dejstvo, da se je pred ustanovitvijo radijske postaje v Ljubljani za njeno ustanovitev in njeno eksploatacijo zavzemala med prosvetnimi organizacijami edinole Prosvetna zveza v Ljubljani. Njen tajnik Vinko Zor pred razpustom Prosvetne zveze in predvojni vodja politično gospodarskih oddaj razen za časa prvega komesariata od 1933 do 1936 l. - je dal med drugim uredniku Radia Ljubljana Niku Kuretu ob šesti obletnici ljubljanskega radia med drugim tudi naslednjo izjavo na vprašanje: »Kako je prišlo do ustanovitve slovenskega radia?« [...] Izjavil je: 'V zapisniku sej PZ / Prosvetne zveze / je zapisano, da sem 31. marca 1925 poročal o važni nalogi radia za širjenje narodne prosvete. Pri isti seji se je osnoval radio-klub. [...] Že aprila smo poslali osnutek za radio-pravilnik Jugoslovanskemu klubu v Beograd. Popravili smo ga v tem smislu, da bi naj radiofonija služila pri nas bolj ljudskoprosvetnemu delu kakor zabavi. Prvi vpogled v radiofonijo sem dobil majnika 1926 v Londonu, kjer sem se mudil tri mesece. Ko sem se vrnil iz Anglije, smo začeli v Akademskem domu na Miklošičevi cesti z radio-večeri. Na jesen istega leta sva se vozila $\mathrm{z}$ ing. Sernecem od Jesenic do Ljubljane. Ob tej priliki je pogovor nanesel na radiofonijo in gospod inženjer me je opozoril, da bo to vprašanje pri nas kmalu aktualno. In 3. marca 1927 je Prosvetna zveza zaprosila za koncesijo. Osnovali smo gospodarski in programski odsek, ki sta začela tekom leta 1927 že pripravljati vse, kar je bilo potrebno za slovensko radiofonijo..." « 
»Temelj kulturnih programov tvori Ljudska univerza. [...] Ljudska univerza bo potom Radia priredila 360 predavanj, katera tvorijo zaključno celoto. [...] Estetsko bo širila prosveto z glasbenim programom pevske in glasbene umetnosti. $\aleph^{22}$

Radio Ljubljana ni postal v Slovenskem okolju le novi medij, ki se je kot gospodarsko podjetje moral prilagajati ekonomskim razmeram trga, temveč je v svojem primarnem poslanstvu uresničeval prosvetno-vzgojno idejo.

V poročilu iz prvega leta delovanja Radia Ljubljana je med drugim zapisano:

»Vsaka postaja ima nekaj samoniklega, sebi lastnega. Tako tudi naša postaja, kakor pravijo inozemski kritiki, se odlikuje tako po ljudsko-prosvetnem programu, kakor tudi po narodno-glasbenem delu programa. ${ }^{23}$

Da je bilo štirideset procentov programa namenjenega prosveti in izobrazbi (jezikovna, kmetijska, gospodinjska, higijenska predavanja itd.) kaže tudi statistično poročilo o oddajah iz leta 1931. Zavest o tem, da sta bili informativna in zabavna funkcija največ enakovredni če ne že podrejeni prosvetni, in da je bil potencialni kapital $\mathrm{v}$ domačih rokah, je dajala suverenost in legitimiteto začetnim letom delovanja Ljubljanske radijske postaje. »Logično nujno je bilo in je, da slovenski radio ni delniška družba s tujim kapitalom, ki računa na mastne dividende marveč resnična prosvetna ustanova, ki hoče služiti in dejansko služi prosveti našega ljudstva, «je napisal urednik radijskega glasila Radio Ljubljana Niko Kuret. ${ }^{24}$

Za osvetlitev razsežnosti delovanja Radia Ljubljana je pomenljiva statistika naročnikov, ki kaže, da je bilo v prvih letih njihovo število majhno. ${ }^{25}$ Ob upoštevanju dejstva, da je Prosvetna zveza leta 1923 imela najmanj 26.000 članov opažamo, ${ }^{26}$ da je število naraščalo izjemno počasi. To sugerira misel, da je imel radio kot nova „inštitucija“ v slovenskem prostoru (še posebej ob primerjavi s takratnimi evropskimi razmerami) bolj sporadično

22 Jože Zorn, »Kronika Radia Ljubljana september-oktober 1928 «, 16, v: Arhiv Slovenije, AS 1215, Fond Radiotelevizija Slovenije, t.e. 56.

23 Zorn, »Kronika Radia Ljubljana za leto 1928-1929«, 14.

24 Niko Kuret, »Dve leti slovenskega radia!«, Radio Ljubljana 2, 43 (1930): 1.

25 Statistiko naročnikov je redno objavljalo glasilo Radio Ljubljana, prav tako pa je bila vključena v vsa poročila o delovanju Radia.

26 Prim. Dolenc, Kulturni boj: slovenska kulturna politika v Kraljevini SHS 1918-1928, 310. 
vlogo, saj so njegovo prisotnost, vplivnost in nenazadnje pomen, vsaj navzven, določali potrošniki.

Tabela ı: Statistika radijskih naročnikov (povzeto po France Bizjak: »Kako rastemo in padamo.« Radio Ljubljana I2, št. 16 (1940), I.)

\begin{tabular}{|c|c|}
\hline Leto & Število radijskih naročnikov \\
\hline 1924 & 12 \\
\hline 1925 & 202 \\
\hline 1926 & 615 \\
\hline 1927 & 1108 \\
\hline 1. september 1928 & 2030 \\
\hline 31. december 1928 & 3616 \\
\hline 1929 & 6105 \\
\hline 1930 & 6813 \\
\hline 1931 & 7946 \\
\hline 1932 & 8204 \\
\hline 1933 & 9335 \\
\hline 1934 & 10759 \\
\hline 1935 & 12648 \\
\hline 1936 & 14253 \\
\hline 1937 & 16514 \\
\hline 1938 & 19406 \\
\hline 1939 & 21615 \\
\hline
\end{tabular}

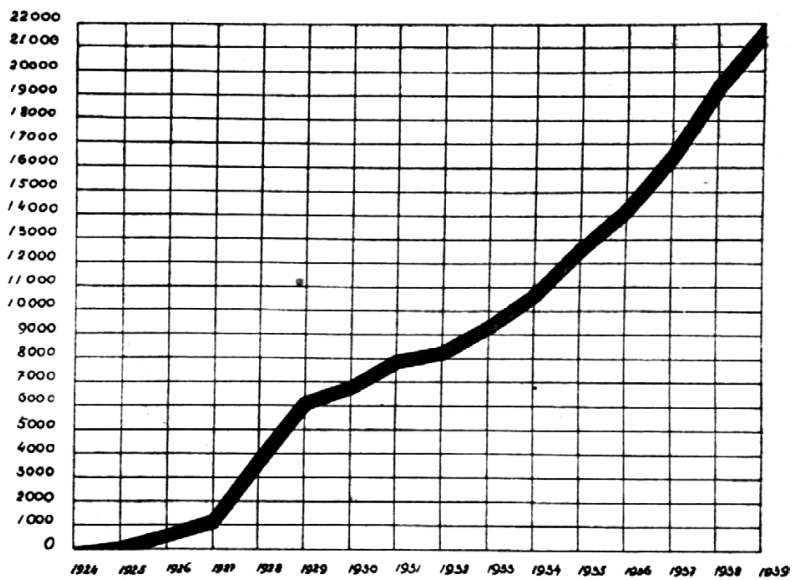

Slika 3: Porast radijskih naročnikov (Radio Ljubljana I2, št. I6 (I940), I.) 
$\mathrm{V}$ začetku radia še ni bilo kriterijev za vrednotenje programa, zato je razumljivo, da je bilo $\mathrm{v}$ prvih letih malo kritičnih poročil o njegovem delovanju. Glasilo Radio Ljubljana, ki ga je ustanovila PZ, je bilo primarno namenjeno objavljanju tedenskih sporedov (vseh treh jugoslovanskih ter 21 evropskih postaj) ter člankov $\mathrm{z}$ vsebinskim težiščem na razvoju radiofonije. Ko je bila s političnimi spremembami leta $1933 \mathrm{PZ}$ razpuščena ${ }^{27}$ (posledično je tudi zgubila koncesijo) in je postajo prevzelo novo (oz. liberalno) vodstvo, je začelo leta 1934 izhajati še eno radijsko glasilo - Naš val. Naš val bi težko razumeli kot vsebinski odgovor na glasilo Radio Ljubljana, prej kot nekakšno dopolnitev, razširitev, ali pa celo eno od variant konkurenčnega glasila. Na ozadju obeh glasil se je uresničevala ideološka bitka dveh nasprotnih političnih drž, zlasti Našega vala, ki je, po tem ko je PZ leta 1935 (po političnih zasukih) dobila nazaj koncesijo, skušal njeno delo ocenjevati s kazalniki premajhnega števila naročnikov. Diskurz je prešel na raven političnega, ko je eden izmed piscev Novega vala zagovarjal centralizacijo in popolno državno oblast nad radijsko postajo. ${ }^{28}$

27 Razpustitev Prosvetne zveze je bila posledica hudega unitarističnega pritiska kraljeve diktature, ko je oblast leta 1933 razpustila vsa katoliška društva. Katoliške društvene zveze so bile po zamenjavi vlade - z vstopom voditelja SLS Antona Korošca v vlado - leta 1935 obnovljene. Glej: Dolenc, »Glavni problemi slovenske kulture v prvi Jugoslaviji«, 93.

Z razpustitvijo Prosvetne zveze je Radio Ljubljana prešel v državno upravo (februarja 1933), kot novi upravnik pa je bil imenovan tričlanski komisariat. Po političnih zasukih leta 1935 je novi minister za PTT Kaluđerić razveljavil odlok o popolnem podržavljenju radijske postaje in dodelil upravljanje le-te nazaj Prosvetni zvezi, ki je z 9. januarjem 1936 ponovno prevzela vodenje Radia Ljubljana. Glej: Jože Zorn: »Kronika Radiotelevizije Ljubljana za leto 1936«, 2-34, v: Arhiv Slovenije, AS 1215, Fond Radiotelevizija Slovenije, t.e. 57.

V Zornovem poročilu za leto 1936 beremo, da so se od meseca aprila dalje »vrstili mnogi napadi na odločitev vlade, ki je vrnila radijsko ljubljansko postajo v privatno izrabljanje in jo dala v zakup Prosvetni zvezi. Dnevno časopisje tako imenovane napredne smeri, predvsem Slovenski narod in Jutro, tednik Naš val so objavljali protestne sestavke, protestno pismo je poslala Zveza kulturnih društev, senator dr. Kramar pa je napadel odločitev na razpravi v finančnem odboru skupščine. [...] Meseca aprila je bila v skupščini v Beogradu proračunska razprava. Minister Kaluđerić je dejal, da je protest kulturnih slovenskih organizacij proti enostranski rešitvi ljubljanske radijske postaje upravičen in da se bo potrudil za takšno rešitev, ki bo ustrezala splošnim nacionalnim interesom in potrebam. Senator dr. Kramar pa je med drugim izjavil, da se organizacija radiofonije ne bi smela prepustiti v eksploatacijo privatnim družbam. [...] Tik pred proračunsko razpravo v skupščini so tako imenovane napredne kulturne organizacije poslale ministru dr. Kaluđeriću protestno pismo, ker je dal ljubljansko radijsko postajo ponovno v zakup Prosvetni zvezi. Kajti Prosvetna zveza nikakor ne predstavlja niti kulturne Ljubljane niti kulturne Slovenije. Spomenico so podpisali: Sokolski župi Ljubljana in Maribor, 


\section{Inštitucija: glasbenost Radia Ljubljana}

$\mathrm{Na}$ mesto urednika glasbe je ob ustanovitvi RL in leto po promociji v doktorja muzikoloških znanosti na Dunaju nastopil dr. Anton Dolinar, ki je ob Mariju Osani ostal na svojem položaju nepretrgoma celotno predvojno radijsko obdobje. Po prevzemu referata je odpotoval na večdnevni obisk dunajskega in praškega radia, $\mathrm{z}$ namenom, da bi se seznanil $\mathrm{z}$ načinom in metodami dela obeh radijskih postaj. Kot glasbeni izobraženec je poznal in razumel domače glasbene razmere, obenem pa se je zavedal specifike novega medija in značilnih lokalnih glasbenih potreb znotraj le-tega. Med prioritetne naloge si je zadal »spraviti do veljave slovensko glasbo«, s poudarkom na slovenski ljudski pesmi in njenih priredbah. Dolinar se je zelo dobro zavedal pomena umetne glasbe ${ }^{29}$ obenem pa tudi funkcije radijskega medija, ki je moral ustreči potrebam širših ljudskih množic oz. ekonomskim interesom, kjer se je kvaliteta sprva in predvsem merila s številom naročnikov. Da si je Dolinar želel sistematične urejenosti celega glasbenega programa postane očitno, ko je po dvoletnem delu izjavil, da "programa ni mogoče shematizirati, vnanje razmere ga nujno silijo k nekemu valovanju «. ${ }^{30}$

Južnoslovenska pevska zveza, Hubadova in Ipavčeva župa, Narodna odbrana, Dramatski društvi v Ljubljani in Mariboru, Oblastna odbora Jadranske straže v Ljubljani in Mariboru, obe Zvezi jugoslovanskih naprednih starešin, Vodnikova družba, Zveza slovenskih fantov in deklet, Zveza kulturnih društev v Ljubljani in Mariboru ter Ciril-Metodova družba. Na protestno pismo so odgovarjali prokatoliški časopisi, Radio Ljubljana pa v VIII/20 - 10. maja z uvodnikom ,Kdo so in kaj hočejo'." V: Zorn: »Kronika Radiotelevizije Ljubljana za leto 1936«, 4-9.

"Naloga našega radia $v$ glasbenem oziru je, da spravi do veljave slovensko glasbo. [...] Zborov in pevskih ansamblov imamo nekaj, radijski orkester je med najboljšimi. Posebno poglavje pač tvorijo pevci solisti. Držimo se načela, naj bolj priznani pevci ne nastopajo prepogosto, ker postane sicer njih nastop prevsakdanji. [...] Šlo mi je vse doslej za to, da ustrežemo čim več odjemalcem. [...] V načrtu za prihodnjo sezijo pa imam sistematično izgradnjo glasbene izobrazbe naših poslušalcev. Uvesti mislim tečaj pevskega pouka (glasovne vaje), ki bo dobrodošel vsakemu našemu, zlasti podeželskemu pevcu. Nujen in važen bo s tem v zvezi tečaj iz glasbene teorije. Prav tako bo dobrodošel tečaj iz harmonije. Za najširše kroge poslušalstva in dvig njih glasbene kulture pa bo važen tečaj iz oblikoslovja, ki bo sistematsko uvajal v razne vrste glasbenih umetnin (sonata itd.) v zvezi s predavanji o splošnih glasbenih vprašanjih, o glasbeni zgodovini, slogu itd. V tem okviru bo treba urejati glasbene programe. Podčrtati moram pri tem razumevanje večine naših glasbenih faktorjev za sodelovanje pri delu naše postaje, zlasti opere in njenega ravnatelja g. dr. M. Poliča, ter Glasbene Matice ljubljanske. [...] Težko je sestaviti stalen program za štirinajst dni naprej. Pri orkestru in predavanjih koncem koncev ni take težave. Težko je s solisti in drugimi opernimi močmi, za katere je težko določiti vnaprej, kdaj morejo biti na razpolago.« »'Glasba v našem radiu' pogovor z glasbenim referentom Dr. Antonom Dolinarjem«, Radio Ljubljana 1, 4 (1929): 1-2. 
Dolinarjevo delo je možno vrednotiti šele ob temeljitem poznavanju predvojnega glasbenega programa, razmer $\mathrm{v}$ katerem je ta nastajal, širine s katero je vstopil $\mathrm{v}$ zaprto in po tihem strankarsko razdvojeno slovensko okolje ter vztrajnosti, s katero je postopno pridobival zaupanje domačih profesionalnih glasbenih krogov. $\mathrm{Na}$ tej poti je prihod v tujini šolanega glasbenika, perspektivnega, nadarjenega, mladega Draga Maria Šijanca na radio, okrepila institucionalizacijo radijskega glasbenega programa in radijskega orkestra.

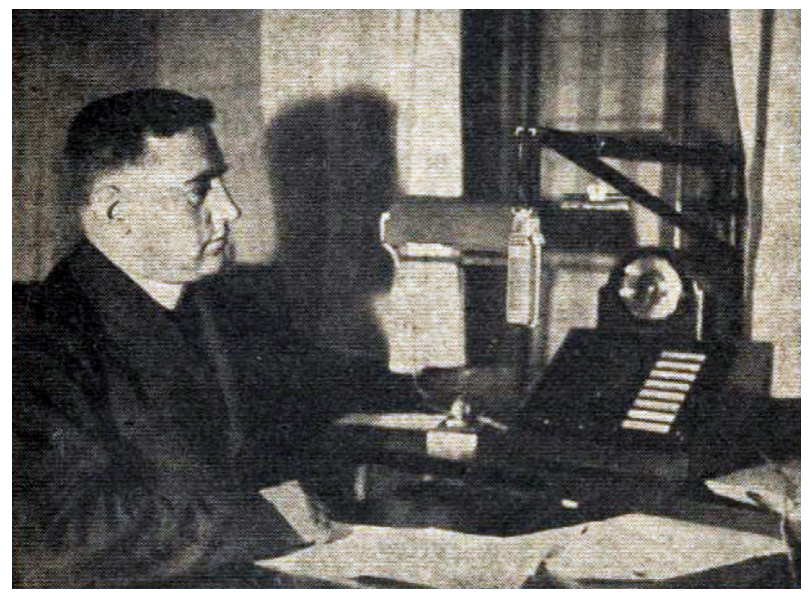

Slika 4: Anton Dolinar (Radio Ljubljana II, št. 43 (1939), I.)

Dvom šolanih glasbenikov v nov medij ni bil le lokalna specifika, temveč vprašanje s katerim so se soočale številne evropske radijske hiše. Skepsa je bila zaradi tehnoloških omejitev reproducirane glasbe vsekakor upravičena, najbrž pa jo je pogojeval tudi strah pred izgubo publike. Ker v domačem prostoru z izjemo opernega orkestra in Godbe Dravske divizije ni bilo profesionalno delujočega orkestra, je domače glasbenike bolj kot negotovost navdajalo nezaupanje in najbrž tudi nepoznavanje razsežnosti razvijajočega se medija (izjema je bil tu Josip Čerin, ki je delovanju radijskega orkestra nasprotoval z mislijo da "poklicnim glasbenikom diletanti jemljejo kruh in zaslužek « $\left.{ }^{31}\right)$. Nezaupanje in zadržanost sta še posebej značilni za starejše generacije skladateljev in glasbenikov (Lajovic, Hubad), ki iz različnih razlogov (tvegamo pomisliti nemara celo iz ideoloških) niso sodelovali

31 Dopis J. Čerina Radiu Ljubljana, 1. 3. 1929. Čerin, Josip. Mapa 6, ovojna mapa Radio, NUK M. 


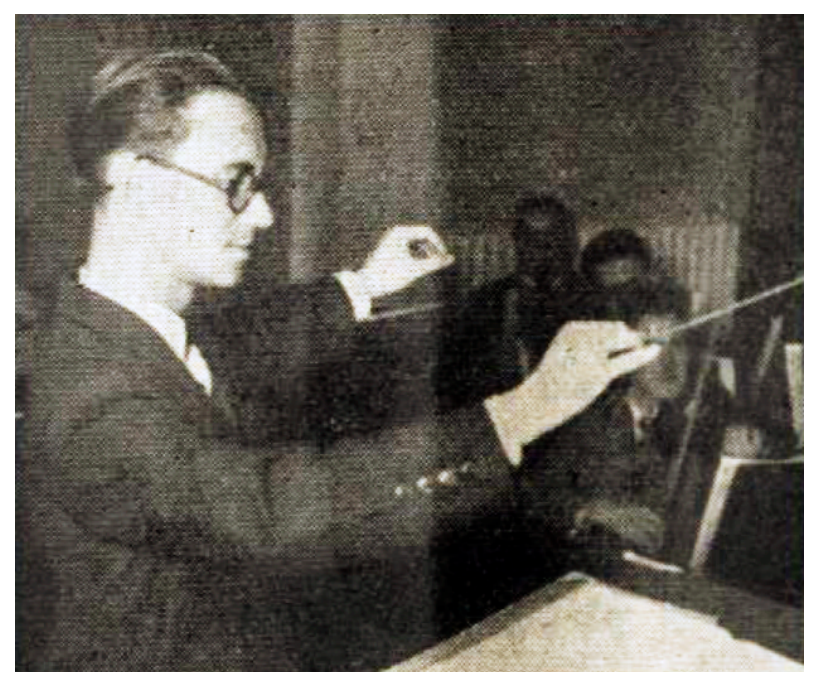

Slika 5: Drago Mario Šijanec (Radio Ljubljana 9, št. 7 (1937), 49.)

z Radiem Ljubljana. Generacija glasbenikov rojenih nekje v začetku 2o. stoletja je v novi medij vstopila postopno, a suvereno.

Ker ima v radijskem mediju glasba nepogrešljivo vlogo, se bo zadnji del razprave usmeril v polje glasbenosti Radia Ljubljana. To lahko opazujemo na ravni neposrednih oddaj iz studija, radijskih prenosov, predvajanja gramofonskih plošč, ${ }^{32}$ pozneje pa tudi kritik ${ }^{33}$ in glasbenih oddaj o glasbeno-

32 »Za reproducirano glasbo je imel v letu 1932 radijskih glasbeni arhiv na voljo kakšnih 150 plošč s slovensko glasbo, vendar jih je bilo med temi samo okrog 50 uporabnih. Hrvaških in srbskih plošč je bilo v arhivu po kakšnih sto. Tuje / večinoma sposojene / pa so bile pri poslušalcih deležne večje kritike. Razen Radio-orkestra, ki je štel 12 godbenikov, so bile oddaje odvisne od tujih sodelavcev, ki pa so po programu sodeč, radi sodelovali.« V: Zorn, "Kronika Radia Ljubljana za leto 1932«, 5, v: Arhiv Slovenije, AS 1215, Fond Radiotelevizija Slovenije, t.e. 56.

O tehničnih in kadrovskih pogojih Radia Ljubljana priča tudi vloga napovedovalcev, ki so poleg napovedovalskega dela pripravljali glasbeni reproducirani program, nastavljali in vrteli gramofonske plošče, izbirali poročila in jih brali; po oddaji pa opravili še spisek izvajanih del za avtorsko pravo. Njihova naloga je bila tudi izplačati izvajalcem honorarje takoj po oddaji. Radio Ljubljana v letih pred drugo svetovno vojno, str. 5, v: Osnutek za kratko kronologijo RTV, v: Arhiv Slovenije, AS 1215, Fond Radiotelevizija Slovenije, t.e. 54.

33 Prve kritike sporeda in glasbenih oddaj Radia Ljubljana so začele izhajati leta $1932 \mathrm{v}$ dnevniku Slovenec. Nekaj mesecev kasneje je pri Radiu Ljubljana vlogo kritika prevzel Vilko Ukmar. Glasbena kritika se je pogosteje pojavljala nekje od leta 1934; v časopisu Naš val jo je pod naslovom Kritičen pregled glasbenega sporeda ljubljanske radijske postaje pisal L. M. Škerjanc, v časopisu Radio Ljubljana pa jo je redno začel 
-zgodovinskih temah, ki so jih pripravljali Anton Dolinar, L. M. Škerjanc, Josip Mantuani, Vilko Ukmar, Srečko Koporc, Slavko Osterc idr. ${ }^{34}$

Glasbo za neposredne oddaje iz studija je delno priskrbel hišni dvanajst članski orkester, ${ }^{35}$ delno pa zunanji izvajalci najrazličnejših glasbenih profilov: od profesionalnih glasbenikov, solistov in komornih skupin, amaterskih zborov (pod okriljem PZ je delovala Pevska zveza, ki je združevala 130 zborov $^{36}$ iz vse Slovenije), do številnih amaterskih glasbenih ljubiteljev - citrarjev, harmonikarjev ter kmečkih godcev in pevcev iz podeželja.

objavljati Vilko Ukmar. Skladatelja sta v svojih kritikah povzemala glavne glasbene točke preteklega tedna ter ocenjevala tako glasbeni spored, kot nastope izvajalcev, kvaliteto izbranih gramofonskih plošč, kakovost zvoka in tehnične nepopolnosti, kot je na primer nerodna postavitev izvajalcev pred mikrofon. V svojih prispevkih sta obravnavala tudi glasbena predavanja, ponudila svoje nasvete in obveščala o glasbenih zanimivostih drugih radijskih postaj. V tem oziru je Vilko Ukmar svoje delo opisal takole: »S pričetkom izhajanja našega lista v novi sezoni [1934/33 op. a.] bom skušal zopet na tem mestu kritično spremljati umetnejše glasbeno življenje ljubljanske radijske postaje. Takoj v začetku pripominjam, da ne bom spremljal vsakega nastopa, (da bi se tako ne počutil kdo prezrtega in s tem užaljenega) pač pa bom skušal v teku raznih nastopov zasledovati vse nastopajoče umetnike in opredeljevati vrednost njihovega izvajanja. Na drugi strani pa bom skušal vsaj v glavnih črtah govoriti o glasbeno umetniški snovi sami, o njeni vrednosti, pomembnosti, privlačnosti ali obratno. V tem pogledu bo pač moj cilj isti, kot mora biti cilj vodstva naše postaje $\mathrm{z}$ ozirom na odgovornost do vsega slovenskega naroda: vzdrževati izbero glasbenih umetnin za izvajanje na čim dostojnejši višini in usmerjati jo v možni višini proti domači produkciji, pa tudi ne dopuščati, da pada izvajanje pod gladino, ki loči resnega umetnika od neizvežbanega diletanta - vse to, da se nudijo domačim poslušalcem resnične vrednote in da se pred svetom ne damo osramotiti.« Vilko Ukmar, »Nekaj uvoda", Radio Ljubljana 6, 33 (1934): 3.

34 Program je ob samostojnih koncertih resne glasbe vključeval tematsko zaokrožene glasbeno-izobraževalne oddaje, ki jih je uvajalo kratko predavanje (narodni večer, večer slovenske glasbe, ljudski večer, varietetni večer, večer ruske, poljske, italijanske glasbe). V prvih letih je koncerte ter oddaje o slovenskih skladateljih uvajal pogosto urednik sam, sčasoma se je število govorcev začelo širiti. V prvih treh letih je bilo na sporedu mogoče prisluhniti posameznim samostojnim glasbenim predavanjem (kot na primer: Stane Vurnik Uvod v glasbeni svet; Josip Mantuani Gerbičev večer; Anton Dolinar O slovenskih glasbenih listih), od leta 1932 naprej pa so poslušalci lahko sledili ciklu predavanj Uvod v glasbo L. M. Škerjanca ter Slovenska glasbena zgodovina Josipa Mantuanija. V naslednjem letu je predavalo že več različnih skladateljev, med njimi Srečko Koporc, Matija Bravničar, Heribert Svetel, Zorko Prelovec, Mirko Polič, Vilko Ukmar. Vilko Ukmar in Matija Bravničar sta od leta 1935 naprej prevzela kratka predavanja o operi, ki sta jih predstavila med pavzami prenosov.

35 Več o tem: Jasna Nemec Novak, »Radijski orkester med leti 1928-1955", v Simfonični orkester RTV Slovenija: 50 let, ur. Matej Venier (Ljubljana: Mladinska knjiga, 2006), 46-77.

36 Matjaž Brojan piše, da je radio postal glasnik zborovske pesmi. »Poslušalci so že v letu 1930 želeli vplivati na pogostejše sodelovanje zborov. V domačih ožjih okoljih 


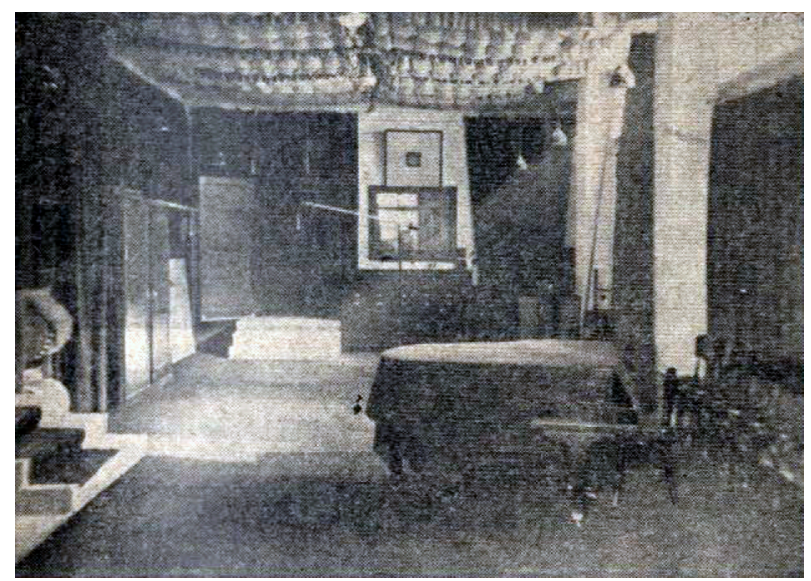

Slika 6: Pogled v notranjost velikega studia (Radio Ljubljana II, št. 49 (1939), 7.)

Orkester je najprej deloval pod vodstvom Kazimirja Petriča, ki je prispeval tudi precej priredb, zlasti slovenskih ljudskih pesmi, v času političnih sprememb, leta 1933, pa ga je zamenjal in orkester dve leti vodil Danijel Grum, operni kapelnik in korepetitor. Zanimiv je podatek, da naj bi v Grumovem času vsak član orkestra igral po dva inštrumenta. Tako se je osnovna zasedba lahko skrčila na kvintet, ki je izvajal bolj komorno glasbo ali pa se je preoblikovala v večji jazz orkester. ${ }^{37}$

Radijski orkester je zaradi premajhne zasedbe, pomanjkanja not v svojem dnevnem programu izvajal odlomke iz operet, oper, občasno posameznih stavkov klasicistično-romantičnega repertoarja in tudi slovanske literature, koračnice, valčke, ter zlasti priredbe slovenskih ljudskih pesmi. $\mathrm{V}$ poznih večernih urah pa občasno jazz. Orkester je izpolnjeval vsak dan precej glasbenega programa, ker je moral nastopati vedno v živo dvakrat ali celo trikrat na dan. Glasbeni program, ki ga je izvajal, bi lahko označili kot

se zbori niso mogli uveljaviti, saj so njihovim dosežkom lahko prisluhnili le domačini in bližnji sorodniki. Na radiu pa je bilo drugače: $z$ nastopom je tudi širša okolica izvedela za zbor, pevce, pevovodje ... [...] Poslušalci radijskega programa so lahko v posameznem letu slišali po šestdeset in več različnih zborov. Kolikšno je bilo to zborovsko delo (nastopi so bili mogoči samo v neposrednih prenosih v živo, saj snemanj še niso poznali), si lahko samo mislimo. [...] Prenašali so tudi veliko nastopov slovenskih zborov, običajno iz Unionske dvorane, Slovenske filharmonije ali operne hiše.« V: Matjaž Brojan, Začetki radia na Slovenskem (Ljubljana: Modrijan, Radio Slovenija, 1999), 56.

37 Zorn, »Kronika Radia Ljubljana za leto 1933«, 13, v: Arhiv Slovenije, AS 1215, Fond Radiotelevizija Slovenije, t.e. 56. 


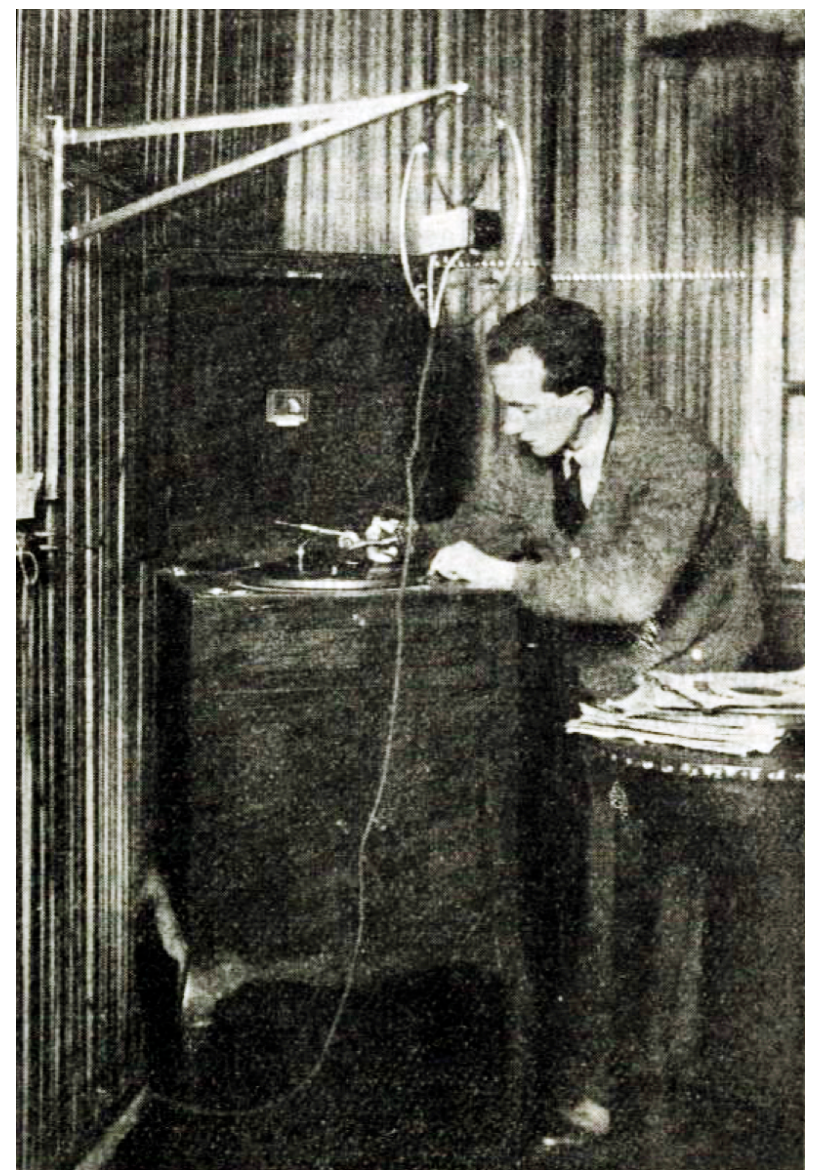

Slika 7: Predavateljska soba v studiu (Radio Ljubljana I, št. 9 (1929), I.)

lahko glasbo, poutpourri različnega in dosegljivega, ne preveč zahtevnega in obenem publiki všečnega. Ko se je leta 1931 orkester skrčil na salonski kvintet, je programska zasnova ostala bolj ali manj enaka. Manjša sprememba je nastopila po ponovni vzpostavitvi radijskega orkestra leta 1933, ko so se tudi zaradi večje dostopnosti notnega gradiva in najbrž novega dirigenta v programu znašla še druga dela, kot denimo odlomki Wagnerjevih in Puccinijevih oper, značilno je tudi povečanje del jugoslovanskih skladateljev. Prav tako je opazna diferenciacija glasbenih žanrov, ki se kaže v naslovih lahka glasba, plesna glasba in radiojazz.

Iz tega izhaja, da sta večji del gostujočih glasbenikov kakor tudi radijski ansambel izvajala lahko glasbo oz. glasbo, ki je po eni strani zadovo- 
ljevala pričakovanja širših množic mesta, po drugi pa potrebe prebivalcev podeželja.

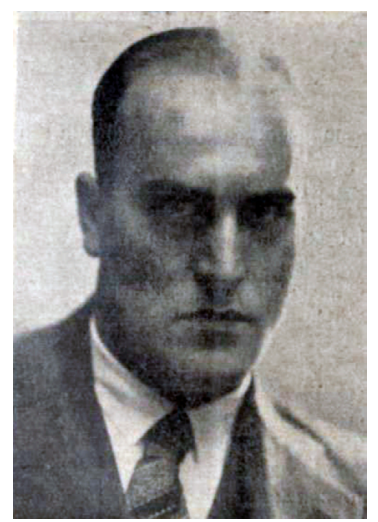

Slika 8: Danijel Grum (Radio Ljubljana II, št. 47 (1933),3.)

Tabela 2: Delež glasbe na radiu (statistika povzeta po Radio Ljubljana 10, št. 46 (1938), 8.)

\begin{tabular}{|c|c|c|c|c|}
\hline & $\begin{array}{c}\text { Izvajana glasba } \\
\text { in prenosi (\%) }\end{array}$ & $\begin{array}{c}\text { Gramofonske } \\
\text { plošče (\%) }\end{array}$ & $\begin{array}{c}\text { Skupaj } \\
\text { (vsa glasba) (\%) }\end{array}$ & $\begin{array}{c}\text { Operna in resna } \\
\text { glasba }(\%)\end{array}$ \\
\hline 1929 & 26,5 & 24,5 & 51 & 8,9 \\
\hline 1930 & 29,4 & 21,5 & 50,9 & 10,2 \\
\hline 1931 & 29,1 & 21,2 & 50,3 & 10,6 \\
\hline 1932 & 32,6 & 20,1 & 52,7 & 11,6 \\
\hline 1933 & 32,7 & 18,5 & 51,2 & 11,2 \\
\hline
\end{tabular}

Delež resne glasbe so v največji meri polnili prenosi iz tujine, posamezni nastopi domačih uveljavljenih glasbenikov, največkrat pevcev ter predvajanje gramofonskih plošč. Opazna je prisotnost mlajše generacije pianistov (Šivic, L. M. Škerjanc, Danilo Švara, Marta Osterc in Marjan Lipovšek; slednji je po številu nastopov že skoraj veljal za hišnega pianista), ki so nov medij sprejeli najbrž brez večjih predsodkov in zadržkov.

Na ravni glasbene reprodukcije je bila dirigentova vloga zelo pomembna. To se ne kaže le v poznejših pravilnikih Radijske postaje temveč tudi v odločilnih premikih, ki so jih nekateri med njimi - zlasti Drago Mario Šija$n e c-v$ delu $\mathrm{z}$ orkestrom uresničili. Velikega pomena je bila uvedba stalnih prenosov med tremi jugoslovanskimi postajami (1930)..$^{38}$

38 Jože Zorn, »Kronika Radia Ljubljana za leto 1927-1928 «, str. 4, v: Arhiv Slovenije, AS 1215, Fond Radiotelevizija Slovenije, t.e. 56. 


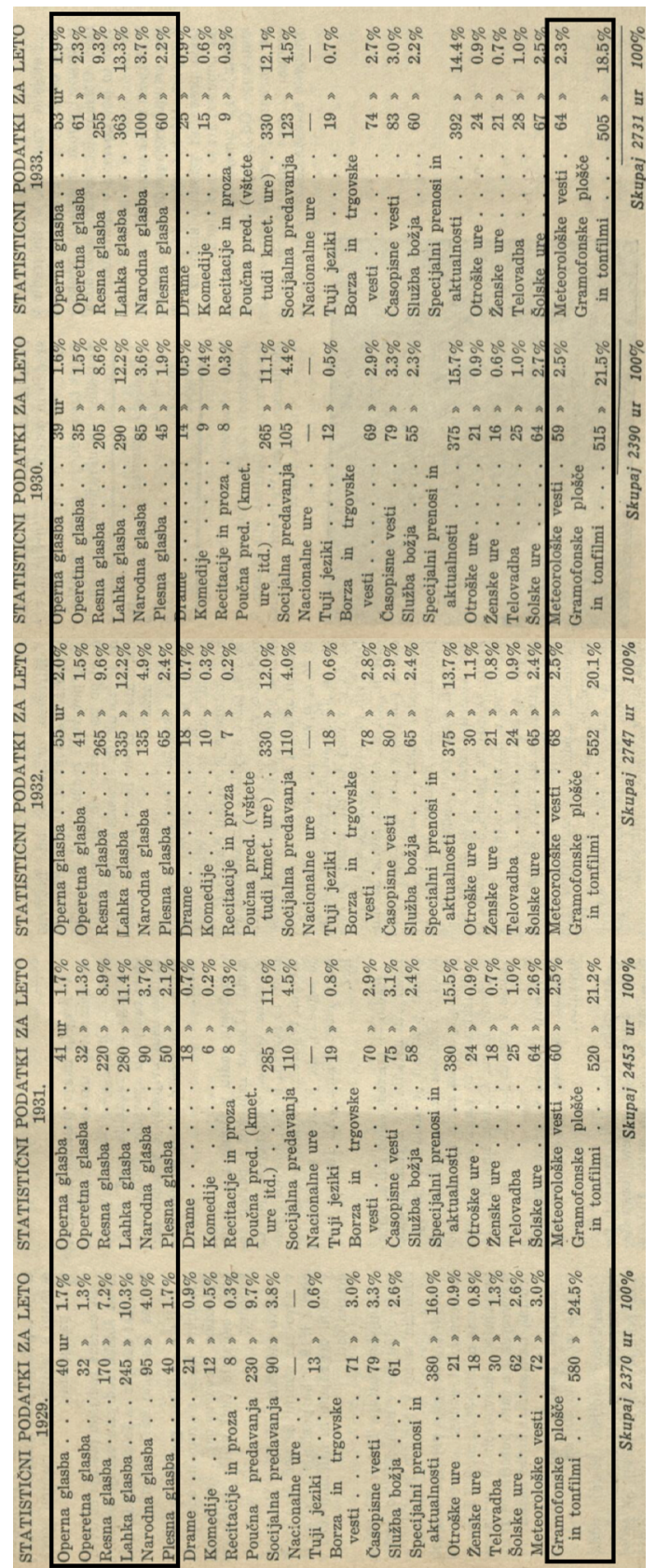

Slika 9: Statistični podatki za leto 1929, 1930, 1931, 1932 in 1933 (Radio Ljubljana Io, št. 46 (1938), 8.) 


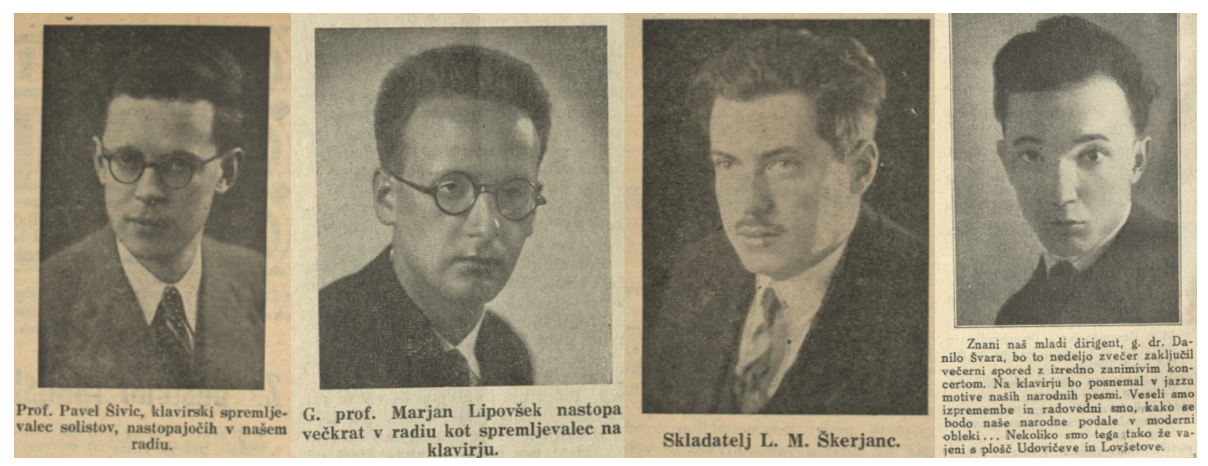

Slika ıo: Mladi pianisti na Radiu Ljubljana (po vrsti: Radio Ljubljana I2, št. I4 (1940), 2.; Radio Ljubljana Io, št. 48 (1938), 5.; Radio Ljubljana II, št. 19 (1839), 2.; Radio Ljubljana 4, št. 45 (1932), 386.)

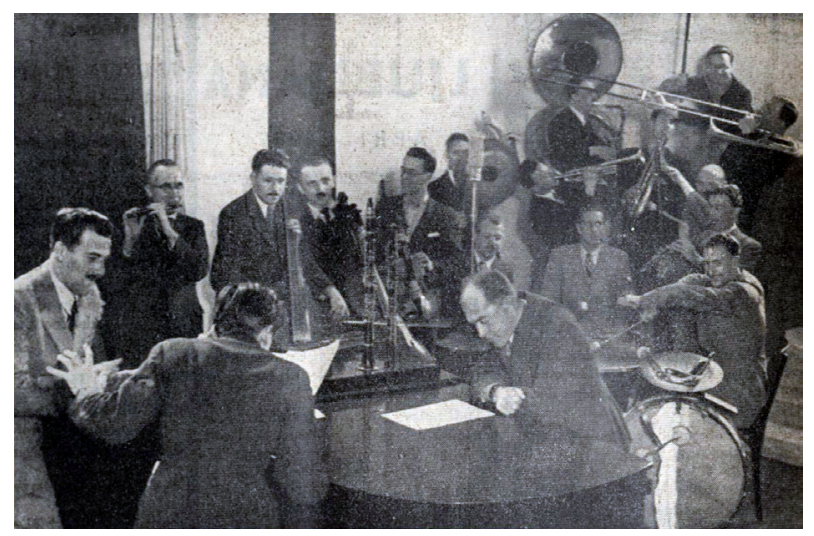

Slika II: Radijski orkester - večer zabavne glasbe (Radio Ljubljana 9, št. I8 (1937), I54.)

Ob ljubljanski Operi je Radio Ljubljana postal edini delodajalec (domačim) profesionalnim glasbenikom, ki so z letom 1935 začeli nastopati na javnih koncertih v okviru Ljubljanske filharmonije. Prav tako je začel spodbujati in nabirati po eni strani za takratni čas specifičen „radijski“ repertoar, po drugi pa novo domačo simfonično literaturo.

$\mathrm{V}$ kontekstu pričujoče razprave je bilo razvidno, da se je glasbenost prvega radia pri nas uresničevala heterogeno in večplastno, pri čemer je dajala prednost vključevanju, prisotnosti različnega. Ob poznavanju radijskega formata $v$ tujini in specifično lokalnih glasbenih razmer je krmarila med zahtevami ekonomskega trga oz. prilagajanju pričakovanjem poslušal- 
cev ter hotenjem po vključevanju domače glasbene elite v novi medij na način ozaveščanja o sodobni domači ustvarjalnosti. Radijska glasbenost je izoblikovala novo funkcijo glasbe s tako imenovano „radijsko glasbo“, ta pa je slonela na popularni lahki in popularni „narodni“ glasbi. Tako kot na tujem je tudi doma radio odprl vrata prihajajoči vseglasbeni industriji.

\section{Bibliografija}

Arhivsko gradivo Radia Ljubljana. Fond Radiotelevizija Slovenije, AS 1215, tehnične enote $2-5,8,10,54-57$.

Jacobshagen, Arnold in Reininghaus, Frieder, ur.. Musik und Kulturbetrieb. Medien, Markte, Institutionen. Laaber: Laaber-Verlag, 2006.

Dolenc, Ervin »Glavni problemi slovenske kulture v prvi Jugoslaviji«. V Preteklost sodobnosti: izbrana poglavja slovenske novejše zgodovine, ur. Zdenko Čepič. Ljubljana: Inštitut za novejšo zgodovino, 1999, 86-94.

Dolenc, Ervin. Kulturni boj: slovenska kulturna politika v Kraljevini SHS $1918-$ 1928. Ljubljana: Cankarjeva založba, 1996.

Dolenc, Ervin. »Kulturni boj v Sloveniji«. Zgodovina v šoli 14, 1-2 (2005): 14-21.

Dolenc, Ervin. Med kulturo in politiko: kulturnopolitična razhajanja $v$ Sloveniji med svetovnima vojnama. Ljubljana: Inštitut za novejšo zgodovino, 2010.

Dopis J. Čerina Radiu Ljubljana, 1. 3. 1929. Čerin, Josip. Mapa 6, ovojna mapa Radio, NUK M.

Hahr, Henrik. »Radio Broadcasting in Sweden«. Hollywood Quarterly 1, 3 (Autumn, 1947): 11-14. Obiskano 15. februarja 2017. http://www.jstor.org/ stable/1209627.

Kuret, Niko. »Dve leti slovenskega radia!«. Radio Ljubljana 2, 43 (1930).

Kuret, Niko. »'Glasba v našem radiu' pogovor z glasbenim referentom Dr. Antonom Dolinarjem«. Radio Ljubljana 1, 4 (1929).

»Naši obiski«. Radio Ljubljana 3, 4 (1931).

Nemec Novak, Jasna. »Radijski orkester med leti 1928-1955«. V Simfonični orkester RTV Slovenija: 50 let, ur. Matej Venier. Ljubljana: Mladinska knjiga, 2006, 46-77.

Osnutek za kratko kronologijo RTV. V: Arhiv Slovenije, AS 1215, Fond Radiotelevizija Slovenije, t.e. 54 .

Radio Ljubljana. Knjiga naročnikov 1924-1930. Rokopis. NUK M.

Sojar, Tone. »Iz zgodovine našega Radia«, 4-5. V: Arhiv Slovenije, AS 1215, Fond Radiotelevizija Slovenije, t.e. 2. 
Ukmar, Vilko. »Nekaj uvoda«. Radio Ljubljana 6, 33 (1934).

Zorn, Jože. »Kronika Radia Ljubljana september-oktober 1928«, 16. V: Arhiv Slovenije, AS 1215, Fond Radiotelevizija Slovenije, t.e. 56.

Zorn, Jože. »Kronika Radia Ljubljana za leto 1928-1929«, 25. V: Arhiv Slovenije, AS 1215, Fond Radiotelevizija Slovenije, t.e. 56.

Zorn, Jože. »Kronika Radiotelevizije Ljubljana za leto 1936«, 2-34. V: Arhiv Slovenije, AS 1215, Fond Radiotelevizija Slovenije, t.e. 57. ${ }^{39}$

39 Poglavje je nastalo kot del projekta J6-7180, ki ga je sofinancirala Agencija za raziskovalno dejavnost Republike Slovenije.

This chapter is part of the project J6-7180 funded by Slovenian research agency ARRS. 



\title{
Ustvarjalnost primorskih skladateljev
} med italijansko okupacijo Primorske $\mathrm{v}$ času fašizma - kompozicijski, slogovni in družbeni uvidi

\author{
Ivan Florjanc \\ Univerza v Ljubljani \\ University of Ljubljana
}

Primorska se je v obdobju med obema svetovnima vojnama znašla v skrajno hudi zgodovinski in družbeno-politični situaciji. Sredi genocidnih razmer pa je iznašla in razvila poseben model odporništva in dobre oblike reševanja konfliktnih pojavov. Iz teh uvidov je črpala modrost po vojni in deloma še danes. $\mathrm{V}$ ta okvir se umešča tudi naša razprava o nenasilni odporniški ustvarjalnosti primorskih skladateljev $v$ obdobju italijanske okupacije Primorske v času fašizma. Izpostavili bomo marsikateri pomenljiv primer uspešnih dobrih praks uporabe glasbe pri nenasilnem, miroljubnem a odločnem odporu genocidnemu nasilju. Ta odpor je izviral iz enakih humanističnih vrednot, ki so deklariran temelj sožitja tudi v sedanji evropski skupnosti narodov. Glasba je tu odigrala ne le terapevtsko vlogo, marveč je bila ves čas močan identitetni in družbeno-političen komunikacijski stabilizator, ki je podoben tistemu, ki ga opravlja nervus vagus v človeku, če uporabimo pomenljivo prispodobo iz anatomije.

Prispevek se pretežno umešča na glasbeno-sociološko področje in je zastavljen interdisciplinarno. Dotika se najprej vprašanj družbeno-političnega stanja, v katerem so živeli in ustvarjali skladatelji, pa tudi odnosov med njihovo glasbo in družbeno-političnim okoljem, kar se je ves čas tes-

1 Glede na zgodovinski potek dogajanj v razpravi ne enačimo italijanske okupacije Primorske leta 1918 in fašizma. Okupacija Primorske je bila posledica italijanskega militantnega iredentizma in odločitve italijanske vlade, ki je s podpisom Londonskega pakta prevzela program ekspanzionizma z znanimi posledicami. Fašizem je le nadaljeval in na še bolj grob način zaostril, kar je okupacija že prej sprožila. 
no prepletalo. Na teh področjih in njihovih presečiščih je brstelo, živelo in usihalo novo. $\mathrm{V}$ oporo bodo zato discipline, ki so običajno opredeljene kot delne discipline sistematične in historične muzikologije. Poleg tega bodo v pomoč nekateri uvidi komunikativnih struktur glasbe v istem družbenem kontekstu. S tem smo opredelili zasnovo in vsebinski okvir razprave.

\section{Slovenija in zlasti Primorska kot stičišče evropskih narodov in križišče navzkrižnih interesov}

Področje Primorske je v slovenskem, slovanskem in tudi evropskem prostoru posebnega značaja. Gre za stičiščno točko slovenskega - in zato tudi slovanskega - sveta $\mathrm{z}$ romanskim in germanskim, v miru in žal tudi v vojni, kar na tem področju ni bila redkost.

Celotna Slovenija je dežela, ki jo je Stvarnik postavil kot vrata v srce Evrope. Je srednjeevropska dežela, ki počiva na križišču poti med mediteranskim in balkanskim jugom, germanskim severom, slovanskim in madžarskim vzhodom in romanskim zahodom. Enak položaj križišča dobimo, če pogledamo iz vidika globalne razmejitve severne poloble: pri Nanosu se stikata Vzhod in Zahod - t. i. Postojnska vrata. Skoraj nič drugačna ni bila srednjeveška cerkvena razdelitev ozemlja Slovenije: meja je potekala na čuden način kar po sredini enotnega ozemlja - in to diagonalna po Dravi. Tako jo je na neobičajen način določil Karel Veliki leta 811 zaradi ostrih sporov med Oglejskim patriarhatom in Salzburško škofijo. To je ustvarilo velike probleme svetima bratoma Cirilu in Metodu že pol stoletja zatem. Pomeljiv je ukaz Karlovega odloka:

\section{"Predictam provinciam Karantanorum ita inter (se) dividere iussimus, ut Dravus Fluvius qui per mediam provinciam currit, terminus ambarum dyoceseon esset." ${ }^{2}$}

Tak potek meje po sredini enotne politične tvorbe je bil za tedanji čas ne le izjemen, temveč $» v$ nasprotju s takrat veljavnim načelom, naj cerkvene pravice ene dežele izvaja ena sama metropolija." " Takšnih križanj tujih nasprotnih interesov nad ozemljem Slovenije v zgodovini ni bilo malo.

Križiščna zemljepisna lega je za narode in kulture zelo ugodna $\mathrm{v}$ času miru. V nemirnih in zlasti v vojnih časih pa postane prostor, kjer se spo-

2 »Ukazujemo, da se omenjena provinca Karantanija tako razmeji, da bo reka Drava, ki teče po sredini province, meja obeh škofij (diocez).« Prevod I. F.. Cit. po: Janez Höfler, O prvih cerkvah in župnijah na Slovenskem (Ljubljana: Viharnik, 2013), 13. 
padajo navzkrižni globalni interesi, pogostoma na nasilen in tudi krvav način. Nasilno premikanje meja je bilo za Slovenijo vso zgodovino boleča stalnica. Prebivalci dežel na tem srednjeevropskem prostoru, ki se čutijo pripadni slovenski narodni identiteti, so posledično menjaje prebivali zdaj znotraj in zdaj zunaj upravnih meja, ki niso sovpadale z mejami naroda, ki mu pripadajo. Meje so določale usode na bojiščih in interesi mejašev. Da je zemlja ob meji najslajša, je pregovorno stoletna izkušnja kmetov. Za maloštevilne narode pa je lahko tak princip v določenih obdobjih anomije in nasilja usoden.

Ob pogledu v zgodovino - tudi zelo daleč - opazimo pomenljivo zakonitost, da moramo govoriti ne o »vojnah Slovencev«, temveč o »vojnih spopadih na slovenskih tleh «. ${ }^{4}$ Tak je bil npr. davni vojni spopad »ad Frigidum « med vzhodnorimskim cesarjem Teodozijem I. in samozvancem zahodnega dela rimskega cesarstva Flavijem Evgenijem leta 394 - ne po naključju - ravno na področju Primorske pod Nanosom, pri reki Vipavi (lat. Frigidus). Tudi obe veliki vojni dvajsetega stoletja sta bili takšni, le da spopad ni bil frontalen med vojskama, marveč okupacijski. Da je Slovenija od leta 1945 pa vse do nedavnega služila za tečaj »železne zavese«, oz. kot »latentna vojna kraji$n a$ v času t. i. hladne vojne, je bolj pravilo kot izjema. To je veljalo še posebej za njeno zahodno mejo, ki je zopet razdelila isto provinco in isti narod - pimorske Slovence. Če se je Slovenija po letu 1991 znova znašla tam, kjer je bila ves čas od konca antike pa vse do leta 1918, pomeni le, da se je vrnila v svoj prvotni položaj križišča - zemljepisno, civilizacijsko, kulturno in interesno.

Dokaz povedanemu je zgodovinsko dejstvo, da je po rapalski pogodbi (12.11.1920) - mimo Wilsonove zahteve - celotna Primorska in Notranjska vse do Planine, Javornika in Snežnika pristala pod italijansko kraljevino. S tem je bil izpolnjen pogoj, s katerimi je Italija leta 1915 - po navidezni devetmesečni nevtralnosti ob izbruhu prve svetovne voje - s podpisom londonskega pakta (26. aprila 1915) prestopila iz svojega zavezništva centralnih sil (Avstro-Ogrska, Nemčija, Bolgarija in Otomanski imperij) v antantno zvezo in z vojno napovedjo dotedanji zaveznici Avstriji zakrivila »verolomstvo«. ${ }^{5}$ Vojna napoved Italije in dejstvo, da je vojna napoved začela ve-

4 Ker ni neposreden predmet naše razprave, tukaj odmislimo segment krvavega revolucionarnega spopada, ki ga je bolj ali manj tajno pripravila in izvedla komunistična partija, o čemer še teče zgodovinska razprava ob vedno novih dejstvih in dokumentih. Spopad sam pa tudi ni bil ekspanzionistično agresorski, marveč se je zgodil znotraj naroda samega kot državljanska vojna v vojni.

5 Tako je slovenski časopis Domoljub 27. maja 1915 na prvi strani označil italijansko vojno napoved. 
ljati prav na binkoštno nedeljo 24. maja 1915, je sprožilo med Slovenci velik politični in propagandni učinek.

Tako je širok pas na zahodni (romanski) in severni (germanski) meji Slovenije, ki meri četrtino sedanje Republike Slovenije, postal predmet na pogajalski mizi mejašev na zahodu in severu. Del primorskega in koroškega ozemlja in življa je tam še danes.

Italijanska okupacija, ki je sledila rapalski pogodbi, se je takoj po letih 1922 (ustanovitev fašistične stranke) prelevila $v$ genocidni fašistični teror, ki je trajal vse do leta 1945. Ravno v tem času pa so Slovenci na okupiranem področju samodejno in mimo omejevalnih uradnih struktur razvili živahno glasbeno dejavnost, kot eno od oblik nenasilnega odpora italijanskemu genocidnemu načrtu. $O$ tem bo govor v zadnjem poglavju. Tašna glasbena dejavnost je bila močan pispevek pri vzdrževanju nenasilnih humanističnih vrednot $\mathrm{v}$ času tega krvavega obdobja ozemeljskih apetitov na krilih nacionalističnega ekspanzionizma, kar nakazujejo že imena Grande Italia, Großdeutschland, Nagy-Magyarország. Zaključek 2o. in začetek 21. stoletja pa je krvavo zapečatila zopet ideja o Veliki Srbiji, če se omejimo na sile, ki so si prilaščale slovensko ozemlje v 2o. stoletju. Umestno je tukaj spomniti na dejstvo, da so Slovenci v vsej zgodovini uporabljali le izraze kot Zedinjena Slovenija ali Združena Slovenija ipd..

$\mathrm{V}$ nadaljevanju razprave bomo posebej pozorni le na zahodni primorski del Slovenije, ki je na obeh straneh njene zahodne meje poseljena s Slovenci. Ker je ta meja določena podobno kot ona iz leta 811, obravnavamo tukaj ime Primorska kot enoten prostor. Za lažje razumevanje potrebujemo na tem mestu vsaj kratek zgodovinski oris družbeno-političnega dogajanja $v$ času fašistične okupacije Primorske.

\section{Kratek zgodovinski oris družbeno-političnega dogajanja}

v obdobju italijanske okupacije Primorske v času fašizma

Tisti del globalne prve svetovne vojne, ki se je odigraval - podobno kot ostale - na slovenskih tleh, je bil posledica tajnih pogajanj velikih sil z ozemeljskimi apetiti.

Da so bili v igri italijanski ekspanzionistični apetiti premišljeno dolgega dometa, je simptomatičen datum zaščitnega zakona št. $38 \mathrm{z}$ dne 23. februarja 2001 (Zakonska določila za zaščito slovenske jezikovne manjšine v 
deželi Furlaniji -Julijski krajini). ${ }^{6} \mathrm{Z}$ njim je Republika Italija šele več kot pol stoletja po zaključku druge svetovne vojne - točneje 56 let kasneje - izpolnila formalno juridično zavezo, ki ji je bila ob zaključku drugega svetovnega konflikta naložena kot poraženi soudeleženki agresorske strani. S tem je bila dana priložnost, da vsaj na moralnem področju popravi škodo, ki so jo povzročala tri desetletja fašističnega genocidnega terorja na celotnem okupiranem ozemlju, ki je trajalo od maja leta 1915 pa do maja leta 1945 . Več paragrafov tega zakona po 15-tih letih še vedno ni izpolnjenih. Polstoletna zamuda in več kot petnajstletno neizpolnjevanje več členov tega zakona nakazuje nadaljevanje (upajmo, da ne zametke) konfliktnega naboja v odnosu do italijanskih državljanov slovenske narodne manjšine (zlasti onih v Benečiji), ki so ob - ne ravno transparentnih geostrateških in političnih kupčkanjih, kjer tudi povojna Jugoslovanska stran ni čisto nedolžna ${ }^{7}-$ morali $^{-}$ ostati v tuji državi zunaj svojih narodnostnih mejà.

Tukaj ni prostor, kjer bi poglobljeno analizirati takšna dogajanja. $\mathrm{V}$ skladu z našo temo pa se moramo vsaj okvirno dotakniti družbeno-političnega dogajanja v obdobju italijanske okupacije Primorske, ki se je že takoj še močneje zaostrila ob nastopu fašizma.

Pri tem opisu se namenoma opiramo na en sam bibliografski vir mešane italijansko-slovenske skupine zgodovinarjev: Slovensko-italijanski odnosi 188o-1956. Poročilo slovensko-italijanske zgodovinsko-kulturne komisije, Koper-Capodistria, 25. julij 2000 (v razpravi uporabljamo okrajšano: Poročilo). ${ }^{8}$ Gre za usklajeno dvojezično italijansko/slovensko besedilo, ki je

6 Uradna objava zakona: Legge 23 febbraio 2001, n. 38, 'Norme per la tutela della minoranza linguistica slovena della regione Friuli - Venezia Giulia', Gazzetta Ufficiale n. 56 dell'8 marzo 2001. / Zakon štev. 38, z dne 23. februarja 2001, 'Zakonska določila za zaščito slovenske jezikovne manjšine v deželi Furlaniji - Julijski krajini’, Uradni list (Republika Italija), št. 56, z dne 8. marca 2001. Italijansko/slovensko besedilo zakona je dostopno na spletu: http://www.primorski.it/dossiers/priloge/14/48/. Italijansko uradno besedilo pa je na spletnih straneh Italijanskega parlamenta poslancev/Parlamento italiano, Camera dei deputati: http://www.camera.it/parlam/leggi/o1038l.htm. Oboje obiskano 20. septembra 2017.

7 Bibliografija o tem ravno v zadnjih desetletjih narašča. Objavljajo se številni dokumenti in študije. Na uravnovešeno zaključno sodbo bo potrebno še malo počakati.

8 Poročilo je objavljeno v slovenščini, italijanščini in angleščini. Citiramo po: Slovensko-italijanski odnosi 188o-1956. Poročilo slovensko-italijanske zgodovinsko-kulturne komisije. / I raporti italo-sloveni 1880-1956. Relazione della commissione storico-culturale italo-slovena. Koper-Capodistria, 25. julij - luglio 20oo. Izdajo je pripravil Inštitut za novejšo zgodovino, uredili Milica Kacin Wohinz, Nevenka Troha, prevod v angleščino Breda Negro Marinič, založila pa je ljubljanska revija Nova revija leta 2001. Po tej izdaji povzemamo vse citate. 
dostopno tudi v angleškem prevodu. ${ }^{9}$ Komisija je bila postavljena na najvišji meddržavni ravni, kot beremo $\mathrm{v}$ uvodnem spremnem pismu obeh sopredsednikov komisije Poročila:

"Z izmenjavo not sta ministra za zunanje zadeve Slovenije in Italije oktobra 1993 določila ustanovitev mešane slovensko-italijanske zgodovinsko-kulturne komisije $z$ nalogo, da celovito in natančno prouči vse pomembne vidike v zgodovini političnih in kulturnih odnosov med dvema narodoma ${ }^{\mathrm{IO}}$.

Člane vsake strani sta $\mathrm{z}$ ministrskimi odloki določila slovenski in italijanski zunanji minister. Delo komisije je trajalo sedem let: od leta 1993 do 20oo. Komisija je bila pri svojem delu popolnoma avtonomna in svobodno zasedala na plenumih, kjer je pretresala gradiva. Kljub pomanjkljivostim, ki jih takšen podvig pričakovano vsebuje, je to trenutno najbolj avtoritativno zgodovinsko besedilo, ki se nanaša na to specifično vprašanje.

V besedilu je jasno prepoznana želja, da bi skupaj ustvarili besedilo, ki bo vsebovalo le neizpodbitna zgodovinska dejstva, sodbe in interpretacije dogajanj, ki jih ne bi bilo mogoče obojestransko zanikati. Tudi časovni razpon obravnavanega obdobja (188o-1956) je razumno širok, da je lahko zajel poglobljeno tudi korenine, filogenezo in vzročne povezave nekaterih kontroverznih a bolečih in tragičnih dogajanj med leti 1915 in 1945, pa vse do leta 1956. Pobuda in delo te komisije je vzoren primer dobre prakse na podobnih konfliktnih področjih, konkretno pa je močno orodje in opora pri normalizaciji odnosov obeh narodov ob slovenski zahodni oz. na italijanski severo-vzhodni meji. ${ }^{\text {"I }}$

S tem smo podali že prvi konkreten učinek večdesetletnih naporov prebivalcev na primorskem delu Slovenije, kjer je ravno slovenska stran pri

Slovenska stran: dr. Milica Kacin Wohinz (sopredsednica), dr. Nevenka Troha, dr. France Dolinar, dr. Branko Marušič, dr. Andrej Vovko, dr. Boris Mlakar; dr. Boris Gombač, g. Aleksander (Saša) Vuga. Italijanska stran: prof. Sergio Bartole (sopredsednik, do 9.3.1999), prof. Giorgio Conetti (sopredsednik, od 10.3.1999), prof. Fulvio Tomizza, prof. Lucio Toth, prof. Fulvio Salimbeni, prof. Elio Apih, prof. Paola Pagnini, prof. Angelo Ara, prof. Raoul Pupo, prof. Marina Cattaruzza. Slovensko-italijanski odnosi 1880-1956. Poročilo ... (Ljubljana: Nova revija, 2001), str. 4.

10 Slovensko-italijanski odnosi 1880-1956. Poročilo ..., prav tam, str. 14.

11 V isto smer kaže predlog obeh sopredsednikov komisije ministroma za zunanje zadeve Republike Slovenije in Italije, kjer konkretno nakažata »nekaj možnosti, kako praktično uporabiti ta dokument: (1) uradna javna predstavitev dokumenta $v$ glavnih mestih obeh držav, po možnosti v akademskem okolju, kot znak trdne sprave med obema narodoma, (2) objava teksta $v$ dvojezični obliki, (3) objava temeljnih študij in (4) vključitev poročila med vsebine, obravnavane na srednjih šolah.« V: Prav tam, str. 16. 
tem in podobnih projektih odigrala odločilno pobudniško in gonilno vlogo. Takšne pobude pa ne vzniknejo hipoma, še manj iz nič.

Prostor te razprave dovoljuje močno okrajšano navedbo le nekaj bistvenih trditev v obliki sodb, ki sta jih obe strani v času sedemletnega dela vzajemno uskladili.

"Komisija je na prvem zasedanju ugotovila, da je za njeno obravnavo pomembno zgodovinsko obdobje od 1880 do 1956, to je od začetkov nacionalno politične diferenciacije obmejnega prostora do neposrednih posledic razmejitve po londonskem memorandumu. $\mathrm{Za}$ boljšo preglednost poročila je obdelavo tematike razdelila po uveljavljeni periodizaciji na štiri obdobja: 1880-1918, 1918-1941, 19411945 in $1945-1956$. . $^{12}$

Predmet naše razprave je drugo obdobje (1918-1941), čeprav v tretjem in celo četrtem-povojnem obdobju odnosi niso postali čez noč drugačni. V malce bolj sofisticirani in manj očitni obliki so ostajali podobni, kot so bili v prejšnjih obdobjih genocidnega zatiranja. V tem se je Poročilo izkazalo kot potrebno orodje $\mathrm{v}$ medsebojnih odnosih.

Poročilo takoj v začetku poseže $\mathrm{v}$ daljno zgodovino, $\mathrm{v}$ obdobje pred tisočpetsto leti, ki ga označi kot prvi začetek slovensko-italijanskih odnosov. $\mathrm{S}$ tem je podan pomenljiv uvod $\mathrm{v}$ obravnavo prvega konfliktnega obdobja 1880-1918.

"Slovensko-italijanski odnosti na jadranskem območju se začenjajo v kriznem obdobju, ki je sledilo propadu rimskega imperija, ko se je po eni strani iz rimskih osnov razvilo italijanstvo, po drugi strani pa je prišlo do poselitve ozemlja s slovenskim prebivalstvom. Iz večstoletnega sosedstva in sožitja obravnavamo obdobje, ki je napočilo okoli leta 1880 in je zaznamovano s konfliktnim odnosom in slovensko-italijanskim narodnostnim sporom. Konflikt se je pletel v državno - političnem okviru habsburške monarhije. Tej so se med drugo polovico 14. stoletja in letom 1797 postopoma priključila razna območja Avstrijskega primorja. Večnarodna habsburška monarhija $v$ drugi polovici 19. stoletja ni mogla izoblikovati političnega sistema, ki naj bi v državnem ustroju v celoti zrcalil večnarodno družbo. Zato jo je pretresalo narodnostno vprašanje, ki ga ni znala razrešiti. V okvir habsburškega narodnostnega vprašanja sodi tudi slovensko-italijanski nesporazum, na katerega so vpliva- 
li tudi procesi modernizacije in ekonomskih sprememb, ki so prevevali vso srednjo Evropo, pa tudi prostor ob Jadranu. [...] Vprašanje je še bolj zapletal nedvoumno kulturni in čustveni, čeprav ne vselej tudi politični odziv, ki ga je med italijanskim prebivalstvom $v A v$ striji spodbudila ustanovitev Kraljevine Italije, nemara pa še bolj vključitev sosednjega ozemlja Veneta in Furlanije v njen državni okvir. Medtem ko so se Italijani ozirali preko meje monarhije, pa so si Slovenci prizadevali razbiti politično upravne meje, ker so jih $v$ Avstriji delile med več dežel (poleg treh primorskih še Kranjska, Koroška in Štajerska), saj jih je to omejevalo pri medsebojnih odnosih in narodno-političnem sodelovanju. Priključitev Veneta h Kraljevini Italiji je tudi zbudila vprašanje, ki neposredno zadeva slovensko-italijanske odnose. Leta 1866 je postala dolina Nadiže ali Beneška Slovenija del italijanske države. Politika, ki jo je tu Italija izvajala do slovenskega prebivalstva, pa je neposredno odražala razliko med staro deželno državo Beneško republiko, in novo nacionalno državo. Kraljevina Italija se je zaradi stremljenja po izenačevanju razmer $v$ državi zatekala k zatiranju jezikovnih posebnosti in se sploh ni zmenila za lojalnost prebivalstva, ki so mu bili ukrepi namenjeni. ${ }^{13}$

Kot Poročilo pravilno ugotavlja, je zatiranje jezikovnih posebnosti zlasti usodno doživljala Beneška Slovenija in Rezija. Stanje še do danes ni ne odpravljeno niti popravljeno, saj je ostalo skoraj enako, kot se je zgodilo v letih po 1866. Tako imenovano Avstrijsko primorje (istrski, tržaški in goriški del Primorske) pa se je v drugi polovici 19. stoletja gospodarsko in politično močno razvilo in se je enakovredno spojilo s političnimi gibanji v osrednji Sloveniji. Poročilo nadaljuje z zanimivimi analiza$\mathrm{mi}$ in tezami.

"Značilna lastnost italijanske in slovenske poselitve Avstrijskega primorja je bila $v$ tem, da so sestavljali Slovenci izrazito podeželsko prebivalstvo, Italijani pa pretežno mestno prebivalstvo. Tega pojava ne kaže jemati v absolutnem smislu. [...] Čeprav se velja ogibati pretiranemu poudarjanju ločevanja med mestno in podeželsko stvarnostjo, je bilo razmerje med mestom in podeželjem dejansko eno od temeljnih vozlišč političnega boja v Primorju [...] Vozlišče razmerja med mestom in podeželjem je bilo obenem $v$ središču še 
vedno trajajoče politično-historiografske razprave o pravi narodni podobi Primorja. Slovenska stran je zagovarjala pripadnost mesta podeželju bodisi zato, ker naj bi podeželska območja hranila nedotaknjeno, od kopičenja kulturnih in socialnih procesov neokrnjeno izvorno identiteto danega okolja, pa tudi zato, ker naj bi bila narodna podoba mest posledica raznarodovalnih procesov, ki so osiromašili slovenski narod. Slovenci so doživljali torej izgubo narodne identitete $v$ procesu raznarodovanja tudi po več desetletjih kot še vedno bolečo in pretresljivo izkušnjo, ki se ne sme več ponoviti. Italijanska stran je to zavračala ... Iz tako različnih zasnov je pozneje klil spor o pojmu etnične meje ter o pomenu statističnih podatkovo narodnosti prebivalstva na obmejnih območjih ... " ${ }^{\mathrm{I4}}$

Poleg tega je »italijanska stran [v obdobju 1880-1918] ${ }^{15}$ pripisovala nagel vzpon slovenskega političnega in gospodarskega gibanja ter demografsko rast Slovencev $v$ mestih tudi dejavnosti avstrijske državne oblasti, češ da naj bi ta politično podpirala slovenski živelj [...], da bi se postavil po robu italijanskemu avtonomizmu in nacionalizmu. ${ }^{16} \mathrm{~V}$ takem ozračju se razumljivo Slovenci in Italijani v desetletjih pred vojno niso povezovali. Nenavadno zavezništvo med slovenskimi katoličani in italijanskimi liberalci na Goriškem je precejšnja izjema.

»V italijanskem taboru je narodnjaštvo pri Ruggeru Timeusu preraslo $v$ sicer manjšinski, a skrajni in radikalni nacionalizem, $k i$ se je skliceval na kulturno in narodnostno poslanstvo mesta ter na imperativ gospodarskega prodora italijanstva na jadransko območje. [...] V napetem in razgretem ozračju so se pojavile tudi zamisli ljudi [...] okoli florentinske revije La Voce, ki je objavila pobude za sožitje med narodi in želela spoznati ter priznati večnacionalno stvarnost Trsta in njegove okolice. Pri tej reviji so sodelovali nekateri mladi Tržačani, med njimi tudi Scipio Slataper ter brata Carlo in Giani Stuparich. V nasprotovanju političnemu iredentizmu so svoj položaj označevali kot kulturni iredentizem in nameravali razvijati italijansko kulturo $v$ soočanju in sodelovanju zjužnoslovansko in nemško kulturo. Trst naj bi po njihovem postal kraj, kjer bi se srečevali različni narodi in civilizacije. ${ }^{17}$

\footnotetext{
14 Prav tam, str. 27-28.

15 Opozorilo avtorja I. F.

16 Prav tam, str. 29.

17 Prav tam, str. 31-32.
} 
Nekateri mladi Tržačani, med njimi tudi Scipio Slataper ter brata Carlo in Giani Stuparich so imeli inovativno zamisel o razvijanju italijanske kulture $\mathrm{v}$ soočanju in sodelovanju z južnoslovansko in nemško. Vendar so ostali popolnoma preslišani $\mathrm{v}$ takratnem italijanskem in sloveneskem okolju.

"Slovencem je bila bližje južnoslovanska rešitev temeljnih kriznih problemov, ki so pretresali avstrijsko monarhijo tik pred začetkom prve svetovne vojne. ${ }^{18}$

Dokončno in nepovratno zaostritev je sprožila prva svetovna vojna, ko "je postal program iredentizma sestavni del programa italijanske državne politike « ${ }^{19}$. V prvem letu vojne in v času navidezne nevtralnosti Italije je bilo - zaradi strahu, da bo monarhija le nekako preživela vojno - na italijanski strani sicer nekaj taktičnih namigov za stik s slovenskimi predstavniki, in to po naročilu italijanske vlade. Toda prelom Italije s starimi zavezniki osi in podpis tajnega londonskega pakta 26. aprila 1915 pa sta stvari dokončno zapečatila. Takole trdi usklajeno Poročilo:

"Toda že s podpisom londonskega pakta (1915) je prevzela italijanska vlada program ekspanzionizma, ki je poleg narodnega načela upošteval še zemljepisne in strateške razloge. Splošna privrženost Slovencev avstrijski državi se je dodatno napajala ob objavljanju prvih vesti o imperialističnem aspektu londonskega pakta in ob rešitvah, ki jih je vseboval $v$ zvezi $z$ vzhodno mejo italijanske kraljevine, pa tudi zaradi ravnanja italijanskih vojaških oblasti na prvih zasedenih ozemljih. V odnosu do Slovencev je prinesel novosti poraz Italijanov pri Kobaridu, saj je obrodil politiko sporazumevanja med podjarmljenimi narodi Avstro-Ogrske, ki je dosegla svoj vrh na rimskem kongresu aprila 1918, ter v sporazumu $z$ Jugoslovanskim odborom. Medtem ko se je privrženost habsburški monarhiji zdela vse bolj v protislovju s procesi notranjega razkrajanja avstrijske države, se je med Slovenci širilo načelo o pravici do samoodločbe ter zamisel o južnoslovanski vzajemnosti. Ob vojaškem razpletu in po njem je prišlo do polnega izraza nasprotje med slovensko in jugoslovansko tezo o "narodnostni" meji, ki je temeljila $v$ naziranju, da sodijo mesta $k$ podeželju, in ki se $v$ bistvu ujema zitalijansko-avstrijsko mejo iz leta 1866, ter italijansko tezo, ki se je zavzemala za geografsko in strateško mejo in ji je do veljave pomagala prevlada najradi- 
kalnejših tokov ob politično-psihološki potrebi, da bi javnemu mnenju postregla z otipljivimi znamenji ozemeljskih pridobitev, da bi zagotovila varno mejo mestom in istrski obali, ki so bila po večini italijanska, s tem pa upravičila ogromne žrtve, ki jih je terjala vojna. - Obdobje 1918-1941- Italija, zmagovalka v prvi svetovni vojni, je tako sklenila proces narodnega zedinjenja in obenem zajela $v$ svoje meje poleg Slovencev $v$ mestih in manjših središčih z italijansko večino tudi povsem slovenska območja, celo tista, ki leže zunaj meja nekdanjega Avstrijskega Primorja in jih ne zajema niti pojem italijanske Julijske krajine, ki se je izoblikoval v zadnjih desetletjih. «"

Slovenci so - ob intenzivnih prizadevanjih za samoodločbo - vključitev v italijansko državo razumljivo doživeli kot hudo travmo, saj so bile še vedno žive medvojne travmatične izkušnje $z$ italijansko vojsko in oblastjo na zasedenih krajih bojne črte ob Soči, ki so že tedaj jasno nakazale genocidne namene. Dodatno je stvari poslabšala tudi italijanska okupacijska oblast, ki se je še pred določitvijo jugoslovansko-italijanske meje v letih 1918-1920 trdo znašala nad Slovenci z napadi in požigi slovenskih šol in kulturnih domov. Podatki so srhljivi.

"Nova meja na severnem Jadranu, ki jo je določil že londonski pakt leta 1915 ter jo je v glavnem potrdila rapalska pogodba (1920) in je tekla po razvodju med Črnim in Jadranskim morjem, je odtrgala od matice četrtino narodnega telesa (327.230 ljudi po avstrijskem štetju leta 1910, 271.305 po italijanskem štetju leta 1921, 290.00o po ocenah Carla Schiffrerja), toda večje število Slovencev v Italiji ni vplivalo na položaj Beneških Slovencev (ok. 34 tisoč po štetju iz leta 1921), ki so že dotlej živeli pod Italijo, oblasti pa so jih obravnavale kot dokončno poitalijančene in jim zato niso priznavale nikakršne narodne pravice." Okupacijska oblast je sprejela »številne omejevalne ukrepe - razpuščala je občinske uprave in narodne svete, omejevala svobodo združevanja, pošiljala ljudi pred vojaška sodišča, zapirala vojne ujetnike, internirala in izganjala zlasti izobražence - in z njimi izpodkopala obnovo kulturnega in političnega življenja slovenske skupnosti. Hkrati so okupacijske oblasti podpirale manifestacije italijanstva tudi zato, da bi pogajalcem za novo razmejitev prikazale deželo kot italijansko. ${ }^{2 I}$ 
Številke in dejstva so zgovorni sami po sebi. Dodatnega olja je prilil D’Annunzijev pohod na Reko in dogodki ob njem. Do danes pa odmeva dogodek v Trstu leta 1920, ki mu je bil priča 104-letni slovenski pisatelj tržačan Boris Pahor, ki ga Poročilo opiše takole:

»Požig Narodnega doma, sedeža slovenskih organizacij v Trstu julija 1920, pod pretvezo povračilnega udarca zavoljo nemirov $v$ Splitu, ki so terjali žrtve med italijanskim in med slovanskim življem, je bil zato le prvi javni znanilec ${ }^{22}$ dolgotrajnega nasilja: kriza liberalne države je namreč $v$ Julijski krajini pa tudi drugod po Italiji spodbudila fašistično pogromaštvo, z njim pa se je zaradi zakoreninjenega protislovanskega sovraštva še tesneje kot drugod $v$ Italiji odkrito povezal državni aparat... Nastajali so tudi načrti za razbijanje jugoslovanske države ....13

Nadaljni razplet je vse bolj srhljiv, ki ga niti usklajeno italijansko-slovensko Poročilo ne more omiliti tudi s skrbno izbranim iskanjem izrazov, ki naj bi izražali suha dejstva tedanjih dogodkov in družebeno-plitičnih razmer na okupiranem ozemlju.

»Fašizem se je tudi z zakonodajnimi ukrepi poglobljeno lotil raznarodovanja vseh narodnih manjšin. Tako so bile druga za drugo prepovedane vse slovenske [...] narodne ustanove, ki so oživele po prvi svetovni vojni. Vse šole so poitalijančili, učitelje večinoma upokojili, premestili $v$ notranjost države ali jih odpustili in prisilili $v$ emigracijo. Slovencem so omejili dostop do javnih služb, zatrli so več sto kulturnih, športnih, mladinskih, socialnih, strokovnih društev, več desetin gospodarskih zadrug in denarnih zavodov, narodnih domov, knjižnic itd. Z zakonom so prepovedali politične stranke in periodični tisk, odpravili vsakršno predstavništvo narodnih manjšin, prepovedali uporabo [slovenskega] jezika v javnosti.

... Fašistično raznarodovanje ni prizaneslo niti Katoliški cerkvi... Preganjanje je neposredno prizadelo nižjo duhovščino, saj je bila deležna napadov in policijskih ukrepov. nadaljevanju. 
... Ključna prelomnica [...] sta bili odstranitev goriškega nadškofa Frančiška Borgie Sedeja, in tržaškega škofa Luigija Fogarja.

... Romanizacijski ukrepi so v Julijski krajini načelno vsebovali prepoved uporabe slovenskega jezika pri verskih obredih in verouku, vendar so zlasti na podeželju krščanskosocialni struji pripadajoči duhovniki pri njem protipostavno vztrajali.

... Gospodarska stiska in moreče politično ozračje sta $v$ času med obema vojnama ustvarjali močen migracijski tok iz Julijske krajine. [...] Po jugoslovanskih ocenah je odšlo skupno 105.ooo Slovencev in Hrvatov. ${ }^{24}$

Vsaka sila - zlasti nasilna - redno sproži podoben odpor, kot je v fizikalnih zakonih v naravi. Nastanek odpora na Primorskem opiše Poročilo takole.

»V Julijski krajini je namreč fašizem skušal uresničiti program popolnega uničenja slovenske narodne identitete. [...] Vendar so se na splošno nesoglasja med obema narodnostnima poglabljala in na ozemlju Julijske krajine se je izoblikoval razvejen odpor do fašističnega zatiranja. Predvsem slovenska mladina narodnjaške smeri, zbrana $v$ organizaciji TIGR in povezava z jugoslovanskimi, pred začetkom druge svetovne vojne pa tudi angleškimi službami, se je odločila, da bo na nasilje odgovorila z nasiljem. Segla je po demonstrativnih in terorističnih sredstvih in s tem izzvala najstrožjo represijo... Za to odporniško dejavnost je Posebno sodišče za zaščito države izreklo mnoge zaporne kazni in širinajst smrtnih obsodb, deset je bilo izvršenih. ${ }^{25}$

TIGR je bil organizacijsko močna ne pa edina oblika odpora. Ni naklučje, da so prvi spopad z okupatorjem v Sloveniji in sploh v Jugoslaviji imeli ravno pripadniki TIGRa 13. maja 1941 na Mali gori pri Ribnici. ${ }^{26} \mathrm{O}$ drugih oblikah odpora pa bo govor v zadnjem poglavju.

Razumljivo in razumno se je vzajemno Poročilo italijansko-slovenske skupine zgodovinarjev zavestno in načrtno izognilo naštevanju imen kriv-

24 Prav tam, str. $38-41$.

25 Prav tam, str. 41-43.

26 O konfliktem odnosu komunistične partije do tigrovcev glej med drugim v: Tatjana Rejc, Partija in Tigrovci - medvojna in povojna usoda nekaterih vodilnih tigrovcev (Ljubljana: Slovenska matica, 2006). 
cev in opisov konkretnih zločinov. Ob vztrajni uporabi le sintagme »fašizem « in/ali »fašističen" v Poročilu pa ne gre pozabiti, da je bil fašizem od nastopa Musolinijeve vlade pa do njene odstranitve 8.9.1943 uradna polnomočna oblast $\mathrm{v}$ Italiji $\mathrm{z}$ vsemi tremi funkcijami in $\mathrm{z}$ močno podporo najširših množic. ${ }^{27}$ Torej je bila ta vlada in s tem država Italija odgovorna. Številna okrutna dejanja so se namreč dogajala še pred uradnim nastopom fašizma oziroma Mussolinijeve vlade, ki nastopi z mandatom šele 3o. oktobra 1922.

Zgovoren je dogodek, o katerem priča spomenik v Strunjanu, da so 19. marca 1921 Italijani streljali iz vlaka na gručo otrok, ki so se ob progi $\mathrm{La} P a$ renzana igrali: dva so ubili, pet pa hudo ranili. Podoben pečat ima terorističen napad na škofijsko palačo v Trstu 29. decembra 1918, ki je bil gesta protesta proti škofu - Slovencu, mons. Andreju Karlinu, z namenom, da se umakne s svojega sedeža. Leto kasneje (15.12.1919) so dosegli, da je moral odstopiti. ${ }^{28}$ Znake nasilnega izživljanja kaže mučenje in zapor dveh pastirjev kot povračilo za poškodovanje spomenika na vrhu Krna, ki so ga Italijani postavili nekemu heroju (16. junija 1922). Spomenik je porušila strela in ne pastirji, ${ }^{29}$ saj je kmalu zatem ubila tudi dva stražarja, ki so ju Italijani postavili tja. ${ }^{30}$ Brezštevilni so bili požigi šol, kulturnih domov in celo župnišč. Proti tem kriminalnim dejanjem ni bila s strani oblasti izvedena ne preiskava, niti so bila ta dejanja kaznovana. ${ }^{31}$ Prav tako niso bili ne zaprti ne obsojeni znani storilci, ki so zastrupili s strojnim oljem pomešanim z bencinom skladatelja Lojzeta Bratuža (27.12.1936) v Podgori, čeprav je zaradi tega na predvečer svojega petintridesetega rojstnega dne umrl (16.2.1937). Italijanska oblast je prepovedala javen pogreb. Kljub tajnosti in zgodnji jutranji uri se je spontano na pogrebu zbrala zelo velika množica iz vseh krajev Primorske. Takoj je spontano postal simbol in vzor nenasilnega odpora

27 Navajanje literature, ki je o tem vprašanju zelo obsežna, tukaj opuščamo.

28 Prim. Milica Kacin Wohinz, Jože Pirjevec, Storia degli sloveni in Italia 1866-1998 (Venezia: Marsilio, 1998), 33.

29 Prim. časopis Slovenec, št.176, 15. 8. 1922, 4.

30 Renato Podbersič ml. Ivan Koršič. V: Tvorci slovenske pomorske identitete, uredil Andrej Rahten, zbirka Življenja in dela VI: Biografske in bibliografske študije, Ljubljana: ZRC SAZU, 2010), 145.

31 Podobno so ostali do danes nedodatknjeni likvidatorji, ki so med in po vojni izvrševali zločine po ukazih VOSa (varnostno obveščevalne službe). Umor zelo vplivnega krščanskega socialista dr. Stanka Vuka in njegove žene Danice Tomažič v dneh, ko sta se odpravljala v partizane, tudi kaže v to smer. Prim. Martin Brecelj, Anatomija političnega zločina. Trojni umor $v$ Rossettijevi ulici med ugibanji in dejstvi (Trst: Mladika, 2016). 
proti fašizmu. Anonimna knjižica Čisti žrtvi svetal spomin, ki jo je napisal Rado Bednarik (1902-1975), se je tajno razširila. Odpor, kot ga je nakazal Bratuž s svojim zgledom, je postal še bolj odločen. Njegove skladbe zlasti tiste na besedilo njegove žene pesnice Ljubke Šorli - so še danes vir navdiha.

Ob razmejitvi je po letu 1918 ostala v Italiji tudi Gorica, kjer je bil Mozartov libretist Lorenzo da Ponte (1749-1883) še 1. septembra leta 1777 v veliki zagati, ker ni razumel niti besede tistega, kar mu je lepa hotelirka-Slovenka želela povedati, pa tudi ona ni razumela tega, kar ji je on - v italijanščini, oz. v venetskem dialektu) - pravil: »Per mia disgrazia non parlava che tedesco, o cragnolino ${ }^{32}$, ed io non capia una parola di quello ch'ella diceva a me, né ella di quel ch 'io a lei. ${ }^{33} \mathrm{Da}$ Ponte pač ni razlikoval med nemškim jezikom in »cragnolino", tj. kranjščino-slovenščino. Dogodek pa lepo pokaže jezikovna razmerja in razmere v mestu Gorici dobro stoletje pred italijansko okupacijo.

Da tudi po drugi svetovni vojni družbeno-politično ozračje na italijanski lokalni in državni ravni ni postalo bistveno drugačno, kažejo dejstva, da je ravno v tem predelu ob meji, ki je naseljen s Slovenci, najaktivneje delovala tajana organizacija s skritim kodnim imenom Gladio. ${ }^{34} \mathrm{Knjiga}$ Gli anni bui della Slavia je med prvimi, ki je dokumentirano spregovorila o tajnem povojnem delovanju proti Slovencem na Primorskem, zlasti pa v Benečiji. Gladio je v koordinaciji s karabinjerji deloval v Benečiji še po letu 1990, ${ }^{35}$ kar dodatno osvetli naše izsledke.

$\mathrm{V}$ takšnih genocidnih razmerah načrtnega državnega jezikovnega in fizičnega etničnega čiščenja, ki je dajal proste roke in celo podpiral delovanje najbolj grobih pripadnikov italijanske fašistične stranke, bi med slovenskim prebivalstvom upravičeno pričakovali popoln kulturni molk,

32 Izraz »cragnolino « je da Ponte zapisal fonetsko in po spominu in ne »carniolano« /kranjsko.

33 Lorenzo da Ponte, Memorie, Prva knjiga, drugi del (Nuova-Jorca [New York]: Gray \& Bunce, 1829), str. 4.

34 Gladio je bil italijanska tajna organizacija, ki je bila ustanovljena takoj po drugi svetovni vojni. Kasneje, po ustanovitvi leta 1947, se je vanj vključila še CIA, ki je isto organizacijo poimenovla Stay-behind (biti onstran meje). Obstoj Gladija je uradno razodel tedanji predsednik italijanske vlade Giulio Andreotti šele 24. oktobra 1990. Sumi o obstoju pa segajo v leto 1979 (W. Colby) in 1984 (neofašist V. Vinciguerra med sodnim procesom). V Benečiji je deloval odsek Gladia z imenom O (Osopo).

35 Več o tem v: NAZ [Natalino Zuanella], Marino Qualizza. Gli anni bui della Slavia. Attività delle organizzazioni segrete nel Friuli orientale (Čedad / Cividale del Friuli, Società Cooperativa Editrice Dom, 1996). 255 strani. 
vdanost v usodo in splošno mrtvilo. Vendar je bila reakcija Slovencev popolnoma drugačna. Poleg mreže tajnih trojk organizacije TIGRA je spontano vzniknilo splošno odporniško vzdušje, kjer so sodelovali vsi sloji. O tem bomo spregovorili v nadaljevanju.

\section{Oris ključnih ustvarjalnih predvsem glasbenih osebnosti, dogajanj in vloge glasbe $\mathrm{v}$ času italijanske okupacije na Primorskem}

Družba ni anonimen in peščeno amorfen skupek posameznikov, saj običajno deluje kot organsko povezana enota, kot zapleten organizem. Nekateri pripisujejo temu družbenemu organizmu celo samostojno zavest, drugi celo dušo, duha. $V$ tem organizmu pa vznikajo določene osebnosti, ki so ključni nosilci samoohranitvenih in ustvarjalnih, ali pa tudi razdiralnih in samouničevalnih idej. Družba jih prepozna in prizna ali pa zavrne.

Tako je bilo med obema vojnama tudi na Primorskem nekaj ključnih ustvarjalnih osebnosti, ki so v tedanjih družbeno-političnih razmerah izpeljale - poleg že omenjenega TIGRA - veličasten kulturni podvig nenasilnega odpora s posebnim povdarkom na glasbi. Vsem je skupno to, da so kot edino "orožje" uporabjali zgolj umetnost, predvsem glasbo in pesništvo. V tem je izjemnost njihovega družbenega podviga.

Zanimivo je, da se predvsem v goriškem predelu Primorske $\mathrm{v}$ času med obema vojnama zbere skupina ljudi, ki deluje povsem usklajeno. Prednostno se posvečajo preprostemu ljudstvu, ki je v časih stiske najbolj ranljivo. Status izobraženca občutijo kot dolžnost in službo, ne kot prestiž nad drugimi. Njihovo delovanje zavestno poteka na področju kapilarne glasbene vzgoje $\mathrm{v}$ vseh starostnih dobah. Zaradi italijanskih genocidnih zakonov je njihovo delovanje tajno in na meji zarotništva. Glasba (predvsem zborovska ljudska in najširšemu krogu dostopna umetna pesem) in beseda (poezija, spevoigre in tajne dramske predstave) sta njihovo glavno in edino orožje.

Po tajnih dogovorih in Rimski pogodbi Mussolini-Pašić (27. 1. 1924), ki sovpada s popolnim zatrtjem javnega življenja med Slovenci na Primorskem, je vsako gibanje in druženje omejeno na cerkveni prostor. Škofa Frančišek B. Sedej (1854-1931) v Gorici in tržaško-koprski škof furlanskega rodu Luigi Fogar (1882-1971) v Trstu kljub prepovedim državnih oblasti ščitita rabo slovenščine pri bogoslužju in poučevanju verouka vse do njune odstavitve (Sedej 1931, Fogar 1936). Primorska duhovščina je z delom nada- 
ljevala nemoteno naprej tudi pod škofi italijanske narodnosti. Razumljivo je, da je bilo to izjemno organizirano delovanje izvajano $\mathrm{v}$ popolni tajnosti. Tako bi lahko govorili o paralelnem »duhovniškem TIGRU«. Opis tega narodnoobrambnega dela primorske duhovščine in krščanskih socialcev najdemo v obsežni monografiji Egona Pelikana Tajno delovanje primorske duhovščine pod fašizmom. ${ }^{36}$

$\mathrm{S}$ tem v tesni zvezi in pod zaščito obeh cerkvenih dostojanstvenikov zaživijo pogosta skoraj konspirativno organizirana romanja $\mathrm{v}$ odročne cerkve na Primorskem, na katera se ljudje množično in povsem spontano odzivajo. Za takšne priložnosti pripravljajo in $\mathrm{v}$ samozaložbi tiskajo notno gradivo skladb na skrbno izbrana besedila, ki vsebujejo jasna osvobojevalna sporočila. V tem posebej izstopa pesnica Ljubka Šorli. Podobno ostali: Filip Terčelj, Venceslav Belè, Stanko Stanič in drugi. Skladatelji ta besedila uglasbijo na način, ki je zelo blizu melosu ljudskih pesmi. V tem je posebno uspešen skladatelj Vinko Vodopivec. Zaznati pa je mogoče očiten glasbeno-vzgojni namen, da želijo skladatelji postopoma negovati pri pevcih rast izvajalskih zmožnosti. Takšen načrt pokaže pregled tiskanih sporedov in notnih knjižic za ta romanja, kjer je glasbeni stavek nekaterih pesmi (zlasti Bratuževih, Komelovih in Vodopivčevih) vsakič za spoznanje zahtevnejši in sodobneje zastavljen. Tako se v pevcih nezavedno dogaja pevska in s tem osebnostna rast, kar dviguje osebno samozavest. Morda je ravno v tem najbolj dragocena opora, ki jo je ta neformalni glasbeno-kulturni TIGR podaril svojim rojakom, da je nahranil njihovo lakoto po lepem, humanem, dobrem, po iskanju smisla njihovega trpljenja.

V času med obema vojnama je tako samo na Primorskem skomponirano in natisnjeno $\mathrm{v}$ tiskarni ali s hektografom na tisoče novih skladb. Samo Vodopivec, ki je bil med temi skladatelji najbolj plodovit, jih je zložil približno tisočpetsto. Večina teh hektografiranih (oz. šapirografiranih) skladb lahko danes izgine $\mathrm{v}$ pozabo, saj črnilo na partiturah nepovratno bledi. Zbirka Zbrana dela primorskih skladateljev, ${ }^{37}$ ki monografsko objavlja celotne opuse skladateljev v tiskani in digitalni obliki. S tem želi oteti pozabe in uničenja to glasbeno ustvarjalno bogastvo Primorske iz časa italijanske okupacije.

36 Egon Pelikan, Tajno delovanje primorske duhovščine pod fašizmom (Ljubljana: Nova revija, 2002). 776 strani.

37 Najaktivneje se je doslej pri tem izkazalo Združenje cerkvenih pevskih zborov - Gorica. Doslej so izšli opusi vseh trenutno dosegljivih skladb Lojzeta Bratuža (2005), Stanka Jericija (2010), Emila Komela (2016) in Mirka Fileja (2017). Avtorske pravice vseh publikacij so odprtega tipa. 
Ena od posebej iztopajočih in ključnih osebnosti, okoli katerega se je vrtel niz drugih, je bil v tem času skladatelj, učitelj, pianist, glasbeni teoretik in organist Emil Komel (1875-1960). Prebival in deloval je v Gorici in njenem širokem zaledju kot dejaven soustvarjalec njenih kulturnih korenin. Kljub hudim grožnjam, šikaniranju, izgubi službe in zlodejanjem (npr. zažig njegovega učbenika Harmonija s strani fašistov leta 1934) ni bežal preko meje, kar so številni storili, saj je tudi svojo Gorico imel za Slovenijo. Zato je neustrašeno ostal v Gorici. Kot verujoči v evolucijo, je skromno in tiho opravljal svojo svečeniško vlogo dobesedno $\mathrm{v}$ katakombah mračnih desetletij med obema vojnama. Nepregledna je vrsta učenk in učencev, ki so bili sad njegovega učiteljskega žara. Lahko bi to poimenovali očetovstvo, ali z besedami psihoanalitika Matjaža Lunačka »univerzalno starševstvo « ${ }^{38}$. Vrsta njihovih imen je zelo dolga: Breda Šček-Orel, Ivan Šček, tenorist Josip Rijavec, pevka Cirila Medvedova, pianist Anton Neffat, skladatelj Mirko Filej, skladatelj Zorko Harej, pa tudi mladi Marij Kogoj in Joško Jakončič, sinovski prijatelj Lojze Bratuž in nenazadnje le tri leta mlajši skladatelj Vinko Vodopivec, če omenimo le izstopajoče.

Pred kratkim objavljena Zbrana dela Emila Komela, ${ }^{39}$ predstavljajo le majhen izsek tistega, kar je v neposrednem osebnem stiku Komel zapisal $\mathrm{v}$ srce in vest rojakov v Gorici in daljni okolici. Osebna nacionalna zavest mu ni branila, da bi ne bil enako prijateljski tudi do Italijanov, Furlanov in Nemcev. Vse, kar imamo sedaj prvič skoraj v celoti objavljeno (Harmonija in Glasbena priloga s praktičnimi vajami, zvezek Skladb za orgle, klavir in harmonij ter zvezek Vokalna dela - izbor), je le del tistega, kar je Komel ustvaril.

V Komelov krog pa moramo nujno pritegniti ustvarjalni napor skladateljev, ki so delovali v tistem času. To sta bila najprej Vinko Vodopivec (1878-1952) in Lojze Bratuž (1902-1937). Vse tri bi - v skladu z njihovim delom in zaslugami - lahko označili kot prostovoljno ,neformalno trojko glasbenega TIGRA«, ki je delovala na Goriškem in okolici vse do Idrije in v Posočju. Vsak od njih je imel svojo posebno vlogo, vsak v skladu s svojim značajem in osebno nadarjenostjo. Poleg njih so bili še drugi. Na tržaškem v tem času izstopata npr. skladtelja Vasilij Mirk (1884-1962) do svojega umi-

38 Prim. Matjaž Lunaček, »Potrebe so mi bile že od nekdaj sumljive«, Delo, Sobotna pri$\log a, 22.7 .2017,6$.

39 Trije zvezki: faksimile učbenika Harmonija in Glasbena priloga s praktičnimi vajami, zvezek Skladb za orgle, klavir in harmonij ter zvezek Vokalna dela - izbor. Poleg tega je tudi CD s celotnim zbranim opusom v digitalni obliki. Izdalo Združenje cerkvenih pevskih zborov - Gorica, 2016. 
ka v Slovenijo, Stane Malič (1904-1984) in Ubald Vrabec (1905-1992), ki je ob umiku v Slovenijo deloval v primorskem društvu emigrantov Jadran. Kori in prosvetna društva so posejani z rokopisi, ki so jih skladatelji podarili temu ali onemu pevovodju. Od vsega tega je veliko za vedno izgubljenega, celo sežganega (npr. v Gorici ob požigu Trgovskega doma leta 1926, Katoliške tiskarne in Goriške straže) ali preprosto uničenega. Skladatelja Rada Simonitija (1914-1981) v tem medvojnem času ne zaznamo aktivnega na Primorskem; študij in svojo kariero je ustvaril po vojni v povsem drugem okolju od tukaj opisanega.

V sklopu ključnih odporniških podvigov na Primorskem, ki so glasbene narave, ne moremo mimo vloge, ki jo je odigrala tovarna glasbil Cecilija. Ob podjetnosti predvsem Lojzeta Bratuža in škofa Sedeja je ta tovarna začela v Gorici načrtno izdelovati harmonije, ki so jih zasnovali tako, da so bili cenovno dostopni tudi najrevnejšim glasbenikom na podeželju. S takšnim neprofitnim in predvsem narodnoobrambnim pristopom je tovarna s temi glasbili docela napolnila vso tržaško in goriško pokrajino s Posočjem. Učbenik Harmonije, ki ga je Emil Komel napisal, je namenoma tako zasnovan, da je prikladen samoukom pri učenju glasbenega stavka, kot je v predgovoru sam zapisal. Poleg tega je Komel zasnoval še vrsto kratkih skladb, ki so kot praktični del Harmonije pomagale samoukom pri utrjevanju glasbenega stavka, ali pa kot vzorci za improviziranje na orglah, harmoniju ali klavirju, namenjene pa so tudi kot uvod v skladanje. To je Komel v uvodu svoji Harmoniji izrecno izpostavil. Zamisel o učbeniku kontrapunkta in kompozicije pa je Emil Komel zaradi fašističnega zažiga Harmonije (1934) povsem opustil.

Znotraj tega dogajanja srečamo v istem času tudi mladega Marija Kogoja (1892-1956). Njegova goriška zgodba se neposredno dotika teme naše razprave. Emil Komel je tudi Marija Kogoja povedel v svet glasbe v njegovih nežnih letih, po letu 1909. Kogoja v Gorici srečamo najprej kot mladega gimnazijca-malosemeniščnika, pa tudi kot organista po okoliških cerkvah (Podgora, Šempeter, Anhovo), kmalu nato pa že kot nadebudnega komponista, ki išče lastno podobo. Kasneje - po študiju na Dunaju - srečamo Kogoja zopet v Gorici. To je bl čas - po letu 1920 - Kogojevega iskanja trdnejšega kruha in novih poti v glasbo. Če bi ne bilo na italijanski strani toliko nakopičenega grobega nacionalizma, bi zelo verjetno mladi Marij Kogoj aktivno vstopil v skupino futuristov tistega znamenitega 1. aprila 1923, ko je na klavirju improviziral pri uprizoritvi scenskega dela Il peccato. Delo je napisal mladi goriški futurist Sofronio Pocarini. Ob Kogoju bi gledališč- 
na skupina Teatro Semifuturista zelo verjetno zares zaživelo znotraj skupnih ustvarjalnih brstičev, ki sta jih obetala tedanji modernistični čas in Marinettijevi podvigi - in to navkljub odbijajoči agresivnosti njegovega futurističnega Manifesta. Ta dogodek je za to obdobje paradigmatično razodevajoč, saj razkriva notranjo dinamiko porajajočega se fašizma, ki je italijansko okupacijsko oblast $\mathrm{z}$ roko v roki še bolj odločno zapeljal v sektaško genocidne vode.

$\mathrm{V}$ letih 1920 je Gorica postala v novoustanovljem Pocarinijevem in Vucetićevem futurističnem gibanju Movimento Futurista Giuliano neke vrste stičišče dveh velikih avatngardnih krožnic, ki sta imeli svoji središči v Milanu in Berlinu. Italijanski nacionalizem in takoj zatem novonastali fašizem, v katerem so se Filippo Tomaso Marinetti in somišljeniki futurističnega Manifesta počutili čisto domače, je že ob spočetju zatrl obetavne ustvarjalne sadove tako pri Kogoju kot pri marsikom drugem iz slovenskega okolja, še preden so se dodobra razcveteli. Razumljivo. Ob takratnem množičnem požiganju slovenskih kulturnih domov po Primorskem pač gibanje futuristov, ki so takšna početja odobravali kot skladna s svojimi manifesti, ni moglo zaživeti $\mathrm{v}$ teh večinsko slovenskih krajih. Verbalno razglašanje svobode ob grobem nasilju ni moglo najti privržencev ne med Slovenci in niti med Italijani. Toliko bolj se je čutil izključenega rahločutni Marij Kogoj. Slaviti militarizem, ali razdiralno gesto libertincev, grobo verbalno zaničevati žensko in častiti vojno kot edino čistilno sredstvo sveta (člen 9 Marinettijevega Manifesta), vse to ni moglo ne pri Komelu, Bratužu ali pri Kogoju in niti pri mnogih drugih vzbuditi željo za sodelovanje. Marij Kogoj se je takoj zatem umaknil v Ljubljano. V Gorico se ni več vračal. Kasneje pa se je morda tudi zaradi teh ran - poleg ostalih - popolnoma umaknil na senčno stran duha.

Pri celostnih vrednotenjih in zgodovinsko-estetskih ocenah takrat nastajajočega modernizma moramo vzeti v poštev tudi takšna dejstva konkretnih družbeno-političnih udejanjenj abstraktnih futurističnih manifestov, ki so bolj kot estetiko v svoja jadra zajemali razdiralne silnice ekspanzionističnih nacionalizmov - v Italiji in Nemčiji. Teh dejstev pa vsekakor ne gre spregledati tudi takrat, ko se vprašujemo o vzrokih nastajanja vse večjega prepada med temi in podobnimi modernističnimi tokovi in širšo družbo, ki se prvič močneje pojavi ravno v tem času. Futurizem in podobni modernistični tokovi so razumljivo zlasti na Primorskem postali sinonim za odtujenost in celo nasilje, kar pa ni bilo vprašanje estetike marveč etike in nasploh človečnosti. Tudi slogovne izbire skladateljev med italijan- 
sko okupacijo Primorske v času fašizma nam ob tem postanejo bolj razumljive. S tem pa smo nakazali snov že za novo raziskavo.

Čeprav smo se - glede na obširnost tematike - bistva lahko le dotaknili, pa lahko zaključimo takole. Če je stiska - poleg čudenja - mati modroslovja in poezije, nikakor ne more biti naključje, da je slovenska Primorska ravno $\mathrm{v}$ času svoje največje moralne in fizične stiske ustvarila zajetno število preprostih a dragocenih glasbenih stvaritev. Prav stiska je vzbudila v najbolj pronicljivih duhovih silno nujo uma in srca po notranji jasnovidnosti in duhovni prečiščenosti. Jasnovidnost uma zato, da ne bi ob neznanski krutosti zblazneli. Prečiščenost srca pa zato, da se ob dotiku s sovraštvom ne bi zastrupili. Takšni ljudje, ki zmorejo to storiti, so zato upravičeno jasnovidci in preroki svojega časa. Znotraj neformalne zaveze "kulturnega TIGRA« so vsi to zares bili. Zaradi skoraj samoumevne vsakdanjosti pa je le redkim dano uvideti to trajno sodobno dragocenost takšnih osebnosti v vsej njihovi globini, ki je - mutatis mutandis - še kako potrebna novi Evropi 21. stoletja. V mislih imamo osebnosti, ki status izobraženca oz. intelektualca ne občutijo kot prestiž in moč, marveč ga $\mathrm{v}$ vesti občutijo kot dolžnost in službo do bližnjih neglede na nacionalno pripadnost. Srž rodoljubja je ravno v tem. Omenjene osebnosti na Primorskem v času fašizma in številni, ki so ostali anonimni, so zato ustvarili dragocen model, kako lahko glasba postane močan identitetni in družbeno-politični komunikacijski stabilizator tudi v skrajnih konfliktnih situacijah.

\section{Bibliografija}

Bratuž, Lojze. Lojze Bratuž 1902-1937. Zbrano skladateljsko delo. V: Florjanc, Ivan, zbral in ur.. Zbrana dela primorskih skladateljev I. Gorica: Združenje cerkvenih pevskih zborov - Gorica, 2005.

Dolinar, M. Franc in Tavano, Luiggi, ur. Chiesa e società nel Goriziano fra guerra e movimenti di liberazione. Gorica: Istitiuto di storia sociale e religiosa, 1997.

Filej, Mirko. Zbrano skladateljsko delo. V: Florjanc, Ivan, ur.. Mirko Filej 19121962. Zbrano skladateljsko delo. Gorica: Združenje cerkvenih pevskih zborov - Gorica, 2017.

Kacin Wohinc, Milica in Pirjevec, Jože. Storia degli sloveni in Italia 1866-1998. Venezia: Marsilio, 1998.

Komel, Emil. Harmonija in Glasbena priloga s praktičnimi vajami. Faksimile, v: Florjanc, Ivan, ur.. Emil Komel 1875-196o, Zbrana dela. Gorica: Združenje cerkvenih pevskih zborov - Gorica, 2016. 
Komel, Emil. Skladbe za orgle, klavir in harmonij. V: Florjanc, Ivan, ur.. Emil Komel 1875-196o, Zbrana dela. Gorica: Združenje cerkvenih pevskih zborov - Gorica, 2016.

Komel, Emil. Vokalna dela. V: Florjanc, Ivan, ur.. Emil Komel 1875-196o, Zbrana dela. Gorica: Združenje cerkvenih pevskih zborov - Gorica, 2016.

NAZ [Natalino Zuanella], in Qualizza, Marino. Gli anni bui della Slavia. Attività delle organizzazioni segrete nel Friuli orientale. Čedad / Cividale del Friuli, Società Cooperativa Editrice Dom, 1996.

Pelikan, Egon. Tajno delovanje primorske duhovščine pod fašizmom. Ljubljana: Nova revija, 2002.

Pompeo, Augusto, ur. Forte Bravetta 1932-1945. Storie memorie teritorio. Roma: XVI Circoscrizione ANPI Roma, 2000.

Primorski slovenski biografski leksikon.

Schifrer, Carlo. Sguardo storico sui rapporti fra italiani e slavi nella Venezia Giulia. Trieste: Istituto di storia moderna dell'Università di Trieste, 1946.

Tuta, Slavko. Cena za svobodo. Uredil Igor Tuta. Gorica: Goriška Mohorjeva družba, 1999.

Slovensko-italijanski odnosi 1880-1956, poročilo slovensko-italijanske zgodovinsko-kulturne komisije. I raporti italo-sloveni 1880-1956, relazione della commissione storico-culturale italoslovena. Slovene-ltalian Relations 1880-1956, report of the Slovene-ltalian historical and cultural commission. Koper- Capodistria, 25. julij -Iuglio - July 20oo. Kacin Wohinz, Milica, in Troha, Nevenka, ur. Angl. prevod Negra Marinič, Breda. Ljubljana: Nova revija, 2001. 
Kačji pastir - La Libellula: Glasbena večjezičnost opere Pavleta Merkuja

\author{
Sara Zupančič \\ Univerza v Ljubljani \\ University of Ljubljana
}

Pavle Merkù je svojo edino zaključeno opero Kačji pastir oz. La Libellula komponiral na izviren libreto slovenske pesnice Svetlane Makarovič, in sicer v obdobju med letoma 1975 in 1976 . Že zaradi svoje glasbene vsebine in časa nastanka zaseda opera pomemben položaj v Merkujevem opusu: to je njegova zdaleč najdaljša zaključena kompozicija, ${ }^{\mathrm{I}}$ predvsem pa označuje zrelo fazo njegovega glasbenega ustvarjanja. Sredi sedemdesetih let, ko je delo nastajalo, je Merkù prehodil že polovico svoje skladateljske poti in presegel svoje zgodnje neoklasicistično obdobje »spoznavanja, asimiliranja in oponašanja « ${ }^{2}$ ter kasnejša eksperimentiranja z modernističnimi tehnikami in ljudsko glasbo. ${ }^{3} \mathrm{~V}$ istem obdobju kot opera je bila izdana dvojezična knji-

1 Opera Kačji pastir traja približno eno uro, druga najdaljša Merkujeva kompozicija, to je kantata Von der Kindermörderin Marie Farrar za bariton, mešani zbor, dva klavirja in tolkala iz leta 1958, pa obsega približno 26 minut glasbe. Prim. Pavle Merkù, Catalogo delle opere $=$ Katalog skladb $=$ Systematisches Werkverzeichnis (Adliswil: Pizzicato Verlag Helvetia, 2007), 9, 18; Pavle Merkù, pismo Primožu Ramovšu, 7. avg. 1975, v Primož Ramovš, »Kronika: Korespondenca: Ramovš-Merkù« (NUK, Glasbena zbirka, Ljubljana).

2 Pavle Merkù, Poslušam (Trst: Založništvo tržaškega tiska, 1983), 24.

3 Merkujevo neoklasicistično fazo, ki obsega privatni študij kompozicije pod mentorstvom tržaških skladateljev Ivana Grbca in Vita Levija, zaznamujejo vplivi Paula Hindemitha, Dmitrija Šostakoviča, Igorja Stravinskega in Goffreda Petrassija. V petdesetih letih prejšnjega stoletja se je zaradi preučevanja Kogojevega življenja in dela, ki ga je razširil tudi na glasbeno obdobje, v katerem je Marij Kogoj živel, začel podrobneje zanimati za drugo dunajsko šolo, dodekafonijo, Paula Hindemitha, Kurta Weilla, Leoša Janáčka, Ferruccia Busonija in druge skladatelje. Prav zaradi vpliva glasbenega ekspresionizma, ki ga je najbolj cenil v delih Antona Weberna in 
ga Ljudsko izročilo Slovencev $v$ Italiji $=$ Le tradizioni popolari degli sloveni in Italia, ${ }^{4}$ sad desetletnega raziskovanja in Merkujev najpomembnejši doprinos na področju etnomuzikologije, $\mathrm{v}$ dvanajstem zvezku Muzikološkega zbornika pa je izšel članek, ${ }^{5} \mathrm{v}$ katerem je Pavle Merkù na podlagi uradnih listin orisal tragično otroštvo skladatelja Marija Kogoja v Trstu. Tako ljudska pesem kot poglobljeno raziskovanje obdobja, v katerem je Marij oz. Julij Kogoj živel in ustvarjal, sta korenito vplivala na Merkujev glasbeni razvoj. Oba vpliva lahko zasledimo tudi v Kačjem pastirju. Poskusi komponiranja glasbeno-scenskega dela in glasbeno dozorevanje so namreč potekali vzporedno: že decembra 1953 se je Primož Ramovš pohvalno izrazil glede Merkujeve želje, da bi se lotil opere. ${ }^{6}$ Vendar je do julija 1976, ko je Merkù potegnil zadnjo taktnico na partituri Kačjega pastirja, vodila dolga pot, polna dvomov in zavrženih načrtov, a tudi novih ugotovitev, ki so pripomogle k premišljenemu oblikovanju osebnega glasbenega sloga. ${ }^{7}$ Opera ima tako ekspresionistični okvir, v katerega je skladatelj vpletel glasbene izkušnje iz svojega zgodnjega neoklasicističnega obdobja in kasnejših raziskav na področju ljudske glasbe. V njej ne prepoznamo samo glasbenih vplivov: dejstvo, da se opera lahko izvaja tako v slovenščini kot v italijanščini, nam

še posebej Albana Berga, se je Pavle Merkù proglašal za »zapoznelega ekspresionista« (Merkù, Poslušam, 29) ali "neoekspresionista« (Merkù, Catalogo, 6). Kasneje je svoj slog oplajal z značilnostmi ljudske glasbe, ki jo je pobliže spoznal med snemanjem, zapisovanjem in preučevanjem slovenskega ljudskega izročila v Italiji med letoma 1965 in 1974. Prim. Pavle Merkù, »Autobiografia« ([Trst: P. Merkù, 2012]), 36; Merkù, Catalogo, 5-7; Pavle Merkù, »Dodekafonija (Vprašanja o govorici in o obliki v sodobni glasni)«, Naša sodobnost 9, št. 10 (1961): 865-876; Pavle Merkù, Ljudsko izročilo Slovencev $v$ Italiji: Zbrano v letih 1965-1974 = Le tradizioni popolari degli sloveni in Italia: Raccolte negli anni 1965-1974, 2. izd., P. 483E (Udine: Pizzicato Edizioni Musicali, 2004), 5-13; Merkù, Poslušam, 27-32, 49-52; Pavle Merkù, pismo Primožu Ramovšu, 26. jul. 1958, v Ramovš, »Kronika«.

Pavle Merkù, Ljudsko izročilo Slovencev v Italiji: Zbrano v letih 1965-1974 = Le tradizioni popolari degli sloveni in Italia: Raccolte negli anni 1965-1974 (Trst: Založništvo tržaškega tiska, 1976).

Pavle Merkù, »Identiteta in otroštvo Marija Kogoja«, Muzikološki zbornik 12 (1976): 50-66.

Prim. Primož Ramovš, pismo Pavletu Merkuju, 21. dec. 1953, v Ramovš, »Kronika«.

Glede Merkujevih opernih poskusov pred Kačjim pastirjem, gl. Miroslav Košuta, "Kačji pastir«, Dan 52 (1976): 11; Merkù, "Autobiografia«, 39; Pavle Merkù, pismo Petru Liparju, 1. nov. 1976, v Pavle Merkù, »Kronika: Korespondenca: Pisma« (NUK, Glasbena zbirka, Ljubljana); Merkujeva in Ramovševa korespondenca med 25. marcem 1955 in 23. aprilom $1957 \mathrm{oz}$. med 26. februarjem 1973 in 24. majem $1974 \mathrm{~V} \mathrm{Ra}$ movš, »Kronika«; [Giorgio Cesare], »la libellula di mercù «, Il Meridiano di Trieste, 18. mar. 1976: 8; Sodobna slovenska operna ustvarjalnost, zbornik referatov simpozija, 26., 27. november 1985 (Maribor: Opera in balet SNG, [1986]), 33. 
daje slutiti vpliv Merkujevega okolja. Že Pierluigi Petrobelli je v svoji analizi Kačjega pastirja uvidel, da to svojevrstno delo zaradi svoje slogovne raznoterosti in dvojezičnosti nudi strnjen prikaz skladateljevega rojstnega mesta. ${ }^{8}$ To je seveda Trst, po definiciji Luigija Dallapiccole »strana inquieta città dove confluiscono tre culture e tre civiltà «.

\section{Kačji pastir - La Libellula}

Najizrazitejša multikulturna poteza opere Kačji pastir je prav njena dvojezičnost. Tiskana izdaja libreta je pri založbi Sonzogno izšla leta $1976 \mathrm{v}$ slovenščini in italijanščini, ${ }^{10}$ partitura in klavirski izvleček pa ravno tako

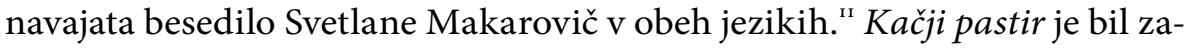
snovan že od samega začetka kot dvojezična opera, saj naj bi k temu botrovale zunanje okoliščine. Delo je namreč naročil Giampaolo de Ferra, odvetnik in rektor tržaške univerze, ki je bil tudi superintendant tržaškega opernega gledališča Giuseppa Verdija. Z Merkujem sta se poznala od leta 1943, ko sta bila sošolca na klasičnem liceju Francesca Petrarke v Trstu, med letoma 1953 in 1965 pa sta skupaj opravljala poklic glasbenega kritika. Podobna gledanja na glasbo so nekaj let pozneje, domnevno leta $1972,{ }^{12}$ prepričala de Ferro, da je bivšemu sošolcu in kolegu zaupal operno noviteto.

Prim. Pierluigi Petrobelli, »La Libellula di Pavle Merkù«, Muzikološki zbornik 19 (1983): 84-85. Pomembna dopolnila Petrobellijevim ugotovitvam nudijo prispevki Bruna Bidussija, Giannija Gorija in Boruta Loparnika, gl. Gianni Gori, »Merkù: due ali di poesia«, Sipario 368 (1977): 45; Borut Loparnik, »Pismo neznancu«, Sodobnost 25, št. 3 (1977): 280-287; La manna, La Libellula (Trieste: Teatro Comunale Giuseppe Verdi, [1976]) $\rightarrow$ Bidussijev prispevek so kasneje prevedli v slovenščino in ga objavili v gledališkem listu v Mariboru ob slovenski praizvedbi Merkujeve opere, gl. Kačji pastir, ur. Tone Partljič (Maribor: Opera in balet SNG, 1985 (Gledališki list 1985/86, št. 2)), 13.

9 Čudno nemirno mesto, v katero se stekajo tri kulture in tri civilizacije. Cit. po Petrobelli, »La Libellula di Pavle Merkù«, 84. Prim. Luigi Dallapiccola, Parole e musica, ur. Fiamma Nicolodi, 2. izd., Saggi di arte e di letteratura 53 (Milano: il Saggiatore, 1980), 302.

10 Svetlana Makarovič in Pavle Merkù, La Libellula = Kačji pastir, libreto (Milano: Casa musicale Sonzogno di Piero Ostali, 1976).

11 Pavle Merkù, »Kačji pastir: Opera v dveh dejanjih na libreto Svetlane Makarovič«, part. [Trst: P. Merkù, 1976]; Pavle Merkù, Kačji pastir: Opera v dveh dejanjih = La Libellula: Opera in due atti, kl. izv. (Milano: Casa musicale Sonzogno di Piero Ostali, 1976).

12 Tega leta je nastala skladba Epistola a Giampaolo de Ferra za violončelo in pet izvajalcev, domnevno Merkujev glasbeni odgovor ob naročilu. Prim. Merkù, Catalogo, 17; Pavle Merkù, Pajčevina in kruh (Trst: Založništvo tržaškega tiska, 1987), 150. 
Merkù se je povabilu odzval šele leta $1974,{ }^{13}$ ko je v Tržaški knjigarni odkril pesniški list Svetlane Makarovič z naslovom Vojskin čas. Verzi so Merkuja tako navdihnili, da je na osnovi petih izbranih pesmi (Božja volja, V tem mrazu, Odštevanka, Sončnice in Preštevanje) komponiral istoimenski ciklus samospevov za alt, violino, violončelo, mali klarinet v es, fagot in boben. ${ }^{14}$ Poezija Svetlane Makarovič, s katero je skladatelj delil »mnogo tematičnih interesov ter eksistencialnih tegob «, ${ }^{15}$ je v njem vzbujala močne dramske predstave, ${ }^{16}$ zato je pesnici naročil libreto, ki ga je prejel že januarja 1975. Opero je začel komponirati marca 1975 in jo po šestnajstih mesecih zaključil julija $1976 .^{17}$

Pred začetkom skladanja pa je Pavle Merkù moral presekati gordijski vozel. Zavedal se je, da italijanskemu gledališču ne more ponuditi prevoda, ravno tako ne more od slovenske pesnice zahtevati italijanskega libreta. Odločil se je za kompromis: Makarovičeva je libreto napisala v slovenščini, nato ga je skladatelj z njeno pomočjo prevedel v italijanščino. Šele po tem se je lotil skladanja. Ob podpisu pogodbe z založbo Sonzogno je zato zahteval klavzulo, po kateri naj se obe verziji libreta, kot tudi obe verziji partitu-

13 Letnica se opira na leto izida pesniškega lista Vojskin čas v Trstu. Gl. Svetlana Makarovič, Vojskin čas, Pesniški list 18 (Trst: Založništvo tržaškega tiska; Koper: Lipa, 1974).

14 Poezija Svetlane Makarovič je na Merkuja naredila izjemen vtis: v eseju Biti narod je zapisal, da je njen jezik zaradi vraščenosti v ljudsko kulturo "posoda slovenskega kulturnega sporočila« (Merkù, Pajčevina in kruh, 14). V skladu s svojim zanimanjem za ljudsko izročilo, ki je po letu 1965 krojilo njegov glasbeni jezik, je slovenski pesnici posvetil kar pet del. To so Vojskin čas za alt, violino, violončelo, mali klarinet v es, fagot in boben (1974), Pelin, tri pesmi za alt solo (1975), opera v dveh dejanjih Kačji pastir oz. La Libellula (1976), skladba za ženski zbor Mračnina (1977) in Dvanajsta ura, tri pesmi za sopran solo (1986). V vseh omenjenih delih je glasbena govorica izredno asketska, z reducirano spremljavo ali celo brez nje, saj je skladatelj hotel postaviti v ospredje izraznost verzov. Druga skupna značilnost je izbira tipa glasu: Merkù se je v vseh primerih odločil za ženski glas, naj bo to ženski zbor ali samospev za alt oz. sopran (v operi je sicer prisotnih več solistov, vendar prevzema glavno vlogo Mesečnica). Prim. Merkù, Catalogo, 9, 19, 21, 25; Merkù, Pajčevina in kruh, 151-153, 157. Makarovič in Merkù, La Libellula = Kačji pastir, 32.

16 Prim. Andrej Rijavec, Slovenska glasbena dela (Ljubljana: Državna založba Slovenije, 1979), 185-186.

17 Libreto je prispel po pošti 6. januarja 1975 (gl. Pavle Merkù, pismo Primožu Ramovšu, 7. jan. 1975, v Ramovš, „Kronika«). Na podlagi datumov v klavirskem izvlečku in v partituri lahko sklepamo, da je Merkù začel s komponiranjem opere marca 1975. Klavirski izvleček je dovršil 30. aprila 1976, partitura pa je bila na čisto prepisana do 18. julija 1976. Prim. Košuta, »Kačji pastir«, 11-12; Merkù, Kačji pastir, 54, 96; Merkù, »Kačji pastir«, 81, 151. Potek dela podrobneje opisuje Merkujeva korespondenca med 30. aprilom 1975 in 22. julijem 1976 v Ramovš, »Kronika«. 
re, upoštevata za izvirni. Tako je prišlo do edinstvenega primera, saj je celo Merkù priznal, da gre za njemu edino znano opero, ki je bila pisana $z$ originalnim tekstom v dveh jezikih. ${ }^{18}$

Domnevno pa so za odločitev o dvojezičnosti opere obstajali osebnejši razlogi, ki jih je Merkù delno potrdil z izjavo, da mu je prisotnost dveh jezikov ljuba, ker je bila italijanščina njegov materni jezik. ${ }^{19}$ Skladatelj se je dobro zavedal svojega življenja na robu: tako kot številni Tržačani je bil tudi sam mešane krvi, saj je bila mati Katarina Bortolotti Italijanka slovenskih, furlanskih, čeških oz. nemških korenin, oče Josip Merkù pa Slovenec. Na njegovo kulturno razklanost so poleg tega vplivale napete zgodovinske okoliščine, v katerih se je rodil in odraščal. Leta 1927 je namreč v Trstu gospodaril fašizem s svojo nasilno politiko poitalijančevanja: skladatelj se je zato rodil kot Paolo Mercù, njegova družina pa je iz strahu pred fašističnim zatiranjem potajila svoje slovenske korenine. ${ }^{20}$ Družinski občevalni jezik je bila torej italijanščina oz. tržaško narečje, edina izjema je bila babica, potomka ponemčenih Čehov, s katero se je skladatelj pogovarjal v nemščini. Etnično mešana družina, prisilna vzgoja v italijanskem jeziku, nato skrivno učenje prepovedanega jezika, to je slovenščine, in materina smrt leta 1943 tik po kapitulaciji Italije so bili že zadostni dejavniki, da je bil Pavle Merkù ob koncu vojne globoko razpet med svojo slovensko in italijansko narodno identiteto. Nazadnje se je opredelil za Slovenca in svojo odločitev podkrepil z maturo na slovenskem klasičnem liceju v Gorici ter z diplomo iz slavistike na Univerzi v Ljubljani. Ta korak, ki ga je od takrat vodil v aktivnejše vključevanje v slovensko kulturno in vsakdanje življenje, je utemeljil na naslednji način:

"Biti rob pomeni biti izpostavljen pisanim igram in pritiskom; občutiti vsaj občasno kak dvom o tem, kam spadaš in kako je najbolj prav, da si glede narodnosti; biti prisiljen, da se opredeliš za eno ali drugo narodno skupnost. [...] Kdor se je taki odločitvi

18 Prim. Košuta, »Kačji pastir«, 11-12; Merkù, »Autobiografia«, 17-20, 39-41; Merkù, Pajčevina in kruh, 131-133; Marjana Mrak, »Kačji pastir: Premiera v mariborski Operi«, Naši razgledi 35, št. 2 (1986): 44; N. C., »Appartengo alla minoranza di triestini che non rinuncia a nessuna parte di sé«, Il Piccolo, 17. apr. 2001: 17; Ivan Silič, »Premalo opažena slovenska opera«, Primorska srečanja 71-72 (1987): 230.

19 Prim. Košuta, »Kačji pastir«, 12.

20 Takratne politične in zgodovinske okoliščine so se globoko vtisnile v Merkujevo zavest, saj svoj Biografski intermezzo začenja s stavkom: »Rodil sem se sedem let po požigu Narodnega doma, v petem letu fašistične ere ( $\mathrm{k}$ datumu je bilo obvezno dodati: $V E$. F.), eno leto potem, ko so zaprli zadnje slovenske šole v Julijski krajini.« Merkù, Poslušam, 63. 
izognil, je tvegal shizoidne posledice, kakršnih je poln Trst s svojo književnostjo vred. ${ }^{21}$

Kljub pristopu na slovensko stran pa Merkù ni nikoli pozabil, da je tudi sam proizvod tiste »mešanice ras« (v ital. »croginolo di razze«), ${ }^{22} \mathrm{o} \mathrm{ka-}$ teri je pisal tržaški pesnik Umberto Saba, ko je opisoval svoje rojstno mesto. Skladatelj se je zato $\mathrm{v}$ kasnejših letih raje prišteval v tisto tržaško manjšino, ki se ne želi odpovedati nobeni komponenti svojega multietničnega ozadja. Kot se je sam izrazil, »biti mešanec je končno bogastvo, ki ni dano vsakomur ${ }^{23}$ Po letu 1954, ko je Trst $\mathrm{z}$ londonskim sporazumom postal del Italije, se je posledično odločil, da svoj »utraquismo etnico «" ${ }^{24}$ uveljavi predvsem na kulturnem področju in si je zato nadel vlogo kulturnega posrednika med slovenskim in italijanskim narodom, katerima je po lastnih besedah hkrati pripadal. ${ }^{25}$

»Manjšinska vprašanja«, kot jih je označila Marjana Mrak, pa so domnevno le nekateri izmed razlogov, ki so privedli do nastanka dvojezične opere. Nanjo so verjetno v večji meri vplivale že omenjene zunanje okoliščine, ki jih je Merkù sprejel kot ustvarjalni izziv, kajti »obe besedili dajeta skladatelju kot ustvarjalcu $\mathrm{z}$ velikim posluhom za govorico, jezikovno narečje, besedo, vokal - široke možnosti za ritmične in melodične posebnosti in različice ${ }^{26}{ }^{6}$ Opera je torej dokaz hkratnega pristopa do dveh izrazito različnih jezikov: italijanščine, Merkujeve materinščine, ki je zanj predstavljala enega izmed najlepših in uravnovešenih jezikov, in slovenščine, ki je bila po njegovem mnenju suha, trda, zvočno bogata in primerna za refleksivno poezijo. ${ }^{27}$

21 Merkù, Pajčevina in kruh, 105.

22 Umberto Saba, Tutte le prose, ur. Arrigo Stara, I meridiani (Milano: Arnoldo Mondadori Editore, 2001), 982.

23 Merkù, Pajčevina in kruh, 106.

24 Izraz »etnični utrakvizem«si je Merkù izposodil iz religije, kjer utrakvizem pomeni obhajanje pod obema podobama. Za označitev svojega multietničnega ozadja ga je uporabil v intervjuju za časopis Messaggero Veneto iz leta 1994. Prim. Stefania Amisano, "Per i sensi profondi: Scelte poetiche e poetiche musicali in Pavle Merkù «, v Lungo il Novecento: La musica a Trieste e le interconnessioni tra le arti, Festschrift in onore del centenario della fondazione del Conservatorio Giuseppe Tartini di Trieste 1903-2003, ur. Maria Girardi (Venezia: Marsilio Editori, 2003), 334; Luciano Morandini, »Quel far musica nella Mitteleuropa«, Messaggero Veneto, 11. febr. 1994: 11. Prim. Merkù, »Autobiografia«, 1-11, 46-49; Merkù, Pajčevina in kruh, 97-136; Merkù, Poslušam, 61-74; N. C., »Appartengo alla minoranza«, 17.

26 Mrak, »Kačji pastir«, 44.

27 Prim. Merkù, »Autobiografia«, 34. Opera Kačji pastir sicer ni edini primer Merkujevega skladanja v dveh jezikih. Kljub njegovi izjavi, da ima vsak jezik oz. narečje 
Pavle Merkù je v italijanskem prevodu skušal obdržati smisel slovenskega besedila, zato nimamo pomenskih razhajanj, kvečjemu glasbene prilagoditve. Skladatelj se namreč poslužuje skoraj deklamativnega petja, ki zvesto sledi prozodiji slovenskega in italijanskega besedila. Kot je razvidno iz spodnjih notnih primerov, se pevska linija prilagaja različnima jezikoma, vendar se glasbena podoba bistveno ne spreminja. Samo v eni točki se slovenska in italijanska partitura očitno razhajata: $\mathrm{v}$ drugem dejanju se med nastopom Spomina-Sonca (t. 19-123) pojavi verz »čas je« oz. »il tempo c‘è«. Merkù je zaradi različnega števila zlogov v italijanščini in slovenščini moral spremeniti taktovski način glede na jezik, kar nazorno dokazuje notni primer $1 \mathrm{z}$ izpisanimi skladateljevimi opombami.

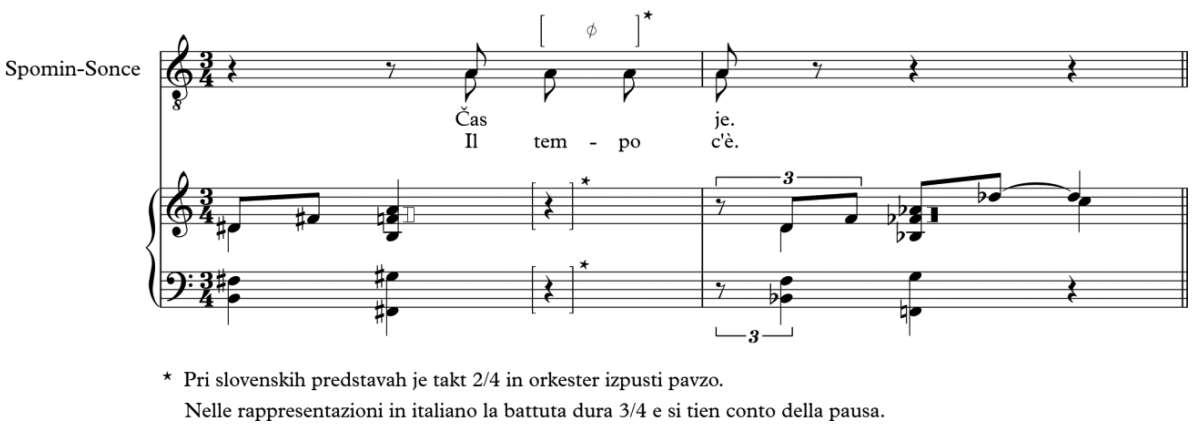

Notni primer I: Pavle Merkù, Kačji pastir (klavirski izvleček: drugo dejanje, t. 8I-82).

Per gentile concessione della Casa Musicale Sonzogno, Milano. Objavo je dovolila milanska glasbena založba Sonzogno.

\section{Merkujev glasbeni utrakvizem}

Omenili smo, da je že Pierluigi Petrobelli v svoji analizi Kačjega pastirja ugibal o multietničnem izvoru opere. Ekspresionistična govorica, ki jo preveva, naj bi bila izraz srednjeevropske dediščine: Pierluigi Petrobelli in Bru-

svojo glasbo in da prav zaradi tega ni nikoli želel prevajati besedil svojega obsežnega vokalnega opusa, poznamo poleg opere še eno dvojezično izjemo. Opera namreč korenini, tako glasbeno kot jezikovno, v starejšem delu Vojskin čas (1974). V pismih Primožu Ramovšu je Merkù priznal glasbeno sorodnost med ciklusom samospevov in opero, saj obe deli karakterizira suha, bistvena pisava $\mathrm{z}$ namigi na ljudski melos (prim. Pavle Merkù, pismi Primožu Ramovšu, 25. febr. in 9. jul. 1976, v Ramovš, »Kronika«), v prizor Tete Miši (prvo dejanje, sedma scena, t. 573-636) pa je vključil citat iz samospeva Preštevanje. Kot priča oznaka v partituri Vojskinega časa, je skladatelj sam poskrbel za prevod pesmi v italijanščino. 
no Bidussi prepoznavata v libretu Svetlane Makarovič Kafkove ter Brechtove vplive, v glasbenem smislu pa jima Gianni Gori pritrdi z izjavo, da je Pavle Merkù potomec dunajsko-dallapiccolovskih smernic. ${ }^{28}$

Pavle Merkù izraža svojo neoekspresionistično držo predvsem v izredno asketski instrumentaciji. Sam je svojo operno partituro v raznih pismih označil za »frančiškansko«, ${ }^{29}$ saj je raba celotnega orkestra izredno redka. Izjemo predstavlja Mrtvečeva ljubezenska izpoved (gl. drugo dejanje od t. 271 dalje), ki v Mesečnici obudi spomin na njeno staro življenje in tako sproži preobrat opernega dogajanja. Drugače ima Merkujeva opera značaj komornega, če ne celo solističnega dela. Skromna instrumentalna spremljava včasih popolnoma utihne in tako še bolj izpostavi pevca: oznaka orchestra tacet na ta način opero približuje Merkujevim zbirkam samospevov Pelin za alt solo (1975) in Dvanajsta ura za sopran solo (1986). Sorodnost ni naključna: obe deli sta nastali na podlagi verzov Svetlane Makarovič, »okleščeno izražanje « ${ }^{30}$ svojih samospevov (in širše tudi opere) pa je Merkù opravičil z izjavo, da so pesmi nabite z izraznostjo in zato trpijo malo not zraven. $^{31}$

Tako iskanje preprostega in bistvenega izraza je po Ivanu Klemenčiču značilno za glasbeni ekspresionizem. Redukcijo na bistveno namreč razlaga kot "prizadevanje umetnika, da odkriva pod videzom, površjem stvari in pojavov vse kar je bistveno, globlje, notranje in izloča vse materialno, nebistveno in moteče, eno in drugo v želji, da se kar najbolj približa svoji predstavi resnice in jo kar najbolj verno upodobi«. ${ }^{32}$ Tržaški skladatelj Fabio Nieder pa je ponudil še dodatno razlago. Na Merkujevo iskanje največje izrazne koncentracije $\mathrm{z}$ minimalnimi sredstvi naj bi vplivali predvsem ljudska in baročna glasba. Le-ti naj bi izpilili Merkujevo esencialno glasbeno govorico in težnjo po skladanju za skromne zasedbe, ki se v skrajnih primerih omejujejo le na solistični glas ali glasbilo:

28 Prim. Gori, „Merkù: due ali di poesia«, 45; Petrobelli, »La Libellula di Pavle Merkù«, 84; Kačji pastir, 13.

29 Prim. Pavle Merkù, pismo Petru Liparju, 1. nov. 1976, v Merkù, „Kronika«; Pavle Merkù, pismi Primožu Ramovšu, 9. in 19. jul. 1976, v Ramovš, »Kronika«.

30 Rijavec, Slovenska glasbena dela, 186.

31 Prim. Pavle Merkù, pismo Primožu Ramovšu, 28. jan. 1975, v Ramovš, »Kronika«. Skladanje za sam glas sicer ni redkost v Merkujevem opusu. Že v samospevu Življenje ječa, čas v nji rabelj hudi iz ciklusa Prijazna smrt (1965) je Prešernovo besedilo uglasbil samo za bas, brez klavirja, da bi strnil vso izraznost v solistični glas. Prim. Pavle Merkù, pismo Primožu Ramovšu, 23. jun. 1963, v Ramovš, »Kronika«. Ivan Klemenčič, »Ekspresionizem kot glasbeni slog«, Muzikološki zbornik 17, št. 2 (1981): 36 . 
»Mislim, da se pravzorci tega načina glasbenega ustvarjanja kažejo tako $v$ monodični preprostosti ljudskega petja (in vsi vemo, koliko je Merkù kot etnomuzikolog prispeval k spoznavanju kmečke ljudske pesmi zamejskih Slovencev) kot $v$ partitah za violino oz. violončelo J. S. Bacha. Nikjer drugje ni bil veliki nemški mojster zaradi omejenosti omenjenih instrumentov primoran posluževati se umetnosti aluzije. $V$ primerih popolne homofonije namiguje melodična linija na stranske kontrapunkte in na zaporedja akordov. $S$ tem postopkom je dal avtor prednost vodoravni dimenziji. $V$ linearni pisavi se torej izraža najbolj značilno podajanje Merkujeve glasbene misli..33

Merkujeva težnja po bistvenem naj bi bila torej posledica skladateljevega zanimanja za baročno glasbo, glasbeni ekspresionizem in ljudsko pesem, torej za sloge in obdobja, ki so pomembno zaznamovali njegovo glasbeno življenje. Baročno glasbo je vzljubil že v mladosti, ko je študiral violino, in jo pozneje vedno bolj cenil kot pa »dolgoveznost « Ludwiga van Beethovna in glasbene romantike. ${ }^{34}$ Glasbeni ekspresionizem in ljudska glasba sta bila $\mathrm{v}$ središču njegove pozornosti v odrasli dobi: $\mathrm{v}$ času študija kompozicije se je vneto ukvarjal z Marijem Kogojem in njegovimi sodobniki, kasneje pa je med službovanjem na Radiu Trst A prišel v stik s slovenskim ljudskim izročilom $v$ Italiji zaradi snemanja in zapisovanja na terenu. Trem osnovnim glasbenim vplivom bi lahko dodali še četrtega, in sicer komorno glasbo. Merkujevi prvi spomini segajo v rano otroštvo, ko so starši vsak teden organizirali komorne večere $\mathrm{z}$ domačim klavirskim triom. Glasbena srečanja

33 Fabio Nieder, »Prvo srečanje s Pavletom Merkujem«, prev. Simona Slokar, Primorski dnevnik, 27. sept. 1987: 12. Borut Loparnik je pri opisu Merkujevega sloga združil ljudske in baročne vzore $\mathrm{z}$ nadčasovno ekspresionistično dediščino: »Dasi eden redkih, ki jim je vokal že dolgo poglaviten instrument, je znal Merkù ohraniti dikcijo in duha domačih napevov tudi v jeziku glasbil [...]. In to ni bilo naključje, „skrivnost“ tiči v njegovi fakturi, $v$ prozorno komornem, lapidarnem in domišljeno vodenem glasbenem toku, ki ceni strogost, skopari z okraski in se ne zgublja čez rob vsebine. Takšna je drža ljudskega pevca in Merkù je ni šele privzel, klesal jo je že od novobaročnih začetkov. [...] Pove, kar sodi k jedru, domala v miniaturah in z močno napetim izraznim lokom, brez uvodov, finalov in kompozicijskih umetnij, ki bojda pričajo o tehtnosti. Pogosto z enim samim glasbilom, dvema ali tremi, še v zboru raje dosledno kakor bežno, bolj trpko kakor zlagoma, da le izostri, kar se je bil namenil - sporočilo. Tega doživlja, misli in izraža de profundis, z ekspresijo, ki je mamila vse rodove njegovih duhovnih prednikov od Monteverdija do Berga in Kogoja, pa z refleksijo, ki mu jo je dosodila alkimija narave.« Borut Loparnik, »Ob sedemdesetletnici Pavleta Merkuja«, Glasnik Slovenske matice 21 (1997): 61.

34 Prim. Pavle Merkù, pismi Primožu Ramovšu, 12. in 24. sept. 1955, v Ramovš, »Kronika«. 
so bila odlična šola za spoznavanje glasbenega repertoarja do praga dvajsetega stoletja, predvsem pa so pustila globoko sled v Merkujevi ustvarjalnosti..$^{35}$ Že samo površen pregled instrumentalnega opusa razkrije nagnjenost do manjših zasedb: v njem odkrijemo zajeten korpus del za solistična glasbila in komorne skupine, manj pozornosti pa je skladatelj namenil velikim simfoničnim delom, saj je raje skladal za komorni ali godalni orkester. ${ }^{36} \mathrm{~V}$ primeru opere je zato pristopil $\mathrm{k}$ simfonični partituri kot komorni skladatelj, ki izpostavlja posamezna glasbila ali instrumentalne skupine in ne išče podvojitev ali mešanja barv.

Velja pa poudariti, da kljub nedvomnemu ekspresionističnemu okviru opera Kačji pastir ne nudi izrazite modernistične govorice Merkujevih starejših del. Aleatorični odseki in tonski grozdi stopnjujejo grozečo atmosfero v operi, a so le barvne kulise. Dodekafoni prijemi so samo nakazani, kot na primer $\mathrm{v}$ prvem dejanju ali $\mathrm{v}$ medigri, ravno tako omejene so razširjene izvajalske tehnike (npr. oznake za izvajanje najvišjega ali najnižjega poljubnega tona, nenotirani glissandi v godalih, Flatterzunge oz. tresoči se jeziček $\mathrm{v}$ rogovih in flavti). Neredko se pojavljajo akordi terčne gradnje in kadence: v primeru podobe vrbe (gl. notni primer 2) bo razloženi sekstakord v glasu in oboi prevzel vlogo osnovnega motiva opere. Namigi na tonalnost in modalnost so še posebno prepoznavni v prizorih s simboli. Pavle Merkù je v intervjuju za revijo Dan leta 1976 sicer priznal, da bi se v svoji operi lahko posluževal hujših prijemov, vendar se je odločil za omiljen izraz v imenu enotnosti:

"Zato bi lahko rabil veliko hujše prijeme, kakor jih rabim $v$ koncertnih skladbah, pa mi to ni potrebno, ker mora imeti odrska pravljica le neko svojo enotnost in razpon med ekspresionističnimi izbruhi ranjenih človeških bitij, če rabim ta ekspresionistični izraz, in abstraktnostjo izjav simbolov ne sme biti tako huda, da bi čutili poslušalci razpor, prelom. To sta dva pola enega in istega dogajanja, dva aspekta enega in istega življenja. Enotnost mora kljub temu biti. Mogoče je to najtežja naloga, ki sem si jo zadal: ustvariti enotnost s tako različnimi sredstvi. ${ }^{37}$

Prim. Merkù, »Autobiografia«, 36; Merkù, Poslušam, 22-23; Merkujevi glasbeni pismi z dne 24. sept. 1955 in 26. jul. 1958 v Ramovš, »Kronika«; Lida Turk, Glas v ... etru (Trst: Deželni sedež RAI za Furlanijo-Julijsko krajino, 1991), 144-149. 
Bruno Bidussi je v svoji predstavitvi Kačjega pastirja obrazložil, da ima Merkujeva slogovna raznoterost dramaturški pomen, saj »drzen poskus, uporabljati izmenoma tri različne govorice, je opravičen z namenom, da bi gledalec vsakokrat dojel prehod od subjektivnega sveta čustev stvarnih oseb do sveta njihovih projekcij v prozaično in monotono neizogibnost življenja pa še do pravljičnega, simboličnega, grotesknega sveta «. ${ }^{38}$ Razlikovanje je razvidno predvsem $v$ načinu petja, saj ravno glasba definira psihologijo opernih karakterjev. Protagonista opere, to sta Mrtvec in Mesečnica, zaradi svoje človeške narave komunicirata $\mathrm{v}$ atonalnem, ekspresionistično nabitem slogu, da bi direktno posredovala svoje notranje tesnobe in čustva. Ona se od njega razlikuje, ker verjame v poezijo, simbol poezije pa je Kačji pastir, ki ga interpretira plesalka. Tudi preostali nastopajoči niso stvarne osebe, ampak le simboli s točno določenim pomenom: Hrošč Oklepnik je oblast, Teta Miš je življenje, ki nas vsak dan po malem grize, Spomin-Sonce je spomin na lepe trenutke v življenju. Simboli zaradi svoje nečloveške narave ne trpijo, zato jih karakterizira realistična, objektivna, nevtralna in čustveno neprizadeta diatonična govorica ljudskega melosa, »zakaj melodija ljudske pesmi je lahko ista pri žalostnem in pri veselem besedilu, šele besedilo daje viži nek pomen ${ }^{39}{ }^{39}$ Merkù je poudaril, da je pri skladanju upošteval značilnosti ljudskega petja, vendar se je izognil direktnemu citiranju. Ljudska obarvanost simbolov se tako izraža z namigi na tonalnost in modalnost, ki jih skladatelj pod vplivom svoje neoekspresionistične govorice deformira in zamegli s pomočjo disharmoničnih alteracij, kromatičnih prehodov, kvartnih akordov, pogostih izmikov v druge tonalitete, bitonalnosti in diatoničnih tonskih grozdov, ki bi jih lahko interpretirali kot ostanke tonalitet in modusov, zamrznjene $\mathrm{v}$ politonalno in polimodalno mrežo harmonskih spominov (gl. arioso Hrošča Oklepnika, prvo dejanje, drugi prizor, t. 125-140). Včasih je tonalna zamegljenost tako gosta, da izgubimo vsak občutek jasne tonalne polarizacije: politonalne in polimodalne harmonije, bitonalni akordi in vzporedno gibanje kvintakordov namreč onemogočajo vzpostavitev jasnega tonalnega centra. Tak slog precej spominja na Merkujeve predelave slovenskih ljudskih pesmi v šestdesetih letih prejšnjega stoletja..$^{40}$

\section{Kačji pastir, 13.}

39 Košuta, »Kačji pastir«, 12.

40 Sorodnost med opero in Merkujevimi predelavami slovenskih ljudskih pesmi lahko ugotovimo na podlagi vzporednega gibanja kvintakordov v basu. Prim. operna prizora s Teto Mišjo (prvo dejanje, šesti prizor, t. 467-471) in Spominom-Soncem (drugo dejanje, t. 37-40) z Merkujevo predelavo pesmi Eno drevcè (t. 5-8) iz zbirke Tri 
Prisotna pa je še tretja govorica: glasba ne razlikuje samo med človeškimi in nečloveškimi bitji, ampak tudi med sanjskim svetom in realnim življenjem. Pravljico Svetlane Makarovič, na kateri opera temelji, bi lahko interpretirali kot nočno moro, $\mathrm{v}$ kateri privrejo na plan notranje stiske Mesečnice. Ime protagonistke in številni namigi v besedilu nam jasno povedo, da je glavna junakinja $v$ spečem stanju. Zato $v$ njenem sanjskem, iracionalnem svetu ljudje in simboli pojejo, med prebliski iz realnega življenja pa se pevci poslužujejo deklamiranega ali govornega petja. Tak primer sta mimični vlogi Moža in Žene, ki zdolgočasenost in suhoparnost svojega odnosa izdajata $\mathrm{z}$ diatonično obarvano ritmično-melodično deklamacijo. Njuno »surovo, realistično, močno deklamirano petje«, kot ga je predpisal skladatelj v partituri, temelji na ponavljanju istega tona $\mathrm{z}$ manjšimi melodičnimi odstopi. $^{41}$

Slogovna raznolikost pa ni preprečila Merkujevega stremljenja po enotnosti. Bruno Bidussi je namreč ugotovil, da homogenost Kačjega pastirja omogočajo t. i. vodilne glasbene misli, ki med seboj trdno povezujejo prizore in dejanja. ${ }^{42}$ Osnovni glasbeni parametri, kot so ritem, melodija, harmonija in instrumentalna barva, posamezno ali v kombinaciji skušajo orisati značaje protagonistov in njihova čustva, ustvarjajo pa tudi prepoznavne glasbene objekte, s katerimi poudarjajo bistvene pojme libreta. Merkujeva korespondenca nam razkriva, da se je skladatelj že v svoji starejši in nedokončani operi na literarni predlogi Pregljevih Tolmincev posluževal samostojnih glasbenih misli. Podobno se je odločil tudi v primeru Kačjega pastirja, saj v pismu iz leta 1975 omenja osnovne motive in njihove anticipacije v prvem prizoru. ${ }^{43} \mathrm{Na}$ ta način se skladatelj približuje Richardu Wagnerju in njegovim vodilnim motivom, čeprav Wagnerjeva glasba ni povsem ustrezala njegovemu glasbenemu okusu. Merkù je vsekakor redno poslušal Wagnerjeve glasbene drame v tržaškem opernem gledališču, kar tudi omenja v pismih Primožu Ramovšu, v svojo klavirsko Balado (1949) in v tretji godalni kvartet "Romantico" (1987) pa je celo vključil namige

ljudske pesmi iz Benečije za sopran in klavir (1966). Tonalno zabrisanost lahko zasledimo tudi v Merkujevi kasnejši skladbi za violo solo z naslovom Alba (1986). Slogovno vez solističnega dela $z$ opero, in še posebno s Spominom-Soncem, je skladatelj potrdil v pismu Primožu Ramovšu. Prim. Pavle Merkù, pismo Primožu Ramovšu, 22. jan. 1986, v Ramovš, »Kronika«. mo Petru Liparju, 1. nov. 1976, v Merkù, »Kronika«.

42 Prim. Kačji pastir, 13.

43 Prim. Pavle Merkù, pismi Primožu Ramovšu, 25. mar. 1955 in 30. apr. 1975, v Ramovš, »Kronika«. 
na Tristanov akord. ${ }^{44}$ Poznavanje nemškega mojstra sta verjetno poglobila njegova profesorja kompozicije, to sta Ivan Grbec in Vito Levi, oba bivša študenta Antonia Smareglie, ki je veljal za enega izmed »največjih italijanskih „wagnerjancev“ konec devetnajstega in v začetku dvajsetega stoletja «. ${ }^{45}$ Wagnerjanski vplivi na tematološko zasnovo Kačjega pastirja so torej možni, vendar jih ne moremo točneje določiti, saj se je Wagnerjev gosti simfonizem izgubil v prid Webernove esencialnosti. Merkujevi motivi so namreč zaradi redke instrumentacije skoraj klesani v tišino.

Opera temelji na mreži motivov, vendar predvsem dva motiva krojita glasbeno in vsebinsko podobo Kačjega pastirja. Prvi se pojavi že v prvem prizoru prvega dejanja, kjer sovpada s podobo vrbe (gl. notni primer 2), zato bi ga lahko poimenovali motiv vrbe ali vrbni motiv.

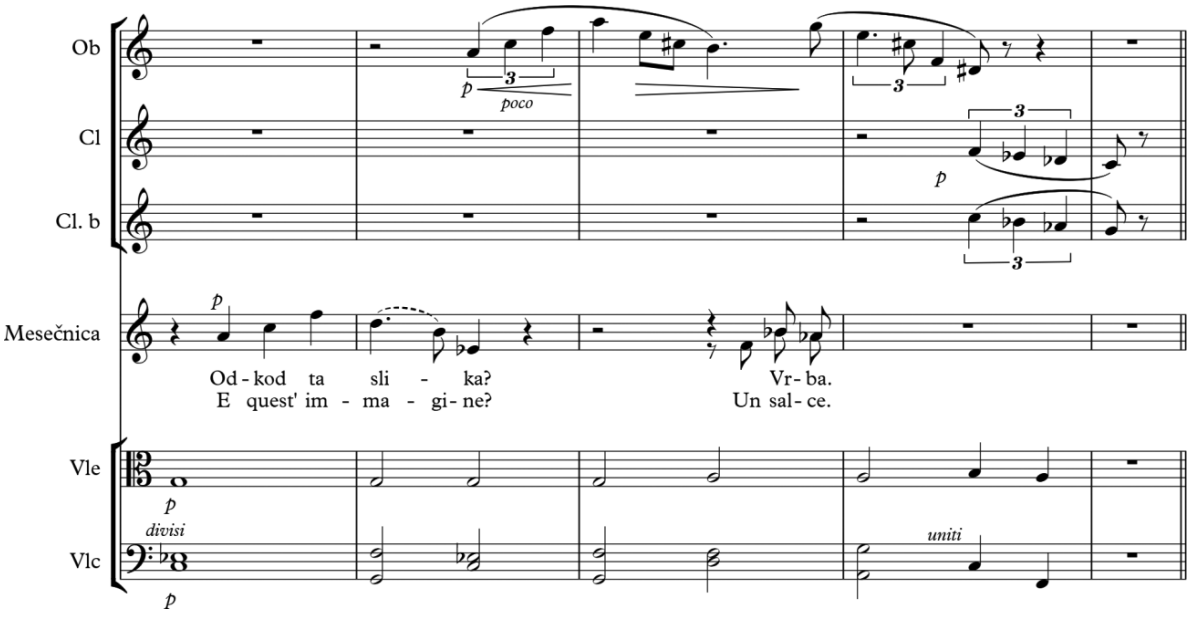

Notni primer 2: Pavle Merkù, Kačji pastir (prvo dejanje, prvi prizor, t. 27-31).

Per gentile concessione della Casa Musicale Sonzogno, Milano. Objavo je dovolila milanska glasbena založba Sonzogno.

Na tej točki se Mesečnica, ki brez spomina tava $\mathrm{v}$ praznem in brezčasnem prostoru, prvič sreča s podobo. Nezavedno jo poimenuje, saj je vrba drobec zabrisanega spomina na njeno življenje v vrbovju, kjer se je kot Kač-

44 Prim. Pavle Merkù, pismi Primožu Ramovšu, 16. jan. 1957 in 12. mar. 1987, v Ramovš, »Kronika«.

45 Rijavec, Slovenska glasbena dela, 180. Prim. Diego Redivo, "Cara Patria, già madre e reina": la Nazione in musica«, in Matteo Sansone, »Alla ricerca di un pubblico per il „teatro di poesia“ di Smareglia«, v Lungo il Novecento, 9-10, 19-25. 
ji pastir predajala le pesmi in plesu. Njen glas in nato oboa melodično orišeta figuro vrbe žalujke na podlagi razloženega akorda, ki se bo v operi vsakič pojavljal ob besedah »vrba«, »vrbovje«, »Kačji pastir«, »krila«, "peti«, "plesati« itd. Vrba je namreč simbol sveta umetnosti, narave in svobode, v katerega se Mesečnica skuša zateči pred družbenim pritiskom. Zato jo lahko razumemo tudi kot simbol odrešujoče moči umetnosti.

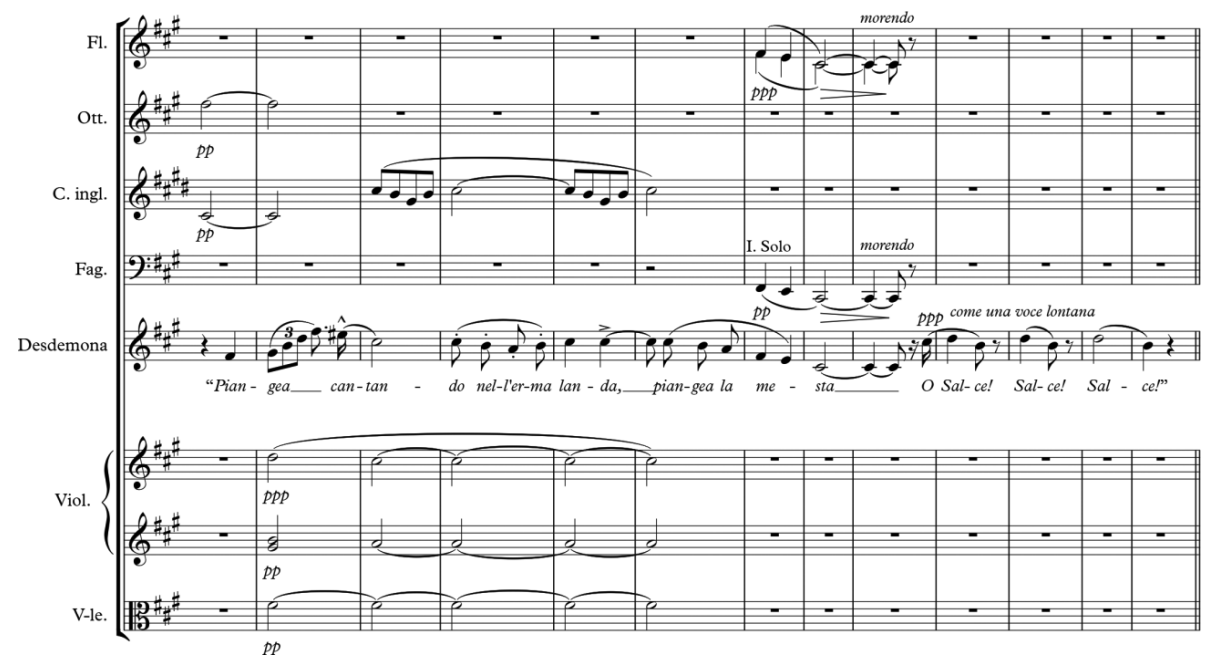

Notni primer 3: Giuseppe Verdi, Otello (četrto dejanje, t. 75-87).

V notnem primeru 2 lahko opazimo zanimivo povezavo $\mathrm{z}$ delom Giuseppa Verdija. Omemba vrbe, podobna instrumentacija in sama oblika vrbnega motiva, to je razložen trizvok, nam prikličejo v spomin Verdijevo arijo iz četrtega dejanja opere Otello (1887). Povezava je naključna in nimamo dokazov, da je to dejansko citat. Izraz salce $v$ italijanskem besedilu vsekakor preseneča, saj je v pogovorni italijanščini pogostejša uporaba besede sali$c e$. Varianta salce je zelo literarna, med drugim jo najdemo v libretu Arriga Boita, ko nesrečna Desdemona zapoje staro pesem o vrbi (v Verdijevi operi znana kot »la canzon del Salice«). Uvodni motiv pesmi najprej izpostavi angleški rog na začetku dejanja, torej spet glasbilo z dvojnim jezičkom, kasneje ga prevzame sopran nad zadržano harmonijo tonike v godalih in padajočo figuro v pihalih, podobno kot v Merkujevem Kačjem pastirju (prim. notna primera 2 in 3$)^{46}$

46 Kot že rečeno, ni mogoče ugotoviti, če je to dejansko citat. Merkù je v svojih mikroesejih o tržaški operni sezoni 1962/1963 sicer priznal, da obožuje Giuseppa Verdija 
Drugi osnovni motiv opere se prvič pojavi v šestem prizoru prvega dejanja (gl. notni primer 4), ko nastopi Teta Mišs, in ima značilno instrumentalno barvo godal. Na njem temeljita medigra $\mathrm{z}$ naslovom Uspavanka nerojenim detetom in odsek iz drugega dejanja (t. 124-267), kjer je ravno govor o Mesečničinih otrocih. Melodični fragment padajoče male terce $\mathrm{z}$ malo sekundo, ki ga v motivu izpostavijo prve violine, se včasih prikrade tudi v vokalno linijo Tete Miši ali v pihala. Motiv se ne navezuje enostavno na Mesečničino družino, temveč je $\mathrm{v}$ povezavi $\mathrm{z}$ besedilom Tete Miši (gl. prvo dejanje, sedmi prizor, t. 719-721) izraz psihološkega pritiska, ki ga družba izvaja nad Mesečnico. Teta Miš namreč s svojo obsedenostjo s preštevanjem in urejevanjem skuša uničiti svobodni svet domišljije, v katerega se zateka Mesečnica.

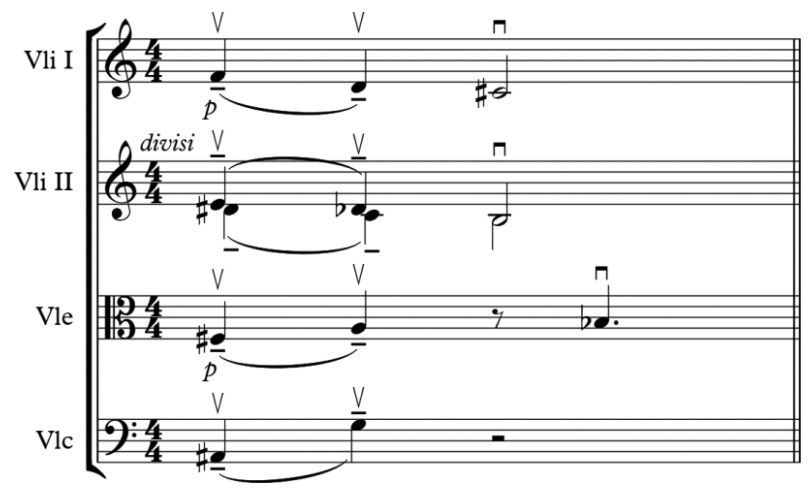

Notni primer 4: Pavle Merkù, Kačji pastir (prvo dejanje, šesti prizor, t. 408).

Per gentile concessione della Casa Musicale Sonzogno, Milano. Objavo je dovolila milanska glasbena založba Sonzogno.

Ta dva osnovna motiva sta torej glavna pola, med katerima se pne bivanjska stiska Mesečnice, vendar so v operi prisotni tudi drugi motivi, ki glasbeno nakazujejo njena duševna stanja, označujejo pojme (pogosta je na

zaradi njegovih zadnjih oper: »Verdi [...] mi je bil preveč površen, preveč zum-pa-pa, preveč diletantski. Sodil sem ga seveda po neštetih Trubadurjih in Traviatah, ki sem jih slišal, medtem ko sta mi bila tedaj še neznana Otello in Falstaff. Danes obožujem Verdija: Otello in Falstaff sta mi ga približala, Don Carlos, ki sem ga te dni slišal prvič, je dokončno potrdil to moje mnenje. Don Carlos sicer ne ostaja vseskozi na tako visoki ravni, nima tako strnjene krivulje napetosti, ni tako popolnoma mojstrovina, kot sta Otello in Falstaff; nasprotno, pozna tudi stagnacijo in nekatere strani so kar konvencionalne. Toda nekateri prizori so vredni omenjenih oper in sodijo med najboljše, najpristnejše, najgenialnejše Verdijeve strani.« Pavle Merkù, »Tržaška glasbena sezona«, Naši razgledi 12, št. 3 (1963): 58. 
primer raba besede »ime«, ki jo spremlja statični akord v godalih) ali karakterizirajo pravljične like. Zanimivo je, da so se nekateri osnovni motivi iz opere osamosvojili in se pojavljajo v kasnejših Merkujevih delih. Drobec iz Mrtvečeve ljubezenske izpovedi (gl. drugo dejanje, t. 271) in motiv Spomina-Sonca (gl. drugo dejanje, t. 19-22) sta na primer glavni tematski jedri $\mathrm{v}$ skladbi za violončelo solo $\mathrm{z}$ naslovom Madrigale (1985). Njuno zavestno uporabo potrjuje dejstvo, da je bila skladba zasnovana med pripravami za slovensko praizvedbo opere Kačji pastir v Mariboru. ${ }^{47}$

Pierluigi Petrobelli je v svoji analizi Kačjega pastirja skušal poiskati tudi elemente slovenske in italijanske glasbene tradicije. Za slovensko komponento je sicer dejal, da je ni sposoben prepoznati, glede italijanske pa je v opombi navedel diskusijo, med katero naj bi Merkù priznal vpliv Claudia Monteverdija »nell'essenzialità della dizione e nel valore attribuito alla declamazione della parola « (v bistvenosti dikcije in v pomenu, ki se pripisuje deklamaciji besede), zgled Giuseppa Verdija pa naj bi bil zaznaven "nell'economia dei mezzi musicali impiegati e la loro organizzazione» (v ekonomičnosti uporabljenih glasbenih sredstev in v njihovi organizaciji). ${ }^{48}$ Merkù se je pri tem skliceval na Dallapiccolove analize v spisu $\mathrm{z}$ naslovom Parole e musica nel melodramma. ${ }^{49}$ Podatek je izredno zanimiv za razumevanje Merkujeve opere, saj nam pomaga analizirati gradnjo Mesečničine arije na koncu prvega dejanja.

Na začetku tega poglavja je bil govor o Merkujevi glasbeni askezi, tudi $\mathrm{v}$ vokalnem partu, ki ga je Borut Loparnik zaradi tega označil za recitativ »secco po naravi, accompagnato na videz $« .{ }^{5 \circ}$ Vendar so v operi le prisotne točke, kjer se vokalna linija nekoliko razmahne: tako izjemo predstavlja na primer trenutek, ko protagonistka izpove svojo vero v poezijo (prvo dejanje, sedmi prizor, t. 661-733). Merkù je ta odsek poimenoval Grande aria tripartita per il soprano, ${ }^{\text {,I }}$ saj arijo oblikuje tridelna shema, ki jo jasno razmejujejo prekinitve alta oz. Tete Miši. V tretji oz. zaključni del arije je skladatelj umestil štirivrstično kitico, ki jo je zaradi njene vsebine izbral za motto Kačjega pastirja. Ravno v tem ključnem trenutku opere lahko zasledimo Merkujevo zavezanost italijanski operni tradiciji: Dallapiccolov spis Parole e musica nel melodramma namreč izčrpno opisuje zgradbo Verdijevih arij in Merkù, ki je ta spis po pričevanju Pierluigija Petrobellija dobro

\footnotetext{
47 Prim. Pavle Merkù, pismo Primožu Ramovšu, 29. dec. 1985, v Ramovš, »Kronika«.

48 Petrobelli, »La Libellula di Pavle Merkù«, 84-85.

49 Gl. Dallapiccola, Parole e musica, 66-93.

50 Loparnik, »Pismo neznancu«, 285.

51 Prim. Pavle Merkù, pismo Primožu Ramovšu, 4. mar. 1976, v Ramovš, »Kronika«.
} 
poznal, je domnevno skušal vpeti podoben dramatični lok tudi v svojo edino operno arijo. ${ }^{52}$

Luigi Dallapiccola je v svojih analizah opazil, da Verdijevi ariosi, arije in kavatine, ki slonijo na štirivrstičnih kiticah, sledijo že skoraj standardnemu načinu gradnje. $V$ prvih dveh verzih sta navadno metrika in vokalni obseg precej podobna, le drugi verz nekoliko stopnjuje dramatičnost, ki bo svoj višek dosegla v tretjem verzu. Temu sledi emocionalni diminuendo v četrtem verzu. Ta višek je Dallapiccola poimenoval gesta (v ital. gesto): tretji verz se navadno razlikuje od prejšnjih zaradi metrične ali harmonske spremembe, včasih tudi izpostavi najvišji ton arije. Giuseppe Verdi je omenjene postopke uporabljal posamezno ali kombinirano, redkeje mu je bila $\mathrm{v}$ pomoč instrumentacija (Dallapiccola navaja le primer iz Otella). Da bi podkrepil svojo teorijo, je avtor spisa navedel primere iz oper Rigoletto, Il trovatore, La traviata, Un ballo in maschera in Otello, analiziral pa je tudi daljše kitice ali kompleksnejše vokalne oblike (npr. tercet iz opere Un ballo in maschera). V vseh primerih je prišel do istega zaključka: tako v mikro- kot $\mathrm{v}$ makrostrukturi predstavlja tretji par verzov oz. tretji odsek emocionalni višek arije, šlo pa naj bi za ustaljeno italijansko operno tradicijo, ki se je predajala ustno ali s pomočjo vzorov. V prid te teze je dodal primere Gioacchina Rossinija, Gaetana Donizettija in Vincenza Bellinija."

Podobno shemo lahko opazimo tudi v Merkujevi ariji (gl. notni primer 5). Prva dva verza sekvenčno silita v višji register, vendar hkrati ohranjata isto metrično strukturo. Šele tretji verz prevzame Dallapiccolovo gesto: instrumentalna spremljava se na tem mestu zgosti, v glasu nastopi najvišji ton celotne arije $\left(\mathrm{a}^{2}\right)$, verz pa se zaradi daljših notnih vrednosti nekoliko raztegne v pričakovanju emocionalnega diminuenda v četrtem verzu.

Tako kot izdaja zgradba arije sledi italijanske operne tradicije, tako zborovski odseki kažejo na tiste slovenske vplive, ki jih je Pierluigi Petrobelli v svoji analizi sicer zaslutil, a ne definiral. Že v baladi Tete Miši za alt, mešani zbor in godalni orkester (prvo dejanje, sedmi prizor, t. 573-636) pritegne pozornost gibanje pevskih linij: spodnji glasovi se namreč večkrat zaustavijo na istem tonu in prevzamejo vlogo borduna, nad katerim homoritmično kontrapunktirajo soprani. Prisotnost borduna nam takoj prikliče

52 Pismo Primožu Ramovšu iz leta 1975 potrjuje izredni trud, ki ga je skladatelj vložil v komponiranje tega dela opere. Merkù namreč piše, da je zadnji del sopranske arije napisal kar sedemkrat. Prim. Pavle Merkù, pismo Primožu Ramovšu, 1. dec. 1975, v Ramovš, »Kronika«.

53 Prim. Dallapiccola, Parole e musica, 76-92. 

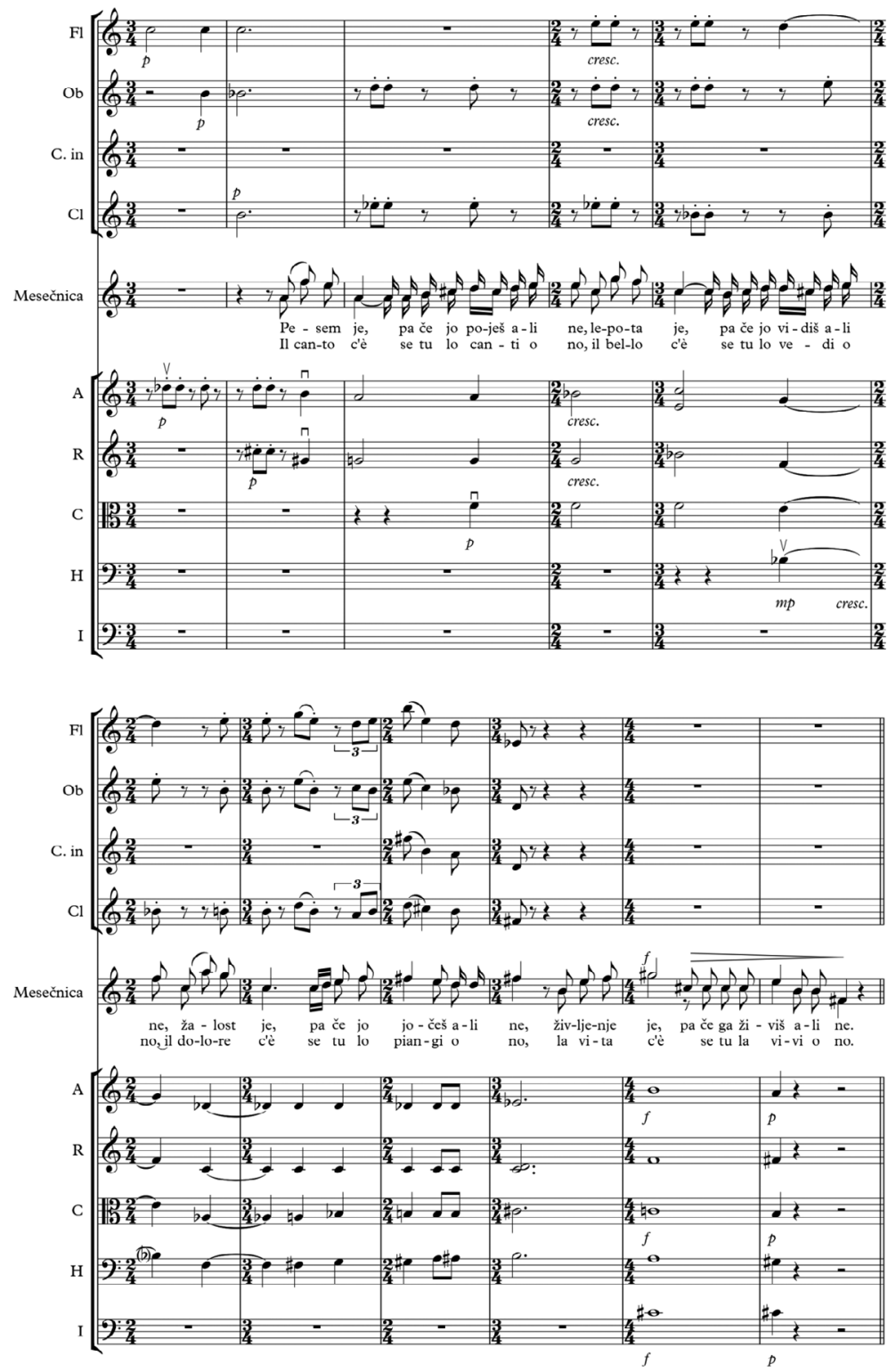

Notni primer 5: Pavle Merkù, Kačji pastir (prvo dejanje, sedmi prizor, t. 723-733).

Per gentile concessione della Casa Musicale Sonzogno, Milano. Objavo je dovolila milanska glasbena založba Sonzogno. 
v spomin rezijansko petje, vendar nam domnevno povezavo potrdi šele zborovski odsek iz prizora Spomina-Sonca (gl. notni primer 6).

Vključevanje ljudskih prvin ni redkost v Merkujevi glasbi. V šestdesetih letih se je skladatelj še omejeval na predelave ljudskih pesmi: sem spadajo poleg zborovskih predelav tudi zbirka Tri ljudske pesmi iz Benečije za sopran in klavir (1966) ter ciklus petih pesmi iz Benečije za tenor in komorni orkester z naslovom Divertimento $I I^{\circ}(1967)$. V omenjenih delih se izvirni napev navadno nahaja $\mathrm{v}$ pevčevi liniji in ohranja svojo melodično konturo, ritem ter modalno oz. tonalno vpetost. Tudi diatonična spremljava ima izrazite tonalne obrise, kot je prisotnost tonalnega centra ali kadenc, vendar se skladatelj poslužuje tudi celotonskih in kromatičnih prehodov. Prav srečanje med modalnimi oz. tonalnimi ljudskimi napevi in spremljavo, ki jo zaznamuje razširjena tonalnost, neizogibno vodi $\mathrm{v}$ trenutke politonalnosti in polimodalnosti.

V sedemdesetih letih prejšnjega stoletja, to je tik pred nastankom Kačjega pastirja, se je Merkù odločil, da korenito spremeni svoj glasbeni slog. ${ }^{54}$ Prepričan je bil, da doživlja avantgarda svoj zaton, zato je tudi sam kot številni drugi skladatelji začel iskati novih poti. Zaradi svojega temeljnega načela iskanja in posredovanja resnice, »ki bi izražala celotnega človeka v njegovi živi kompleksnosti«, se je usmeril v ljudsko glasbo, saj je ta po njegovem mnenju "posoda najstarejših, najpristnejših notranjih resnic«."s" Ljudski napev mu ni bil le golo tematsko gradivo, kajti Merkù je podobno kot citirani Marij Kogoj in nenazadnje kot Béla Bartók zahteval, da se $\mathrm{z}$ dobrim poznavanjem naravnega habitata ljudske glasbe in upoštevanjem bistvenih značilnosti ljudskega petja oživi ljudski duh, tako da priredba ne izpade kot $» m r t v a$ črka ali mistifikacija $:^{56}$

"Med rešitvami me danes zanima predvsem ena: presaditev ljudske glasbe $v$ novo kulturno posodo. Oplajanje pri koreninah (naše) nacionalne glasbene kulture. [...] Ni ga recepta, po katerem naj bi pristopil k taki operaciji: pač pa je pred tabo meja, ki je ne smeš prestopiti. To je meja spoštovanja prvinskih značilnosti slovenske ljudske glasbe. Zato jo moraš poznati, poznati moraš njene žive Prim. Pavle Merkù, pismo Primožu Ramovšu, 5. okt. 1974, v Ramovš, »Kronika«. Merkù, Poslušam, 14, 38 .

56 Pavle Merkù, »Značilnosti in posebnosti: Zborovske priredbe ljudskih pesmi slovenske etnične manjšine v Italiji«, Naši razgledi 26, št. 7 (1977): 180-181. Prim. Béla Bartók, Scritti sulla musica popolare, ur. Diego Carpitella, Universale Bollati Boringhieri 153 (Torino: Bollati Boringhieri, 2001), 101-107. 
nosilce in družbeni ambient, $v$ katerem je ta glasba živela oziroma tu in tam zaenkrat še živi. Le s tem pogojem bo skladatelj potem svoboden, da si izbere pot in način, ki mu ustreza. Potem bo odprta vsaka pot od preproste predelave do svobodnega preoblikovanja, potem bo vse odvisno od skladateljeve sposobnosti in izrazne nuje. ${ }^{57}$

Svoj novi glasbeni jezik je Merkù preizkušal predvsem v instrumentalni glasbi, kjer je navidezno ločena idioma, modernističnega in ljudskega, skušal združiti v enovit slog. V skladbi za solo rog Metamorfosi di un canto popolare (1973) je na primer jasno izpostavljeni ljudski napev na začetku skladbe osnova za ritmično in melodično preoblikovanje. V kasnejših delih pa je skladatelj postopoma opuščal jasne namige na prisotnost ljudskega motiva v skladbi. Citate je raje mimetiziral znotraj svoje neoekspresionistične govorice, tako da so prepoznavni le s pomočjo analize ali branja skladateljevih osebnih pisem. Ljudska pesem se je tako nerazdružljivo spojila s sodobnejšimi prijemi Merkujeve neoekspresionistične govorice, vendar bi bilo zgrešeno govoriti o dvojnosti Merkujevega sloga. Skladatelj se je tega izraza izogibal, saj po njegovem mnenju staro in novo, ljudsko in ekspresionistično, tradicionalno in sodobno izvirajo iz iste človeške vsebine ter se med seboj dopolnjujejo. To je poudaril v intervjuju za tržaško revijo Mladika ob italijanski praizvedbi opere Kačji pastir:

"Ljudski melos se ne bije z ekspresionizmom, kolikor sta to dva komplementarna izraza iste človeške vsebine. [...] Ljudski melos je danes priraščena komponenta mojega človeškega obraza: uporabljam ga v zavesti, da je to izraz večnega: in večno naj se v umetnosti bije $z$ novim? Novo in staro, kontingentno in večno imata $v$ umetnosti svojo težo! Dvojnost je izraz, ki ga mrzim. s8 $^{8^{8}}$

Kačji pastir sovpada s tem ključnim obdobjem, ko je skladatelj začel sintetizirati svoje glasbene izkušnje. V operi sicer ni citiral ljudske pesmi, vendar je v omenjenem zborovskem odseku (gl. notni primer 6) prevzel nekatere značilnosti rezijanskega tradicionalnega petja. Pavle Merkù je prišel v stik z Rezijo že med svojim slavističnim študijem v Ljubljani, prvič pa jo je obiskal leta 1967, ko je snemal rezijanske ljudske pesmi za sloven-

57 Merkù, Poslušam, 50-52.

58 Trn [Zora Tavčar], »Let Kačjega pastirja: Pogovor s skladateljem nove slovenske opere«, Mladika 21, št. 1 (1977): 8. 
sko radijsko postajo v Trstu. ${ }^{59}$ Kar ga je privlačilo v tej geografsko in zgodovinsko izolirani dolini, niso bili samo jezikovni arhaizmi, ampak tudi glasbene specifike rezijanske glasbe, ki jih je podrobneje opisal in predstavil v svojih etnomuzikoloških spisih. V njih je izpostavil tri osnovne značilnosti: netemperirani sistem, za katerega je Merkù sicer priznaval, da počasi izginja pod vplivom medijev; bordun kot edino spremljavo glasu ali glavnega glasbila (posledično sta prisotna samo dva glasova, melodični in bordunski glas); peterni ritem, kjer se izmenjujeta binarni in ternarni ritem (npr. $2 / 4+3 / 4$ ali $6 / 8+9 / 8){ }^{60}$ Nazorne primere take glasbe lahko najdemo v Merkujevi knjigi Ljudsko izročilo Slovencev v Italiji, še posebno med tistimi ljudskimi napevi, ki jih je Merkù posnel v vasi Bila med letoma 1968 in $1974 .{ }^{61}$

V notnem primeru 6 lahko vidimo, kako je Merkù zvesto sledil tem vzorom in jih potem variiral, tako da petje ohranja svoje arhaično vzdušje, vendar rezijanski vpliv ni takoj prepoznaven. Skladatelj je najprej odstranil vsak možni namig na temperiran sistem, saj zbor nastopi sam, brez instrumentalne spremljave, to zahtevo pa je Merkù podkrepil z oznako orchestra tacet. Nato je v petje vključil dvojni bordun, ki ga je postavil v zgornje glasove (soprane, tenorje) in ne v bas, kot je sicer značilno za tradicionalno rezijansko petje. Tudi prisotnost štirih glasov je nenavadna, saj je rezijansko petje večinoma dvoglasno. Nenazadnje je tu še metrična podoba: Merkù je rezijanski peterni ritem podvojil, tako da je namesto značilnega $2+3$ uporabil metrično oznako $4+6$. S tem je slovenski vpliv vsaj deloma izpričan: Merkù ga je prevzel iz ljudskega izročila in to v njegovi najbolj arhaični podobi, ki se je v periferni in izolirani Reziji ohranila skozi dolga stoletja. ${ }^{62}$

59 Prim. Merkù, Pajčevina in kruh, 23-24; Pavle Merkù, pismo Primožu Ramovšu, 23. nov. 1967, v Ramovš, »Kronika«.

60 Izjemoma v članku »Značilnosti in posebnosti« iz leta 1977 dodaja še heterofonijo v triglasnih pesmih. Prim. Pavle Merkù, »Polifonia primitiva nei canti popolari religiosi della Val di Resia«, v Le polifonie primitive in Friuli e in Europa, atti del congresso internazionale Cividale del Friuli, 22-24 agosto 1980, Miscellanea musicologica 4, ur. Cesare Corsi in Pierluigi Petrobelli (Roma: Edizioni Torre d'Orfeo, 1989), 349-354; Merkù, Poslušam, 19-20; Merkù, »Značilnosti in posebnosti«, 180.

61 Prim. Merkù, Ljudsko izročilo, 397-40o.

62 Podoben način komponiranja lahko zasledimo v zborovski skladbi Mračnina (1977), ki je ravno tako kot opera nastala na podlagi besedila Svetlane Makarovič. Tudi v tem primeru je skladatelj razširil vokalno zasedbo na štiriglasni ženski zbor SSAA, vendar nam prisotnost borduna, nad katerim se večkrat pojavlja interval sekunde, in pogosto izmenjavanje binarnega ter ternarnega ritma takoj prikličeta $\mathrm{v}$ spomin rezijansko pesem. 


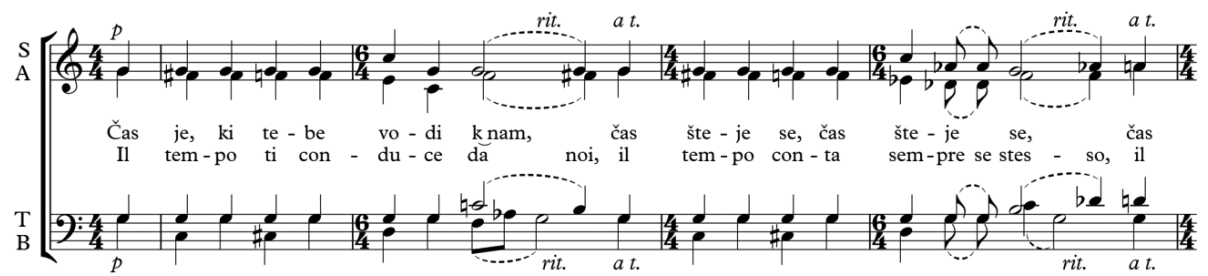

Orch. tacet
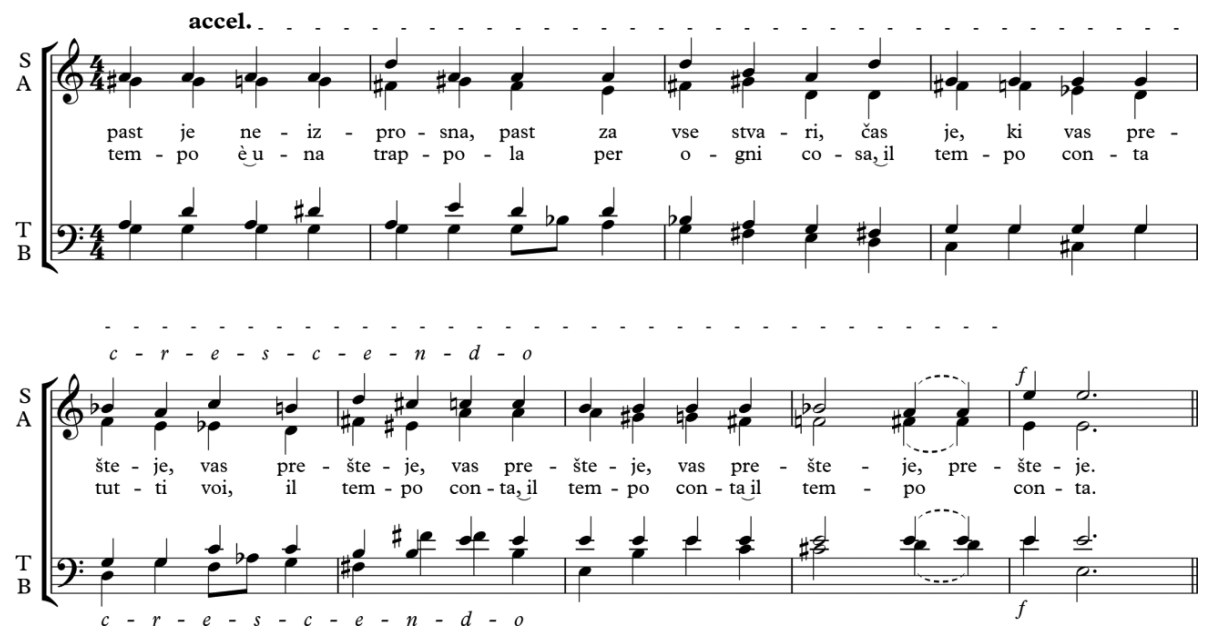

Notni primer 6: Pavle Merkù, Kačji pastir (drugo dejanje, t. III-I23).

Per gentile concessione della Casa Musicale Sonzogno, Milano. Objavo je dovolila milanska glasbena založba Sonzogno.

\section{Sklep}

Opero Kačji pastir bi lahko označili za sintezo Merkujevega glasbenega ustvarjanja. Dejansko je opera mnogo več kot to, saj je tudi odraz skladateljevega življenja in mnogostranskega delovanja na področju jezikoslovja ter etnografije. Želja, da bi komponiral opero, je v Merkuju dozorevala dvajset let in je posledično vase vsrkala slogovne usmeritve, prepričanja ali zanimanja, ki so ga spremljali na njegovi ustvarjalni poti. Pomenljiva je že odločitev, da je Kačji pastir dvojezična opera, komponirana na podlagi dveh izvirnih besedil v slovenščini in italijanščini, ki se v partituri razlikujeta le v malenkostih. Obe besedili in obe partituri imata enako vrednost, na ta način pa zrcalita skladateljevo mešano etnično ozadje.

Tudi na čisto glasbeni ravni izraža opera podobno kulturno mešanico, saj je skladatelj v operi združil svoje najznačilnejše glasbene poteze, ki 
jih je črpal iz svojih dolgoletnih raziskav glasbenega ekspresionizma in slovenske ljudske pesmi v Italiji. Posledično se glasba giba med ekspresionističnim in ljudsko obarvanim slogom $\mathrm{z}$ občasnimi namigi na italijansko ter nemško operno tradicijo. Opero zaznamuje izredno napet in strnjen izraz instrumentalne glasbe, ki ima že skoraj komorno oz. solistično fakturo. V njej lahko zasledimo Merkujevo ekspresionistično težnjo po esencialnosti, kjer skladatelj dosega maksimalne efekte $\mathrm{z}$ minimalnimi sredstvi, obenem pa opera zrcali njegovo zakoreninjeno ljubezen do komorne glasbe, do izrazne koncentracije baročne instrumentalne glasbe in do preprostega, a $\mathrm{z}$ globokimi resnicami nabitega ljudskega petja.

Zato je Kačji pastir oz. La Libellula večjezična opera. Poleg zunanje podobe, ki jo krojita slovensko in italijansko besedilo, tvori njeno notranjo vsebino glasbena govorica. Njena izmuzljiva narava je vase sprejela vplive različnih kultur in glasbenih tradicij, predvsem pa sega onkraj besedila in se izogne njegovemu narodnostnemu predznaku. Na ta način je Pavle Merkù lahko poudaril svoj glasbeni utrakvizem in se opredelil za skladatelja, ki brez razlik sprejema vse tiste elemente, s pomočjo katerih je oblikoval svojo osebnost in delo.

\section{Bibliografija}

\section{Neobjavljeno gradivo}

Merkù, Pavle. »Autobiografia«. [Trst: P. Merkù, 2012].

Merkù, Pavle. »Divertimento II ${ }^{\circ} 5$ canti popolari della Slavia italiana per tenore e orchestra da camera: 5 ljudskih pesmi iz Beneške Slovenije za tenor in komorni orkester«. Part. [Trst: P. Merkù], 1967.

Merkù, Pavle. »Dvanajsta ura: Tri pesmi Svetlane Makarovič za sopran solo«. Part. [Trst: P. Merkù], 1986.

Merkù, Pavle. »Kačji pastir: Opera v dveh dejanjih na libreto Svetlane Makarovič«. Part. [Trst: P. Merkù, 1976].

Merkù, Pavle. »Kronika: Korespondenca: Pisma«. NUK, Glasbena zbirka, Ljubljana.

Merkù, Pavle. »Pelin: Tri pesmi Svetlane Makarovič za Sabiro Hajdarović«. Part. [Trst: P. Merkù], 1975.

Ramovš, Primož. »Kronika: Korespondenca: Ramovš-Merkù«. NUK, Glasbena zbirka, Ljubljana. 


\section{Objavljeno gradivo}

Bartók, Béla. Scritti sulla musica popolare. Ur. Diego Carpitella. Universale Bollati Boringhieri, 153. Torino: Bollati Boringhieri, 2001.

[Cesare, Giorgio]. »la libellula di mercù «. Il Meridiano di Trieste, 18. mar. 1976: 8.

Dallapiccola, Luigi. Parole e musica. Ur. Fiamma Nicolodi. 2. izd. Milano: il Saggiatore, 1980.

Gori, Gianni. »Merkù: due ali di poesia«. Sipario 368 (1977): 45.

Klemenčič, Ivan. »Ekspresionizem kot glasbeni slog«. Muzikološki zbornik 17, št. 2 (1981): 29-49.

Košuta, Miroslav. »Kačji pastir«. Dan 52 (1976): 10-12.

Loparnik, Borut. »Ob sedemdesetletnici Pavleta Merkuja«. Glasnik Slovenske matice 21 (1997): 59-61.

Loparnik, Borut. »Pismo neznancu«. Sodobnost 25, št. 3 (1977): 280-287.

Makarovič, Svetlana. Vojskin čas. Pesniški list 18. Trst: Založništvo tržaškega tiska; Koper: Lipa, 1974.

Makarovič, Svetlana in Pavle Merkù. La Libellula = Kačji pastir. Libreto. Milano: Casa musicale Sonzogno di Piero Ostali, 1976.

Merkù, Pavle. Alba (da quattro monologi per archi - 1986) per viola sola. Part. P. o49E. Udine: Pizzicato Edizioni Musicali, 1986.

Merkù, Pavle. Balada za klavir op. 4. Part. Ljubljana: samozaložba, 1949.

Merkù, Pavle. Catalogo delle opere $=$ Katalog skladb $=$ Systematisches Werkverzeichnis. Adliswil: Pizzicato Verlag Helvetia, 2007.

Merkù, Pavle. »Dodekafonija (Vprašanja o govorici in o obliki v sodobni glasbi)«. Naša sodobnost 9, št. 10 (1961): 865-876.

Merkù, Pavle. Kačji pastir: Opera v dveh dejanjih = La Libellula: Opera in due atti. Kl. izvl. Milano: Casa musicale Sonzogno di Piero Ostali, 1976.

Merkù, Pavle. Ljudsko izročilo Slovencev v Italiji: Zbrano v letih 1965-1974 = Le tradizioni popolari degli sloveni in Italia: Raccolte negli anni 1965-1974. 2. izd. Udine: Pizzicato Edizioni Musicali, 2004.

Merkù, Pavle. Madrigale (da quattro monologi per archi - 1986) per violoncello solo. Part. Udine: Pizzicato Edizioni Musicali, 1986.

Merkù, Pavle. Metamorfosi di un canto popolare per corno solo. Part. Ed. DSS 580. Ljubljana: Edicije Društva slovenskih skladateljev, 1974.

Merkù, Pavle. »Mračnina«. Naši zbori 31, št. 4 (1979): 113-115.

Merkù, Pavle. Pajčevina in kruh. Trst: Založništvo tržaškega tiska, 1987. 
Merkù, Pavle. »Polifonia primitiva nei canti popolari religiosi della Val di Resia«. V Le polifonie primitive in Friuli e in Europa, atti del congresso internazionale Cividale del Friuli, 22-24 agosto 1980, Miscellanea musicologica, ur. Cesare Corsi in Pierluigi Petrobelli, 349-354. Roma: Edizioni Torre d'Orfeo, 1989.

Merkù, Pavle. Poslušam. Trst: Založništvo tržaškega tiska, 1983.

Merkù, Pavle. Prijazna smrt: Ciklus samospevov za bas in klavir op. 34. Part. Ed. DSS 26o. Ljubljana: Društvo slovenskih skladateljev, 1965.

Merkù, Pavle. Quartetto $n_{3}^{\circ}$ «Romantico» per archi. Part. Udine: Edizioni Musicali Pizzicato, 1991.

Merkù, Pavle. Tri ljudske pesmi iz Benečije za sopran in klavir. Part. Ed. DSS 343. Ljubljana: Društvo slovenskih skladateljev, 1969.

Merkù, Pavle. »Tržaška glasbena sezona«. Naši razgledi 12, št. 3 (1963): 58.

Merkù, Pavle. Vojskin čas za alt, violino, violončelo, mali klarinet $v$ es, fagot in boben. Part. Ed. DSS 687. Ljubljana: Edicije Društva slovenskih skladateljev, 1975.

Merkù, Pavle. »Značilnosti in posebnosti: Zborovske priredbe ljudskih pesmi slovenske etnične manjšine v Italiji«. Naši razgledi 26, št. 7 (1977): 180-181.

Morandini, Luciano. »Quel far musica nella Mitteleuropa«. Messaggero Veneto, 11. febr. 1994: 11.

Mrak, Marjana. »Kačji pastir: Premiera v mariborski Operi«. Naši razgledi 35, št. 2 (1986): 44.

N. C. »Appartengo alla minoranza di triestini che non rinuncia a nessuna parte di sé«. Il Piccolo, 17. apr. 2001: 17.

Nieder, Fabio. »Prvo srečanje s Pavletom Merkujem«. Prev. Simona Slokar. Primorski dnevnik, 27. sept. 1987: 12.

Petrobelli, Pierluigi. »La Libellula di Pavle Merkù«. Muzikološki zbornik 19 (1983): 83-92.

Rijavec, Andrej. Slovenska glasbena dela. Ljubljana: Državna založba Slovenije, 1979.

Saba, Umberto. Tutte le prose. Ur. Arrigo Stara. I meridiani. Milano: Arnoldo Mondadori Editore, 2001.

Silič, Ivan. »Premalo opažena slovenska opera«. Primorska srečanja 71-72 (1987): 230-232.

Trn [Tavčar, Zora]. »Let Kačjega pastirja: Pogovor s skladateljem nove slovenske opere«. Mladika 21, št. 1 (1977): 7-8.

Turk, Lida. Glas v ... etru. Trst: Deželni sedež RAI za Furlanijo-Julijsko krajino, 1991. 
Verdi, Giuseppe. Otello. Part. Milano: G. Ricordi \& C., 1913.

Kačji pastir. Ur. Tone Partljič. Maribor: Opera in balet SNG, 1985 (Gledališki list 1985/86, št. 2).

La manna. La Libellula. Trieste: Teatro Comunale Giuseppe Verdi, [1976]. Gledališki list.

Lungo il Novecento: La musica a Trieste e le interconnessioni tra le arti. Festschrift in onore del centenario della fondazione del Conservatorio Giuseppe Tartini di Trieste 1903-2003. Ur. Maria Girardi. Venezia: Marsilio Editori, 2003.

Sodobna slovenska operna ustvarjalnost. Zbornik referatov simpozija, 26., 27. november 1985. Maribor: Opera in balet SNG, [1986]. ${ }^{63}$

63 Poglavje je nastalo kot del projekta J6-7180, ki ga je sofinancirala Agencija za raziskovalno dejavnost Republike Slovenije.

This chapter is part of the project J6-7180 funded by Slovenian research agency ARRS. 


\section{Povzetki}

\section{Peter Andraschke}

\section{Raznolikost moderne. Glasbeni dnevi v Donaueschingenu}

in Baden-Badnu v 20. letih 20. stoletja

Dnevi komorne glasbe v Donaueschingenu v letih od 1921 do 1926 in njihovo nadaljevanje v Baden-Badnu v letih od 1927 do 1929 kažejo predvsem s svojimi praizvedbami različne obraze moderne med tradicionalnostjo in eksperimentiranjem. Bili so povod za številne pobude. V Donaueschingenu je bil poudarek na glasbi nemško govorečega prostora, vključno z ozemlji nekdanje Habsburške monarhije. Baden-Baden ni bil omejen na komorno glasbo in je postal forum za aktualna vprašanja, ki je vključeval nove tehnične medije (radio, radijske igre, film, gramofonsko ploščo), osvetljeval zgodovinske zvrsti z novega vidika (minutna opera, komorna opera, poučna igra, scenska kantata) in začel razlikovati med glasbo kot umetnostjo in uporabno glasbo (pihalna glasba, glasba za ljubitelje, mladinsko glasbeno gibanje). Premestitev dnevov komorne glasbe v Berlin je že po enem letu pomenila njihov konec. Začetki latentnega antisemitizma so se v kritikah mednarodno oblikovanega programa $\mathrm{v}$ nekaterih glasilih sicer kazali že v Donaueschingenu, vendar so Hitlerjev prevzem oblasti v začetku leta 1933 in njegove posledice pomenile konec takratne moderne na vseh področjih umetnosti. Hitlerjev prevzem oblasti je onemogočil nadaljevanje idej, ki so se prvotno razvile v Donaueschingenu. Šele po drugi svetovni vojni so na novo ustanovljeni glasbeni dnevi v Donaueschingenu postali 
poleg Darmstadta nov in vpliven oder za usmeritev mednarodne glasbene moderne in avantgarde.

Ključne besede: uporabna glasba, mehanska glasba, nacionalsocializem, neoklasicizem, tehnični mediji, dunajska šola

\section{Matjaž Barbo}

\section{Anton Dolinar kot doktorski študent Guida Adlerja}

Prispevek se osredotoča na glasbeni študij Antona Dolinarja na Dunaju. Dolinar je v obdobju med obema vojnama v Sloveniji veljal za nesporno avtoriteto na glasbenem področju. Njegovo pionirsko delo pa ni bilo osnovano zgolj na ljubiteljskem entuzijazmu, temveč je bilo visoko strokovno podprto. Vzporedno s študijem na dunajskem konservatoriju (od 1923), kjer je obiskoval oddelek za cerkveno glasbo, je poslušal tudi predavanja iz muzikologije na Filozofski fakulteti dunajske univerze. Svoj študij je sklenil s tezo Die Behandlung der Kirchentöne bei Palestrina (1927), ki jo je obranil pri slovitem Guidu Adlerju.

Dolinar se je sicer na Dunaj odpravil potem, ko je dokončal študij teologije in bilo posvečen $\mathrm{v}$ duhovnika (1917). Pozneje je njegovo delovanje zajemalo vse od požrtvovalnega dela na ljubljanskem radiu, do dirigiranja, širšega kulturnega in organizacijskega dela, publicistike ter poučevanja. Temeljito izobražen in široko razgledan glasbenik je sodeloval pri osnovanju in vodenju radijskega glasbenega programa tedaj nastajajočega radia. Bil je dolgoletni urednik Radia Ljubljana in dirigent ljubljanskega Glasbenega društva. Po vojni je leta 1945 odšel najprej v Italijo, od tam pa se je nato odselil v Združene države Amerike, kjer je leta 1953 v prometni nesreči tudi umrl.

Čeprav je Dolinar bil v svojem času nedvomno eden najbolj razgledanih glasbenih intelektualcev, široko dejaven na najrazličnejših področjih, pa je po vojni kot duhovnik in del politične emigracije postopoma žal njegovo delo po krivici v veliki meri utonilo v pozabo.

Ključne besede: Anton Dolinar, študij muzikologije, Guido Adler, cerkveni modusi

\section{Nada Bezić}

«Intimni glasbeni večeri« ali Kako je Hrvaški glasbeni zavod v Zagrebu odprl vrata v sodobnost

Intimne muzičke večeri je naslov ciklusa, ki je med obema vojnama dal svoj pečat glasbenemu življenju Zagreba in do danes njegova kombinacija kako- 
vosti izbire izvajalcev in programa, spremljanja sodobnih ustvarjalnih tendenc $v$ glasbi in izredno informativnih programskih knjižic še ni bila presežena. Koncerte je organiziral Hrvaški glasbeni zavod v svoji dvorani, glavni iniciator in organizator pa je bil tedanji tajnik Artur Schneider, umetnostni zgodovinar, obenem pa tudi zelo dober glasbeni pisec. Od septembra 1922 do junija 1926 se je zvrstilo 9o koncertov, samo v sezoni 1923/24 pa kar 32 koncertov ciklusa, kar je neverjetna številka tudi za današnji čas.

Schneider je s koncerti vztrajno skrbel za hrvaške skladatelje in prve izvedbe njihovih skladb, toda $\mathrm{v}$ mednarodnem kontekstu je še bolj pomembno to, da je bilo mogoče v Zagrebu slišati skladbe Milhauda in Poulenca le nekaj let po tem, ko so bile skomponirane; leta 1924 je bil koncert skladb Caselle, Malipiera, Santoliquida in Castelnuovo-Tedesca, pa tudi Schönberga, Bartóka in drugih. Notni material je Schneider priskrbel od založnikov („Chester“, London) ali s pomočjo kulturnih inštitutov v Zagrebu, predvsem Francoskega inštituta.

Pomembno je tudi, da se je Artur Schneider povezal z Mednarodnim društvom za sodobno glasbo (ISCM) in postal leta 1925 njegov tajnik za Jugoslavijo, katerega sedišče je bilo v Zagrebu (do leta 1930).

Ključne besede: Hrvaški glasbeni zavod v Zagrebu, Artur Schneider, koncerti, sodobna glasba

Katarina Bogunović Hočevar, Ana Vončina

Radio Ljubljana v prvem desetletju svojega delovanja - medij, ideologija in inštitucija v luči glasbe

Za razumevanje začetkov delovanja Radia Ljubljana je potrebno osvetliti kontekst začetkov brezžične telegrafije in telefonije $v$ Evropi in tedanji državi, Kraljevini Jugoslaviji, v kateri je nastala mreža bolj ali manj medseboj povezanih radijskih postaj. Radio Ljubljana ni predstavljal le novosti na ravni tehnologije, ki je skušala slediti evropskim trendom, temveč je v obstoječi prostor posegel veliko globlje in širše kot katerikoli medij dotlej. Na polju glasbe je bil prispevek Radia večplasten: $v$ radijskem programu je glasba zasedala največji delež. Glasba v programu je imela različna izhodišča: lahko je bila glasba, ki jo je poustvarjal radijski kvartet (pozneje orkester) v studiju, glasba zunanjih izvajalcev, glasba neposrednih prenosov domačih in tujih opernih predstav, ali pa glasba z gramofonskih plošč. Glasbenost se ni manifestirala le v okviru re(produkcije) in tako imenovanih različnih tipov glasbe, temveč tudi na ravni radijskih oddaj o glasbi in glasbenikih. Ob vsem tem je imelo pomembno vlogo tudi glasilo Radia Ljubljana, ki ne 
izpričuje le programske sheme domačih in tujih radijskih postaj, temveč osvetljuje tiste teme ob katerih se je postopno oblikovala nova inštitucija. Tako kot vsaka, je bila tudi ta v ozadju „obremenjena“ $z$ določeno ideologijo. To lahko opazujemo tako na institucionalni ravni (novo vodstvo in ustanovitev tednika Novi Val) kot $\mathrm{v}$ glasbeni naravnanosti programa.

Ključne besede: Radio Ljubljana, glasba, medij, inštitucija, ideologija, Prosvetna zveza, Anton Dolinar

\section{Ivan Florjanc}

\section{Ustvarjalnost primorskih skladateljev med italijansko okupacijo Primorske v času fašizma - kompozicijski, slogovni in družbeni uvidi}

Celotna slovenska Primorska z zaledjem in še čez (mimo Willsonove zahteve) je po rapalski pogodbi (12.11.1920) pristala pod italijansko okupacijo do leta 1945, del pa je tam še danes. Stanje so močno poslabšali tajni dogovori med Jugoslavijo in Italijo in Rimska pogodba Mussolini-Pašić (27.1.1924), kar oboje sovpada $\mathrm{z}$ okrepljenim terorjem nove stranke fašistov in s popolnim zatrtjem javnega življenja Slovencev na Primorskem. Nadaljevanje je stvari samo še zaostrilo vse do popolnega kulturnega gnenocida in jezikovnega etničnega čiščenja Primorske (po 1926). V takšnih razmerah pa so prav primorski skladatelji - poleg TIGRa, tajno organiziranega odpora duhovnikov in ostalih - razvili proniciljiv in načrten nenasilni odpor proti stopnjevanju agresije fašistov nad Primorci. Kaže se v močnem in usklajenem ustvarjalnem naboju skladateljev (E. Komel, L. Bratuž, V. Vodopivec, deloma tudi M. Kogoj idr.), ki so razvili poseben, samonikel in učinkovit način komunikacijskih vezi med pesniki (L. Šorli, F. Terčelj, V. Bele, S. Stanič idr.) in skladatelji. Ti so svoja dela načrtno namenili duhovni in človeški omiki svojih rojakov. Ta napor je ustvaril zanimive tudi glasbeno slogovne nastavke $\mathrm{v}$ marsikaterem medvojnem skladatelju. Zadnji čas poteka načrtno zbiranje, katalogiziranje, digitaliziranje in izdaja del posameznega skladatelja, da se zavarujejo pred dokončnim uničenjem in pozabo.

Ključne besede: Primorska, glasba kot nenasilni odpor, fašizem, slovensko italijanski odnosi, 20. stoletje 
Luba Kijanovska

\section{Ukrajinska skladateljska šola v dvajsetletnem obdobju med obema vojnama: med modernizmom in socialističnim realizmom}

Ukrajinska skladateljska šola se je $\mathrm{v}$ prvih dveh desetletjih 20. stoletja začenjala zelo uspešno vpenjati v evropski kulturni prostor. Ta naravni proces so prekinile in izkrivile politične razmere, tj. nasilna pripojitev $\mathrm{k}$ ZSSR s tragičnim vrhuncem v »usmrčenem preporodu « v 30. letih. Zato je bil razvoj glasbene kulture prisiljen nihati med nasprotujočima si poloma: željo po razvoju inovativnih estetskih in slogovnih trendov (ekspresionizem, neoklasicizem, itd.) ter socialističnim realizmom, ki ga je propagirala komunistična ideologija. Iz te konfrontacije so se nenehno rojevali ostri spori s tragičnimi posledicami za skladatelje, kot so Boris Ljatošinski, Levko Revucki, Mihajlo Verikivski, Pilip Kozicki in drugi. Nekateri umetniki, ki so se želeli rešiti so združevali specifične narodnotradicionalne oblike $\mathrm{z}$ najnovejšimi smernicami, a so kljub temu bili fizično uničeni, med njimi Gnat Hotkevič, ki je moderni izrazni sistem obarval z zvokom starega ukrajinskega inštrumenta bandure, ter Vasil Verhovinec, ki je na osnovi ukrajinskega plesa prilagodil sistem Émila Jaques-Dalcroza. Oba sta bila leta 1937 ustreljena.

Ideološke ovire niso preprečile ukrajinskim glasbenikom, da bi uporabljali moderni glasbeni jezik po svojih prepričanjih, zato so bili tarča brutalnih kritik ideoloških organov. Vsaka inovacija je obveljala za »čaščenje buržujskega Zahoda«, narodne teme pa za »buržujski nacionalizem«. Ljatošinskega so na primer obtožili, da »vratovi in zastavice njegovih not gledajo proti Zahodu«. Če so umetniki želeli obvarovati svoje ustvarjalno delo in celo življenje, so morali pisati skladbe $\mathrm{v}$ duhu socialističnega realizma. Tako so nastajali paradoksalni ambivalentni individualni slogi, ko so v ustvarjalnem svetu skladateljev soobstajali svetli inovativni artefakti in ideološko pogojene opere. Avtorji so svoj izrazni sistem zavestno omejili na slog 19. stoletja, osredotočen predvsem na dediščino ruske peterke in Čajkovskega. Folklora je bila pogosto vez med modernizmom in socialističnim realizmom, saj so jo skladatelji inovativno uporabljali za izražanje svojih ustvarjalnih idej, ne da bi bili pri tem izpostavljeni neusmiljeni komunistični kritiki.

Ključne besede: modernizem, socialistični realizem, ukrajinska glasba, slogovne tendence 
Darja Koter

\section{Idejna in umetniška identiteta mladinskih zborov med obema vojnama}

Obdobje med obema vojnama je skladno $\mathrm{z}$ družbenimi spremembami in $\mathrm{v}$ težnji po približevanju sodobnim slogovnim glasbenim trendom širšega evropskega prostora tudi na Slovenskem spodbujalo mladinsko zborovstvo, ki je vsestransko nadgradilo prej prevladujoče šablonsko razredno petje. Po čeških vzorih so najprej nastajali učiteljski zbori, ki so spodbujali sodobnejši repertoar slovenskih in slovanskih skladateljev, pevce pa izobraževali v vokalni tehniki in dirigiranju ter jih spodbujali k ustanavljanju in vodenju mladinskih pevskih zborov. $\mathrm{Za}$ tranzicijo $\mathrm{k}$ "novemu« so najzaslužnejši umetnostni ideolog Stanko Vurnik, skladatelj in zborovodja Emil Adamič ter primorska učitelja Srečko Kumar in Avgust Šuligoj. Slednja sta bila najpomembnejšega akterja pri nastajanju in promoviranju mlade slovanske glasbene literature za mladinske zbore, ki se je končno odtegnila od prej prevladujočih narodnobuditeljskih in moralnih vsebin ter romantične slogovne orientacije. »Nova" glasba je sledila sodobnejšim kompozicijskim in literarnim vzgibom tistega časa, se slogovno razvijala in opozarjala na aktualne družbene, predvsem socialne razmere. Vzorčni primer mladinskega pevskega zbora, tako po socialni kot glasbeni plati, je bil Trboveljski slavček, ki ga je ustanovil in vodil Avgust Šuligoj ter z njim dosegel evropsko priznano raven, primerljivo $\mathrm{z}$ dunajskimi dečki. Zanj so slovenski in drugi skladatelji takratnega jugoslovanskega prostora napisali okrog 800 skladb, izvedenih na koncertih in radijskih postajah $\mathrm{v}$ domačem in mednarodnem prostoru, kar je umetniško in družbeno poslanstvo mladinskega zborovstva razširjalo na ves slovenski prostor. Posebej prelomno je bilo leto 1934, ko je bil v Ljubljani izveden prvi mladinski pevski festival. Odmevna prireditev ni ostala brez dolgoročnih vplivov, kot so rast novih mladinskih zborov, razširjanje umetniško in vsestransko sodobno naravnanega programa ter poglobljeno pevsko izobraževanje. Čeprav je druga svetovna vojna razmah mladinskega zborovstva nasilno prekinila, je tradicija preživela in se nadaljevala po letu 1945 . Novi časi so prinesli drugačno poslanstvo zborovskega petja, nove idejne poglede ter ideološko obarvane repertoarje, med kompozicijskimi načeli pa skorajda ni bilo sledi modernistov predvojnega časa. Zborovodje mladinskih zborov so hote ali nehote sledili idejnim zapovedim socializma, kjer pa ni bilo prostora za najnovejše kompozicijske tehnike zahodnega sveta. 
Ključne besede: mladinsko zborovsko petje, glasbena literatura, Emil Adamič, Srečko Kumar, Avgust Šuligoj, Trboveljski slavček

\section{Hartmut Krones}

\section{Govor in govorjeno petje kot izrazna oblika družbenokritičnih vsebin $\mathbf{v}$ glasbi med obema vojnama}

Od Schönbergovega dela Pierrot lunaire naprej je govorjeno petje, Sprechgesang, neortodoksni medij za neortodoksne vsebine, kmalu pa je vse bolj postajal medij za družbenokritične in politične izpovedi. Ostrino te izrazne oblike je dodatno povečala paleta oblik od čistega govora do »tradicionalnega petja«, ki so jih kmalu skoraj sistematično uporabljali; za posebno ostre, politično obtožujoče izjave se je pretežno uporabljal čisti govor. Poleg Arnolda Schönberga (npr. v delu Mojzes in Aron) in Albana Berga (npr. $\mathrm{v}$ delu Wozzeck) je v pesmih in oblikah, podobnih oratoriju, celotni spekter te palete uporabljal predvsem Wladimir Vogel, dela izključno za deklamatorski zbor pa so pisali tudi "politični skladatelji«, kot so Ernst Toch, Hanns Eisler, Paul Amadeus Pisk in Berta Lask, ki so želeli na posebno prodoren način posredovati svoja sporočila prek čim večjih zborov. Prispevek vsebuje pregled tega področja in na podlagi nekaj primerov analizira kompozicijskotehnične podrobnosti in izrazne ravni teh del.

Ključne besede: deklamatorski zbor, govorjeno petje, politična glasba, futurizem, dadaizem

\section{Helmut Loos}

\section{Sveta zmernost. Skladatelj v moderni.}

\section{Bolj kontinuiteta kot prekinitev}

Koliko je romantični glasbeni nazor kljub vsem civilizacijskim kritikam »dolgega 19. stoletja« živel naprej, je sporno. Predstava umetnikov, predvsem glasbenikov, ki so menili, da kot izjemne osebnosti zavzemajo posebno mesto v človeški zgodovini in imajo vodilno vlogo v družbi, je vsekakor ostala. V prvi vrsti je to veljalo za skladatelja kot ustvarjalca, dirigent pa je najučinkoviteje predstavljal vlogo voditelja skupine glasbenikov. To temeljno predstavo je mogoče najti pri tako nasprotujočih si skladateljih, kot so Hans Pfitzner, Ferruccio Busoni in Paul Hindemith.

Ključne besede: religija umetnosti, romantični glasbeni nazor, nova stvarnost, umetniška slika, mladinsko glasbeno gibanje 
Andrej Misson

Nekaj misli o slovenskem zborovskem skladanju med obema svetovnima vojnama

Avtor v uvodu razpravlja o splošnih zgodovinskih dejstvih, ki so vplivala na zborovsko glasbo in njeno ustvarjanje v medvojnem obdobju. Zborovska ustvarjalnost je bila razpeta med prilagajanjem sposobnostim naših tedanjih zborov in hotenju skladateljev po sledenju modernim umetniškim dosežkom tedanje evropske glasbene ustvarjalnosti. Takoj po vojni je bilo med skladatelji opazno navdušenje nad novo domovino, kar se vidi v pisanju domoljubnih pesmi, posvečenih njej. To navdušenje pa je že kmalu splahnelo. V nadaljevanju sledijo kratka razmišljanja o zborovskih skladateljih, izvajalcih, zborih in zborovodjih ter nazadnje še poslušalcih. Skladatelji so bili dobro izobraženi; številni so pisali v tradicionalnem, postromantičnem slogu, nekaj skladateljev pa je ubralo nove smeri (Kogoj, Osterc). Skladatelji so lahko svoja dela tiskali v glasbenih revijah, založbah in samozaložbah. Pisali so za številne zbore, med katerimi je bilo vsaj nekaj vrhunskih, sposobnih izvesti najzahtevnejše skladbe. Pozornost je veljala tudi poslušalcem in njihovi vzgoji. $\mathrm{V}$ drugem delu avtor navede nekaj primerov medvojnih zborov izbranih slovenskih skladateljev različnih generacij (Foerster, Adamič, Lajovic, Vodopivec, Premrl, Kogoj, Osterc idr.).

Ključne besede: glasbena kompozicija, zborovska glasba, slovenska zborovska glasba, glasbena teorija, muzikologija

\section{Niall O'Loughlin}

\section{Skladateljska pot Slavka Osterca in njegovo vključevanje novih tehnik}

Skladateljska kariera vodilnega slovenskega skladatelja Slavka Osterca (1895-1941) je trajala dvajset let, od leta 1921 do leta 1941. Med letoma 1921 in 1925 je v Sloveniji napisal približno štirideset skladb, ki naj bi bile še nekoliko nezrele, a s številnimi zelo zanimivimi značilnostmi. Med študijem pri Jiráku in Aloisu Hábi v Pragi (1925-27) se je naučil osnov novih tehnik. Po vrnitvi v Slovenijo je Osterc v letih 1927-30 skladal miniature za komorno glasbo, ki so bile pogosto harmonsko neubrane, kompozicijsko zanimive in po slogu neoklasicistične, in vokalno glasbo, ki vključuje intenzivne Gradnikove pesmi, štiri minutne opere, zaznamovane s porogljivim smislom za humor, in celovečerno opero Krog s kredo, ki predstavlja obsežen povzetek njegovih slogovnih značilnosti na tej stopnji razvoja. Vredno je omeniti, kako so navidezno samostojna dela, na primer arije, recitativi in zbo- 
rovske skladbe, umetelno združena s spretnimi prehodi. Pomembni so tudi harmonski postopi, ki so pogosto $\mathrm{v}$ nasprotju $\mathrm{z}$ morebitnimi tonalno-harmonskimi težnjami številnih vokalnih linij. Po letu 1930 je Osterc razširil svoje melodične, harmonične in kontrapunktične tehnike ter pomembno razvil svoje daljnosežne ideje o formalni konstrukciji. To je razvidno predvsem v enostavčnih skladbah z različnimi tempi, kot so Passacaglia in koral, Mouvement symphonique in simfonična pesnitev Mati, pa tudi v nenavadnih formalnih načrtih za Nonet, Godalni kvartet št. 2 ter sonate za saksofon in violončelo. Osterc je poleg tega postal zelo dejaven v Mednarodnem združenju za sodobno glasbo (ISCM) ter bil v stiku s številnimi naprednimi skladatelji iz vse Evrope in njihovo glasbo. Osterčeva glasba danes ne velja za posebej napredno po zahodnoevropskih merilih, čeprav je večina njegovih del še vedno razmeroma malo znanih. Toda s svojo glasbo je raziskoval nove formalne postopke in harmonični idiom, ki je mejil na atonalnost in dvanajsttonski sistem namesto stroge serialne tehnike. Razumljen in cenjen je v lastnem okviru, tj. brez pretiranega navezovanja na modernistične ideje. Vsekakor pa je imel $\mathrm{v}$ vseh pogledih velik vpliv na razvoj slovenske glasbe.

Ključne besede: Slavko Osterc, Slovenija, Praga, medvojna leta, nove tehnike, nove oblike

\section{Gregor Pompe \\ Slavko Osterc in Lucijan Marija Škerjanc: estetski razkol in poetsko bratstvo}

Slovensko glasbeno življenje se zdi še dandanes zaznamovano $\mathrm{z}$ napetostno dvojico, ki jo povezujemo s skladateljskima sodobnikoma Slavkom Ostercem (1895-1941) in Lucijanom Marijo Škerjancem (1900-1973). Oba lahko razumemo kot izstopajoča predstavnika slovenske glasbe med obema svetovnima vojnama, pri čemer njuna vplivnost ni izhajala le iz recepcije njunih del, temveč predvsem iz pedagoškega dela: Osterc je pomembno zaznamoval predvojne generacije, ki so študirale na Konservatoriju Glasbene matice oz. Državnem konservatoriju, Lucijan Marija Škerjanc pa kot dolgoletni profesor na Akademiji za glasbo po koncu druge svetovne vojne. Estetska usmeritev obeh skladateljev se zdi na prvi pogled zelo jasna in nasprotna: Osterc je po izkušnji praškega študija sledil novim glasbenim tokovom in zagovarjal radikalni odklon od glasbenih tradicij, tudi poudarjenega subjektivizma, medtem ko je Škerjanc ostajal zvest izrazni estetiki 19. stoletja in razširjeni tonalnosti moderne in impresionizma še globo- 
ko v drugo polovico 2o. stoletja. Takšna pozicija ni razberljiva le iz njunih del, temveč tudi programatskih zapisov. Toda na ravni poetike se zdi, da sta bila oba zapisana precej podobni obrtni logiki: ko sta se enkrat dokopala do lastne glasbene "govorice «, sta v njej vztrajala in nista iskala bistveno novih vzpodbud, niti pomembnejših zunajglasbenih vsebin, s katerimi bi napolnila svoje umetnine. Njuno delo je mogoče oceniti visoko predvsem s stališča kompozicijsko-tehnične dovršenosti, ki je bila v obdobjih pred njim v slovenski glasbi precejšnja redkost. Prispevek razkriva, kako je treba Osterčevo in Škerjančevo delo motriti v okviru skupnega slovenskega konteksta glasbe med obema vojnama, ki je zapustil več skupnih sledi v njuni ustvarjalnosti, kot smo to ponavadi pripravljeni priznati.

Ključne besede: Slavko Osterc, Lucijan Marija Škerjanc, slovenska glasba, glasba 2o. stoletja

Karmen Salmič Kovačič

O polislogovnosti klasicističnega modernizma po razkritju sadornovske zmote« - na primerih iz opusa Demetrija Žebreta

Prispevek uvodoma obravnava ključne pomisleke o adornovski miselnosti, ki je krojila pojmovanje avantgardizma, tradicionalizma in modernizma skozi daljše obdobje 2o. stoletja pri večini glasbenih teoretikov, filozofov, zgodovinarjev ter ustvarjalcev. $V$ času postmodernizma se je namreč začela vse bolj jasniti slika o njeni nacionalno in ideološko pogojeni konstrukciji glasbene zgodovine 20. stoletja oz. glasbenega modernizma, ki jo različni premišljevalci in pisci danes vse pogosteje prepoznavajo kot »zmoto«. Zato dobiva v luči najnovejšega pojmovanja "pluralistični« modernizem nasproti »konstruktivističnemu" svoje jasnejše poteze, njegova bistvena značilnost pa je polislogovnost v okviru »širše vključujočega « klasicističnega modernizma oz. modernističnega klasicizma. Pojma uvaja Hermann Danuser in želi z njima označiti široki tok modernističnih del skladateljev iz prve polovice 20. stoletja, ki so vključevali elemente tradicije v svoja dela zgolj kot gradnike nove glasbe na različne načine ter na različnih kompozicijskih ravneh. $\mathrm{V}$ drugem delu bomo poskušali polislogovnost kot posledico kompozicijsko-tehničnega pluralizma predstaviti na primeru analiz nekaterih del slovenskega skladatelja iz Osterčevega kroga - Demetrija Žebreta (1912-1970).

Ključne besede: "adornovska zmota«, klasicistični modernizem, slovenska glasba, 2o. stoletje, Demetrij Žebrè 


\section{Lubomír Spurný}

\section{Delo in izvedba: nekaj komentarjev o češki moderni glasbi}

Prispevek opisuje razvoj izvajanja v češki glasbi. O interpretaciji so na primer izrazili svoje mnenje skladatelj in pianist Erwin Schulhoff, Karel Reiner, Alois Hába, E. F. Burian, violončelist Váša Černý in klarinetist Milan Kostohryz. Za tovrstno obravnavo najprimernejše področje se zdi komorna glasba, še zlasti tako imenovana »šola češkega kvarteta«. Gre za eno redkih umetniških dejavnosti v češki glasbeni kulturi, pri kateri lahko opazujemo neprekinjen razvoj z vsemi poznejšimi razhajanji in odkloni. Temelje te šole gre pripisati Češkemu kvartetu. V začetku 2o. stoletja so jo sestavljali v glavnem Kvartet Ševč́k-Lhotský, Zikov kvartet (češkoslovaški) in Praški kvartet. Interpretacije Češkega kvarteta so se začele spreminjati predvsem z izumom fonografa in gramofonske plošče. Dejstvo, da je glasbo mogoče zapisati tudi v zvočni obliki, in ne samo na papirju, ter da je poleg njenega poteka mogoče ujeti še lastnosti, ki jih je sicer težko zapisati z notami, je preusmerilo pozornost na potek trenutnega izvajanja glasbe. $\mathrm{V}$ tem lahko najdemo tudi (pogosto spregledan) vzgib za razvoj nove tradicije izvajanja. Ključne besede: češka glasba, muzikologija, izvedba, partitura, raziskovalna interpretacija, analiza posnetkov

\section{Jurij Snoj}

\section{Misel o glasbi v spisih treh slovenskih medvojnih glasbenih esejistov}

V času med obema vojnama je bilo pisanje o glasbi na Slovenskem močno razvito. Med tistimi glasbenimi pisci, ki so se med drugim posvečali tudi glasbenoestetskim vprašanjem, so bili najpomembnejši: skladatelj Anton Lajovic (1878-1960), skladatelj Marij Kogoj (1892-1956) in umetnostni zgodovinar Stanko Vurnik (1898-1932). Njihovi pogledi na glasbo so bili različni in možno jih je razlagati tudi $\mathrm{z}$ njihovimi življenjskimi potmi. Lajovic je bil priča časa, ko se je premoč nemške kulture zlorabljala v politične namene. Odklanjal je internacionalizem v umetnosti, ki se mu je zdel le krinka za prevlado ene nacionalne kulture nad drugo. Za slovensko glasbo je bil prepričan, da lahko obstoji le kot nacionalna umetnost $\mathrm{v}$ zdravi konkurenci z glasbenimi kulturami drugih narodov. Kogoj, napredno usmerjeni skladatelj svojega časa, je nasprotno zagovarjal mnenje, da je glasba lahko le izraz nadpovprečne osebnosti, taka pa ne more ostati zaprta v kulturni krog naroda, ki mu umetnik pripada. Biti umetnik je bilo zanj nekaj, kar zadeva bolj kot narod celotno človeštvo. Spet drugače je pristopal k umetno- 
sti Vurnik, ki se je zanimal predvsem za stilni razvoj glasbe in zakonitosti tega razvoja. Sledeč svojemu učitelju Izidorju Cankarju je bil prepričan, da se preko menjajočih se glasbenih slogov odražajo ključne ideje v evropski kulturni zgodovini.

Ključne besede: estetika glasbe, slovenska kulturna zgodovina, zgodivina slovenske glasbe

\section{John Tyrrell}

\section{Janáčkov maestoso}

Razen redkih besed, kot sta "espressivo« in »dolce«, se je Janáček v svojih partiturah izogibal uporabi izraznih oznak. Obstaja pa ena izjema, in sicer beseda "maestoso «, ki jo je mogoče zaslediti od njegove najzgodnejše do najpoznejše opere, Iz mrtvega doma. Izraz »maestoso « se je pojavil v 18. stoletju. Uporabljal ga je na primer Haydn v počasnih uvodih nekaterih svojih simfonij. Njegova uporaba se je močno povečala v orkestralni glasbi 19. stoletja: češki domoljubi, začenši s Smetano, so ga izkoristili za označevanje patriotske vsebine. Janáček je sledil tej tradiciji v svoji prvi operi Šárka ter v nekaterih domoljubno obarvanih delih o ustanovitvi neodvisne Češkoslovaške. Izraz pa je uporabljal tudi na več drugih načinov, in sicer kot strukturni označevalec na koncu oziroma proti koncu dejanja ali stavka, za poudarjanje pomembnih besed ali trenutkov $\mathrm{v}$ delu, le občasno pa je z njim nakazal nezemeljsko vzdušje. Janáčkova raba izraza »maestoso« je predstavljena in razvrščena skozi njegov celotni opus, nato pa primerjana $\mathrm{z}$ nenavadno rabo v operi Iz mrtvega doma (1928). V tej operi, ki jo je končal malo pred smrtjo, je Janáček pomen izraza razširil, da bi izkazal čast in sočutje zločincem, zaprtim $\mathrm{v}$ sibirskem ujetniškem taborišču.

Ključne besede: Janáček, Smetana, Dvořák, maestoso

\section{Jernej Weiss}

\section{Alois Hába in slovenski študenti kompozicije na Državnem konservatoriju v Pragi}

Prispevek skuša določiti kompozicijsko-idejne vplive Aloisa Hábe, enega izmed največjih novotarjev obdobja med obema svetovnima vojnama, na njegove slovenske študente. Med slovenskimi slušatelji Hábinega tečaja četrttonskega komponiranja na Državnem konservatoriju v Pragi velja izpostaviti Slavka Osterca (1926-27), Pavla Šivica (1931-33), Marijana Lipovška (1932-33), Franca Šturma (1933-35), Demetrija Žebreta (1934-36), pa tudi po- 
zabljenega Ivana Pučnika (1935-36). Le ti so po vrnitvi s praškega študija nadvse pomembno sooblikovali podobo tukajšnjega glasbenega življenja. Četudi med njimi v dvajsetih in tridesetih letih 2o. stoletja $v$ idejnem smislu prevladuje dokaj enotno prepričanje o potrebi po novih glasbenih perspektivah, se le to kompozicijsko uresničuje na različne načine. Omenjeni skladatelji so si namreč v večini dokaj izvirno prikrojili Hábine konstruktivistične postopke, podobno kot $\mathrm{v}$ domala istem obdobju niso čutili potrebe po dosledni rabi atonalnosti oziroma dodekafonije. Seveda je poleg Hábinega vpliva, v mnoštvu najrazličnejših skladateljskih poetik 2o. stoletja, mogoče tudi pri njih zaslediti številne druge bolj ali manj vplivne skladateljske reference. Vendar pa je prav praški študij $\mathrm{v}$ mnogočem zaznamoval njihovo tipično razpetost med ideali nove glasbe na eni in največkrat polislogovno kompozicijsko stvarnostjo na drugi strani. Kljub temu slovensko avantgardno gibanje tridesetih let vendarle zaznamuje novo dejstvo, ki ga avantgarda dvajsetih let ni poznala $\mathrm{v}$ tako izdatni meri: mednarodna razsežnost. Prav ta pa je eden izmed pomembnejših razlogov, da je bil v tridesetih letih vendarle napravljen določen odmik od kompozicijsko-teoretične nesistematičnosti t.i. »Osterčeve kompozicijske šole«, iz katere je sicer izšla večina izmed prej omenjenih skladateljev.

Ključne besede: Alois Hába, slovenski študenti, kompozicija, Državni konservatorij v Pragi

\section{Sara Zupančič}

\section{Kačji pastir - La Libellula: Glasbena večjezičnost opere Pavleta Merkuja}

Pavle Merkù (1927-2014) se je rodil v Trstu, kjer je odraščal med različnimi jeziki in kulturami. Njegovo prvo in edino zaključeno opero $\mathrm{z}$ naslovom Kačji pastir ali La Libellula bi lahko označili za sintezo kompozicijskih prijemov in glasbenih vplivov, ki so do nastanka opere zaznamovali Merkujev opus. Različne glasbene govorice namreč karakterizirajo in razlikujejo človeške ter simbolne protagoniste: prve označuje ekspresionistična govorica, ki jo obarvajo čustva in eksistencialna stiska, simboli pa se izražajo v diatonični in objektivni govorici ljudskega petja. V operi lahko zasledimo rabo osnovnih motivov po zgledu wagnerjanskih vodilnih motivov, poleg tega italijanski operni elementi oblikujejo t. i. Grande aria tripartita per il soprano na koncu prvega dejanja, v zborovskih scenah pa so prisotne značilnosti rezijanskega ljudskega petja, ki ga je skladatelj obdelal in preoblikoval. 
Pomembna značilnost Merkujeve opere je njena dvojezičnost: izvirni libreto slovenske pesnice Svetlane Makarovič je bil preveden v italijanščino pred začetkom komponiranja opere, tako da bi lahko skladatelj uglasbil glasbene značilnosti obeh jezikov $\mathrm{z}$ ozirom na njune ritmične in melodične odtenke. Opera tako ni samo sinteza glasbenega ustvarjanja, ampak zrcali skladateljevo osebno in kulturno življenje. Na ta način se je Pavle Merkù lahko predstavil kot slovenski skladatelj, čigar materni jezik je italijanščina, in kot glasbenik, ki je globoko navezan na multietnično ozadje svojega rojstnega mesta.

Ključne besede: Pavle Merkù, opera, Kačji pastir, La Libellula 


\section{Summaries}

\section{Peter Andraschke}

\section{Vielfalt der Moderne. Die Musiktage in Donaueschingen und Baden-Baden in den 1920er Jahren}

Die Kammermusiktage in Donaueschingen 1921-1926 und ihre Fortsetzung in Baden-Baden 1927-1929 zeigen vor allem mit ihren Uraufführungen die vielfältigen Ausprägungen der Moderne zwischen Traditionsbezogenheit und Experiment. Sie waren Vorbild für zahlreiche Initiativen. In Donaueschingen bildete die Musik aus dem deutschsprachigen Raum, einschließlich der aus der ehemaligen Habsburgischen Monarchie hervorgegangenen Territorien einen Schwerpunkt. Baden-Baden wurde, nun ohne eine Begrenzung auf die Kammermusik, zum Forum aktueller Fragestellungen, das die neuen technischen Medien (Rundfunk, Hörspiel, Film, Schallplatte) einschloß, historische Gattungen aus neuer Sicht beleuchtete (Minutenoper, Kammeroper, Lehrstück, Songspiel) und die Gegensätze zwischen Kunst- und Gebrauchsmusik öffnete (Blasmusik, Musik für Liebhaber, Jugendmusikbewegung). Die Verlegung nach Berlin bedeutete nach bereits einem Jahr das Ende. Ansätze zu einem latenten Antisemitismus zeigten sich zwar bereits in Donaueschingen in den Kritiken einiger Presseorgane an der internationalen Programmgestaltung. Aber die Machtergreifung Hitlers Anfang 1933 und die daraus resultierenden Folgen bedeuteten ein Ende der zeitgenössischen Moderne in allen Bereichen der Künste. Die schloß eine Fortführung der ursprünglichen in Donaueschin- 
gen entwickelten Ideen aus. Erst nach dem Zweiten Weltkrieg wurden die neu gegründeten Donaueschinger Musiktage neben Darmstadt zu einem neuen und einflußreichen Podium der Orientierung für die internationale musikalische Moderne und Avantgarde.

Schlüsselwörter: Gebrauchsmusik, Mechanische Musik, Nationalsozialismus, Neoklassizismus, Technische Medien, Wiener Schule

\section{Matjaž Barbo}

\section{Guido Adler's doctoral student Anton Dolinar}

The paper focuses on the Anton Dolinar's study of music in Vienna. Dolinar considered to be the undisputed authority in the period between the wars in Slovenia. His pioneering work was not based solely on amateur enthusiasm, but it was highly professionally supported. Parallel to his studies at the Vienna Conservatory (since 1923), where he attended the department of church music, he listened to the lectures of musicology at the Faculty of Arts of the University of Vienna where he defends with G. Adler his doctoral thesis with the title Die Behandlung bei der Kirchentöne Palestrina (1927).

Dolinar went to Vienna after he finished his studies in theology and was ordained a priest (1917). At his return to Ljubljana he was active at the Ljubljana radio. Thoroughly educated and broad-minded musician, he participated from the very beginning in the establishment and management of the emerging radio station. He was thus a longtime editor of musical programmes of Radio Ljubljana. At the same time he conducted the Orchestra of the Ljubljana Music Society, and was devoted to a wider cultural and organisational work, journalism and teaching. After the war, in 1945, he went first to Italy, and then moved to the United States, where in 1953 he died in a car accident.

Although Dolinar was undoubtedly one of the most educated musical intellectuals of his time, active in a wide variety of areas, he became after the war unfortunately as a priest and a member of the political emigration together with his work gradually forgotten.

Keywords: Anton Dolinar, musicological study, Guido Adler, church modes 


\section{Nada Bezić}

"Intimate musical evenings" or How the Croatian Music Institute in Zagreb opened the door to modernity

Intimne muzičke večeri [intimate musical evenings] is the title of a cycle of concerts that left their mark on the musical life of Zagreb between the wars. To this day, the cycle's combination of high-quality performers and programmes, a selection of works reflecting contemporary creative tendencies in music, and remarkably informative programme notes has not been surpassed. The concerts were organised by the Croatian Music Institute ( $\mathrm{Hr}-$ vatski glazbeni zavod) in its own concert hall, but their main promoter and organiser was the institute's then secretary Artur Schneider, an art historian and at the same time a fine music critic. Between September 1922 and June 1926 the cycle included a total of 90 concerts -32 of them in the 1923/24 season alone, which is an incredible number even by today's standards.

Schneider's concerts consistently gave space to Croatian composers and the premiere performances of their works, but even more important in the international context is the fact that it was possible to hear, in Zagreb, works by Milhaud and Poulenc within just a few years of their completion. A concert in 1924 included compositions by Casella, Malipiero, Santoliquido and Castelnuovo-Tedesco, alongside works by Schoenberg, Bartók and others. Schneider obtained the scores from publishers (such as Chester of London) or with the help of cultural institutions in Zagreb, particularly the Institut Français.

Also notable is the fact that Artur Schneider forged ties with the International Society for Contemporary Music (ISCM) and in 1925 became its secretary for Yugoslavia. The ISCM's Yugoslav branch was, in fact, based in Zagreb (until 1930).

Keywords: Croatian Music Institute, Zagreb; Artur Schneider, concerts, contemporary music

\section{Katarina Bogunović Hočevar, Ana Vončina \\ The first decade of Radio Ljubljana - the media, the institution and its ideology in the light of music}

In order to understand the early years of Radio Ljubljana, it is necessary to shed some light on the context of the beginnings of wireless telegraphy and telephony in Europe and the then Kingdom of Yugoslavia, where a network of more or less interconnected radio stations began to form. Radio Ljubljana did not only represent a new development at the technological level in its 
efforts to follow European trends, it penetrated more deeply and more widely into the Slovene region than any media before it. In the field of music, Radio Ljubljana made a contribution at a number of levels: music occupied the biggest share of radio programming. The music it broadcast had a range of origins: it could be music performed by the radio station's own quartet (later orchestra) in the studio, music by outside performers, live broadcasts of operas at home and abroad, or music from gramophone records. The musicking did not only manifest itself in the context of the production/reproduction of various types of music, but also at the level of radio broadcasts about music and musicians. An important role was also played by Radio Ljubljana's own newspaper, which now provides us with information on the programming of domestic and foreign radio stations at the same time as shedding light on those topics that conditioned the gradual formation of the new institution. Like every other institution, Radio Ljubljana was also „burdened“ by a specific ideology. This may be observed both at the institutional level (the new management and the founding of the weekly newspaper Novi Val [New Wave]) and in the musical orientation of the programming.

Keywords: Radio Ljubljana, music, media, institution, ideology, Prosvetna zveza, Anton Dolinar

\section{Ivan Florjanc}

\section{The creativity of the composers of the Primorska region during the italian occupation in the fascist period - social, compositional and stylistic insights}

Following the signing of the Treaty of Rapallo on 12 November 1920, the whole of Slovene Primorska (corresponding to those parts of the three provinces of the former Austrian Küstenland/Litorale historically inhabited by Slovenes) passed, along with its hinterland (despite the objections of US president Woodrow Wilson), under Italian control, where it remained until 1945 (and where a part still remains today). The situation worsened considerably after Mussolini and Pašić signed the secret Treaty of Rome between Italy and Yugoslavia on 27 January 1924, an event which coincided with heightened terror ramped up by the new Fascist party and the total suppression of the public life of the Slovenes in Primorska. Subsequent events saw a further deterioration, eventually culminating in the "cultural genocide" and linguistic ethnic cleansing of Primorska (after 1926). In these conditions, it was the composers in the Primorska region - in addi- 
tion to the TIGR, a covert insurgent organisation consisting of the clergy and others - who developed a remarkably perceptive strategy of deliberate non-violent resistance to the intensification of Fascist aggression over the Primorska Slovenes. This is clear from the powerful and harmonised creative charge of composers (E. Komel, L. Bratuž, V. Vodopivec, even in part M. Kogoj, among others), who developed a particular, spontaneous and effective form of communication between poets (L. Šorli, F. Terčelj, V. Bele, S. Stanič, etc.) and composers. The latter deliberately dedicated their works to the spiritual and human culture of their fellow Slovenes. This effort also resulted in interesting stylistic offshoots in many composers of the interwar period. Recently a deliberate process of collecting, cataloguing, digitising and publishing the works of individual composers has been under way in order to safeguard them from destruction and oblivion.

Keywords: Primorska region, music as a form of non-violent resistance, Fascism, Slovene-Italian relations, 2oth century

\section{Luba Kijanovska}

\section{Ukrainische Komponistenschule in der Zwischenkriegsperiode des XX Jahrhunderts: Zwischen Modernismus und sozialistischem Realismus}

Die ukrainische Komponistenschule am Anfang des XX. Jahrhunderts integrierte sich sehr erfolgreich in den europäischen Kulturraum. Dieser natürliche Prozess war radikal gebremst und gebrochen durch die ungünstigen politischen Umstände in der sog. „Ukrainischen Sowjetischen Sozialistischen Republik", besonders in 30-er Jahre mit ihrer tragischen Kulmination - „Erschossene Renaissance“. Denn pendelte sich die nationale Musikkultur zwischen zwei entgegengesetzten Pole: der natürlichen Strebung zu den innovativen ästhetischen und stilistischen Tendenzen (Expressionismus, Neoklassizismus, Neofolklorismus etc.) - und dem sozialistischen Realismus, der obligat für die kommunistische Ideologie war. Diese Konfrontation führte zu den tragischen Konsequenzen für die führenden ukrainischen Komponisten wie Borys Latoschynskyj, Lewko Rewutskyj, Mychajlo Werykiwskyj, Pylyp Kozytskyj etc. Um sich zu retten, versuchen sie diese neue kompositorische Technik auf Grunde der nationalen Folklore adaptieren, aber es half auch nicht immer. So wurden solche talentvolle Musiker wie Hnat Chotkewytsch, der moderne Ausdruckssystem auf das spezifische Timbre der ukrainischen Volksinstrument Bandura bezogen hat, oder Wassyl Werchowynec', der das System von Émile Jaques-Dalcro- 
ze's zu ukrainischem Volkstanz angepasst hat, - verfolgt, dann verhaftet und im Jahr 1937 vernichtet.

Die ideologischen Hindernisse waren nicht in der Lage, die ukrainischen Komponisten zu verhindern, die moderne musikalische Sprache nach ihren Überzeugungen zu benutzen, so dass sie eine brutale Kritik an ideologischen Organen erlitten hatten. Jede Neuerung wurde als „Verehrung des bürgerlichen Westens", dementgegen national-charakteristische Thematik - als „bürgerlicher Nationalismus“ erklärt. Zum Beispiel wurde Latoschynskyj von seinen „Notizhaken, die nach dem Westen schauten“ beschuldigt. Um die kreative Arbeit und sogar das Leben zu retten, mussten die Künstler die Kompositionen im Geist des sozialistischen Realismus schreiben. So kann man ein Paradox von ambivalenten individuellen Stilen beobachten, wenn im Schaffen des Komponisten benachbarten originelle innovative Werke - und ideologisch bedingte Opera, wo die Autoren bewusst ihr eigenes Expressionssystem auf den Stil des 19. Jahrhunderts beschränkten, vor allem auf das Erbe von „Mächtiges Häuflein“ und Tschaikowski. Die Folklore diente oft als eigenartige Brücke zwischen den Pole der Moderne und des sozialistischen Realismus, durch die erfinderische Verwendung, die es den Komponisten man erlaubte, die kühnsten kreativen Ideen anzuwenden, ohne der gnadenlosen kommunistischen Kritik ausgesetzt zu sein. Schlüsselwörter: Modernismus, sozialistischer Realismus, ukrainische Musik, Kanon der Kunst, stilistische Tendenzen

\section{Darja Koter}

\section{The ideological and artistic identity of youth choirs between the wars}

In keeping with the social changes and to come closer to the Europe-wide contemporary music styles, the period between the two world wars was conducive to youth choral singing, which was a universal step up from the previously prevailing conventional class singing. Following the Czech model, this was initially manifested in the establishment of teachers' choirs, which advocated a more contemporary repertoire of Slovene and Slavic composers, while the singers were taught the vocal and conducting techniques and encouraged to establish and lead youth choirs. The merit for this transition to "the new" mostly belongs to art ideologist Stanko Vurnik, composer and choir master Emil Adamič and two teachers from the Primorska region, Srečko Kumar and Avgust Šuligoj. These two teachers were vital in the creation and promotion of the young Slavic music literature for youth 
choirs, which finally detached itself from the previously prevalent national-awakening and moral subject-matters, and preference for the romantic style. This "new" music followed the contemporary compositional and literary impulses of the time, it developed its style and called attention to the current societal circumstances, particularly social conditions. A model example of a youth choir, both socially and musically, was the Trboveljski slavček choir, which was founded and led by Avgust Šuligoj, and achieved recognition across Europe, comparable to that of the Vienna Boys' Choir. Slovene and other composers from what was then Yugoslavia composed around 800 pieces for the choir, which performed them at concerts and radio stations in Slovenia and internationally, disseminating the artistic and social mission of youth choral singing throughout Slovenia. The year of 1934 was a particular milestone as this is when the first youth choir festival took place in Ljubljana. The long-term impact of this resounding event could be seen in the growing number of new youth choirs, the expansion of the programme, which was contemporary from the artistic as well as general aspect, and comprehensive singing training. Although WWII put a violent stop to the flourishing tradition of youth choral singing, the tradition survived with the resumption of activities after 1945. The new times imbued choral singing with a different mission, new conceptual views, and ideologically tinted repertoires, while virtually no trace of the pre-war modernists could be detected in the composition principles. Either unintentionally or by design, the youth choir leaders followed socialist principles, which allowed no room for the latest composition techniques from the West.

Keywords: youth choral singing, music literature, Emil Adamič, Srečko Kumar, Avgust Šuligoj, Trboveljski slavček

\section{Hartmut Krones}

\section{Sprechen und „Sprechgesang“ als Ausdrucksform}

für sozialkritische Inhalte in der Musik

\section{der Zwischenkriegszeit}

Seit Schönbergs Pierrot lunaire ist der "Sprechgesang“ ein unorthodoxes Medium für unorthodoxe Inhalte, bald aber in erhöhtem Maße für sozialkritische und politische Aussagen. Zusätzlich verschärft wurde diese Ausdrucksform durch eine bald geradezu systematisiert eingesetzte Palette, die von reinem Sprechen bis hin zu "traditionellem Singen“ reichte, wobei für die besonders scharfen, politisch anklagenden Aussagen bevorzugt das reine Sprechen eingesetzt wurde. Neben Arnold Schönberg (so in Moses 
und Aron) und bald auch Alban Berg (so im Wozzeck) war es vor allem Wladimir Vogel, der in Liedern sowie in oratorienähnlichen Formen die gesamte Bandbreite dieser Palette einsetzte, aber auch „politische Komponisten“ wie Ernst Toch, Hanns Eisler, Paul Amadeus Pisk oder Berta Lask schrieben vor allem reine Sprechchöre, um ihre Botschaften durch möglichst große Chöre besonders eindringlich vermitteln zu können. Das Referat gibt einen Überblick über die Szene und analysiert an Hand einiger Beispiele kompositionstechnische Details sowie Ausdrucksebenen dieser Werke.

Schlüsselwörter: Sprechchor, Sprechgesang, politische Musik, Futurismus, Dadaismus

\section{Helmut Loos}

\section{Heilige Nüchternheit. Der Komponist in der Moderne. Kontinuität statt Bruch}

Inwieweit die romantische Musikanschauung trotz aller zivilisatorischer Kritik am „langen 19. Jahrhundert“ weiter existiert hat, ist umstritten. Das Selbstverständnis der Künstler, insbesondere der Musiker, war jedenfalls ungebrochen, als Ausnahmeerscheinungen in der Menschheitsgeschichte eine herausragende Position einzunehmen und eine führende Rolle in der Gesellschaft zu spielen. Der Komponist als Schöpfer war davon in erster Linie betroffen, der Dirigent präsentierte die Rolle als Führer der Gemeinschaft am wirkungsvollsten. Das zugrundeliegende Bild lässt sich bei so gegensätzlichen Komponisten finden wie Hans Pfitzner, Ferruccio Busoni oder Paul Hindemith.

Schlüsselwörter: Kunstreligion, romantische Musikanschauung, neue Sachlichkeit, Künstlerbild, Jugendmusikbewegung

\section{Andrej Misson}

\section{Some thoughts on Slovene choral composition between the two world wars}

The author begins with a discussion of the general historical facts affecting choral music and its composition in the interwar period. Choral music was torn between the need to adapt to the capabilities of Slovene choirs at that time and the desire of composers to keep pace with the modern artistic achievements of contemporary European musical creativity. Immediately after the war there was an evident enthusiasm among composers for the new homeland, reflected in the composition of patriotic songs dedicated to 
it. This enthusiasm, however, soon waned. The introductory section is followed by brief reflections on choral composers, performers, choirs, choir directors and, finally, listeners. Composers were well trained. Many of them wrote in a traditional, post-Romantic style, while others took new directions (Kogoj, Osterc). They published their works in music periodicals, via publishing houses or in self-published form. They composed for numerous choirs, including at least some at the very highest level, capable of performing the most demanding pieces. Attention was also paid to listeners and to their musical education. In the second part, the author offers some examples of the interwar choirs of selected Slovene composers from different generations (Foerster, Adamič, Lajovic, Vodopivec, Premrl, Kogoj, Osterc, etc.).

Keywords: musical composition, choral music, Slovenian choral music, music theory, musicology

\section{Niall O'Loughlin \\ Slavko Osterc's Compositional Journey and his Assimilation of New Techniques}

The composing career of the leading Slovene composer Slavko Osterc (18951941) spanned twenty years from 1921 to 1941 . There are some forty compositions of his written in Slovenia dating from 1921-25, reportedly somewhat immature, but showing numerous very interesting features. His studies in Prague (1925-27) with Jirák and Alois Hába gave him a grounding in new techniques. After returning to Slovenia, during the years 1927-30 Osterc composed chamber music miniatures often harmonically discordant, interestingly scored and neo-classical in style and vocal music. The latter included the intense Gradnik songs, four mini-operas characterised by a wry sense of humour and the full-length opera Krog s kredo which presents a wide-ranging synthesis of his stylistic traits at this stage in his development. Notable is the way that apparent set-pieces such as arias, recitatives and choruses are seamlessly joined by skilful transitions; significant too are harmonies that often contradict the possible tonal-harmonic implications of many of the vocal lines. From 1930 Osterc extended his melodic, harmonic and contrapuntal techniques and importantly developed his far-reaching ideas of formal construction. This is found especially in single-movement multi-tempo works such as the Passacaglia in koral, the Mouvement symphonique and the symphonic poem Mati, as well as in the unusual formal plans of the Nonet, String Quartet No.2, and the Saxophone 
and Cello Sonatas. Osterc also became very active with the International Society for Contemporary Music (ISCM) making contacts with many forward looking composers and their music from all over Europe. Osterc's music is not today considered especially advanced according to Western European criteria, even if much of his music is still relatively little known. His music explored new formal workings, however, and a harmonic idiom that verged on atonality and twelve-note working rather than strict serial technique. It is now understood and appreciated on its own terms, that is, without too much reference to the ideas of modernism. In all ways, however, Slovene music developed enormously under his influence.

Keywords: Slavko Osterc, Slovenia, Prague, Interwar years, new techniques, new forms

\section{Gregor Pompe \\ Slavko Osterc and Lucijan Marija Škerjanc: aesthetic division and poetic brotherhood}

Even today Slovene musical life seems to be characterised by the tension between the different schools represented by two composers: Slavko Osterc (1895-1941) and his contemporary Lucijan Marija Škerjanc (1900-1973). Oba lahko razumemo kot izstopajoča predstavnika slovenske glasbe med obema svetovnima vojnama, pri čemer njuna vplivnost ni izhajala le iz recepcije njunih del, temveč predvsem iz pedagoškega dela: Osterc je pomembno zaznamoval predvojne generacije, ki so študirale na Konservatoriju Glasbene matice oz. Državnem konservatoriju, Lucijan Marija Škerjanc pa kot dolgoletni profesor na Akademiji za glasbo po koncu druge svetovne vojne. Estetska usmeritev obeh skladateljev se zdi na prvi pogled zelo jasna in nasprotna: Osterc je po izkušnji praškega študija sledil novim glasbenim tokovom in zagovarjal radikalni odklon od glasbenih tradicij, tudi poudarjenega subjektivizma, medtem ko je Škerjanc ostajal zvest izrazni estetiki 19. stoletja in razširjeni tonalnosti moderne in impresionizma še globoko v drugo polovico 2o. stoletja. Takšna pozicija ni razberljiva le iz njunih del, temveč tudi programatskih zapisov. Toda na ravni poetike se zdi, da sta bila oba zapisana precej podobni obrtni logiki: ko sta se enkrat dokopala do lastne glasbene "govorice «, sta v njej vztrajala in nista iskala bistveno novih vzpodbud, niti pomembnejših zunajglasbenih vsebin, s katerimi bi napolnila svoje umetnine. Njuno delo je mogoče oceniti visoko predvsem s stališča kompozicijsko-tehnične dovršenosti, ki je bila v obdobjih pred njim $\mathrm{v}$ slovenski glasbi precejšnja redkost. The paper will reveal how it is necessary 
to consider Osterc's and Škerjanc's creative endeavours within the common context of Slovene music between the wars, a context that left more shared traits in their work than we are usually prepared to admit.

Keywords: Slavko Osterc, Lucijan Marija Škerjanc, Slovenian music, 2oth Century music, musical poetics

\section{Karmen Salmič Kovačič}

\section{On the polystylistic nature of classicist modernism following the revelation of the "Adornian fallacy" - in examples from the works of Demetrij Žebrè}

The paper begins by looking at some key doubts about the Adornian mode of thinking that shaped understanding of avant-gardism, traditionalism and modernism throughout a lengthy period of the twentieth century in the majority of theorists, philosophers, historians and creators of music. In the post-modernist period, a clearer picture began to form of its nationally and ideologically conditioned construction of the musical history of the twentieth century, or musical modernism, which various thinkers and writers today increasingly frequently identify as a "fallacy“. In the light of the latest conception, "pluralist“ modernism is gaining clearer outlines in contrast to „constructivist pluralism“. One of its significant characteristics is its polystylistic nature within the context of "broadly inclusive“ classicist modernism or modernist classicism. The latter two terms were introduced by Hermann Danuser, who uses them to designate the broad current of modernist works by composers from the first half of the twentieth century who incorporated elements of tradition into their works merely as the building blocks of new music in a variety of ways and at various compositional levels. In the second part of the paper we will attempt to present polystylism as the consequence of the pluralism of compositional techniques through analysis of a number of works by a Slovene composer from Osterc's circle Demetrij Žebrè (1912-1970).

Keywords: »Adornian fallacy«, classicist modernism, Slovenian music, the 2oth century, Demetrij Žebrè

\section{Lubomír Spurný \\ Work and performance: A few comments on the Czech modern music}

The study describes development of performance in the Czech music. For example, composer and pianist Erwin Schulhoff, Karel Reiner, Alois Hába, 
E. F. Burian, cellist Váša Černý and clarinetist Milan Kostohryz expressed their opinions on the topic of interpretation. Area that appears most suitable for processing is chamber music and particularly one specific part, so called "Czech quartet school." It is one of few artistic activities in the field of Czech musical culture where we can observe the continual development with all eventual divides and deviations. The founding significance belongs to the Bohemian Quartet. In the beginning of the 2oth century it was primarily the Ševčík-Lhotský Quartet, Zika's (Czechoslovak) and Prague Quartets. Interpretation of the Bohemian Quartet especially began to change with the inventions of the phonograph and a gramophone record. The fact that music can be written not only in the sheet but also as a sound, not only its progression but also qualities elusive in the notation, redirects the attention to topical and currently ongoing flow of music. Here we can also find the impulse (which is often overlooked) of the development of new tradition of performance.

Keywords: Czech music, musicology, performance, score, interpretation research, analysis of recorded music

\section{Jurij Snoj \\ The Concept of Music in the Writings of Three Slovenian Interwar Music Essayists}

In Slovenia, a large amount of various articles on music came into being during the interwar period. Among the writers discussing issues of musical aesthetics, the most importeant were: the composer Anton Lajovic (18781960), the composer Marij Kogoj (1892-1956), and the art historian Stanko Vurnik (1898-1932). The three developed different views on music which may be interpreted also from the point of view of their personal careers. Lajovic was a witness of the time as the German cultural supremacy was being misused for specific polical purposes. He rejected the cultural internationalism as a pretext for the domination of one nation over the others; he was convinced that Slovenian music could prosper just as a national musical culture taking part in a strong yet healthy international competition. Kogoj was a forward looking composer of his time. In opposition to Lajovic he regarded music as expression of an outstanding personality. As such music, in his view, cannot remain limited to the boundaries of the nation; to be artist therefore does not concern the nation but rather the whole humanity. Still another approach to the qestions of music can be encountered in the writings of Vurnik, who was interested especially in the development 
of musical styles and the principles guiding this development. Following his teacher, the art historian Izidor Cankar, Vurnik believed that through the history of musical styles basic ideas in the history of the European culture can be discerned.

Keywords: aesthetics of music, Slovenian cultural history, history of Slovenian music

\section{John Tyrrell \\ Janáček's maestoso}

Apart from a few words such as espressivo and dolce Janáček avoided expression markings in his scores. There is one exception: the word maestoso, which can be found in his earliest opera up to his final opera, From the House of the Dead. The term maestoso emerged in the eighteenth century and is used, for instance by Haydn in slow introductions to some of his symphonies. Its use greatly increased in nineteenth-century orchestral music; Czech nationalists, starting with Smetana, harnessed it as a useful signifier of nationalist content. Janáček followed this tradition in his first opera Šárka and in a few, patriotically-inclined works around the creation of an independent Czechoslovakia. But he used the term in several other ways: as a structural marker at the end or towards the end of an act or movement; to highlight important words or moments in a work, or, very occasionally, to suggest an otherworldly atmosphere. Janáček's use of maestoso is demonstrated and categorized throughout his oeuvre and is then contrasted with the puzzling use of the term in From the House of the Dead (1928). In this opera completed shortly before his death, Janáček extends the term to dignify and show compassion for the criminals held in a Siberian prison camp. Keywords: Janáček, Smetana, Dvořák, maestoso

\section{Jernej Weiss}

\section{Alois Hába and Slovene students of composition at the State Conservatory in Prague}

The paper attempts to determine the influence of Alois Hába, one of the greatest innovators of the interwar period, on his Slovene students in terms of compositional ideas. Notable Slovenes who took Hába's course in quarter-tone composition at the State Conservatory in Prague include Slavko Osterc (1926-27), Pavel Šivic (1931-33), Marijan Lipovšek (1932-33), Franc Šturm (1933-35), Demetrij Žebre (1934-36) and the now forgotten Ivan Pučnik (1935-36). Following their return from Prague, these composers played an extremely important role in shaping musical life in Slovenia. 
Although in the 1920 and 1930 s they shared a fairly uniform belief in the need for new musical perspectives, they realised this in compositional ter$\mathrm{ms}$ in a variety of ways. Most of these composers adapted Hába's constructivist procedures in a fairly original manner, rather as, in practically the same period, they did not feel the need for a consistent use of atonality or twelve-tone technique. Naturally it is also possible to trace in them, alongside Hába's influence, references to many other more or less influential composers amid the diverse wealth of compositional approaches of the twentieth century. In practice, however, their studies in Prague characterised in many ways a typical split between the ideals of new music on the one hand and what in most cases was a polystylistic compositional reality on the other. Despite this, the Slovene avant-garde movement of the 1930s was also characterised by a new fact that had not been present in such abundance in the avant-garde of the 1920s: the international dimension. This is in fact one of the more important reasons why the 1930s saw a certain retreat from the non-systematic approach (in terms of compositional theory) of the "Osterc School" of composition, from which the majority of the aforementioned composers in fact came.

Keywords: Alois Hába, Slovene students, composition, State Conservatory in Prague

\section{Sara Zupančič}

\section{Kačji pastir - La Libellula: Musical multilingualism in Pavle Merkù's opera}

Pavle Merkù (1927-2014) was born in Triest and was close to several linguistic and cultural sources since he was a child. His first and only complete opera Kačji pastir or La Libellula (The Dragonfly, in English) could be considered a synthesis of musical resources and influences of the composer until then. Different musical languages are used within it to characterize and differentiate human characters from symbolic ones: namely, an Expressionistic style illustrates existential anguish and emotions of the former, whereas the latter use a diatonic and objective language derived from folk singing. Wagnerian influences can also be traced in the use of recurring motifs throughout the opera, while Italian operatic elements are present in the so-called Grande aria tripartita per il soprano at the end of Act I and Slovenian choral chanting from Resia valley, modified and reworked, is brought up in choral scenes. 
A striking feature of Pavle Merkù 's opera is its bilinguism: the original libretto by Slovene poet Svetlana Makarovič was translated into Italian before the composition started, so that the composer could set it to music with the characteristics of both languages in mind as they are regarded to the issues of rhythm and melody. Hence, not only is Merkù's opera the synthesis of a musical career, but it also reflects his personal and cultural life. Through this work, he presents himself both as a Slovene composer whose mother tongue is Italian and as a musician profoundly related to the multiethnicity of his own hometown.

Keywords: Pavle Merkù, opera, Kačji pastir, La Libellula 



\section{Avtorji}

Peter Andraschke (p.andraschke@kabsi.at)

je študiral glasbeno pedagogiko, muzikologijo, germanistiko in etnografijo v Münchnu, Berlinu ter opravil državni izpit, doktorat in bil habilitiran v Freiburgu im Breisgau. Do leta 2005 je bil profesor glasbene zgodovine na Univerzi Justusa Liebiga v Gießnu. Od leta 2005 do leta 2008 je bil gostujoči profesor na Znanstvenem centru Arnolda Schönberga Univerze za glasbo in upodabljajočo umetnost na Dunaju. $\mathrm{V}$ tujini je bil večkrat gostujoči profesor, predaval in poučeval. Objavil je številna dela o glasbeni zgodovini po letu 1750 s težiščem na glasbi 19. in 20. stoletja, glasbi v vzhodni Evropi, glasbeni analizi, glasbeni folklori, kot tudi na odnosu med pesništvom, upodabljajočo umetnostjo in glasbo.

\section{Matjaž Barbo (matjaz.barbo@ff.uni-lj.si)}

je predstojnik Oddelka za muzikologijo Filozofske fakultete Univerze v Ljubljani. Je avtor več knjig in znanstvenih prispevkov, bil je predsednik Slovenskega muzikološkega društva ter dolgoletni urednik revije Muzikološki zbornik. V svojih raziskavah se posveča glasbi od 18. stoletja do danes, zlasti $\mathrm{v}$ povezavi s slovenskim kulturnim življenjem, pa razvoju simfonične glasbe ter izbranim glasbeno-estetskim vprašanjem. 


\section{Nada Bezić (nada.bezic@zg.t-com.hr)}

je voditeljica knjižnice Hrvaškega glasbenega zavoda (HGZ) v Zagrebu, kjer je zaposlena od leta 1988. Muzikologijo je diplomirala, magistrirala in doktorirala (2011) na Glasbeni akademiji v Zagrebu in diplomirala bibliotekarstvo na Univerzi v Zagrebu (1992). Glavna področja njenega raziskovanja so zgodovina HGZ-a (npr knjiga o Društvenem orkestru HGZ-a, 2009) in glasbeno življenje $\mathrm{v} Z$ Zagrebu $\mathrm{v}$ 19. in 20. stoletju oziroma na glasbeno topografijo: knjige Glazbena topografija Zagreba od 1799. do 2010. (2012 ) in Glazbene šetnje Zagrebom (2016). Tehnični je urednik projekta Sabrana djela Blagoja Berse HGZ-a, v katerem je skupaj z Evo Sedak uredila knjigo Blagoja Berse Dnevnik i Uspomene (2010). Sodelavec je Tretjega programa Hrvaškega radia; sourednik dva muzikološka zbornika, avtor več seznamov skladb hrvaških skladateljev, več kot 100 znanstvenih in strokovnih člankov in razstav o temah iz zgodovine hrvaške glasbe.

\section{Katarina Bogunović Hočevar (Katarina.BogunovicHocevar@ff.uni-lj.si)}

je docentka na Oddelku za muzikologijo Filozofske fakultete v Ljubljani, kjer je tudi zaposlena. Njeno področje raziskovanja je zgodovina glasbe 19. in prve polovice 20. stoletja, zgodovina slovenske glasbe, analiza in estetika glasbe. Znanstvene članke objavlja $\mathrm{v}$ domačih in tujih revijah. Bila je tudi urednica in sourednica strokovnih ter znanstvenih publikacij. Sodeluje je z vsemi najpomembnejšimi domačimi glasbenimi ustanovami, za katere je pripravljala in še pripravlja strokovne publikacije, strokovna besedila, glasbene oddaje, in razstave (Cankarjev dom, Slovenska filharmonija, RTV Slovenija, NUK, DSS, Festival Ljubljana, Festival Brežice).

\section{Ivan Florjanc (ivan.florjanc@guest.arnes.si)}

je skladatelj, raziskovalec in učitelj. Leta 1981 je diplomiral na TF v Ljubljani. Študij glasbe je zaključil leta 1989 z magisterijem iz kompozicije na Papeškem inštitutu za sakralno glasbo v Rimu z oratorijem Abraham in Isaac za soliste, zbor in orkester. Do leta 2004 je na isti ustanovi predaval. Leta 1999 se je habilitiral tudi na AG, kjer je redni profesor za kompozicijske in glasbenoteoretične predmete. Skladateljsko ga odlikuje izrazito polifono zastavljen vokalni, komorni in orkestralni opus (nad sto enot). Raziskovalno je pisec poglobljenih glasbenoanalitičnih monografij in člankov (nad stopetdeset enot) s poudarkom na zgodovinsko-teoretičnih in modroslovnih izhodiščih. 


\section{Luba Kijanovska (luba.kyjan@gmail.com)}

je študirala muzikologijo na Državnem konservatoriju "Mikole Lisenka" v Lvovu (1979). Doktorirala je leta 1985 (Funktionen des Programms in der Wahrnehmung des Musikwerkes), habilitirala se je leta 2000 (Die Evolution der galizischen Musikkultur der XIX.-XX. Jahrhunderte); leta 1987 je bila izvoljena v naziv docentke in leta $1995 \mathrm{v}$ naziv profesorice. Od leta 1991 je vodja katedre za glasbeno zgodovino na Državni glasbeni akademiji »Mikole Lisenka« v Lvovu. Osrednje teme njenih raziskav so glasbena kultura Galicije, glasbena psihologija, zgodovina ukrajinske glasbe, ukrajinska glasba v odnosu do drugih evropskih glasbenih nacionalnih šol, glasbena pedagogika. Je avtorica 6 monografij, 8 učbenikov in približno 400 referatov v znanstvenih zbornikih in revijah (Ukrajina, Poljska, Nemčija, Avstrija, Slovenija, ZDA, Litva, Rusija itd.).

\section{Darja Koter (darja.koter@ag.uni-lj.si)}

je redna profesorica za zgodovino glasbe na Akademiji za glasbo Univerze v Ljubljani. Raziskovalno se ukvarja s historičnimi instrumenti, z glasbeno ikonografijo, zgodovino glasbene poustvarjalnosti in opusi slovenskih skladateljev. Sodeluje v raziskovalnih projektih Univerze v Bonnu in Univerze v Ljubljani. Monografije: Glasbilarstvo na Slovenskem (2001, 2004), Musica coelestis et musica profana. Glasbeni motivi v likovni dediščini od severne Istre do Vremske doline (2008), Slovenska glasba 1848-1918 (2012), Slovenska glasba 1918-1991 (2012). Je dobitnica Mantuanijevega priznanja za dosežke v muzikologiji (2014).

\section{Hartmut Krones (Krones@mdw.ac.at)}

je študiral glasbeno pedagogiko, germanistiko, petje, pedagogiko petja in muzikologijo; od leta 1970 poučuje na Akademiji (danes Univerzi) za glasbo in upodabljajočo umetnost na Dunaju; do septembra 2013 je vodil Inštitut za raziskovanje glasbenih slogov (oddelka Stilistika in poustvarjalna praksa in Znanstvenega centra Arnolda Schönberga). Je avtor številnih člankov o poustvarjalni praksi stare in nove glasbe, glasbeni simboliki in retoriki, glasbi 2o. stoletja (vključno z Musik in der Emigration in "NS-Geschichte“ der A.K.M.) ter knjig, med drugim o življenju in delu Ludwiga van Beethovna in Arnolda Schönberga. Sodeloval je pri pripravi Musik in Geschichte und Gegenwart (član strokovnega sveta za področje Avstrija/2o. stoletje), New Grove Dictionary in Historische Wörterbuch der Rhetorik. Je urednik izdaje spisov Kritischen Gesamtausgabe der Schriften Arnold Schönbergs, ki je leta 2016 začela izhajati v prvih zvezkih. 


\section{Primož Kuret (primoz.kuret@gmail.com)}

je leta 1954 maturiral na Klasični gimnaziji v Ljubljani, leta 1959 z odliko diplomiral na Akademiji za glasbo (glasbena zgodovina) in na Filozofski fakulteti (umetnostna zgodovina). Leta 1960 je dobil Prešernovo nagrado za študente. Promoviral je leta 1965 na Filozofski fakulteti v Ljubljani. Leta 1978 je postal docent, od 1983 izredni in od 1988 redni profesor za svetovno glasbeno zgodovino in za zgodovino slovenske glasbe na Akademiji za glasbo v Ljubljani. Večkrat je bil predstojnik oddelka za glasbeno pedagogiko, v letih 1993-2001 prodekan Akademije za glasbo, v letih 2000-2004 pa predsednik Slovenskega muzikološkega društva. Med leti 1973 in 1987 je urejal Revijo GM (glasbene mladine), več let je vodil različne odbore, član UO Prešernovega sklada in predsednik njegove komisije za glasbo. Med leti 2001 in 2005 je vodil Nacionalno komisijo za vsebinsko prenovo glasbenega šolstva. Leta 1986 je skupaj s skladateljem M. Stibiljem ustanovil Slovenske glasbene dneve $\mathrm{z}$ vsakoletnim mednarodnim muzikološkim simpozijem. Med pomembnešimi priznanji so medalja Češke republike (1985), častni član Accademie Filarmonica di Bologna (2001), Betettova listino (2003), Herderjeva nagrada na Dunaju ter avstrijski častni križ za znanost in umetnost I. reda za zasluge na področju muzikologije (2005), državna nagrada Republike Slovenije za življenjsko delo na področju glasbenega šolstva (2005), Mantuanijeva nagrada (2006), red za zasluge Republike Slovenije (2012). Sodeloval je na številnih mednarodnih muzikoloških simpozijih, kjer je predstavljal slovensko glasbo (Belgija, Bolgarija, Češka, Hrvaška, Italija, Kanada, Latvija, Litva, Luxemburg, Nemčija, Norveška, Romunija, Švica, Slovaške, Slovenija in Turčija).

Med pomembnejšimi deli so: Glasbeni instrumenti na srednjeveških freskah v Sloveniji (1973), Glasbena Ljubljana 1899-1919 (1985), Glasba in družba (1988), Mahler in Ljubljana (1997 in 2011, razširjeni nemški prevod je izšel 2001 na Dunaju), Slovenska filharmonija - Academia philharmonicorum 1701-2001 (2001), Zgodbe o glasbi in glasbenikih (2004), Slovenski skladatelji $v$ portretih Saše Šantla (skupaj z Vereno Koršič Zorn, 2005), Ljubljanska filharmonična družba 1794-1919 (2005), 100 let Slovenske filharmonije (2008), Zanesenjaki in mojstri (2011). - V domačih in tujih publikacijah (Avstrija, Bolgarija, Češka, Italija, Japonska, Nemčija, Slovaška) je objavljal razprave o slovenski glasbi. Bil je vabljeni predavatelj na univerzah v Münchnu in v Freiburgu im Breisgau. 


\section{Helmut Loos (hloos@uni-leipzig.de)}

je študiral glasbeno pedagogiko v Bonnu (državni izpiti), nato muzikologijo, umetnostno zgodovino in filozofijo na Univerzi v Bonnu; leta 1980 je promoviral, leta 1989 pa habilitiral. Od leta 1981 do leta 1989 je bil znanstveni sodelavec na Oddelku za muzikologijo Univerze v Bonnu. Med letoma 1989 in 1993 je bil direktor Inštituta za nemško glasbo na Vzhodu v Bergisch Gladbachu. Od aprila 1993 je bil predstojnik katedre za historično muzikologijo na Tehniški univerzi v Chemnitzu, od oktobra 2001 do marca 2017 pa na Univerzi v Leipzigu.

22. oktobra 2003 je bil imenovan za zaslužnega profesorja Glasbenega konservatorija Mikole Lisenka v Lvovu. Od leta 2003 do leta 2005 je bil dekan Fakultete za zgodovino, umetnost in orientalistiko Univerze v Leipzigu. Leta 2005 je postal častni član društva za nemško glasbeno kulturo v jugovzhodni Evropi v Münchnu in od leta 2014 je častni doktor Nacionalne glasbene univerze $\mathrm{v}$ Bukarešti. Je član mednarodnih uredniških svetov revij Hudební věda (Praga), Lituvos muzikologija (Vilna), Menotyra. Studies in Art (Vilna), Ars \& Humanitas (Ljubljana), Musicology Today (Bukarešta), Muzica: Romanian Music Magazine (Bukarešta) in Studies in Penderecki (Princeton, New Jersey).

\section{Andrej Misson (andrej.misson@siol.net)}

je slovenski skladatelj, raziskovalec, strokovnjak za glasbeno teorijo in kompozicijsko tehniko kontrapunkt, pedagog, zborovodja, organist ter poustvarjalec na orglah, klavirju in čembalu. Je izredni profesor na Akademiji za glasbo za teoretske in kompozicijske predmete. Njegov skladateljski opus sega na raznovrstna področja. Med večjimi stvaritvami so skladbe: Himna evropski Sloveniji za zbor in orkester, Slovenski vojni requiem za solista, mešani zbor in orkester, kantata Primorska za moški zbor in orkester, Tea 4Two za orkester, Dim nad vodo za orkester, božični Te Deum za zbor in orkester. Ustvarja tudi solistično, komorno glasbo, zbore, pesmi, šansone. $\mathrm{V}$ raznih strokovnih revijah je objavil več glasbenoteoretičnih člankov. Živi in ustvarja v Škofji Loki.

\section{Niall O'Loughlin (N.Oloughlin@lboro.ac.uk)}

je študiral na univerzah v Edinburgu in Leicestru. Specializiral se je za področje slovenske, angleške in poljske glasbe 20. stoletja. Leta 2000 je bila v Ljubljani izdana njegova knjiga Novejša glasba $v$ Sloveniji. Objavil je številne članke v revijah Muzikološki zbornik, publikacijah ob Slovenskih glasbenih dnevih, v revijah The Musical Times in Tempo ter prispeval posame- 
zna poglavja v številnih knjigah in različnih izdajah New Grove Dictionary of Music. Leta 2007 je bil izvoljen za dopisnega člana Slovenske akademije znanosti in umetnosti.

\section{Gregor Pompe (gregor.pompe@ff.uni-lj.si)}

je izredni profesor na Oddelku za muzikologijo Filozofske fakultete. Njegovi raziskovalni interesi veljajo predvsem sodobni glasbi, operi in semantiki glasbe. Do sedaj je izdal tri monografije (Pisna podoba glasbe na Slovenskem skupaj z J. Snojem, Postmodernizem in semantika glasbe, Zveneča metafizika - skladateljski opus akademika Lojzeta Lebiča) ter vrsto znanstvenih člankov v domačih in tujih revijah. Med letoma 2008 in 2012 je bil predsednik Slovenskega muzikološkega društva in med letoma 2012 in 2016 predstojnik Oddelka za muzikologijo. Za svoje delo je prijel Mantuanijevo priznanje Slovenskega muzikološkega društva. Dejaven je tudi kot glasbeni kritik in skladatelj.

\section{Karmen Salmič Kovačič (karmen.salmic@um.si)}

je muzikologinja in bibliotekarka, strokovna referentka in skrbnica Glasbene in filmske zbirke v Univerzitetni knjižnici Maribor. Pred tem je bila šest let asistentka za zgodovino glasbe na Oddelku za glasbo Pedagoške fakultete v Mariboru. Po končani gimnaziji v Brežicah in Srednji glasbeni šoli v Ljubljani je nadaljevala študij na Oddelku za muzikologijo Filozofske fakultete v Ljubljani, kjer je leta 1990 diplomirala, leta 2007 magistrirala, leta 2016 pa zagovarjala doktorsko tezo Demetrij Žebrè in sodobne slogovne tendence slovenske glasbe. Je avtorica številnih projektov, razstav, strokovnih in znanstvenih prispevkov. Raziskuje predvsem slovensko glasbo prve polovice 20. stoletja.

\section{Lubomír Spurný (L.Spurny@seznam.cz)}

je profesor muzikologije na Inštitutu za muzikologijo Masarykove univerze v Brnu. V središču njegovega raziskovalnega zanimanja je predvsem glasbena teorija in estetika v prvi polovici 20. stoletja. Poleg tega je avtor knjig o Heinrichu Schenkerju in Aloisu Hábi ter urednik številnih drugih monografij in znanstvenih revij.

$$
\text { Jurij Snoj (snoj@zrc-sazu.si) }
$$

doktor muzikoloških ved, je od leta 1980 raziskovalec na Muzikološkem inštitutu ZRC SAZU. Med leti 1994 in 2009 je bil tudi profesor zgodovine starejše glasbe na Univerzi v Ljubljani. Glavna področja njegovega dela 
so: srednjeveški koralni rokopisi v Sloveniji in srednji Evropi, antična in srednjeveška glasbena teorija, estetika glasbe. Med njegovimi pomembnejšimi publikacijami so: uvod v gregorijanski koral, komentirani prevod Boetijevega spisa De institutione musica / Temelji glasbe, zgodovina glasbe na Slovenskem do konca 16. stol. (s sodelavci), zgodovina glasbe v obdobju baroka, itd.

\section{John Tyrrell (jtyrrell@saqnet.co.uk)}

je poučeval na univerzah v Nottinghamu (1976-95) in Cardiffu (20002008), kjer je zdaj zaslužni profesor glasbe. Od leta 1995 do leta 2000 je bil izvršni urednik sedme izdaje The New Grove Dictionary of Music and Musicians. Med drugim je napisal monografijo Czech Opera (1988), delo Janáček's Operas: a Documentary Account (1992), katalog z naslovom Janáček's Works (kot soavtor, 1997) in biografijo $\mathrm{v}$ dveh knjigah $\mathrm{z}$ naslovom Janáček: Years of a Life (2006-7). Uredil je prvotni izdaji Janáčkovih oper Jenůfa (skupaj s Charlesom Mackerrasom, 1996) in Iz mrtvega doma (2018).

\section{Ana Vončina (ana.voncina@ff.uni-lj.si)}

je raziskovalka na Oddelku za muzikologijo ljubljanske Filozofske fakultete. Leta 2014 je doktorirala s temo o zgodovini klavirske improvizacije zahodnoevropske glasbe in potencialu glasbene improvizacije za razvoj mladega glasbenika. Trenutno je njeno področje raziskovanja usmerjeno v zgodovino slovenskih glasbenih ustanov.

\section{Jernej Weiss (jernej.weiss@ag.uni-lj.si)}

je študiral muzikologijo na Oddelku za muzikologijo Filozofske fakultete Univerze v Ljubljani (1999-2002) in Inštitutu za muzikologijo Filozofske fakultete Univerze v Regensburgu (2002-03). Med letoma 2005 in 2009 je deloval kot asistent na Oddelku za muzikologijo Filozofske fakultete v Ljubljani. Od leta 2011 deluje kot glavni in odgovorni urednik osrednje slovenske muzikološke publikacije Muzikološki zbornik. Od leta 2016 je redni profesor za področje muzikologije na Univerzi v Mariboru.

Raziskovalno se osredotoča na vprašanja, povezana z glasbo od 19. stoletja do danes, posebej s tisto, ki se tako ali drugače dotika slovenskega in češkega kulturnega prostora. Je avtor treh znanstvenih monografij. Od leta 2016 vodi mednarodni muzikološki simpozij Slovenskih glasbenih dnevov in je glavni urednik zbirke znanstvenih monografij Studia musicologica Labacensia. 
Sara Zupančič (sarazpn@gmail.com)

se je po diplomi iz klavirja na Glasbenem konservatoriju Giuseppa Tartinija v Trstu posvetila študiju muzikologije. Na tem področju je leta 2016 magistrirala na Filozofski fakulteti v Ljubljani, kjer je trenutno zaposlena kot asistentka raziskovalka pri projektu »Slogovna in kompozicijsko-tehnična raznolikost slovenske glasbe od leta 1918 do sodobnosti v luči družbenih sprememb «. Redno sodeluje s slovensko radijsko postajo Radio Trst A pod upravo italijanske ustanove RAI, ukvarja pa se tudi z operno dramaturgijo. 


\section{Contributors}

Peter Andraschke (p.andraschke@kabsi.at)

studierte Schulmusik, Musikwissenschaft, Germanistik und Volkskunde in München, Berlin und, Staatsexamen, Promotion und Habilitation in Freiburg i.Br.. Bis 2005 Professor für Musikgeschichte an der Justus-Liebig-Universität in Gießen. 2005-08 Gastprofessor am Wissenschaftszentrum Arnold Schönberg der Universität für Musik und darstellende Kunst in Wien. Internationale Gastprofessuren, Lehraufträge und Vorträge. Zahlreiche Veröffentlichungen zur Musikgeschichte seit 1750 mit den Schwerpunkten 19. und 20. Jahrhundert, die Musik im östlichen Europa, musikalische Analyse, Musikfolklore sowie das Verhältnis von Dichtung, Bildender Kunst und Musik.

\section{Matjaž Barbo (matjaz.barbo@ff.uni-lj.si)}

is a head of the Department of Musicology at the Faculty of Arts of the University of Ljubljana. He is an author of several books and scientific articles. He has been a president of the Slovenian Musicological Society and for several years an editor of the journal Musicological Annual. His research focuses on music from the $18^{\text {th }}$ century to the present, especially that which is associated with Slovenian cultural life, the development of symphonic music and selected questions related to the aesthetics of music. 


\section{Nada Bezić (nada.bezic@zg.t-com.hr)}

studied and got her doctorate (2011) in musicology from the Zagreb $\mathrm{Mu}$ sic Academy. She graduated in librarianship at the Faculty of Philosophy in Zagreb (1992) and is since 1988 in charge of the library in the Croatian Music Institute in Zagreb. Her main fields of research are the history of the Croatian Music Institute (book Društveni orkestar Hrvatskoga glazbenog zavoda, 2009) and musical life in Zagreb in the $19^{\text {th }}$ and $20^{\text {th }}$ centuries, regarding musical topography, book: Glazbena topografija Zagreba od 1799. do 2010. (2012) and Glazbene šetnje Zagrebom (2016). She is executive editor of the project Sabrana djela Blagoja Berse at the Croatian Music Institute. For many years she contributed to the Third Programme of Croatian Radio. She wrote many articles and essays, edited the musicological collections and made several exhibitions in the field of the history of Croatian music.

\section{Katarina Bogunović Hočevar (Katarina.BogunovicHocevar@ff.uni-lj.si)} is a lecturer at the Department of Musicology, Faculty of Arts in Ljubljana, where she is also employed. Her research field is the history of music of the 19th and first half of the 2oth century, the history of Slovenian music, analysis and music aesthetics. She publishes scientific articles in Slovenian and international journals. She is an editor an coeditor of professional and scientific publications. She collaborates with all important Slovenian music institutions, for which she prepares professional publications, professional texts, music broadcast shows and exhibitions (Cankarjev dom, The Slovenian Philharmonic, RTV Slovenija, NUK, DSS, Festival Ljubljana, Festival Brežice).

\section{Ivan Florjanc (ivan.florjanc@guest.arnes.si)}

is a composer, researcher and teacher. He graduated from the University of Ljubljana's Faculty of Theology in 1981. In 1989, he completed his music studies with a master's degree in composition from the Pontifical Institute of Sacred Music in Rome with the oratorio Abraham et Isaac for soloists, choir and orchestra. He worked as a lecturer there until 2004. In 1999, he also qualified at the Academy of Music, where he currently works as a full professor, teaching composition and music theory. As a composer, he is distinguished by his polyphonic vocal, chamber and orchestral opus (over 100 items of work). In terms of the research he conducts, this centres mainly on writing detailed monographs and articles on musical analysis (over 
150 items of work), with an emphasis on historical-theoretical and philosophical starting points.

Luba Kyyanovska (luba.kyjan@gmail.com)

Studium der Musikwissenschaft am Lviver Staatlichen Konservatorium "Mykola Lyssenko“ (1979). PhD 1985 (Funktionen des Programms in der Wahrnehmung des Musikwerkes), habilitiert 2000 (Die Evolution der galizischen Musikkultur der XIX.-XX. Jahrhunderte); von 1987 - Dozent, von 1995 - Professor, von 1991 - Inhaberin des Stuhls für Musikgeschichte an Lviver Nationalen Musikakademie „Mykola Lyssenko“. Forschungsschwerpunkte - Musikkultur Galiziens, Musikpsychologie, Geschichte der ukrainischen Musik, Beziehungen der ukrainischen Musik zu anderen europäischen musikalischen Nationalschulen, Musikpädagogik. Autorin der 6 Monographien, 8 Lehrbücher und za. 400 Veröffentlichungen in den wissenschaftlichen Bänden und Zeitschriften (Ukraine, Polen, Deutschland, Österreich, Slowenien, USA, Litauen, Russland u. a.).

dosežke v muzikologiji (2014).

\section{Darja Koter (darja.koter@ag.uni-lj.si)}

is full professor at the Academy of Music of Ljubljana University. Research works on various topics like history of musical instruments, music iconography, music performing and about works of composers. Collaboration in research projects of the University of Bonn and of the University of Ljubljana. Monographs: Glasbilarstvo na Slovenskem (2001, 2004), Musica coelestis et musica profana. Glasbeni motivi v likovni dediščini od severne Istre do Vremske doline (2008), Slovenska glasba 1848-1918 (2012), Slovenska glasba 1918-1991 (2012). In the year 2014 she has recived the Mantuani award.

\section{Hartmut Krones (Krones@mdw.ac.at)}

studierte Musikerziehung, Germanistik, Gesang, Gesangspädagogik sowie Musikwissenschaft und unterrichtet seit 1970 an der Akademie (jetzt Universität) für Musik und darstellende Kunst Wien; bis September 2013 Leiter des „Instituts für Musikalische Stilforschung“ (Abteilungen „Stilkunde und Aufführungspraxis" und „Wissenschaftszentrum Arnold Schönberg"). Zahlreiche Publikationen zu: Aufführungspraxis Alter und Neuer Musik, Musikalische Symbolik und Rhetorik, Musik des 20. Jahrhunderts (incl. Musik in der Emigration und „NS-Geschichte“ der A.K.M.); Bücher u. a. über Leben und Werk von Ludwig van Beethoven sowie Arnold Schönberg. Mitarbeiter u. a. des Lexikons Musik in Geschichte und Gegenwart (MGG; 
Fachbeirat für das Gebiet Österreich/20. Jahrhundert), des New Grove Dictionary sowie des Historischen Wörterbuchs der Rhetorik. Leiter der 2016 mit den ersten Bänden erscheinenden Kritischen Gesamtausgabe der Schriften Arnold Schönbergs.

\section{Primož Kuret (primoz.kuret@gmail.com)}

finished grammar school in Ljubljana in 1954 and graduated at the Academy of Music (music history) and at the Faculty of Arts (art history) in 1959. In 1960 he won the Student Prešeren Award. In 1965 he received his doctorate, later he became assistant professor (1978), associate professor (1983) and finally full professor in 1988 - in the fields of world music history and history of Slovene music - at the Academy of Music in Ljubljana. He was head of the Department of Music Education several times, between 1993 and 2001 he was deputy dean of the Academy of Music, between 2000 and 2004 he was president of the Slovene Musico- logical Society. He was editor of Revija GM (Jeunesses Musicales) from 1973 till 1987, for a number of years he was chairing different boards, a member of Steering Commi- ttee of the Prešeren Fund and the president of its jury for music. Between 2001 and 2005 he was head of the National Committee for the Renewal of Musical Education. In 1986 - together with the composer M. Stibilj - he established the Slovene Music Days that are each year accompanied by an international musicology symposium. He has received numerous awards, the most important are: the Medal of Merit of the Czech Republic (1985), honorary member of the Accademie Filarmonica di Bologna (2001), Betetto Award (2003), Herder Prize in Vienna and the Cross of Honour for Science and Art 1st Class, for accomplishments in the fields of musicology (2005), National Award of the Republic of Slovenia for his life-work in Musical Education (2005), Mantuani Award (2006), the Order of Merit of the Republic of Slovenia (2012). He partook in many international symposiums where he introduced and represented Slovene mu- sic (Belgium, Bulgaria, the Czech Republic, Croatia, Italy, Canada, Latvia, Lithuania, Luxemburg, Germany, Norway, Romania, Switzerland, Slovenia and Turkey). His most important works include: Glasbeni instrumenti na srednjeveških freskah v Sloveniji (1973), Glasbena Ljubljana 1899-1919 (1985) Glasba in družba (1988), Mahler in Ljubljana (1997 in 2011, the revised German translation was published in 2001 in Vienna), Slovenska filharmonija - Academia philharmonicorum 1701-2001 (2001), Zgodbe o glasbi in glasbenikih (2004), Slovenski skladatelji v portretih Saše Šantla (together with Verena Koršič Zorn, 2005), Ljubljanska filharmonična družba 1794-1919 (2005), 100 let Sloven- 
ske filhaonije (2008), Zanesenjaki in mojstri (2011). In domestic and foreign journals (Austria, Bulgaria, the Czech Republic, Italy, Japan, Germany, Slovakia) he published articles on Slovene music. He was guest professor at the University of Munich and in Freiburg im Breisgau.

\section{Helmut Loos (hloos@uni-leipzig.de)}

Geboren 1950; Studium der Musikpädagogik in Bonn (Staatsexamina), anschließend Musikwissenschaft, Kunstgeschichte und Philosophie an der Universität Bonn; 1980 Promotion, 1989 Habilitation. 1981 bis 1989 Wissenschaftlicher Mitarbeiter am Musikwissenschaftlichen Seminar der Universität Bonn. 1989 bis 1993 Direktor des Instituts für deutsche Musik im Osten in Bergisch Gladbach. Seit April 1993 Inhaber des Lehrstuhls für Historische Musikwissenschaft an der Technischen Universität Chemnitz, von Oktober 2001 bis März 2017 an der Universität Leipzig. 22.10.2003 Ernennung zum Professor honoris causa der Lyssenko-Musikhochschule Lemberg/L'viv. 2003 bis 2005 Dekan der Fakultät für Geschichte, Kunst- und Orientwissenschaften der Universität Leipzig. 02.04.2005 Ernennung zum Ehrenmitglied der Gesellschaft für deutsche Musikkultur im südöstlichen Europa (München). 30.10.2014 Ehrendoktor der Universitatea Naţională de Muzică din Bucureşti. Mitglied in den internationalen Editionsräten der Zeitschriften Hudební věda (Prag), Lituvos muzikologija (Vilnius), Menotyra. Studies in Art (Vilnius), Ars \& Humanitas (Ljubljana), Musicology Today (Bukarest), Muzica. Romanian Music Magazine (Bukarest) und Studies in Penderecki (Princeton, New Jersey).

\section{Andrej Misson (andrej.misson@siol.net)}

is a Slovene composer, researcher, expert in music theory and counterpoint, teacher, choir director, organist and performer (organ, piano and harpsichord). He is an associate professor at the Academy of Music, where he teaches theory and composition. His compositional oeuvre covers a wide range of genres. His major compositions include: Himna evropski Sloveni$j i$ for choir and orchestra, Slovenski vojni requiem for two soloists, mixed choir and orchestra, the cantata Primorska for male choir and orchestra, Tea4Two for orchestra, Dim nad vodo for orchestra, and a Christmas Te Deum for choir and orchestra. He also writes chamber music, solo pieces, choir music, songs and chansons. He has published numerous articles on music theory in a range of specialist publications. He lives and works in Škofja Loka. 
Niall O'Loughlin (N.Oloughlin@|boro.ac.uk)

studied at the Universities of Edinburgh and Leicester and has specialised in the 2oth-century music of Slovenia, the United Kingdom, and Poland. His book Novejša glasba $v$ Sloveniji was published in Ljubljana in 2000. His many articles have appeared in Musicological Annual, the proceedings of Slovene Music Days, The Musical Times, Tempo, chapters in books and in various editions of the New Grove Dictionaries of Music. In 2007 he was elected Corresponding Member of the Slovenian Academy of Sciences and Arts.

\section{Gregor Pompe (gregor.pompe@ff.uni-lj.si)}

is an associate professor at the Department of Musicology of the University of Ljubljana's Faculty of Arts. As a researcher, he is mainly focused on contemporary music, opera and music semantics. He has published three monographs (Pisna podoba glasbe na Slovenskem with J. Snoj, Postmodernizem in semantika glasbe, Zveneča metafizika - skladateljski opus akademika Lojzeta Lebiča) and a series of scholarly articles in domestic and foreign journals. From 2008 to 2012, he was President of the Slovenian Musicological Society, and the Chairman of the Department of Musicology from 2012 to 2016. For his work, he received the Mantuani award by the Slovenian Musicological Society. He is also an active music critic and composer.

\section{Karmen Salmič Kovačič (karmen.salmic@um.si)}

is a musicologist, librarian, expert consultant and curator of the Music and Film Collection of Maribor University Library. Before taking up her present position, she was employed for six years as a research assistant (history of music) in the Music Department of the University of Maribor's Faculty of Education. After completing her secondary education in Brežice and at the Secondary School of Music in Ljubljana, she continued her studies at the Department of Musicology (Faculty of Arts, University of Ljubljana), graduating in 1990 and completing a master's degree in 2007. In 2016 she defended a doctoral dissertation on "Demetrij Žebrè and contemporary stylistic tendencies in Slovene music". She is the author of several projects and exhibitions and has published numerous articles in professional and scholarly journals. Her principal area of research is Slovene music in the first half of the twentieth century. 
Lubomír Spurný (L.Spurny@seznam.cz)

is a Professor of Musicology at the Institute of Musicology, Masaryk University, Brno. In his research, he concentrates himself on the music theory and aesthetics of the first half of the 2oth century. He is the author of the books on Heinrich Schenker and Alois Hába and editor of several other books and journals.

\section{Jurij Snoj (snoj@zrc-sazu.si)}

$\mathrm{PhD}$ - musicology, is since 1980 a researcher at the Institute of Musicology, Scientific Research Centre of the Slovenian Academy of Sciences and Arts. In the years 1994-2009 he was also professor of early music history at the University of Ljubljana. His main topics of interest are: medieval plainchant manuscripts in Slovenia and central Europe, ancient and medieval music theory, and related issues in musical aesthetics. Among his major publications are: an introduction to Gregorian chant, the commented translation of Boethius' De institutione musica into Slovenian language, the history of music in Slovenia up to the end of the $16^{\text {th }}$ century (with collaborators), the history of music in the Baroque period, etc.

\section{John Tyrrell (jtyrrell@saqnet.co.uk)}

taught at the universities of Nottingham (1976-95) and Cardiff (20002008), where he is now Honorary Professor of Music. From 1995 to 2000 he was Executive Editor of the seventh edition of The New Grove Dictionary of Music and Musicians. His writings include Czech Opera (1988), Janáček's Operas: a Documentary Account (1992), the catalogue Janáček's Works (co-author, 1997) and a two-volume biography, Janáček: Years of a Life (2006-7). He has edited authentic editions of Janáček's operas Jenůfa (with Charles Mackerras, 1996) and From the House of the Dead (2018).

\section{Ana Vončina (ana.voncina@ff.uni-lj.si)}

is as a researcher at the Department of Musicology, Faculty of Arts in Ljubljana. In 2014 she completed her Phd on the history of keyboard improvisation in western art music and the potential of music improvisation for development of young musicians. Currently, her research is focused on the history of Slovenian music institutions. 
Jernej Weiss (jernej.weiss@ag.uni-lj.si)

studied musicology in the Department of Musicology at the University of Ljubljana's Faculty of Arts, and at the Institute of Musicology of the University of Regensburg. From 2005 to 2009 he worked as an Assistant at the Department of Musicology in Ljubljana. Since 2011 he is editor-in-chief of the main, peer-reviewed, Slovenian musicological periodical Muzikološki zbornik (Musicological Annual), is on the editorial boards of several scientific and specialised periodicals, and is also participating in various domestic and international scientific projects. He has been a full professor of musicology at the University of Maribor since 2016. He was a visiting lecturer at the universities of Graz, Brno, Cardiff, etc.

His research work deals with issues related to music from the 19th century to the present, focusing particularly, in one way or another, on the Slovenian and Czech cultural environments. He is the author of three scientific monographs. Since 2016 he has headed the international musicology symposium of the Slovene Music Days. He has also been editor-in-chief of the new scholarly monograph collection Studia musicologica Labacensia since 2016.

\section{Sara Zupančič (sarazpn@gmail.com)}

graduated in piano at the Conservatory of Music Giuseppe Tartini in Trieste, and turned to musicology after that. She completed her Master's degree in 2016 at the Faculty of Arts in Ljubljana, where she is currently taking part as research assistant in the project »The stylistic and compositional-technical diversity of Slovenian music from 1918 to the present day in the light of social changes «. She regularly writes for the Slovenian RAI Radio Trst A radio station and trains as dramaturg in opera productions. 


\section{Imensko kazalo/Index}

A

Abendroth, Walter 52

Adamič, Emil 20, II 8, 190, 239, 240 , $243,246,247,248,251,253,261,262$, $263,264,265,268,270,271,272$

Adamy, Bernhard 52

Adler, Guido 135, 136, 137, I38, 139, I 40, I 4 I, I 42, I 43, I 4 4, I 45, I 46, I 47, I 49, I52, I53, 258

Adler, Hugo 146

Adorno, Theodor I0, I4, I5, 57, 58, 59, $218,219,220,223$

Ajlec, Rafael 265, 267, 269

Aljaž, Jakob 248

Amar, Licco 65, 66, 118

Ambrožič, Matjaž I36

Amisano, Stefania 322

Ančerl, Karel 204

Andraschke, Peter 65, 70, 179

Andrejev, Leonid I8

Andreotti, Giulio 309

Antheil, George 69
Apih, Elio 300

Apollinaire, Guillaume 94 Apollonio, Umbro 74 Ara, Angelo 300

Arnič, Blaž 20, 248

Arnold, Jurij I8, I 49, 218, 260

Aškerc, Anton 25I

Auden, W.H. I80

Auer, Max 140

B

Bach, Johann Sebastian 57, I 42, I6I, I 62, I72, I92, 221, 226, 235, 325

Bajuk, Marko 153, 267, 268

Balla, Giacomo 74

Ball, Hugo 75

Bandur, Markus 218, 219, 220

Baranović, Krešimir 183

Bartók, Béla 69, 98, I1 7, II 8, 227, 228, 233, 234, 235, 335

Bartole, Sergio 300

Barwinskyj, Vasil 92,96

Becher, Johannes 59 
Bedina,Katarina I88,I89,191,192,202,2 II

Bednarik, Rado 309

Beethoven, Ludwig van 24, 26, 37, 57, 60, II2, I39, I 45, I51, I56, I61, I62, I70, 221, 235, 325

Beissner, Friedrich 58

Bekker IO, I 4

Belè, Venceslav 3 II

Bellini, Vincenzo 333

Berg, Alban 19, 64, 65, 67, 69, 182, 207, $228,253,318,325$

Bergamo, Marija I82

Berlioz, Hector 53,56

Bernik, Stane 260

Bersa, Blagoje II 8

Berté, Heinrich 56

Bidussi, Bruno 319,324,327,328

Bingulac, Petar 183

Birjulow, Jurij 92

Bizjak, France 28I

Bláha, Miloš ıo8

Blažek, Vlastimil 202

Bliss, Arthur II 8

Bogunović Hočevar, Katarina I87, I89

Boguslawskyj, Kostjantyn 102

Bojtschuk, Mychajlo 94, 98

Borgia Sedej, Frančišek 307,310, 313

Borris, Siegfried 58

Bortolotti, Katarina 32I

Botstein, Leon 219

Boulanger, Nadia 224

Boulez, Pierre 22I

Bowen, José Antonio 108

Brahms, Johannes IO, I 4, 24 , II2

Brand, Max 80

Bratuž, Lojze 308, 309, 311, 312, 313, 314

Bravničar, Matija 19, 20, 192, 243,259, 260, 27I, 286
Brecelj, Martin 308

Brecht, Bertolt I8, 69, 70, 80, 83, I8०

Brentano, Clemens 59

Brezar, Štefan 24I

Brojan, Matjaž 155, 286, 287

Bruch, Max 24, 5I, 54

Bruckner, Anton 24, 57, I39, I 40

Bučar, Danilo 239, 248

Budkovič, Cvetko 265

Burkard, Heinrich 63, 64, 66, 70

Busoni, Ferruccio 52, 53, 55, 56, 64, 192, 203,258,317

Butler, Christopher 219

C

Carpitella, Diego 335

Carter, Elliot 228

Casella, Alfredo 21, 66, II 8, 223, 22 4, 225

Castelnuovo-Tedesco, Mario II 8

Cellini, Benvenuto 53,56

Cerer, Avgust 248

Ciperle, Jože 20I

Ciril (Konstantin Filozof), misijonar 296

Clayton, Alfred I80

Clementi, Muzio 22I

Conetti, Giorgio 300

Cook, Nicholas I08, 219, 220

Corsi, Cesare 337

Craft, Robert 221, 222

Cvetko, Dragotin I6I, I77, I83, I87, I88, 198, 206,210

Cankar, Ivan I35, I36, I56, I64, I65

Cankar, Izidor 135, 136, 166

Cattaruzza, Marina 300

Ciglič, Zvonimir 20

Cigoj Krstulović, Nataša I35, I54 
$\check{\complement}$

Čajkovski, Peter Iljič 24, 100, 223

Čech, Svatopluk 34

Čepič, Zdenko 278

Čerin, Josip I 43, 284

Černigoj, Avgust 26I

Černý, Váša i Io

Čipić Rehar, Marija 24I

Colić, Dragutin I83, 205

D

Dahl, Ingolf 223

Dallapiccola, Luigi 21, I83, 225, 319, 332, 333

D’Annunzio, Gabriele 306

Danuser, Hermann I08, 218, 220, 222, $223,224,225,226,227$

da Ponte, Lorenzo 309

Davies 228

Debussy, Claude 229, 230

de Falla, Manuel 20

de Ferra, Giampaolo 319

Dekleva, Tatjana 20 I

Delak, Ferdo 260, 26I

Despić, Dejan 213

Dessau, Paul 70

Destinn, Emmy II 2

Dev, Oskar II 8, 239, 248

Dickinson, Peter II9

Dietz, Max I39, I 4 I, I 42

Dobronić, Antun II 7

Doflein, Erich 58

Dolenc, Ervin 26I, 278, 279, 280, 282

Dolinar, Anton I35, I36, I37, I38, I39, I 40, I 4 I, I 42, I 43, I 44, I 45, I 46, I 47, I 48, I 49, I5O, I 5 I, I 52 , I 53 , I 54 , I55, 248, 279, 283, 284, 286

Dolinar, France 300
Dolinar, Martin M. I36

Doll, Jürgen 79

Donizetti, Gaetano 333

Dowshenko, Walerian IO2

Draeseke, Felix 52

Dremluha, Mykola 102

Dunajevski, Izak Io3

Dvořák, Antonín 27,31,33,35, II7, I72, 207

Dvořak, Max 166

E

Eder, Helmut 57

Eggebrecht, Heins Heinrich 219

Egk, Werner 53, 56

Ehmann, Wilhelm 58

Einstein, Alfred 84,85

Eisler, Hanns 69, 80, 82, 83, 84

Elgar, Edward 25

Eltz, Erwin H. 67

Erben, Karel Jaromír 3I

Erchmeyer, Arno 67

Erdmann, Eduard 63, 64, 65

Erikson, Erik 245

Erjavec, Fran 248

Erlich, Viktor 223

Esser, Heribert ro9

F

Falco (Johann Hölzel) 57

Fauré, Gabriel 120

Ferenc, Nadia IoI

Filej, Mirko 3 I 2

Finke, Fidelio F. 67

Fischer, Ernst 79, I 4I

Fischer, Wilhelm I39, I 40, I 4I, I 42

Flavij Evgenij 297

Flotow, Friedrich von 56

Foerster, Anton 246, 250, 251, 264

Foerster, Josef Bohuslav $20 \mathrm{I}$ 
Fogar, Luigi 307,310

Franklin, Peter 219

Friberg, Anders 108

Fuchs, Robert 25I

G

Geheeb, Paul 57

Geiger, Friedrich 76

Gerbič, Fran 89, 202, 250

Gershwin, George 18

Giordano, Umberto 56

Girardi, Maria 322

Glinka, Mihail 223

Gluck, Christoph Willibald 53

Gobec, Radovan 248

Goethe, Johann Wolfgang 53

Gogolj, Nikolaj Vasiljevič 30

Gombač, Boris 300

Gončarova, Natalija Sergejevna II9

Goossens, Eugene ir 8

Gori, Gianni 319

Gorki, Maksim Io I

Gotovac, Jakov I83, 253

Gradnik, Alojz I78, 182, 232

Grbec, Ivan 263, 264, 265, 272, 317,329

Grdina, Igor 9, 13

Gregor Veliki I 45

Grgošević, Zlatko II 8, 27I

Grieg, Edvard I4I

Gröbming, Adolf 267, 268

Gronostay, Walter 70, 80, 8I

Gronski, Ivan IoI

Grosz, Wilhelm in 8

Gruenberg, Louis 118

Gruhn, Wilfried 58

Grum, Danijel 287,289

$\mathrm{H}$

Haas, Joseph 63, 64, 70
Haas, Robert ${ }^{4} 42$

Hába, Alois 20, 21, 64, 65, 67, I10, I76, I7 8, I83, I93, 202, 203, 204, 205, 206, 207, 208, 209, 2IO, 2II, 2I 2, 2 I3 , $229,231,235,260,261,387$

Hahr, Henrik 276

Halm, August 57

Harej, Zorko 312

Hartmann, Karl Amadeus I83

Hauer, Joseph Matthias 65

Hausegger, Siegmund von 64

Häusler, Josef 7 I

Hausmann, Raoul 74, 75, 84

Haydn, Franz Joseph 23, 53, I38, 22 I

Hegar, Friedrich 117

Heile, Björn 219

Heine, Heinrich I78, 206

Helfert, Vladimír 205

Herrmann, Hugo $7 \mathrm{I}$

Hesse, Horst-Peter 203

Hindemith, Paul 53, 54, 55, 56, 59, 64, $65,66,67,69,70$, I18, I78, 191, 192, 221, 222, 223, 224, 226, 227, 229, 253 , 258,317

Hinton, Stephen 68

Hitler, Adolf 7 I

Hladnik, Ignacij 248

Hochreiter, Emil 239, 240

Hoffmann, E. T. A. 53, 56

Höfler, Janez 296

Hölderlin, Friedrich 58,59,65

Holzknecht, Václav i ı

Honegger, Arthur I 8, 21, I78, I83

Horwitz, Karl 64, 65

Hubad, Matej 239, 248, 250, 284

Hudales, Oskar 270

Huelsenbeck, Richard 74

Humperdinck, Engelbert 73 
Hus, Jan 25

Hutcheon, Linda 53

Hutcheon, Michael 53

Hybašek, Vojteh I36

I

Ibert, Jacques i 8

Ibsen, Henrik I 4I

Iliev, Konstantin 204

J

Jacobshagen, Arnold 275

Jakac, Božidar 260

Jakončič, Joško 312

Jakopič, Rihard 260

Jakymenko, Fedir 96

Janáček, Leoš 23, 27, 28, 29, 30, 31, 32 ,

$33,34,35,36,37,38,39,40,4 \mathrm{I}, 42,43$,

$44,45,46,47,48,49,203,253,317$,

387

Janco, Marcel 75

Janowskyj, Borys 95, 96

Jaques-Dalcroze, Émile 99

Jarc, Miran 260

Jarnach, Philipp 64, 67

Javornik, Marjan I35

Jeglič, Anton Bonaventura 136, I37, I 43,

$24 \mathrm{I}$

Jemnitz, Alexander (Sándor) 65

Jericijo, Stanko 3I I

Ježek, Jaroslav 204

Jirák, Karel Boleslav 176, I83, 202, 213, 26I

Jiránek, Josef 202

Jobst, Anton 243

Jöde, Fritz 58

Johne, Eduard 64

Jones, David Wyn 23

Julien, Stanislas 179
K

Kabuzan, Vladimir 90

Kacin Wohinz, Milica 299,300, 308

Kaiser, Georg 54

Kant, Immanuel 139

Karajan, Herbert von III

Karalus, Maria 90, 9I

Karau, Elisa 79

Karel, Rudolf 207,26I

Karel Veliki 296

Karl, Ibaschitz 64, 7 I, 74, 79, 83

Karlin, Andrej 308

Kartin, Monika I87, I 88

Kasjanow, Grigorij 99

Kästner, Erich 79

Kemp, Friedhelm 59

Kernjak, Pavel 239

Khotkevych, Hnat 99

Kimovec, Franc iI8, I54

Klabund (Alfred Henschke) i 8, I76, I79, I80

Kleist, Heinrich von 58

Klemenčič, Ivan 137, I79, 190, 193, 209, 2I 2, 240, 243, 252, 324

Klemenčič, Josip I37, 179, 190, 193, 209, 2I2, 240, 243, 247, 252, 324

Klemenčič, Jože I37

Klemenčič, Vlado 270

Knoch, Hans 53

Koblar, France I55, 240

Kocbek, Edvard 2 II

Koch, Heinrich Christoph 23

Kodály, Zoltan 70

Koepke, Wulf 59

Koffler, Joseph 96

Kogoj, Marij I8, I9, II8, I59, I60, I63, I 64, I65, I66, I67, I68, I72, I73, I77, $239,243,246,247,252,254,255,259$, 
260, 26I, 264, 265, 266, 267, 27I, $312,313,314,317,318,325,335,346$

Kokoschka, Oskar 53

Kolessa, Mykola 92, 93,96

Kolleritsch, Otto 75

Komel, Emil 264, 311, 312, 313,314

Komelj, Milček 260

Kondel, Arthur 223

Koporc, Srečko 20, 207, 208, 248, 254, 26I, 286

Korngold, Julius 54, 55

Korošec, Anton 282

Koršič, Ivan 308

Kos-Anatolski, Anatol 103

Kosovel, Srečko I7, 19, 239

Kossenko, Wiktor 9I

Kostohryz, Milan i ı

Košuta, Miroslav 318, 320, 321, 326, 327,328

Koter, Darja 187, 260, 262, 263, 268

Kozina, Marjan 20, I83, 208

Kozytskyj, Pylyp 99

Kradordević, Aleksander, kralj i 8

Kramar, Franc 242

Kramolc, Luka 240

Krečič, Peter 166

Kreft, Bratko I 42, I 88, 260

Krek, Uroš 20, I83, 246

Křenek, Ernst 53, 54, 55, 56, 64, 65, 67, 68, 258, 259, 26I

Křička, Jaroslav 202, 26I

Krilov, Ivan 27 I

Krisper, Anton 146

Krones, Hartmut 83

Krstić, Peter $27 \mathrm{I}$

Krstulović, Zoran I35, I54, I63, I76

Kubelik, Jan II 2

Kucher, Primus-Heinz 79

Kumar, Srečko 259, 263, 264, 265, 266,

$$
\text { 267, 268, 27I, } 272
$$

Kuna, Milan 108

Kuret, Niko I55, 245, 279, 280

Kuret, Primož 89, I59, I60, I6I, I62, I63, I66, I69, I70, I79, I8I, I93, 202

Kurz, Vilém 208, 209

Kwartin, Claudia 65

L

Lach, Robert I38, I39, I 40, I 4I, I 42, I53

Lajovic, Anton 20, II8, I59, I60, I6I, I62, I63, I67, I72, I73, I8I, I93, 204, $239,244,245,247,251,253,263$, $264,265,267,284$

Lask, Berta 79, 84

Latoschynskyj, Borys 96, 97, 98, 99, IOO, 102

Léger, Fernand 69

Lehár, Franz 55, 56

Lenin, Vladimir Iljič 99, I00

Leskovic, Bogo I 83

Levay, Sylvester 57

Levi, Vito 317

Lhotka, Fran 183

Lhotský, Bohuslav i I I

Liebknecht, Karl 79

Lietz, Hermann 57

Lipar, Peter 318, 324, 328

Lipovšek, Marijan 20, I83, I87, 208, 209, 212, 248, 289

Liszt, Franz 209

Lobanowskyj, Borys IoI

Loos, Helmut 52

Loparnik, Borut 163, 267,319, 325, 332

Lord Berners (sir Gerald Hugh Tyrwhitt-Wilson) II9, I20

Löwenberg, Bruno 80, 8I

Ludkewytsch, Stanislav 92

Lunačarski, Anatolij Vasiljevič ıo I 
Lunaček, Matjaž 312

Lustgarten, Egon 26I

Lutosławski, Witold 228

Luxemburg, Rosa 79, 384

Lyssko, Zynowij 96

M

Mahler, Gustav 23, 92, I38

Maister, Rudolf 17

Makarovič, Svetlana 317, 319, 320,324, 328,337

Malič, Stane 313

Malipiero, Gian Francesco II 8, 225

Mal, Josip 66, 8I, IOO, IOI, I03, 209, 240, 24I, 242, 244, 248,255

Mann, Thomas 53, 74, 80, 81, II9

Mantuani, Josip I 46, I 49, 286

Marić, Ljubica I83, 204, 213

Marinetti,FilippoTommaso 73,74,75,314

Marolt, France 239, 247, $248,249,250$, $252,253,259$

Martelanc, Ivan 155

Martinů, Bohuslav 69, 203

Marušič, Branko 300

Masaryk, Tomáš Garrigue 30, 387

Matečić-Ronjgov, Ivan 270

Matejka, Viktor 84

Matetić-Ronjgov, Ivan 270, 27 I

Matičič, Janez 190

Matz, Rudolf II 8

Mav, Alojzij 136, 137, 239, 240, 248

Medvedova, Cirila 3 I2

Melik, Vasilij 201

Mendelssohn, Felix 24

Merkù, Josip 32I

Merkù, Pavle 317, 318, 319, 320, 321, 322 , $323,324,325,326,327,328,329,330$, $331,332,333,335,336,337,338,339$

Messing, Scott 227
Metodij, misijonar 296

Metzinger, Janez Valentin 166

Michl, Josip 247, 252, 262, 263

Mihalović, Hugo in 6

Milhaud, Darius I8, 53, 56, 69, 70, II 8, 224

Milin, Melita 213

Milojević, Miloje r83, 27 I

Mirk, Vasilij 239, 240, 247, 252, 259, 26I, 264, 27I, 272, 3II, 3I2

Mlakar, Boris 300

Mokranjec, Stevan 27I

Molotov, Vjačeslav io I

Monteverdi, Claudio 53, 56, 325, 332

Morandini, Luciano 322

Mortimer, Peter I 49

Mozart, Wolfgang Amadeus 56, 57, 22I

Mrak, Marjana 321, 322

Mussolini, Benito 308,310

N

Neffat, Anton 312

Negro Marinič, Breda 299

Nejedlý, Zdeněk 203

Nemec Novak, Jasna 286

Nieder, Fabio 324, 325

Niemöller, Klaus Wolfgang 52

Nietzsche, Friedrich 52, 54, 58

Nigg, Walter 59

Nikisch, Arthur 64

Novak, Vilko 166

Novák, Vítězslav 69,92, II7,201, 202, 203

Nowakowytsch, Myroslava 96,97

Nyshankiwskyj, Nestor 92,93

0

Oberborbeck, Felix 58

Oberländer, A. I 49

Ocvirk, Ivan 240

Odak, Krsto 69, I83 
Offenbach, Jacques 53,55, 56

Okuljar, Tadeusz 66

O'Loughlin, Niall I8I

Ondříček, František II 2

Onič, France 19

Orel, Albert I39, I 40, I 4 I, I 42, I 49

Orel, Rihard 242

Orff, Carl 53, 56

Osana, Marij 277, 278, 283

Osterc, Marta 289

Osterc, Slavko IO, I 4, I5, I8, I9, 20, 21, $70,72,175,176,177,178,179,180$, I8I, I82, I83, I84, I87, I88, I89, I90, I91, 192, 193, 194, 196, 197, 198, 199, 202, 203, 204, 205, 206, 207, 208, 209, 2IO, 2II, 2I2, 2I3, 215, 229, 230, 234, 239, 243, 244, 246, 247, 252, 253, 254, 259, 260, 26I, 27I, 286

Ostrčil, Otakar 202,26I

Otrin, Blaž 24I

P

Pagnini, Paola 300

Pahor, Boris 20, 183, 206, 239, 240, $248,263,264,265,306$

Pahor, Karol 20, 183, 206, 239, 240, $248,263,264,265,27 \mathrm{I}$

Palestrina, Giovanni Pierluigi da 52, 53 , 56, I 44, I 45, I 48, I 5 I, I 52

Panagl, Oswald 53

Papandopulo, Boris II7, II 8, I83, 27I

Partljič, Tone 319

Pašić, Nikola 310

Pauer, Max von 64

Pavčič́, Josip II 8, 239

Pawlytschko, Solomia 93

Pečić, Bela II

Pelikan, Egon 3II

Pepping, Ernst 67
Peters, Rudolf 64

Petrassi, Goffredo 317

Petrič, Kazimir 287

Petrobelli, Pierluigi 319, 323,324,332, 333,337

Petyrek, Felix 66, 67

Pfeifer, Leon 202

Pfitzner, Hans 52, 53, 55, 56, 64

Philipp, Franz 64

Piascator, Erwin 17

Pirjevec, Jože 308

Pirnik, Makso 239, 272

Pisk, Paul Amadeus 79, 80

Plamenac, Dragan 120

Pocarini, Sofronio 313,314

Podbersič ml., Renato 308

Podbevšek, Anton 19, 260

Pokorn, Danilo I8I, 190, 202

Polič, Mirko 259, 26I, 286

Poljanec, Taras 202

Pompe, Gregor 16I, 206, 243

Pople, Anthony 219, 220

Poulenc, Francis II 8, I20

Pozajić, Mladen II 8, 27I

Pregelj, Ciril 272

Prelovec, Zorko 239, 245, 246, 247 , $252,267,271,286$

Premrl, Stanko 136, 239, 243, 246, 247 , 250, 252, 262,264

Premru, Vladimir 19

Prokofjev, Sergej 103, I83, 221, 227, 231, 233, 259, 26I

Puccini, Giacomo 56, 288

Pučnik, Ivan 2II, 2I 2, 213

Pupo, Raoul 300

Purvis, Philip 54

Puškin, Aleksander Sergejevič 56

Puš, Ludvik 136, 248, 250, 253 
2

Qualizza, Marino 309

$\mathrm{R}$

Rahten, Andrej 308

Rajičić, Stanojlo 204

Ramovš, Primož 20, 246,317,318,320, $323,324,325,326,328,329,332,333$, 335, 337

Rathert, Wolfgang 227

Ravel, Maurice I8, 233

Ravnik, Anton 202

Ravnik, Bonita 202

Ravnik, družina 202

Ravnik, Janko II 8, I87, I89, 202, 239, 243,260, 264

Reger, Max 63

Reiner, Karel IIO, III, 204, 205

Reininger, Robert 139

Reininghaus, Frieder 275

Reittererová, Vlasta 205

Rejc, Tatjana 307

Respighi, Ottorino 223, 225

Reutter, Hermann 67

Rewutskyj, Lewko 91, 96, 99, I00, IO2

Richter, Hans 75

Riemann, Hugo I 46

Riethmüller, Albrecht 219

Riha, Karl 74, 75

Rijavec, Andrej I75, I81, I82, I89, I92, $320,324,329$

Rijavec, Josip 312

Rimski-Korsakov, Nikolaj 56

Ristić, Milan I83, 204

Robinson, Simon I8I

Rogotschenko, Oleksij IOI

Roretz, Karl I 40

Rosenfeld, Fritz 79
Rossini, Gioachino 223, 333

Rothfarb, Lee A. 57

Rubinig, Richard 75

Rudnyckyj, Antin 96

Russolo, Luigi 74

Rzewska, Maja 91, 95

S

Saba, Umberto 322

Sachs, Hans 53

Saint-Saëns, Camille 24

Salmič Kovačič, Karmen I66, 218, 228 , 230

Salimbeni, Fulvio 300

Salzer 228

Salzman, Eric 224

Samson, Jim II 7

Satie, Alfred Eric Leslie II 8, II9, 22 I

Sattner, Hugolin 239, 240,248

Savin, Risto 183

Scarlatti, Domenico 223

Schebera, Jürgen 68

Schedl, Gerhard 57

Schenker 228

Schenker, Heinrich I09, II 2

Scherchen, Hermann 69, I83, 205

Scherliess, Volker 227

Schewtschenko, Taras 93, I00

Schiffer, Marcellus 69

Schiffrer, Carl 305

Schlick, Friedrich Albert Moritz I 4I

Schmid, Alfons 7I

Schneider, Artur II5, II 6, II7, I19, I20

Schneider, L. 56

Schober, Arnold I 40

Schopenhauer, Arthur 52, 59

Schönberg, Arnold I0, I 4, I 8, I9, 65, 66, 69, 73, 80, 83, 96, II7, II 8, I38, I 82 , 193, 204, 207, 210, 218, 219, 221, 222, 
$223,226,227,231,258,260,261,345$, 383

Schreckenberger, Helga 59

Schreker, Franz 19, 53, 56, 64, 203, 260

Schubel, Dorothee 66

Schubert, Franz in 6

Schulhoff, Erwin 67, 110, 203

Schumann, Robert 116

Seitz, Robert 70

Sekles 20

Siebenschein, Robert 120

Sivec, Jože I35, I79

Sievers, Rolf 75

Simon, Ernst 59

Skrjabin, Aleksander 9I

Slataper, Scipio 303,304

Slokar, Simona 325

Smetana, Bedřich 25, 26, 28, 30, 31, 35, I72, 203

Smolej, Tone 142

Snoj, Jurij 136, 190

Snoj, Venčeslav 136

Sojar, Tone 277,278

Sonewytskyj, Igor 93

Spurný, Lubomír 203, 205, 213

Stalin, Josif Visarionovič 99, IOI, IO3

Stanič, Stanko 3I I

Stara, Arrigo 322

Stefanija, Leon I78, 206, 207

Steiner, Karl 83, 219

Steiner, Rudolf 210

Stelmaschtschuk, Roman 92

Stemmle, Adolf 80, 8I

Stenzl, Jürg 53

Stepowyj, Jakiv 9I

Stern, James i 80

Stern, Luitpold 79,80

Stern, Tanya r8o
Strauss, duhovnik 5I

Strauss, Richard 51, 52, 55, 56, 57, 64, I38, I79

Strauß, Richard 64, 92

Stravinski, Igor I8, I9, 66, 70, 98, I I 2, II 4, II 8, II9, I20, I77, I92, I93, 22 I, 222, 223, 224, 226, 227, 229, 235, 258, 259, 261, 317

Strossmayer, Josip Juraj II6

Strozzi-Pečić, Maja II9, I20

Stuparich, Carlo 303, 304

Stuparich, Giani 303, 304

Suk, Josef 2I, 20I, 203, 208, 209, 2I 2, 213, 229, 231, 235, 26I

Suppé, Franz von 56

Svetel, Heribert 286

Switlytschna, Wira 90

Š

Šaban, Ladislav II5, II7

Šantić, Aleksa 204

Šarabon, Mitja 230, 233

Šček, Breda 248,312

Šček, Ivan 3 I2

Šegula, Tomaž 253

Ševčík, Otakar I II

Šjanec, Drago Mario 284, 285,289

Š́n, Otakar 213

Širok, Albert 263, 264, 265, 266

Šebesta, Josef 202, 208, 209, 210, 212

Šivic, Pavel 20, I83, 209, 21 2, 248, 289

Škerjanc, Lucijan Marija 20, 2I, II 8, I83, I87, I88, I89, I90, I91, I92, I93, I94, I96, I97, I98, $243,244,246,248$, $254,285,286,289$

Šklovski, Viktor 223

Škulj, Edo I35, I36, I37, I 43

Šorli, Ljubka 309, 3 I I

Šostakovič, Dmitrij 229, 23I, 233, 259,317 
Štěpan, Václav 202

Štolcer-Slavenski, Josip 67, 70, II 7, II9, I 83, 253

Šturm, Franc 20, I83, 209, 210, 2II, 212

Šuligoj, Avgust 265, 267, 269, 270, 27I, 272

Švara, Danilo 20, I83, 239, 248,289

T

Tajčević, Marko II 8, 27I

Takacs, Jenö II

Talich, Václav 20I, 204, 212

Tavčar, Zora 336

Teodozij I., cesar 297

Terčelj, Filip 3 II

Thieme, Karl 7I

Timms, Andrew 219, 220

Tinjanov, Jurij 223

Toch, Ernst 65, 66, 67, 69, 84, 85

Toller, Ernst 79

Tolstoj, Aleksej ror

Tomažič, Danica 308

Tomc, Matija I36, I37, I43, I 44, I56, 239, $240,243,248,249,253$

Tomizza, Fulvio 300

Tommasini, Vinzenco 223

Toth, Lucio 300

Trakl, Georg 65

Troha, Nevenka 299,300

Turkewytsch-Lukijanowytsch, Stefania 96

Turk, Lida 326

Twittenhoff, Wilhelm 58

Tzara, Tristan 74

U

Uebersberger, Hans I $_{42}$

Uhland, Ludwig $5 \mathrm{I}$

Ukmar, Kristijan 166, I67
Ukmar, Vilko 20, I36, I 40, I66, I68, I72, 239, 243, 248, 285, 286

V

Vach, Ferdinand 262, 263

Václav IV., kralj 29

Varèse, Edgard 22I

Vasnjecov, Viktor 9I

Veber, France 166

Venier, Matej 286

Venturini, Fran 248

Verdi, Giuseppe 319, 330, 331, 332, 333

Vidmar, Josip I90, 254, 255

Viljem Osvajalec 5I

Villa-Lobos, Heitor 226

Vladigerov, Pančo 2 I

Vodopivec, Vinko 247, 251, 264, 265 , 3II, 3I2

Vogel, Wladimir 76, 77, 78, 84

Voglar, Dušan 201

Vorošilov, Kliment Jefremovič ıoI

Vovko, Andrej 300

Vrabec, Ubald 248,313

Vremšak, Ciril 248

Vreže, Jurče 272

Vrubel, Mihail 9I

Vucetić, Mario Mirko 3I 4

Vučković, Vojislav I83, 204, 205

Vuga, Aleksander (Saša) 300

Vuk, Stanko 308

Vurnik, Matej 166

Vurnik, Stanko I9, 20, I40, I59, I60, I66, I67, I68, I69, I70, I 7 I, I72, I73, $242,244,249,255,257,258,259$, 260, 26I, 286

Vysloužil, Jiř́i 203, 204

W

Wagner, Peter 149 
Wagner, Richard 51,52, 58, 60, I38, I42, I 45, I6I, I 62, 288

Walter, Bruno 52, 59, 70, 80, 8I, I38

Walther, Johann Gottfried 23

Warner, Theodor 58,59, 60, 6I

Webern, Anton 65, 80, 138, 182, 218, 221, 226,317

Weigl, Karl 137

Weill, Kurt 18, 54, 56, 68, 69, 317

Weinert, Erich 77

Weisenborn, Günther 80, 8I

Weiss, Jernej 178

Wellesz, Egon 65, I39, I 40, I 4 I, I 42

Werchowynets, Vasyl 99

Werykiwskyj, Mychajlo 96, 99, I00

Whittall, Arnold 221, 227, 228, 234, 235

Willner, Arthur 64

Wilson, Woodrow 17, 297

Wolf-Ferrari, Ermanno 56

Wolters, Gottfried 58

Wyneken, Gustav 57

Wytschulkowski, Leon 94

\section{Z}

Zemlinsky, Aleksander 92, I38, I76, I 80, I $8 \mathrm{I}$

Zich, Otakar II3

Ziegler, Hans Severus 85

Zika, Richard III

Zorn, Jože 263, 264, 267, 268, 278, 279, $280,282,283,285,287,289$

Zor, Vinko I55, 279

Zuanella, Natalino 309

Zweig, Stefan 58

$\check{Z}$

Žebre, Demetrij 20, I8I, I83, 2II, 2I 2, 2I 8, $228,230,231,232,233,234,236,261$

Železnik, Martin 243, 247, 252

Župančič, Jože 212, 269 

ISBN 978-961-7023-72-5

III 